\title{
Filozofska sastavnica u spisima Benedikta Kotruljevića
}

Papo, Demian

Doctoral thesis / Disertacija

2020

Degree Grantor / Ustanova koja je dodijelila akademski / stručni stupanj: University of Zagreb, University of Zagreb, Faculty of Humanities and Social Sciences / Sveučilište u Zagrebu, Filozofski fakultet

https://doi.org/10.17234/diss.2020.8584

Permanent link / Trajna poveznica: https://urn.nsk.hr/urn:nbn:hr:131:691044

Rights / Prava: In copyright/Zaštićeno autorskim pravom.

Download date / Datum preuzimanja: 2023-04-26

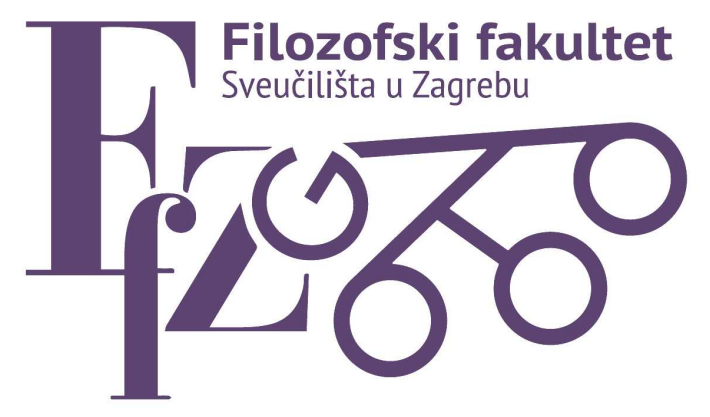

Repository / Repozitorij:

ODRAZ - open repository of the University of Zagreb

Faculty of Humanities and Social Sciences
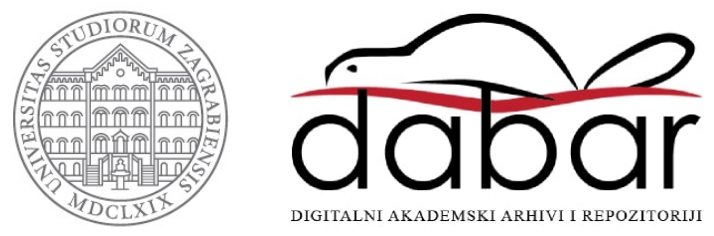
Sveučilište u Zagrebu

Filozofski fakultet

Demian Papo

\title{
FILOZOFSKA SASTAVNICA U SPISIMA BENEDIKTA KOTRULJEVIĆA
}

\author{
DOKTORSKI RAD
}

Mentor: izv. prof. dr. sc. Davor Balić

Zagreb, 2020. 
Faculty of Humanities and Social Sciences

\author{
Demian Papo
}

\title{
PHILOSOPHICAL COMPONENT OF BENEDIKT KOTRULJEVIĆ'S WRITINGS
}

\author{
DOCTORAL THESIS
}

Supervisor: Davor Balić, PhD, associate professor 


\section{O MENTORU}

Davor Balić (1969) radi kao izvanredni profesor na Odsjeku za filozofiju Filozofskog fakulteta Sveučilišta Josipa Jurja Strossmayera u Osijeku. Dosadašnji znanstveno-istraživački rad posvetio je istraživanju hrvatske filozofske baštine. Naime, na Hrvatskim je studijima 1993. godine upisao filozofiju i kroatologiju te je pod vodstvom mentora prof. dr. sc. Ivice Martinovića 1998. godine obranio diplomski rad pod naslovom Petrićev nauk o počélima iz perspektive Panarchije. Magistarski rad pod naslovom Hrvatska renesansna etika obranio je pod vodstvom mentora prof. dr. sc. Ante Čovića 2004. godine na Filozofskom fakultetu Sveučilišta u Zagrebu. Doktorski rad pod naslovom Etička misao Marka Marulića obranio je pod vodstvom mentorā prof. dr. sc. Ante Čovića i prof. dr. sc. Ivice Martinovića 2011. godine na Filozofskom fakultetu Sveučilišta u Zagrebu.

Autor je znanstvene monografije pod naslovom Etički nauk Marka Marulića koja je, a u izdanju Hrvatske akademije znanosti i umjetnosti te Zavoda za znanstvenoistraživački i umjetnički rad Koprivničko-križevačke županije, objavljena 2016. godine. Radove iz područja povijesti hrvatske filozofije objavio je u časopisima Dubrovnik, Scopus, Prilozi za istraživanje hrvatske filozofske baštine, Cris: časopis Povijesnog društva Križevci, Filozofska istraživanja, Metodički ogledi i Fluminensia. U njima je najčešće tematizirao sljedeće hrvatske mislioce: Marko Marulić, Frane Petrić, Ruđer Bošković, Franjo Marković, Đuro Arnold, Albert Haler, Miroslav Krleža i Pavao Vuk-Pavlović.

Mentor Balić objavio je i dva znanstvena rada o Benediktu Kotruljeviću: 1) Davor Balić, »Vrste plovilā u Kotruljevićevu udžbeniku plovidbe«, Metodički ogledi: časopis za filozofiju odgoja 17/1-2 (2010), pp. 61-86; 2) Davor Balić, »Filozofi i filozofski izvori u Kotruljevićevu spisu o umijeću trgovanja«, Cris: časopis Povijesnog društva Križevci 14 (Križevci, 2012), pp. 205-271.

Redoviti je sudionik znanstvenih skupova koje organizira Hrvatsko filozofsko društvo, naročito međunarodnog znanstvenog skupa Dani Frane Petrića u Cresu i domaćeg znanstvenog skupa Mediteranski korijeni filozofije u Splitu. U rujnu 2011. godine dodijeljeno mu je priznanje Hrvatskog filozofskog društva ıza znatan doprinos djelovanju, razvoju i promicanju znanstveno-kulturne manifestacije Dani Frane Petrića«. Uz to, sudjelovao je i na skupovima u organizaciji Instituta za filozofiju, kao i na skupovima u organizaciji Povijesnog društva Križevci. 
Mentor Balić bio je suradnik na znanstvenom projektu Instituta za filozofiju u Zagrebu, a na projektu Ruđer Bošković i hrvatske filozofske tradicije (2002-2005), kao i istraživač na znanstvenom projektu Instituta za filozofiju u Zagrebu, a na projektu Boškovićeva Theoria philosophiae naturalis $i$ hrvatske filozofske tradicije (2006-2011). Osim toga, bio je voditelj znanstvenog projekta Hrvatski renesansni polihistori u Morhofovu djelu Polyhistor, koji je trajao tijekom akademske 2013./2014. godine, a koji je odobrilo i financiralo Sveučilište Josipa Jurja Strossmayera u Osijeku.

Član je Hrvatskog filozofskog društva od 1999. godine, a u njemu je bio i član Nadzornog odbora (2000-2002), potom član Upravnog odbora (2004-2006) te tajnik Društva (20042006). Član je i Hrvatskog bioetičkog društva (2005). Od 2002. do 2012. godine bio je član Programskog odbora međunarodnog znanstvenog skupa »Petrić i renesansne filozofske tradicije«, koji se održavao u sklopu međunarodnog znanstvenog skupa Dani Frane Petrića. Od 2016. godine je član Programskog odbora međunarodnog znanstvenog skupa »Hrvatska filozofija u interakciji i kontekstu«, koji se održava u sklopu međunarodnog znanstvenog skupa Dani Frane Petrića.

U časopisu Filozofska istraživanja bio je član uredništva »Krug mladih urednika« (20062009). Član je uredničkog vijeća u časopisu Cris, a od 2009. godine i član uredništva, dok je od 2019. godine glavni i odgovorni urednik tog časopisa. 


\section{SAŽETAK}

U radu je istražena filozofska sastavnica dvaju spisa hrvatskog renesansnog mislioca Benedikta Kotruljevića (oko 1416-1469). Prvi je spis Kotruljević dovršio 1458. godine, a prema posljednjim spoznajama naslovio ga je Libro del arte dela mercatura. Četiri knjige toga spisa posvetio je trgovanju. Drugi spis dovršio je 1464. godine, a uvriježeno ga je nazivati De navigatione. U četirima knjigama tog spisa promišljao je o plovidbi.

Filozofska sastavnica u spisu o umijeću trgovanja očituje se trojako. U njemu se Kotruljević iskazao kao poznavalac povijesti filozofije, tako što se oslanjao na čak četrdesetak mislilaca od antike do svojega vremena. U svim četirima knjigama spisa prisutna je etička sastavnica. U prvoj je Kotruljević trgovačko umijeće ustrojio na pravedno uređenu poslovanju, u drugoj je ukazao na važnost trgovčeve vjere iz etičke perspektive, u trećoj je izgradio savršena trgovca kojeg odlikuju brojne etičke vrline, dok je u četvrtoj trgovčev ekonomski život zasnovao na etičkim i političkim zasadama. U prvoj, trećoj i četvrtoj knjizi bavio se i temama iz filozofije odgoja. U prvoj je nužnim smatrao istodoban duševni, duhovni i tjelesni razvoj djece, u trećoj je u odgoju i obrazovanju djece prepoznao ključ napretka čovječanstva, dok je u četvrtoj upozorio na presudan utjecaj roditeljā u odgoju.

Filozofska sastavnica spisa De navigatione također se očituje na tri načina. U prvom se poglavlju prve knjige Kotruljević iskazao kao poznavalac povijesti filozofije, raspolažući znanjima o antičkim grčkim i srednjovjekovnim filozofima. U prvoj i trećoj knjizi zastupljene su teme iz filozofije prirode. Prva se, primjerice, odnosila na razmatranje vode kao elementa, a treća na meteorološke pojave i astronomsko-astrološke teme. U drugoj i trećoj knjizi spisa ogleda se etička sastavnica. U drugoj su izložena etička obilježja četvorice članova zapovjednog lanca na brodovima, a u trećoj su razmotreni utjecaji koje nebeska tijela ostvaruju na etičko djelovanje ljudi.

Ključne riječi: Benedikt Kotruljević, Libro del arte dela mercatura, De navigatione, filozofska sastavnica, povijest filozofije, etika, filozofija prirode, filozofija odgoja. 


\section{SUMMARY}

The thesis focuses upon research of the philosophical component of two writings by the Croatian Renaissance thinker Benedikt Kotruljević (c. 1416-1469). He completed his first writing in 1458 and entitled it, according to the most recent research results, Libro del arte dela mercatura. In its four books he considered the art of trade. This writing received its reception from two of the most prominent Croatian Renaissance philosophers: Franciscus Patricius and Nicolò Vito di Gozze. Since he recognized the value of its contents, Patricius edited and published the first printed edition of the writing on the art of trade in 1573. In his most significant work on political philosophy Dello stato delle Republiche (On the Structure of States) published in 1591, Nicolò Vito di Gozze recommended Kotruljević's writing on the art of trade stating that it is "most useful to every researcher of this trade" and that it will teach them "how to trade justly and thereto very successfully." Kotruljević completed his second writing, which is commonly known as De navigatione, in 1464. In its first three completed books, as well as in its fourth uncompleted book, he exposed his thoughts on navigation. The delayed reception of De navigatione must be attributed to the fact that the handwritten version of its transcript was first found as late as 1995.

The philosophical component in the writing on the art of trade manifests itself in three ways. In it, Kotruljević proved himself to be a connoisseur of the history of philosophy. Apart from the information offered by previous research that he relied on more than twenty philosophers and philosophical sources in it, the thesis provides information that he also relied on the thoughts of the following fourteen philosophical thinkers: Callisthenes of Olynthus, Zeno of Citium, Marcus Terentius Varro, Valerius Maximus, Pliny the Elder, Pliny the Younger, Gaius Julius Solinus, Basil the Great, John Chrysostom, Isidore of Seville, Dante Alighieri, Francesco Petrarca, Giovanni Boccaccio, and Antonino Pierozzi or Antoninus of Florence. Therefore, in his writing on the art of trade Kotruljević referred to the philosophical thought of as many as forty thinkers from antiquity to his day.

Secondly, all of the four books of the writing on the art of trade contain an ethical component. For instance, in the first book he constituted the art of trade on justly (iustamente) arranged business. He also claimed that God gave humans free will (libero arbitrio), egregious mind (ingiegno egregio) and prudence (prudentia) in order for them to be able to resist the influence of higher celestial bodies. This proves that Kotruljević deemed human beings capable of self-determination (homo secundus Deus / Deus in terris). In the second book, he 
pointed out the importance of merchant's faith from an ethical perspective. Merchants should practice religion to renounce their vices, and they should nurture the virtue of wisdom (sapiencia) at the same time. Kotruljević built the perfect merchant who is supposed to obtain numerous ethical virtues in the third book. In his opinion, three of these virtues were of utmost importance for merchants: prudence (prudentia) which is a common virtue (comune virtu), justice (justitia) which is a virtue that incorporates many other virtues (questa virtu incorpora multe altre), and temperance (temperantia) which is the highest virtue (summa virtu). The contents of the third book also prove that Kotruljević advocated the Renaissance ideal of the universally educated man (homo universalis). In the fourth book, he founded merchant's economic life (la vita yconomica) on both ethical and political grounds. For instance, the merchant should govern his household and family (governo dela casa et dela famiglia) same as a king who rules over his subjects, and in so doing he should be very prudent (havere multa prudencia), venerable (venerabile), and honest (honesto).

In the first, third and the fourth book of his writing on the art of trade, Kotruljevic also considered issues belonging to philosophy of education. In the first book he believed that it was necessary for children to nurture their souls, spirits and bodies at the same time. Kotruljević also named three prerequisites for children to become perfect merchants: 1) they should be sons of a merchant, since they will possess intrinsic virtues (virtu intrinseche) similar to their fathers; 2) they should get acquainted with the rules of trade from a very young age and should absorb the movements, customs and conversations of merchants; 3 ) they should be persistent in doing their job. In the third book, he stated that the key to the progress of mankind lies in education. Young merchants should excel and surpass their parents in acquiring virtues (excellere et passarli in qualche virtu), and they should learn grammar, rhetoric, dialectic, philosophy, astrology, theology and law. Kotruljević accentuated the crucial influence of parents in the educational process in the fourth book. Parents must offer their children education (educare), nutrition (nutrire), and they need to teach them good customs (costumare), whereas children owe their parents obedience (obediencia).

The philosophical component of Kotruljević's writing on navigation also reflects itself in three ways. In the first chapter of the first book, Kotruljević once again proved to be a connoisseur of the history of philosophy, showing that he had knowledge on both ancient Greek (Thales of Miletus, Anaximander, Anaximenes of Miletus, Anaxagoras, Diogenes of Apollonia, Archelaus, Socrates, Plato, Aristotle) and medieval philosophers (Augustine of Hippo, Rabanus Maurus, Peter Lombard, Albert the Great). 
The issues belonging to philosophy of nature are present in the first and the third book of the writing on navigation. For instance, in the first book he mainly focused on water as one of the four elements. But he also tried to reconcile Christian Neo-Platonic worldview, led by Augustine, with the thought of pagan philosophers and astronomers, led by Aristotle and Ptolemy, which shows that his writing on navigation contains another characteristic of Renaissance philosophy: syncretism. In the third book, Kotruljević considered the following meteorological phenomena: winds, rainbows, halos, lightning and, as he called them, fires descending from the air. He wrote the most about winds, mainly on what causes them, what are their characteristics and what is their role in navigation, since he thought they were the most important part of navigation (la potisima parte ne la navigatione). Kotruljević also pondered upon astronomical and astrological issues, namely upon twelve zodiac signs, two ephemerides, properties of the seven known planets, solstices and equinoxes, and time measurement. He paid the most attention to the twelve zodiac signs, considering that type of knowledge useful to sailors for two reasons: 1) each of the zodiac signs brings different weather; 2) zodiac signs affect human inclinations and actions.

The second and the third book of De navigatione contain an ethical component. Kotruljević presented ethical virtues necessary for the four members of the chain of command on ships in the second book. For example, the captain of a ship should be temperate (temperato) and he should not be avaricious (non avaro). In the third book, Kotruljević focused on the influence of celestial bodies on human ethical actions. He was convinced that, for instance, people born in Aquarius will be wise (savio) and evil (malo), and that Jupiter's influence makes people capable of ruling and that they become temperate (temperati).

Key words: Benedikt Kotruljević / Benedetto Cotrugli, Libro del arte dela mercatura, De navigatione, philosophical component, history of philosophy, ethics, philosophy of nature, philosophy of education. 


\section{SADRŽAJ}

1. UVOD 1

2. FILOZOFSKA SASTAVNICA KOTRULJEVIĆEVA SPISA O UMIJEĆU TRGOVANJA 8

2.1. Benedikt Kotruljević kao poznavalac povijesti filozofije 11

2.2. Etika u spisu o umijeću trgovanja 32

2.2.1. Etika u prvoj knjizi spisa o umijeću trgovanja 33

2.2.2. Etika u drugoj knjizi spisa o umijeću trgovanja 47

2.2.3. Etika u trećoj knjizi spisa o umijeću trgovanja 57

2.2.4. Etika u četvrtoj knjizi spisa o umijeću trgovanja $\quad 79$

2.3. Filozofija odgoja u spisu o umijeću trgovanja $\quad 90$

2.3.1. Filozofija odgoja u prvoj knjizi spisa o umijeću trgovanja 91

2.3.2. Filozofija odgoja u trećoj knjizi spisa o umijeću trgovanja 95

2.3.3. Filozofija odgoja u četvrtoj knjizi spisa o umijeću trgovanja 101

3. FILOZOFSKA SASTAVNICA KOTRULJEVIĆEVA SPISA O PLOVIDBI 106

3.1. Benedikt Kotruljević kao poznavalac povijesti filozofije $\quad 110$

3.2. Filozofija prirode u spisu o plovidbi 123

3.2.1. Filozofija prirode u prvoj knjizi spisa o plovidbi $\quad 125$

3.2.2. Filozofija prirode u trećoj knjizi spisa o plovidbi $\quad 145$

3.2.2.1. Meteorološke pojave u trećoj knjizi spisa o plovidbi 147

3.2.2.2. Astronomsko-astrološka razmatranja u trećoj knjizi spisa o plovidbi $\quad 163$

3.3. Etika u spisu o plovidbi 176

3.3.1. Etika u drugoj knjizi spisa o plovidbi 176

$\begin{array}{ll}\text { 3.3.2. Etika u trećoj knjizi spisa o plovidbi } & 187\end{array}$

4. ZAKLJUČAK 194

5. POPIS CITIRANE LITERATURE 210

5.1. Benedikt Kotruljević 210

5.2. Ostala citirana literatura 211 
6. PRILOZI

PRILOG 1: Popis izdanjā cjelovita Kotruljevićeva spisa o umijeću trgovanja

PRILOG 2: Popis rukopisnih inačica prijepisā i izdanjā Kotruljevićeva spisa o plovidbi

\section{7. ŽIVOTOPIS}

7.1. Bibliografija 


\section{UVOD}

Tijekom 15. i 16. stoljeća većinu Europe zahvaća kulturni i duhovni pokret koji je poznat pod nazivom renesansa. Njezin utjecaj snažno se očitovao i u filozofskim promišljanjima onodobnih mislilaca. Interes za istraživanje renesanse budi se na europskom kontinentu tek u drugoj polovici 19. stoljeća, a prisutan je i danas. Neki od najistaknutijih istraživača renesanse i tadašnje filozofije s europskog tla zasigurno su Jacob Burckhardt (1818-1897), Johan Huizinga (1872-1945), Ernst Cassirer (1874-1945), Paul Oskar Kristeller (1905-1999), Eugenio Garin (1909-2004), Cesare Vasoli (1924-2013) i Hanna-Barbara Gerl-Falkovitz. ${ }^{1}$ No, zanimanje za prouke uzleta europske kulture i duha tijekom 15. i 16. stoljeća gotovo istodobno raste i preko Atlantika. Zahvaljujući tome, danas raspolažemo obimnim i značajnim uredničkim ostvarenjima te ništa manje vrijednim rezultatima istraživanjā koje su iznjedrili američki stručnjaci i to, primjerice, John Herman Randall Jr. (1899-1980), Charles Bernard Schmitt (1933-1986) i James Hankins. ${ }^{2}$ Uz to, za postignućima istaknutih istraživača renesansnog mišljenja s europskog, pa i svjetskog obzora nipošto ne zaostaju ona potekla iz perā hrvatskih istraživača. U točnost te tvrdnje lako se uvjeriti uvidom bilo u presjeke renesansnog filozofskog mišljenja s europskog i hrvatskog horizonta, bilo u pozamašan broj radova o pojedinim izdancima renesansnog hrvatskog filozofskog nasljeđa koje su od druge polovice 20. stoljeća naovamo ponudili, primjerice, Vladimir Filipović (1906-1984), Ljerka Schiffler (1941-2016), Mihaela Girardi-Karšulin, Erna Banić-Pajnić te Ivica Martinović. ${ }^{3}$

\footnotetext{
1 Budući da su gotovo svi navedeni istraživači autori brojnih vrijednih prinosa rasvjetljavanju obilježjā renesansne kulture i mišljenja, ovom ću prigodom izdvojiti tek po jedan od njihovih zapaženijih radova: Jacob Burckhardt, Die Cultur der Renaissance in Italien. Ein Versuch (Basel: Druck und Verlag der Schweighauser'schen Verlagsbuchhandlung, 1860); J.[ohan] Huizinga, Herfsttij der Middeleeuwen: studie over levens-en gedachtenvormen der veertiende en vijftiende eeuw in Frankrijk en de Nederlanden (Haarlem: H. D. Tjeenk Willink \& zoon, 1919); Ernst Cassirer, Individuum und Kosmos in der Philosophie der Renaissance, softcover reprint of the hardcover 1st edition 1927 (Wiesbaden: Springer Fachmedien Wiesbaden GmbH, 1927); Paul Oskar Kristeller, Eight Philosophers of the Italian Renaissance (Stanford: Stanford University Press, 1964); Eugenio Garin, Medioevo e Rinascimento: studi e ricerche (Bari: Gius, Laterza \& Figli, 1954); Cesare Vasoli, Umanesimo e Rinascimento (Palermo: Palumbo, 1969); Hanna-Barbara Gerl, Einführung in die Philosophie der Renaissance (Darmstadt: Wissenschaftliche Buchgesellschaft, 1989).

2 Ovom prilikom izdvajam tek ona značajna izdanja u kojima su trojica navedenih američkih istraživača sudjelovali i kao urednici i kao autori zasebnih priloga: Ernst Cassirer, Paul Oskar Kristeller, John Herman Randall Jr. (selections in translation, edited by), The Renaissance Philosophy of Man: Petrarca, Valla, Ficino, Pico, Pomponazzi, Vives (Chicago: University of Chicago Press, 1948); Charles B.[ernard] Schmitt (general editor), Quentin Skinner, Eckhard Kessler (editors), Jill Kraye (associate editor), The Cambridge History of Renaissance Philosophy (Cambridge: Cambridge University Press, 1988); James Hankins (edited by), The Cambridge Companion to Renaissance Philosophy (Cambridge: Cambridge University Press, 2007).

${ }^{3}$ Zbog brojnosti njihovih znanstvenih članaka i studija, upućujem tek na njihova ostvarenja hrestomatske $\mathrm{i}$ monografske naravi: Vladimir Filipović, Filozofija renesanse $i$ odabrani tekstovi filozofa, Filozofska hrestomatija, sv. 3 (Zagreb: Nakladni zavod Matice hrvatske, 1956); Ljerka Schiffler, Humanizam bez granica: hrvatska filozofija u europskom obzoru (Zagreb: Hrvatsko filozofsko društvo, 1992); Mihaela Girardi
} 
Kada je riječ o općim obilježjima filozofije nastale tijekom 15. i 16. stoljeća, priklonit ću se onima koje je istaknula Banić-Pajnić u uvodnoj studiji »Renesansna filozofija« trećeg sveska Hrestomatije filozofije Filozofija renesanse iz 1996. godine, zato što je, smatram, umješno objedinila i sažela najznačajnije spoznaje iz dotad poduzetih istraživanja. Iz njezine studije moguće je zaključiti da se glavna obilježja renesansnog filozofskog mišljenja iskazuju, primjerice, u: 1) traganju za novim izvorima spoznaje; 2) težnji za duhovnom i intelektualnom obnovom (renovatio) te nadogradnji srednjovjekovnih spoznaja antičkim uzorima; 3) sinkretističkom mišljenju koje pomiruje zajedničko u raznolikim filozofsko-teološkim tradicijama; 4) postavljanju čovjeka i njegova djelovanja u središte pozornosti (homo secundus Deus / Deus in terris); 5) stvaranju ideala svestrano obrazovana čovjeka (homo universalis) koji će biti spreman odgovoriti na izazove novovjekovlja. ${ }^{4}$

Ta su obilježja ponajviše zamjetna u stvaralaštvu najistaknutijih europskih predstavnika renesansnog filozofskog mišljenja, a od kojih izdvajam sljedeće: Nikola Kuzanski (14041464), Marsilio Ficino (1433-1499), Giovanni Pico della Mirandola (1463-1494), Erazmo Rotterdamski (1466-1536), Niccolò Machiavelli (1469-1527), Nikola Kopernik (14731543), Giordano Bruno (1548-1600) i Michel de Montaigne (1533-1592). Spomenuta obilježja filozofije nastale u renesansi nesumnjivo su prisutna i u spisima brojnih hrvatskih mislilaca, pri čemu izdvajam sljedeće: Ivan Stojković (oko 1390-1443), Nikola Modruški (1427-1480), Juraj Dragišić (1445-1520), Marko Marulić (1450-1524), Federik Grisogono (1472-1538), Fran Trankvil Andreis (1490-1571), Matija Vlačić ml. (1520-1575), Frane Petrić (1528-1597), Pavao Skalić (1534-1575), Nikola Vitov Gučetić (1549-1610) i Marko Antun de Dominis (1560-1624).

Još jedan od hrvatskih mislilaca u čijem se opusu očituju obilježja renesansnog filozofskog mišljenja bio je Benedikt Kotruljević (tal. Benedetto Cotrugli Raugeo / Raguseo, lat. Benedictus de Cotrullis, hrv. Beno / Benko, Kotrulić / Kotrulj / Kotruljić, oko 1416-1469). Danas raspolažemo s dvama spisima tog Dubrovčanina. U onom koji je završio 1458. godine Kotruljević je promišljao o trgovanju, dok je u onom koji je završio 1464. godine promišljao o plovidbi. No, u četvrtoj knjizi svojih umovanja o trgovanju zabilježio je da je napisao i spis

Karšulin, Hrvatski renesansni aristotelizam (Zagreb: Hrvatsko filozofsko društvo, 1993); Erna Banić-Pajnić, Duhovno-povijesna raskršća: poruke renesansne filozofije (Zagreb: Hrvatsko filozofsko društvo, 1991); Ivica Martinović, Žanrovi hrvatske filozofske baštine od 15. do 18. stoljeća (Split: Filozofski fakultet Sveučilišta u Splitu, 2011).

4 Erna Banić-Pajnić, »Renesansna filozofija«, u: Banić-Pajnić (priređivačica sveska), Filozofija renesanse. Hrestomatija filozofije, sv. 3, pp. 7-42, na pp. 9-16. 
De uxore ducenda (O izboru žene). ${ }^{5} \mathrm{Uz}$ to, dubrovački biograf Franjo Marija Appendini iznio je 1803. godine podatak da je Kotruljević napisao i spis Della natura dei fiori ( $O$ naravi cvijeća). ${ }^{6}$ Spisi De uxore ducenda i Della natura dei fiori nisu pronađeni.

Autograf spisa o umijeću trgovanja također nije pronađen. Ipak, njegov nam je sadržaj uvelike poznat, budući da dosad raspolažemo s trima različitim rukopisnim inačicama prijepisa tog spisa, zatim budući da postoje brojna tiskana izdanja tih prijepisa, od kojih je prvo iz 1573 . godine, te budući da postoje prijevodi tih prijepisa na francuskom, srpskom, hrvatskom, poljskom i engleskom jeziku (vidi Prilog 1.). Kotruljević je spis o umijeću trgovanja podijelio u četiri knjige.

Sadržaj četiriju knjiga Kotruljevićeva spisa postao je aktualan tek tijekom 20. stoljeća, i to ponajprije zahvaljujući istraživačima ekonomskih znanosti. Za to su postojala dva razloga. Prvi je bio u vezi s temom svih četiriju knjiga spisa, dakle s umijećem trgovanja. Drugi je bio u vezi s utvrđivanjem Kotruljevića kao prvog mislioca koji je ustanovio pravila dvostavnog knjigovodstva. Istraživači ekonomskih znanosti koji su na tom polju polučili najdalekosežnije rezultate, kao i najbrojnije te najopsežnije studije su: Karel Petr Kheil (1843-1908), Mihajlo V. Vujić (1853-1913), Milorad Zebić (1883-1976), Rikard Radičević, Ugo Tucci (19172013), Basil S. Yamey, Pavao Ravlić, Vladimir Stipetić (1928-2017), Mladen Habek (19302014), Anđelko Runjić (1938-2015), Đurđica Jurić, Alan Sangster, Anne J. van der Helm i Johanna Postma. ${ }^{7}$ U kontekstu govora o aktualnosti i dosezima istraživanja Kotruljevićeve

\footnotetext{
${ }^{5}$ Benedetto Cotrugli, »Libro del arte dela mercatura«, libro IV, capitulo 6 / Benedikt Kotrulj, »Knjiga o vještini trgovanja«, knjiga IV, poglavlje 6, u: Benedikt Kotrulj, Libro del arte dela mercatura / Knjiga o vještini trgovanja, priredila i prevela Zdenka Janeković Römer (Zagreb - Dubrovnik: Hrvatska akademija znanosti i umjetnosti, Zavod za povijesne znanosti u Dubrovniku i Hrvatski računovođa, 2009), p. 304 [f. 84v]: »Non obstante che de uxore ducenda ne habiamo facto un opera singulare altre volte, come sai, a misser Volce de Baballio, dove s'e decto diffusamente in sermon Latino d' ogni observancia de mugliere et delo officio loro et de alevar figlioli et di tuti ordini deveno esser observati in unoconque dela famiglia, <... «. / p. 479: »O ženidbi smo jednom prilikom napisali posebno djelo, kao što znaš, za gospodina Vukšu de Babalio, u kojem se na latinskom jeziku opširno govori o skrbi za žene, njihovim dužnostima, podizanju djece i o svim pravilima koja valja poštivati u svakoj obitelji.«

${ }^{6}$ Francesco Maria Appendini, Notizie istorico-critiche sulle antichità storia e letteratura de' Ragusei divise in due tomi e dedicate all'Eccelso Senato della repubblica di Ragusa. Tomo II. (Ragusa: Dalle stampe di Antonio Martecchini, 1803), s. v. »Benedetto da Giacomo Cotrugli«, pp. 98-100, na pp. 99-100: »Finalmente convengo coll' erudito Coleti, che l'opera Italiana Della natura dei fiori di Benedetto Cotrulli sia di questo medesimo autore, coincidento perfettamente l' epoca, ed essendo lo stesso il nome, ed il cognome. Il paragone dello stile delle due opere potrebbe agevolarcene la decisione; ma in Ragusa non esiste quella sulla coltura dei fiori.«

${ }^{7}$ Zbog brojnosti radova navedenih ekonomista, izdvajam tek po jedan od njihovih zapaženijih radova: Karel Petr Kheil, Benedetto Cotrugli Raugeo (Dubrovčan). Přispěvek k dějinám účetnictví. (V Praze: Bursik \& Kohout, 1906); Mih.[ajlo] V. Vujić, »Prvo naučno delo o trgovini Dubrovčanina Benka Kotruljića«, Glas Srpske kraljevske akademije, br. 80 (Beograd, 1909), pp. 25-123; Milorad Zebić, Život i rad Dubrovčanina Benka Kotruljića. Sa prevodom njegovog spisa O trgovini i savršenom trgovcu (Titograd: Udruženje knjigovođa Crne gore, 1963); Rikard Radičević, Rudnik blaga Bene Kotruljevića (Zürich: Manuskript sastavio Rikard Radičević, 1987); Ugo Tucci, »Introduzione«, u: Benedetto Cotrugli Raguseo, Il libro dell'arte di mercatura, a cura di Ugo Tucci (Venezia: Arsenale Editrice, 1990), pp. 3-128; Basil S. Yamey, »Benedetto Cotrugli on
} 
misli iz perspektive ekonomskih znanosti ističem $\mathrm{i}$ to da su u proteklih četvrt stoljeća $\mathrm{u}$ Hrvatskoj održana dva znanstvena skupa na tu temu, kao i to da su objavljena dva zbornika radova koji su proizašli iz tih skupova. Prvi je skup održan u Dubrovniku 1996. godine u organizaciji Hrvatske akademije znanosti i umjetnosti te udruge »Hrvatski računovođa«, dok je drugi održan u Zagrebu 2008. godine, a u organizaciji Ekonomskog fakulteta. ${ }^{8}$ Zbog razjašnjavanja sudbine triju dosad pronađenih rukopisnih inačica prijepisa, zatim zbog analize obilježjā Dubrovčaninova jezičnog izričaja, kao i zbog utvrđivanja literarne vrijednosti njegova spisa, na istraživanje Kotruljevićevih promišljanja o umijeću trgovanja prionuli su i povjesničari, primjerice, Arnolfo Bacotich (1875-1940), Nenad Vekarić (1955-2018), Piotr Wróbel te Zdenka Janeković Römer, kao i filolozi te povjesničari književnosti kao što su, također primjerice, Žarko Muljačić (1922-2009), Tiziano Zanato, Luca Boschetto, Bojana Bratić i Paulina Piotrowicz. $^{9}$

bookkeeping (1458)«, Accounting, Business \& Financial History 4/1 (1994), pp. 43-50; Pavao Ravlić, »Benedikt Kotruljević kao preteča Luce Paciolija u prikazu dvostavnog knjigovodstva«, Računovodstvo, revizija i financije 9 (rujan, 1999), pp. 109-114; Vladimir Stipetić, »Beno Kotruljević prvi je upoznao svijet s dvostrukim računovodstvom. Iznenađujući novotkriveni rukopis Bene Kotruljevića«, Računovodstvo, revizija $i$ financije 10 (listopad, 1994), pp. Ia-VIIIb; Mladen Habek, »Kotruljevićevo djelo u svjetskoj računovodstvenoj misli«, Računovodstvo, revizija i financije 11 (studeni, 1994), pp. I-XIV; Anđelko Runjić, »O Benku Kotruljiću i njegovu djelu«, u: Benedetto Cotrugli Raugeo, Della mercatura et del mercante perfetto. Libri quattro, biblioteka reprint izdanja Liber Croaticus (Zagreb: Savez računovodstvenih i financijskih radnika Hrvatske, Sveučilišna naklada Liber, 1975), pp. 243-258; Đurđica Jurić, Djelo Bene Kotruljevića i hrvatska gospodarska misao, magistarski rad, mentor: Anđelko Runjić (Zagreb: Sveučilište u Zagrebu, Ekonomski fakultet, 1995); Alan Sangster, Libr. XV: Cotrugli and de Raphaeli on business and bookkeeping in the Renaissance (Stirling: Lomax Press, 2014); Anne J. van der Helm, Johanna Postma, »La Riegola del Libro. Bookkeeping Instructions from the Mid-Fifteenth Century«, u: Accounting and History: A selection of papers presented at the 8th World Congress of Accounting Historians, Madrid, Spain, 19-21 July 2000 (Madrid: Asociación Española de Contabilidad y Administración de Empresas, 2000), pp. 147-178.

8 Vladimir Stipetić (ur.), Dubrovčanin Benedikt Kotruljević: hrvatski i svjetski ekonomist XV. stoljeća, međunarodni znanstveni skup, Dubrovnik 17-19. X. 1996. Radovi o životu i djelu Benedikta Kotruljevića, knjiga 1. (Zagreb: Hrvatska akademija znanosti i umjetnosti i »Hrvatski računovođa«, 1996); Vladimir Stipetić (ur.), Dubrovčanin Benedikt Kotruljević: hrvatski i svjetski ekonomist XV. stoljeća, međunarodni znanstveni skup, Dubrovnik 17-19. X. 1996. Radovi o životu i djelu Benedikta Kotruljevića, knjiga 2. (Zagreb: Hrvatska akademija znanosti i umjetnosti i »Hrvatski računovođa«, 1997); Danimir Gulin, Ivana Dražić Lutilsky, Branka Glasnović (ur.), Znanstveni skup »Benedikt Kotruljević 2008." (Zagreb: Ekonomski fakultet Zagreb, 2008).

9 Arnolfo Bacotich, »Benedetto Cotrugli da Ragusa primo scrittore di scienze mercantili (1458)«, Archivio storico per la Dalmazia 5/9 (1930), pp. 183-190; Nenad Vekarić, »Dubrovački rod Kotrulj«, u: Stipetić (ur.), Dubrovčanin Benedikt Kotruljević: hrvatski i svjetski ekonomist XV. stoljeća, knjiga 1., pp. 33-52; Piotr Wróbel, »Benedykt Cotruglio (Benko Kotruljević): człowiek na granicy dwóch światów i dwóch epok«, Balcanica Posnaniensia: acta et studia 16 (2009), pp. 125-138; Zdenka Janeković Römer, »Benedikt Kotrulj u potrazi za savršenim trgovcem«, u: Kotrulj, Libro del arte dela mercatura / Knjiga o vještini trgovanja, pp. 15-111; Žarko Muljačić, »Sličnosti i razlike Petrisova izdanja Kotruljevićeva traktata (Mleci, 1573, P) i najstarijeg dosad poznatog prijepisa (Napulj, 1475, R) izgubljenog autografa (1458)«, Prilozi za istraživanje hrvatske filozofske baštine 21 (1995), pp. 57-65; Tiziano Zanato, »Sul testo della 'mercatura' di Benedetto Cotrugli (A proposito di una recente edizione)«, Studi veneziani 26 (1993), pp. 15-65; Luca Boschetto, »Tra Firenze e Napoli. Nuove testimonianze sul mercante-umanista Benedetto Cotrugli e sul suo Libro dell'arte di mercatura«, Archivio storico Italiano 163/4 (Firenze, 2005), pp. 687-715; Bojana Bratić, »Uno scrit[t]ore[]mercante raguseo del XV secolo: Benedetto Cotrugli e il suo trattato 'Della mercatura et del mercante perfetto’ «, Italica Belgradensia 4 (Belgrado / Beograd, 1995), pp. 121-241; Paulina Piotrowicz, »L'immagine 
Drugi Kotruljevićev spis, onaj iz 1464. godine, posvećen je plovidbi. Iako njegov autograf nije pronađen, danas raspolažemo s dvjema rukopisnim inačicama prijepisa tog spisa, od kojih je prva pronađena tek 1995. godine, potom raspolažemo dvama tiskanim izdanjima prvopronađenog i jednim tiskanim izdanjem drugopronađenog rukopisnog prijepisa, a raspolažemo i prijevodom na hrvatski jezik prvopronađenog rukopisnog prijepisa (vidi Prilog 2.). Spis se sastoji od četiriju knjiga. Taj spis uvriježeno je nazivati De navigatione.

Skromno stanje istraženosti Kotruljevićeva spisa o plovidbi u najvećoj mjeri dugujemo činjenici da je pronađen tek potkraj 20. stoljeća. No, to što je iz filozofske perspektive istraživan rijetko i nesustavno, treba pripisati tematici kojoj je posvećen sadržaj njegovih četiriju knjiga, a zbog čega je spis plijenio pažnju istraživačā drugih znanosti. Točnije, njime su se bavili povjesničari, kao i povjesničari književnosti, ekonomije i znanosti, filolozi, kartografi te bibliotekari, a od znanijih istraživača izdvajam ove: Claudio de Polo Saibanti, Paul Oskar Kristeller (1905-1999), Darko Novaković, Patrick Gautier Dalché, Damir Salopek, Ugo Tucci (1917-2013), Piero Falchetta, Stefano Trovato, Chet van Duzer i Žarko Dadić. ${ }^{10}$

Kada je riječ o istraživanjima Kotruljevićevih dvaju spisa iz perspektive filozofije, treba imati na umu da su povjesničari filozofije o Kotruljevićevu spisu posvećenom umijeću trgovanja počeli pisati tek od devedesetih godina 20. stoljeća. Dosadašnja istraživanja filozofske sastavnice tog Kotruljevićeva spisa sastojala su se od razmatranja etičkog sloja poglavito treće

del mercante modello in Il libro dell'arte di mercatura di Benedetto Cotrugli«, Iuvenilia Philologorum Cracoviensium / Źródła Humanistyki Europejskiej 6 (2013), pp. 349-361.

${ }^{10}$ Claudio de Polo Saibanti, »Arte del Navigare, manoscritto inedito datato 1464-1465«, u: Carla Clivio Marzoli, Giacomo Corna Pellegrini, Gaetano Ferro (a cura di), Imago et mensura mundi: atti del IX Congresso internazionale di storia della cartografia (Roma: Istituto della Enciclopedia Italiana, fondata da Giovanni Treccani, 1985), pp. 71-79; Paul Oskar Kristeller, »Ms. 557. cart. XV. 66 fols.«, u: Paul Oskar Kristeller (compiled by), Iter italicum, Volume V (Alia itinera III and Italy III), Sweden to Yugoslavia, Utopia, supplement to Italy (A-F) (Leiden - London: E. J. Brill / The Warburg Institute, 1990), pp. 282-283; Darko Novaković, »Prvi hrvatski udžbenik plovidbe«, Hrvatski kulturni tjednik »Danica«, Zagreb, br. 48 (18. ožujka 1995), pp. 1-20, na p. 17, u: Vjesnik 56 (Zagreb, 1995), br. 17044 (18. ožujka 1995), p. 31; Patrick Gautier Dalché, »L'usage des cartes marines aux XIV et XV ${ }^{\mathrm{e}}$ siècles«, u: Spazi, tempi, misure e percorsi nell'Europa del Bassomedioevo, atti del XXXII Convegno storico internazionale, Todi, 8-11 ottobre 1995 (Spoleto: Centro italiano di studi sull'alto Medioevo, 1996), pp. 97-128; Damir Salopek, »Rasprava De navigatione Benedikta Kotruljevića«, u: Dunja Fališevac, Josip Lisac, Darko Novaković (ur.), Hrvatska književna baština, knjiga 2. (Zagreb: Ex libris, 2003), pp. 11-14; Ugo Tucci, »La trasmissione del mestiere del marinaio a Venezia nel Medioevo«, u: La trasmissione dei saperi nel Medioevo (secoli XII-XV), diciannovesimo Convegno internazionale di studi, Pistoia, 16-19 maggio 2003 (Pistoia: Centro italiano studi di storia e d'arte, 2005), pp. 111-126; Piero Falchetta, »Il trattato De navigatione di Benedetto Cotrugli (1464-1465). Edizione commentata del ms. Schoenberg 473 con il testo del ms. 557 di Yale«, Studi Veneziani 57 (2009), pp. 15-333; Stefano Trovato, »Il manoscritto De navigatione in Marciana: cronaca di un acquisto mancato tra 1913 e 1914«, Studi Veneziani 57 (2009), pp. 549-556; Chet van Duzer, »Benedetto Cotrugli’s Lost Mappamundi Found-Three Times«, Imago Mundi: The International Journal for the History of Cartography 65/1 (2013), pp. 1-14; Žarko Dadić, »Rukopis Benedikta Kotruljevića De navigatione iz 15. stoljeća«, u: Žarko Dadić, Povijest znanosti i prirodne filozofije u Hrvata. S osobitim obzirom na egzaktne znanosti, knjiga I., Srednji vijek (Zagreb: Izvori, 2015), pp. 359-376. 
i četvrte knjige, a onda i od podrobnog izučavanja zastupljenosti filozofã i filozofskih izvora u čitavu spisu. Spomenuta istraživanja poduzeli su isključivo istraživači hrvatske filozofske baštine, i to Ivica Martinović, Ljerka Schiffler, Davor Balić i Marita Brčić Kuljiš. ${ }^{11}$ Što se pak tiče istraženosti filozofske sastavnice Kotruljevićeva spisa o plovidbi, zanimanje za taj aspekt njegova sadržaja započeo je tek na izmaku 20. stoljeća. Dosadašnja istraživanja filozofske sastavnice tog spisa ponajprije su ishodila zaključke vezane uz zastupljenost filozofije prirode u njegovoj trećoj knjizi, a potom i ponudila podatke o nekim od filozofa i filozofskih izvora na koje se dubrovački mislilac u toj knjizi oslanjao. Ta su istraživanja poduzela dvojica spomenutih istraživača hrvatske filozofske baštine: Ivica Martinović i Davor Balić. ${ }^{12}$ Dosadašnja istraživanja Kotruljevićeva stvaralaštva iz filozofske perspektive ne pružaju cjelovit uvid u filozofsku sastavnicu dvaju Dubrovčaninovih spisa. Zbog toga danas ne raspolažemo podatkom o njegovu doprinosu hrvatskoj filozofskoj baštini, već se uvriježila

${ }^{11}$ Ivica Martinović, »Benedikt Kotruljević (1)«, Zbor 4, br. 2(29), prilog u: Mi list mladih: glasilo katoličke mladeži 18 (ožujak, 1994), br. 3, p. 9; Ivica Martinović, »Benedikt Kotruljević (2)«, Zbor 4, br. 3(30), prilog u: Mi list mladih: glasilo katoličke mladeži 18 (travanj, 1994), br. 4, p. 9; I.[vica] M.[artinović], »Benedikt Kotruljević«, u: Greta Pifat Mrzljak (autorica izložbe), Znanost u Hrvata: prirodoslovlje i njegova primjena / Centuries of Natural Science in Croatia: Theory and Application, [sv. 1], katalog izložbe održane od lipnja do listopada 1996. godine u Muzejskom prostoru Muzejsko galerijskog centra na Jezuitskom trgu u Zagrebu (Zagreb: Muzejsko galerijski centar, 1996), pp. 108-109; Ivica Martinović, »Književni žanrovi hrvatskih filozofa od Stojkovića do Boškovića «, u: Fedora Ferluga Petronio (a cura di), Introduzione allo studio della lingua, letteratura e cultura croata / Uvod u studij hrvatskoga jezika, književnosti i kulture / Uvod v študij hrvaškega jezika, literature in kulture (Udine: Forum, 1999), pp. 107-116, na pp. 107-108; Ivica Martinović, »Žanrovi hrvatske filozofske baštine od 15. do 18. stoljeća«, u: Pavo Barišić (ur.), Otvorena pitanja povijesti hrvatske filozofije (Zagreb: Institut za filozofiju, 2000), pp. 69-151, na pp. 73-74; Ivica Martinović, »Benedikt Kotruljević«, u: Neven Budak (osmislio i uredio), Croatica: HR - Hrvatski udio u svjetskoj baštini, [sv. 1] (Zagreb: Profil international, 2007), pp. 170-175; Ivica Martinović, Žanrovi hrvatske filozofske baštine od 15. do 18. stoljeća (Split: Filozofski fakultet Sveučilišta u Splitu, 2011), pp. 13-17; Ljerka Schiffler, »Praktično-etička dimenzija 'savršena trgovca' B. Kotruljevića«, u: Stipetić (ur.), Dubrovčanin Benedikt Kotruljević: hrvatski $i$ svjetski ekonomist XV. stoljeća, knjiga 1., pp. 161-169; Ljerka Schiffler, »Etičkohumanistička misao Benedikta Kotruljevića«, Prilozi za istraživanje hrvatske filozofske baštine 22 (1996), pp. 117-142; Davor Balić, »Benedikt Kotruljević o trgovčevim vrlinama«, u: Davor Balić, Hrvatska renesansna etika, magistarski rad iz filozofije obranjen 20. prosinca 2004. godine na Filozofskom fakultetu Sveučilišta u Zagrebu. Voditelj: Ante Čović (Zagreb: Filozofski fakultet Sveučilišta u Zagrebu, 2004), pp. 3-11; Davor Balić, »Filozofi i filozofski izvori u Kotruljevićevu spisu o umijeću trgovanja«, Cris: časopis Povijesnog društva Križevci 14 (Križevci, 2012), pp. 205-271; Marita Brčić, »Kotruljevićev nauk o pravednu trgovcu: podudarnosti i razlike s Aristotelovim poimanjem pravednosti«, Cris: časopis Povijesnog društva Križevci 11 (Križevci, 2009), pp. 135-143.

${ }^{12}$ Ivica Martinović, »Prva povijest hrvatskog umijeća plovidbe«, Naše more: pomorski znanstveni časopis 41/34 (Dubrovnik, 1994), pp. 181-183; M.[artinović], »Benedikt Kotruljević«, u: Pifat Mrzljak (autorica izložbe), Znanost u Hrvata: prirodoslovlje i njegova primjena / Centuries of Natural Science in Croatia: Theory and Application, [sv. 1], pp. 56-57; Martinović, »Književni žanrovi hrvatskih filozofa od Stojkovića do Boškovića«, pp. 107-108; Martinović, »Žanrovi hrvatske filozofske baštine od 15. do 18. stoljeća«, pp. 73-74; Martinović, »Benedikt Kotruljević«, u: Budak (osmislio i uredio), Croatica: HR - Hrvatski udio u svjetskoj baštini, [sv. 1], pp. 170-175; Ivica Martinović, Žanrovi hrvatske filozofske baštine od 15. do 18. stoljeća (Split: Filozofski fakultet Sveučilišta u Splitu, 2011); Davor Balić, »Vrste plovilā u Kotruljevićevu udžbeniku plovidbe«, Metodički ogledi: časopis za filozofiju odgoja 17/1-2 (2010), pp. 61-86; Davor Balić, »Izvori Kotruljevićeve filozofije prirode u De navigatione (1464)«, u: Marita Brčić, Mira Matijević, Krešimir Babel (ur.), Simpozij Mediteranski korijeni filozofije 5. Split, 24.-26. ožujka 2011 (Zagreb - Split: Hrvatsko filozofsko društvo / Odsjek za filozofiju Filozofskog fakulteta Sveučilišta u Splitu, 2011), p. 21. 
percepcija Kotruljevića kao ekonomista, oceanografa, teoretičara brodogradnje i navigacije, astronoma i meteorologa. Naime, dosadašnja istraživanja uglavnom su se odnosila na prisutnost etike u trećoj i četvrtoj knjizi spisa o umijeću trgovanja, a onda i na prisutnost filozofije prirode u trećoj knjizi spisa o plovidbi. Zbog skromne istraženosti, u radu ću se usmjeriti na zastupljenost filozofske sastavnice u čitavu sadržaju dvaju dosad dostupnih Kotruljevićevih spisa. Pritom ću se služiti tematskim i komparativnim pristupom. Tematski pristup ogledat će se u istraživanju prisutnosti pojedinih filozofskih disciplina, dok će komparativni biti zamjetan u usporednu prikazu i zaključku o Kotruljevićevim stavovima o pojedinim filozofskim temama $\mathrm{u}$ dvama spisima. Prilikom istraživanja sadržaja spisa o umijeću trgovanja koristit ću se isključivo kritičkim izdanjem prijepisa koji je, temeljeći ga na svim trima poznatim rukopisnim inačicama prijepisa spisa, priredila, prevela na hrvatski te 2009. godine objavila Zdenka Janeković Römer. ${ }^{13}$ Prilikom istraživanja sadržaja spisa o plovidbi koristit ću se jedinim hrvatskim prijevodom i usporednim kritičkim izdanjem prijepisa prvopronađene rukopisne inačice prijepisa spisa koje je načinio, priredio te 2005 . godine objavio Damir Salopek. ${ }^{14}$

U razmatranju četiriju knjiga spisa o umijeću trgovanja usmjerit ću se najprije na Kotruljevićevo poznavanje povijesti filozofije, a potom ću njihov sadržaj sagledati iz perspektive prisutnosti dviju filozofskih disciplina: etike i filozofije odgoja. Kada je riječ o spisu o plovidbi, sadržajem njegovih četiriju knjiga poslužit ću se za donošenje zaključka o Dubrovčaninovu poznavanju povijesti filozofije, kao i za utvrđivanje zastupljenosti tema pripadnih dvjema filozofskim disciplinama: filozofiji prirode i etici. Prema mojem sudu, time će biti ostvaren potpun pregled i sinteza Kotruljevićeve filozofske misli, što će stvoriti preduvjete za vrednovanje njegova doprinosa hrvatskoj filozofskoj misli 15. i 16. stoljeća.

\footnotetext{
${ }^{13}$ Benedetto Cotrugli, »Libro del arte dela mercatura«, pp. 113-334 / Benedikt Kotrulj, »Knjiga o vještini trgovanja«, pp. 335-503, u: Benedikt Kotrulj, Libro del arte dela mercatura / Knjiga o vještini trgovanja, priredila i prevela Zdenka Janeković Römer (Zagreb - Dubrovnik: Hrvatska akademija znanosti i umjetnosti, Zavod za povijesne znanosti u Dubrovniku i Hrvatski računovođa, 2009).

${ }^{14}$ Benedictus de Cotrullis, »De navigatione«, pp. 18-234 / Benedikt Kotruljević, »O plovidbi«, pp. 19-235, u: Benedikt Kotruljević, De navigatione / O plovidbi, priredio i preveo Damir Salopek (Zagreb: Ex libris, 2005).
} 


\section{FILOZOFSKA SASTAVNICA KOTRULJEVIĆEVA SPISA O UMIJEĆU TRGOVANJA}

Da Kotruljevićev spis o umijeću trgovanja nesumnjivo sadrži filozofsku sastavnicu, svjedoči već podatak da su Dubrovčaninova umovanja o trgovanju svoju recepciju najprije doživjela od dvojice najznačajnijih hrvatskih renesansnih filozofa. Prvi od njih bio je creski renesansni filozof Frane Petrić. Naime, Petrićevu prepoznavanju vrijednosti sadržaja spisa, zatim njegovim priređivačkim i uredničkim sposobnostima te izdavačkom maru njegova venecijanskog poduzeća »All'Elefanta« dugujemo objavljivanje prvog tiskanog izdanja spisa o umijeću trgovanja iz 1573. godine pod naslovom Della mercatura et del mercante perfetto (O trgovini i o savršenom trgovcu). ${ }^{15}$ Drugi hrvatski renesansni filozof koji je prepoznao vrijednost Kotruljevićeva spisa bio je Dubrovčanin Nikola Vitov Gučetić. On je pak 1591. godine na jednom mjestu u svojem kapitalnom djelu Dello stato delle Republiche ( $O$ ustroju država) sročio preporuku i opis Kotruljevićeva spisa o umijeću trgovanja: »Stoga kažem onome tko bi volio biti upućen u te trgovačke raspre, neka pročita četiri knjige $O$ trgovini i o savršenu trgovcu našega Bena Kotruljevića, iznimno korisne svakom izučavatelju tog umijeća i gdje će moći vidjeti kako se pravedno i k tome vrlo uspješno trguje. ${ }^{16}$

\footnotetext{
15 Zbog toga što danas raspolažemo dvjema inačicama Petrićeva tiskanog izdanja Kotruljevićeva spisa iz 1573. godine, a koje se inačice međusobno razlikuju po posvetama koje slijede nakon sadržaja, među istraživačima je nastala nedoumica po pitanju toga je li riječ o dvama izdanjima ili je riječ o tome da je polovica naklade bila tiskana s jednim, a polovica s drugim posvetama. Istraživači koji zastupaju stav da je riječ o dvama različitim izdanjima, primjerice Žarko Muljačić i Rikard Radičević, prvim izdanjem smatraju ono čiji se jedan od preostalih primjeraka čuva u Bogišićevoj biblioteci u Cavtatu, dok drugim smatraju ono čiji se jedan od preostalih primjeraka čuva u venecijanskoj Biblioteca Nazionale Marciana: Benedetto Cotrugli Raugeo, Della mercatura et del mercante perfetto. (In Vinegia: All'Elefanta, 1573). Primjerak se čuva u Bogišićevoj biblioteci u Cavtatu pod signaturom BB C I 3/26; Benedetto Cotrugli Raugeo, Della mercatura et del mercante perfetto. (In Vinegia: All'Elefanta, 1573). Primjerak se čuva u Biblioteca Nazionale Marciana u Veneciji pod signaturom 133 D 225.

${ }^{16}$ Nikola Vitov Gučetić, »O ustroju država«, u: Nikola Vitov Gučetić, O ustroju država, prevele Snježana Husić, Natka Badurina, priredio i napisao uvodnu studiju Marinko Šišak (Zagreb: Golden Marketing / Narodne novine, 2000), pp. 73-478, na p. 123. Usp. Nicolò Vito di Gozzi, »Dello Stato delle Republiche secondo la mente d'Aristotile con essempi Moderni«, giornata prima, u: Nicolò Vito di Gozzi, Dello stato delle Republiche secondo la mente di Aristotele con essempi moderni Giornate otto (In Venetia: Presso Aldo, 1591), pp. 1-408, na p. 51: »<..> però io dico a cui aggrada haver la cognitione di questi trattati mercantili, ch'ei legga i quattro libri della mercatura, e del mercatante perfetto, del nostro Benedetto Cotrugli utilissimi ad ogni studioso di questa arte, dove potrà vedere il modo, e la maniera di mercantare giustamente, e con maraviglia ancora.«
} 


\section{DELLA MERCATVRA}

\section{ET DEL MERCANTE}

P E R F E T T O.

L I B R I QVA T T R O

Di M. Benedetto Gotrugli Raugeo.

Scritti gia piu di anni $C X$.

Es hora datiin luce.

\section{Vtilisfimi ad ogni Mercante.}

CON PRIVILEGIO.

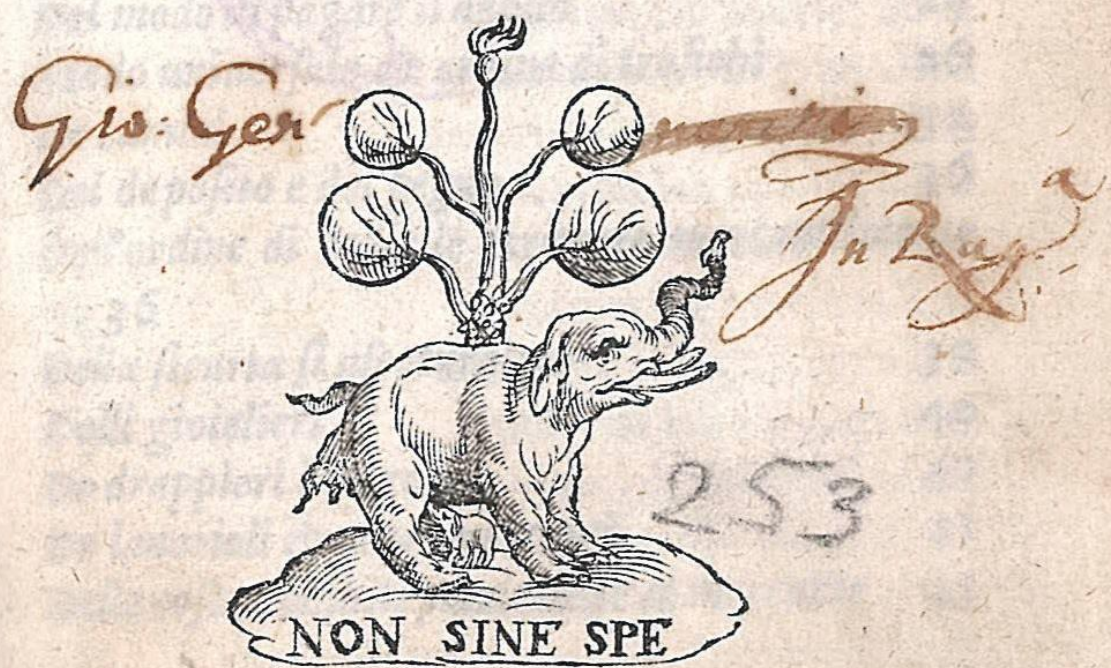

IN VINEGA, all'ELEFANTA。 $M \quad D \quad L \times X I I I$.

Slika 1. Naslovnica prvog izdanja Kotruljevićeva spisa o umijeću trgovanja pod naslovom Della mercatura et del mercante perfetto ( $O$ trgovini i o savršenom trgovcu), koje je uredio i 1573. godine u Veneciji objavio creski renesansni filozof Frane Petrić u svojem tiskarskom poduzeću »All'Elefanta«: Benedetto Cotrugli Raugeo, Della mercatura et del mercante perfetto. (In Vinegia: All'Elefanta, 1573).

Preuzeto iz primjerka koji se čuva u Bogišićevoj biblioteci u Cavtatu pod signaturom BB C I $3 / 26$. 
Potvrdu toga da spis o umijeću trgovanja sadrži filozofsku sastavnicu pružaju i rezultati istraživanja koje su, podsjećam, od devedesetih godina 20. stoljeća podastrli istraživači hrvatske filozofske baštine Ivica Martinović, Ljerka Schiffler, Davor Balić i Marita Brčić Kuljiš. Naime, Martinović je u dvama radovima iz 1994. godine upozorio na etičku sastavnicu u trećoj i četvrtoj knjizi spisa. Iste je stavove izrekao i u svojim kasnijim radovima. Treću knjigu pritom je odredio kao onu koja nudi »prvu etiku jedne renesansne profesije uopće«, a četvrtu kao onu u kojoj je Kotruljević »izložio kršćansku etiku obiteljskog života ${ }^{17} \mathrm{Na}$ etičku sastavnicu spisa upozorila je i Schiffler u dvama radovima iz 1996 . godine,${ }^{18}$ kao i Balić, koji je 2004. godine obradio vrline Kotruljevićeva trgovca te zaključio da je Aristotel bio ključan izvor za Dubrovčaninovu etičku misao. ${ }^{19}$ Brčić Kuljiš je 2009. godine ukazala na podudarnosti i razlike u Kotruljevićevu i Aristotelovu razumijevanju pravednosti, ali i na osobitosti Kotruljevićeva nauka o pravednu trgovcu, pri čemu je zastupala stav da je Aristotelovo razumijevanje pravednosti imalo presudan utjecaj na Kotruljevićeva promišljanja o obilježjima pravedna trgovca. ${ }^{20}$ Osim toga, danas raspolažemo i jednom opsežnom studijom o filozofima i filozofskim izvorima na koje se Kotruljević oslanjao u spisu o umijeću trgovanja. Tu je studiju Balić objavio 2012. godine i u njoj zaključio da je Kotruljević svoje stavove crpio iz djelā brojnih filozofa, i to najčešće Aristotela, Cicerona, Seneke, Augustina i Tome Akvinca, te dodao da se dubrovački mislilac o etičkim temama očitovao i u prvim dvjema knjigama spisa što, prema njegovu sudu, »zacijelo potvrđuje etičku orijentaciju spisa

\footnotetext{
17 Ivica Martinović, »Benedikt Kotruljević (1)«, Zbor 4, br. 2(29), prilog u: Mi list mladih: glasilo katoličke mladeži 18 (ožujak, 1994), br. 3, p. 9, na p. 9b; Ivica Martinović, »Benedikt Kotruljević (2)«, Zbor 4, br. 3(30), prilog u: Mi list mladih: glasilo katoličke mladeži 18 (travanj, 1994), br. 4, p. 9, na p. 9b-d; Ivica Martinović, »Književni žanrovi hrvatskih filozofa od Stojkovića do Boškovića«, u: Fedora Ferluga Petronio (a cura di), Introduzione allo studio della lingua, letteratura e cultura croata / Uvod u studij hrvatskoga jezika, književnosti i kulture / Uvod v študij hrvaškega jezika, literature in kulture (Udine: Forum, 1999), pp. 107116, na pp. 107-108; Ivica Martinović, »Žanrovi hrvatske filozofske baštine od 15. do 18. stoljeća«, u: Pavo Barišić (ur.), Otvorena pitanja povijesti hrvatske filozofije (Zagreb: Institut za filozofiju, 2000), pp. 69-151, na p. 73; Ivica Martinović, »Benedikt Kotruljević«, u: Neven Budak (osmislio i uredio), Croatica: HR Hrvatski udio u svjetskoj baštini, [sv. 1] (Zagreb: Profil international, 2007), pp. 170-175, na p. 173a; Ivica Martinović, Žanrovi hrvatske filozofske baštine od 15. do 18. stoljeća (Split: Filozofski fakultet Sveučilišta u Splitu, 2011), pp. 13-17, na p. 13.

${ }^{18}$ Ljerka Schiffler, »Praktično-etička dimenzija 'savršena trgovca' B. Kotruljevića«, u: Vladimir Stipetić (ur.), Dubrovčanin Benedikt Kotruljević: hrvatski i svjetski ekonomist XV. stoljeća, međunarodni znanstveni skup, Dubrovnik 17-19. X. 1996. Radovi o životu i djelu Benedikta Kotruljevića, knjiga 1. (Zagreb: Hrvatska akademija znanosti i umjetnosti i »Hrvatski računovođa«, 1996), pp. 161-169. Vidi i: Ljerka Schiffler, »Etičko-humanistička misao Benedikta Kotruljevića«, Prilozi za istraživanje hrvatske filozofske baštine 22 (1996), pp. 117-142.

19 Davor Balić, »Benedikt Kotruljević o trgovčevim vrlinama«, u: Davor Balić, Hrvatska renesansna etika, magistarski rad iz filozofije obranjen 20. prosinca 2004. godine na Filozofskom fakultetu Sveučilišta u Zagrebu. Voditelj: Ante Čović (Zagreb: Filozofski fakultet Sveučilišta u Zagrebu, 2004), pp. 3-11, na p. 9.

${ }^{20}$ Marita Brčić, »Kotruljevićev nauk o pravednu trgovcu: podudarnosti i razlike s Aristotelovim poimanjem pravednosti«, Cris: časopis Povijesnog društva Križevci 11 (Križevci, 2009), pp. 135-143.
} 
o umijeću trgovanja. $^{21}$ Znači, dosadašnja istraživanja spisa o umijeću trgovanja iz filozofske perspektive bila su pretežito ograničena na analizu etičkog sadržaja treće i četvrte knjige spisa te su redovito pružala zaključke općenite naravi. Jedino je iz Balićeve studije moguće doznati pouzdane podatke o filozofskoj lektiri na koju se Kotruljević najčešće oslanjao, ali i tvrdnju da je čitav spis o umijeću trgovanja prožet etikom.

Iz takva stanja istraženosti proizlazi da je za upotpunjavanje spoznaja o filozofskoj sastavnici spisa o umijeću trgovanja preostalo otkriti filozofske autore na čije se nauke Kotruljević oslanjao u manjoj mjeri, zatim istražiti u kojim je poglavljima četiriju knjiga spisa etička sastavnica najizraženija, a onda i doznati jesu li u spisu prisutna Kotruljevićeva promišljanja koja pripadaju drugim filozofskim disciplinama. Odgovore na ta pitanja ponudit ću u narednim trima potpoglavljima. U prvom ću dokazati da se dubrovački mislilac u spisu o umijeću trgovanja iskazao kao poznavalac povijesti filozofije, u drugom ću dokazati da je u čitavu spisu najzastupljenija etička sastavnica, dok ću u trećem dokazati da je Kotruljević prožeo spis i tematikom koja pripada filozofiji odgoja.

\subsection{Benedikt Kotruljević kao poznavalac povijesti filozofije}

Sadržaj svih četiriju knjiga umovanja o trgovačkom umijeću dubrovački je mislilac neprestano upotpunjavao i osnaživao znanjima koja je crpio iz povijesti filozofije. Takvo bi stanje možda i čudilo da Kotruljević čitaocima nije to dao do znanja već u predgovoru svojega spisa. U njemu se, naime, izjasnio da ga je nužda nagnala na bavljenje trgovanjem te izrazio nezadovoljstvo time što je bio otrgnut od studija i to upravo onda kada se, kako ističe, najljepše bavio filozofijom (piu bello del nostro philosophare). ${ }^{22}$

Dosadašnja istraživanja Dubrovčaninova stvaralaštva, bilo na europskoj bilo na svjetskoj razini, polučila su tek jednu iscrpnu i vjerodostojnu ocjenu Kotruljevićeve upućenosti i poznavanja baštine koju nam je namrla povijest filozofije. Riječ je o opsežnoj studiji o filozofskim vrelima Kotruljevićevih promišljanja o trgovanju, a koju je poduzeo i 2012. godine objavio Davor Balić. ${ }^{23}$ Iako bi bilo preuzetno ustvrditi da je tom studijom u cijelosti uslišan zaziv Ljerke Schiffler iz 1996. godine da spis o umijeću trgovanja treba doživjeti

\footnotetext{
21 Davor Balić, »Filozofi i filozofski izvori u Kotruljevićevu spisu o umijeću trgovanja«, Cris: časopis Povijesnog društva Križevci 14 (Križevci, 2012), pp. 205-271, na p. 262b.

${ }^{22}$ Cotrugli, »Libro del arte dela mercatura«, prefatio / Kotrulj, »Knjiga o vještini trgovanja«, predgovor, p. 116 [ff. 1v-2r] / p. 339.

${ }^{23}$ Balić, »Filozofi i filozofski izvori u Kotruljevićevu spisu o umijeću trgovanja«, pp. 205-271.
} 
»Svoju cjelovitu adekvatnu prosudbu i vrednovanje «, ${ }^{24}$ a posebice zbog toga što je nemoguće utvrditi kriterije po kojima bi Schiffler ocijenila neku prosudbu cjelovitom i adekvatnom, ipak se može zaključiti da je Balić tom studijom izvršio zadatak koji je 2004. godine u svojem magistarskom radu postavio budućim istraživačima Dubrovčaninova spisa o umijeću trgovanja, rekavši da taj spis »traži prosudbu koja će istaknuti njegove filozofske dosege, i što se tiče definiranja izvora, njihove kolikoće i utjecaja, i što se tiče originalnosti Kotruljevićeva promišljanja.« ${ }^{25} \mathrm{Iz}$ Balićeve studije možemo doznati da se upućenost dubrovačkog mislioca u filozofsko nasljeđe u cjelokupnu sadržaju spisa zasnivalo na »nauku filozofā, točnije na filozofskim izvorima«, i to posebice na onima koji pripadaju »grčkom i rimskom razdoblju antičke filozofije« te »srednjovjekovnom razdoblju filozofije. ${ }^{26}$ Znači, Balićevo istraživanje urodilo je spoznajom da se Kotruljevićeva upoznatost $\mathrm{s}$ filozofskom baštinom ponajviše očitovala u njegovu oslanjanju na stavove koje su zastupali filozofi koji su djelovali u dotadašnjim povijesnofilozofskim razdobljima. Kotruljević je, a što je Balić dokazao u svojoj studiji, oslonac među antičkim grčkim filozofima pronašao u mislima koje su izrekli Pitagora (oko 582. - 496. pr. n. e.), Sokrat (469. - 399. pr. n. e.), Diogen iz Sinope (403. - 353. pr. n. e.), Platon (427. - 347. pr. n. e.), Aristotel (384. - 322. pr. n. e.) i Teofrast (oko 372. - oko 287. pr. n. e.), a među antičkim rimskim filozofima Ciceron (Marcus Tullius Cicero, 106. 43. pr. n. e.) i Seneka (Lucius Annaeus Seneca, 4. pr. n. e.? - 65. n. e.). ${ }^{27}$ No, Kotruljević se uvelike oslanjao i na filozofska promišljanja srednjovjekovnih mislilaca. Balić je dokazao da su znatan utjecaj na Kotruljevićeva promišljanja imali Augustin (Aurelius Augustinus, 354430), Boetije (Anicius Manlius Severinus Boethius, oko 480-oko 525), Avicenna (Abū 'Alī al-Ḥusayn ibn 'Abd Allāh ibn Sīnā, 980-1037), Hugo iz Svetog Viktora (Hugo de Sancto Victore, oko 1095-1141), Averroës (Abū 1-Walīd Muḥammad Ibn 'Aḥmad Ibn Rušd, 11261198), Toma Akvinac (Thomas Aquinas, oko 1225-1274) i Jean Buridan (Johannes Buridanus, oko 1300-oko 1360). ${ }^{28}$ Unatoč tome što su Balićeve izuke spisa o umijeću trgovanja smjerale prema onim filozofima na čije se nauke Dubrovčanin najčešće oslanjao, ${ }^{29}$ njegova studija obuhvaća i one mislioce koji su spomenuti u spisu, ali koji nisu u velikoj mjeri oblikovali Kotruljevićevu misao. Balić je, naime, izvijestio i o onim zapisima dubrovačkog umnika kojima su obuhvaćeni sljedeći mislioci: Aristip (435. - 356. pr. n. e.),

\footnotetext{
${ }^{24}$ Schiffler, »Etičko-humanistička misao Benedikta Kotruljevića«, p. 117.

${ }^{25}$ Balić, »Benedikt Kotruljević o trgovčevim vrlinama«, p. 11.

${ }^{26}$ Balić, »Filozofi i filozofski izvori u Kotruljevićevu spisu o umijeću trgovanja«, p. 262b.

${ }^{27}$ Ibid., pp. 208b-225b i pp. 225b-240a.

${ }^{28}$ Ibid., pp. 240a-260a.

${ }^{29}$ Ibid., p. 240a.
} 
Lastenija iz Mantineje (Lasthenia Mantinea, 4. st. pr. n. e.), Aksioteja iz Flijunta (Axiothea Phliasia, oko 350. pr. n. e.), Apolonije iz Alabande (Apolonio Alebandense), Ambrozije (Aurelius Ambrosius, oko 330-397), Jeronim (Eusebius Hieronymus Stridon/i/ensis, oko 347-420), Ivan Damaščanski (Ioannes Damascenus, oko 675-749), Aleksandar iz Halesa (Alexander of Hales, oko 1185-1245), Raymund iz Peñaforta (Raymundus de Peñafort / Peniafort / Pennafort, oko 1175-1275) te Cecco d'Ascoli (Francesco degli Stabili / Cichus, 1257-1327). ${ }^{30} \mathrm{Uz}$ to, Balićeva potraga za filozofskim vrelima spisa o umijeću trgovanja ishodila je i zaključak o tome da se Dubrovčanin uvjerljivo »najčešće pozivao na stajališta koja je pripisao Aristotelu, Ciceronu, Seneki, Augustinu i Tomi Akvincu. « ${ }^{31}$ Pritom je nužno imati na umu da je riječ o stavovima koje je dubrovački mislilac »pripisao« tim filozofima, što je Balić razjasnio dopunom da to ne znači da je Kotruljević bio »neposredno upoznat sa sadržajem njihovih djela«, već da je njihove stavove nerijetko doznavao posredno i da je najupućeniji bio u sadržaj dvaju djela Tome Akvinca: u sadržaj Sume teologije i u sadržaj tumačenjā četiriju knjiga Sentencija Petra Lombardskog. ${ }^{32}$

Budući da je Balićevo istraživanje pretežito obuhvaćalo one mislioce na čije se nauke Kotruljević oslanjao najčešće, dakle na one koji su polučili najveći utjecaj na oblikovanje njegovih stavova, te na izvore iz kojih ih je doznavao, za cjelovit uvid u Kotruljevićevu filozofsku lektiru preostalo je, prema mojem sudu, ponuditi odgovor na sljedeća dva pitanja: 1. Tko su bili preostali filozofski relevantni autori s kojima je Kotruljević bio upoznat i na čije se nauke oslanjao u manjoj mjeri?; 2. Iz kojih je spisa Kotruljević crpio svoje spoznaje o njima? Odgovori na ta pitanja nesumnjivo će upotpuniti dosadašnje spoznaje i otkriti razinu do koje su sezale Kotruljevićeve prouke dotadašnjeg filozofskog nasljeđa. Da bih ih ponudio, u nastavku ovoga potpoglavlja obradit ću Kotruljevićeve zapise iz svih četiriju knjiga spisa o umijeću trgovanja koji će Balićevu popisu Dubrovčaninova filozofskog štiva pridodati imena još četrnaestorice manje zastupljenih mislilaca. Prilikom obrade zanemarit ću redoslijed kojim ih je Kotruljević spominjao te ću se, a zbog bolje preglednosti, voditi vremenom u kojem su ti mislioci živjeli i djelovali, dakle vodit ću se kronološkim kriterijem, redajući ih od najstarijeg prema najmlađem. Uz to, napominjem da ću za svakog od njih izdvojiti po jedan primjer Kotruljevićeva pozivanja. Uvjeren sam da će time, dakako uz rezultate koje je polučilo Balićevo istraživanje, biti upotpunjen pregled Kotruljevićevih povijesnofilozofskih znanja.

\footnotetext{
${ }^{30}$ Ibid., pp. 211, 213a, 221a, 229b, 242, 243, 249b i 251b.

${ }^{31}$ Ibid., p. 262 b.

32 Ibid.
} 
Prema kriteriju učestalosti spominjanja bilo njihovih imena bilo njihovih djela, a onda i prema kriteriju vremena u kojem su živjeli i djelovali, na čelnom mjestu u plejadi znamenitih mislilaca filozofske orijentacije prisutnih u Kotruljevićevu spisu, nalazi se antički grčki mislilac Kalisten iz Olinta (K $\alpha \lambda \lambda_{1} \sigma \vartheta \varepsilon \dot{v} \vee \eta \varsigma$, oko 360. - 327. pr. n. e.). Riječ je o misliocu o čijim filozofskim nastojanjima ni danas ne raspolažemo s brojnim, pa čak ni pouzdanim podacima. Da je stanje istraženosti Kalistenova lika i djela iz filozofske perspektive takvo, potvrđuje, primjerice, podatak da je istaknuti američki istraživač antičke grčke filozofije Anthony Preus ispustio natuknicu o Kalistenu u prvom izdanju djela Historical Dictionary of Ancient Greek Philosophy iz 2007. godine. ${ }^{33}$ No, osam godina kasnije, dakle 2015. godine, objelodanjeno je i drugo izdanje Preusova djela u koje je ipak uvrštena natuknica o Kalistenu iz Olinta, a iz koje doznajemo podatke da je bio: peripatetik, Aristotelov učenik i pranećak te povjesničar Aleksandra Makedonskog, čija su djela, kojima su se obilato služili antički povjesničari, danas izgubljena. ${ }^{34}$ Kao što bilježi talijanski stručnjak za antičku filozofiju Carlo Natali u monografiji Aristotle: His Life and School iz 2013. godine, jedna od odlika Kalistenovih djela historiografske naravi neosporno je bila prožetost Aristotelovom filozofijom, a mišljenja istraživačā razlikuju se tek u procjeni razine utjecaja koji je Aristotelov nauk ostvario na njega. ${ }^{35}$ Znači, prilikom govora o Kalistenu iz Olinta nipošto se ne smije ispustiti njegovu peripatetičku izobrazbu i naklonost Aristotelovoj filozofiji koju je iskazao u svojem historiografskom radu.

Kotruljević je u spisu o umijeću trgovanja iskazao upućenost u lik i djelo Kalistena iz Olinta. Doduše, ime tog antičkog grčkog mislioca pribilježio je tek u jednom navratu. To je učinio u trećem poglavlju četvrte knjige spisa, dakle u poglavlju koje je naslovio »O glavaru kuće« (»Delo yconomo«). Naime, prilikom obrazlaganja uzročno-posljedične povezanosti vladareva izgleda i ugleda koji ostvaruje pred ukućanima, dubrovački se mislilac poslužio primjerom Aleksandra Makedonskog kao dokaznim materijalom za obranu vlastite teze. Tako je, primjerice, zabilježio da se na Aleksandrovu licu vidjelo poštenje i veličanstvo koje je nosio u srcu, zatim da je bio veći od drugih ljudi, uzdignute glave, veselih očiju i svijetlih obraza koji su rumenilom izazivali radost $\mathrm{u}$ onome tko bi ih vidio, a da ni preostali dijelovi njegova tijela

\footnotetext{
33 Anthony Preus, Historical Dictionary of Ancient Greek Philosophy (Lanham - Maryland - Toronto Plymouth: The Scarecrow Press, Inc., 2007).

${ }^{34}$ Anthony Preus, Historical Dictionary of Ancient Greek Philosophy, second edition (Lanham - Boulder - New York - London: Rowman \& Littlefield, 2015), s. v. »Callisthenes of Olynthus.«, p. 92: »Peripatetic. Student and great-nephew of Aristotle, he became Alexander's historian. Although his work is lost, it was often used by subsequent ancient historians.«

${ }^{35}$ Carlo Natali, Aristotle: His Life and School (Princeton and Oxford: Princeton University Press, 2013), p. 53: »It is not known to what degree the philosophy of Aristotle influenced the historiographical work of Callisthenes; some say greatly $[\ldots]$ others say not much «.
} 
nisu bili bez veličanstvene ljepote, nakon čega je zaključio da je naklonost ljudi stekao krasnim obličjem i učenošću koju je stekao od svojih učitelja Aristotela i Kalistena. ${ }^{36}$ Prilikom izlaganja tih podataka dubrovački je mislilac otkrio vrelo svojih spoznaja. Naime, priopćio je da je opise Aleksandra Makedonskog crpio od Solina, misleći pritom na znamenitog rimskog geografa Gaja Julija Solina (Gaius Iulius Solinus, 3. stoljeće). ${ }^{37}$ I doista, Kotruljević se oslonio na zapise iz devetog poglavlja Solinova djela De mirabilibus mundi $(O$ svjetskim čudima), poznatog i pod naslovima Collectanea rerum memorabilium (Zbirka spomena vrijednih stvari) te Polyhistor (Mnogoznalac). ${ }^{38}$

Drugi u kronološkom slijedu mislilaca koje je Kotruljević spomenuo, a koji je u svojim

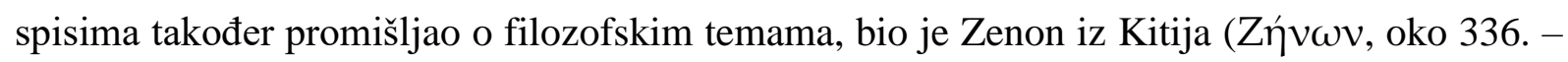
oko 264. pr. n. e.), jedan od najutjecajnijih antičkih grčkih mislilaca helenističkog razdoblja te idejni začetnik i utemeljitelj stoičke škole. Dubrovački ga je umnik u svojem spisu spomenuo dvaput. Kao primjer koji potvrđuje da je Kotruljević bio upoznat s likom i djelom Zenona iz Kitija izdvajam njegov prvi spomen. Naime, Dubrovčanin je Zenona u spisu o umijeću trgovanja spomenuo $\mathrm{u}$ trećem poglavlju treće knjige, a koje je poglavlje naslovio »O trgovčevu znanju« (»Dela sciencia delo mercante«). Tada je, bez da je na tom mjestu otkrio izvor svojih spoznaja, zabilježio da je makedonski kralj Antigon odaslao pismo Zenonu u kojem mu je poručio da je zbog mudrosti više cijenio njegovo dostojanstvo nego kraljevsko. ${ }^{39}$ Ipak, na kraju podužeg odlomka Kotruljević je napomenuo da je to napisao Diogen Laertije, ${ }^{40}$

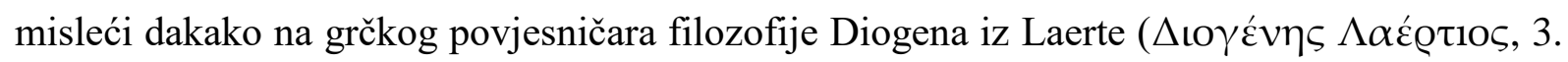
st.) i na njegovo doksografsko-biografsko djelo De vita et moribus philosophorum (Životi $i$

\footnotetext{
${ }^{36}$ Cotrugli, »Libro del arte dela mercatura «, libro IV, capitulo 3 / Kotrulj, »Knjiga o vještini trgovanja«, knjiga IV, poglavlje 3, p. 295 [ff. 80v-81r]: »Che certe bella presentia d' uno yconomo presta una certa autorita apresso la sua famiglia, come anche de uno imperatore, [...] Alexandro Macedone, lo quale in vulto mostrava la integrita et la magnificencia la qual portava dentro lo core. Augusto fo di forma sopra la misura d' omini, capo alta, ochy lieti, guancie ilustre, che di rubore rendevano graciam a cui lo vedeva. Lo resto de lineamenti corporali non senca una maesta di beleça. Et cosi non meno con questa sua venusta forma aquisto gracia apresso ali homini che per doctrina d' Aristotile [et Calistene] li qualli conduceva per maestri.« / pp. 472-473. Priređivačica prijepisa i prijevoda Kotruljevićeva spisa o umijeću trgovanju Janeković Römer pridodala je napuljskom prijepisu spisa Kalistenovo ime služeći se Petrićevim izdanjem iz 1573. godine, jer je, kako kaže, ono »očito slučajno ispušteno. « Vidi i: Cotrugli, »Libro del arte dela mercatura«, libro IV, capitulo 3 / Kotrulj, »Knjiga o vještini trgovanja«, knjiga IV, poglavlje 3, p. 295 [f. 81r], bilješka 118: »S dod. et Calistene.«/p. 473, bilješka 15: »Priklonila sam se Petrisovu [Petrićevu] tekstu, jer je Kalistenovo ime očito slučajno ispušteno.«

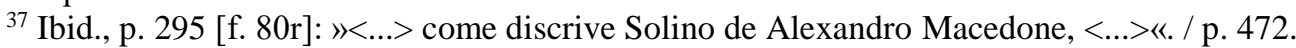

${ }^{38}$ Caius Iulius Solinus, »Collectanea rerum memorabilium sive Polyhistor.«, IX, 18-20, u: C.[aii] Iulii Solini Collectanea rerum memorabilium. Recognovit Th.[eodor] Mommsen. (Berolini: in aedibus Friderici Nicolai, 1864), pp. 2-231, na pp. 73-74.

${ }^{39}$ Cotrugli, »Libro del arte dela mercatura«, libro III, capitulo 3 / Kotrulj, »Knjiga o vještini trgovanja«, knjiga III, poglavlje 3, p. 251 [f. 65v]: »Et cosi Antigonus re, scrivendo a Zenone, preferiva la sua dignita ala reale, per la sapiencia.«/p. 442.

${ }^{40}$ Ibid., p. 251 [f. 65v]: »Et questo scrive Diogenes Laercio <...>«. / p. 442.
} 
mišljenja istaknutih filozofa). Inače, Kotruljević se, što je dokazao Balić, upravo tim djelom »služio kao izvorom svojih zapisa o grčkim filozofima«. ${ }^{41}$ Kotruljević je podatke o Antigonovu pismu upućenom Zenonu iz Kitija doznao i interpretirao iz sadržaja prvog poglavlja sedme knjige djela Diogena iz Laerte. Na tom je, naime, mjestu Diogen iz Laerte prenio sadržaj pisma u kojem je makedonski kralj ustvrdio da izvanjskom srećom i slavom nadmašuje Zenona, no da za njim istodobno zaostaje po znanju, obrazovanju i savršenoj sreći koju je uživao. ${ }^{42}$

Sljedeći mislilac čije ime zavređuje biti pridodano popisu Kotruljevićeva filozofskog štiva bio je rimski pisac i polihistor Marko Terencije Varon (Marcus Terentius Varro, 116. - 27. pr. n. e.). Taj Rimljanin bio je, a prema spoznajama koje je u komparativnom ogledu »Varro and Antiochus« iz 2012. godine izložio profesor klasične književnosti David Blank, drugi

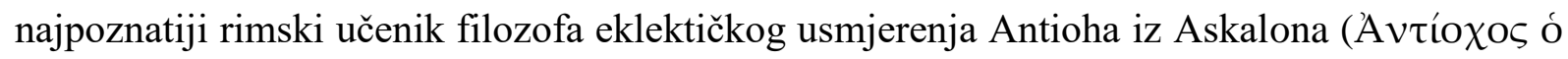

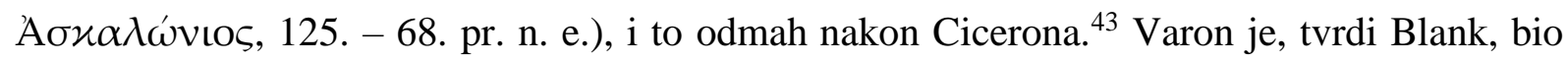
izvorni mislilac, ako ne i izvorni filozof, čija misao nije potekla izravno od Antioha, ali mu je Antioh bio vrijedan izvor stoičkih ideja. ${ }^{44}$

U spisu o umijeću trgovanja dubrovački je renesansni mislilac Marka Terencija Varona spomenuo u dvama navratima. Baš kao što sam to učinio u slučaju Zenona iz Kitija, ovom prigodom izdvojit ću jedan slučaj u kojem je Dubrovčanin oslovio tog rimskog mislioca. To je prvi put učinio u predgovoru trećoj knjizi spisa. Kotruljević je u njemu kritizirao sinove ondašnjih trgovaca koji običavaju ići stopama svojih očeva, pa oblikovao pozamašan zahtjev da bi hvalevrijedni trgovački sinovi trebali nastojati nadmašiti svoje očeve i prestići ih u vrlini, čime bi učinili svijet savršenijim. ${ }^{45}$ Kao primjer sinova koji su nadmašili svoje očeve i postigli slavu naveo je Varona, koji je bio mesar, i Sokrata, koji je bio klesar kamena i

\footnotetext{
${ }^{41}$ Balić, »Filozofi i filozofski izvori u Kotruljevićevu spisu o umijeću trgovanja«, p. 211a.

${ }^{42}$ Diogenes Laertius, De vita et moribus philosophorum. Libri X. (Lugduni: Apud Seb.[astian] Gryphium, 1546), liber septimus., s. v. »Zeno Citticus.«, pp. 261-321, na p. 263: »Rex Antigonus Zenoni phil. S. Ego fortuna me quidem et gloria vitam tuam anteire existimo, caeterum disciplinis studiisque; liberalibus et perfecta felicitate quam tu possides, longe abs te praecelli sentio.«Usp. Diogen Laertije, Životi i mišljenja istaknutih filozofa, sa starogrčkog preveo Albin Vilhar. Predgovor napisao Branko Bošnjak (Beograd: Beogradsko izdavačkografički zavod, 1973), knjiga VII, pp. 203-266, glava 1. - Zenon, pp. 203-250, na p. 205: »'Kralj Antigon šalje pozdrav filozofu Zenonu Mislim da spoljašnjom srećom i slavom nadmašujem tvoj život, ali da po znanju i obrazovanju i savršenoj sreći koji ti uživaš zaostajem za tobom.' «

${ }^{43}$ David Blank, »Varro and Antiochus«, u: David Sedley (edited by), The Philosophy of Antiochus (New York: Cambridge University Press, 2012), pp. 250-289, na p. 250: »After Cicero, Antiochus' second most famous Roman student was the polymath Marcus Terentius Varro (116-27 BCE).«

${ }^{44}$ Blank, »Varro and Antiochus«, p. 251.

${ }^{45}$ Cotrugli, »Libro del arte dela mercatura«, libro III, prohemio / Kotrulj, »Knjiga o vještini trgovanja«, knjiga III, predgovor, pp. 237-238 [ff. 59v-60r] / p. 433.
} 
mramora. ${ }^{46}$ Kotruljević je podatke o Varonovu i Sokratovu zanimanju doznao iz četvrtog poglavlja treće knjige djela Facta ac dicta memorabilia (Spomena vrijedna djela i izreke) rimskog pisca Valerija Maksima. ${ }^{47}$

Naredni mislilac koji zavređuje biti pridodan popisu izvora i mislilaca filozofskog usmjerenja, a čijim se spoznajama Kotruljević u spisu o umijeću trgovanja služio u manjoj mjeri i čije mu je djelo najvjerojatnije bilo izvorom spoznaja o Marku Terenciju Varonu, jest Valerije Maksim (Valerius Maximus, 1. stoljeće). Taj rimski pisac bio je, kao što možemo doznati iz, primjerice, natuknice koju je o njemu 2006. godine napisao i objavio britanski filozof Trevor Curnow u djelu The Philosophers of the Ancient World: An A to Z Guide, najpoznatiji po devet knjiga svoje ranije spomenute zbirke povijesnih anegdota Facta ac dicta memorabilia, a koja je prije svega bila osmišljena kao izvor moralnog obrazovanja pomoću primjerā koji pokazuju kako se vrline nagrađuju, a poroci kažnjavaju. ${ }^{48}$ Iako je, izvještava Curnow u nastavku, bio autor kojeg ne bi trebalo smatrati originalnim, njegova devetodijelna zbirka ipak pruža uvid u isječke iz različitih izvora koji bi u protivnom bili izgubljeni i uživala je popularnost tijekom srednjovjekovlja i renesanse. ${ }^{49}$

U svojim promišljanjima o umijeću trgovanja dubrovački renesansni mislilac spomenuo je Valerija Maksima u pet navrata. Za potrebe dokazivanja da Valerije zaslužuje biti pridodan popisu manje zastupljenih mislilaca filozofskog usmjerenja u Kotruljevićevu spisu, poslužit ću se trećim slučajem Kotruljevićeva spominjanja Valerija. Izdvajam, naime, primjer iz predgovora četvrtoj knjizi Dubrovčaninova spisa, a u kojoj je izlagao o trgovčevim sposobnostima za upravljanje kućanstvom, dakle o trgovčevu ekonomskom životu. Tu knjigu spisa Kotruljević je započeo izjednačavanjem vrijednosti trgovčeva gospodarenja i upravljanja kućom te vlastitom obitelji, dakle ekonomskim aspektom života (la vita

\footnotetext{
${ }^{46}$ Ibid., p. 238 [ff. 60r-v]: »come si legie de Varone macellario et Socrate petraro o marmoraro, et de multi altri li quali de vilissimi padri nati veneno ad tanta excellencia che intra li gloriosi opteneno principato.«/p. 434.

${ }^{47}$ Valerius Maximus, »Factorum et dictorum memorabilium«, III, 4, § 4, u: Valerii Maximi factorum et dictorum memorabilium libri novem. Cum Iulii Paridis et Ianuarii Nepotiani epitomis, iterum recensuit Carolus Kempf. (Lipsiae: in aedibus B. G. Teubneri, 1888), pp. 3-472, na p. 136: »Miro gradu Varro quoque ad consulatum macellaria patris taberna conscendit.«; Maximus, »Factorum et dictorum memorabilium «, III, 4, ext. 1, p. 137: »Sed ut Romanis externa iungamus, Socrates, non solum hominum consensu, verum etiam Apollinis oraculo sapientissimus iudicatus, Phaenarete matre obstetrice et Sophronisco patre marmorario genitus ad clarissimum gloriae lumen excessit.«

${ }^{48}$ Trevor Curnow, The Philosophers of the Ancient World: An A to Z Guide (London: Bristol Classical Press, 2011), s. v. »Valerius Maximus«, p. 276: »Valerius is best known for producing his nine books of Memorable Doings and Sayings. This work was designed primarily as a resource for moral education by means of examples, showing how virtue is rewarded and vice punished."

${ }^{49}$ Curnow, The Philosophers of the Ancient World: An A to Z Guide, s. v. »Valerius Maximus«, p. 276: »A person [Valerius Maximus] of little originality, [...] It [Facta ac dicta memorabilia] preserves many otherwise lost snippets taken from a variety of sources. His books are not much regarded today, but they were popular throughout the medieval and renaissance periods.«
} 
yconomica), i javnim djelovanjem, dakle političkim aspektom života (il vivere politico), rekavši da stvari koje se odnose na kućanstvo nisu ništa manje dostojne trgovca nego što je to javni život. ${ }^{50}$ Kao prvog u nizu autora u čijem je okrilju potražio utočište za osnaživanje tog stajališta naveo je Valerija Maksima. Posegnuo je, naime, za sljedećim iskazom tog znamenitog rimskog pisca: »Što vrijedi vani biti okretan, ako se kod kuće loše živi? « (»Quid oportet foris esse strenuum, si domi male vivitur? «). ${ }^{51}$ Premda Kotruljević nije naveo naslov djela iz kojega je doznao sadržaj tog Valerijeva iskaza, kao ni točnu poziciju, iskaz koji se od Dubrovčaninova zapisa razlikuje tek u korištenju glagola »oportet« (oportere), jer Valerije koristi glagol »prodest« (prodesse), moguće je pronaći u devetom poglavlju druge knjige Valerijeva djela Facta ac dicta memorabilia: »<...> quid enim prodest foris esse strenuum, si domi male vivitur? $\ll^{52}$

Sljedeći na popisu Kotruljevićeve filozofske lektire zastupljene u manjoj mjeri u spisu o umijeću trgovanja jest Gaj Plinije Sekundo Stariji (Gaius Plinius Secundus Maior, 23/24-79). Taj rimski političar, pisac, prirodoslovac i filozof prirode autor je, kako bilježi istaknuti američki povjesničar Anthony Grafton u svojem prilogu o dostupnosti antičkih djela $\mathrm{u}$ renesansi izrađenom za djelo The Cambridge History of Renaissance Philosophy iz 1988. godine, enormne enciklopedije antičke znanosti, filozofije i pseudoznanosti pod naslovom Naturalis historia (Prirodoslovlje). ${ }^{53}$ Prema rezultatima Graftonova istraživanja, utjecaj Plinija Starijeg sezao je do takve razine da su protestantska sveučilišta njegovim tekstom pokušavala zamijeniti Aristotelov nauk iz filozofije prirode, pri čemu su postigli to da je Naturalis historia ostalo polazišnom točkom za sve zainteresirane za razvoj antičke filozofije prirode. $^{54}$

U spisu o umijeću trgovanja Kotruljević je Plinija Starijeg spomenuo dvaput. Potaknut time što se tom prigodom pozvao i oslonio upravo na sadržaj Plinijeva djela Naturalis historia, u nastavku ću izdvojiti prvi slučaj Dubrovčaninova spominjanja njegova imena. Kotruljević je,

\footnotetext{
${ }^{50}$ Cotrugli, »Libro del arte dela mercatura«, libro IV, prephatio / Kotrulj, »Knjiga o vještini trgovanja«, knjiga IV, predgovor, p. 287 [f. 78r] / p. 467.

${ }^{51}$ Ibid., p. 287 [f. 78r]: »La qual cosa [la vita yconomica e governo dela casa et dela famiglia] non n' e men degna nelo mercante che si sia il vivere politico, juxta quello dicto de Valerio Maximo: 'Quid oportet foris esse strenuum, si domi male vivitur?'.«/pp. 467.

${ }^{52}$ Maximus, »Factorum et dictorum memorabilium«, II, 9, § [praefatio], u: Valerii Maximi factorum et dictorum memorabilium libri novem. Cum Iulii Paridis et Ianuarii Nepotiani epitomis, p. 97.

53 Anthony Grafton, »The availability of ancient works«, u: Charles B. Schmitt (general editor), Quentin Skinner, Eckhard Kessler (editors), Jill Kraye (associate editor), The Cambridge History of Renaissance Philosophy (New York: Cambridge University Press, 1988), pp. 767-791, na p. 787: »Pliny the Elder (first century AD) provided in his Naturalis historia an enormous encyclopaedia of ancient science, philosophy and pseudo-science.«

${ }^{54}$ Ibid., p. 767.
} 
naime, Plinija Starijeg i njegovo Prirodoslovlje spomenuo u sedmom poglavlju prve knjige spisa o umijeću trgovanja, dakle u poglavlju koje je naslovio »O prodaji na rok« (»Delo vendere al termine«). Izlažući o drugom pravilu kojeg bi se trgovci trebali pridržavati prilikom prodaje na rok, dubrovački je umnik naglasio da se trgovci u takav način prodaje upuštaju samo s osobom koja je na dobru glasu, od povjerenja, čiste savjesti i dobar platac. ${ }^{55}$ Ukoliko prva metoda provjere tih kriterija, a koja se sastoji od raspitivanja i upoznavanja, ipak zataji, tada bi, upozorava Kotruljević, trgovac trebao najprije obratiti pozornost na crte lica, i to počevši od očiju, a po uzoru na jedno, napominje Kotruljević, savršeno mjesto iz djela Naturalis historia na kojem je Plinije ustvrdio da duša boravi u očima. ${ }^{56} \mathrm{Tu}$ tvrdnju Kotruljević je doznao iz pedeset četvrtog poglavlja jedanaeste knjige tog Plinijeva djela. ${ }^{57}$

Sljedeći mislilac koji zavređuje biti uvršten među Kotruljevićeva filozofska vrela povezan je krvnim srodstvom s Plinijem Starijim. Radi se o nećaku Plinija Starijeg, točnije o Gaju Pliniju Ceciliju Sekundu Mlađem (Gaius Plinius Caecilius Secundus Minor, 61/62-113) ili, kako ga je uobičajeno oslovljavati, Pliniju Mlađem. On je, inače, bio rimski državnik, govornik i pisac na temelju čijeg bi glasovitog djela Epistulae (Pisma), a prema istraživanju koje je o tom djelu poduzeo i 1969. godine objavio britanski stručnjak za antičku povijest Adrian Nicholas Sherwin-White (1911-1993), bilo pogrešno jednoznačno ustanoviti da je Plinije Mlađi bio znanstvenik ili filozof, već bi trebalo zaključiti da je bio racionalist koji je bio upoznat s filozofskim disciplinama svojega vremena. ${ }^{58}$ Iz studije koju je 2007. godine objavila američka istraživačica antičke povijesti i klasične književnosti Miriam Griffin (1935-2018) o tome što je Plinije Mlađi dugovao etici, doznajemo da su, unatoč tome što nije imao formalnog obrazovanja iz filozofije i unatoč tome što nema utemeljenja za pripisivanje njegove pripadnosti nekoj od filozofskih škola, u djelima Plinija Mlađeg ipak zamjetni odjeci stoicizma koji odražavaju dominaciju te filozofske škole u onodobnom Rimu. ${ }^{59}$

\footnotetext{
${ }^{55}$ Cotrugli, »Libro del arte dela mercatura«, libro I, capitulo 7 / Kotrulj, »Knjiga o vještini trgovanja«, knjiga I, poglavlje 7, p. 149 [f. 19r]: »Secundo, devi considerare la persona a chi dai, chel sia homo de bona fama, di bon credito et di bona consciencia, bon pagatore.«/ p. 365 .

${ }^{56}$ Ibid., p. 150 [f. 19r]: »Et ingiegnarte di havere la noticia et cognoscança loro. Et quelli che per cognoscança non cognosci deve advertere in loro multe cose. Et primo ala fisonomia, comminciando dal ochio, come dicie Plinio, De naturali historia in uno loco perfecto: 'In oculis animus inhabitat'.«/ p. 365.

${ }^{57}$ C.[aius] Plinius Secundus, »Naturalis historiae libri VII-XV.«, liber XI, caput 54, § 145, u: C.[aii] Plini Secundi Naturalis historiae libri XXXVII., recognovit atque indicibus instruxit Ludovicus Ianus. Vol. II. Libb. VII-XV. (Lipsiae: sumptibus et typis B. G. Teubneri, 1856), pp. 1-302, na p. 182: »profecto in oculis animus habitat.«

${ }^{58}$ A.[drian] N.[icholas] Sherwin-White, »Pliny, the Man and His Letters«, Greece \& Rome 16/1 (Cambridge, 1969), pp. 76-90, na p. 89.

${ }^{59}$ Miriam Griffin, »The Younger Pliny's Debt to Moral Philosophy«, Harvard Studies in Classical Philology 103 (Cambridge and London, 2007), pp. 451-481, na p. 474.
} 
Tekst Kotruljevićeva spisa o umijeću trgovanja sadrži tek jedno spominjanje Plinija Mlađeg. Ipak, ovom prilikom odlučio sam uputiti na jedno mjesto u spisu na kojem je dubrovački mislilac bio uvjeren da iznosi stav koji je izrekao Ciceron, a zapravo ga je crpio iz Pisama Plinija Mlađeg. Podstrek za odabir upravo tog mjesta iz Kotruljevićeva spisa sastoji se u tome što, kako napominje Sherwin-White, Plinijeva Pisma odražavaju Plinijevu sklonost filozofiji i upućenost u filozofske discipline svojega vremena. Spomenuto mjesto nalazi se u sedmom poglavlju treće knjige spisa o umijeću trgovanja, dakle u poglavlju naslovljenom »O trgovčevoj marljivosti« (»Dela diligentia delo mercante«). U tom poglavlju uočavamo upozorenje trgovcu da mora biti marljiv ne samo u vođenju knjiga, već i u odgovaranju na pisma, jer mu svako pismo može nešto donijeti ili u sadašnjosti ili u budućnosti. ${ }^{60}$ Kotruljević je potom zabilježio da nema pisma koje trgovcu neće donijeti izravne ili neizravne plodove, a po uzoru na, nastavlja Kotruljević, sljedeću Ciceronovu tvrdnju: ne postoji takva knjiga u kojoj se ne može pronaći nešto dobro. ${ }^{61}$ Premda je Kotruljević izvijestio da je ta tvrdnja Ciceronova, priređivačica Janeković Römer izvijestila je da su izvor zapravo Pisma Plinija Mlađeg. ${ }^{62}$ Stav da nijedna knjiga nije toliko loša da se u njoj ne može pronaći nešto korisno, Kotruljević je doista mogao preuzeti iz Pisama Plinija Mlađeg, točnije iz desetog odlomka petog pisma koje se nalazi u trećoj knjizi tog Plinijeva djela. ${ }^{63}$

Sedmi mislilac čije ime svakako zavređuje biti uvršteno u popis Kotruljevićeve filozofske lektire jest već spomenuti istaknuti rimski geograf i prirodoslovac Gaj Julije Solin (Gaius Iulius Solinus, 3. stoljeće). Kotruljević je, podsjećam, bio upoznat sa sadržajem Solinova djela De mirabilibus mundi, koje je poznato i pod naslovima Collectanea rerum memorabilius te Polyhistor, na što sam upozorio prilikom izdvajanja Dubrovčaninova navođenja podataka o prvom manje zastupljenom misliocu u spisu o umijeću trgovanja: peripatetiku Kalistenu iz Olinta. Narav tog Solinova djela ilustrirao je američki istraživač renesansne diplomatske i kulturalne povijesti Paul Dover 2013. godine u studiji »Reading 'Pliny's Ape' in the Renaissance: the Polyhistor of Caius Julius Solinus in the first century of print«, na sljedeći način: Solin je u njemu svoje spoznaje crpio iz djela Naturalis historia Plinija Starijeg, a

${ }^{60}$ Cotrugli, »Libro del arte dela mercatura«, libro III, capitulo 7 / Kotrulj, »Knjiga o vještini trgovanja«, knjiga III, poglavlje 7, p. 260 [f. 69r-v] / p. 448.

${ }^{61}$ Ibid., p. 261 [f. 69v]: »Et questo non falla che cosi como dicie Tulio, che non e simal libro in lo qual legendo non trovi qualche cosa de bono, cosi non e nulla letera la qualle non abia qualche fructo directe o indirecte. «/ pp. 448-449.

${ }^{62}$ Ibid., p. 449, bilješka 33: »Ne radi se o Ciceronu nego o Pliniju, [...] C. Plinije Cecilije Mlađi, Epistolae, III, $\mathrm{V}, 10:<\ldots>\ll$.

${ }^{63}$ Caius Plinius Caecilius Secundus, »C. Plinius Baebio Macro suo s.«, liber III, epistula V, § 10, u: C. Plini Caecili Secundi epistularum libri decem, recognovit brevique adnotatione critica instruxit R.[oger] A.[ubrey] B.[askerville] Mynors (Oxonii: e typographeo Clarendoniano, 1966), pp. 72-75, na p. 73: »<...> dicere etiam solebat nullum esse librum tam malum ut non aliqua parte prodesset.« 
upotpunjavao ih je zapisima iz djela De situ orbis (Opis zemalja) rimskog geografa Pomponija Mele (Pomponius Mela, 1. stoljeće). ${ }^{64}$ Prema rezultatima Doverova istraživanja, interes za Solinovo djelo De mirabilibus mundi ustrajno se održavao tijekom 15. i 16. stoljeća, i to zbog toga što je renesansno oduševljenje antičkim nasljeđem premašivalo područje znanosti te uključivalo geografiju, astronomiju, botaniku i medicinu, kao i zbog toga što se prema antičkim tekstovima zauzimao rudarski pristup u potrazi za filozofskim, političkim i etičkim poukama. ${ }^{65}$

Jedno od svjedočanstava o utjecaju koji je Solinovo djelo De mirabilibus mundi ostvarilo na renesansne mislioce i njihovo stvaralaštvo nedvojbeno pruža Kotruljević i njegov spis o umijeću trgovanja. Osim u sadržaju trećeg poglavlja četvrte knjige spisa, a u kojem je raspravljao o tjelesnoj vrsnoći Aleksandra Makedonskog napomenuvši da su za obrazovanje tog makedonskog vladara bili odgovorni Aristotel i Kalisten iz Olinta, Kotruljević je Solina spomenuo još jedanput. To je učinio u sedmom poglavlju četvrte knjige, dakle u poglavlju u kojem je umovao o djeci, i to onda kada je pisao o temama medicinske naravi. U tom poglavlju Kotruljević je, među ostalim, zabilježio i podatak da su žene u mogućnosti rađati do navršene pedesete godine života, dok su muškarci u stanju praviti djecu do osamdesete godine života. ${ }^{66}$ Da bi dokazao da je taj podatak točan i time osnažio svoju tvrdnju, Dubrovčanin se pripomogao Solinovim djelom De mirabilibus mundi. Izvijestio je, naime, da je od Solina doznao da je numidski kralj Masinisa (oko 238. - 148. pr. n. e.) dobio sina Matumu u dobi od sedamdeset i šest godina, a da je Marko Porcije Katon Stariji (Marcus Porcius Cato Maior, 234. - 149. pr. n. e.) s navršenih osamdeset godina začeo djeda Marka Porcija Katona Utičkoga (Marcus Porcius Cato Uticensis, 95. - 46. pr. n. e.). ${ }^{67}$ Nakon uvida u Solinov opus jasno je da je Kotruljević te podatke uistinu doznao, preveo i parafrazirao iz prvog poglavlja Solinova djela De mirabilibus mundi. ${ }^{68}$

\footnotetext{
${ }^{64}$ Paul Dover, »Reading 'Pliny's Ape' in the Renaissance: the Polyhistor of Caius Julius Solinus in the first century of print «, u: Jason König, Greg Woolf (edited by), Encyclopaedism from Antiquity to the Renaissance (New York: Cambridge University Press, 2013), pp. 414-443, na p. 418: „Solinus' text [Polyhistor], as mentioned above, is drawn primarily from Pliny's Natural History, with additional extensive borrowings from the De situ orbis of Pomponius Mela, $<\ldots>\ll$.

${ }^{65}$ Dover, $\gg$ Reading 'Pliny's Ape' in the Renaissance: the Polyhistor of Caius Julius Solinus in the first century of print «, p. 422.

${ }^{66}$ Cotrugli, »Libro del arte dela mercatura«, libro IV, capitulo 7 / Kotrulj, »Knjiga o vještini trgovanja«, knjiga IV, poglavlje 7, p. 321 [f. 92v]: »Et nota che femene fin a L anni pono parturire, homini fin in LXXX.«/p. 493.

${ }^{67}$ Ibid., p. 321 [f. 92v] / p. 493.

68 Solinus, »Collectanea rerum memorabilium sive Polyhistor.«, I, 59-60, p. 18: »<..> post annum quinquagesimum fecunditas omnium conquiescit: nam in annum octogesimum viri generant, sicuti Masinissa rex Mathumanum filium septuagesimum et sextum annum agens genuit, Cato octogesimo exacto ex filia Salonis clientis suis avum Uticensis Catonis procreavit.«
} 
Osmi od manje zastupljenih mislilaca filozofske orijentacije u Kotruljevićevu spisu o umijeću

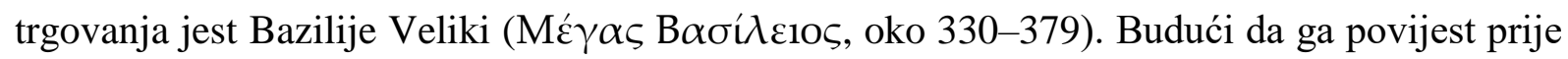
svega pamti po tome što je bio crkveni otac i učitelj iz maloazijske pokrajine Kapadocije te po tome što je bio cezarejski biskup, ne treba čuditi da je, kako zaključuje I. P. Sheldon-Williams u opsežnoj studiji »The Greek Christian Platonist Tradition from the Cappadocians to Maximus and Eriugena« iz 1967. godine, središnja tema Bazilijevih promišljanja, baš kao i u slučaju promišljanjā koja su iznosili drugi kršćanski filozofi, bio Bog i njegov odnos prema svijetu, posebice prema čovjeku. ${ }^{69}$ Kada je riječ o njegovim sklonostima pojedinim filozofskim školama ili pravcima, Bazilije nije bio, kako u monografiji iz 2007. godine ističe američki teolog Stephen M. Hildebrand, stoik, ni aristotelovac, ni srednjeplatonovac ili novoplatonovac, već je njegovo obrazovanje obuhvaćalo učenja svih navedenih filozofskih škola ili pravaca. $^{70}$ Zbog toga ne iznenađuje zaključak koji je američki teolog Mark DelCogliano objavio 2010. godine: povjesničari kasnoantičke filozofije ne bi smjeli zaobići Bazilijeve prinose. ${ }^{71}$

U spisu o umijeću trgovanja Kotruljević je Bazilija Velikog spomenuo tek jednom. Na njegova promišljanja oslonio se u trećem poglavlju druge knjige spisa, dakle u poglavlju koje je naslovio »O milostinji« (»De elemosina«). U njemu je izlagao pravila ili zapovijedi kojih bi se svatko trebao pridržavati pri donošenju odluke o davanju milostinje. Tako je zabilježio i pravilo da milostinja prema siromašnima treba proizlaziti iz trgovčeva viška od potrebnoga. ${ }^{72}$ Uporište za to pravilo dubrovački je mislilac pronašao u Bazilijevu okrilju, točnije $u$ tvrdnjama pripisanima Baziliju, a koje u prijevodu Janeković Römer glase: »Ako kažeš da si ono što imaš dobio od Boga, je li možda Gospodin nepravedan zbog toga što ne dijeli dobra nama? Jer ti obiluješ, a onaj prosjači ni zbog čega drugoga nego zato što ti uživaš plodove dobrog upravljanja, dok se onaj krasi plaštem strpljivosti? Jer kruh koji imaš pripada gladnome, golome pripada haljina što je držiš pod ključem, bosome cipele koje trunu kod

\footnotetext{
${ }^{69}$ I. P. Sheldon-Williams, »The Greek Christian Platonist Tradition from the Cappadocians to Maximus and Eriugena«, u: A.[rthur] H.[ilary] Armstrong, The Cambridge History of Later Greek and Early Medieval Philosophy (New York: Cambridge University Press, 1967), pp. 425-533, na p. 438: »For St Basil, as for every Christian philosopher, the central theme is God, his dealings with the world, and especially with man.«

70 Stephen M. Hildebrand, The trinitarian theology of Basil of Caesarea: a synthesis of Greek thought and biblical truth (Washington, D. C.: The Catholic University of America Press, 2007), p. 115: »It confirms the fact - otherwise demonstrable - that Basil was not a Stoic, an Aristotelian, a Middle Platonist, or a Neoplatonist, pure and simple; rather, his education included them all.«

${ }^{71}$ Mark DelCogliano, Basil of Caeserea's Anti-Eunomian theory of names: Christian theology and late-antique philosophy in the fourth century trinitarian controversy (Leiden - Boston: Koninklijke Brill NV, 2010), p. 265: »Secondly, historians of late-antique philosophy cannot ignore the contributions of Basil.«

${ }^{72}$ Cotrugli, »Libro del arte dela mercatura«, libro II, capitulo 3 / Kotrulj, »Knjiga o vještini trgovanja«, knjiga II, poglavlje 3, p. 211 [f. 47v]/ p. 415
} 
tebe, a potrebitom srebro koje posjeduješ. Zbog toga nanosiš nepravdu svaki put kad si mogao dati.« ${ }^{73}$ Dubrovčanin, međutim, nije naveo mjesto iz kojega je crpio te Bazilijeve tvrdnje. Janeković Römer je ustanovila da ih je Kotruljević preuzeo iz petog članka 32. pitanja drugog odsjeka drugog dijela Sume teologije Tome Akvinca. ${ }^{74}$ I najvjerojatnije je bila u pravu, jer je Toma upravo u tom dijelu Sume probrao i u citat objedinio stavove koje je Bazilije opsežnije izložio o toj problematici u sadržaju svoje homilije o Evanđelju po Luki. ${ }^{75}$

Sljedeći mislilac na čija se filozofska promišljanja Kotruljević oslanjao u spisu o umijeću trgovanja bio je istaknuti predstavnik kršćanske patristike Ivan Zlatousti (Ioannes Chrysostomos, oko 344 - 407). Taj carigradski patrijarh i crkveni naučitelj bio je učenik

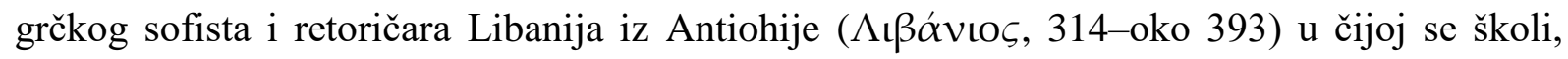
kako tvrdi američki klasični filolog i stručnjak za rimsko pravo Paul Robinson ColemanNorton (1898-1971) u članku »St. Chrysostom and the Greek Philosophers« iz 1930. godine, upoznao s najboljim klasičnim grčkim autorima, kako pjesnicima tako i filozofima. ${ }^{76} \mathrm{O}$ tome kako je Ivan Zlatousti inkorporirao filozofiju u svoj kršćanski život i time zavrijedio biti smatran i filozofom, pisala je, primjerice, australska klasična filologinja i religiologinja Wendy Mayer. Već u naslovu jednog od svojih radova o Zlatoustom iz 2017. godine oslovila ga je moralnim filozofom i liječnikom duša te je zaključila da je Zlatousti, baš kao i brojni filozofi koji su mu prethodili, zamišljao svoju školu, misleći pritom na crkvu, kao medicinsku kliniku, te da je bio filozof-učitelj-svećenik (philosopher-teacher-priest) koji je upravljanje i liječenje bolesnih duša smatrao svojim najvažnijim poslom. ${ }^{77}$ Zlatousti se, kako je Mayer još ranije naglasila u radu »Shaping the Sick Soul: Reshaping the Identity of John Chrysostom» koji je objavljen 2015. godine, otvoreno smjestio unutar etičke škole koja je svoj nauk crpila

\footnotetext{
${ }^{73}$ Ibid., p. 211 [f. 47v] / p. 415.

${ }^{74}$ Ibid., p. 211 [f. 47v] / p. 415, bilješka 51: »Prema: Toma Akvinski, Summa theologica, $2^{\text {a }} 2^{\text {e }}$, q. 32, 5.《

75 Thomas Aquinas, Summa theologiae II-II, q. 32, a. 5, ad. 2. Vidi, primjerice, u: Thomas Aquinas, Summa theologiae II-II, q. 32, a. 5, ad. 2, u: Sancti Thomae Aquinatis Doctoris angelici Opera omnia iussu impensaque Leonis XIII P. M. edita. Tomus octavus. Secunda secundae Summae theologiae a quaestione I ad quaestionem LVI, ad Codices manuscriptos Vaticanos exacta cum commentariis Thomae de Vio Caietani Ordinis praedicatorum S. R. E. Cardinalis, cura et studio fratrum eiusdem Ordinis (Romae: Ex Typographia

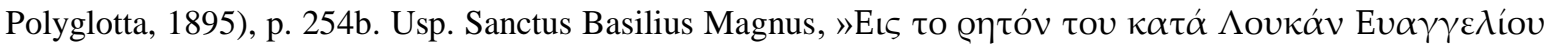
/ In illud dictum Evangelii secundum Lucam«, u: Patrologiae cursus completus, accurante J.-P. Migne. Patrologiae Graecae Tomus XXXI. Sanctus Basilius Caesariensis episcopus. (Lutetiae Parisiorum: Excudebatur et venit apud J.-P. Migne editorem, 1857), cc. 261-278, na cc. 275-278.

${ }^{76}$ P. [aul] R.[obinson] Coleman-Norton, »St. Chrysostom and the Greek Philosophers«, Classical Philology 25/4 (Chicago, 1930), pp. 305-317, na p. 305: »St. John Chrysostom (ca. 347-407) studied under Libanius, the celebrated sophist of Antioch, in whose school he became conversant with the best classical Greek authors, both poets and philosophers.«

77 Wendy Mayer, »John Chrysostom: Moral Philosopher and Physician of the Soul«, u: Doru Costache, Mario Baghos (edited by), John Chrysostom: Past, Present, Future (Sidney: AIOCS Press, 2017), pp. 193-215, na pp. 213-214.
} 
iz medicinsko-filozofskih tradicija s kojima se upoznao tijekom obrazovanja u Antiohiji, pri čemu je bio upućen u obilježja platonovsko-aristotelovske i stoičko-epikurovske tradicije. ${ }^{78}$ Kotruljević se promišljanjima Zlatoustog poslužio na tri mjesta u spisu o umijeću trgovanja. Ovom prilikom izdvojit ću posljednje od njih, točnije mjesto iz sedmog poglavlja treće knjige spisa o umijeću trgovanja, a koje je poglavlje naslovljeno »O trgovčevoj marljivosti« (»Dela diligentia delo mercante«). Na početku tog poglavlja dubrovački je mislilac istaknuo da trgovca mora krasiti velika marljivost i brižnost. ${ }^{79}$ Taj je stav potkrijepio parafraziranjem promišljanja Ivana Zlatoustog o nadi, točnije o tome da je taj kršćanski mislilac naučavao da čovjek ne bi smio gubiti nadu u Božju milost i da bi se trebao više pouzdati u vlastiti trud nego u vrlinu Boga koji daje svako dobro. ${ }^{80}$ Priređivačica i prevoditeljica prijepisā Kotruljevićeva spisa Janeković Römer na tom je mjestu zabilježila da je dubrovački mislilac stav Ivana Zlatoustog doznao iz njegove 23. homilije u kojoj je tumačio Evanđelje po Mateju, uputivši pritom na to da se taj stav nalazi u 57. svesku edicije Patrologia Graeca. ${ }^{81}$ Međutim, nakon što sam analizirao sadržaj 23. homilije u izdanju na koje je uputila Janeković Römer, utvrdio sam da se u njoj ne nalaze navedeni Kotruljevićevi zapisi. Vrlo je izvjesno da je Kotruljević parafrazirao promišljanja koja je Zlatousti zapisao na kraju 22. homilije, dakle homilije koja se odnosi na šesto poglavlje Evanđelja po Mateju, budući da je u njoj tvrdio da ne bismo trebali očajavati zbog toga što svakodnevno griješimo, već bismo trebali tražiti i nadati se Božjem oprostu za počinjene grijehe i usmjeriti se Bogu, jer će nam svojom milošću podariti dobra. ${ }^{82}$

Deseti mislilac koji zavređuje biti pridodan popisu Kotruljevićeve lektire filozofske naravi nesumnjivo je hispanski teolog, fillozof, crkveni učitelj i povjesničar Izidor iz Sevilje (Isidorus Hispalensis, oko 560-636). Riječ je o misliocu čija djela, posebice djelo Originum seu etymologiarum libri XX (Porijekla riječi ili etimologije $u$ dvadeset knjiga) ili samo

\footnotetext{
${ }^{78}$ Wendy Mayer, »Shaping the Sick Soul: Reshaping the Identity of John Chrysostom«, u: Geoffrey D. Dunn, Wendy Mayer (Edited by), Christians Shaping Identity from the Roman Empire to Byzantium: Studies Inspired by Pauline Allen (Leiden - Boston: Koninklijke Brill, 2015), pp. 140-164, na p. 158: »In this sense, John situates himself clearly as a teacher within a particular school [...] of moral philosophy. That school draws strongly on the medico-philosophical traditions in which at Antioch John himself must have been trained, both Platonic-Aristotelian [...] and Stoic-Epicurean.«

${ }^{79}$ Cotrugli, »Libro del arte dela mercatura«, libro III, capitulo 7 / Kotrulj, »Knjiga o vještini trgovanja«, knjiga III, poglavlje 7, p. 260 [f. 68v]: »Diligencia grande deve essere nelo mercante et solicitudine la qual e matre dele richeçe, $<\ldots>\ll . /$ p. 448.

${ }^{80}$ Ibid., p. 260 [f. 68v-69r] / p. 448.

${ }^{81}$ Ibid., p. 448, bilješka 31: »Ivan Zlatousti, In Matthaeum homiliae. PG, sv. 57, XXIII: 77.«

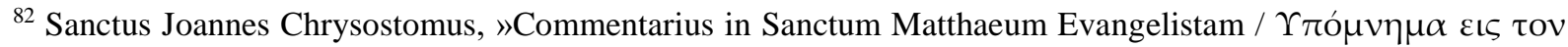

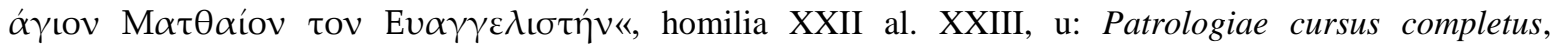
accurante J.-P. Migne. Patrologiae Graecae Tomus LVII. Sanctus Joannes Chrysostomus. (Lutetiae Parisiorum: Excudebatur et venit apud J.-P. Migne editorem, 1862), cc. 13-472, na c. 308.
} 
Etimologije, često sadrže, kako to još 1912. godine tvrdi američko-kanadski povjesničar Ernest Brehaut (1873-1953), supostavljene ideje, primjerice, Aristotela, Nikomaha, Porfirija, Varona, Cicerona, Svetonija, Mojsija, Svetog Pavla, Origena i Augustina, a koje su ponekad zabilježene u izvornu obliku, a ponekad i u obliku koji neznatno odstupa od izvornika. ${ }^{83}$ Unatoč nedostatku izvornosti njegove misli, ali i zahvaljujući izdašnu eklekticizmu, Izidorovo stvaralaštvo bilo je, kako ističe američki stručnjak za romanske jezike i književnost Sandro D’Onofrio, neprocjenjivo za buduće generacije jer je sačuvalo klasični zamah grčke znanosti i filozofije za buduća vremena. ${ }^{84}$ D'Onofrio je pripomenuo i to da bez obzira na činjenicu što Etimologije ne sadrže kritičke komentare i teoretske inovacije koje odlikuju kasnije srednjovjekovlje, to Izidorovo djelo obuhvaća sekularno znanje prosvijetljeno kršćanskim razumijevanjem, pri čemu je u njega i dalje utkana filozofska aktivnost, posebice u području dijalektike, gramatike i retorike. ${ }^{85}$

U spisu o umijeću trgovanja Kotruljević se na nauk Izidora iz Sevilje oslonio u tri navrata. Pritom se u svim slučajevima pouzdao upravo u sadržaj Izidorova enciklopedijskog ostvarenja poznatog pod nazivom Etimologije. Ovom prigodom izdvojit ću primjer posljednjeg Dubrovčaninova pozivanja na Izidorovo djelo, a koje se nalazi u četvrtom poglavlju četvrte knjige spisa o umijeću trgovanja naslovljenom »O odjeći i uresima« (»De veste et ornamenti«). Dubrovački mislilac je, naime, to poglavlje otpočeo ukazivanjem na genezu i razvoj odjevnih predmeta. Najprije je istaknuo da su naši praroditelji u raju nosili odjeću načinjenu od obične ovčje kože kojom su pokrivali stidne dijelove, dok su se kasnije, a što se zadržalo sve do njegova vremena, ljudi počeli pokrivati odjećom do polovice bedara. ${ }^{86}$ Potom je došlo do nastanka vrlo svečane odjeće kojom se iskazivala pripadnost pojedinom društvenom staležu i uloga u političkom životu, pa su tako samo Rimljani dostojni službe i vlasti u svojoj Republici nosili muževne toge, dok su, poziva se Kotruljević na zapise iz Izidorovih Etimologija, vitezovi i slobodni ljudi nosili zlatno, oslobođenici srebrno, a robovi

${ }^{83}$ Ernest Brehaut, An Encyclopedist of the Dark Ages: Isidore of Seville, submitted in partial fulfilment of the requirements for the degree of doctor of philosophy in the Faculty of Political Science in Columbia University (New York: Columbia University, 1912), p. 48.

84 Sandro D’Onofrio, s. v. »Isidore of Seville«, u: Henrik Lagerlund (Ed.), Encyclopedia of Medieval Philosophy: Philosophy Between 500 and 1500 (Dordrecht: Springer Science+Business Media B.V., 2011), pp. 573b-575a, na p. 574a.

${ }^{85}$ D'Onofrio, s. v. »Isidore of Seville«, p. 574b: »Despite the fact that The Etymologies lacks the critical comentaries and theoretical innovation that characterize the later Middle Ages, the general idea that guided it [...] a comprehensive account of secular knowledge enlightened by a Christian understanding. Thus, philosophical activity remained imbibed, to a certain extent, in dialectics, grammar, and rhetoric."

${ }^{86}$ Cotrugli, »Libro del arte dela mercatura«, libro IV, capitulo 4 / Kotrulj, »Knjiga o vještini trgovanja«, knjiga IV, poglavlje 4, p. 297 [f. 81r-v] / p. 474. 
željezno prstenje. ${ }^{87}$ Te je podatke Dubrovčanin doznao iz 32. poglavlja devetnaeste knjige Izidorova djela. ${ }^{88}$

Naredni mislilac kojeg valja pridodati korpusu Kotruljevićeva filozofskog štiva nesumnjivo je znameniti talijanski pjesnik, prozni pisac, teoretičar književnosti, etičar i politički mislilac Dante Alighieri (1265-1321). Da je za tog Firentinca filozofija bila izuzetno važna, potvrđuju brojni radovi koji su posvećeni zastupljenosti filozofske sastavnice u Danteovu opusu. Među njima se izdvaja monografija koju je napisao francuski filozof i povjesničar filozofije Étienne Gilson (1884-1978), a koja u engleskom prijevodu iz 1948. godine nosi naslov Dante the Philosopher. U njoj, među ostalim, stoji da je Dante u filozofiji preuzimao Aristotelova učenja ${ }^{89}$ Mišljenje o Danteu kao filozofu podastro je i istaknuti američki pisac, književni kritičar i izučavatelj Danteova opusa Charles S. Singleton (1909-1985) u članku »Dante and Myth « iz 1949. godine. U njemu je naglasio da je Dante imao vlastitu filozofiju, zatim da ga trebamo smatrati filozofskim pjesnikom, te da je za Dantea filozofija podrazumijevala i vjeru koja je snažno utemeljena na autoritetu i koja je bila prisutna u većini Zapadnoga svijeta Danteova doba. ${ }^{90}$ Do sličnog je zaključka došao i američki profesor teologije Ernest L. Fortin (1923-2002) u svojoj monografiji Dissent and Philosophy in the Middle Ages: Dante and His Precursors. U njoj je ustvrdio da je Dante bio filozofski pjesnik i da je njegovo stvaralaštvo imalo dva različita značenja: teološko i etičko. ${ }^{91}$ Kao posljednje izdvajam istraživanje koje je poduzeo i 2015. godine objavio poljski teolog i filozof Jacek Grzybowski u monografiji Cosmological and Philosophical World of Dante Alighieri. Grzybowski je došao do sljedećih zaključaka: Dante je bio skolastičar, duboko ukorijenjen u srednjovjekovnu intelektualnu atmosferu i koristio se oruđima koja su mu pružala tadašnja znanost, poetika, filozofija i teologija; Dante je bio najbriljantniji talijanski pjesnik kojeg se može jedino razmatrati u okvirima kršćanskog nauka s kojim se duboko poistovjećivao i iz kojeg je crpio inspiraciju;

\footnotetext{
${ }^{87}$ Ibid., p. 297 [f. 81r-v] / p. 474.

${ }^{88}$ Sanctus Isidorus Hispalensis, »Etymologiarum libri XX.«, liber XIX, caput 32, u: Patrologiae cursus completus, accurante J[acques].-P.[aul] Migne. Patrologiae Latinae. Tomus LXXXII. Sancti Isidori Hispalensis. [Opera omnia, recensente Faustino Arevalo. Tomi tertius et quartus] (Parisiis: Venit apud editorem, in via dicta d'Amboise, prope portam vulgo d'Enfer nominatam, seu Petit-Montrouge, 1850), cc. 73-1098, na cc. 701-702.

${ }^{89}$ Étienne Gilson, Dante the Philosopher, translated by David Moore (London: Sheed \& Ward, 1948), p. 281.

${ }^{90}$ Charles S. Singleton, »Dante and Myth«, Journal of the History of Ideas 10/4 (Philadelphia, 1949), pp. 482502, na p. 483.

${ }^{91}$ Ernest L. Fortin, Dissent and Philosophy in the Middle Ages: Dante and His Precursors, translated by Marc. A. LePain (Lanham: Lexington Books, 2002), p. 67: »His [Dante's] work is not that of a poet tout court, but of a philosophical poet who, thanks to his extraordinary gifts of expression, has the advantage over the philosopher of making himself understood by all. [...] Thus his work holds two different meanings, one theological and the other moral.«
} 
Dante se u svojim djelima iskazao kao nastavljač skolastičke misli i dužnik srednjovjekovnoj teologiji i filozofiji koje su bile naučavane u školama i na sveučilištima. ${ }^{92}$

U spisu o umijeću trgovanja Kotruljević je Dantea spomenuo dvaput. Ovom prigodom izdvajam ono Kotruljevićevo spominjanje Dantea koje se nalazi u šesnaestom poglavlju treće knjige spisa, a koje je poglavlje naslovljeno »O trgovčevoj skromnosti« (»Dela modestia delo mercante«). Nakon što je napomenuo da se čednost u njegovo vrijeme najmanje štovala $u$ Italiji te da se pretjerivalo u korištenju sramotnih riječi i pokreta koji označavaju spolne udove, Kotruljević je u poglavlju istaknuo da su među Talijanima manje nepristojni tek Đenovljani, no da su i oni prepuni mana, o čemu je pisao Dante, koji je rekao sljedeće: »Jao, Đenovljani, pokvareni ljudi dobrih običaja, puni svake mane« (»Ai Gienoesi, homini perversi, con bei costumi pien d' ogni magagnia «). ${ }^{93} \mathrm{Uz}$ ovo spominjanje Dantea prevoditeljica i priređivačica prijepisā Kotruljevićeva spisa o umijeću trgovanja Janeković Römer dokazala je da je Dubrovčanin posegnuo za sadržajem trideset trećeg pjevanja Danteova »Inferna« (»Pakao«) iz djela La divina commedia (Božanstvena komedija). ${ }^{94}$ Dakle, može se bez zadrške zaključiti da je Kotruljević bio upoznat sa sadržajem Božanstvene komedije te da zavređuje biti dijelom popisa manje zastupljenih filozofskih izvora u Kotruljevićevu spisu o umijeću trgovanja.

Dvanaesti mislilac koji zaslužuje biti uvršten u popis izvora i mislilaca koji su gajili sklonosti prema filozofiji i na čije se spoznaje Kotruljević oslanjao u spisu o umijeću trgovanja, bio je Francesco Petrarca (1304-1374), pjesnik, učenjak i otac europskog humanizma. Da je Petrarcino stvaralaštvo sadržavalo filozofsku sastavnicu, potvrđuju rezultati brojnih

92 Jacek Grzybowski, Cosmological and Philosophical World of Dante Alighieri: The Divine Comedy as a Medieval Vision of the Universe (Frankfurt am Main: Peter Lang GmbH, 2015), pp. 145-146: »He [Dante] was firmly rooted in the intellectual atmosphere of the Middle Ages, and he used the tools given by the contemporaneous science, poetics, philosophy and theology. [...] Dante is the most brilliant poet of the Italian language, undeniably innovative in style and language, but as a poet he can only be understood when placed within the framework of the Christian doctrine with which Dante deeply identifies, and in which his inspirations are immersed. He appears in all his works as a continuer of the scholastic thought and the debtow of that gift which medieval theology and philosophy offered its disciples in schools and universities."

${ }^{93}$ Cotrugli, »Libro del arte dela mercatura«, libro III, capitulo 16 / Kotrulj, »Knjiga o vještini trgovanja«, knjiga III, poglavlje 16, pp. 276-277 [ff. 74r-v] / p. 460.

${ }^{94}$ Ibid., p. 277 [f. 74v] / p. 460, bilješka 57: »Kotrulj krivo citira. U 'Paklu' stoji: 'Ahi Genovesi, uomini diversi d'ogne costume e pien d'ogne magagna...'. Dante Alighieri, La divina commedia, ur. Eugenio Camerini. Milano: Soznogno, 1927, Inferno, XXXIII, 151-152: 272; U hrvatskom prijevodu: 'Avaj o puče genoveški, što si pun mana, a za dobro čuvstvo tupa zašto te zemlja još nosi’. Dante Alighieri, Djela, prir. Frano Čale, Mate Zorić. Zagreb: SNL, NZMH, 1976, sv. 1.: Pakao, XXXIII, 151-152: 184.« No, uvidom u hrvatsko izdanje Danteove Božanstvene komedije na koje je uputila Janeković Römer utvrdio sam da je priređivačica Kotruljevićeva spisa i sama načinila nekoliko pogrešaka prilikom citiranja. Dante Alighieri, »Pakao«, trideset $\mathrm{i}$ treće pjevanje, 151-153, u: Dante Alighieri, Djela, knjiga druga, priredili Frano Čale i Mate Zorić, preveli Mihovil Kombol, Mate Maras (Raj XVIII-XXXIII) (Zagreb: Sveučilišna naklada Liber / Nakladni zavod Matice hrvatske, 1976), pp. 11-189, na p. 184: »Avaj, o puče genoveški, što si / pun mana, a za dobro čuvstva tupa, / zašto te zemlja još na sebi nosi?« 
istraživanja koja su poduzeli neki od najistaknutijih svjetskih istraživača filozofskih obilježja humanizma i renesanse. Ovom prilikom uputit ću na zaključke tek nekolicine istraživača. Kao prvog izdvajam znamenitog njemačkog filozofa novokantovskog usmjerenja Ernsta Cassirera i njegovu monografiju Individuum und Kosmos in der Philosophie der Renaissance iz 1927. godine. U njoj, među ostalim, stoji da je Petrarcin unutrašnji svijet ostao podijeljen između Ciceronova i Augustinova nauka. ${ }^{95}$ Zaključcima o Petrarci koji slijede domislio se istaknuti njemački klasični arheolog i istraživač renesanse Hans Nachod (1885-1958): 1) Petrarcu ne bismo trebali smatrati filozofom koji je osmislio nove i originalne filozofske ideje koje bi potom smjestio u vlastiti koherentan i harmoničan sustav; 2) Petrarca je bio obožavatelj i zagovaratelj etičkih učenja koja je pronašao u djelima antičkih filozofa, posebice latinskih autora koji su popularizirali grčku filozofiju; 3) Petrarca je osjećao odbojnost prema skolastičkim školama koje su u njegovo doba prevladavale u visokom obrazovanju, a posebice prema onima koje su naginjale arapskom aristotelizmu i Aristotelu; 4) Petrarca je kao vjeran sin Crkve bio potpuno suglasan s crkvenim učenjima, a posebice s učenjima svojeg velikog uzora Augustina; 5) Petrarca je poimao filozofiju kao isključivo praktičnu disciplinu koja poučava umijeće dobrog i sretnog življenja, kako je to formulirao njegov omiljeni antički filozof Ciceron; 6) Petrarca je htio biti moralni filozof, čovjek koji je u stanju naučavati i primjenjivati umijeće dobrog i sretnog življenja na ljude koji ga okružuju. ${ }^{96}$ Među vrijedne zaključke o Petrarcinu filozofskom usmjerenju svakako bi trebalo uvrstiti i one koje je ponudio talijanski filozof Eugenio Garin, jedan od najutjecajnijih istraživača renesanse. Primjerice, u monografiji L'Umanesimo italiano iz 1986. godine izložio je razloge zbog kojih

95 Ernst Cassirer, Individuum und Kosmos in der Philosophie der Renaissance (Wiesbaden: Springer Fachmedien Wiesbaden GmbH, 1927), p. 39: »Petrarcas innere Welt bleibt zwischen Cicero und Augustin geteilt.«

${ }^{96}$ Hans Nachod, »Introduction«, u: Ernst Cassirer, Paul Oskar Kristeller, John Herman Randall, jr. (edited by), The Renaissance Philosophy of Man: Petrarca, Valla, Ficino, Pico, Pomponazzi, Vives, sixth impression (Chicago: The University of Chicago Press, 1959), pp. 23-33, na pp. 23-24: »However, we should not dare to call him [Petrarca] a philosopher in the sense of one who conceives new and original philosophical ideas and is willing or at least attempts to organize them into a coherent and harmonious system of his own. [...] He never pretended to be more than an admirer and propagator of the moral teachings he found in the works of ancient philosophers, particularly in those of Latin thinkers who popularized Greek philosophy in the centuries shortly before and after the beginning of the Christian Era. The great achievements of Scholastic philosophy as far as they had not become the common property of everyone who received a higher education in Petrarca's time - had no noticeable influence on his thinking. Instinctively he felt a strong aversion for the late Scholastic schools, especially for those which tended toward Arabian Aristotelianism; and Aristotle himself was always more or less suspect to him, however hard he tried to appreciate the greatness of a man he found spoken of with so much reverence by his favorite classical authors. [...] As a faithful son of the Church, he was fully satisfied with her teachings and did not need another guide in the labyrinth of this life, in this respect particularly under the spell of his great model Augustine. [...] Philosophy meant to him an exclusively practical discipline teaching the art of living well and happily, the ars bene beateque vivendi, as his beloved Cicero had put it. He did not aspire to be more than a moral philosopher, a man able to show his fellow-men how to learn and to practice this art.« 
se Petrarca opredijelio za pojedine filozofske autoritete. Petrarca je, tvrdi Garin, u učenjima Platona, Cicerona, Augustina, kao i u patrističkoj tradiciji, tražio usmjerenje koje se razlikuje od rigidnog logičkog i fizikalnog usmjerenja kakav su zagovarali okamizam, averoizam te pariška i padovanska skolastika. ${ }^{97}$ Naposljetku, izdvajam i zaključak koji je 2007. godine u tekstu »The revival of Hellenistic philosophies« za The Cambridge Companion to Renaissance Philosophy donijela Jill Kraye, američka povjesničarka filozofije nastale u renesansi. Ona je, naime, zabilježila da je baš Petrarca bio zaslužan za začetak oživljavanja interesa za stoički nauk u renesansi. ${ }^{98}$

Prilikom izlaganja svojih promišljanja o umijeću trgovanja Kotruljević se na Petrarcina učenja oslonio u dvama navratima. Ovom prilikom ukazat ću tek na sadržaj njegova prvog oslanjanja na Petrarcu. Kotruljević je, naime, Petrarcu prvi put spomenuo u osamnaestom poglavlju treće knjige spisa o umijeću trgovanja, dakle u poglavlju »O trgovčevoj umjerenosti« (»Della temperantia delo mercante «). Kada je izlagao o trećem uvjetu trgovčeva postajanja umjerenim, dubrovački je mislilac pribilježio da je uzdržljivost često popraćena ljupkošću ili ozbiljnošću, a smatrao je i to da su uzdržljivost u govoru i ozbiljnost razmišljanja uzvišenih ljudi iznimno lijepi, posebice u mladih ljudi među kojima je to rijetka pojava. ${ }^{99} \mathrm{Da}$ bi potkrijepio taj stav, Kotruljević je posegnuo za Petrarcinom mišlju koja u prijevodu Janeković Römer glasi da je vrlo »rijedak soj ljudi koji su učeni još u nježnoj dobi«, pa dodao da su blaženi oni mladi ljudi koji su dobili taj dar. ${ }^{100}$ Kao što je to Janeković Römer priopćila u bilješci uz hrvatski prijevod, Kotruljević je taj stav doznao iz Petrarcina djela Familiarum rerum libri (Knjige o prijateljskim stvarima), točnije iz osmog pisma jedanaeste knjige tog djela. $^{101}$

$\mathrm{Na}$ Kotruljevićevu popisu manje zastupljenih mislilaca filozofskog usmjerenja u njegovim umovanjima o umijeću trgovanja svoje je mjesto pronašao i pisac te pjesnik Giovanni Boccaccio (1313-1375). Prve zaključke koje ću izdvojiti o njegovu filozofskom usmjerenju

${ }^{97}$ Eugenio Garin, L'Umanesimo italiano. Filosofia e vita civile nel Rinascimento (Roma - Bari: Laterza, 1986), p. 29: »In Cicerone e in Platone, conosciuto piuttosto per fama che non direttamente, attraverso la tradizione patristica e S. Agostino, Petrarca cercava appunto una direzione diversa da quella rigidamente logica e fisica dell'occamismo, dell'averroismo, della scolastica parigina e padovana.«

98 Jill Kraye, »The revival of Hellenistic philosophies«, u: James Hankins (edited by), The Cambridge Companion to Renaissance Philosophy (New York: Cambridge University Press, 2007), pp. 97-112, na p. 100: »Like so much else in the Renaissance, the revival of Stoicism began with the Italian humanist Petrarch (1304-74).«

${ }^{99}$ Cotrugli, »Libro del arte dela mercatura«, libro III, capitulo 18 / Kotrulj, »Knjiga o vještini trgovanja«, knjiga III, poglavlje 18, p. 284 [f. 77r] / p. 465.

100 Ibid., p. 284 [f. 77r] / p. 465.

${ }^{101}$ Ibid., p. 465, bilješka 69. Usp. Franciscus Petrarca, »Epistola VIII. Franciscus Petrarca Andreae Dandulo duci Venetorum «, liber undecimus, u: Franciscus Petrarca, Epistolae de rebus familiaribus et variae, studio et cura Iosephi Fracassetti, volumen secundum (Florentiae: Typis Felicis Le Monnier, 1862), pp. 124-134, na p. 130. 
potekli su iz pera Michaele Paasche Grudin, anglistice i povjesničarke književnosti, te Roberta Grudina, američkog književnika i filozofa, u monografiji Boccaccio's Decameron and the Ciceronian Renaissance iz 2012. godine. Prema njihovu mišljenju, u Boccacciovu Dekameronu ogleda se prvi koherentni izričaj moralnih principa koje istraživači povezuju s renesansom, pri čemu je Boccacciovo stvaralaštvo uvelike počivalo na Ciceronovim promišljanjima. ${ }^{102}$ Stavove koje je o Boccacciovim sklonostima filozofiji zastupao Filippo Andrei ne treba posebno obrazlagati, jer je taj talijanski stručnjak za talijansku, romansku i srednjovjekovnu latinsku književnost već naslovom svoje doktorske disertacije Boccaccio the Philosopher iz 2012. godine jasno dao do znanja da je Boccaccio bio filozof. Boccaccio je, tvrdi Andrei, nastojao načiniti novi i potpuno drugačiji filozofski sustav, zbog čega je u njegovu opusu moguće pronaći elemente aristotelizma i tomizma $\mathrm{u}$ kombinaciji $\mathrm{s}$ novoplatonizmom, averoizmom i epikurejstvom, ${ }^{103}$ a posredstvom Aristotela, Cicerona, Kvintilijana, Seneke i Makrobija zastupljena su i neka obilježja sofističke misli. ${ }^{104} \mathrm{O}$ Boccacciovu filozofskom usmjerenju očitovala se američka komparatistica Janet Levarie Smarr koja je zaključila da je Boccacciov interes bio usmjeren na ponovno otkrivanje grčke književnosti i filozofije. ${ }^{105}$

Dubrovački je mislilac u spisu o umijeću trgovanja Boccaccia spomenuo tek jednom. To je učinio u četvrtom poglavlju četvrte knjige spisa, dakle u poglavlju naslovljenom »O odjeći i uresima« (»De veste et ornamenti«). Naime, da bi dočarao nepriličnost odijevanja stanovnikā nekih talijanskih gradova, oslonio se na zapise iz Boccacciova Dekamerona. Neprikladno odjevene ljude usporedio je s vizijom magarca koji nosi sedlo trkaćega konja ili s vizijom meštra Neznalice (missere Nebia), nakon čega je dodao da tako kaže Boccaccio kroz usta Kolovrata i Nabicijene (Porcograsso et Vindaciena). ${ }^{106}$ Pritom je, kako bilježi i Janeković Römer, aludirao na sadržaj devete novele osmoga dana Boccacciova Dekamerona. ${ }^{107}$

102 Michaela Paasche Grudin, Robert Grudin, Boccaccio's Decameron and the Ciceronian Renaissance (New York: Palgrave Macmillan, 2012), p. 1.

${ }^{103}$ Filippo Andrei, Boccaccio the Philosopher: The Language of Knowledge in the Decameron, a dissertation submitted in partial satisfaction of the requirements for the degree of Doctor of Philosophy in Romance Languages \& Literatures in the Graduate Division of the University of California, Berkeley. Committee in charge: Professor Steven Botterill, Chair, Professor Albert Russell Ascoli, Professor Ignacio Enrique Navarette. (Berkeley: University of California, 2012), p. 9.

${ }^{104}$ Andrei, Boccaccio the Philosopher: The Language of Knowledge in the Decameron, p. 231.

105 Janet Levarie Smarr, »Introduction: A Man of Many Turns«, u: Victoria Kirkham, Michael Sherberg, Janet Levarie Smarr (edited by), Boccaccio: A Critical Guide to the Complete Works (Chicago and London: The University of Chicago Press, 2014), pp. 1-20, p. 3.

${ }^{106}$ Cotrugli, »Libro del arte dela mercatura«, libro IV, capitulo 4 / Kotrulj, »Knjiga o vještini trgovanja«, knjiga IV, poglavlje 4, pp. 299-300 [f. 82v]: »Et per havere visto tali in tanta contrarieta et diformita et per havere considerato la ragione e lo dricto et per havere considerato la comparacione et distinctione dele persone, a me 
Posljednji, četrnaesti mislilac kojeg pridodajem popisu manje zastupljenih filozofskih autora u Kotruljevićevu spisu o umijeću trgovanja jest Antonino Pierozzi (1389-1459) ili Antonin iz Firence, Kotruljevićev suvremenik, talijanski dominikanac, firentinski nadbiskup, teolog i književnik. Premda je ponajprije bio usmjeren na teološke teme, australski istraživač povijesti renesanse u Italiji Peter Howard posvetio mu je natuknicu u projektu Encyclopedia of Renaissance Philosophy švicarske izdavačke kuće Springer, čije je objavljivanje u konačnoj inačici predviđeno tijekom 2021. godine. Iz te natuknice možemo doznati da je Antonin bio obrazovan i da je propovijedao unutar dinamičnog intelektualnog konteksta koji je bio karakterističan za tekovine humanizma u renesansi, zatim da je najčešće omalovažavan kao popularizator Tome Akvinca te da je rado prihvaćao humanističke ideje i oblike mišljenja kao temelje za život u zajednici, pri čemu je usvojio humanističko govorništvo u svojoj nadbiskupskoj službi. ${ }^{108}$ Kako tvrdi izraelski istraživač renesansne i rane novovjekovne filozofije i pjesnik Amos Edelheit u djelu Scholastic Florence: Moral Psychology in the Quattrocento iz 2014. godine, Antonin iz Firence bio je izniman teolog i etičar koji je bio duboko zaokupljen praktičnim problemima lihve i izrazitog siromaštva, koji je imao ključnu ulogu u ekonomskom, socijalnom i političkom životu firentinske republike svojega vremena i koji je u svojim spisima ostavio neizbrisiv trag o brojnim pitanjima moralne psihologije aktualnima tijekom ranog novovjekovlja. ${ }^{109}$ Antoninov opus magnum bila je Summa theologica, djelo koje je nastalo između 1440. i 1454. godine, a u kojem je razvio vlastitu, kako se to uobičajeno naziva, filozofiju djelovanja, točnije u kojem je upozorio na djelovanja unutar općeg okvira svoje etičke misli. ${ }^{110}$

Na nauk svojeg suvremenika Antonina Pierozzija Kotruljević se oslonio tek jednom u spisu o umijeću trgovanja. Spomenuo ga je, naime, u četvrtom poglavlju druge knjige spisa, a koje je poglavlje naslovio »O dvojbama što je dopušteno, a što nije« (»De casi de consciencia liciti et illiciti«). U njemu je razmatrao slučajeve u kojima je prodaja na rok dopuštena, točnije slučajeve u kojima trgovac prilikom prodaje na rok ne počinja lihvu. Zamijetivši da se u

e paruto vedere uno asino inselato con sella de corsiere et paruto me vedere uno missere Nebia, come disse l'Bocacio, Porcograsso et Vindaciena.«/ p. 476.

107 Ibid., p. 476, bilješka 20: »Giovanni Boccaccio, Dekameron, ur. Frano Čale, Mate Zorić. Zagreb: SNL, NZMH, 1981: VIII, 9: 520-529.«

108 Peter Howard, s. v. »Pierozzi, Antonino«, u: Marco Sgarbi (ed.), Encyclopedia of Renaissance Philosophy (Cham: Springer International Publishing, 2015-2021?), pp. 1-4, na p. 1a i na pp. 2b-3a.

109 Amos Edelheit, Scholastic Florence: Moral Psychology in the Quattrocento (Leiden - Boston: Koninklijke Brill, 2014), p. 99.

${ }^{110}$ Edelheit, Scholastic Florence: Moral Psychology in the Quattrocento, p. 99: ॥what is commonly described as Archbishop Antoninus' philosophy of action, that is, his emphasis on actions within the general framework of his moral thought, as expressed in his opus magnum, the Summa Theologica, written roughly between 1440 and 1454.« 
njegovo vrijeme toliko uvriježio takav oblik kupovine i prodaje, istaknuo je da je trgovanje na rok nedopušteno ukoliko pritom postoji loša namjera. ${ }^{111}$ Dubrovčanin je potom izložio primjer dopuštene kupovine na rok iz koje bi proizašla pravedna zarada. Primjerice, kada pristigne brod krcat vunom ili nekom drugom robom i trgovac nasluti da bi ta vuna mogla biti vrijedna pa je otkupi na rok, plati pristojbe i skladištenje te je počne prodavati vunarima na rok po višoj, ali primjerenoj, ograničenoj i pravednoj cijeni, a vunari potom proizvedu tkanine koje također prodaju na rok, nastaju okolnosti koje uključuju obilje troškova, rizika, brige, dobrobiti kupca i čitave zemlje, ali iznad svega dobru i poštenu namjeru. ${ }^{112}$ Takav oblik trgovanja na rok i zaradu koja iz njega proizlazi odobrio je, osnažuje Kotruljević svoje stavove, i prečasni brat Antonin, učitelj teologije i firentinski biskup, u svojoj Antonini. ${ }^{113}$ Kao što je već priopćila Janeković Römer, dubrovački je mislilac prilikom oslovljavanja Antoninove Antonine zapravo mislio na njegovo djelo Summa theologica moralis. ${ }^{114}$

\subsection{Etika u spisu o umijeću trgovanja}

Osim što se u njemu iskazao kao poznavalac povijesti filozofije, Kotruljević je svoj spis o umijeću trgovanja uvelike protkao etičkom tematikom. Podsjećam da su dosadašnja istraživanja etičke sastavnice tog Kotruljevićeva spisa ponajviše bila usmjerena na treću i četvrtu knjigu te pružala zaključke općenite naravi, a poduzeli su ih Martinović, Schiffler,

${ }^{111}$ Cotrugli, »Libro del arte dela mercatura«, libro II, capitulo 4 / Kotrulj, »Knjiga o vještini trgovanja«, knjiga II, poglavlje 4, pp. 221-222 [f. 52r]: »Ma per distinguere questo fato amplamente, perche ogi di lo mundo e tanto acommodato a quisto traficho e questo modo che quasi non si compra ne vende se non al tempo [...] Et illicito lo dicimo quando sia simpliciter malo rispeto dela intencione, come e dicto.«/p. 421 .

112 Ibid., pp. 222-223 [f. 52r-v] / pp. 421-422.

113 Ibid., p. 223 [f. 52v-53r]: »Et cossi lo aprova lo venerabile frate Anthonio, maistro in theologia, vescovo firentino nela sua Antonina.«/p. 422.

114 Ibid., p. 422, bilješka 67: »Antonin iz Firence (Antonino Pierozzi), Sancti Antonini archiepiscopi Florentini ... Summa moralis ad autographorum fidem nunc primum exacta, notis et observationibus illustrata, ur. Thoma M. Mamachi, Dionisio Remedelli, 2. dio, sv. I, Firenca: ex typographia Petri Caietani Viviani, 1756, sv. II, De avaritia, c. II-IV, De venditione ad terminum, c. VII.« Usprkos uputama koje je ponudila Janeković Römer, smatram da je zbog strukture tog djela potrebno pojasniti gdje je točno Pierozzi tematizirao trgovanje na rok. Taj talijanski dominikanac uistinu je opširno raspravljao o slučajevima u kojima je dopuštena prodaja na rok i to od drugog do četvrtog odlomka sedmog poglavlja (capitulum septimum) posvećenog lihvi i prodaji (»De usura in emtione, et venditione«), a koje se poglavlje nalazi unutar prvog naslova (titulus primus) posvećenog lakomosti ili gramzivosti (»De avaritia, et speciebus eius.«). Usp. Sanctus Antoninus de Florentia, »De usura in emtione, et venditione.«, capitulum septimum, II-IV, cc. 169-192, na cc. 172-177, u: Sanctus Antoninus de Florentia, »De avaritia, et speciebus eius.«, titulus primus, cc. 13-448, u: Sancti Antonini Archiepiscopi Florentini Ordinis Praedicatorum Summa moralis ad autographorum fidem nunc primum exacta, et adnotationibus illustrata, cura, et studio ff. Thomae Mariae Mamachi, Antonini Ceccherelli et Dionysii Remedelli, II. partis, volumen I. (Florentiae: Ex typographio Petri Caietani Viviani, 1756). 
Balić i Brčić Kuljiš, pri čemu je posljednje Balićevo istraživanje iz 2012. godine polučilo konstataciju da je čitav spis prožet etikom.

Da bih upotpunio dosadašnje spoznaje o etičkoj sastavnici spisa, u četirima potpoglavljima koja slijede obradit ću etički sadržaj svih četiriju knjiga Dubrovčaninova spisa. Pritom ću analizi sadržaja svake knjige posvetiti po jedno potpoglavlje. Budući da je čitava treća knjiga prožeta etikom i da o njoj postoje brojni zaključci opće naravi koji nisu bili popraćeni detaljnom analizom pojedinih etičkih stavova, njezin ću sadržaj izložiti u cijelosti. No, kada je riječ o preostalim trima knjigama, a budući da one ni naslovima ni sadržajem ne podrazumijevaju prisutnost etičke sastavnice, izdvojit ću i obraditi tek ona poglavlja u kojima prevladava etička tematika. Takvim će pristupom biti omogućeno donošenje zaključka o etičkom usmjerenju čitava spisa o umijeću trgovanja. Naposljetku, zbog toga što raspolažemo Balićevim istraživanjem filozofā i filozofskih izvora u Kotruljevićevu spisu, a onda i istraživanjem sadržanim u prethodnom potpoglavlju ovoga rada, napominjem da ću prilikom izlaganja Dubrovčaninovih stavova etičke naravi izostaviti podatke o vrelima iz kojih ih je crpio i usmjeriti se na stavove koje je oblikovao samostalno.

\subsubsection{Etika u prvoj knjizi spisa o umijeću trgovanja}

Da je sve četiri knjige svojega spisa o umijeću trgovanja namjeravao prožeti etičkom tematikom, Kotruljević je jasno naznačio već u predgovoru spisa. Osim toga, u njemu je otkrio porive za pisanje spisa unutar kojih je, prema mojem sudu, izložio i temeljne postavke svojih stavova o etičkom djelovanju trgovaca. Zbog toga smatram da je nužno izdvojiti one stavove iz predgovora koji su od presudne važnosti za razumijevanje sadržaja Kotruljevićeva spisa te njegovih etičkih nazora.

Naime, dubrovački je mislilac već prvom rečenicom predgovora odaslao nedvosmislenu poruku svim trgovcima svojega vremena koja bi trebala odjekivati njihovom svakodnevnicom i usmjeravati ih prema stjecanju znanja o umijeću trgovanja te življenju na etičkim temeljima, da učeni ljudi u većoj mjeri moraju uživati u izvrsnostima duše i vrline nego u tjelesnim stvarima i bogatstvu. ${ }^{115}$ Učeni ljudi pretakali su, nastavlja Kotruljević, svoja znanja stečena iskustvom $\mathrm{u}$ pismena ne bi li ih tako prenijeli mlađim naraštajima, jer je teško $\mathrm{i}$ gotovo nemoguće u kratkom vremenu spoznati brojne stvari, posebice ako se ne bavimo iščitavanjem

\footnotetext{
115 Cotrugli, »Libro del arte dela mercatura«, prefatio / Kotrulj, »Knjiga o vještini trgovanja«, predgovor, p. 115 [f. 1r]: »Vogliono li eruditi homini non tanto delectarsi nele fateçe del corpo e dela fortuna quanto dela prestancia d' animo et della virtute, la quale consiste nel haver experimentato multe cose, <... « $/$ p. 337.
} 
onoga što baštinimo od učenih ljudi. ${ }^{116}$ Kotruljević je pritom zaključio da su mladi ljudi nerijetko neotesani i nevješti u ljudskim stvarima i da zbog toga ne zaslužuju biti smatrani razboritima (non esser degna di comendatione dela prudentia). ${ }^{117}$ Potom je otkrio da je bio nemalo iznenađen lijenošću i neznanjem onih koji su zapostavili i prezreli duševna dobra ( $l i$ beni dela anima), kao i onih koji su svoju sreću i blaženstvo prepustili nestalnosti i varljivosti sudbine. ${ }^{118}$

Razlozi Kotruljevićeva ustrajanja na stjecanju i usavršavanju vrlina te na zanemarivanju tjelesnosti i izvanjskih dobara potječu iz točaka izloženih u nastavku predgovora, a koje čine temelj njegovih preostalih promišljanja o etičkom djelovanju trgovaca. Riječ je o sljedećim polazišnim točkama: 1) ljudi su sazdani od tijela i duše (de lo corpo e dala anima composti); 2) ljudi su svojim tijelom slični životinjama (siamo con bestie), a po duši Bogu (con Dio comuni); 3) ljudi tjelesno umiru (morimo con lo corpo), a duša im je besmrtna (immortali con l' animo). ${ }^{119} \mathrm{Na}$ temelju toga možemo zaključiti da je Kotruljević bio pobornik stjecanja i usavršavanja vrlina zbog božanske naravi i besmrtnosti ljudske duše, dok je bio protivnik inzistiranja na tjelesnosti zbog životinjske naravi i propadljivosti ljudskog tijela. Iz triju navedenih točaka proizlazi i sljedeći Kotruljevićev apel: ukoliko se čovjek želi služiti razumom i sposobnošću vlastita uma (la ragion e inteligentia mentale), on mora spoznavati zemaljske i vječne stvari (cose terrene [...] e eterne), jer mu je zadatak istražiti što treba činiti da ne bi pošao putem životinja (via di bestie), već putem besmrtnika (via deli inmortali). ${ }^{120}$ Dubrovčanin je pritom pokudio svakog čovjeka koji ne smjera putem besmrtnika i koji taj put ne traži u duševnim dobrima (beni del anima), već u krhkosti, slabosti i besmislenosti sudbine (fragilita, imbecillita et nela amentia dela fortuna), a zato što se vara u svojem nadanju i tako uzalud trati svoje životne napore. ${ }^{121}$

Kotruljevićeva ocjena tadašnjeg stanja u trgovanju počivala je na žalosti i boli koje je osjetio nakon što je uvidio i zatekao neukost, nered, nemarnost i prijevaru u trgovanju te na razočaranju time što je tako potrebna i korisna djelatnost pala u ruke neukim i nesređenim ljudima koji je vode bez načina, bez reda, sa zloupotrebama i bez zakona, dok je mudri ljudi

\footnotetext{
${ }^{116}$ Ibid., p. 115 [f. 1r]: »ma eciamdio di quele che experimentato et inteso anno comendare ala eterna memoria di scripture per seminare doctrina ali posteri. [...] Per che l' e dificile e quasi imposibile che in poco tempo e maxime non avendo lecto, se possa venire ad cognitione di molte cose.«/p. 337.

${ }^{117}$ Ibid., p. 115 [f. 1r] / p. 337.

${ }^{118}$ Ibid., p. 115-116 [f. 1r-v]: »E pertanto spesse volte mi sto con non poca admiratione d' animo dela pigritia overo institia de alcuni, li quali postposti e dispregiati li beni dela anima, ogni loro felicita e beatitudine hanno posto e colocato nela [in]constancia e delusione dela fortuna.«/p. 337.

${ }^{119}$ Ibid., p. 116 [f. 1v] / p. 337.

${ }^{120}$ Ibid., p. 116 [f. 1v] / pp. 337-339.

${ }^{121}$ Ibid., p. 116 [f. 1v] / p. 339.
} 
zapuštaju i zanemaruju, predajući je tako uništenju, kao plijen, kako ističe, neznalicama i kao lakrdiju skitnicama. ${ }^{122}$ Osupnut takvim stanjem često se spremao pisati o pravilima trgovačkog umijeća, stremeći uklanjanju pogrešaka i zloupotreba koje su trgovanje, kako tvrdi, srozale na razinu dosjetki (fazetie), besramnosti (turpiloquio), himbenosti (falsita), nevjere (infidelita), krivokletstva (spergiurio) i bezočnosti (inverecundia), a bez poštovanja (senza veneratione), bez znanja (senza culto), bez skromnosti (senza modestia), bez ozbiljnosti (senza gravita), bez ikakve ljudske odgovornosti (senza alcuno officio penitus de humanitate), a popraćeno svakim mogućim nedjelom i neotesanošću. ${ }^{123}$ Zbog toga se, dakle, napokon odvažio na pisanje spisa o trgovanju, nadajući se da će tako pridonijeti tome da ono bude utemeljeno na etičnom djelovanju i biti, kako kaže, namijenjeno onima koji imaju volju i želju stjecati časno, ne vrijeđajući pritom Boga ni bližnjega. ${ }^{124}$

Sudeći prema dosad izloženom, može se zaključiti da je dubrovački renesansni mislilac u predgovoru spisa o umijeću trgovanja odaslao barem dvije snažne poruke tadašnjim i budućim trgovcima, a koje su nedvosmisleno upućivale na nužnost trgovanja na etičkim principima. Te poruke moguće je uobličiti ovako: 1) svi ljudi, posebice trgovci, moraju usavršavati svoje vrline i tako poći putem besmrtnikā, istodobno nastojeći svoju tjelesnost staviti u podređen položaj; 2) trgovačko umijeće namijenjeno je prije svega onima kojima je cilj časno stjecanje te izbjegavanje bilo kakva nečasna djelovanja koje bi za posljedicu moglo imati povredu Boga i bližnjih. No, tim dvjema porukama nipošto nisu obuhvaćena sva značajna mjesta iz predgovora, a koja omogućavaju sagledavanje sadržaja spisa iz etičke perspektive. Njima bi svakako trebalo pridodati i Kotruljevićeve napomene o tome da se trgovanje zbog raznolikosti i promjenjivosti uobičajilo nazivati znanošću, umijećem ili disciplinom bez pravila (sciencia, arte, over disciplina irrigulare), ali da ono, priopćuje dubrovački mislilac, posjeduje pravila koja su po svojoj naravi opća i posebna. ${ }^{125}$ Prema Kotruljevićevu mišljenju, tako ustrojeno, dobro vođeno i ispravno obavljano trgovanje vrlo je poželjno ljudskom društvu, štoviše, neophodno mu je, zbog čega ga treba smatrati

${ }^{122}$ Ibid., pp. 116-117 [f. 2r]: »Dove nela qual arte di mercatura vi trovai lo culto inepto, disordenato, soluto e frusto, in tanto che mi condusse ad conpasione et dolsemi che questa arte tanto necesaria et tanto bisognosa et utille, sia divenuta in mano deli indocti e indisciplinati homini, et governata senza modo, senza ordene, con abusione et senza legie, e dali savii postposta et pretermisa et data in delaceratione et preda ali inscipienti et fabulla ali eranti.«/p. 339.

${ }^{123}$ Ibid., p. 117 [f. 2r] / p. 339.

${ }^{124}$ Ibid., p. 117 [f. 2v]: »<...> mi sono mosso a scrivere quelo sento dela arte de mercatura et eo maxime che non dubito che con lo scrivere ad vui faro proficto ad molti, et presertim ad quelli che anno volonta e desiderio d' aquistare con honore et senza ofendere Dio et lo proximo.«/ p. 339.

${ }^{125}$ Ibid., p. 117 [f. 2v]: »La quale mercatura probet che se chiami sciencia, arte, over disciplina irrigulare, per la sua multiforme mutabilita che ave e de havere in se, per le varieta occorente per giornata in essa, niente di meno ella have alcune singulari regole in se, in genere et in specie, <... « . / p. 339. 
najplemenitijim umijećem. ${ }^{126}$ Uz to, Kotruljević je smatrao da se teško baviti trgovanjem jer ono zbog svoje promjenjivosti zahtijeva da se svakoga dana i svakoga sata vlastitim umom istražuje što $\mathrm{u}$ pojedinom trenutku treba poduzeti. ${ }^{127}$ Naposljetku, valja istaknuti da Kotruljevićeve tvrdnje iz predgovora nedvojbeno otkrivaju njegovo uvjerenje $u$ to da iz trgovčeva usavršavanja vrlina proizlazi trgovanje kojem je cilj neokaljano i časno stjecanje, kao i to da u spisu ustroji trgovačko umijeće koje će počivati na općim i posebnim pravilima, jer će jedino u takvu obliku koristiti ljudskom društvu. Prema mojem sudu, iz navedenog slijedi da je dubrovački renesansni mislilac već u predgovoru čitaocima ponudio smjer čitava spisa o umijeću trgovanja i dodijelio mu etički predznak.

Da bih ukazao na to da je dubrovački renesansni umnik uistinu pridao etički predznak svojim razmatranjima o trgovanju, u nastavku ovog potpoglavlja usmjerit ću se na prisutnost etičke sastavnice u prvoj knjizi spisa o umijeću trgovanja, dakle u knjizi čijih je devetnaest poglavlja posvećeno promišljanjima o porijeklu i početku trgovanja. Premda bih na prisutnost etičke sastavnice mogao ukazati izdvajanjem Kotruljevićevih zapisa iz svakog od tih devetnaest poglavlja, ovom ću prigodom izdvojiti tek one u kojima je prisutnost etičkog sadržaja najizraženija. Takav pristup će, smatram, dostajati za donošenje zaključka o prisutnosti etičke sastavnice u čitavoj prvoj knjizi spisa o umijeću trgovanja. U svrhu ukazivanja na to da prva knjiga spisa sadrži etičku sastavnicu, poslužit ću se Kotruljevićevim zapisima iz prvog, drugog, trećeg i osamnaestog poglavlja. Iz prvog poglavlja izdvojit ću one Kotruljevićeve stavove koji potvrđuju da trgovanje treba počivati na etičkim temeljima, prilikom obrade drugog poglavlja usmjerit ću se na Kotruljevićevu odredbu trgovanja koje se mora odvijati na pravedan način, prilikom obrade trećeg poglavlja uputit ću na Kotruljevićeve zapise o onim obilježjima trgovca koja su temeljna i presudna za ispravno bavljenje trgovanjem, dok ću prilikom obrade osamnaestog poglavlja ukazati na one načine trgovčeva djelovanja koje je Kotruljević žestoko osudio i potpuno zabranio svakom trgovcu. Pritom napominjem sljedeće: premda je u prvoj knjizi spisa o umijeću trgovanja najzastupljenija etika, sadržaj te knjige otkriva i prisutnost Kotruljevićevih promišljanja koja je moguće sagledati iz perspektive filozofije odgoja. U ovom ću potpoglavlju ukazati na mjesta na kojima se promišljanja takve

\footnotetext{
${ }^{126}$ Ibid., p. 118 [f. 2v]: »La quale mercatura ben culta e drectamente observata e non solamente comodissima, ma eciamdio necessarissima al governo umano, et per consequens nobilissima dele arte. «/p. 341 .

${ }^{127}$ Ibid., p. 118 [f. 2v-3r]: »La qual per la multiforme varieta dele cose che ave in se, come e decto, l'e dificile, [...] perche ogni scientia ave li soi canoni et regole le qual observando l' omo diventa perfecto in quella. Sola mercatura consiste in la investigatione del proprio intelecto naturale da essere per di et per ora arbitrato. «/p. 341.
} 
naravi isprepliću s etičkim sadržajem, dok ću na prisutnost odgojnofilozofske sastavnice ukazati u zasebnom, točnije narednom potpoglavlju ovoga poglavlja.

Da prva knjiga Kotruljevićeva spisa sadrži etičku sastavnicu, zamjetno je već u njezinu prvom poglavlju koje, inače, nema zaseban naslov. Sadržaj tog poglavlja, a baš kao i sadržaj predgovora čitavu spisu, rasvjetljuje četiri polazišne točke Kotruljevićeva umovanja o umijeću trgovanja i pruža temelj za razmatranje njegovih promišljanja iz etičke perspektive. Prva Kotruljevićeva polazišna točka nalazi se u njegovu razumijevanju odnosa unutarnjeg umovanja (teorija) i vanjskog djelovanja (praksa). Kotruljević je, naime, prvo poglavlje prve knjige spisa o umijeću trgovanja otpočeo tvrdnjom da teorija ima primat nad praksom, jer je, kako kaže, prirodno i autoritetom filozofā (natural e, et per auctorita de philosophi) dokazano da je za dobro i prikladno upravljanje svim ljudskim stvarima neophodno da stvari najprije uobličimo te poredamo u umu, i to tako da se prilikom djelovanja dokaže da je za vanjsko djelovanje nužno prethodno unutarnje umovanje koje se naziva teorijom. ${ }^{128}$ Praksa je, bilježi Kotruljević, kći teorije, baš kao što je, ukoliko je uređena na prikladan način, teorija kći prirode. ${ }^{129}$ Uporište za takvo razumijevanje odnosa prirode, teorije i prakse Dubrovčanin je pronašao u filozofskim autoritetima, no posegnuo je i za božanskim autoritetom. Pritom je ukazao na to da je zbog grijeha naših praroditelja bio narušen prirodni red koji je Bog uspostavio prilikom stvaranja, zbog čega je za upravljanje svijetom i spas ljudskog roda bilo nužno utemeljiti pisane zakone kojima se čovječanstvo treba rukovoditi. ${ }^{130}$ No, ljudske mane uzrokovale su nepoštivanje prvih zakona predanih Mojsiju, zbog čega je bilo potrebno iznaći novi, evanđeoski zakon koji bi onima koji ga se pridržavaju pružao postojanu i vječnu nagradu. ${ }^{131}$ Uvažavajući filozofski i božanski autoritet, dubrovački je renesansni mislilac

${ }^{128}$ Cotrugli, »Libro del arte dela mercatura«, libro I, capitulo 1 / Kotrulj, »Knjiga o vještini trgovanja«, knjiga I, poglavlje 1, p. 120 [f. 3v]: »Cosa natural e, et per auctorita de philosophi chiaramente provata, che tutte le cose che apartengono al governo deli homeni acio che le sano ben recte et actamente governate, e neciessario che le siano prima formate nel intelecto et in tal modo hordinate che da poi quando si prociede al operacione si dimostri per evidentia che nançi che si procieda al operacioni exteriori, fu necessario la intelligencia interiore, la quale se chiama theorica.«/p. 343.

${ }^{129}$ Ibid., p. 120 [f. 4r]: »Et da lei [theorica] come da madre prociede la pratica, la quale non altramente e figlia dela theorica, che sia la theorica dela natura quando e ordinata con debiti modi che si rechiegono. «/p. 343.

${ }^{130}$ Ibid., p. 120 [f. 4r]: »<...> l' e necessario chel intenda, chel omnipotente Dio nela creatione del mundo hordino tutte le cose con le condicion loro naturalli. Et perche qualo hordine, fu depravato per lo peccato de li primi nostri parenti, fu necessario al governo del mundo e ala salute de la generatione humana, che s' agiognesse la legie scripta, la qual chiarisse per volunta expressa dal nostro Salvatore Idio, qual fusseno le cose che si dovesseno sequitare et versa vice qual fusseno quelle dele qualle si doveseno guardare.«/p. 343.

131 Ibid., pp. 120-121 [f. 4r]: »Et questa fu legie la qual fu data al popullo d' Isdrael per man di Moise, antiquissimo di tucti l' altri propheti. Et perche dopo multi tempi la dicta legie non fecie per difecto deli observanti quello fructo alu quale fu hordinata, fu consequetemente neciessario che per salute de la humana generacione intervenisse un' altra legie nova la qual et emendasse quela antiqua et eciamdio ciertifficasse per bene delli observatori quel premio di qualunque l' observasse fusse non caduto ne fragile, ma piu tosto solido et sempiterno: questa fu la legie evangelica.«/p. 343. 
zabilježio da je prilikom stvaranja svijeta uređeno da se prirodne stvari razumijevaju prije svega izvana uz pomoć urođene sposobnosti, a kada se to razumijevanje postigne, treba ga proslijediti prema vanjskom djelovanju i primijeniti ono što se u umu pokazalo korisnim za ljudski rod. ${ }^{132}$ Tim su putem, osnažuje Kotruljević svoje tvrdnje, pošli i prvi filozofi (primi philosophanti) koji su, iako pogani, bili obasjani prirodnim svjetlom i marljivo istraživali prirodni red te ga, nakon što su ga shvatili, proslijedili vanjskom djelovanju, zbog čega su bili prvi teoretičari, točnije promatrači prirodnog reda. ${ }^{133}$ Njihovi su nasljednici, bilježi Dubrovčanin u nastavku, bili praktičari koji su sproveli u djelo sve ono što su teoretičari velikim marom i zadivljujućim umom prethodno promislili i razumjeli. ${ }^{134}$ Tvrdnjama o prvim filozofima teoretičarima i njihovim sljedbenicima praktičarima Kotruljević je razotkrio upućenost u naslijeđe antičke grčke filozofije. Takvim razumijevanjem početaka filozofije on je, a kao što je Balić zaključio u svojoj studiji iz 2012. godine, »podijelio grčko razdoblje antičke filozofije«, smatrajući pritom prvim filozofima »one koje danas običavamo nazivati predsokratovcima«, a njihovim je nasljednicima, dodaje Balić, »zacijelo smatrao Sokrata, Platona, Aristotela, kao i filozofe koji su slijedili njihov nauk. « ${ }^{135} \mathrm{Uz}$ to što se razlikovanjem teoretičarā od praktičarā iskazao kao poznavalac antičke grčke filozofije, Dubrovčanin je odmah potom izrekao zaključak kojim je ponudio vizuru kroz koju je nužno promatrati njegov ukupni svjetonazor, a koji se posljedično odrazio i na njegove nazore o etičkim pitanjima. Zaključio je, naime, da je praksa kći teorije, teorija kći prirode, dok je priroda Božja kći. ${ }^{136}$ Tim zaključkom o hijerarhijskom poretku i uzročno-posljedičnom odnosu teorije i prakse Kotruljević je, kako je to još 1996. godine zaključila Ljerka Schiffler, pristao uz »Aristotelovu distinkciju teorijske filozofije kao oblika znanja i praktičke filozofije, kćeri teorije koja pruža

\footnotetext{
${ }^{132}$ Ibid., p. 121 [f. 4r-v]: »Et pertanto esendo hordinato nela creatione del mondo ale cose naturali quello che per instincto di natura intendere se devesse, prima da se quel che s' avia da fare da la banda di fuori et di poi con efecto et con opere. Et questa intelligentia fu data in sul hordine naturalle, inançi che si procieda agli acti exteriori. [...] Et avuta dicta inteligencia per instincto naturale et per consideration di multe cose, fo utile prociedere ali acti exteriori, admectere di fuori quello che intrinsecamente sera inteso per utilita de la humana generatione.«/pp. 343-344.

133 Ibid., p. 121 [f. 4v]: »Et per questa via se prociedere da primi philosophanti li quali ben che fuseno gintili, illustrati tamen dalo lume naturale investigorno con diligentia 1' ordine dela natura et intesolo si prociedectono nele opere exteriori in manera che si puo dire che queli primi predecti fusero theorici speculatori del ordine naturale.«/ p. 344.

134 Ibid., p. 121 [f. 4v]: »Et chi dopoi suciedetono fusseno li pratichi, i quali inteseno in opera quelo che predeciessor loro aviano con grande industria et maravigliosa intelligentia inteso et considerato.«/p. 344 .

${ }^{135}$ Balić, »Filozofi i filozofski izvori u Kotruljevićevu spisu o umijeću trgovanja«, p. $209 \mathrm{~b}$.

${ }^{136}$ Cotrugli, »Libro del arte dela mercatura«, libro I, capitulo 1 / Kotrulj, »Knjiga o vještini trgovanja«, knjiga I, poglavlje 1, p. 121 [f. 4v]: »Et pero posamo inferire che la pratica sia figliuola dela theorica et la theorica de la natura et la natura de Dio.«/p. 344
} 
norme izbora najvećeg dobra pojedinca i polisa, sreće i dobra života «. ${ }^{137}$ Da je Schiffler bila u pravu, svjedoči Kotruljevićev zapis koji je uslijedio. Zabilježio je da iz hijerarhijskog slijeda Bog-priroda-teorija-praksa proizlazi da je bez unutarnjeg umovanja i promišljanja o prirodnim stvarima posve nemoguće razumski napredovati prema bilo kojem plodu vanjskog djelovanja. ${ }^{138}$ No, pritom ne treba zanemariti činjenicu da čelno mjesto u njegovu uzročnoposljedičnom hijerarhijskom stupnjevanju ipak zauzima Bog. Znači, ispravno je tvrditi da bi prva polazišna točka Kotruljevićevih promišljanja o umijeću trgovanja, a time i onih promišljanja koja imaju etičku konotaciju, bila sljedeća: bez teoretiziranja o prirodi stvorenoj od Boga, nemoguća je praksa utemeljena na razumu.

Izravna posljedica takva Dubrovčaninova razumijevanja odnosa teorije i prakse bila bi da je i umijeće trgovanja uspostavljeno tako da teorija prethodi praksi. To se već može naslutiti iz njegova stava da umijeća (le arte), posebice praktična (che consisteno nela pratica), proizlaze iz prirode i da im se pridodaje promišljanje reda prirodnih stvari, dakle spoznaje stečene teorijskim uvidima. ${ }^{139}$ Premda bi to trebalo biti tako, nerijetko se, obrazlaže Kotruljević, događa da se postupa obrnutim redoslijedom, i to zbog toga što se u nekim umijećima pokazalo da se iskustvom i indukcijom dolazi do spoznaje općenitosti, a upravo su to zasade znanosti i umijećá. ${ }^{140}$ Da bi dokazao te tvrdnje, Dubrovčanin je iznio dva primjera koja su o takvim umijećima počivala na njegovu iskustvu. Prvo je travarstvo, jer je na temelju upotrebe istih trava na različitim mjestima, na različite načine, na različitim osobama i u različito vrijeme uvedeno pravilo i sveopća pouka. ${ }^{141}$ Drugo je govorničko umijeće (arte oratoria), budući da je i prije osmišljavanja toga umijeća bilo ljudi koji su po urođenoj sposobnosti bili toliko umješni u tom umijeću da su vrlo dobro znali što trebaju činiti u pojedinim dijelovima govora, i to onako kako se znalo nakon uspostavljanja pravila tog umijeća, a zato što su

137 Schiffler, »Praktično-etička dimenzija 'savršena trgovca' B. Kotruljevića«, p. 167. Isto vidi i u: Schiffler, »Etičko-humanistička misao Benedikta Kotruljevića«, p. 134.

${ }^{138}$ Cotrugli, »Libro del arte dela mercatura«, libro I, capitulo 1 / Kotrulj, »Knjiga o vještini trgovanja«, knjiga I, poglavlje 1, p. 121 [f. 4v]: »Con questo ordine prociedendo intendemo che al tuto sia inpossibile che sença intrenseca intelligencia et consideratione de cose naturali si possa ragionevelemente (sic!) prociedere in alcun fructo d'opere exteriori.«/p. 344.

${ }^{139}$ Ibid., p. 121 [ff. $\left.4 \mathrm{v}-5 \mathrm{r}\right] /$ p. 344.

${ }^{140}$ Ibid., pp. 121-122 [f. 5r]: »Et per ben che cussi sia, niente di meno appare alguna volta che si procieda ordine retrogrado, perche in algune arte si dimostra che per experiencia et per inductione di piu particolari si viene di piu universali, che sono cagioni delle sciencie et dela arte. «/p. 344.

${ }^{141}$ Ibid., p. 122 [f. 5r]: »<...> pero per la experiencia dele erbe in varii luogi diversamente et in diverse persone et in tempi sempre provate, como si da l' exempio delo riobarbaro lo quale di sua natura sempre in ogni loco ave purgato et purga la colera, se inducta regola et disciplina universale che ogni riobarbaro purga la colera. «/p. 344. 
pravila govorničkog umijeća, dodaje Kotruljević, proizašla iz upotrebe ili iz korištenja te prirodne vještine. ${ }^{142}$

Kotruljevićevo izlaganje o redoslijedu Bog-priroda-teorija-praksa, kao i njegovo izlaganje o dvojakoj mogućnosti uspostave umijećā, od općeg prema pojedinačnom (od teorije do prakse) i od pojedinačnom prema općem (od prakse do teorije), nezaobilazna su za razumijevanje sadržaja čitavog spisa o umijeću trgovanja. Uspostava znanosti i umijeća je, kako proizlazi iz Kotruljevićevih primjera koji se odnose na travarstvo i govorništvo, očito moguća i tako da se odvija u smjeru da praksa prethodi teoriji, dakle sljedećim redoslijedom: Bog-priroda (urođena sposobnost)-praksa-teorija. To potvrđuje i nastavak Dubrovčaninovih promišljanja o trgovanju. Naime, zapisao je da je trgovačko umijeće (arte mercatoria) na istom stupnju kao travarstvo i govorništvo te da je, ako se o njemu dobro promisli, proizašlo iz prirode. ${ }^{143}$ Upravo taj stav sačinjava drugu polazišnu točku Dubrovčaninovih promišljanja o trgovačkom umijeću: trgovanje je praktično umijeće koje potječe iz prirode, a čija se uspostava odvijala po redoslijedu Bog-priroda-praksa-teorija.

Nudeći u nastavku genezu i eksplikaciju nastanka ljudske potrebe za trgovanjem, Kotruljević je otkrio i treću polazišnu točku svojega spisa. Prema njegovim spoznajama, za začetak trgovanja presudno je bilo množenje ljudskog roda, koje je zatim dovelo do pojave bračnog združivanja, a onda i do ustroja država te potrebe za upravljanjem privatnim, ekonomskim te javnim aspektom života (tre stati o privato, oyconomico o publico), što je izrodilo potrebu za osmišljavanjem jednog općeg sredstva koje bi vrijedilo u svako vrijeme i na svakom mjestu te kojim bi se uzajamnom razmjenom moglo dobiti stvari potrebne za prehranu. ${ }^{144}$ Riječ je, dakako, o novcu. Dubrovački je renesansni mislilac pritom novac odredio kao sredstvo iz

${ }^{142}$ Ibid., p. 122 [f. 5r]: »Et quello medesmo dico nel arte oratoria, perche inançe ch' ela fuse trovata erano li homini delo instincto in tal manera in decta arte amaistrati, che facievano non men bene quelo che se riechideva in tute le parte dele oracioni chi si faciese poi che fu trovata l' arte, la quale prociedecte dalo uso di quel natural exercicio«. / p. 344.

${ }^{143}$ Ibid., p. 122 [f. 5r]: »Et in quisto grado ardiro a dire sia la nostra arte mercatoria la qual ebbe a chi ben considera l' origine de la natura, $<\ldots>\ll . /$ p. 345.

${ }^{144}$ Ibid., pp. 122-123 [f. 5r-v]: »<...> poi che la multiplicatione dela generation humana fu propagata sopra la terra. Pero che sendo necessaria la multiplication di multe cose a sustenamento del homo privato et dela famiglia sua, poi che sera congionto con la donna, et ultimamente poi che gli 11 ' a diventato civile et governatore dela republica, non poteva governarsi in qualunque deli tre stati o privato, oyconomico o publico, senca la comutatione dele cose che gli erano necessarie et altre che a lluy per ventura erano superabundanti, perche per ancora non era trovato per industria humana l' uso de la pecunia, la qual di poi fu mezo universale, senza la comutatione di cosa ad cosa como fu neciessario da principio inanci l' uso de decta pecunia. Multiplicando dipoi li homini et acsotigliandosi nel exercicio, come di natura loro, inteseno che con uno mezo universale poteano meglio satisfarre ad tucti e bisogno loro presenti et futuri con lo mezo universale che in ogni tempo et in ogni loco valesse, che con la vicissitudinaria commutatione le cose neciessarie al victo humano se potesseno avere.«/p. 345. 
kojega kao iz živog izvora proizlazi počélo trgovanja. ${ }^{145}$ Zbog toga je moguće zaključiti da je treća polazišna točka Kotruljevićevih promišljanja o trgovačkom umijeću sljedeća: novac je počélo trgovanja.

U preostalom dijelu prvog poglavlja prve knjige Kotruljevićeva spisa krije se i posljednja, dakle četvrta polazišna točka njegovih promišljanja. Nju je moguće oblikovati na sljedeći način: trgovanje nema prijeko potrebnu teorijsku osnovu. Dubrovčanin je najprije ponudio zaključak na temelju prethodnih spoznaja o tome da sve znanosti, poneke discipline i sva umijeća imaju začetak u prirodnoj sposobnosti, ali da su se neke, kao što dokazuju primjeri travarstva i govorništva, osnažile te uznapredovale upotrebom i praktičnom primjenom vještine. ${ }^{146}$ Trgovanje ima, dodaje Kotruljević, svoje prvo i istinsko porijeklo u prirodi, a zatim su ga ljudi proširili i razgranali tako da pomoću njega sobom lakše upravljaju, i to ne samo pojedinac, nego i kućanstva, obitelji, republike, kneževine, kraljevstva te carstva. ${ }^{147}$ Znači, Kotruljević je bio uvjeren da trgovanje crpi svoje porijeklo iz prirode, a da dobrobit koja proizlazi iz njega osjeća svatko ponaosob, kao i cjelokupno društvo. Dubrovački umnik zato je izrazio začuđenost time što trgovanje još uvijek nije bilo posebna znanost, no istodobno je zamijetio da su se u trajnoj praksi očitovali i razvili načini rada, postupci i običaji. ${ }^{148}$ Tako uspostavljeno trgovačko umijeće nadmašilo bi, uvjerava nas dubrovački mislilac, svaku disciplinu. ${ }^{149}$ Uzrok tome što ne postoji teorijska osnova i pisano pravilo za trgovanje koje je prirodno, potrebno i korisno, Kotruljević je pronašao u onima koji su ga kvarili te uzrokovali nered i prijestupe, čemu je i sâm svjedočio u doticaju s trgovcima svojega vremena. ${ }^{150}$ To mu je, kako kaže, bio glavni razlog zbog kojega se odvažio na to da

${ }^{145}$ Ibid., p. 123 [f. $5 \mathrm{v}$ ]: »Et pero trovarono questo mezo dela pecunia dal quale come da fonte vivo derivo el principio dela mercatura.«/p. 345 .

${ }^{146}$ Ibid., p. 123 [f. 5v-6r]: »Et in questo modo ad nostro proposito posian dire che benche d' istincto naturale ogni scientia e qualunque discipline et ogni arte habia avuto l' origine suo, niente di meno son pure alcune che, non obstante la dicta vera sentencia, si dimostrano havere havuto l' augmento et lo crescimento loro dal uso e dala pratica del exercicio di decte cose, come pare per li exempli decti de sopra.«/ p. 345.

${ }^{147}$ Ibid., p. 123 [f. 6r]: $\gg<\ldots>1$ ' arte mercantile dela qual intendiamo nela presente nostra opera tractare, per ben chel habia principio dela natura como e dicto, niente di meno, indocta dala necessitta dele cose pertinente al vivere humano fu per uso propagata et per multi seculi fin ala nostra eta derivata, in manera tale che si puo veramente dire che la prima e la vera sua origine si da essa natura et di poi per destreza deli homini propagata et amplifichata in manera tale che con essa et con lo suo exercicio multo piu facil se governano, non solamente li particular homini, ma ancora le case, le famiglie, le republice, principati, li regni e l'imperii. «/ p. 345 .

148 Ibid., p. 123 [f. 6r]: »Et per ben che di decto exercicio condocto in fin a nostri tempi non apaira alguna disciplina, niente di meno se ne vede per continuo exercicio l' uso e la pratica et la consuetudine, $<\ldots .<\ll$. p p. 345.

${ }^{149}$ Ibid., p. 123 [f. 6r]: »<...> la qual e di tal natura, apresso di colloro che non la violaseno, che secundo el mio parere avançarebbe ogni altra disciplina che di cio se ne potrebe dare.«/ p. 345.

${ }^{150}$ Ibid., pp. 123-124 [f. 6r]: »Et questo credo che sia stata la cagione el perche di questa arte si naturale, si necessaria e si utile non se ne trovi alcuno precepto scripto. Et io similmente con silentio me ne passarei se 
izloži sustavan nauk o umijeću trgovanja, što nije učinio, naglašava Kotruljević, nijedan pisac od stvaranja svijeta do njegova vremena. ${ }^{151}$ Dakle, Kotruljevićeva nakana prilikom pisanja spisa o umijeću trgovanja bila je ispraviti dotadašnju navadu neetičnog trgovanja, i to tako što će ponuditi teorijsku osnovu, a time i dovršiti niz Bog-priroda-praksa-teorija, te uspostaviti trgovanje kao umijeće.

Uspostavu teorijske osnove trgovačkog umijeća hrvatski je ranorenesansni mislilac otpočeo u drugom poglavlju prve knjige spisa, a koje je poglavlje naslovio »O biti i definiciji trgovine« (»De la quidita e definitione di mercatura«). Na početku tog poglavlja trgovanje je odredio kao umijeće ili disciplinu (arte overo disciplina) koja pravedno (iustamente) uređuje trgovačke poslove među ovlaštenim osobama, a zbog očuvanja ljudskog roda i s nadom $u$ dobitak. ${ }^{152}$ Dubrovčanin je, dakle, odredbu trgovanja zasnivao na etičkim postavkama, budući da je bio uvjeren $u$ to da trgovanje mora počivati na pravednosti. Osim toga, iz njegove odredbe proizlazi i to da postoje osobe koje nisu ovlaštene za bavljenje trgovanjem, kao i to da trgovanje ima opću korist za očuvanje ljudskog roda. Svoju odredbu smatrao je savršenom zato što sadrži ono što je općenito te ono što je razlikovno i posebno, ali i zato što je smatrao da upravo na njoj počiva njegov cjelokupni spis o umijeću trgovanja. ${ }^{153}$ Ipak, u nastavku poglavlja odlučio je dodatno rasvijetliti posebnosti trgovanja u usporedbi s drugim umijećima. Prva posebnost koju je Kotruljević detaljnije obrazložio u drugom poglavlju prve knjige spisa o umijeću trgovanja odnosila se na razlikovanje ovlaštenih od neovlaštenih osoba. Pritom valja naglasiti da su njegovi kriteriji za procjenu ovlaštenosti pojedinca za upuštanje u trgovačke poslove bili izrazito etičke naravi. Osobe mogu biti, poručuje Kotruljević, neovlaštene na dva načina: 1) s obzirom na dostojanstvo (nel primo modo illegiptimi respeto ala dignitate); 2) s obzirom na svoju nesposobnost (secundo modo sono persone inabili), a koja se može odnositi ili na nedostatnost njihove osobe ili na manjkavosti robe koju žele

mediante la pratica che o del decto exercicio non m' avessi inteso et manifestamente palpato e veduto el disordine et la transgresione che usano tuto giorno li mercanti di nostra eta. « / pp. 345-346.

${ }^{151}$ Ibid., p. 124 [f. 6r-v]: »La qual cosa e sucta potissima cagione che m' a indocto ad scrivere per ordine de doctrina de arte mercature quello che dala creation dal mundo in fino ala nostra eta per aventura da nisuno scriptore per ancora e suto facto.«/p. 346.

${ }^{152}$ Cotrugli, »Libro del arte dela mercatura«, libro I, capitulo 2 / Kotrulj, »Knjiga o vještini trgovanja«, knjiga I, poglavlje 2, p. 125 [f. $6 \mathrm{v}$ ]: $»<\ldots>$ ci pare dovere prociedere ala difinitione dala mercatura, la quale definiamo in questo modo: mercatura e arte overo disciplina intra le persone legiptime [legitime] iustamente ordinata in cose mercantili, pro conservatione dela humana generatione, con sperança niente di meno de guadagno. $\ll / p$. 347.

${ }^{153}$ Ibid., p. 125 [ff. 6v-7r]: »Et perche in questo consiste lo fundamento di tucta questa nostra opera, ci par dover chiarire un poco meglio tucte le parte poste nela diffinitione de la mercatura. Et pero dicimo che questa deffinictione secundo lo nostro parere l' e perfecta, perche l' e compresa dal suo genere in universali et dale sue diferentie in specie.«/p. 347. 
prodati. ${ }^{154} \mathrm{Na}$ prvi način, dakle s obzirom na dostojanstvo, neovlaštene su dvije vrste osoba: 1) one koje se ne mogu baviti trgovanjem bez povrede ugleda i zabrane, a to su kraljevi, knezovi, baruni, vitezovi, plemići i ostala gospoda; 2) one koje su primljene u sveti red. ${ }^{155} \mathrm{Na}$ drugi način, neovlaštene se osobe također dijele na dvije skupine: 1) oni koji su manjkavi ili nesposobni, a to su dječaci prije punoljetnosti, žene svake dobi, seljaci neovisno o dobi, štićenici pod tutorstvom, robovi, mahniti, rasipnici te druge neuke i nesposobne osobe; 2) oni koji prodaju manjkave stvari, a to su lopovi, pljačkaši, krivotvoritelji, alkemičari i njima slični. ${ }^{156}$ Izuzev neovlaštenosti za trgovačko poslovanje koja proizlazi iz tjelesne manjkavosti te iz dobnih, spolnih i klasnih razlika, dubrovački mislilac je, znači, za procjenu ovlaštenosti osoba uspostavio kriterije etičke naravi. To je razvidno iz, primjerice, zabrane poslovanja s obzirom na dostojanstvo, zatim zabrane zbog duševnih nedostataka (mahnitost, rasipnost), a onda i zabrane zbog neetičnog djelovanja pojedinaca (lopovi, pljačkaši, krivotvoritelji, alkemičari i slični).

Druga posebnost odredbe trgovanja o kojoj se Kotruljević imao potrebu dodatno očitovati također je etičke naravi i tiče se pojašnjenja pojma pravednog. Prema Kotruljevićevu mišljenju, u trgovanju pojam pravedno podrazumijeva kupovinu ili prodaju robe po pravednoj cijeni (preço iusto). ${ }^{157}$ Osim toga, Dubrovčanin je smatrao da postoji i roba kojom nije dopušteno trgovati unatoč postavljanju pravedne cijene. U takvu robu, kako ističe, spadaju svete, založene, položene i ukradene stvari. ${ }^{158}$ Naposljetku, dubrovački je mislilac naglasio da je uvijek i svakome strogo zabranjeno trgovati otrovima i kockama, kao i stvarima koje se kupuju za vlastitu ili obiteljsku upotrebu, kao i onima koje se kupuju kao dar drugima. ${ }^{159}$

Treće poglavlje prve knjige spisa o umijeću trgovanja sljedeće je od onih kojima ću se poslužiti da bih ukazao na to da je čitava prva knjiga Kotruljevićevih promišljanja prožeta etičkom tematikom. U njemu je dubrovački umnik raspravljao o duševnim i tjelesnim

\footnotetext{
154 Ibid., p. 126 [f. $7 \mathrm{r}-\mathrm{v}] /$ p. 348.

155 Ibid., p. 126 [f. 7r]: »<..> persone inlegitime intendiamo in duo modi, cio e quele persone che non posono exercitare la dicta arte sença preiudicio et sença prohibicione et in questo intendiamo li re, principi, baroni, cavalieri, gentilomeni et tuti altri signori ali quali e interdicto l' exercicio del acto mercantile, secundo la sententia di ragion civile, $[\ldots]$ L' altre persone illegitime sono chi e instituto in qualche hordene sacro, $<\ldots>\ll /$ p. 348 .

156 Ibid., pp. 126-127 [f. 7v]: »Quilli li quali dal lato dele persone loro hano mancamento e sono inabili, sono fanciulli nançi la eta legiptima, done in ogni eta, rustichi, pupilli socto tutorie, servi, furiosi, prodigi et altre persone ignorante et inabili. L' altri sono inabili per respeto del mancamento dela cosa et questi sono ladri, robadori de strata, contrafacitori dele cosse, archimiste et loro simili.«/ p. 348.

${ }^{157}$ Ibid., p. 127 [f. 7v] / p. 348.

${ }^{158}$ Ibid., p. 127 [f. 7v]: »In cose mercantili, si dice per la diferencia dele cose le quali non sono contractabili mercantilmente et queste cose sono cose sacre et cose impegnate, dipositate over furate «. / p. 348 .

${ }^{159}$ Ibid., p. 127 [f. 7v]: »<..> cose prohibite sempre et in ogni tempo ed ad ognuno, como sono veneni, dadi et similia, over cose che si comprano per uso suo o di sua famiglia o per donare ad altri.«/pp. 348-349.
} 
obilježjima trgovca ili, kako glasi naslov poglavlja, »O svojstvima trgovčeve osobe« (»Dela qualita dela persona delo mercante «). Prije negoli se usmjerim na obradu etičkog sloja u tom poglavlju, ističem da je iz njega moguće iščitati i zastupljenost još barem jedne filozofske discipline: filozofije odgoja. U nastavku ću upozoriti na ona mjesta u trećem poglavlju na kojima se etički sadržaj isprepliće sa sadržajem koji pripada filozofiji odgoja. Ta ću mjesta detaljnije obraditi u narednom potpoglavlju ovoga poglavlja.

Treće poglavlje prve knjige spisa o umijeću trgovanja Dubrovčanin je otpočeo navođenjem uzrečice uglednih pisaca o tome da nižim stvarima vladaju utjecaji viših nebeskih tijela, a koja tijela mogu, po Božjem redu, svim nižim stvarima propisivati pravila i način djelovanja. ${ }^{160} \mathrm{Uz}$ to, smatrao je da su ljudi pod brojnim utjecajima zviježđa skloniji obavljanju različitih poslova. ${ }^{161}$ Potom je zabilježio da isključivo ljudi mogu umaknuti utjecaju nebeskih tijela, i to zato što im je Bog dao tu povlasticu. ${ }^{162}$ Nakon toga je ustvrdio da su jedino ljudi, a ponajprije zahvaljujući svojoj slobodnoj volji (libero arbitrio) koja im je dana pri stvaranju duše, izvrsnom umu (ingiegno egregio) i razboritosti (prudentia), slobodni (liberi) oduprijeti se svakoj sklonosti ili sposobnosti koja bi ih na različite načine priklanjala mijenama položaja zvijezda. ${ }^{163}$ Početak trećeg poglavlja spisa o umijeću trgovanja otkriva Kotruljevićev stav o položaju čovjeka u svijetu, a koji je presudan za daljnja Kotruljevićeva promišljanja koja se odnose na etiku. Čovjek je, dakle, za njega jedino biće koje je slobodno jer posjeduje Bogom danu slobodnu volju, izvrstan um i razboritost, te je zbog toga u mogućnosti oduprijeti se utjecajima koji viša nebeska tijela inače vrše na sve niže stvari. Iz takva razumijevanja čovjekova položaja može se zaključiti da je Kotruljević zastupao stav da je čovjek jedino biće koje ima mogućnost samoodređivanja te da je čovjek secundus Deus ili Deus in terris, a što je karakteristično za filozofsku misao nastalu u renesansi.

U nastavku trećeg poglavlja prve knjige Kotruljević je izložio smjernice za odgajanje trgovaca, čime je etičkoj pridružio sastavnicu koja se odnosi na filozofiju odgoja. Unatoč

${ }^{160}$ Cotrugli, »Libro del arte dela mercatura«, libro I, capitulo 3 / Kotrulj, »Knjiga o vještini trgovanja«, knjiga I, poglavlje 3, p. 129 [f. 8v]: »E antica et cielebrata sentencia degli idonei auctori che le cose inferiori siano governate dali influxi di corpi supercielesti i quali possono tanto per l' ordene dato da Dio in tucte le cose inferiori, che le dano regola et modo.«/p. 350.

${ }^{161}$ Ibid., p. 129 [f. 8v]: »<...> che benche [gli homini] sianno inclinati secundo li varii influxi de le constelationi piu ad uno exercicio che ad un altro, $<$... $>$ «. / p. 350.

162 Ibid., p. 129 [f. 8v]: »Dal qual non anno possança di poterse guardare se non solamente gli homini i qual soli ano questo brivilegio (sic!) da Dio, <... « / p. 350.

${ }^{163}$ Ibid., p. 129 [ff. 8v-9r]: »<..> niente di meno per la dignita delo libero arbitrio che e data nela creation del anima sono si liberi che possono resistere ad ogni dispositione o abilita che li inclinasse variamente secondo la varieta de le diverse constelacioni. [...] per ben che sia difficile il potere fare questa resistencia per tal inclination che inchina osai, niente di meno e non e impossibile el poterlo fare, specialmente dagli homeni i quali si trovano doctati d' ingiegno egregio fuor degli altri, pero che con la loro prudentia resisterano ad tal inclinacione in modo tale che non saranno ne menati ne governati da quela.«/p. 350. 
tome što je smatrao da je čovjek jedino biće koje je slobodno oduprijeti se nebeskim utjecajima, otpor koji čovjek može pružati utjecajima zviježđa na njegove sklonosti nerijetko je popraćen teškoćama koje uzrokuju to da se pojedini ljudi posvećuju obavljanju poslova u kojima u konačnici ne ustraju. ${ }^{164}$ Kotruljević je rješenja tih teškoća vidio upravo u ispravnim odgojnim postupcima, čemu ću posvetiti pozornost u narednom potpoglavlju ovoga rada.

U prvoj knjizi spisa o umijeću trgovanja etički sadržaj prisutan je i u osamnaestom poglavlju. Kotruljević je to poglavlje naslovio »O stvarima koje su trgovcima potpuno zabranjene« (»De cose prohibite omnino ali mercadanti«). Na njegovu početku upozorio je na to da su trgovcima zabranjena brojna djelovanja koja su drugima dopuštena, a zato što se nerijetko radi o djelovanjima koja su nespojiva sa skromnošću, postojanošću, ozbiljnošću i ćudorednošću (modestia, saldeça, gravita et morigeratione). ${ }^{165}$ Ta obilježja, nastavlja Kotruljević, trgovac mora trajno nositi u sebi i očitovati ih prema van, budući da tijekom obavljanja svojega posla mora steći povjerenje brojnih ljudi. ${ }^{166}$ Prema Kotruljevićevu mišljenju, trgovci su gotovo poput riznica ljudskih vrijednosti (li mercanti sono quasi l' archa delo thesauro humano). ${ }^{167}$ Trgovac za njega mora biti čestit i uzdržan (honesto et moderato), zbog čega ne čudi da mu je Kotruljević odlučio zabraniti djelovanja koja su drugima ponekad dozvoljena. ${ }^{168}$

U nastavku osamnaestog poglavlja prve knjige Kotruljević je iznio deset načina djelovanja koji su trgovcima zabranjeni. Prvi od njih je igranje igara na sreću, kao što su, primjerice, kockanje i kartanje. ${ }^{169}$ Za razliku od igara na sreću, Kotruljević je odobravao igre koje, kako kaže, vježbaju tjelesne vrline, kao što su, primjerice, igre s loptom, bacanje motke ili koplja, trčanje i hrvanje, budući da se ljudi njima bave zbog vježbe i osobne vrline. ${ }^{170}$ Najgore je, ističe Kotruljević, ako čovjek stekne naviku igranja igara na sreću zbog lakomosti (avaricia), jer se to protivi čestitu trgovačkom životu (l'onesto vivere mercantile) i smrtni je grijeh

\footnotetext{
${ }^{164}$ Ibid., pp. 129-130 [f. 9r]: »Ma prociedera tal disistencia con difficulta et rivolgiendosi ad altro exercicio che a quelo che si trovano pro predecto influxo supercieleste naturalmente inclinati el piu dele volte non vi perseveranno. «/p. 350

${ }^{165}$ Cotrugli, »Libro del arte dela mercatura«, libro I, capitulo 18 / Kotrulj, »Knjiga o vještini trgovanja«, knjiga I, poglavlje 18, p. 191 [f. 38r] / p. 399.

166 Ibid., p. 191 [f. 38r]: »< _..> che deve al continuo nel mercante non solamente essere intrinsecus, ma eciamdio aparera ab extra. Respecto anche ala fede che deve havere da ogni generationi de homini, <...>«. / p. 399.

${ }^{167}$ Ibid., p. 191 [f. 38r] / p. 399.

${ }^{168}$ Ibid., p. 191 [f. 38r]: »Et pero non se de maravigliare nesuno se lo mercante lo volemo honesto et moderato et prohibimo le cose che alcuna volta et alcun tempo son ad altri permisse.«/ p. 399.

169 Ibid., p. 191 [f. 38r]: »Et primo e prohibito alo mercante lo gioco de fortuna come sono dadi, carte, et reliqua.«/p. 399.

${ }^{170}$ Ibid., p. 191 [f. 38r]: »Non dico giochi che si fanno per l' exercicio dela virtu del corpo, come gioco della palla, lanciar di palo o dardo, il correre, lo loctare et similia, perche questo si ffa per lo exercicio et virtu personale«. / p. 399
} 
(peccato mortale). ${ }^{171}$ Osim toga, tijekom igranja igara na sreću često su, tvrdi Kotruljević, prisutni i sljedeći grijesi: krivokletstvo (pergiurio), kao i laži (busie), psovke (blasfemie), prijevare (inganni) te krađe (rapine). ${ }^{172}$ Drugi način djelovanja koji je Kotruljević zabranio trgovcima bilo je opijanje vinom ili prejedanje. ${ }^{173}$ To je zabranjeno zato što je trgovac, smatra Kotruljević, u većoj mjeri javna osoba nego drugi ljudi. ${ }^{174} \mathrm{U}$ skladu s tim, Kotruljević je istaknuo da bi trgovac trebao izbjegavati opijanje i prejedanje, budući da je to nečestito (desonesto) i budući da ga dovodi na loš glas (infamia). ${ }^{175}$ Osim toga, iz opijanja proizlaze, misli Kotruljević, i sljedeće posljedice po zdravlje trgovca: postaje lijen, troma duha, sanjiv, drhte mu glava i ruke, zapliće mu se i povećava jezik, ne može začeti djecu, gubi vid i zahvaćaju ga brojne i različite bolesti, kao što su trbobolja, bolesti želuca, vrućica, ulozi, vodena bolest. ${ }^{176} \mathrm{Na}$ kraju izlaganja o tom zabranjenom načinu djelovanja, Kotruljević je zaključio da trgovac mora biti umjeren (temperato) u jelu i piću. ${ }^{177}$ Sljedeći, dakle treći zabranjeni način djelovanja je zastupanje drugih u parnicama i parničenju, kao i pripremanje sporova. ${ }^{178}$ Kotruljevićevo obrazloženje zabrane takva djelovanja počivalo je na tome da trgovac ne treba parničiti, bilo za svoje potrebe bilo za potrebe drugih ljudi. ${ }^{179}$ Četvrti zabranjeni način djelovanja odnosi se na razgovor sa zlim i ozloglašenim ljudima, budući da oni ne samo da kvare običaje ljudi i odvraćaju od dobra ophođenja, nego mogu biti i uzrokom propasti. ${ }^{180}$ Kao peti zabranjeni način trgovčeva djelovanja Kotruljević je naveo bavljenje alkemijom, i to zbog toga što je smatrao da se trgovac treba baviti samo postojanim i sigurnim

${ }^{171}$ Ibid., p. 191 [f. 38r] / p. 399.

172 Ibid., p. 192 [f. 38r] / p. 399.

173 Ibid., p. 192 [f. 38v]: »Secundo, e prohibito alo mercante imbriacarsi di vino over di çibo, <...>«. / p. 400.

${ }^{174}$ Ibid., p. 193 [f. 38v-39r]: »Lo quale vicio l' e piu abominabile nelo mercante che neli altri homini, perche lo mercante l' e piu bublica (sic!) persona che li altri et per consequens li altri homini, <..> «. / p. 400.

175 Ibid., p. 193 [f. 39r]: »Lo mercante, per contrario, al continuo de comparer in publico per le facende chel tirano et non puo scondere lo male lo quale e cosi come glie desonesto, li puo esser nocivo per li erori chel puo commetere a llui molto damnosi. Il perche, per fugire lo opprobrio, deve lo mercante fugire la crapula dela quale oltra la infamia e li danni particulari che li possono et sogliono el piu dele volte avenire, $<\ldots>$ «. / pp. $400-401$.

176 Ibid., p. 193 [f. 39r]: »<...> seguitane anche pigricia, groseça de inçegno, sonno, tremore di capo et mano, ligar et ingrosare la lingua, non possere ingenerare, perdere la vista et in fine multe et varie infirmita fianchi, stomachi, febre, gothe et idropisi, le quali sonno molestissime ad hogni humano et maxime al mercante.«/p. 401.

${ }^{177}$ Ibid., p. 194 [f. 39v]: »Deve essere adunche temperato lo mercante per le ragioni sopra dicte nel mangiare et nelo bevere.«/p. 401

178 Ibid., p. 194 [f. 39v]: »Tercio, alo mercante l' e prohibito l' essere procuratore ad lites et litigare o vero comprare piaidi.«/p. 401.

${ }^{179}$ Ibid., p. 194 [f. 39v]: »Se per lo suo bisognio e decto non litigi, che devemo dire per alienis?«/ p. 401.

${ }^{180}$ Ibid., p. 194 [f. 39v]: »Quarto, e l' e prohibito alo mercante la conversacione di cativi et infami, li quali non solamente son caxione a discostumare et divertere li homini dal ben fare, ma anche possono essere cagione de disfacione per multi modi.«/p. 401. 
stvarima, kao i pouzdanim obavijestima, a ne onim što bi ga moglo dovesti do propasti. ${ }^{181} \mathrm{Uz}$ to, trgovcu je zabranjeno i nadmetanje, budući da je ono, smatra Kotruljević, lakoumno te skupo (ligiero et di spesa), i budući da ga skreće s pravoga puta (desviamento), a trgovac bi trebao uživati u razmišljanju o vlastitoj dobrobiti (la sua salute). ${ }^{182}$ Nakon toga, Kotruljević je istaknuo da se trgovac ne smije baviti krijumčarenjem, kako u svojoj tako ni u drugim zemljama, jer je to često izvor velikih nevolja. ${ }^{183}$ Također, trgovcu je zabranjeno, piše Kotruljević, varati (commetere falsita) na robi, vagi i mjeri, kao i prilikom razmjene roba, jer to čine lopovi (sono acti di ladri). ${ }^{184}$ Kao deveto, Kotruljević je naveo da je trgovcu zabranjeno imati previše ispraznih i površnih prijatelja ili onakvih ljudi koji bi mu mogli naškoditi. ${ }^{185}$ Trgovac se ne smije upuštati u prijateljstva (amicicia) do te mjere da nije u mogućnosti odbiti činjenje usluga. ${ }^{186}$ Naposljetku, Kotruljević je istaknuo i to da trgovca ne smije obilježavati rasipnost (prodigalita). To je potkrijepio primjerom u kojem je naglasio da je rasipnost trgovaca jednako nepoželjna kao lakomost (avaricia) gospode i uzvišenih ljudi. ${ }^{187}$ Osim toga, upozorio je na to da trgovac mora izbjegavati rasipnost i zbog toga što ona, kako kaže, razara i uništava stjecanje bogatstva, koje je cilj trgovčeva zanimanja. ${ }^{188}$

\subsubsection{Etika u drugoj knjizi spisa o umijeću trgovanja}

Druga knjiga Kotruljevićevih umovanja o trgovanju također sadrži etičku sastavnicu. Taj opsegom najskromniji dio Dubrovčaninova traktata do današnjeg je dana neprestano izmicao pažnji istraživačā filozofske baštine. Razlog za to trebalo bi, prema mojem sudu, potražiti u tome što je riječ o knjizi čiji naslov odiše teološkim prizvukom, budući da je dubrovački mislilac već njime dao do znanja da će u četirima poglavljima te knjige raspravljati o vjerskom aspektu trgovčeva života (»Comincia libro secundo dela religione che convene alo

\footnotetext{
${ }^{181}$ Ibid., p. 194 [f. 39v]: »Quinto, l’ e prohibito alo mercante lo fare del archimia, perche l' arte delo mercante e ad inquidere cose stabile, certe et avisi firmi, et non quelle che possono esser cagion di disfacimento suo. $/ \mathrm{p}$. 402.

182 Ibid., pp. 194-195 [f. 39v] / p. 402.

${ }^{183}$ Ibid., p. 195 [ff. 39v-40r]: »Septimo, lo mercante per nulla, tanto in la terra sua quanto aliena non de fare contrabandi, perche sono multe volte cagion di gran disfacimento«. / p. 402.

${ }^{184}$ Ibid., p. 195 [f. 40r] / p. 402.

185 Ibid., p. 195 [f. 40r]: »Novo, l' e prohibito alo mercante havere troppi amici vani et poveri et homini che li possono essere damnosi.«/p. 402.

${ }^{186}$ Ibid., p. 195 [f. 40r]: »Et non si vol astringere con homini tanto in amicicia che alguna volta non possa dire de non quando l' e dimandato servicio.«/p. 402.

${ }^{187}$ Ibid., p. 195 [f. 40r]: »Decimo, non deve essere prodigo, pero che come l' avaricia l' e magiore vicio neli signori et magniffici homini che la prodigalita, cosi la prodigalita l' e multo piu gran vicio imo omnino prohibito neli mercanti che l' avaricia.«/p. 402.

188 Ibid., p. 195 [f. 40r]: »Et percio vole schivare lo mercante, perche l' e contraria al tuto al fine suo et ala sua professione, lo quale e ad essere richo, e la prodigalita destrue le richece et anichila.«/p. 402.
} 
merchante«). Međutim, njegovo bavljenje temama religijskog karaktera ni najmanje ne treba čuditi, posebice ako u obzir uzmemo stavove koje je zastupao u predgovoru cjelokupnoga spisa i u prvoj knjizi spisa, a u kojima nije skrivao svoj kršćanski svjetonazor. Da bih ukazao na prisutnost filozofske, točnije etičke sastavnice u drugoj knjizi spisa, u nastavku ovog potpoglavlja izdvojit ću Kotruljevićeve zapise etičke naravi iz njezina predgovora i iz triju od četiriju njezinih poglavlja. Pritom ću najveću pozornost posvetiti njezinu predgovoru i četvrtom poglavlju, jer je u njima etički sloj najzastupljeniji, dok ću iz prvog i trećeg poglavlja izdvojiti tek pogdjekoji etički stav. Time će, smatram, biti omogućeno donošenje valjanog zaključka o etičkoj orijentaciji i druge knjige Kotruljevićeva spisa o umijeću trgovanja. Iz predgovora ću izdvojiti Dubrovčaninove stavove koji upućuju na važnost trgovčeva posjedovanja i njegovanja mudrosti, potom ću iz sadržaja prvog poglavlja ukazati na ulogu koju pohađanje mise ima za trgovčev etički život, zatim ću iz sadržaja trećeg poglavlja obrazložiti etičke implikacije davanja milostinje, dok ću iz četvrtog poglavlja upozoriti na dopušteno trgovčevo djelovanje u zajednici, a koje bi za njega trebalo biti pravedno.

Predgovor drugoj knjizi spisa o umijeću trgovanja pruža uvid u Kotruljevićevo komplementarno razumijevanje vjerske sfere trgovčeva života i njegova etičkog djelovanja. U njemu je Kotruljević najprije ponudio vlastito viđenje važnosti prisustva vjerskog sadržaja u životu. Naime, na početku predgovora naveo je podatak da se brojna ljudska svojstva mogu susresti i kod divljih životinja: glas, smijeh, ljubav prema družici i potomstvu, pribavljanje i čuvanje hrane za budućnost, kao i prepoznavanje škodljivih tvari i ljekovitih trava. ${ }^{189}$ Ponad drugih životinja postavio je pčele, o kojima je tvrdio da se razboritima pokazuju time što prikupljaju med, poštuju svojega kralja, razvrstavaju se i uređuju svoje stvari. ${ }^{190}$ Kotruljević je vjeri dodijelio razlikovnu ulogu prilikom uspoređivanja ljudi i životinja, jer unatoč tome što su životinje gotovo u svim stvarima slične čovjeku, one zasigurno ne poznaju vjeru. ${ }^{191} \mathrm{Za}$ donošenje takva zaključka presudan je bio i sljedeći stav: sve životinje imaju razum da bi

\footnotetext{
${ }^{189}$ Cotrugli, »Libro del arte dela mercatura «, libro II, prohemio / Kotrulj, »Knjiga o vještini trgovanja«, knjiga II, predgovor, p. 199 [ff. $41 \mathrm{v}-42 \mathrm{r}$ ]: »<...> pero che l' altre cose chel huomo a, eciamdio neli altri animali bruti se trobano: la vocie nela qualle par se intenda l' un l' altro, nel rider pareno chareçando l' un l' altro, conformi nel amare le conjugie, li figlioli et cet., nel provedere del cibo et conservare di quello in futuro, nel cognoscere cose loro nocive et le mediche herbe.«/p. 405.

${ }^{190}$ Ibid., p. 199 [f. 42r]: »Et in questo et multe altre cose appareno prudenti le ape: congrando lo mele, lo re loro honorano, disponenose et hordinano.«/p. 405.

191 Ibid., p. 199 [f. 42r]: »Sendo in multe et quasi in tute le altre cose con li bruti communi li homini, certe ignorano la religione.«/p. 405.
} 
sačuvale život, a čovjeku je dan razum da bi ga produžio. ${ }^{192}$ Štoviše, čovjek ima, tvrdi Kotruljević, savršen razum (perfecta ragione) koji nazivamo mudrošću i koji je ono zbog čega je čovjek izuzetan, jer je samo njemu omogućeno razumijevanje božanskih stvari. ${ }^{193}$ Znači, Kotruljević je bio uvjeren da se čovjek od životinje razlikuje po tome što posjeduje mudrost, a zbog čega je sposoban razmatrati božanske stvari i prakticirati vjeru. Nakon što je istaknuo da vjeru moramo štovati, dubrovački je mislilac ustvrdio da onaj tko ne prihvaća vjeru slijedi život divljih životinja i da niječe ljudskost, pa zaključio da čovjek mora težiti i žudjeti za vjerom i mudrošću. ${ }^{194}$ Da bi ukazao na međusobnu uvjetovanost ljudske mudrosti i vjere, Kotruljević je zabilježio da se brojni ljudi prevare onda kada ili uzimaju vjeru bez mudrosti (la religione pigliano sença sapiencia) ili mudrost bez vjere (la sapiençia sança religione), jer jedno bez drugoga ne može. ${ }^{195}$ Predgovor drugoj knjizi Dubrovčanin je dovršio najavom da će u narednim poglavljima knjige trgovcima ponuditi nekoliko djelotvornih lijekova, budući da rade brojne dvojbene poslove, te da će ih, ukoliko se budu pridržavali tih lijekova, Bog privesti spasenju. ${ }^{196}$

U prvom poglavlju druge knjige spisa o umijeću trgovanja Kotruljević je, kako je prethodno najavio, ponudio prvi od spomenutih djelotvornih lijekova za razrješavanje dvojbi s kojima se trgovci susreću. Da je riječ o misi, otkrio je već u naslovu poglavlja: »O misi« (»Dela messa «). U tom je poglavlju također zamjetna etička komponenta. Kao što smo se već imali priliku uvjeriti, Kotruljević je njegovanje vjerskog života poimao kao ispravnu primjenu ljudske mudrosti, pa čak i kao uvjet ljudskosti. Zato ne iznenađuje da je poglavlje o misi otpočeo stavom da je svaki ljudski naraštaj odvajkada održavao vjerske obrede, ali su se naraštaji razlikovali u razumijevanju Boga, kao i u počastima, žrtvama i svečanostima. ${ }^{197}$ Nakon opsežne kritike rimskog mnogoboštva, dubrovački je mislilac izrazio svoju naklonost katoličkoj vjeri, koja je uslijedila nakon raznovrsnih žrtava po različitim vjerskim zakonima i

192 Ibid., p. 199 [f. 42r]: „Et cusi credo ad universi animali essere data la ragione ad conservare la vita, ma homo ad propagare.«/ p. 405.

${ }^{193}$ Ibid., pp. 199-200 [f. 42r]: »Et perche nel homo e perfecta ragione, la chiamamo sapiencia, la quale in questo solo egli e eximia, che ad esso solo e dato ad intendere le cose divine, $<\ldots$.. « . / p. 405.

${ }^{194}$ Ibid., p. 200 [f. 42r]: »Devemo adunche servire ala religione, la quale chi non recieve e se giecta in terra et sequendo la vita de bruti animali renega la humanita. [...] Il perche l' homo deve esser cupido et appetente de religione et sapiencia.«/p. 405.

${ }^{195}$ Ibid., p. 200 [f. 42r] / pp. 405-406.

196 Ibid., p. 200 [f. 42v]: »<..> perche avendo multi scropulosi ligamenti e di bisogno habino li modi deli scogliere. [...] ma habiamo trovato alcuni medicamenti efficacissimi li quali servando, non dubito che Idio mediante le sancte opere li fara penitenti, et per consequens salvi.«/ p. 406.

${ }^{197}$ Cotrugli, »Libro del arte dela mercatura «, libro II, capitulo 1 / Kotrulj, »Knjiga o vještini trgovanja«, knjiga II, poglavlje 1, p. 201 [f. 42v]: »In ogni tempo et ogni etate et da ogni generacione di homini e stato servato lo culto dela religione, [...] diversifficando pero l' intendere di Dio variamente et cosi ano servato vario modo di veneratione, sacrificii et cerimonie.«/p. 407. 
mišljenjima i koja je iznašla misu u kojoj se posvećuje pravo tijelo Kristovo. ${ }^{198}$ No, završni dio poglavlja sadrži Dubrovčaninovo obrazloženje nužnosti trgovčeva pohađanja mise i uloge koju misa ima za etičku dimenziju trgovčeva života. Pribilježio je, naime, da trgovci trebaju usvojiti običaj i navadu svakodnevno slušati misu jer taj sakrament, primjerice, tješi dušu (confortativo dela anima), prosvjetljuje um (illuminativo delo intelecto), čisti od porokā (purgativo deli vicii), potvrđuje vrline (ratifficativo dele virtu), liječi zablude (medico deli errori) te upućuje na dobar put (dispositivo ala bona via). ${ }^{199}$ Poglavlje je zaključio tvrdnjom da misa čuva od neprestanog griješenja i zlih djela, kao i to da pere lake grijehe pomoću opće ispovijedi koja se odvija tijekom njezina trajanja te da uz svećenikov blagoslov, a zbog čega je nužno da trgovac tijekom trajanja mise ne pomišlja na posao nego otvori ruke i um Bogu. ${ }^{200}$ Može se, dakle, zaključiti da je Kotruljević pohađanju mise pridao dalekosežne etičke implikacije za trgovčev život, jer je taj vjerski obred smatrao sredstvom za učvršćivanje postojećih trgovčevih vrlina te za njegovanje sklonosti dobru djelovanju, kao i za otklanjanje porokā i zala.

Etička sastavnica prisutna je i u trećem poglavlju druge knjige spisa o umijeću trgovanja, a koje je poglavlje naslovljeno »O milostinji« (»De elemosina«). U njega je Kotruljević uvrstio barem tri stava koji zavređuju biti razmotreni iz etičke perspektive. Prvi od njih izložio je već u prvoj rečenici poglavlja, a odnosio se na jedno od poželjnih obilježja trgovca. Naime, zabilježio je da trgovca treba krasiti velikodušnost (essere largo) kada pruža ruku siromahu i da treba siromahu dati milostinju u skladu sa svojim mogućnostima, a da onda kada mu nema što dati, treba barem samilosno uzdisati. ${ }^{201}$ Drugi stav etičke naravi Kotruljević je izložio usred trećeg poglavlja. Nudeći odredbu neophodnog dijela materijalnih i živežnih dobara te opisujući slučajeve u kojima nije nužno davati milostinju, ustvrdio je da je prvi slučaj u kojem se ne daje milostinja onaj u kojem se pojedinac nalazi u oskudici i ima samo toliko da njegova obitelj može preživjeti, pa bi davanjem milostinje ugrozio vlastiti život, kao i život svojih

\footnotetext{
198 Ibid., p. 202 [f. 43r-v] / pp. 407-408.

199 Ibid., p. 204 [f. 44r] / p. 409.

200 Ibid., p. 204 [f. 44v]: »La qualle messa e preservativa del continuo pecare et mal fare, et lava li pecati veniali per confessione generale che l' omo fa nela messa et per la benedicione che ricieve dal sacerdote. [...] Ala qual messa deve stare lo mercante sulevato le mano e l' intelecto a Dio, senca vacillacione d' alguna negociatione.«

${ }^{201}$ Cotrugli, »Libro del arte dela mercatura«, libro II, capitulo 3 / Kotrulj, »Knjiga o vještini trgovanja«, knjiga II, poglavlje 3, p. 210 [f. 46v]: »Deve lo mercante essere largo ad porgere la mano alo povero et farli elemosina dela sua faculta, quanto se extende et si nulla have da dare, deve almeno pietosamente suspirare «. / p. 414.
} 
bližnjih. ${ }^{202}$ Ipak, dubrovački je mislilac odmah potom naveo da izuzetak od prethodno izložene situacije čini slučaj u kojem pojedinac otkidajući od sebe želi dati nekoj značajnoj osobi koja bi sačuvala Crkvu ili državu. ${ }^{203}$ Razlog zbog kojega je odobravao takvo djelovanje, leži u stavu da je opće dobro (ben commune) važnije od vlastita (ben proprio). ${ }^{204} \mathrm{Na}$ kraju poglavlja Kotruljević je zapisao i treći stav etičke naravi. Naime, poručio je da je milostinja koristan, izvrstan i najbolji lijek koji čovjeka dovodi do savršena pokajanja i poboljšava mu život, a zbog toga što, kako navodi, suza sućuti iz iskrena srca ima veliku snagu kojom može nagnati čovjeka da poboljša vlastiti život i dovesti ga najboljem kraju. ${ }^{205}$

U četvrtom i posljednjem poglavlju druge knjige spisa o umijeću trgovanja dubrovački je ranorenesansni mislilac raspravljao o trgovčevu djelovanju unutar zajednice te o dvojbenim oblicima trgovčeva poslovanja, a zbog čega je poglavlje naslovio »O dvojbama što je dopušteno, a što nije« (»De casi de consciencia liciti et illiciti«). To je poglavlje najopsežnije poglavlje druge knjige spisa. Kotruljević ga je, kao što je već naslovom sugerirao, prožeo etičkom tematikom. U obilju primjera djelovanja koji se tiču ispravne primjene pravnih uredbi na trgovačko poslovanje, ograničit ću se na one u kojima se ponajbolje ogleda etički sadržaj, a koji se odnose na pravedno trgovčevo djelovanje u zajednici. Osim njih, izdvojit ću i primjere djelovanja koja je Kotruljević žestoko osudio i smatrao nedopuštenima.

Dubrovački je mislilac poglavlje otvorio znakovitom tvrdnjom kojom je iznova kudio trgovce svojega vremena, a time je otkrio i svoje porive za nastanak poglavlja posvećenog dvojbama o dopuštenosti djelovanja trgovaca. Pribilježio je da su trgovci njegova vremena najnemarniji, najprizemniji i najokaljaniji ljudi koji jedva da mogu živjeti, a da neprestano ne griješe. ${ }^{206}$ Takvo ga je stanje nagnalo da iznese pravila koja prethode uobičajenom lijeku koji vodi do obraćenja trgovca na činjenje dobra i koji za posljedicu ima njegovo spasenje, zbog toga što

202 Ibid., p. 212 [f. 48r]: »<...> lo primo modo sença lo quale alcuno non puo essere et de tal necessario la limosina non si de dare. Come se alcuno posto in articulo de necessita havesse solamente donde esso e la famiglia sua havesse a vivere de questo, dando elimosina seria subtrahere vita ad se et ali soi.«/p. 415.

${ }^{203}$ Ibid., p. 212 [f. 48r]: »Exepto se subtrahendo ad se volesse dare ad qualche grande persona per la qualle la Chiesia o la republica se sustentaria, <... «. / p. 415.

${ }^{204}$ Ibid., p. 212 [48r] / pp. 415-416.

205 Ibid., p. 213 [f. 48v]: »Et non mi stendo ad dire de illicitamente guadagniato che non si deve fare elimosina, pero che ne tractaremo nel suo capitulo, ma solamente concludo che la limosina e salubre, singulare e optimo medicamento ad ridure l' homo ad perfecta contricione et per consequens al emendacione di vita, perche la lacrima dela compassione che viene da intro al dricto core have grande virtute ad fare 1' homo emendare la sua vita et ad fare lo optimo fine.«/p. 416.

${ }^{206}$ Cotrugli, »Libro del arte dela mercatura«, libro II, capitulo 4 / Kotrulj, »Knjiga o vještini trgovanja«, knjiga II, poglavlje 4, p. 214 [f. 48v]: »<..> ma perche comunemente li mercatanti sono homini inobservantissimi, mundani et coinquinati, in modo che difficilissimamente possono vivere sensa continuo peccare $<\ldots>\ll$. / p. 417. 
trgovcu nikakav lijek ne može pomoći ukoliko je vezan dugom. ${ }^{207}$ Prilikom poučavanja trgovca o dopuštenim i nedopuštenim ugovorima, Kotruljević je najviše pažnje odlučio posvetiti lihvi (usura). Lihvu je pritom odredio ovako: zarada ostvarena od pozajmljena novca i to bilo u slučajevima u kojima je o tome načinjen ugovor bilo u slučajevima kad postoji nakana ostvarivanja takve vrste zarade. ${ }^{208}$ Unatoč brojnosti primjera koje je Kotruljević naveo o lihvi, usmjerit ću se tek na dva koji najbolje oslikavaju Dubrovčaninova etička promišljanja i koji upućuju na pravedno trgovčevo djelovanje u zajednici.

Prvi primjer koji sadrži Kotruljevićevo razmatranje odnosa pravednog djelovanja i lihve tiče se uzimanja miraza. Dubrovački se mislilac, naime, upitao postoji li način da zet pravedno (iustamente) uzme miraz od svekra koji je lihvar. ${ }^{209}$ Potom je odgovorio da to nije dopušteno i da zet mora vratiti miraz u slučaju da je bio upoznat s činjenicom da mu je svekar lihvar prije ugovaranja braka, a dopušteno mu je uzeti ako je saznao kasnije, makar je bolje da to ni tada ne učini, ili ako svekar ima i pošteno stečenih dobara, u kojem je slučaju to nesumnjivo dopušteno. ${ }^{210}$ Kotruljević je drugi put spomenuo pravedno djelovanje trgovca onda kada je objašnjavao slučajeve u kojima je razlikovao dopuštenu lihvu od nedopuštene, pri čemu je kao jedan od slučajeva u kojem je lihva dopuštena naveo i, primjerice, ovaj: dopušteno je uzeti zajam uz kamate zbog neprijatelja domovine protiv kojega se vodi pravedan rat (iusta guera). ${ }^{211}$

Naredni primjeri iz četvrtog poglavlja u kojima se očituje etički sloj odnose se na Kotruljevićeva razmatranja pravedne cijene, pravedne zarade i pravedna trgovanja. Naime, Dubrovčanin je spomenuo pravedno djelovanje trgovca i onda kada je govorio o slučajevima u kojima se cijena koju trgovac postavlja može smatrati pravednom (preço justo) te o slučajevima u kojima je pravednom smatrao zaradu koju trgovac ostvaruje (justo lucro). Jedan od takvih slučajeva bio je onaj u kojem trgovac preprodaje kupljenu vunu vunarima na rok, pri čemu je Kotruljević naglasio da je u tom slučaju, ukoliko se ne prelazi pravedna i

\footnotetext{
${ }^{207}$ Ibid., p. 214 [f. 48v]: »<...> pero queste sono precedente regole per solemne rimedio ala conversione delo mercante alo ben fare et per consequens ala salute loro. Ala qual conversione pervenendo, nullo rimedio giova se lu (sic!) homo e contrapesato et tenuto ad restitucione, <...>«. / p. 417.

208 Ibid., p. 215 [f. 49r]: »Usura se chiama guadagno facto dela pecunia per lo impresto fato per pacto o per intencione, <...>«. / p. 417.

${ }^{209}$ Ibid., p. 219 [f. 51r]: »Se lo gienero suo pigliare dote iustamente del socero usuraro, <... « . / p. 420.

${ }^{210}$ Ibid., p. 219 [f. 51r]: »<..> dico che se lo sapeva che fusse usuraro prima che contraesse, alora non e licito, et se l' ave pigliata la deve restituire. Ma se non lo sapeva, poi sapendolo pote, ma piu sicuro e di non. Ma se lo socero have deli beni eciam liciti, alora e licito sença dubio.«/ p. 420.

${ }^{211}$ Ibid., p. 220 [f. 51v]: »Licito e pigliare usura contra inimico dela tua patria, contra lo quale se fa iusta guera.« / p. 420.
} 
primjerena cijena, zarada pravedna. ${ }^{212}$ Sljedeći put kada je Kotruljević spomenuo pravedno djelovanje trgovca bio je onda kada je govorio o slučajevima u kojima trgovci jeftino kupuju žito u vrijeme žetve te ga nakon nekog vremena prodaju skuplje. Kotruljević je istaknuo pet načina kojima se može činiti takvo trgovanje, pri čemu je smatrao da je to ponekad grijeh, a ponekad nije. ${ }^{213}$ Prvi način obavljanja onakva trgovanja koje za Kotruljevića nije za osuđivanje bio je onaj kada se trgovanje obavlja za opće dobro (pro comune bene), a drugi je pak bio onaj kada ga trgovac obavlja za opskrbu vlastite kuće iz straha od poskupljenja, dok je treći bio onaj kada se trgovanje obavlja iz milosrđa, zato da bi se pomoglo siromasima. ${ }^{214}$ Prilikom obrazlaganja četvrtog načina obavljanja takva trgovanja Kotruljević je istaknuo da trgovanje prilikom kojeg trgovac ne namjerava izazvati oskudicu, već obavlja svoj posao, smatra pravednim (justa mercantia). ${ }^{215}$ Peti je način obavljanja takva trgovanja bio jedini kojem je dubrovački mislilac pridao izrazito negativnu konotaciju. Riječ je o slučaju u kojem trgovci, kako kaže, silno griješe tako što obavljaju tu vrstu trgovanja iz pohlepe (per avaricia), primjerice onda kada trgovac prodaje skuplje ne misleći ni na čiju potrebu ili korist negoli na vlastitu ili kad namjerno izaziva nestašicu tako da prikupi žito, nakon čega svi budu primorani kupovati kod njega po cijeni koja mu se svidi. ${ }^{216}$

Pitanje pravedne cijene zaokupljalo je Kotruljevićevu pažnju i u kontekstu govora o mjenicama. Tom zgodom Kotruljević je pribilježio da je zarada proizašla iz prometovanja mjenicama pravedna onda kada se radi o stvarnoj razmjeni novca prema tržišnom tečaju i onda kada je zarada neizvjesna, dakle onda kada se radi o istinskom prebacivanju i stvarnom dogovoru stranaka, bez kamata i na temelju zalaganja i obavijesti te opasnosti i napora, a u protivnom je riječ o lihvarskim razmjenama. ${ }^{217}$ Kotruljević nije izostavio spomenuti pravedno djelovanje trgovaca ni onda kada je postavio pitanje o tome je li dopušteno prodavati neku

${ }^{212}$ Ibid., p. 223 [f. 52v]: »<...> dico che non excedendo lo preço justo e conveniente, che l' e justo lucro.«/p. 422.

${ }^{213}$ Ibid., p. 224 [f. 53v]: »Che diremo di queli li qualli comprano lo grano in tempo dele ricolte a bon mercato per tenerlo et venderlo poi a bono preço. Respondo: questo se po fare en cinque modi et alcuna volta e peccato et alcuna volta non.«/p. 423.

214 Ibid., p. 224 [f. 53v]: »Et primo, pro comune bene [...] Secundo, provedere si la casa per li soi bisogni, per tema che poi non diventa piu caro, e poi li avança e non e have bisogno e vende piu caro per che tanto valeria nelo mercato. Terço, per pieta, che delo guadagno proveda ali poveri.«/ p. 423.

215 Ibid., p. 224 [f. 53v]: »Quarto, per exercitare justa mercantia, come mercante non che intenda in dare la carestia, ma che exerciti la sua arte, la qual cosa have loco quando questo e proprio sua mercantia, che per lo exercicio suo ricieve guadagno.«/p. 423.

${ }^{216}$ Ibid., pp. 224-225 [f. 53v]: »Quinto, per avaricia, cioe chel venda piu caro, non pensando altra utilità o necessita, o per fare caristia, che congregato lo grano siano aforçati comprare da lui a preço che a lui piacera. Et questi talli peccano enormamente.«/p. 423.

217 Ibid., p. 226 [f. 54v]: »<..> nulla di meno lo cambio riale facto per lo curso dela piaça, respecto dela incertitudine del lucro, comutacion vera et reale accomodacion dele parte, vitacion d' interesso, industria et avisacion sola, periculo et faticha, dico l' e iusto lucro, secus e de li cambii usuratichi non riali.«/p. 425. 
stvar skuplje od njezine vrijednosti. ${ }^{218}$ Ponudio je nedvosmislen odgovor: nije dopušteno ni pravedno (non e licito ne justo) prodavati neku stvar skuplje ili je kupovati jeftinije od njezine vrijednosti. ${ }^{219}$ Izuzetak pritom čine, dodaje Dubrovčanin, situacije u kojima je prodavač prodajom na veliku gubitku jer mu je ta stvar iznimno potrebna, zbog čega u pravednu cijenu treba uračunati vrijednost stvari i štetu prodavača, pa mu je neku stvar dopušteno prodati skuplje od njezine stvarne vrijednosti. ${ }^{220}$ Međutim, u situaciji u kojoj kupac ima veliku korist od kupovine, a prodavač nema gubitaka, ne smije se prodavati skuplje, a zato što nitko ne smije prodavati ono što mu ne pripada. ${ }^{221}$ Dubrovački se mislilac potom obrušio na zakonodavstvo jer ono, kako kaže, mnogo toga propušta kazniti, pa je tako za slučaj prekomjernog naplaćivanja zakonom predviđeno da ugovor ne vrijedi tek ukoliko prodajna cijena za polovicu premašuje pravednu. ${ }^{222}$ U zaključnom dijelu tog primjera Kotruljević je naveo da božanski zakon ništa ne ostavlja nekažnjenim i da se po njemu smatra nedopuštenim ako se pri kupovini i prodaji ne poštuje ravnoteža pravednosti (la equalita dela iusticia), točnije da onaj tko ima više mora vratiti ako je gubitak znatan. ${ }^{223}$ Pritom je napomenuo da pravednu cijenu nije moguće odrediti, ali da ipak postoje određeni okviri u kojima se ona kreće te da malo sniženje ili povišenje neće narušiti spomenutu ravnotežu pravednosti. ${ }^{224}$ Opsežan primjer koji je Dubrovčanin izložio u nastavku četvrtog poglavlja druge knjige spisa o umijeću trgovanja odnosio se na pravedno trgovanje, točnije na pravednu prodaju. Prodaju je, naime, smatrao nepravednom (iniusta) u slučaju da stvar koja je na prodaju ima nekakav nedostatak ili neku skrivenu prednost. ${ }^{225}$ Prema Kotruljevićevu mišljenju, tri su vrste nedostataka stvari za prodaju: 1) s obzirom na vrstu stvari, primjerice u slučaju kada se razvodnjeno vino prodaje pod čisto; 2) s obzirom na kolikoću, točnije težinu ili mjeru; 3) s obzirom na kakvoću, primjerice kada se bolesni konj ili neka druga životinja prodaje pod

${ }^{218}$ Ibid., p. 228 [f. 55v]: »Se l' e licito a vendere una cosa piu che non vale, <...>«. / p. 426.

${ }^{219}$ Ibid., p. 228 [f. $\left.55 \mathrm{v}\right] /$ p. 426.

${ }^{220}$ Ibid., p. 228 [f. 55v]: »< ..> excepto se alo venditore torna in multo danno a vendere quella cosa, ut puta che ne haveva bisogno multo et alora et in questo caso justro preçio non solamente computara la valuta de quella cosa, ma eciamdio lo danno del vendente, et in questo caso licito e vendere la cosa piu che non vale. $/ \mathrm{p}$. 426.

${ }^{221}$ Ibid., p. 228 [f. 55v]: »Ma se lo compratore se megliora multo de quella compra, e lo venditore non pegiora, non si de sopravendere, perche non de nissuno vendere quello che non e suo.«/p. 426.

${ }^{222}$ Ibid., p. 228 [f. 55v]: »Perche adunche la liegie humana non veta questo? Dico che la legie humana molte cose consente impunite, donde in questo caso have provisto che excedendo la mita del justo preço, che lo contrato non vale.«/p. 426.

${ }^{223}$ Ibid., p. 228 [f. 55v]: »Ma la legie divina non lasa alcuna cosa impunita, et pero nela legie divina illicito e reputato se nelo comperare et nelo vendere non e observata la equalita dela iusticia, et quello che piu a l' e tenuto a restitucione se lo danno e notabile, <...>«. / p. 426.

${ }^{224}$ Ibid., p. 228 [f. 55v]: »<..> perche lo justo preçio dele cose non e pontalmente diterminato, ma el sta in una diterminacione in modo che pocha diminucione o acrescimento non tole la equalita dela justicia. «/p. 426.

${ }^{225}$ Ibid., p. 228 [f. 56r]: »La vendicione e iniusta rispecto al difecto dela cosa venduta, overo per la bonta sua nascosa.«/p. 426. 
zdravu. ${ }^{226}$ Ukoliko prodavač svjesno šteti kupcu na neki od triju spomenutih načina, čini prijevaru (fraudo) i takav je ugovor nedopušten, ali ne griješi ukoliko nije prethodno znao da prodana stvar ima neki nedostatak, međutim kupcu mora nadoknaditi počinjenu štetu. ${ }^{227}$ Zbog toga je, priopćava Kotruljević, jasno da nije dopušteno prodavati alkemijom dobiveno zlato i srebro pod pravo, jer se ne radi o zlatu jednake čistoće, no to ne bi bilo zabranjeno kada bi se alkemijom uistino dobivalo pravo zlato. ${ }^{228}$ Dubrovački je mislilac i u nastavku četvrtog poglavlja druge knjige spisa o umijeću trgovanja promišljao o pravednu trgovačkom poslovanju, točnije bavio se odgovorom na pitanje je li čovjek dužan kupcu spomenuti nedostatak stvari koju prodaje. Prodaja je, tvrdi Kotruljević, zlonamjerna (dolosa) i prodavač je obavezan obeštetiti kupca u slučaju da stvar koju prodaje ima nevidljive greške, a ukoliko je greška očita, prodavač može pravedno zadržati za sebe sve što zna o greški. ${ }^{229}$ Kotruljević je potom raspravljao o slučaju u kojem trgovac taji informaciju o prenošenju svoje robe $u$ drugo mjesto. Ako netko nosi robu u neko mjesto znajući pritom da brojni ljudi dolaze za njim i da ako to razglasi neće moći svoju robu skupo prodati, prodavaču je, bilježi Dubrovčanin, dopušteno to zatajiti i može nesmetano prodavati svoju robu po cijeni koju zatekne u tom mjestu bez da ikome počini nepravdu. ${ }^{230}$ Kao posljednji slučaj Kotruljevićeva spominjanja pravedna djelovanja trgovca, ističem onaj u kojem je Kotruljević naglasio da je upraviteljima dopušteno uzeti pravednu i umjerenu zaradu (iusto et moderato guadagnio), ali nipošto ne nepravednu i neumjerenu (iniusto et inmoderato). ${ }^{231}$

Premda u preostalom dijelu četvrtog poglavlja druge knjige spisa o umijeću trgovanja nije izrijekom spomenuo pravedno djelovanje trgovaca, Kotruljević je ipak govorio o dopuštenosti nekih oblika trgovanja prosuđujući s etičkog gledišta. Primjerice, razmatrao je pitanje

${ }^{226}$ Ibid., pp. 228-229 [f. 56r]: »Et pero circa la cosa che si vende triplice difecto se puo considerare. L' uno secundo la specie dela cosa, ut puta, si vendesse vino con aqua pro vino puro; l' altro defecto e secundo la quantita, come del peso o vero mensura. Terço defecto e secundo la qualita, come se uno cavalo o altro animale infermo vendessi come sano.«/pp. 426-427.

${ }^{227}$ Ibid., p. 229 [f. 56r]: »Adonche in queste tre cose prenominate si alcuno venditore scientemente offende, commette fraudo et illicito e lo contracto. Sepure lo venditore non lo sapeva et alcuno defecto era nela cosa venduta, lo venditore non a peccato, ma poi chel a saputo lo diffecto deve recompensare lo danno alo compratore.«/p. 427.

${ }^{228}$ Ibid., p. 229 [f. 56r]: »Et per questo comprendi che non e licito a vendere l' oro overo argento alchimiato per vero, perche non e cosi puro come lo vero auro, non seria illicito a venderlo per lo vero. «/p. 427.

${ }^{229}$ Ibid., pp. 229-230 [f. 56r-v]: »Sel homo e tenuto a dire lo defecto dela cosa venduta, [...] Esendo questi vicii occulti e lo venditore non li dicie, l' e dolosa vendicione e lo venditore l' e tenuto a ricompensacione del danno. Se lo vicio l' e maniffesto, ut puta, se vendi lo cavallo sença l' ochio o vero se lo uso dela cosa non compete ad uno, compete ad un' altro et vendesi per quello vicio meno de quanto deveria valere, non e tenuto maniffestare quello vicio, perche lo compratore forse voria haverla per mancho preço per rispecto delo vicio. Donde in questo caso lo venditore puo iustamente lo vicio retenere.«/p. 427.

${ }^{230}$ Ibid., p. 230 [f. 56v]: »Se alcuno porta merça ad uno locho et sa che multi li vengono drito, la qual cosa se diciesse non poria le sue vendere care, [...] se lo venditore vende le soe merce per preço che trova, non fa iniuria a nesuno, $<\ldots>$ «. / p. 427.

${ }^{231}$ Ibid., p. 232 [f. 57 v] / p. 429. 
trgovaca koji ne znaju poslovati bez laži (bugie), zakletvi (juramenti) i krivokletstava (pergurii). Prema Dubrovčaninovu mišljenju, smrtno griješi onaj tko se prilikom zakletve posluži krivokletstvom (perjurano) ili lažima (menteno), dok se lakim grijehom smatra laž (mendacio [...] veniale) koju je izrekao onaj tko se nesvjesno poslužio neistinom (lo falso) vjerujući da govori istinu ili laž koja je izrečena svjesno, ali bez namjere da naškodi drugima, već s namjerom da se zaštiti od štete te ako zbog toga ne prodaje skuplje nego što smije. ${ }^{232} \mathrm{U}$ nastavku poglavlja ponudio je razgraničenje dopuštenih i nedopuštenih poslova. Tako je zabilježio da su nedopušteni oni poslovi koji se po svojoj naravi ne mogu izvršavati bez grijeha i zabranjeni su svim ljudima (prohibite ad hogni homo), a među njih spadaju lihva (usura), simonija (simonia) i krađa (furti). ${ }^{233}$ Neki poslovi su, dodaje Kotruljević, zabranjeni zato što su po sebi zli, dok drugi nisu nedopušteni po svojoj naravi, kao što su, primjerice, skrbništvo, starateljstvo i sve mehaničke vještine (tkanje i krojenje). ${ }^{234}$

Uz to, dubrovački je mislilac smatrao da poslovi koji su po sebi dopušteni također mogu biti nedopušteni, i to na četiri načina. Prvi način odnosi se na razlog (dela causa) zbog kojeg se posluje, primjerice u slučaju kada netko inače dopušten posao obavlja zbog pohlepe, drugi se pak odnosi na trenutak (per lo tempo), primjerice na posao koji se odvija za vrijeme blagdana, treći se odnosi na osobu (dela persona), primjerice na klerike i redovnike kojima je poslovanje zabranjeno, a četvrti se odnosi na mjesto odvijanja poslovanja (respecto alo locho), a koje može biti neprikladno zbog nečestitosti i sumnjivosti ili zbog izvrsnosti. ${ }^{235}$ Kotruljević je potom iznio svoja promišljanja o krađi (furto). Prema njegovim spoznajama, dva su načina počinjanja krađe: 1) kada je netko uhvaćen s onim što je ukrao; 2) kada netko nije uhvaćen s onim što je ukrao. ${ }^{236}$ Krađa je, bilježi Kotruljević, ista neovisno o tome radi li se o maloj ili velikoj stvari, jer se u krađi ne razmatra kolikoća već namjera da se prevari. ${ }^{237}$ Dubrovčanin je potom zaključio da je krađa smrtni grijeh i da lopova obavezuje na povrat

${ }^{232}$ Ibid., pp. 230-231 [ff. 56v-57r] / p. 428

${ }^{233}$ Ibid., p. 231 [f. 57r] / p. 428.

${ }^{234}$ Ibid., p. 231 [f. 57r]: »Alcuni sono prohibiti che sono per se mali. Alcuni non sono illiciti di sua natura, come e tutela, cura et tute le arte mechaniche, come sono tessituri, cusitori et cet.«/p. 428.

${ }^{235}$ Ibid., pp. 231-232 [f. 57r-v]: »Se li negocii che sono per se liciti possono essere illiciti, [...] possono essere illiciti per piu modi. Primo, dela causa, come quando se faciesse per improba cupidita dele richeçe, non ad necessita ma ad altro fine malo. Et secundo questo modo sono prohibiti ad ogni uno, [...] Secundo, per lo tempo, cio e faciendose neli giorni di festa neli quali da tal opera si deve cessare. Item per lo tempo, cioe faciendose judici di nocte et non di giorno chiaro et cosi di giorni feriati. Tercio, per respecto dela persona, perche ali clerici et a religiosi son prohibite, [...] Quarto, respecto alo locho inhonesto et suspecto, [...] Item alcuna volta per la excelencia delo loco, come quando nela chiesia se faciesse«. / pp. 428-429.

${ }^{236}$ Ibid., p. 232 [f. 57v]: »Diremo delo furto, per ben che non risguarda directe al tractato mercantile. Dui manere sono de furto, l' uno manifesto, cioe quando l' homo e deprehenso con quello che ave furato, l' altro e quando l' homo non e deprehenso.«/p. 429.

${ }^{237}$ Ibid., p. 232 [f. 57v]: »Et cosi e furto nela cosa picula come nela grande, perche nel furto non se guarda la quantita, ma se guarda la mente che frauda, <..>«. / p. 429. 
ukradenih stvari, no da se lopovu ipak može oprostiti krađa sitnica ukoliko to nije veliki gubitak za vlasnika niti je protiv njegove volje. ${ }^{238}$

Četvrto poglavlje druge knjige, a time i čitavu drugu knjigu spisa o umijeću trgovanja, dubrovački je ranorenesansni mislilac okončao promišljanjima o nužnosti vraćanja dugova te o postizanju konačnog spasenja. Upozorio je, naime, da se trgovcima najčešće događa da umiru očajni zbog nevraćanja dugova, nakon čega je dodao da je trgovcima vraćanje dugova najteža zadaća i da im ponekad nije dovoljan čitav imetak da bi je izvršili, a čak i kada je dovoljan, dugove ne vraćaju zato da ne bi zapali u siromaštvo ili ostavili svoju djecu ubogima. ${ }^{239}$ Napomenuo je i to da su malobrojni oni trgovci koji vraćaju dugove, jer svoju sreću vide samo u bogatstvu. ${ }^{240}$ Međutim, Dubrovčanin je rješenje tog poroka vidio $u$ pohađanju mise, molitvi, pobožnosti, obraćenju i pokajanju, jer je bio uvjeren da će tako trgovac dobiti mogućnost da se Stvoritelju vrati bez grijeha. ${ }^{241} \mathrm{Uz}$ to, trgovce je savjetovao i poticao na, kako kaže, anđeoski nauk i utjehu, pa im poručio da ne sputavaju vlastitu dušu i um da ne bi bili zarobljeni onime što trebaju vratiti. ${ }^{242}$

\subsubsection{Etika u trećoj knjizi spisa o umijeću trgovanja}

Svih osamnaest poglavlja treće knjige spisa o umijeću trgovanja Kotruljević je vrlo očigledno prožeo etičkim sadržajem, a što je otkrio već u naslovima poglavlja. Zbog toga su se, kao što sam ranije naglasio, istraživači Dubrovčaninova opusa iz filozofske perspektive redovito bavili njezinim sadržajem i pomoću nje zaključivali da je Kotruljević bio etičar. Dubrovački mislilac je, naime, tu knjigu posvetio razmatranjima o trgovčevu ophođenju u zajednici, što proizlazi iz naslova knjige: »Počinje treća knjiga o građanskom životu trgovca« (»Comincia

\footnotetext{
${ }^{238}$ Ibid., p. 232 [f. 57v]: »<...> se alcuna fura cose minime non reputando nocimento alo patrone ne contra la volunta delo patrone extima essere lo excusato. Altrimenti lo furto sempre l' e peccato mortale et si tenuto ad restitucione.«/p. 429.

${ }^{239}$ Ibid., p. 235 [f. 59r]: »Pero che per avissarti che a mercanti per questo solo vicio del restituire intravene che la piu parte moreno disperati, perche lo rendere e durissima cosa e de volte la faculta non basta a satisffare et se la basta li pare duro a venire lui in poverta, o lassare i suo (sic!) figlioli poveri. «/p. 431.

${ }^{240}$ Ibid., p. 235 [f. 59r]: »Et pochi de molti vedete ala fine restituire, perche ano posto la fellicita loro nele richeçe, $<\ldots>\ll . /$ p. 431.

${ }^{241}$ Ibid., pp. 234-235 [f. 59r]: »Visto adunche queste condicioni contenute in questi capituli da esserno observate nel mercante, le qualli, observando come se non dubitare, che per la virtute dela messa, con l' oracione la quale e maravigliosa, e per virtu dela pieta la quale e multo accepta da Dio lo nostro Creatore, ti dara la gracia sença fallo che non morirai sença pentire e ritrovare a lo Creatore tuo. Et convertendoti ad penitencia, trovarati necto de havere ad ristituire ad altri et per consequens, faciendo leve penitencia la quale ad te sera ingiunta per lo tuo sacerdote, sara cagione dela tua salute. «/p. 431.

${ }^{242}$ Ibid., p. 235 [f. 59r-v]: »Pero, faciendo l' fine di questo secundo libro, exorto li mercanti a queste discipline angieliche e conforto e priego che non legino l' animo et l' intellecto ad essere captivati che gli siano tenuti ad restituire.«/p. 431.
} 
lo terço de vita politica delo mercante«). Za razliku od prethodnih dviju knjiga, etički je sadržaj treće knjige odavno prepoznat i istaknut u stručnoj literaturi. Zbog toga što o prisutnosti etičke sastavnice u trećoj knjizi spisa o umijeću trgovanja postoje brojni zaključci opće naravi, u nastavku potpoglavlja detaljno ću razložiti sadržaj predgovora i svakog od osamnaest poglavlja te knjige, a poradi cjelovita uvida u obilježja Kotruljevićeva etičkog nauka. U predgovoru ću se usmjeriti na razloge koji su nagnali Dubrovčanina na pisanje o političkom aspektu trgovčeva života, a koji su razlozi sadržavali etičke implikacije, dok ću se prilikom obrade zasebnih poglavlja usredotočiti na vrline koje, dakako prema Kotruljevićevu mišljenju, trgovac mora posjedovati ukoliko želi biti savršen i doprinositi zajednici.

$\mathrm{Na}$ početku predgovora trećoj knjizi Kotruljević je donio kratak pregled sadržaja i odredbe prethodnih dviju knjiga, a onda i uputio na tematiku kojom se namjerava baviti u trećoj knjizi. Priopćio je tako da je u prvoj knjizi raspravljao o bîti, koristi i vrstama trgovanja, u drugoj o vjeri, koju je smatrao prvim temeljem čestita života (lo primo fundamento dela vita honesta) te koja krasi dušu i vodi željenu cilju, pa će se u trećoj, počevši redom od dobra čestitosti (bene honesto), koje je začin života čovjeka svake dobi, položaja i načina življenja (condimento de la vita humana in deli homini de ogni etate, de ogni condicione et de ogni vita), usredotočiti na moralni i politički život (lo vivere morale et politico) s obzirom na vrlinu (circa le virtu) koja je svojstvena ljudskoj skladnosti i priliči svakom izvrsnom trgovcu (pertinente ad ogni mercante optimo). ${ }^{243}$ Potom je izložio oštru kritiku ondašnjeg društva, posebice trgovaca, i upozorio na uzroke takva stanja u društvu. Zamijetivši da se u pravilu zbiva da prosti ljudi, a osobito trgovci, koji ne traže nauk na pravom vrelu najčešće idu stopama svojih očeva pa ih, uzimajući ih za uzore, ili ne dostignu ili dostignu, ali ne i prestignu, zbog čega se, zaključuje Dubrovčanin, svijet srozava i postaje kaljuža. ${ }^{244}$ Događa se, naglašava Kotruljević, to da su trgovci puni zabluda i lakoumnosti (pieno d'errori e levità) te da u njima nema ni traga razuma, štoviše brojni od njih sveli su trgovačko zvanje na praksu i kao majmuni čine ono što vide. ${ }^{245}$ Rješenje takva stanja Kotruljević je vidio u tome da dični i hvale dostojni sinovi moraju nastojati ne samo oponašati svoje očeve, već ih nadmašiti i prestići u nekoj vrlini (excellere et passarli in qualche virtu), što bi za posljedicu imalo da bi

${ }^{243}$ Cotrugli, »Libro del arte dela mercatura«, libro III, prohemio / Kotrulj, »Knjiga o vještini trgovanja«, knjiga III, predgovor, p. 237 [f. 59v] / p. 433.

${ }^{244}$ Ibid., p. 237 [ff. 59v-60r]: »Et perche sogliono el piu dele volte li homini vulgari et maxime mercanti, li quali non ciercano la doctrina nel vero fonte, seguire li paterni vestigii et come sono li patri loro mercanti, cosi segueno li figlioli et continuo traendo ala mira o non li adjungono o se alguni v' agiungono, non li passano et cosi lo mundo continuo deteriorando e divenuto in sentina. «/p. 433.

${ }^{245}$ Ibid., pp. 237-238 [f. 60r]: »Dove sel ci e alcuno mercante e pieno d'errori e levità, sença alguno fundamento di ragione, imo piu anno riducto lo culto mercantile in praticha et come le scimie fanno quello vegono, sança fundamento alcuno di ragione.«/ p. 433. 
svijet postajao savršeniji (lo mundo sarebbe intanto piu perfection), a ne bi, kao tada, tonuo u ponor. ${ }^{246}$ Zato što je uvidio da je, kako kaže, ljudski rod, a posebice trgovci, toliko nisko pao da jedva da se može pronaći netko tko posjeduje vrline, smatrao je prikladnim posvetiti treću knjigu moralnim vrlinama (virtu morale) koje trgovci moraju imati. ${ }^{247} \mathrm{Na}$ kraju predgovora najavio je da će se najprije baviti trgovčevim dostojanstvom i zvanjem (della dignita et officio delo mercante), a potom prijeći na vrline (ale virtu). ${ }^{248}$

U skladu s najavom iz predgovora, Kotruljević je prvo poglavlje treće knjige spisa o umijeću trgovanja naslovio »O trgovčevu zvanju i dostojanstvu« (»Delo officio e dignita delo mercatante«). Dubrovački je mislilac i u to poglavlje uključio svoja promišljanja koja se odnose na etiku. U njemu je, naime, branio ugled trgovaca i upućivao na društveni položaj koji trgovci trebaju uživati u zajednici, pri čemu je isticao njihove odlike i doprinos koji pružaju zajednici. Kotruljevićev obrambeni stav prema trgovcima očit je već u prvoj rečenici poglavlja, a u kojoj je zastupao mišljenje da su dostojanstvo i zvanje trgovaca veliki i uzvišeni iz brojnih razloga, posebice iz njih četiriju. ${ }^{249}$ Upravo se u Kotruljevićevu iznošenju i obrazlaganju spomenutih razloga ogleda etički moment prvog poglavlja treće knjige. Tako je već kao prvi razlog zbog kojeg treba poštovati trgovačko dostojanstvo i zvanje istaknuo opće dobro (ben comune) kojem trgovci doprinose, a bio je pritom uvjeren da za korist javnog dobra i dobra čestitosti (la utilita delo bene publico e bene honesto) vrijedi i umrijeti. ${ }^{250}$ Upozorivši na to da se prethodna tvrdnja ne odnosi na proste i obične trgovce, već na slavnog trgovca (mercante gloriosso) kojega je osmislio i hvalio u svojem spisu, zabilježio je stav da korist, probitak i spas država (la utilitate, lo commodo e la salute dele Republice) u velikoj mjeri potječu od trgovaca. ${ }^{251}$ Taj je stav potkrijepio navođenjem višestruke koristi koju trgovci priskrbljuju zajednici: 1) opskrbljuju neplodne zemlje namirnicama i potrepštinama; 2) pribavljaju uvozne stvari i prevoze ih na mjesta koje tim stvarima oskudijevaju; 3) donose obilje novca, dragulja, zlata, srebra i utječu na procvat različitih vještina i obrta, a onda i gradova te država; 4) potiču obrađivanje zemlje, umnažanje stoke i održavanje vrijednosti prihoda i dohotka; 5) pomažu siromasima da prežive, potpomažu upravitelje poslovima sa

\footnotetext{
246 Ibid., p. 238 [f. 60r] / p. 433.

${ }^{247}$ Ibid., pp. 238-239 [f. 60v]: »Pertanto, vista la humana generatione et maxime tra mercanti, sequendo l' uno a l' altro, essere tanto declinata che ad pena si puo trovare uno virtuoso, par me necessario, sequendo l' opera nostra, ingiongiere in questo tercio libro qual sono quelle virtu morale le qualle de necessario deveno essere nelo mercatante.«/p. 434.

${ }^{248}$ Ibid., p. 239 [f. 60v] / p. 434.

${ }^{249}$ Cotrugli, »Libro del arte dela mercatura«, libro III, capitulo 1 / Kotrulj, »Knjiga o vještini trgovanja«, knjiga III, poglavlje 1, p. 240 [f. 60v]: »La dignitate e lo officio delo mercante e grande e sublime per multi rispecti et potissime per quatro.«/p. 435.

${ }^{250}$ Ibid., p. 240 [f. 60v] / p. 435.

${ }^{251}$ Ibid., p. $240[$ f. $60 \mathrm{v}] /$ p. 435.
} 
zakupima, zatim uvozom i izvozom robe čuvaju vrijednost poreza i carina vlastelina i država te tako pune javnu i općinsku blagajnu. ${ }^{252}$ Drugi razlog Kotruljevićeve obrane trgovačkog dostojanstva i zvanja sastojao se od njihova korisnog i čestitog upravljanja vlastitim kućama i privatnim dobrima (lo governo utile et honesto de loro case et beni privati), zbog toga što, prema njegovu uvjerenju, samo trezven (sobrio), umjeren (temperato), postojan (saldo) i pristojan (ben costumato) trgovac uvećava i unapređuje svoj imetak. ${ }^{253}$ Osim što je, kao što proizlazi iz prethodne tvrdnje, smatrao da postoji povezanost između trgovčevih vrlina i upravljanja imovinom, Dubrovčanin je naglasio da trgovcima raste i građanski ugled (ben civile) zbog izobilja pokretnih i nepokretnih dobara, zatim zbog lijepo odjevene i urešene obitelji, potom zbog uljuđena i pristojna života u kućanstvu, a onda i zbog nasljedstva i miraza za svoje sinove i kćeri, kao i zbog neprestanog napretka uzrokovanog privređivanjem dobara. $^{254}$ Da bi ukazao na vrijednost i dobrobit koju trgovanje donosi kućanstvima, Kotruljević je potom izložio okolnosti s kojima se susreću vlasnici kućanstava koji odluče ne upuštati se u trgovačke poslove. Njima se, bilježi Dubrovčanin, događa upravo suprotno, jer ne oplođuju imovinu trgovanjem pa kada udaju kćeri, moraju prodavati nekretnine i oduzimati od vlastitih usta, što u konačnici dovodi do propasti kuće. ${ }^{255}$ Obrazloženje drugog razloga Kotruljević je dovršio tvrdnjom da onako kako trgovac poboljšava položaj svojih sinova i kćeri ženidbenim vezama te unapređuje svoj stalež, tako siromašan plemić pada u vrlo jadno stanje zbog neimaštine koja ga gura sve niže. ${ }^{256}$ Treći razlog poštivanja trgovčeva

${ }^{252}$ Ibid., pp. 240-241 [ff. 60v-61r]: »Et questo per rispecto dele facende et exercicio mercantile, mediante lo quale si munisceno le patrie sterile di victo e municioni. Acomodanosse eciamdio de diverse cose et peregrine, facendo venire da lochi unde abunda in lochi dove mancano le mercie. Fanno eciamdio abundare di pecunie, gioe, oro, argento et ogni sorte di metallo, fanno abundare arte de diverssi mestiere inde le cita et patrie, fanno cultivare le terre, abundare li armenti, valere le intrate et rendite, fanno campare li poveri mediante li loro exercici, fanno excitare li massari mediante la industria di arrendamenti, fanno valere le vectigali e le gabele deli signori et dele republice mediante le extracioni e le immissioni dele loro mercantie, et per consequens acresceno lo errario publico et commune.«/p. 435.

${ }^{253}$ Ibid., p. 241 [f. 61r] / p. 435.

${ }^{254}$ Ibid., p. 241 [f. 61r]: »Il perche vedemo li mercatanti fiorire inde le robe mobile et stabile, in richeçe et supelectilli di casa, in ornamenti et vestimenti di sua famiglia, in dotare di figli et le figle, et per consequens in augmentare et migliorare al continuo in lo aparentare sempre in piu condicione. Acrescie eciamdio nelo ben civile con splendido e abundante nel vivere domestico in la sua casa politico et costumato et sempre prosperando et acrescendo et accumulando li beni sui.«/pp. 435-436.

255 Ibid., p. 241 [f. 61r-v]: »E tuto lo contrario adviene ad quelli li quali non hano questa industria gloriosa et pero se dicie nel usitato et trito proverbio apresso de nostri antiqui: 'Trista la casa che non fette de mercanthia'. Pero che lo massaro e lo gentilhomo che vive di rendita, per grande che la sia, non ajutandola con la industria dela mercanthia, vale multo meno che non valeria in mano delo mercante, e non dico solamente del cultivare, ma eciamdio dopoi che la ricolta di saperla vendere a tempi e a stagioni. Quantunque el piu dele volte hanno deli figlioli maschi et femine et volendo maritare le femine bisognia vendere delo stabile et aminuire lo pane dela bocha sua.«/p. 436.

${ }^{256}$ Ibid., p. 242 [f. 61v]: »Et come lo mercante migliora di condicione ali figli et ale figlie nelo apparentare et tira lo suo stato in avanti, cosi lo povero gentilomo per impotencia bisognia che le dia im pigiore grado sempre desgradando a vilissime condicioni.«/p. 436. 
dostojanstva i zvanja također sadrži etički sloj. Naime, Kotruljević je naglasio da trgovčevo dostojanstvo treba vrednovati i cijeniti zbog kruga ljudi među kojima se kreće privatno i javno (privatim e publice). ${ }^{257} \mathrm{U}$ trgovčevoj kući, dakle privatno, živi čestita obitelj (famiglia honesta) koja stalno i vrlo (virtuoso) radi, a tamo gdje se, bilježi Dubrovčanin, premeću novac, srebro, zlato i druge vrijedne stvari, nužno je voditi računa o tome da se ne primaju nevaljalci, klipani, sluge, članovi stranaka, lopovi, bjegunci i igrači. ${ }^{258}$ Što se pak tiče ljudi s kojima se trgovci susreću javno, riječ je o obrtnicima, plemićima, gospodi, vladarima, kraljevima, prelatima svakog položaja te velikim stručnjacima kojima je uvijek potreban trgovac. ${ }^{259}$ Trgovci su im potrebni ne samo za zadovoljavanje njihovih potreba, već i za savjetovanje, jer se, prema Kotruljevićevu mišljenju, pripadnik nijednog zvanja ne razumije bolje u svjetovnu vlast i državu vezano uz upravljanje novcem, a o kojem ovise sve države, od dobrog i učenog trgovca (lo bono e docto mercante). ${ }^{260}$ Kao četvrti razlog uvažavanja dostojanstva i zvanja trgovaca Kotruljević je naveo povjerenje (fede) koje trgovac uživa u jednakoj mjeri kao i oni koji pouzdano čuvaju pologe i pošteno plaćaju dugove. ${ }^{261}$ Dubrovački je mislilac potom upozorio na tadašnje društveno stanje, ističući da ni kraljevi ni vladari ni prelati ni bilo koja vrsta ljudi ne uživaju takvo povjerenje ili ugled (tanta fede o credito) kao dobar trgovac (lo mercante bono) te da se trgovac zbog toga može dičiti svojim dostojanstvom (tanto prestante dignita). ${ }^{262}$ No, budući da uživaju toliko povjerenje i zavređuju toliko dostojanstvo, Dubrovčanin je, čini se, smatrao da trgovci imaju odgovornost prema očuvanju takva poimanja javnosti i svojeg položaja u društvu. Zbog toga je, među ostalim, naveo da ukoliko trgovac želi sačuvati svoje dostojanstvo mora odbaciti bilo kakav

\footnotetext{
${ }^{257}$ Ibid., p. 242 [f. 61v] / p. 436.

${ }^{258}$ Ibid., p. 242 [f. 61v]: »Privatim, id est in casa sua in la qual conversano famiglia honesta et in continuo et virtuoso exercicio, pero che dove si manegia denari, argiento, oro et altre simili cosse di valore, doveti pensare che non ci alberga gaglioffi, ragaçoni, famigliaci d' ogni mena, partesani, ladri, fugitivi, et giocatori, $<\ldots>\ll . /$ p. 436.

${ }^{259}$ Ibid., pp. 242-243 [f. 62r]: »Conversano eciamdio li mercanti publice, id est fuori de casa, con artigiani, gintilomeni, signori, principi, regi et prelati d' ogni stato et tuti concorreno al mercatante, sempre bisognando di lui, et multissime volte lo vengono vissitare in casa di gran maistri.«/p. 436.

${ }^{260}$ Ibid., p. 243 [f. 62r]: »Li qualli mercatanti non solamente sono lor necessarii in favorirli et socorrerli neli loro bisogni, in che sono aptissimi, ma anche aptissimamente li sanno consigliare, pero che nullo mestieri ogi et sempre intese ne intende la mundana monarchia e lo stato circa lo governo dela pecunia, circa lo quale dependono tuti li stati mundani, come lo sa intendere, consigliare et remediare lo bono e docto mercante. $\ll / \mathrm{p}$. 436.

${ }^{261}$ Ibid., p. 243 [f. 62r]: »Quarto, e servata la dignita alo mercante per rispecto dela fede, la quale e tanta dalo canto suo quanta dali altri dal canto suo, che fidelissimamente conservano li depossiti et rialmente pagano li debiti, come al continuo vedemo.«/p. 437.

${ }^{262}$ Ibid., pp. 243-244 [f. 62r-v] / p. 437.
} 
nedoličan ures, bilo s duše bilo s tijela. ${ }^{263}$ Zatim je naveo nekoliko načina kojima trgovac to može učiniti: 1) kretnje mu ne smiju biti divlje kao kod kršnih ratnika niti mlitave kao kod brbljava lakrdijaša; 2) mora ozbiljno govoriti i hodati; 3) nemala je prednost ako je prirodno obdaren lijepim tijelom, skladnih oblika i dobre građe; 4) mora nastojati da mu govor bude blag, dotjeran i uglađen, bez srdžbe, površnosti i duševnog nemira; 5) u hodu ne smije biti brz nego uzdržan i ozbiljan. ${ }^{264}$

Nakon poglavlja u kojem je stao u obranu trgovčeva dostojanstva i zvanja, Kotruljević je, ponovno u skladu s najavom iz predgovora, drugo poglavlje treće knjige spisa o umijeću trgovanja posvetio razmatranju prve na popisu vrlina koje trgovac mora posjedovati: razboritost (prudentia / prudencia). Prilikom razmatranja Kotruljevićevih vrlina koje moraju krasiti trgovca valja imati na umu da je Martinović naznačio da se Dubrovčaninov i Aristotelov popis vrlina »djelomice podudaraju«, ali i to da se na mjestima na kojima se podudaraju Kotruljevićevo obrazloženje »razlikuje od Aristotelova. ${ }^{265}$ Poglavlje prigodna naslova $\gg \mathrm{O}$ trgovčevoj razboritosti« (»De prudentia delo mercante«) Kotruljević je otpočeo tvrdnjom da je Bog odredio da razboritost bude opća vrlina (comune virtu) koja pristaje ljudima svakog stupnja, staleža i položaja, a ponajviše trgovcima, jer se, kako kaže, druge znanosti i umijeća ravnaju čvrstim zakonima i posebnim pravilima, a samo se trgovanje ravna po slobodnoj prosudbi. ${ }^{266}$ Martinović je u stavu da se trgovanje ravna po slobodnoj prosudbi prepoznao još jedan Kotruljevićev etički stav, zato što, kako kaže, »slobodno odlučivati pripada pak srži etičke prosudbe. $\ll^{267}$ Trgovcu je, nastavlja dubrovački mislilac, izrazito potrebna razboritost jer je ona glavni dio čestitosti (principal membro del honesto) i u sebi

${ }^{263}$ Ibid., p. 244 [f. 62v]: »Et sequendo lo preposito nostro, dicimo che per conservare questa dignitate cosi fata l' e necessario alo mercante di rimovere da se ogni indegno ornamento, cosi del animo como anche del corpo, $<\ldots>$..«/p. 437.

${ }^{264}$ Ibid., p. 244 [f. 62v]: »<...> et non de havere giesti fieri deli homini d' arme robusti ne anche deve havere giesti molli di boffoni et d' istrioni, ma deve essere grave nel suo parlare, nel andare et in tucti li acti servando quam maxime la sua dignitate. Ale quale cose intravenendo l' ornamento del corpo per la gracia dela natura e chel sia di forma proporcionato et ben formato sia non pocha gratia. Donde per conservarla et per condimento de tute le predicte cose devessi sforçare di havere lo suo parlar mansueto, compto et humano, sença ira et sença levita e sença alcuna perturbacione del animo [...] Et nelo andare suo non deve esser leve ma moderato et grave.«/p. 437.

${ }^{265}$ Martinović, »Benedikt Kotruljević (2)«, p. 9c. Isto vidi u: Martinović, »Benedikt Kotruljević«, u: Budak (osmislio i uredio), Croatica: HR - Hrvatski udio u svjetskoj baštini, [sv. 1], p. 173b; Martinović, Žanrovi hrvatske filozofske baštine od 15. do 18. stoljeća, p. 14.

${ }^{266}$ Cotrugli, »Libro del arte dela mercatura«, libro III, capitulo 2 / Kotrulj, »Knjiga o vještini trgovanja«, knjiga III, poglavlje 2, p. 245 [f. 63r]: »Avegna Dio che la prudencia sia comune virtu et conveniente ad ogni grado, stato et condicione de homini, niente di meno e l' e quodammodo piu pertinente, piu propria et piu conveniente alo mercante che al' altre generacioni di homini, pero che altre cose, sciencie et arte viveno et governanosse con cierti canoni et regole specialle, sola mercatura si governa per arbitrio, <...>«./ p. 438.

267 Martinović, »Benedikt Kotruljević (2)«, p. 9b. Isto vidi u: Martinović, »Benedikt Kotruljević«, u: Budak (osmislio i uredio), Croatica: HR - Hrvatski udio u svjetskoj baštini, [sv. 1], p. 173b; Martinović, Žanrovi hrvatske filozofske baštine od 15. do 18. stoljeća, p. 14. 
sadrži sposobnost razlučivanja dobra i zla (la discrecione delo bene et delo male), a sastoji se od pamćenja prošlih, razmatranja sadašnjih i predviđanja budućih događaja. ${ }^{268}$ Zbog toga što su, pojašnjava Kotruljević, trgovčeve greške uglavnom štetne i nepopravljive, trgovac mora imati dobru i razboritu glavu koja može jasno rasuđivati i razborito odlučivati te mora biti oprezan i neprestano biti pripravan mijenjati planove i sprečavati nezgode koje bi se mogle dogoditi. ${ }^{269}$ Kotruljević je zatim zaključio da iz trgovčeve razboritosti proizlaze i dodatne sposobnosti te opisao slučajeve u kojima su one korisne trgovcu. Naime, pribilježio je da iz razboritosti proizlaze sljedeće četiri sposobnosti: 1) predviđanje (providencia); 2) promišljenost (circumspectione); 3) oprez (cautione); 4) poučljivost (docilita). ${ }^{270}$ Prva mu sposobnost služi za predviđanje budućnosti i sređivanje sadašnjih poslova pomoću kojih može postići željeni cilj, druga mu služi za izbjegavanje poroka suprotnih promišljenosti (cavere deli vicii contrarii) i pristajanje uz korisno (conservando la utillita), treća za razlučivanje dobra od zla (lo bene dalo male), bijelog od crnog, koristi od štete (lo utile dalo danno), pravo od krivog (lo vero dal falso) i laži od istine (lusinge dale verita), dok ga četvrta čini sklonim učenju i spoznavanju sebe (docile et imparare im prima se), a onda i drugih, jer, zaključuje Dubrovčanin, tko sebe poznaje, sve poznaje (che qui se novit omnia novit). ${ }^{271} \mathrm{U}$ preostalom dijelu drugog poglavlja treće knjige spisa o umijeću trgovanja Kotruljević je ponudio savjete za osnaživanje trgovčeve poučljivosti, zatim razlučio koja su znanja trgovcu korisna i potrebna, a potom i kritizirao ondašnju mladež i trgovce. Znači, ostatak poglavlja o razboritosti sadrži Kotruljevićeva promišljanja u kojima se ponovno očituje prožimanje etike i filozofije odgoja. Zato sam ta promišljanja odlučio obraditi u onom potpoglavlju ovoga poglavlja koje se odnosi na odgojnofilozofsku sastavnicu spisa o umijeću trgovanja.

Tema trećeg poglavlja treće knjige spisa o umijeću trgovanja odnosila se na znanja koja su trgovcima prijeko potrebna. Zbog toga ga je dubrovački mislilac i naslovio »O trgovčevu znanju« (»Dela sciencia delo mercante«), a započeo ga tvrdnjom da ga već pomisao na to

${ }^{268}$ Cotrugli, »Libro del arte dela mercatura«, libro III, capitulo 2 / Kotrulj, »Knjiga o vještini trgovanja«, knjiga III, poglavlje 2, p. 245 [f. 63r] / p. 438.

${ }^{269}$ Ibid., p. 245 [f. 63r]: »Pero che li errori delo mercante sono ut plurimum o damnosi o inemendabili et pero deve havere capo da bene, prudente et omnipotente intender chiaramente et deliberare prudentemente, et circa ogni sua facienda essere circumspecto et sempre de hora in hora habia ciervello di mutare proposito et deliberare et obviare ale cose siniestre che occorrere poteseno.«/p. 438.

${ }^{270}$ Ibid., pp. 245-246 [f. 63r] / p. 438.

${ }^{271}$ Ibid., p. 246 [f. 63r-v]: »Et pero deve essere lo mercante provido ale cose future, desiderando la fine ala qual andando de ordinare le cose presente, mediante le qualli possa atingere al proposito fine. Deve essere eciamdio circumspecto e cavere deli vicii contrarii, conservando la utilita. Cauto eciamdio deve essere, discernendo lo bene dalo male, lo bianco dalo negro e lo utile dalo danno, lo vero dal falso et lusinge dale verita. [...] Deve essere eciamdio lo mercante docile et imparare im prima se et dopoi altri, che qui se novit omnia novit.«/pp. 438-439. 
kakvo i koliko trgovčevo znanje mora biti vodi u beskonačnost, jer za obuku savršena i uglađena trgovca (lo mercante perfecto et compiuto) mora stvoriti iznimno svestrana čovjeka (uno homo universalissimo), koji je nadaren svim sposobnostima i koji se može sporazumijeti te pristupiti svakoj vrsti ljudi. ${ }^{272}$ Da bi uzmaknuo poniranju u beskonačnost, Kotruljević je probrao značajne, temeljne (sciencie proprie et principali) i prirodne znanosti (naturale sciencie) koje trgovac mora poznavati, a bez kojih je ništavan i isprazan (inane et vacuo). ${ }^{273} \mathrm{U}$ poglavlju o trgovčevu znanju također se očituje isprepletenost Kotruljevićevih etičkih i odgojnofilozofskih stavova. Na ovom ću se mjestu usmjeriti tek na onaj dio tog poglavlja u kojem su etičke konotacije snažno izražene, dok ću njegov odgojnofilozofski sadržaj obraditi u potpoglavlju posvećenom razmatranju zastupljenosti filozofije odgoja u spisu o umijeću trgovanja.

Dubrovački je mislilac posjedovanju znanja pridao snažne etičke konotacije. Naime, zamijetivši da neuki i najneobuzdaniji ljudi često polude te ogovaraju i kude one koji posjeduju znanje, zabilježio je da su neznalice općenito zli te da je zlo suprotno dobru koje je vrlina (e lo male e opposto a lo bene, lo quale e virtu). ${ }^{274} \mathrm{Zbog}$ toga, nastavlja Dubrovčanin, na svijetu nema većeg rata ni neprijateljstva nego između glupog i mudroga te neukog i učenoga (dal ignorante alo savio et dalo indocto alo docto), i baš kao što se voda ne zna i ne može pomiriti s vatrom, tako se ni učen ne može pomiriti s neukim, pa gdje god se među pukom nađe učen čovjek, poput Sokrata i Dantea, neuki ga kude i preziru, ubijaju, tjeraju i progone. ${ }^{275}$ Etički sloj izražen je i u Kotruljevićevu inzistiranju na nužnosti trgovčeva poznavanja logike. Prema njegovu mišljenju, izrazito je važno da trgovac bude logičar (essere loyco), i to zbog razlikovanja istinitog od lažnog (discernere lo vero dai falso), kao i zbog

${ }^{272}$ Cotrugli, »Libro del arte dela mercatura«, libro III, capitulo 3 / Kotrulj, »Knjiga o vještini trgovanja«, knjiga III, poglavlje 3, p. 248 [f. 64r]: »Volendo consequentemente tractare dela scienca del mercante, quale e quanta deve essere, io mi vengo meno al pensarvi, per che la mi mena in infinitum, che volendo instituire lo mercante perfecto et compiuto mi bisognia fare uno homo universalissimo, dotato d' ogni faculta che possa intendere et comparere con ogni generacion di homini.«/p. 440.

${ }^{273}$ Ibid., p. 248 [f. 64r] / p. 440.

${ }^{274}$ Ibid., p. 251 [ff. 65v-66r]: »Et sono niente di meno alcuni indocti et indisciplinatissimi homini li qualli prorumpono et biastimano coloro i quali sanno alcuna cosa et questi sono comunamente li homeni ignoranti et vulgari li quali per doglia che si vegono inferiori deli altri homini prorumpeno in insania et biasimano quelli li quali sanno, perche l' ignoranti tuti comunamente sono cativi, [...] E lo male e opposto a lo bene, lo quale e virtu.«/p. 442.

${ }^{275}$ Ibid., pp. 251-252 [f. 66r]: »<...> pertanto e non ci e magiore guera et inimicicia in questo mundo che dal ignorante alo savio et dalo indocto alo docto et come l' aqua non sa ne puo stare in pace con lo fuoco, cosi lo docto con lo indocto. Et pero comunamente dove intra lo vulgo si trova homo literato, egli e o biasimato o despregiato o morto o vero discaciato et persequitato dalo vulgo. Come da multi si legie et precipue di Socrate, lo quale sendo non solamente per delli homini judicato sapientissimo del mundo, ma eciamdio nel oraculo d' Apollo fo pronosticato el piu savio. Niente di meno, per la invidia de la sua doctrona fu constrecto dal populo et detenoli ad bevere veneno et cosi mori. E pero Dante, discaciato dala sua patria, mori in Ravenna.«/p. 442. 
pobijanja lažnih tvrdnji i silogizama (confundere li falsi argumenti et silogismi), jer postoje neki ljudi koji su po prirodi sofisti (homini di natura sophiste). ${ }^{276}$

Četvrto poglavlje treće knjige spisa o umijeću trgovanja dubrovački je ranorenesansni mislilac posvetio još jednoj vrlini koja treba krasiti trgovca: pouzdanje (confidentia). Na početku tog poglavlja koje je naslovio »O trgovčevu pouzdanju« (»Dela confidentia delo mercante«) najprije je ponudio odredbu pouzdanja: sigurnost i spokoj duše u radu, a što je uvjet trgovčeva poštenja. ${ }^{277}$ Odmah potom upozorio je da trgovac ne smije biti prenagao niti prekomjerno srčan (troppo temerario et animoso che exceda modo), jer je takav trgovac opasan (periculoso), već mora biti osrednje odvažan (mediocriter audere) i ono što smiono poduzme S pouzdanjem prepustiti u ruke Bogu i sreći (fortuna). ${ }^{278}$ Pravo poduzetništvo mora, bilježi Dubrovčanin, biti razumno, vrlo ozbiljno i smišljeno te bez lakoumnosti (sença legereça), a ostatak se treba prepustiti sreći. ${ }^{279}$ Poglavlje je dovršio napomenom da uvijek, a posebice onda kad se okrene sudbina nagore, trgovac mora biti pouzdan i odvažan (confidente et audacie) pa što ga više sudbina udara, on joj se treba snažnije i srčanije suprotstavljati, zbog toga što, kako tvrdi, loša sreća udara one koji joj okreću leđa, a bježi od onih koji joj pokazuju odvažno lice. ${ }^{280}$

Sadržajem skromno peto poglavlje treće knjige spisa o umijeću trgovanja dubrovački je mislilac posvetio sreći, zbog čega je poglavlje i naslovio »O trgovčevoj sreći« (»De fortuna delo mercante«). Otpočeo ga je tvrdnjom da trgovac, baš kao i liječnik, mora imati sreće. ${ }^{281}$ Na nužnost prisustva sreće u trgovčevu životu Kotruljević je ukazao sljedećim primjerom iz iskustva: svjedoci smo da postoje uredni, uzdržani i sređeni ljudi kojima sve što čine propada, dok nasuprot vidimo da nekim nesposobnim, nesmotrenim, gotovo nerazumnim i neukim ljudima poslovi vrlo dobro napreduju. ${ }^{282}$ Tome nije tako zato što su to, piše Dubrovčanin,

276 Ibid., p. 254 [f. 67r] / p. 443.

${ }^{277}$ Cotrugli, »Libro del arte dela mercatura«, libro III, capitulo 4 / Kotrulj, »Knjiga o vještini trgovanja«, knjiga III, poglavlje 4, p. 255 [f. 67r]: »Confidentia e proprio sicurita et bono animo in agendis et questa condicione sta bene apposta nela integrita del mercadante, <...>«./ p. 445.

${ }^{278}$ Ibid., p. 255 [f. $\left.67 \mathrm{r}-\mathrm{v}\right] /$ p. 445.

${ }^{279}$ Ibid., p. 255 [f. 67v]: »Vero intraprehendere vol essere ragionevole et cum grande gravitade et sentimento, sença legereça et poi lassare in mano dela fortuna.«/p. 445.

${ }^{280}$ Ibid., pp. 255-256 [f. 67v]: »Et pero in ogni evento et masime in adversa fortuna, lo mercante de essere confidente et audacie et quanto piu la fortuna lo percute piu robusto et animoso la deve invadere, perche la fortuna sole maxime percotere quelli li qualli li mostrano le spale et al contrario fugire da quelli di quali li mostrano lo vulto animoso.«/p. 445.

${ }^{281}$ Cotrugli, »Libro del arte dela mercatura«, libro III, capitulo 5 / Kotrulj, »Knjiga o vještini trgovanja«, knjiga III, poglavlje 5, p. 257 [f. 67v]: »Per cierto ell' e di bisognio anche lo mercante essere fortunato non meno che lo medico, <... > . / p. 446.

282 Ibid., p. 257 [f. 68r]: »Et questo per sola experiencia si puo mostrare pero che vedemo homini asestati, moderati et ordinatissimi in ogni soa facenda, tamen tuto lo suo fato essere sempre ruina et fanola et per 
svojim dobrim djelima zaslužili od Boga, već zato što im je, čini se, sreća prijateljica. ${ }^{283} \mathrm{U}$ zaključnom dijelu poglavlja Kotruljević je ponudio obrazloženje nastanka te pojave, a koje je obrazloženje prirodnofilozofske naravi. Naime, priopćio je da se sreća može naslutiti pri rođenju, jer se naša tijela ravnaju prema nebeskom utjecaju i baš kao što kod tjelesnih svojstava vidimo da su ljudi različite građe, pa je jedan čovjek vičan oružju, a drugi knjizi, tako je netko sretniji u jednoj stvari, dok je netko u drugoj. ${ }^{284}$

Šesto poglavlje treće knjige Kotruljevićeva spisa o umijeću trgovanja nosi naslov »O trgovčevu poštenju« (»De la integrita delo mercante«). Kotruljević je u njemu najprije pripomenuo da je trgovac toliko uljudan, prisan i potreban u svakom društvu da je potrebno da bude i pošten (integro). ${ }^{285}$ Kao suprotnost poštenu čovjeku Dubrovčanin je postavio čovjeka koji je ništarija, lakouman i nepostojan (çacaro, legiere et instabile). ${ }^{286}$ Potom je naglasio da trgovac mora biti čovjek staložena duha, pošten i postojan (homo di ben conposta mente, integro et saldo), zatim da mora s velikim dostojanstvom (grande dignita) cijeniti svoju riječ i da mora najpoštenije (in suma integrita) održati svoje obećanje. ${ }^{287}$ Poštenje se, nastavlja Dubrovčanin, ne može dobro poznavati ako nije stavljeno na kušnju, pa se poštenima mogu smatrati samo oni koji su imali tajne pologe i mogli su ih bez zadrške zanijekati, ali su ih ipak bez odlaganja i razmišljanja vratili. ${ }^{288}$ Prema tome, tek kad je čovjek iskušan, može se smatrati poštenim, jer se u suprotnom može sumnjati da će za puno novca učiniti neko zlodjelo u koje se inače ne bi upustio. ${ }^{289}$ Kotruljevićev je stav bio da čovjek mora biti pošten ne samo u djelima (in facto), nego i u mislima (in pensamento), da mora biti postojane duše i neosporno dobar čovjek (saldo d' animo et indubitato bon homo) koji nikada

contrario vedemo omini imperiti, improvidi et quodammodo irracionali et sença letere, le loro cose essere prosperissime.«/p. 446.

${ }^{283}$ Ibid., p. 257 [f. $68 \mathrm{r}$ ]: »Ne anco questo meritano per via dele bone operacione quanto a Dio, ma pare che la fortuna l' e amica«. / p. 446.

${ }^{284}$ Ibid., p. 257 [f. 68r]: »<...> et questo presumo che si coglie a nativitate, che li nostri corpi se governano dal influxo cieleste et come in naturalibus vedemo uno che e d' una complexione, l' altro de l' altra, l' uno apto

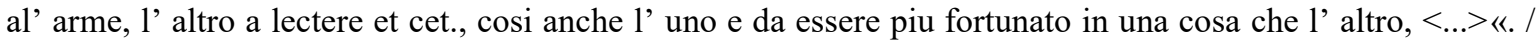
p. 446.

${ }^{285}$ Cotrugli, »Libro del arte dela mercatura«, libro III, capitulo 6 / Kotrulj, »Knjiga o vještini trgovanja«, knjiga III, poglavlje 6, p. 258 [f. 68r]: »Volendo consequentemente tractare dela integrita delo mercante diremo che esendo lo mercante tanto civile et domestico et necessario in omni modo conversacione, per consequens ci pare necessario chel sia integro, <... >«. / p. 447.

286 Ibid., p. 258 [f. 68r] / p. 447.

${ }^{287}$ Ibid., p. 258 [f. 68 r] / p. 447.

${ }^{288}$ Ibid., pp. 258-259 [f. 68v]: »La qual integrita nel vero non bene si puo cognoscere sela non e provata e pare a mi che soli quelli si possono chiamare integri li qualli hanno avuto li depositi occulti e posutoli negare et senca scropilo anno renduto sença dilacione di pensamento.«/p. 447.

${ }^{289}$ Ibid., p. 259 [f. 68v]: »Et per quanto e provato pertanto si puo apelare integro, che per 1' asay si fara una tristicia, che per lo poco l' homo non sinci mete. «/p. 447. 
neće svoju dušu (l'animo suo) okaljati prijevarom (fraudem) ${ }^{290}$ Pritom je zaključio da propali trgovci ne bi nikada trebali uživati povjerenje ni ugled, naročito ako su propali zbog nevaljalosti, a zato što, kako kaže, tko jednom bude zao, takav će i ostati te ga treba smatrati zloglasnom osobom (persona infame) i oskvrniteljem trgovanja. ${ }^{291}$

U sedmom poglavlju treće knjige spisa o umijeću trgovanja Kotruljević je ukazao na to da trgovca treba obilježavati marljivost (diligentia). Na to je uputio i naslovom poglavlja: »O trgovčevoj marljivosti« (»Dela diligentia delo mercante«). Obrazloženje za trgovčevo posjedovanje te vrline izložio je već u prvoj rečenici, a u kojoj je istaknuo da trgovca mora krasiti velika marljivost (diligencia grande), ali istodobno i brižnost (solicitudine) koja je, prema njegovu sudu, majka bogatstva. ${ }^{292}$ Osudu nemarnih (negligenti) ljudi Kotruljević je oblikovao u stav da je zbog njih lijenost ( $l$ 'accidia) ubrojena među smrtne grijehe (peccati mortali). ${ }^{293}$ Potom je istaknuo da trgovac mora biti marljiv ne samo po pitanju onoga što mora učiniti i brižno i brzo popraćeno umskim istraživanjem, već i za očuvanje onoga što je prethodno završio. ${ }^{294}$ Naglašavajući da trgovca trebaju obilježavati obje vrste marljivosti, napomenuo je da iz govora o tome isključuje opsjenare koji se samo doimaju vrlo brižnima, pa mašu rukama i nogama te trčkaraju zbog slabosti mozga, a ne zbog prirodnog pokreta. ${ }^{295}$ Kotruljević je u nastavku poglavlja zabilježio i to da brižljivost mora dolaziti iznutra, jer je tamo izvor svih trgovačkih poslova, pa dodao da je tjelesna brižnost ili fizički rad, namijenjena nižim i manualnim radnicima. ${ }^{296}$ Poglavlje je dovršio napomenom da trgovac također treba biti marljiv s perom, bilo vezano uz vođenje poslovnih knjiga bilo za odgovaranje na pisma, jer svako od njih donosi trenutnu ili buduću korist. ${ }^{297}$

Osmo poglavlje treće knjige spisa o umijeću trgovanja otkriva još jednu vrlinu koju je Kotruljević namijenio trgovcu, a to je okretnost (facilitate). U tom je poglavlju naglasio da

${ }^{290}$ Ibid., p. 259 [f. 68v] / p. 447.

${ }^{291}$ Ibid., p. 259 [f. 68v]: »Et pero li faluti mai piu deveriano havere fede ne credito et potissime quelli li qualli per cativita anno faluto, perche qui semel malus semper presumitur esse malus, [...] Et devesse havere come persona infame et adulteratore de la mercatura.«/p. 447.

${ }^{292}$ Cotrugli, »Libro del arte dela mercatura«, libro III, capitulo 7 / Kotrulj, »Knjiga o vještini trgovanja«, knjiga III, poglavlje 7, p. 260 [f. 68v] / p. 448.

${ }^{293}$ Ibid., p. 260 [f. 69r] / p. 448.

${ }^{294}$ Ibid., p. 260 [f. 69r]: »La qual diligencia non solamente deve essere circa le cose have da fare lo mercante et investigare solicito del intelecto et prompto, ma eciamdio di quelle che ave facte non le de fare ruinare.«/p. 448.

${ }^{295}$ Ibid., p. 261 [f. 69r]: »Et pero la diligencia l' una e l' altra deve servarse dalo mercante. Non dico di quelli iocolani li quali con la persona parno solicitissimi et tamen sono incomposti et quello menar le mano, li piedi et correre lo fanno ex debilitate celebri (sic!) et non per movimento naturale.«/p. 448.

296 Ibid., p. 261 [f. 69r]: »La solicitudine vuol essere [...] ad intra donde anno l' origine tute le faciende mercantile che la manual solicitudine partene ali minori et a mechanici.«/p. 448.

${ }^{297}$ Ibid., p. 261 [f. 69r-v]: »Et anche vol essere diligente ala penna, tanto inotar in libri le faciende soe, quanto inelo respondere a letere. E may non lassare nulla litera per trista che la sia che non li facia la risposta, perche ogni litera te porta qualche cosa, o in instanti o in futurum. «/ p. 448. 
trgovac mora biti okretan u poslu (facile in agendis), a okretnost uvijek potječe iz staložena i dobro uređena duha (mente composita et bene hordinata). ${ }^{298} \mathrm{Kad}$ god zamijetimo da netko teško piše, govori ili izvršava koju drugu radnju, riječ je, tvrdi Kotruljević, o nekome tko je nevješt $\mathrm{u}$ tome, jer okretnost dolazi od dobra uma (bon intelecto) naviknutog na tu vrstu posla i izvršava ga spretno. ${ }^{299}$ Neki su, smatra Dubrovčanin, toliko vični pisanju da ostavljaju dojam da im se slova rađaju jedno iza drugoga, dok se drugi preznojavaju sastavljajući mjenicu. ${ }^{300}$ Prema Kotruljevićevu mišljenju, uzrok tome nalazi se u poučljivosti ili nepoučljivosti uma (docilita et indocilita del ingiegno), što je potkrijepio, kako kaže, filozofskim razlogom (la ragione philosophica) koji je pripisao Aristotelu (come dicie Aristotile) da ne izaziva muku ono što je uobičajeno (quia ab assuetis non fit passio). ${ }^{301}$ Dubrovački je mislilac okončao osmo poglavlje izjavom da po pitanju navedenih poteškoća pomaže ako čovjek ima dara, jer daroviti sve čega se prihvate rade dotjerano i vrlo uredno, a oni koji to nisu moraju se pomučiti da bi to postigli. ${ }^{302}$

U devetom poglavlju treće knjige spisa o umijeću trgovanja Kotruljević je ukazao na to da trgovca mora obilježavati lukavost (astucia) ili prepredenost (callidita). Poglavlje je naslovio »O trgovčevoj lukavosti« (»Dela astucia delo mercante«). Otpočeo ga je tvrdnjom da trgovčeva lukavost ili prepredenost mora biti uzdržana (moderata) do te mjere da ne povrijedi drugoga i da se ne da povrijediti, kao i da mora biti takva da trgovac može razumijeti i domisliti gdje se kriju obmana (l' inganno) i zabluda (la fallacia). ${ }^{303}$ Ako je trgovac čist i priprost, bolje mu je, tvrdi Kotruljević, da se ne bavi trgovanjem, a zbog toga što među trgovcima postoji tisuću zamki, prijevara i obmana (mille laciuoli, fraude et inganni). ${ }^{304}$ Preostali dio poglavlja o lukavosti Dubrovčanin je posvetio upozorenjima vezanim uz to trgovčevo obilježje, a od kojih izdvajam sljedeća: 1) lukavu prijevaru ne smijemo koristiti čak ni za dobro; 2) ponekad je dobro biti lukav da se ne bismo dali prevariti; 3) trgovac mora

\footnotetext{
${ }^{298}$ Cotrugli, »Libro del arte dela mercatura«, libro III, capitulo 8 / Kotrulj, »Knjiga o vještini trgovanja«, knjiga III, poglavlje 8, p. 262 [f. 69v]/ p. 450.

${ }^{299}$ Ibid., p. 262 [f. 69v]: »<..> semper che vedete uno scrivere con difficultate, orare sforçatamente o alcuna altra cosa fare, dite che l' e ignorante de quella cosa, perche la facilita viene dalo bon intelecto, lo quale have gia facto habito in quello exercicio et fa quella cosa facilmente sença alcuna difficulta.« / p. 450.

${ }^{300}$ Ibid., p. 262 [f. 69v]: »Alcuni scriveno che pare che le lictere li nascano inançi cum ordine signulari, et alcuni sudano quando volno fare una lictera de cambio.«/p. 450.

${ }^{301}$ Ibid., p. 262 [f. 69v] / p. 450.

${ }^{302}$ Ibid., p. 262 [f. 69v]: »Et in questo multo giove havere 1' homo gracie che sono alcuni che anno gracia, dicio et pare che cio che lor escie de mano pare sia expolito et hordinatissimo et chi non la si de sforçare d' averla." /p. 450.

${ }^{303}$ Cotrugli, »Libro del arte dela mercatura«, libro III, capitulo 9 / Kotrulj, »Knjiga o vještini trgovanja«, knjiga III, poglavlje 9, p. 263 [f. 70r] / p. 451.

${ }^{304}$ Ibid., p. 263 [f. 70r] / p. 451.
} 
uvijek postupati s dobroćudnom jednostavnošću i čista srca te ne smije ni pomišljati na prijevaru niti je činiti. ${ }^{305}$

Deseto poglavlje treće knjige spisa o umijeću trgovanja Kotruljević je naslovio »O trgovčevoj građanskoj skladnosti« (»Dela urbanita delo mercante«). Ponovno naglašavajući trgovčevu svestranost u kojoj treba nadmašivati sve druge ljude, dubrovački je mislilac istaknuo i to da je trgovac građanska i domaća životinja usmjerena prema aktivnu životu (vita activa), a zbog čega mora biti ispunjena građanskom skladnošću. ${ }^{306}$ Naime, trgovac ne smije biti, tvrdi Kotruljević, isključen iz onoga što pripada građanskom i domaćem životu (vivere civille et domestico), već mora biti dosjetljiv (faceto), uzdržan (moderato), pun poštovanja (pieno di veneratione) i građanske skladnosti (urbanita). ${ }^{307} \mathrm{U}$ desetom poglavlju treće knjige spisa Dubrovčanin je kritizirao lakome trgovce koji zanemaruju sve druge aspekte života osim poslovnog. O njima je priopćio da su im zlato i srebro postali bogom i da ne brinu o rođacima, prijateljima, domovini, pa ni o svojim sinovima i kćerima, a u svakom se drugom pogledu građanskog života doimaju seljacima te se usmjeravaju samo na zgrtanje novca. ${ }^{308}$ Takve bi, ističe Kotruljević, zbog lakomosti trebalo izgnati iz ljudske zajednice, jer je lakomost suprotna ljubavi prema bližnjem, domovini i Bogu, pri čemu onaj tko stječe na takav način, uvijek smrtno griješi. ${ }^{309} \mathrm{Na}$ koncu poglavlja Dubrovčanin je zaključio sljedeće: 1) trgovac mora biti skladan (urbano) i uzdržan s novcem (havendo moderacione circa la pecunia) te dati svakome što mu duguje sukladno položaju, mjestu i vremenu, bilo da je riječ o domovini, bližnjima, robovima pa i sebi; 2) oni koji su neuzdržano (immoderamente) obuzeti poslom dosadni su sami sebi zbog beskonačne pohlepe (la infinita cupidita) i nezasitnosti svoje duše (insaciabile del animo) te ih se može usporediti s divljim životinjama. ${ }^{310}$

Jedanaesto poglavlje treće knjige spisa o umijeću trgovanja Kotruljević je posvetio još jednoj vrlini koja mora krasiti trgovca: pravednost (justitia / justicia). Dubrovački je mislilac već u

\footnotetext{
${ }^{305}$ Ibid., p. 263 [f. 70r]: »La qual astucia in fraude non devemo eciam in bono usare, [...] Alcuna volta e tamen bono a saperla per non lasarse ingannare, [...] Et questo quanto nella operacione, che lo mercante inquanto ad luy, deve sempre usare una bona simplicita e nectita delo core, sença ne pensare ne fare dolo.«/p. 451.

${ }^{306}$ Cotrugli, »Libro del arte dela mercatura«, libro III, capitulo 10 / Kotrulj, »Knjiga o vještini trgovanja«, knjiga III, poglavlje 10, p. 264 [f. 70r]: »Sendo lo mercante piu che altri homini universalissima persona et animale civille et dimestico (sic!) versante nela vita activa, deve esere pieno de urbanitate, <... «. / p. 452.

${ }^{307}$ Ibid., p. 264 [f. 70r] / p. 452.

${ }^{308}$ Ibid., p. 264 [f. 70r-v]: »Pero che sono alcuni et multi li qualli hanno fato lo dio loro oro et argento et non curano de parenti, de amici, de consigli dela patria, non sanno collocare figluoli loro ne le figluole, sonsi dati ad quello uno exercicio et in ogni altra urbanita parno homini de vila, solum in congreganda pecunia versantur.«/p. 452.

${ }^{309}$ Ibid., p. 264 [f. 70v]: »Questi talli sono per la loro avaricia da esserno caciati dal humano consorcio [...] et questo e proprio contra la carita del prossimo, dela patria et de Dio. Et sempre qui aquista con questo modo e peccato mortale.«/p. 452.

${ }^{310}$ Ibid., pp. 264-265 [f. 70v] / p. 452.
} 
prvoj rečenici tog poglavlja, a koje je naslovio »O trgovčevoj pravednosti« (»Dela justitia delo mercante«), otkrio koju je odredbu te vrline zagovarao. Naime, zabilježio je da pravednost znači svakome dati što je njegovo (rendere ad ognuno quello che e suo) te da ta vrlina u sebi sadrži i brojne druge vrline (questa virtu incorpora multe altre). ${ }^{311} \mathrm{U}$ članku iz 2009. godine u kojem je usporedila Kotruljevićevo i Aristotelovo poimanje pravednosti, Marita Brčić Kuljiš zaključila je da se upravo u Dubrovčaninovu zagovaranju spomenute odredbe pravednosti nalazi »ključni element Aristotelova utjecaja na Kotruljevićevu filozofsku misao«, a zbog toga što se u njoj krije »specifičnost Aristotelova shvaćanja pravednosti kao vrline koja je savršena i koja za svoje ozbiljenje traži prisutnost ostalih vrlina ${ }^{312}$ Prema Dubrovčaninovu shvaćanju, pravednost zahtijeva da joj trgovac služi, i to ne samo u očitim, već i u skrivenim stvarima, a ukoliko to ne čini ne može se zvati pravednim. ${ }^{313}$ Brčić Kuljiš je na temelju toga zaključila da je Kotruljevićev stav bio da je za ostvarenje općeg dobra, koje je svrha trgovanja pa i svake druge praktične djelatnosti, nužno da bude »ozbiljena vrlina pravednosti«. ${ }^{314}$ Kotruljević je u nastavku poglavlja priopćio da trgovac mora biti pravedan ne samo onda kada upravlja novcem, već i prilikom dijeljenja pravde, jer su trgovci nerijetko i arbitražni suci. ${ }^{315} \mathrm{U}$ ulozi sudaca moraju voditi računa o sljedećem: 1) moraju suditi i na blagdane, već prema potrebi; 2) moraju izbjegavati odlaganja, iznimke, prizive i nepotrebno odugovlačenje; 3) moraju odbijati prepirke odvjetnika i zastupnika; 4) moraju zauzdati brojne svjedoke; 5) moraju izvući potrebne i zakonite dokaze; 6) moraju postupati jednostavno i potiho, bez buke, sudske forme i privida, istražujući samo srž istine (sola substantia veritatis). ${ }^{316} \mathrm{U}$ zaključnom dijelu poglavlja dubrovački je mislilac poručio da se ljudska prosudba može izopačiti (perverti l' umano iudicio) na četiri načina: strahom (paura), pohlepom (cupidita), mržnjom (odio) i ljubavlju (amore). ${ }^{317}$

${ }^{311}$ Cotrugli, »Libro del arte dela mercatura «, libro III, capitulo 11 / Kotrulj, »Knjiga o vještini trgovanja«, knjiga III, poglavlje 11, p. 266 [f. 70v] / p. 453.

312 Marita Brčić, »Kotruljevićev nauk o pravednu trgovcu: podudarnosti i razlike s Aristotelovim poimanjem pravednosti«, Cris: časopis Povijesnog društva Križevci 11 (Križevci, 2009), pp. 135-143, na p. 142a.

${ }^{313}$ Cotrugli, »Libro del arte dela mercatura «, libro III, capitulo 11 / Kotrulj, »Knjiga o vještini trgovanja«, knjiga III, poglavlje 11, p. 266 [f. 71r]: »Et questo richiede la justicia delo mercante non solamente in le cose palese, ma eciam in ocultis alienam servare justiciam. La qual cosa non faciando, non ti chiamaro justo.«/ p. 453.

314 Brčić, »Kotruljevićev nauk o pravednu trgovcu: podudarnosti i razlike s Aristotelovim poimanjem pravednosti «, p. 142a.

${ }^{315}$ Cotrugli, »Libro del arte dela mercatura«, libro III, capitulo 11 / Kotrulj, »Knjiga o vještini trgovanja«, knjiga III, poglavlje 11, p. 266 [f. 71r]: »Justo eciamdio deve essere non solamente in administracione pecunie, ma eciamdio in faciendo judicio, perche in plurimum li mercanti sogliono essere judici arbitri.«/p. 453.

${ }^{316}$ Ibid., pp. 266-267 [f. 71r]: »Deveno fare rasone procedendo eciam nel tempo feriato secundo la necessita deli homeni, amputando dilacioni, excepcioni, apelacioni et dilacione frustratorie, repella li jurgii deli advocati et procuratori, refreni la multitudine di testimonii, ma pigli probacioni necessarie et legitime, procedendo simpliciter et de plano, sine strepitu, forma et figura judicii, sola substantia veritatis inspecta.«/p. 453.

${ }^{317}$ Ibid., p. 267 [f. 71r] / p. 453. 
I u dvanaestom poglavlju treće knjige spisa o umijeću trgovanja prisutna je etička sastavnica. U njemu je dubrovački ranorenesansni mislilac raspravljao o još jednoj vrlini koja mora obilježavati trgovca, a koju je, kao i dosad, uvrstio u naslov poglavlja: »O trgovčevoj postojanosti« (»Dela constancia delo mercante«). Prva rečenica poglavlja otkriva da trgovac uvijek mora biti postojan (constante), čak i onda kada je žrtva hireva sudbine (casi dela fortuna) i poneke nepravde (iniurie). ${ }^{318}$ Međutim, to sadržajem neveliko poglavlje sadrži i Kotruljevićev stav o još trima vrlinama koje je uz postojanost izdvojio kao one koje trgovac mora imati: trezvenost, snošljivost i strpljivost. Zabilježio je, naime, da trgovac mora imati leđa magarčića zbog postojanosti (propter constanciam), svinjsku njušku zbog trezvenosti (propter sobrietatem) te uho trgovca zbog snošljivosti i strpljivosti (propter tolleranciam et pacienciam). ${ }^{319}$ Kotruljević je potom korio lakoumne, nestrpljive i hirovite trgovce (li mercanti ligieri et impacienti, biçari), a koje zbog tih obilježja i ne treba smatrati trgovcima. ${ }^{320}$ Takvi bi, bilježi Dubrovčanin, bili dobri svirači, zato što hiroviti ljudi imaju nepostojan um koji lebdi i zato što su svi pomalo ludi. ${ }^{321}$ Prema Kotruljevićevu mišljenju, nepostojanost ( $l$ ' inconstancia) je ženski porok (proprio vicio feminille), dok je postojanost muška vrlina (virtu virile). ${ }^{322}$ Naposljetku, dubrovački je mislilac naglasio da trgovac mora biti postojan i čvrst (constante et fermo) u donošenju odluka, a nipošto promjenjiv i lakouman (mutabile, et ligiero). ${ }^{323}$

Trinaesto poglavlje treće knjige spisa o umijeću trgovanja Kotruljević je posvetio trgovčevu društvenom utjecaju, moći ili, kako glasi prijevod naslova poglavlja u izvedbi Janeković Römer, ugledu: »O trgovčevu ugledu« (»Del' auctorita delo mercante«). Prema Dubrovčaninovu mišljenju, trgovac mora u sebi imati ugled i ljupkost (auctoritate et venusta) zbog dostojanstva (la dignita) koje ima zbog svoje dužnosti i zbog toga što to uvelike doprinosi njegovoj službi pred strancima s kojima se neprestano susreće, ali i zbog toga što su upravo ta dva obilježja vanjski pokazatelji duševnog poštenja koje trgovac nosi u sebi. ${ }^{324}$

\footnotetext{
${ }^{318}$ Cotrugli, »Libro del arte dela mercatura«, libro III, capitulo 12 / Kotrulj, »Knjiga o vještini trgovanja«, knjiga III, poglavlje 12, p. 268 [f. 71r-v] / p. 454.

${ }^{319}$ Ibid., p. 268 [f. 71v] / p. 454.

${ }^{320}$ Ibid., p. 268 [f. 71v] / p. 454.

${ }^{321}$ Ibid., p. 268 [f. 71v]: »Seriano boni biffari che comunamente li biçari anno ciervello ligiero che li vola et tuti senteno di ramo di paçia.«/p. 454.

322 Ibid., p. 268 [f. 71v] / p. 454.

${ }^{323}$ Ibid., p. 268 [f. 71v] / p. 454.

${ }^{324}$ Cotrugli, »Libro del arte dela mercatura «, libro III, capitulo 13 / Kotrulj, »Knjiga o vještini trgovanja«, knjiga III, poglavlje 13, p. 269 [f. 71v]: »Per la dignita che lo mercante have ex officio, deve havere in se auctoritate et venusta, pero che multo agiongeno al officio suo et potissime apresso a forestieri, li quali ex improvisu s' afrontano teco. Avisandote che la auctorita e venusta multo demostrano fuori dela integrita d' animo che have dentro la criatura.«/p. 455.
} 
Uporište za takav stav Kotruljević je potražio u anegdoti u kojoj je Aristotel prilikom pojašnjavanja Aleksandru Makedonskom o tome kako bi trebao izgledati čovjek prirodno savršene građe, opisao ljupkost (venustatem) koja bi, popraćena ozbiljnošću, trebala proizlaziti iz izgleda, kretnji i glasa. ${ }^{325}$ Baš kao što su, poručuje Dubrovčanin, ljupkost i mirnoća (la venusta et quiete) ugledna čovjeka znak dobro sređene duše i duha (animo di mente ben composta), lakoumne ljude (li homini ligieri) obilježava nepostojanost i površnost duše (instabilitate et levitate grande nel animo), a to se najčešće vidi kod ljudi koji su lakoumni u govoru, postupcima, glasu i izgledu, što je znak slaba mozga i slabašne duševne vrline (ligiereça nela virtu del' anima). ${ }^{326}$ Prema Kotruljevićevim kriterijima, isto se može zaključiti i o ljudima s kapuljačom do pola glave koji kade oltare, a po različitim položajima i načinima nošenja kapuljače mogu se donijeti i dalekosežni zaključci koji imaju etičke implikacije: 1) oni koji nose kapu ili kapuljaču povučenu na oči oholi su i nagli; 2) oni koji puštaju kapu da pada straga tašti su ili zaljubljeni; 3) oni koji kapu nose na jednom uhu, zaneseni su, lakoumni, slaboumni, svadljivi, umišljeni, razmetljivi, budalasti, tašte pričalice i puno blebeću; 4) oni koji kapu nose dobro i ravnomjerno namještenu kao krunu, sređena su duha, vrlo ugledni i skromni, jer je prema Aristotelovu nauku vrlina izabrano stanje koje se drži sredine. ${ }^{327}$

Četrnaesto poglavlje treće knjige Kotruljevićeva spisa o umijeću trgovanja nosi naslov »O trgovčevoj darežljivosti« (»Dela liberalita delo mercante«). Svoja razmatranja o darežljivosti potrebnoj trgovcu Dubrovčanin je otpočeo opsežnom odredbom te vrline. Prema njegovu mišljenju, darežljivost je: 1) vrlina (virtu) koja pruža blagodati (benefficii); 2) vrlina koja se po osjećaju (per lo afecto) može nazivati dobrostivošću (benignita), a po učinku (per lo efecto) dobročinstvom (benefficencia); 3) vrlina koja se sastoji od davanja i uzvraćanja dobročinstava (nel dare e nel rendere di benefficii), zbog čega trgovac mora biti spreman uzvratiti dobrim djelima onima od kojih ih prima i činiti dobra djela kada procijeni da je to

\footnotetext{
${ }^{325}$ Ibid., p. 269 [f. 71v]: »Et pero Aristotile ad Alexandrum, volendo formare uno homo perfecto in phisonomia per viam nature, esso formo quandam venustatem la qual de essere in vulto, giesto et vocie, con venusta et gravitate, <... $>\ll . /$ p. 455.

326 Ibid., p. 269 [ff. $71 \mathrm{v}-72$ r] / p. 455.

${ }^{327}$ Ibid., pp. 269-270 [f. 72r]: »Et maxime quando vedete questi con capucio a meça testa quod altaria fumant. Et ut plurimum quelli che portano la bareta o lo capucio ritirato nanti l' ochii sono superbi et iracundi. Quelli li quali scopreno dinanti et lassano la calare drieto sono homini vani o namorati. Quelli li quali la portano ad una rechia sonno homini fantastichi, ligieri, debelissimi di cerebro, litigiosi, presumptuosi, vanagloriosi et bestiali et ut plurimum sono vani parlatori, et abundano in multiloquio. Quelli li quali la portano ben posta, cum equalitate, quasi coronam, sono homini bene composite mentis et pieni d' auctorita et modestia, quoniam virtus est Aristotele nel II Ethicorum.«/p. 455. Dio Kotruljevićeve tvrdnje da je Aristotel zastupao stav da je sredina izabrano stanje u sredini vidi u bilješci 400 na istoj stranici.
} 
potrebno. ${ }^{328}$ No, Kotruljević je upozorio na štetnost pretjerane darežljivosti po trgovca. Poručio je da trgovcu priliči obilno uzvraćati dobročinstva, ali ne previše, jer je darežljivost vrlina koja u većoj mjeri pripada gospodi i uzvišenim ljudima nego trgovcima, zbog toga što je dužnost gospode davanje, a dužnost i cilj trgovaca prikupljanje bogatstva. ${ }^{329}$ Kotruljević je u preostalom dijelu poglavlja iznio sljedećih dvanaest savjeta trgovcu vezanih uz davanje i uzvraćanje dobročinstava: 1) mora uvijek spremno i brzo uzvraćati dobročinstva, baš kao što je dužan svakome platiti na vrijeme; 2) nezahvalan je onaj tko dugo ne uzvraća, a blizu je odbijanja onaj tko dugo oklijeva; 3) onaj tko kasno pomaže, čini to preko volje; 4) kada kasni, trgovac gubi zahvalnost, jer je najvećem broju ljudi draže da ih se odmah odbije, nego da dugo čekaju na dobročinstvo; 5) treba paziti da dobročinstvo koje čini nekome ne našteti drugome, jer se takvi ne zovu dobročiniteljima nego laskavcima; 6) kada učini neko dobročinstvo, trgovac to ne smije predbacivati niti nabijati na nos, jer time gubi svu hvalu za učinjeno; 7) kada netko traži uslugu, ne smije ga se prikriveno odbijati ili mu se ispričati nadmudrivanjem; 8) ne smije se žaliti na nezahvalnika kojem je učinio dobročinstvo, jer tako pokazuje da se razlikuje od nezahvalnika; 9) treba biti velik u davanju i ne biti oštar u potraživanju; 10) treba voditi računa o tome da drugi uvijek njemu duguju više nego on njima; 11) ako je netko nezahvalan, sebi čini nepravdu; 12) treba razlikovati darežljivost prema potrebitima i prema dobrostojećima, zato što je bolje činiti dobro dobrima nego bogatima, jer oni ne žele biti obvezani dobročinstvom. ${ }^{330}$

U petnaestom se poglavlju treće knjige spisa o umijeću trgovanja dubrovački mislilac bavio smirenošću (tranquilita). Naslovivši poglavlje sukladno tematici »O trgovčevoj smirenosti«

${ }^{328}$ Cotrugli, »Libro del arte dela mercatura«, libro III, capitulo 14 / Kotrulj, »Knjiga o vještini trgovanja«, knjiga III, poglavlje 14, p. 271 [f. 72r] / p. 456.

${ }^{329}$ Ibid., p. 271 [f. 72r]: »Tuctavia, o mercante, ad te convene retribuire li benefficii amplamente, ma non da farne abundanter et maxime dove non bisognia. Pero che virtu partene piu ali signiori et magnifici homini che ali mercanti, pero che come l' officio di signori e nel dare, cosi l' officio de mercanti e nel adunare et congregare le divicie, e questo e lo fine del mercante.«/p. 456.

${ }^{330}$ Ibid., pp. 271-273 [ff. 72r-73r]: »Ma el deve sempre essere promptisimo al rendere di benefficii et prestissimo che come lo mercante de pagare ognuno a tempi, sença dilacioni, cosi anche el deve rendere ad ognuno li beneficii ricievuti sença diferire. Perche l' e ingrato benefficio lo quale lungamente tieni intro le mano et e proximo alo negante collui che lungamente dubito. E chi tardi fecie, lungamente non volle. Et quanto tardi, tanto perdi di gracia e multi voglion piu tosto audire presto de non che lungamente ricievere. Et nota che lo benefficio che tu fai ad uno non facia danno ad altro, che collui che fa lo benefficio ad uno di quello che nocie ad altro non se chiama benefficio ma adulatore. [...] Ceterum, quando fai benefficio, non lo exprobare ne gietaglielo in faccia, perche con lo exprobare perdi tuta la gratia, [...] Imo quando te dimandato lo benefficio, non devi denegare con velamento o alcuna cavilacione excusante. [...] Et nota che avendo fato bene ad uno ingrato non te lamentare di lui, perche se lui non n' e come speravamo siamo nui allui disimilli come fumo nel dare. Sia magnifico nel dare e non acerbo nel rivolere. Fa che sempre te siano altri piu debitori che tu ad loro, se l' e ingrato e non fa iniuria a me ma a se. [...] Et nota che altramente devi essere liberale a coloro li quali anno bisognio e sono prostrati dala fortuna che a quelli che stano bene e vogliono stare meglio. E meglio e fare bene ali boni che ali richi, perche li ricchi non voleno essere tenuti al benefficio.«/pp. 456-457. 
(»Dela tranquilita delo mercante«), Kotruljević je zabilježio da je smirenost duše vrlina (la tranquilita del animo e una virtu) koja dobro pristaje svakoj vrsti ljudi, posebice trgovcu. ${ }^{331}$ Smatrao je, naime, da one ljude čija je duša mirna obilježava sljedeće: imaju dobru tjelesnu građu i dobro raspoređene životne sokove; veseli su i radosni; u miru su sa sobom i drugima; sa svakim su prijatelji; nisu zavidni, ni himbeni, ni nepravedni, ni osvetoljubivi, ni sumnjičavi, ni pohlepni, ni lihvari, ni zloćudni. ${ }^{332}$ Nasuprot njima, ljude koji nemaju mirnu dušu, već su melankolični (malenconici), pognuta čela i uvijek gledaju u pod, obilježava sljedeće: imaju sve prethodno navedene loše osobine (tute male disposicioni); najpokvareniji su (viciosissimi); uvijek misle i čine zlo (pensano e fano male) te su vrlo pohlepni (avarissimi) u odnosu prema bližnjima, sebi i svojoj obitelji; lažljivci su i prijetvornici (bugiardi et simulatori), pa dok se na van pokazuju bolećivima i melankoličnima, u srcu uvijek gaje zlobu (intro lo core sempre sta in malicia). ${ }^{333}$ Uzrok Kotruljevićeve oštre kritike ljudi koji nemaju mirnu dušu, temelji se na tome što je bio uvjeren da trgovac pomućene i mračne duše ne može niti dobro savjetovati ni odlučivati, jer takva duša, primjerice, umnaža loše životne sokove te guši ljudski um. ${ }^{334}$ Trgovac treba, zaključuje Kotruljević, dopustiti da u njemu prevladaju žuč i krv te biti vedar i miran neovisno o događajima, jer takvi ljudi dugo i dobro žive (viveno assai et viveno bene) te iskreno razmišljaju, a takvih se loših navika treba čuvati od mladosti. ${ }^{335}$

Premda ga je naslovio »O trgovčevoj skromnosti« (»Dela modestia delo mercante«), Kotruljević je šesnaesto poglavlje treće knjige spisa o umijeću trgovanja zapravo posvetio raspravljanju o dvjema trgovčevim vrlinama: skromnosti (modestia) i čestitosti (honesta). Već je na početku poglavlja dao do znanja da trgovcu dolikuju skromnost i čestitost više nego drugim ljudima. ${ }^{336}$ Baš kao što mora biti izvrsniji od drugih u radu i poslu, trgovac bi, dodaje

${ }^{331}$ Cotrugli, »Libro del arte dela mercatura «, libro III, capitulo 15 / Kotrulj, »Knjiga o vještini trgovanja«, knjiga III, poglavlje 15, p. 274 [f. 73r]: »La tranquilita del animo e una virtu la qual sta bene in ogni generacion di homini et maxime nelo mercante. $/$ p. 458.

${ }^{332}$ Ibid., p. 274 [f. 73r-v]: »Et tuti colloro li qualli sono tranquilli del animo significa bona complexione et disposicione di boni humori et per consequens sono homini leti, gaudenti, anno pacie seco et con altrui, sono amici d' ogni homo, non invidiosi, non vafri, non iniqui, non vindicativi, non suspectosi, non avari, non usurari, non maligni, <... «. / p. 458.

${ }^{333}$ Ibid., p. 274 [f. $\left.73 \mathrm{v}\right] /$ p. 458.

${ }^{334}$ Ibid., p. 275 [f. 73v]: »Avisandovi che lo mercante lo qual have l' animo implicato e scuro non sa ne po bene consigliare ne deliberare, perche multiplica li mali umori et oprime l' intelleto, l' umor flematico et fa l' homo de ebete inçegnio.«/p. 458.

335 Ibid., p. 275 [ff. 73v-74r]: »Lassa predominare la colera e lo sangue et sta lieto et tranquilo in utroque successu. Et questi homini viveno assai et viveno bene et ogni cosa deliberano con sincerita. [...] Et pero da gioventu si deve l' homo guardare di non incorere in uso di tal costume, $<\ldots>\ll$. / pp. 458-459.

${ }^{336}$ Cotrugli, »Libro del arte dela mercatura «, libro III, capitulo 16 / Kotrulj, »Knjiga o vještini trgovanja«, knjiga III, poglavlje 16, p. 276 [f. 74r]: »Dela modestia delo mercante et honesta volendo tractare, diremo che lo 
Kotruljević, trebao skromnošću i čestitošću nadmašivati bilo svoje ukućane bilo ljude s kojima se susreće izvan kuće i pred kojima se treba ponašati kao djevica i redovnik. ${ }^{337}$ Dubrovački je mislilac potom izložio kritiku ondašnjeg stanja u Italiji ne bi li prikazao načine kojima se iskazuje čestitost. Zapisao je da se čestitost najmanje štuje u Italiji, jer se tamo događalo sljedeće: očevi idu u kupalište sa sinovima, a majke sa kćerima; svi hodaju bez rukava i u kratkim suknjicama čak i pred očevima, sinovima i ženama; pretjeruju u razbacivanju psovkama i sramotnim riječima; u različitim pokrajinama koriste pokrete koji označavaju spolne udove. ${ }^{338}$ Naposljetku, Kotruljević je napomenuo da trgovcu priliči biti skroman i pristojan (modesto et costumato) u govoru, hodu, ophođenju s ljudima i u svim preostalim stvarima. ${ }^{339}$

Sedamnaesto poglavlje treće knjige spisa o umijeću trgovanja Kotruljević je naslovio »O trgovčevim pohvalnim osobinama« (»Dela laudabile condecioni delo mercante«). Kako bilježi na početku poglavlja, u prethodnim je poglavljima razmatrao posebne vrline (le virtu speciali) koje moraju krasiti trgovca za politički život, zbog čega su na red došle pohvalne osobine (le laudabile condicioni) koje bi trgovac trebao u sebi nositi. ${ }^{340}$ Dubrovčanin je, naime, naveo sljedeće pohvalne osobine, pri čemu je uz neke od njih priložio i razloge zbog kojih ih trgovac treba imati: mora biti razgovorljiv i okretan u ophođenju (conversativo et agile) s dobrima (li boni), ali ne i sa zlima (li mali); mora biti ljubazan i dobroćudan (amabile et benigno), blaga i ljupka lica, svakome ugodan (piacevole), a posebno vedar i veseo kod prodaje i kupnje; mora biti vrijedan slave (glorioso), jer slava čini čovjeka čistim i gade mu se poroci (abominante li vicii) u težnji za slavom; mora biti čist s jednom suprugom, zato što snošaj razara novčanik i osobu te smanjuje um i zato što postoje brojni ludi i bezumni ljudi koji se prepuštaju razbludi puti (volupta dela carnacia); mora biti postojan (saldo) i ne smije lamatati rukama ili nogama ni trzati se tijelom, kao što to čine lakoumni i divlji ljudi (homini

mercante preter ceteros homines convene essere modesto et pieno de honesta, <... «. / pp. 460-461, na p. 460.

${ }^{337}$ Ibid., p. 276 [f. 74r]: »< ...> che cosi come de essere nela faciende sue et negocii essere preexcelente sopra 1 ' altri homini, cosi anche de modestia et honesta dela sua persona, jo dico tanto in casa quanto fuori de casa, tanto con sui parenti, amici et compagni quanto eciamdio con sui figluoli, sua dona, sue schiave et schiavi. Et infine inter homines deve servarsi come una donçela e come religioso, <... $>$ «. / p. 460.

${ }^{338}$ Ibid., p. 276 [f. 74r-v]: »Questo ancor se observa in multisiime patrie e la meno veneracion de honesta che sia ogi et in Italia, dove non solamente hanno costume d' andare in bagni con li figlioli et madre con le figlie, ma e li homini esbrachiati et in giuparelli curti nanci ali patri, figlioli et donne, ma eciamdio hanno cierta manera exorbitante in alcuni vocabuli scialaquati et desonesti et secundo varie provincie, varii moti, nominando membri pudendi.«/p. 460.

339 Ibid., p. 277 [f. 74v]: »Li atribui li beli costumi et questo e coveniente alo mercante, essere modesto et costumato nel parlare, nel andare, nel conversare et in tute le cose del mundo, <... « $/$ p. 461.

${ }^{340}$ Cotrugli, »Libro del arte dela mercatura «, libro III, capitulo 17 / Kotrulj, »Knjiga o vještini trgovanja«, knjiga III, poglavlje 17, p. 278 [f. 74v] / p. 462. 
legieri et bestialli); mora biti postojan i zreo (saldo et maturo), nimalo lakomislen (sença alcuna levitate); mora biti svestran (universale), kao i znati se ophoditi sa svim ljudima. ${ }^{341}$ Potom je izdvojio i one osobine koje smatra porocima (vicii) koji su drugim ljudima ponekad dopušteni, ali trgovcu nisu nikada i nigdje: trgovac ne smije biti srdit (iroso), osvetoljubiv (vendicativo), drzak (protervo), tvrdoglav (opinionoso), hirovit (biçaro), opsjenar (ioculario), tašt (vano), rasipan (prodigo), divlji (bestiale), bučan (canaruto) ni izjelica (giotone). ${ }^{342}$

Osamnaesto, ujedno posljednje i sadržajem najbogatije poglavlje treće knjige spisa o umijeću trgovanja Kotruljević je posvetio umjerenosti (temperantia / temperancia). Zbog toga je i naslovio poglavlje »O trgovčevoj umjerenosti« (»Della temperantia delo mercante«). Promišljanja o toj vrlini započeo je sljedećom odredbom: umjerenost je vrhovna vrlina (summa virtu) koja sa sobom nosi brojne druge vrline. ${ }^{343}$ Da bi što sustavnije i podrobnije izložio pojedinosti vezane uz načine trgovčeva ispoljavanja te vrhovne vrline, Dubrovčanin je ostatak poglavlja podijelio na pet primjera slučajeva u kojima trgovac nužno mora biti umjeren. Zato ću se u nastavku obrade osamnaestog poglavlja treće knjige spisa o umijeću trgovanja voditi upravo tim primjerima, kao i pojašnjenjima koja je Kotruljević ponudio uz svaki od njih.

Prvi primjer glasi: trgovac mora biti umjeren i u uspjehu i u nevolji. ${ }^{344}$ Dubrovčanin je uz taj primjer donio i dva pojašnjenja ili obrazloženja: 1) trgovac se ne smije uznositi (extolere) u uspjehu (prosperita), a u nevolji (adversita) se ne smije smesti (conturbare); 2) svaka ćud (temperamento) mora naći sredinu (lo meço) u kojoj se nalazi vrlina (la virtu) ${ }^{345}$ Drugo pojašnjenje ili obrazloženje temeljio je, priznaje, na Aristotelovoj odredbi vrline iz druge knjige Nikomahove etike, a koju je odredbu zabilježio na latinskom jeziku: »Virtus est habitus electivus in medio existens «. ${ }^{346}$ Time je, napominje Martinović, »prihvatio temeljnu definiciju Aristotelove etike«, a indikativno je $\mathrm{i}$ to što je na nju uputio »upravo u razglabanju o umjerenosti, kojoj i u Aristotelovu popisu kreposti pripada središnje mjesto«, te je, zaključuje Martinović, »pri pisanju etike za renesansnoga trgovca« u Aristotelovoj Nikomahovoj etici

\footnotetext{
${ }^{341}$ Ibid., pp. 278-279 [ff. 74v-75r] / p. 462.

342 Ibid., p. 279 [f. 75r] / p. 462.

${ }^{343}$ Cotrugli, »Libro del arte dela mercatura «, libro III, capitulo 18 / Kotrulj, »Knjiga o vještini trgovanja«, knjiga III, poglavlje 18, p. 280 [f. $75 \mathrm{r}-\mathrm{v}] /$ p. 463.

${ }^{344}$ Ibid., p. 280 [f. 75v]: »Et primo de essere temperato nele cose prospere et adverse le qual occoreno piu al mercante et quasi al continuo che ali altri, <... «. / p. 463.

345 Ibid., p. 280 [f. 75v] / p. 463.

${ }^{346}$ Ibid., p. 280 [f. 75v] / p. 463.
} 
pronašao »važan izvor nadahnuća. ${ }^{347}$ Kada je u studiji o filozofskim izvorima spisa o umijeću trgovanja istraživao ulogu Nikomahove etike u oblikovanju Kotruljevićeve etičke misli, Balić je zaključio da je podatke o latinskoj inačici Aristotelove odredbe vrline Dubrovčanin mogao doznati od Alberta Velikog ili od Tome Akvinca. ${ }^{348}$

Drugi Kotruljevićev primjer bio je sljedeći: trgovac mora biti umjeren u jelu i piću. ${ }^{349}$ Ako je neumjeren, obilježit će ga dva poroka: pijanstvo i prejedanje. Dubrovčanin je naveo i pojasnio opasnosti koje leže u tim dvama porocima te ponudio savjete za njihovo izbjegavanje: pijanstvo je najgori porok, jer je štetno za trgovca koji je javna osoba više od drugih ljudi; pijanstvo obeščašćuje trgovca i može nauditi njegovu poslovanju, jer je pijan sklon činjenju grešaka; trgovac mora izbjegavati prejedanje, ali i opijanje, jer je ono za njega najopakija pošast; iz opijanja proizlaze i brojne posljedice, poput sramote, lijenosti, tuposti uma, pospanosti, petljanja jezikom te različite slabosti i bolesti; hranu treba cijeniti samo kao sredstvo za održavanje tijela; iz proždrljivosti se ne rađa nikakvo dobro, već svaka opačina i neprimjerena raskalašenost. ${ }^{350}$

Treći primjer koji se odnosi na umjerenost Kotruljević je oblikovao na sljedeći način: trgovac mora biti umjeren u govoru. ${ }^{351}$ Kao i u prethodnom primjeru, Dubrovčanin je bio rječit u obrazloženjima. Prema njegovu mišljenju, trgovac ne smije previše govoriti, jer je takvo pretjerivanje dostojno prijekora kod svakoga, pa dok je drugima to zabranjeno samo zbog dobra čestitosti (ad bonum onestum), trgovcu je zabranjeno i zbog koristi (ad bonum utile), zato što brbljavost trgovcu uzvraća najvećom štetom. ${ }^{352}$ Nasuprot tome, šutnja nije,

${ }^{347}$ Martinović, »Benedikt Kotruljević (2)«, p. 9c. Isto vidi u: Martinović, »Benedikt Kotruljević«, u: Budak (osmislio i uredio), Croatica: HR - Hrvatski udio u svjetskoj baštini, [sv. 1], p. 173b; Martinović, Žanrovi hrvatske filozofske baštine od 15. do 18. stoljeća, p. 14.

${ }^{348}$ Balić, »Filozofi i filozofski izvori u Kotruljevićevu spisu o umijeću trgovanja«, pp. 223b-224a.

${ }^{349}$ Cotrugli, »Libro del arte dela mercatura «, libro III, capitulo 18 / Kotrulj, »Knjiga o vještini trgovanja«, knjiga III, poglavlje 18, p. 280 [f. 75v]: »Secundo, deve essere lo mercante temperato nel mangiare et nelo bevere «. / p. 463.

${ }^{350}$ Ibid., pp. 280-282 [ff. 75v-76r]: »<...> et l' extremo di questo vicio e ebrieta et e molto piu nocivo al mercante che ad altri, perche lo mercante e piu publica persona, perche li altri avendo crapulato pono schivare la conversacione deli homini et smaltire ocultamente quello erore et lo mercante al continuo de comparere in publico et non puo scondere lo male, lo qual cosi come l' e desonesto cosi anche li puo essere nocivo per li conti et compere, che puo fare di errori che li sariano molto damnosi. Deve donche schivare lo tropo mangiare et multo piu lo tropo bevere perche l' e peste nequissima nelo mercante et oltra al' infamia la qual se de tropo fugire, sequitane anche piegricia, groseça d' intelecto, somnolencia, et ingrosare la lingua et infine diverse infirmita, malatie, [...] Anche non deve apreçare lo cibo si non per simplice sustentacione del corpo, $[. .$.$] che nisun bene anci ogni flagicio et inepta luxuria ne nascie dala gola.«/pp. 463-464.$

${ }^{351}$ Ibid., p. 282 [f. 76r]: »Terço, deve essere temperato lo mercante nel parlare $<\ldots>$ «. / p. 464.

${ }^{352}$ Ibid., p. 282 [f. 76r-v]: »<...> et non deve parlar troppo, pero che lo troppo parlare non solamente in tuti li homini e reprehensibile ma eciamdio multo et in excessivo modo nel mercante, pero che neli altri e prohibito solamente quantum ad bonum onestum, ma nelo mercante eciam quantum ad bonum utile, perche nel multiloquio infinite volte al mercanto tornao gravissimo danno, perche lo compagno ti toglie l' aviso lo quale ti torna al danno si non statim in prociesso di tempo«. / p. 464. 
pojašnjava Kotruljević, nikada nikome naštetila, no razborit čovjek ne mora uvijek šutjeti, već mora govoriti na pravom mjestu i u pravo vrijeme. ${ }^{353}$ Pri odabiru mjesta i vremena trgovac mora voditi računa o sljedećih pet stvari: 1) mora paziti što će reći zbog toga da ne bi govorio nevezano s prethodno rečenim, kao i zbog toga da bi izbjegao neumjesne, sramotne, tašte, prijekora vrijedne, nečestite ili nedostojne stvari; 2) mora procijeniti kad ne treba upadati u riječ drugima i prekidati ih; 3) treba prosuditi koliko će dugo govoriti, jer divljaci ne daju drugima da govore, a kad dobije priliku govoriti, ne smije biti opširan nego jasan, razgovijetan i kratak; 4) mora misliti kome se obraća, uzimajući u obzir položaj osobe, pri čemu treba imati na umu da izvuče korist časteći druge; 5) mora znati kako će govoriti. ${ }^{354}$ Što se tiče načina govorenja, Kotruljević je napomenuo da trgovac mora razlagati s ljupkošću i uzdržanošću u glasu, izgledu i kretnjama, i to na sljedeći način: trgovčev glas mora biti blag, ovisno o tome govori li o uzvišenim ili niskim stvarima, a mora ga mijenjati da bude oštar, sućutan, uzvišen, spušten i slično; trgovčev izgled mora biti takav da ne maše glavom, očima, ustima, rukama i nogama, već mora ostati postojan i miran te umarati samo jezik; trgovčeve kretnje trebaju biti takve da pazi na izraz lica, usne i držanje tijela te mora pokazati blago lice i što je moguće ljupkiji izgled. ${ }^{355}$ Izlaganje o trećem primjeru slučaja u kojem trgovac nužno mora biti umjeren, Kotruljević je zaključio stavom da uzdržanost (moderacione) ide uz ljupkost (venusta) ili ozbiljnost (gravita), jer je toliko lijepa uzdržanost u govoru i ozbiljnost razmišljanja (la moderacione nel parlamento, e la gravita nel ragionare) uzvišenih ljudi, još više mladih koji su rijetko takvi, a blaženi (beati) su oni koji jesu. ${ }^{356}$

${ }^{353}$ Ibid., p. 282 [f. 76v]: »<...> si che lo taciere non fu mai damnoso a nesuno, ma lo parlare multe volte a multi. Vero e che l' omo prudente non de sempre taciere, ma parlare deve loco et tempore secundo la cosa richiede «. / p. 464.

${ }^{354}$ Ibid., pp. 282-283 [ff. 76v-77r]: »<...> maxime havendo rispecto a cinque cose. Et primo ad avedere che vol dire che timore de parlare cose impertinente ali precedenti parlamenti ne fuor di propossito, ne cose turpe, ne vane, ne reprensibile, ne dishoneste, ne indegne ala tua condicione. Secundo, devi considerare quando non devi interponere lo parlamento tuo al parlamento d' altri, interrupendo: specta tempo quando te pare chel te toca, perche con lo tempo sera acepta e pesata la tua parola. Non fare come ut plurimum fanno quelli dela nostra nacione li quali parlano sete al' trato et tuti se intendeno. Terço, deve considerare quanto, perche devi dare termine al tuo parlare, non essere lungo, da loco ad altri non volere sempre parlare tu, che questo e usança de bestie. Et quando hai a parlare non excedere lo modo con la tua prolixita cominciado dal uovo per volere narar la ystoria Troiana, [...] Lo parlamento tuo sia chiaro et lucido et breve, chel sia obscuro, [...] Quarto, devi considerare a cui. Questo e che non debi respondere sempre et ad ognuno et anche secondo lo grado dele persone, ma sempre abi a mente di far vantagio del honore ad altri, perche gli e bello e non costa nulla et lo honor che fai ad altro l' e tuo, [...] Quinto e da sapere in che modo devi parlare. «/pp. 464-465.

355 Ibid., pp. 283-284 [f. 77r]: »Lo porgiere del tuo parlare vol essere di vocie, vulto, giesto, moderatione con venustate. Vocie deve havere remissa et secundo le cose alte o basse che tracti, cussi mutare la vocie acra, pietosa, superba, remissa et cet. Vulto non devi fare aleto, di capo, ochi, bocha, mano, piedi, ma star deve saldo, quieto, fatigando solamente la lingua et quiescando li altri membri. Giesto, del aere, dela boca e del porgiere, non obstante che l' uno a miglior gracia de altro, ma l' omo deve sforçare la sua natura e mostrarsi benigno nela ciera et gratioso nelo aspecto, quanto l' e posibile.«/ p. 465.

${ }^{356}$ Ibid., p. 284 [f. 77r] / p. 465. 
Četvrti Kotruljevićev primjer koji se odnosi na trgovčevu umjerenost bio je sljedeći: trgovac mora biti umjeren u trgovanju, točnije u kupovanju, prodavanju, plovidbi i poslovanju $s$ kojekakvima. ${ }^{357}$ Prema Kotruljevićevu mišljenju, trgovac se treba kloniti lakoumnih duša i pohlepnih u poslu koji žele uhvatiti svaku priliku, jer može odmah zaključiti da će propasti, te treba tražiti one koji rade na umjereno, dostatno, razmjerno imetku te opsegu rada. ${ }^{358}$

Peti Kotruljevićev primjer trgovčeva ispoljavanja umjerenosti glasi: trgovac mora biti umjeren u prijateljstvu (neli amici) i u ljubavi (nelo amare). ${ }^{359}$ Dubrovčanin je to obrazložio na sljedeći način: za trgovačko umijeće nije dobro imati brojne prijatelje, kao ni ispraznih i prisnih prijateljstava, pogotovo s ljudima koji ne znaju platiti kad su dužni, što ih naposljetku čini trgovčevim neprijateljima; trgovac mora imati brojne poznanike, a malobrojne prijatelje, koje je ionako teško pronaći. ${ }^{360}$ Nakon što je izložio pet primjera, Kotruljević je poglavlje o umjerenosti, a time i treću knjigu spisa o umijeću trgovanja, zaključio savjetom da trgovac treba paziti da ne zalaže i ne posuđuje novac, jer je, kako kaže, bolje jednom pocrvenjeti nego sto puta problijedjeti, pa dodao da se trgovac može nazivati trgovcem tek onda kada posjeduje ćud koja je popraćena preostalim prethodno navedenim vrlinama i osobinama. ${ }^{361}$

\subsubsection{Etika u četvrtoj knjizi spisa o umijeću trgovanja}

Sadržaj četvrte i posljednje knjige Kotruljevićeva spisa o umijeću trgovanja istraživači hrvatske filozofske baštine dosad su, kao i uostalom sadržaj treće knjige, prepoznali kao onaj u kojem se očituju Dubrovčaninova etička promišljanja. U ovom potpoglavlju usmjerit ću se na istraživanje prisutnosti etičke sastavnice u deset poglavlja četvrte knjige, a sa svrhom upućivanja na njezinu etičku orijentaciju. Ovom prigodom izdvojit ću Kotruljevićeve zapise iz onih poglavlja u kojima je etička sastavnica najzastupljenija. Točnije, izdvojit ću njegove

${ }^{357}$ Ibid., p. 284 [f. 77r]: »Quarto, deve essere lo mercante temperato in nello mercantare, cio comprare, vendere, navicare et introprendere quomodocumque.«/p. 465.

${ }^{358}$ Ibid., p. 284 [f. 77r-v]: »Perche, come trovate animi ligieri, avidi di faciende et che vogliono pigliare ogni ucello che vola, presto judicare che siano per falire, e con loro non vi avolupate, guardate quelli che fanno temperatamente tanto quanto la loro sustancia lor par bastare e la proportione dela loro industria. «/pp. 465466.

${ }^{359}$ Ibid., p. 285 [f. 77v] / p. 466.

${ }^{360}$ Ibid., p. 285 [f. 77v]: »Non si fa per questa arte havere multi amici et amicicie vane et instrinseche, ut puta, donne, preti, frati, viandanti, signori, poveri et homini che quando deveno dare non sanno pagare, perche sendo multo intrinseco besognia lo servi, se non lo servi tu lo perdi. Se lo servi te diventa inimico, perche al scodere ti sia fatica e la tua prompteça delo dimandare et deli tuo gioveni lo fa inimico. Et pero lo mercante vuol havere asai cognoscenti e pochi amici, ben che questo nome d' amici lo dicimo abusive, per che pochissimi si trovano amici et multi ne chiamano, ma per dire bene si de dire cognoscenti. «/p. 466.

${ }^{361}$ Ibid., p. 285 [f. 77v]: »Et abi a mente di non plegiare ne prestare denari, meglio e una volta arossire che ciento impalidire. Et cosi havendo questo temperamento con l' altre virtu et condicioni apposte in questa opera, potra veramente chiamarsi mercatante.«/p. 466. 
zapise iz predgovora te trećeg, četvrtog, šestog, sedmog, osmog i desetog poglavlja. Iz predgovora ću izdvojiti Kotruljevićeve stavove o važnosti trgovčeva ekonomskog života, zatim ću iz trećeg poglavlja opisati muškarčevu ulogu u kućanstvu i obilježja koja muškarac mora imati, potom ću iz šestog poglavlja izdvojiti obilježja koja moraju krasiti trgovčevu ženu, iz sedmog ću izdvojiti dužnosti roditelja prema djeci i djece prema roditeljima, dok ću iz osmog obrazložiti trgovčev odnos prema robovima i slugama, a onda ću iz desetog poglavlja izdvojiti obilježja trgovčeva umirovljenja i kraja njegova života. Prije toga valja napomenuti da je u četvrtoj knjizi spisa o umijeću trgovanja najzamjetnija etička sastavnica, no iz te se knjige mogu iščitati i Kotruljevićevi stavovi koji pripadaju filozofiji odgoja. Na ta ću mjesta upozoriti u slučajevima kada se njihov sadržaj preklapa s etičkim, a o prisutnosti odgojnofilozofskih stavova bit će govora u narednom potpoglavlju ovoga poglavlja.

Nakon što je u prvim trima knjigama raspravljao o porijeklu i početku trgovanja, kao i o trgovčevoj vjeri, te o trgovčevu moralnom i političkom djelovanju, Kotruljević je u četvrtoj knjizi spisa o umijeću trgovanja naučavao o trgovčevu ekonomskom životu (la vita yconomica). Pod takvim životom podrazumijevao je trgovčevo upravljanje kućanstvom i obitelji, ${ }^{362}$ pri čemu je najviše pozornosti pridao odnosu trgovca prema ženi i djeci. Kotruljević je, smatram, zastupao i stav da zasnivanje i ispravnost trgovčeva ekonomskog života počiva na filozofskim, posebice etičkim i političkim zasadama. Njegovo zastupanje takva stava uočljivo je već u predgovoru četvrtoj knjizi. U njemu je Kotruljević ponudio popis koji sadrži sljedeće odredbe o fillozofskim zasadama trgovčeva ekonomskog života: 1) ekonomski život trgovca važan je kao i politički (il vivere politico); 2) trgovac mora vladati kućanstvom kao kralj (lo re de regiere) i brinuti o svojoj obitelji (cura dela sua famiglia); 3) ako se bavi isključivo trgovanjem, trgovac je grubo i nekorisno oruđe (uno instrumento rustico et desutile); 4) trgovac mora biti usmjeren na upravljanje obitelji (lo governo di sua famiglia) i na stjecanje posjedā (havere possessioni et care), a ne na zgrtanje novca (acumulare pecunia); 5) ako je usmjeren isključivo na novac, trgovac je igračka sudbine (gioco di fortuna); 6) ako mu je cilj gomilanje novca, trgovac je živina i nerazumna zvijer (animale et [...] bestia irracionale), a život mu se sastoji od beskrajne pohlepe (cupidita sença fine). ${ }^{363} \mathrm{Iz}$ navedenoga proizlazi da je ispravno trgovčevo djelovanje u političkom, dakle javnom životu zajednice, jednako važno kao i ispravno djelovanje u kućanstvu. Na jednaku

\footnotetext{
${ }^{362}$ Cotrugli, »Libro del arte dela mercatura «, libro IV, prephatio / Kotrulj, »Knjiga o vještini trgovanja«, knjiga IV, predgovor, p. 287 [f. 78r]: »Havendo fato lo transcurso secundo lo nostro proposito per li tre libri precedenti, con l' adiutorio divino, seguiremo lo quarto libro, in che modo lo mercante si de havere circa la vita yconomica e governo dela casa et dela famiglia.«/p. 467.

${ }^{363}$ Ibid., pp. 287-289 [ff. 78r-78v] / pp. 467-468.
} 
važnost tih dviju sfera trgovčeva života zorno ukazuje i Kotruljevićevo inzistiranje na trgovčevu rukovođenju kućanstvom i brizi o obitelji kakvo dolikuje kralju nad njegovim podanicima. Štoviše, dubrovački je mislilac trgovca koji pridaje preveliku važnost poslovanju i zgrtanju novca srozao na razinu iracionalne životinje i zvijeri te ga odredio kao onoga čiji je život obilježen porokom beskrajne pohlepe.

Potvrdu da je Kotruljević trgovčev ekonomski život temeljio na etici i politici, pružaju i zapisi iz onih poglavlja četvrte knjige u kojima je promišljao o ustroju kućanstva, zatim o obilježjima i vrlinama ukućana te o njihovim međusobnim odnosima. To se najprije očituje u trećem poglavlju naslovljenom »O glavaru kuće« (»Delo yconomo«). Prema Kotruljevićevu mišljenju, nužno je da glavar kuće bude muškarac, dok mu se žena, djeca i ostali ukućani moraju pokoravati. ${ }^{364}$ Odredivši glavara vladarom kućanstva, ponudio mu je dva savjeta za uspješno vladanje. Prvi se odnosio na to da bi trebao naizmjenično pokazivati strašno i ljubazno lice, a usprkos tome što mu njegova narav nalaže suprotno. ${ }^{365}$ Drugi savjet odnosio se na to da glavar treba nastojati prikriti svoju narav, jer je u suprotnom izgubljen. ${ }^{366} \mathrm{Za}$ uspješnu provedbu tih dvaju savjeta potrebno je, misli Kotruljević, da glavar bude vrlo razborit (havere multa prudencia). ${ }^{367} \mathrm{Uz}$ to, glavar bi trebao biti častan (venerabile), pristojan (costumato) i čestit (honesto), te bi trebao djelovati tako da obitelj uči iz njegova primjera (dal operacione), više negoli iz izgovorene pouke (dale parole). ${ }^{368} \mathrm{Za}$ uspješno održavanje učinkovitosti kućanstva glavar bi, nastavlja Kotruljević, trebao svakih petnaest dana obići i pregledati kuću, te ukoriti ukućane zbog svakog nedostatka u njoj, i ukućanima naložiti da nešto poprave ili naprave. ${ }^{369}$ Takvim će pristupom postići da se ukućani boje njegova nadzora i, samim time, drže kuću u redu. ${ }^{370}$ Kada je riječ o glavarevim tjelesnim obilježjima, Kotruljević je smatrao da lijep izgled (bella presentia) gospodara jamči ugled (autorita) pred

${ }^{364}$ Cotrugli, »Libro del arte dela mercatura«, libro IV, capitulo 3 / Kotrulj, »Knjiga o vještini trgovanja«, knjiga IV, poglavlje 3, p. 294 [f. 80r]: »Et perche tractamo del viver yconomico, per consequens ci pare conveniente tractare del homo yconomo, lo qual deve essere imprimis maschio et farse ubidire dala donna, dali figlioli et da tuta et universal famiglia«. / p. 472.

${ }^{365}$ Ibid., p. 294 [f. 80v]: »Et lo modo tuo sia alcuna volta mostrati terribile ancor che tu non sia, et alcuna volta piacevole, per viver iocundo et fare iocunda la tua casa.«/p. 472.

366 Ibid., p. 294 [f. 80v]: »Et sopra tuto ingegnati che la tua famiglia non cognosca lo tuo naturale, che como te 'l cognoscerano tu se' spaciato.«/p. 472.

${ }^{367}$ Ibid., p. 294 [f. 80v] / p. 472.

368 Ibid., p. 294 [f. 80v] / p. 472.

${ }^{369}$ Ibid., pp. 294-295 [f. 80v]: »<..> et delectate ad minus in XV di una volte circuire la casa tua tuta et vedere soto et sopra ogno loco, eciam dove dormeno li servicialli e le serviciale et reprendi ogni mancamento et sempre aconcia alcuna cosa o fa conciare, $<\ldots>$ «. / p. 472.

${ }^{370}$ Ibid., p. 295 [f. 80v]: »<...> acio che temano l' advento tuo improviso et tengano ornatamente le cose.«/p. 472. 
ukućanima. ${ }^{371}$ Ukoliko glavarevo tijelo kojim slučajem nije razmjerno, on bi usprkos tome trebao biti u stanju uspostaviti autoritet nad ukućanima, pa čak i pravovremenim kažnjavanjem. ${ }^{372}$ No, glavar to ne smije činiti zbog ljutnje (non per ira), nego isključivo zbog pouke (per doctrina). ${ }^{373}$

Da je Kotruljevićeva namjera bila prožeti svako područje trgovčeva ekonomskog života etikom i politikom, očituje se i u razmatranjima o naizgled irelevantnoj tematici iz etičke perspektive, konkretno o trgovčevu odijevanju. Tako je u četvrtom poglavlju četvrte knjige spisa o umijeću trgovanja, dakle u poglavlju naslovljenom »O odjeći i uresima« (»De veste et ornamenti«), Kotruljević izrazio nezadovoljstvo odijevanjem onoga vremena, i to iz dvaju razloga: zbog otežavanja mogućnosti razlučivanja staleške pripadnosti i zbog neumjerenosti u odijevanju. ${ }^{374}$ Zatim je istaknuo da je svijet naopak i pokvaren te da bi ljudi poput divljih životinja trebali slijediti svoju vrstu, razlikovati službe i dati svakome što je njegovo, jer tako nalaže istinska pravednost (la vera iusticia). ${ }^{375}$ Zbog toga je napomenuo da čovjek kojeg obilježava građanska skladnost i ozbiljnost ne smije prekoračiti onu mjeru u odijevanju koja je sukladna njegovoj prirodi, upozorivši da se odijevanje iznad staleških mogućnosti protivi moralnosti i poštovanju. ${ }^{376}$ Štoviše, takvo odijevanje nije, dodaje Kotruljević, uljudno (non e urbanita), uzdržano (non moderatione), duhovito (non e facete), ozbiljno (non graviter), skromno (non modeste), pristojno i uglađeno (non humaniter), obzirno (non observanter), pobožno (non religiose), velikodušno (non magnanime), mudro (non sapienter), pažljivo (non diligenter), suzdržano (non abstinenter) ni dobroćudno (ne benigne). ${ }^{377}$ Uzdržano odjeven

${ }^{371}$ Ibid., p. 295 [f. 80v] / p. 472.

372 Ibid., pp. 295-296 [f. 81r]: »Et per ben che tu havessi la proporcione inabile de vite, niente di meno ingegniare a superare la natura pero che multi anno aquistato parte quello che la natura denegava, [...] Et quando bisogna, castiga la tua famiglia con parole aspere et mite, loco et tempore interdum con lo bastone, $<\ldots>\ll$. / p. 473.

${ }^{373}$ Ibid., p. 296 [f. 81r] / p. 473.

${ }^{374}$ Cotrugli, »Libro del arte dela mercatura«, libro IV, capitulo 4 / Kotrulj, »Knjiga o vještini trgovanja«, knjiga IV, poglavlje 4, pp. 297-298 [ff. 81v-82r]: »Poi in dies, come in multe altre cose, cosi in questa li moderni homini hano riducto in abusione et pervertito ogni stile et ogni dignita, in mode che non si discerne intra plebeio et gintilomo, intra mercante et signore, imo quid peius est, li conti et li signori hanno temperato li vestimenti et riducto in paucita et moderacione et li plebei hanno producto sumptuosita et in policia nel vestire, che parno loro conti, se la ciera non li acusase, [...] Et per cierto vedete uno plebeio o una plebeia bene et ornate vestita pare che quelli vestiti l' accusano et quanto a piu preciose veste tanto piu pare scimia amantata. Et vedete uno gintilomo in uno simplice mantelleto o una gentildonna in dobleto; judicarai per aspecto la nobilita et pare come ala plebeia piangeva l' ornamento rico, cosi in costor ride l' umile.«/pp. $474-475$.

375 Ibid., p. 298 [f. 82r]: »Et pero lo mundo e depravato et guasto, perche come l' animal bruti deve et tira ogni specie sua propria specie, cosi anche deveriano li homini distinguere li officii et dare ad ognuno quello che e suo, come la vera iusticia ricierca.«/p. 475.

${ }^{376}$ Ibid., p. 300 [f. 83r]: »<...> ma contro ad ogni moralità et observancia, pero che 1' homo nela urbanita et nela gravita sua non deve excedere modo conforme al nostro naturalle.«/ p. 476.

${ }^{377}$ Ibid., p. 300 [f. 82v-83r] / p. 476 
trgovac ima uzdržanu dušu i trebao bi nositi dug ogrtač do pola noge, prikladnu donju haljinu crne, ljubičaste ili druge tamne boje, čarape s potplatima ili cipele te kapuljaču kada je potrebno. ${ }^{378}$

Najopsežnije poglavlje koje sadrži Kotruljevićeva promišljanja o obilježjima i odnosima među ukućanima, zasigurno je šesto poglavlje četvrte knjige spisa o umijeću trgovanja, a koje nosi naslov »O ženi« (»Dela muliere«). Promišljanja o obilježjima žena i njihovu odnosu s muškarcima Kotruljević je uvelike prožeo etikom. To je primjetno već u njegovu navođenju triju dobara (tre beni) koje žene općenito mogu i trebaju posjedovati. Kotruljević je prvim dobrom žena smatrao čestitost (bono honesto), koja leži u njihovim vrlinama (nele virtu), drugim dobrom smatrao je korist (bono utile), koja se sastoji od miraza, nasljedstva i bogatstva, dok je trećim dobrom smatrao nasladu (ben delectabile), točnije ljepotu (le belece). ${ }^{379}$ Međutim, ljepota i korist su, kako tvrdi, prolazne, pa s vremenom svaka žena postaje stara i ružna, a nestankom tih dobara nestaje i ljubav. ${ }^{380}$ Zbog toga bi muškarac trebao žudjeti za vrlinom, točnije za prvim od tih triju dobara koje je Kotruljević nazvao dobrom čestitosti, a koje živi zajedno sa stvorenjem te nikada ne jenjava i ne iščezava. ${ }^{381}$ Dubrovački je mislilac zagovarao muškarčevo traganje za dobrom ženom koja sa sobom nosi duševni miraz (dote del anima), dakle vrlinu (virtu), te muškarcu savjetovao da ne mijenja trajno dobro za prolazno (non cambiare lo ben perpetuo per lo transitorio). ${ }^{382}$ Kotruljević je zatim iznio osamnaest osobina i vrlina koje žena mora posjedovati zato da bi ostvarila dobro čestitosti. Prema njegovu mišljenju, žena mora biti razborita (prudente), postojana (constante), ozbiljna (grave), mila (piacente), revna (studiosa), blaga (humana), skromna (modesta), milosrdna (misericorde), nježna (pia), pobožna (religiosa), velikodušna (magnanima), suzdržana (continente), stidljiva (pudica), marljiva (diligente), trezvena (sobria), suzdržljiva (abstinente), oštroumna (sagacie) i radina (operosa), točnije uvijek zaokupljena nekim poslom (sempre nel exercicio di lavorare). ${ }^{383} \mathrm{No}$, dvije stvari mogu,

\footnotetext{
${ }^{378}$ Ibid., p. 301 [f. 83v]: »Et per contrario, quelli li quali vesteno moderatamente cosi sono con animo moderato. [...] Lungo vestire de manto che non exceda modo, cioe a meça gamba e la vesta sotana destra chel a te sia sença graveça e sença importunita, che tu signorigi le veste e non esse te. Laudo colore negro, paunaço et meschio scuro, calce solate o scarpe, dove si usa. In capo guarda la tua sanita et sapite moderare con capuci o capucieti, berete o beretine, pero che dala intemperie dela testa scendeno mille infirmitate.«/p. 477.

${ }^{379}$ Cotrugli, »Libro del arte dela mercatura«, libro IV, capitulo 6 / Kotrulj, »Knjiga o vještini trgovanja«, knjiga IV, poglavlje 6, p. 304 [f. 84v] / p. 479.

${ }^{380}$ Ibid., pp. 304-305 [ff. 84v-85r]: »<..> ma le beleçe passano con lo tempo, che ogni donna diventa vechia e bruta et si tu l' ai pigliata per rispecto dela beleça, passando la beleça passa lo amore. Et cosi e dela utilita.« / p. 479.

381 Ibid., p. 305 [f. 85r]: »Ma le virtu, cioe lo primo bene lo qual chiamai ben honesto, sempre dura et vive insieme con la creatura et mai non mancha.«/p. 479.

${ }^{382}$ Ibid., p. 305 [f. 85r] / pp. 479-480.

${ }^{383}$ Ibid., p. 305 [f. 85r] / p. 480.
} 
napominje Kotruljević, dovesti ženu do posrnuća: dokolica ( $l$ ' oçio) i siromaštvo (la poverta). ${ }^{384}$ Njih žena može ukloniti radom. ${ }^{385}$ Radom suzbija dokolicu, koja hrani ljubav i strast, te uklanja mogućnost siromaštva, zbog toga što će na taj način nešto steći. ${ }^{386} \mathrm{U}$ preostalom dijelu poglavlja »O ženi« Kotruljević je izložio stavove o odnosu muškarca i žene. Na muškarcu je, misli Kotruljević, da ženi već na početku braka uvede pravila i red (lo modo et ordene del vivere). ${ }^{387}$ Osim toga, nikada ženi ne smije popustiti uzde, nego ih uvijek mora držati u ruci i ne dopustiti joj da ikada pobijedi. ${ }^{388}$ Nadalje, muškarac ne smije ženu ozlojeđivati svojom osornošću, nego je mora umjereno milovati (chariçie con temperamento) i poticati je blagom rukom (mano dilicata), potruditi se da ga zavoli, ali i da ga se istovremeno boji (tema) te štuje (honori). ${ }^{389}$ No, Kotruljević je smatrao da muškarac mora i kažnjavati ženu, ali da u tome ne smije pretjerivati. ${ }^{390}$ Potom je muškarcu savjetovao da ženu ne čini ljubomornom (gielosa) i sumnjičavom (sospecta), nego da joj uzvraća ljubav. ${ }^{391}$ Ženu ne bi trebao učiniti požudnom (volentorosa), jer mu je supruga (la donna), a ne bludnica (non meretrice). ${ }^{392}$ Zatim je napomenuo da bi odnos muškarca i žene trebao biti obilježen velikom umjerenošću (gran temperança), stidom (vergogna) u riječima i djelima, pristojnošću (costume) i čestitošću (honesta) u razgovoru, a onda i vjernošću (fede) te uzdržanošću (moderacione). ${ }^{393}$ Osim u navedenim općim savjetima koji se odnose na pospješivanje muškarčeva odnosa prema ženi, a time i bračnog odnosa, Kotruljević je iz etičke, ali još više iz odgojnofilozofske perspektive promatrao pet različitih inačica ženske naravi (le nature di donne) o kojima uvelike ovise načini muškarčeva postupanja prema ženama, a onda i izložio koji su načini postupanja najprikladniji pojedinoj inačici ženske naravi. Zbog toga ću se sadržaju tog dijela poglavlja »O ženi« posvetiti u potpoglavlju o odgojnofilozofskoj sastavnici spisa o umijeću trgovanja.

No, poglavlje »O ženi« sadrži i Kotruljevićeve stavove još jednom etički dvojbenom djelovanju, točnije o preljubu. Prema njegovu mišljenju, razborit čovjek (l'omo prudente) ne

\footnotetext{
${ }^{384}$ Ibid., p. 305 [f. 85 r] / p. 480.

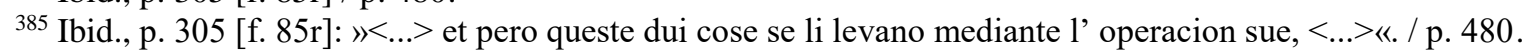

${ }^{386}$ Ibid., p. 305 [f. 85r]: »<...> perche operando fa dui cose. Primo, se leva dal ocio, el qual nutrisce l' amore e Venere, [...] Secundarie, operando non schade in poverta et sempre si trova havere.«/p. 480.

${ }^{387}$ Ibid., pp. 306-307 [ff. 85v-86r] / p. 482.

${ }^{388}$ Ibid., p. 307 [f. 86r]: »< ..> et non li de lassare la briglia, ma sempre de tenere in mano et non li lasare vincere mai nulla punta.«/p. 482.

${ }^{389}$ Ibid., p. 307 [f. 86r] / p. 482.

${ }^{390}$ Ibid., p. 307 [f. 86r]: »< _..> cosi la castigatione continua sença intervallo diventa dura et incorrigibile et non e piu doctrina, ma l' e scherço et gioco. Et ingengnate de non la condure al batere, perche come tu li meti la mano adosso, tu sei impaciato.«/p. 482.

${ }^{391}$ Ibid., p. 312 [f. 88r] / p. 485.

392 Ibid., p. 312 [f. $88 \mathrm{r}-\mathrm{v}$ ] / p. 485.

${ }^{393}$ Ibid., p. 312 [f. 88v] / pp. 485-486.
} 
bi smio zanemariti čast koju duguje roditeljima, djeci i ženi, te bi svakome od njih morao pružati ono što mu pripada zbog toga što je to pravedno i sveto (justo et sancto). ${ }^{394}$ Supružnici si, misli Dubrovčanin, duguju svetu, besprijekornu i potpunu povezanost. ${ }^{395}$ Osim toga, muškarac preljubom ženi oduzima čast (honore), djeci čini nepravdu (iniuria), a sebi sramotu (dishonore). ${ }^{396} \mathrm{Na}$ pitanje gubi li žena koja je počinila preljub pravo na potraživanje bračnog čina, dakle spolnog odnosa, dubrovački je mislilac odgovorio da gubi prema sudu duše, jer je griješenjem okaljala brak i ne može zahtijevati spolni odnos dok se ne očisti od grijeha. ${ }^{397}$ Prema Kotruljevićevu mišljenju, brak se mora temeljiti na savršenoj ljubavi (perfecto amor), jer je ustanovljen zbog dvaju razloga: zbog prihvaćanja i odgoja djece (susceptione et educatione di figlioli) te zbog izbjegavanja bluda (per evitare fornicatione). ${ }^{398}$ Kao dodatne razloge, Kotruljević je istaknuo izbjegavanje grijeha, pomirbu, ljepotu i bogatstvo. 399

U sedmom poglavlju četvrte knjige spisa o umijeću trgovanja, a kojem je poglavlju naslov »O djeci« (»Deli figliuoli«), Kotruljević je izložio promišljanja o ispravnu odgoju djece i o muškarčevu odnosu prema djeci. Premda u tom poglavlju prevladava odgojnofilozofska tematika, Kotruljevićevo izlaganje o odgoju djece također sadrži etički sloj. Taj je sloj zamjetan u njegovim stavovima o poučavanju djece vrijednosti novca. Naime, Kotruljević je naglasio da otac u odnosu sa sinovima ne smije dopustiti da se oni upuštaju u poslove s novcem sve dok ne nauče njegovu vrijednost, čime će otac suzbiti mladenačku rasipnost svojih sinova. ${ }^{400}$ Zbog toga je bio uvjeren da je bolje da sin na svojem prvom putovanju izgubi nego da zaradi, jer će tako razumijeti teškoće pri zarađivanju te postati marljiviji i nastojati spriječiti buduće gubitke. ${ }^{401}$ Time će se, uvjeren je dubrovački mislilac, spriječiti sinove da budu smioni i umišljeni, jer im donosi veliku štetu kada im se čini da će uvijek

${ }^{394}$ Ibid., pp. 312-313 [f. 88v]: »Adonche, l' omo prudente non deve ignorare l' honore debito ali parenti, ali figluoli et ala mugliere, accio che dando ad ognuno quello che e suo, justo et sancto sia, perche molestamente porta ognuno essere privato delo honor suo, $<\ldots>\ll$. / p. 486.

395 Ibid., p. 313 [f. 89r]: »Et niente e piu suo ala donna ne da essere piu dato dal marito, che sancta et intemerata et integra compagnia.«/p. 486.

${ }^{396}$ Ibid., p. 313 [f. 89r] / p. 486.

${ }^{397}$ Ibid., pp. 318-319 [ff. 91v-92r]: »Se la donna per lo adulterio comisso perde la ragione del debito, [...] pare che si almeno quanto al juditio del anima, perche peccando contra la legie rende lo matrimonio indegno et pero non de dimandare si non purgata la culpa, ma dar lo deve come e tenuto chi a la mugliere parente rendere, ma non puol domandare.«/p. 486.

${ }^{398}$ Ibid., p. 314 [f. 89r-v] / p. 487.

${ }^{399}$ Ibid., p. 314 [f. 89v]: »Et questo fu per evitacion del peccato. Secundario, cagioni sono multe, ut puta, alcuna volta per far pacie, alcuna volta beleça, richeça et cet.«/ p. 487.

${ }^{400}$ Cotrugli, »Libro del arte dela mercatura«, libro IV, capitulo 7 / Kotrulj, »Knjiga o vještini trgovanja«, knjiga IV, poglavlje 7, pp. 324-325 [f. 94r-v]: »Et per consenquens, fa che al tuo figluolo non lassi manegiar denari fin che non cognosce che cosa e lo denaro et quanto vale et con quanta fatica si guadagnia. [...] Et cosi, cognoscendo lo figluolo la dificulta del guadagnare, refrenara la prodigalita juvenile.«/p. 495.

${ }^{401}$ Ibid., p. 325 [f. 94v]: » Et nota che se aliqualiter perde lo primo viagio, l' e meglio che sel guadagnasse, perche comprende la dificulta et studia circa la industria e contra contraria«. / p. 495. 
zarađivati. ${ }^{402}$ Veću pozornost poglavlju o djeci posvetit ću u potpoglavlju o filozofiji odgoja u spisu o umijeću trgovanja, a zbog didaktičke naravi preostalog sadržaja tog poglavlja.

Osmo poglavlje četvrte knjige spisa o umijeću trgovanja Kotruljević je naslovio »O robovima i slugama« (»De servi et famigli«). Etički sadržaj tog poglavlja ogleda se u kriterijima trgovčeva odabira robova i sluga prema njihovim karakternim i tjelesnim obilježjima, a onda i u trgovčevu odnosu prema njima. Dubrovčanin je najprije naveo da su trgovcu potrebni robovi, koji to postaju po vlastitu pristanku ili po rođenju. ${ }^{403}$ Oni su nužno vezani uz posjede na kojima moraju obrađivati zemlju i mogu biti prodani zajedno sa zemljom. ${ }^{404}$ Kotruljević je zapisao da se trgovac prema robovima mora odnositi uljudno (humanamente), lijepo živjeti s njima i iskazivati im čast (honorare), ovisno o njihovim zaslugama ili krivnji. ${ }^{405}$ Međutim, trgovcu su potrebne i sluge. Njih čine muškarci i žene koji su kupljeni ili koji rade za plaću. ${ }^{406}$ Sluge moraju, nastavlja Kotruljević, biti čiste (neti), pristojne (puliti), smotrene (discreti), vjerne (fidi) i provjerene (aprobati) osobe, budući da se u trgovčevoj kući rukuje novcem i robom. ${ }^{407}$ Zbog toga što se slugama povjeravaju odgovorni poslovi, trgovac bi se trebao opredijeliti za one sluge čije roditelje poznaje. ${ }^{408}$ Trgovčevu kućanstvu potrebno je, dodaje Kotruljević, nekoliko mladića dobra roda, sinova uglednih ljudi za rad u pisarnici i za obavljanje trgovačkih poslova. ${ }^{409}$ Trgovac mora imati jednog upravitelja kuće koji će se baviti poslovima oko hrane, te momka za brigu o konjima. ${ }^{410}$ Što se tiče odnosa prema njima, glava obitelji, dakle trgovac, ih mora držati u strahu i ne smije se s njima zbližavati. ${ }^{411}$ Doduše, ponekad se može nasmijati i s njima, slaviti, ali pritom ne smije pretjerivati. ${ }^{412}$ Kotruljević je

402 Ibid., p. 325 [f. 94v]: »<..> cioe, quando guadagna li pare sempre guadagnara et diventa temerario et presumptuoso in modo che poi da de multi stravaçi.«/p. 495.

${ }^{403}$ Cotrugli, »Libro del arte dela mercatura«, libro IV, capitulo 8 / Kotrulj, »Knjiga o vještini trgovanja«, knjiga IV, poglavlje 8, p. 326 [f. 94v]: »Sono eciamdio alcuni altri servi, in altro modo, dicti ascripticii o vero originarii, <...>«. / pp. 497-498, na p. 497.

${ }^{404}$ Ibid., p. 326 [ff. $94 \mathrm{v}-95 \mathrm{r}$ ]: »< ...> cioe quelli che sono astricti a certe terre, che non si puono partire et deno cultivare et vendenosse con la terra. [...] Ma volendo parlare de servi pertinenti al mercante, ne de havere primo de questi ultimi li qualli sono per lo culto dela terra«. / p. 497.

405 Ibid., p. 326 [f. 95r] / p. 497.

${ }^{406}$ Ibid., p. 326 [f. 95r]: »L' altri servi sono et maschi et femene che deve tenere in casa comprati o a soldo, $<\ldots>\ll . /$ p. 497.

${ }^{407}$ Ibid., p. 326 [f. 95r] / p. 497.

${ }^{408}$ Ibid., p. 327 [f. 95r]: »Et perche al garçon del mercante si da fede, ingeniate di havere homini che tu cognosca lor parenti et se tu poi havere plegaria saria bene.«/p. 497.

${ }^{409}$ Ibid., p. 327 [f. 95r]: »Et perche li officii in casa delo mercante devenno essere distincti, de havere alcuni gioveni ben nati et figli di homini di condicione et questi sono per lo scriptorio et per faciende mercantilli.«/ p. 497.

410 Ibid., p. 327 [f. 95r]: »De havere famigli, cioe uno maistro di casa che governi et servi tute cose da mangiare. De havere ragaço per governo de cavalli.«/pp. 497-498.

${ }^{411}$ Ibid., p. 327 [f. 95r]: »Li qualli tutti lo padre di famiglia de tenere in timore et non dimestigarse con loro $<\ldots>\ll$. / p. 498.

412 Ibid., p. 327 [f. 95r]: »<..> et ale volte rider et festigiare, ma non excedere modo.«/ p. 498. 
trgovcu savjetovao da prilikom izbora sluga mora gledati u njihovo lice, koje treba biti dobroćudno (benigno), ljubazno (amorevole), blago (mansueto) i ljupko (gratioso), zatim da sluga ne smije biti zapušten ili upleten u neke loše poslove (malla arte), kao i to da ne smije biti razrok ni šepav. ${ }^{413}$ Trgovac ih treba poučiti kao da su njegova djeca i ne smije prema njima biti popustljiv. ${ }^{414}$ Nipošto im ne smije uzrokovati patnju, nego ih treba nahraniti, napiti, odjenuti, dobro ih izmoriti, pri čemu se ne treba ustručavati upotrijebiti štap, ukoliko počine nekakav prekršaj. ${ }^{415}$

Deseto poglavlje četvrte knjige spisa o umijeću trgovanja Kotruljević je također prožeo etičkim sadržajem. Naslovivši poglavlje »O trgovčevu svršetku« (»Dela fine delo mercante«), ukazao je na potrebu za trgovčevim pravovremenim umirovljenjem, a onda i iznio obilježja trgovčeva života od mirovine do smrti. Trgovcu je, naime, savjetovao da se povuče u mirovinu kada navrši pedesetu godinu života, jer je, kako kaže, trgovačko umijeće takvo da zahtijeva pronicljive umove, krepku krv i odvažno srce, a u toj se dobi to hladi i umire. ${ }^{416} \mathrm{Ta}$ dob sa sobom nosi to da čovjeku pada prirodna toplina, krv se usporava, um otupljuje i pamćenje slabi, zbog čega su ljudi skloniji činjenju brojnih pogrešaka, posebice oni koji su po naravi pohotni (libidinosi) i koji neprestano uništavaju robu. ${ }^{417}$ Iako se u toj dobi ne bi trebali baviti trgovanjem, ljudi su, priznaje Kotruljević, mudriji (piu savii) u političkim i građanskim poslovima (cose politiche et civile) te je njihovo mišljenje pouzdano (saldo). ${ }^{418}$ Trgovca koji je stekao novac, posjede, oženio sinove i kćeri, odgojio sinove u trgovačkom zvanju i vidio ih kako vješto obavljaju posao, a koji se usprkos tome i dalje želi baviti trgovanjem, Kotruljević je osudio s obzirom na pet zakona (legie): 1) katolički (catolica); 2) građanski (civille); 3) filozofski i naravni (philosophica et naturale); 4) zakon prirode (di essa natura); 5) moralni i politički (morale et politica). ${ }^{419}$ Da bi ilustrirao razinu svojeg neslaganja s trgovčevom odlukom da se nakon pedesete godine nastavi baviti trgovanjem, dubrovački je mislilac

\footnotetext{
${ }^{413}$ Ibid., p. 327 [f. $95 \mathrm{r}-\mathrm{v}$ ] / p. 498.

414 Ibid., p. 327 [f. 95v]: »Et devi studiar da doctrinarli, come ti fusseno figluoli, la qual cosa non faciendo, pecchi [...] Ne circa questo deve essere remisso, perche quando perdona ad uno, provoca ad cogitacion tuti: $<\ldots>\ll . /$ p. 498.

${ }^{415}$ Ibid., pp. 327-328 [f. 95v]: »Et non li far mal patere da mangiare, bevere et vestire et faticalli bene et non li perdonare del bastone quando fanno fallo.«/p. 498.

${ }^{416}$ Cotrugli, »Libro del arte dela mercatura«, libro IV, capitulo 10 / Kotrulj, »Knjiga o vještini trgovanja«, knjiga IV, poglavlje 10, p. 330 [f. 96r]: »Et perche comunamente la mercatura vol intelecti prospicaci, sangue vivido et cor animoso, la qual cosa in elli homini li qualli passano L anni comunemente rifreda et more. «/ p. 500.

${ }^{417}$ Ibid., p. 330 [f. 96r]: »Et questo ci dimostra la cotidiana experiencia, che come 1' homo viene a quella etate rifreda lo callore naturale, quietassi lo sangue et diventano ebeti d' ingegno et piu fredi di memoria. Et fano in questa arte mille erori et maxime quelli li qualli sono di natura libidinosi et continuo disfanno la roba.«/p. 500.

${ }^{418}$ Ibid., p. 330 [f. 96r] / p. 500.

${ }^{419}$ Ibid., pp. 330-331 [f. 96r] / p. 500.
} 
apelirao na njegov um (intelecto) i plemenitu dušu (anima gentile), koja je obdarena izvrsnim osjećajima (excelenti effecti), pamćenjem (memoria), umom (intellecto) i voljom (volunta), dodavši da je trgovac zasigurno smetnuo s uma svoju svrhu i blaženstvo (lo fine e la beatitudine), izgubio pamćenje da ih se podsjeti i oslabila mu je volja koja bi trebala težiti razumskim stvarima (cose rationali). ${ }^{420}$ Prema Kotruljevićevu mišljenju, trgovčev bi život od umirovljenja do kraja trebao izgledati ovako: treba razdijeliti kuću kćerima, a sinove združiti i dati im dio novca; treba sačuvati ostatak novca za sebe, kako mu se čini razboritim (prudentemente); treba se smjestiti u jedan od svojih ljetnikovaca na kojem može preživjeti sa ženom i slugama; treba sa sobom povesti kapelana, slušati misu, posvetiti se molitvi i Bogu; treba ponovno pročitati svoje trgovačke knjige, očistiti svoju savjest (aneta la conscientia) i vratiti nepošteno uzeto ( $m a l$ tolto); treba neprestano čitati Sveto Pismo; treba uvijek misliti na vječni život i rajske stvari, a ne vraćati se u grad niti misliti na svjetovne novosti; ne treba biti dokon (ocioso), nego treba moliti, pisati, čitati, raditi rukama, biti u poslu, živjeti u spokoju mira duše i tijela (pacie dela anima et delo corpo); treba se što manje družiti sa svjetovnim ljudima, i to sve dok mu Bog ne zatvori tjelesne oči i ne povede ga u vječni život (vita eterna). ${ }^{421}$ Takav način življenja Kotruljević je nazvao blaženim (beata), anđeoskim (angelica), svetim (sancta) i filozofskim (philosophica) životom koji hvali ne samo katolička vjera, već i svaka država i vjera. ${ }^{422}$ Dubrovčanin je potom ustvrdio da se u takvu načinu življenja krije opća vrlina (universal virtu), vrlina bez greške (virtu sença erore), život bez sumnje (vita sença dubio), najbolji život (vivere primario) te spasenje kršćana, koje su stari nazivali samotnjačkim (vita solitaria), a on pustinjačkim životom (vita heremiticha), zbog toga što se provodi na osami i u pustoši ${ }^{423}$ Kao dodatne prednosti pustinjačkog i kontemplativnog života, dubrovački je mislilac naveo i sljedeće: čovjek koji tako živi uživa najizvrsniju povlasticu slobode (liberta), jer je slobodne duše i navikava se na svoj položaj; nitko mu ne zapovijeda i ne gospodari, nego sam sebe vodi i svjedoči nebo; nije ni arbitar ni

\footnotetext{
${ }^{420}$ Ibid., p. 331 [f. 96v] / pp. 500-501.

${ }^{421}$ Ibid., pp. 331-332 [ff. 96v-97r]: »Poi che serai pervenuto ad fine de possere quiescere, dispone domui tue, quia morieris. Disponi la tua casa, figliole se tu le ay et li toi figlioli acompagna et dali una parte dela tua pecunia et lo resto ti riserva per li tui besogni secundo che prudentemente li parira. Guardate non lasare in mano di tuo fioli la tua sostancia, eligite una dele tue ville et aconciati in quella remoto dala citate, che di rendita te possi campare con la tua donna et serviciali, secundo ti pare lo bisogno tuo. Abi lo tuo capelano per audire la messa et vaca al' oracioni et recomandate a Dio. Rilegi li toi libri di mercancie et aneta la conscientia tua et rendi lo mal tolto et continuo legi la Sancta Scriptura. Et non ritorna piu ala cita, ne pensar piu d' essa ne de novelle del mundo. Pensa sempre de vita eterna et di cose di paradiso. Et non star mai ocioso, orando, scrivendo, dictando, legiendo, operando manualmente, sempre in fare et cosi dure la vita tua in quiete, in pacie dela anima et delo corpo. Et multo poco conversa con omeni mundani et cosi fin che 1' altrissimo Dio ti chiuda li ochi corporali et conduca in vita eterna.«/ p. 501.

422 Ibid., p. 332 [f. 97r] / p. 501.

${ }^{423}$ Ibid., p. 332 [f. 97r] / p. 501.
} 
sudac, a to je najopasnija vrsta ljudi; nije ni pohlepni zastupnik, ni nemarni skrbnik, ni krivi odvjetnik, ne svjedoči lažno (falso testimonio), ni tužitelj; nije nesretni bogataš kojeg uvijek nešto mori; nije himben (astuto) ni podmukao (vafro); ne izjeda ga gorka zavist (invidia); ne govori zlo o drugima; ne kosi u tuđem polju; ne crveni se zbog tuđe dobrobiti; ne živi od lažnog prijateljstva; ne razmeće se među bezvrijednim ljudima; ne pozdravlja neiskreno (falsamente); ne govori laži (bugie); ne pije i ne hrani se loše; ne pljačka i ne pljačkaju ga; ne sastavlja oporuku po čitav dan; živi bez pohote i razbludnosti (libidine et volupta). ${ }^{424}$ Konačan opis i obol hvaljenju trgovčeva života u mirovini Kotruljević je izložio u zaključnom dijelu desetog poglavlja, a time i cjelokupne četvrte knjige spisa o umijeću trgovanja. Poručio je, naime, sljedeće: riječ je o životu koji provode blaženi ljudi ravni svecima (i homini beati et equalli a sancti), a to je jedini život kojim služimo Bogu i filozofiji (philosophia); sretan (felicie) je onaj koji dotle dođe i uzdržava se samo hranom i odjećom, hrani dušu vrlinama (nutrica l' anima nele virtu) i budno živi oštreći svoj um (acuto l' ingiegno) te se druži s ljudima koji su pisali o tome što čini vrline svijeta (virtu l' universo); takav život nazvao je sretnim (felicie vita), vedrom javom, najslađim snovima, najugodnijom dokolicom (oçio iocundissimo), sretnom vježbom duha i tijela (felicie exercicio del corpo et del anima) u kojoj ništa ne nedostaje dobru i blaženu življenju (bene et beato vivere) te koja se uzdiže i oživljava molitvom, čitanjem i poljodjelstvom daleko od životnih iskušenja; takvim se življenjem dostiže duboka starost, a blažen je onaj život (beata vita) u kojem se napuštaju neugodnosti koje tište, uništavaju i ubijaju smrtnike; na osami se zbiva to da ljudski život otpočine, a duh (spirito) odahne, tamo se sretno živi (vive felicie) i vedro umire (more chiaro), vraća se dug Bogu, svijetu, sebi i drugima. ${ }^{425}$

\footnotetext{
${ }^{424}$ Ibid., pp. 332-333 [f. 97r-v]: »Questa golde de optimo privilegio di liberta. L' animo tien libero et usase ad sua posta, dela qual cosa in nela vita presente non puo essere alcuna iocundita magiore. A questa ninsun comanda, ninsun signoregia, a se comanda et in testimonio del cielo vive. Constui non e arbitro ne judicie, periculosissima generacion di homini, non procurator avaro, non curatore impio, non reo advocato, non falso testimonio, non reo ne actore, non richo infelicie, mai sença pena, non timoroso d' essere avenenato, ne tira ne e tirato. Non serve custui a Venere et Bacho, non sta astuto, vafro, non ferve, non per invidia se consuma acierba, non parla mal d' altri, ne mete falcie in campo alieno, non arosiscie nel bene d' altrui, non vive col vano favore, non si vanagloria intra li homini levissimi, non saluta falsamente, non diciendo bugie fingie mille parole, non beve et mangia male spectando factori et nave, non roba et non n' e robato, non fa tuto l' di plorando li sui testamenti, dolendo a cui lassare la roba et tal volta a chi non se lo crede, o a chui forse non voria et finalmente sença libidine et volupta vive, sença li qualli rarissimi songo nela cita. « / pp. 501-502.

${ }^{425}$ Ibid., p. 333 [ff. 97v-98r] / p. 502.
} 


\subsection{Filozofija odgoja u spisu o umijeću trgovanja}

Osim etičkih tema, Kotruljevića su u spisu o umijeću trgovanja zaokupljale i teme koje pripadaju korpusu tema iz područja filozofije odgoja. Radi se o disciplini koja je, prema prosudbi koju je 2003. godine izrekao britanski epistemolog i filozof odgoja Paul Heywood Hirst, jednako stara kao i filozofija, zbog toga što sva pitanja koja se odnose na narav znanja, dobar život ili pravedno društvo uključuju i pitanja o učenju, točnije o praksama u koje bi ljudi trebali biti uključeni i o vrijednostima koje bi posljedično trebali zagovarati. ${ }^{426}$ Zato ne treba čuditi da je, a prema spoznajama koje je također 2003. godine priopćio američki filozof Randall Curren, filozofija odgoja disciplina koju njeguju filozofija politike i etika, a ona ih zauzvrat uvelike ispomaže, pa većina sadržaja kojem se divimo u filozofiji odgoja zapravo pripada politici i etici odgoja. ${ }^{427}$ Štoviše, filozofija odgoja bila je, ponovno se oslanjam na Currena, integralni dio etike i filozofije politike tijekom velikog dijela povijesti filozofije, što potvrđuje, primjerice, podatak da je za Aristotela i druge filozofe svrha etike bila ne samo znati što je vrlina, nego je posjedovati i upražnjavati. ${ }^{428}$ Upravo zbog toga što je Kotruljević u svojem spisu koji je pretežito etičke naravi kanio izgraditi svestrano obrazovana trgovca koji bi trebao steći i upražnjavati one vrline koje bi ga učinile savršenim trgovcem, glavom obitelji i članom političke zajednice, kao i zbog toga što je u tom kontekstu mjestimično, ali minuciozno progovarao o načinima primjerena odgoja i obrazovanja djece te mladih ljudi, smatram da je opravdano zaključiti da ta njegova razmatranja nesumnjivo pripadaju filozofiji odgoja. Da bih to dokazao, u nastavku ovog potpoglavlja izdvojit ću najupečatljivija mjesta iz spisa o umijeću trgovanja na kojima se ispoljavaju njegova promišljanja o odgoju i obrazovanju. Zapravo, jedina knjiga u kojoj se dubrovački mislilac nije bavio tim temama bila je druga knjiga spisa o umijeću trgovanja. U nastavku ću zato izdvojiti njegova promišljanja o odgoju iz predgovora spisu te trećeg poglavlja prve knjige, zatim iz treće knjige, točnije iz njezina predgovora, drugog i trećeg poglavlja, te iz četvrte knjige, točnije iz njezina šestog i

${ }^{426}$ Paul H.[eywood] Hirst, »Foreword«, u: Nigel Blake, Paul Smeyers, Richard Smith, Paul Standish (edited by), The Blackwell Guide to the Philosophy of Education (Oxford: Blackwell Publishing Ltd, 2003), pp. xv-xvi, na p. Xv: »In a sense philosophy of education is as old as philosophy. Enquiries into the nature of knowledge, or of the good life, or of the just society, all involve, either explicitly or implicitly, questions about learning about the practices people should be initiated into and the values they should come to espouse.«

${ }^{427}$ Randall Curren, »Introduction«, u: Randal Curren (edited by), A Companion to the Philosophy of Education (Oxford: Blackwell Publishing Ltd, 2003), pp. 1-4, na p. 1: »Philosophy of education is a field that is nourished by and largely ancillary to political philosophy and ethics, and much of what is most admirable in philosophy of education pertains to the politics and ethics of education.«

${ }^{428}$ Curren, »Introduction«, p. 2: »Hence, although philosophy of education was integral to moral and political philosophy through much of the history of philosophy (the point of ethics being, in the view of Aristotle and others, not just to know what virtue is, but to possess and exercise it), $<\ldots>\ll$. 
sedmog poglavlja. Prema mojoj procjeni, time ću ukazati na to da je u spisu o umijeću trgovanja itekako zastupljena i odgojnofilozofska sastavnica.

\subsubsection{Filozofija odgoja u prvoj knjizi spisa o umijeću trgovanja}

Da će u spis o umijeću trgovanja uvrstiti teme koje pripadaju području filozofije odgoja, Kotruljević je dao do znanja već u predgovoru prvoj knjizi i cjelokupnu spisu. Učinio je to na početku predgovora izloživši kritiku mladih ljudi zbog nedostatka iskustva i znanja. Zapisao je, naime, da su učeni ljudi, koji više uživaju u izvrsnosti duše i vrline nego u tjelesnim stvarima i bogatstvu, pohranili svoje iskustvo i znanje u pismena sa svrhom rasprostiranja znanja među potomcima, nakon čega je dodao da je od istih tih mudrih i učenih ljudi doznao da je mladež neotesana i nevješta u ljudskim stvarima te da ne zaslužuje pohvalu zbog razboritosti. ${ }^{429}$ Slijedeći primjer neimenovanih učenih i mudrih ljudi te pretakajući svoje trgovačko iskustvo i znanje u pisano ostvarenje, Kotruljević je time otkrio didaktičku svrhu svojeg spisa o umijeću trgovanja. To je zamjetno i u nastavku predgovora. Primjerice, dubrovački je mislilac istaknuo da trgovanje, usprkos uvriježenoj zabludi da je riječ o znanosti, umijeću ili disciplini bez pravila, ipak ima opća i posebna pravila koja mladići i momci moraju dobro razumijeti ukoliko žele postići njegov hvaljeni plod. ${ }^{430}$ Zatim je, a obrazlažući svoju odluku pisanja spisa na narodnom, dakle na talijanskom jeziku, ukazao na to da je prevagu u donošenju odluke činila njegova namjera da stvori djelo koje bi bilo korisno trgovcima koji su, kako kaže, neznalice i nevični književnosti, i to ne zbog manjkavosti trgovačkog umijeća, već zbog naopaka običaja da ih se loše odgaja (male alevati). ${ }^{431} \mathrm{Na}$ koncu, Kotruljević je i potkraj predgovora iznio težnju da njegov spis služi za

${ }^{429}$ Cotrugli, »Libro del arte dela mercatura«, prefatio / Kotrulj, »Knjiga o vještini trgovanja«, predgovor, p. 115 [f. 1r]: »Vogliono li eruditi homini non tanto delectarsi nele fateçe del corpo e dela fortuna quanto dela prestancia d' animo et della virtute, la quale consiste nel haver experimentato multe cose, ma eciamdio di quele che experimentato et inteso anno comendare ala eterna memoria di scripture per seminare doctrina ali posteri. [...] Inde iudico, come o usurpato dali savii et eruditi homini, la iuventute quodamodo rude et inexperta dele cose humane non esser degna di comendatione dela prudentia.«/ p. 337.

${ }^{430}$ Ibid., p. 117 [f. 2v]: »La quale mercatura probet che se chiami sciencia, arte, over disciplina irrigulare, per la sua multiforme mutabilita che ave e de havere in se, per le varieta occorente per giornata in essa, niente di meno ella have alcune singulari regole in se, in genere et in specie, le qual sono da esserno ben intese da queli li quali anno volunta di conseguire lo fructo laudabile de quela, come son li gioveni et li adolescentuli, <...> «. / pp. 339-340.

${ }^{431}$ Ibid., p. 118 [f. 3r]: »Et per la parte de scrivere in volgare mi occoreva che io scrivendo l'opera per utile di mercanti li quali per abusione d'esserno male alevati e non per difecto del arte, il piu dele volte si trovano imperiti et ignoranti dele lectere.«/pp. 341-342. 
pouku budućim naraštajima, dakle da ima didaktičku svrhu, istaknuvši da želi da spis bude koristan ne samo njegovim suvremenicima, već i potomstvu u čije bi ruke mogao doći. ${ }^{432}$

Kao potvrdu toga da se dubrovački ranorenesansni mislilac bavio odgojnofilozofskom tematikom u prvoj knjizi svojega spisa posvećenoj porijeklu i početku trgovanja, izdvajam njegova promišljanja iz trećeg poglavlja naslovljenog »O svojstvima trgovčeve osobe « (»Dela qualita dela persona delo mercante«). Podsjećajući na zapise iz prethodnog potpoglavlja, dakle iz potpoglavlja o etičkoj sastavnici spisa o umijeću trgovanja, naglašavam da je riječ o poglavlju u kojem je Kotruljević isprepleo teme koje pripadaju dvjema filozofskim disciplinama: etici i filozofiji odgoja. $\mathrm{Na}$ ovom ću se mjestu posvetiti onom dijelu poglavlja koji se ponajviše, ali ne i isključivo, a zbog spomenute isprepletenosti, odnosi na filozofiju odgoja.

Po završetku početnog izlaganja o, ponovno podsjećam na sadržaj prethodnih potpoglavlja, ljudskoj mogućnosti odupiranja utjecajima koji viša nebeska tijela, obično uspješno, ostvaruju na niže stvari zahvaljujući Bogom im danim darovima slobodne volje, izvrsnog uma i razboritosti, kao i o teškoćama koje nerijetko prate ljudski otpor tim utjecajima zbog prirodnih sklonosti određenim poslovima, Kotruljević je ponudio odgojne smjernice za pospješivanje tog otpora od malena. Savjetovao je, naime, onome tko svojega sina ili rođaka hoće uputiti u trgovanje da mora od malih nogu posebno obratiti pažnju na dječje sklonosti toj vrsti posla, jer ako je dijete sklono drugom poslu neće postići željeni cilj, a koji se sastoji od časna stjecanja bogatstva. ${ }^{433} \mathrm{U}$ slučaju da tijekom djetetova odrastanja trgovac zamijeti da dijete obilježava živahna narav (de natura vivo), ugodan izgled (bon aspecto), izvrsna ćud (egregia indole), kao i težnja za časti i dobiti te želja za dobivanjem bitki, a da pritom nije prevrtljivo ni lutalica (non sia tropo vario ne vagabundo), trgovac može zaključiti da je ono sposobno baviti se umijećem čiji je cilj časno stjecanje, dakle trgovanjem. ${ }^{434}$ Nadalje, nakon što ustanovi takve sklonosti kod sinova ili kod drugih bližnjih, trgovac ih treba usmjeravati na

${ }^{432}$ Ibid., p. 119 [f. 3v]: »Et desiderando che questa nostra opera sia utile non solo a questi nostri delo presente seculo, ma eciamdio a posteri ale man de quali per aventura ella perverra, habiam deliberato de procedere in questo nostro tractato con hordine singulare.«/p. 342.

${ }^{433}$ Cotrugli, »Libro del arte dela mercatura«, libro I, capitulo 3 / Kotrulj, »Knjiga o vještini trgovanja«, knjiga I, poglavlje 3, p. 130 [f. 9r]: »Et pero e de avere singulare riguardo nel principio del volgier uno suo figlio o d' altri per governacion o affinita congionti devolgierli ad tal exercicio mercantile, perche se fusse inclinato ad altro o da contrario exercicio, non prosperarebe per aventura over prociederebe con difficulta et rimarebbe a meça via et con poco proficto et non consequirebbo el fine delo desiderio suo, el qual e d' aquistare richeçe con honor.«/ pp. 350-354, na p. 350.

${ }^{434}$ Ibid., p. 130 [ff. 9r-9v]: »Et di haver noticia di tal inclinatione ell' e de havere singular consideracione nel eta puerile non dipravata di che exercicii si dilecta et a che naturalmente transcore. E se l' e de natura vivo e bon aspecto et egregia indole e non sia tropo vario ne vagabundo et pretenda ad questo o di honore o di utile o di vincere le pugne allora posiamo arbitrare che siano acti a tal exercicio dove lo fine e aquistare con honore.«/ pp. 350-351. 
prikladan posao i ne bi se trebao hvatati ukoštac s prirodom te je pokušavati pobijediti i nadvladati, jer bi, kako kaže, priroda pobijedila i najjačeg čovjeka. ${ }^{435}$

Odgojnofilozofski i etički aspekt Kotruljevićevih promišljanja međusobno se prožimaju i u nastavku trećeg poglavlja prve knjige spisa o umijeću trgovanja. Naime, to se očituje u dijelu tog poglavlja u kojem je dubrovački mislilac izložio tri dodatna preduvjeta za usmjeravanje mladog čovjeka na bavljenje trgovanjem, a uz pretpostavku prisutnosti prethodno navedenih prirodnih sklonosti. Kao prvi od njih bio je da dijete bude sin trgovca, budući da će na taj način imati unutarnje vrline (virtu intrinseche) slične očevima, jednako kao što se putem sjemena s oca na sina prenosi mnoštvo sličnosti u tjelesnom izgledu. ${ }^{436}$ Zatim je kao drugi preduvjet istaknuo da je potrebno da se dijete na vrijeme, točnije od kolijevke, upoznaje s pravilima i ustrojstvom discipline (con precepti et con l' ordene de la disciplina), a onda i to da od djetinjstva upija kretnje, običaje i razgovore trgovaca (da puericia imbiba li giesti, modi, costumi e conversacioni mercantili), koje trebaju biti združene s rječitošću i ozbiljnošću (con facundia et gravita) u svakom pokretu i činu (giesto et acto). ${ }^{437}$ Treći od preduvjeta sastojao se od poznavanja reda i pravila discipline te od upornosti i ustrajnosti u izvršavanju posla. ${ }^{438}$ Prema Kotruljevićevu sudu, ispunjavanjem tih triju preduvjeta mlad će čovjek postati savršen trgovac (mercante perfecto), a za to će mu još biti potrebna i sreća, koja najčešće pomaže onom tko se razborito vlada i slijedi razumski red. ${ }^{439}$ Nakon izlaganja o prirodnim sklonostima, trima preduvjetima te načinima usmjeravanja djeteta u trgovačko umijeće, a koje je nazvao izlaganjem o sklonostima trgovčeve duše i duha, Dubrovčanin je nužnim smatrao i istodoban razvoj tjelesnih sposobnosti budućeg savršenog trgovca. ${ }^{440} \mathrm{Da}$ duševne sposobnosti ne trebaju prednjačiti naspram tjelesnih, Kotruljević je ukazao stavom da riječ 'osoba' (nome persona), a koju je, podsjećam, upotrijebio upravo u naslovu trećeg poglavlja, za njega

\footnotetext{
435 Ibid., p. 130 [f. 9v]: »Et secundo che nui trovamo tal inclinatione in tal nostri o figli o altramente actinenti li dobian volgiere ad quel exercicio dove sono inclinati et non dobianno pigliare la contesa con la natura per volerla vincere et superare che la vincerebbe ogni gagliardo huomo.«/p. 351.

436 Ibid., p. 132 [ff. 10r-10v]: »Avendo adonche actitudine naturale come diciamo quel tal fanciulo che debe esser instituito al arte mercantile de havere l' altra condicione la qual sança dubio e non solamente assai nota per l' experientia ma eciamdio di ragion naturali aprobata cioe chel sia nato di mercante, [...] Et se la vista dichiara l' intrinseco et la vista e proceduta per virtu del seme in figura paterna, consequentemente non n' e da dubitare che le virtu intrinseche siano simile al padre.«/p. 352.

${ }^{437}$ Ibid., pp. 132-133 [f. 10v] / pp. 352-353.

438 Ibid., p. 133 [f. 10v]: »Et quando queste dui condicioni si agiungono insieme, che l' una aiuti l' altra et ci si agiunga la terça di precepti dela disciplina ordinaria e dela consuetudine continua in decti exercicii«. / p. 353.

${ }^{439}$ Ibid., p. 133 [ff. 10v-11r]: »<...> si fara mercante perfecto et consequitara mirabilmente si fara punto aiutato e favorato dala prosperita dala fortuna. La qual el piu dele volte sol prestar favora a chi se governa con prudencia et con hordene dela ragione et versa vice sol abandonare coloro il piu dele volte che si governano sença ragione et sença ordine.«/ p. 353.

${ }^{440}$ Ibid., p. 133 [f. 11r]: »Et perche le cose dicte di sopra del actitudine dela persona del mercante reguardano solamente a la disposicione del animo, resta el suguignere brevemente dela aptitudine del corpo.«/ p. 353.
} 
podrazumijeva dušu i tijelo. ${ }^{441}$ Iz toga se, dakle, može iščitati Dubrovčaninovo razumijevanje čovjeka kao cjeline sastavljene od duše i tijela, što je uostalom i naznačio u predgovoru čitavu spisu. Zato ne treba čuditi da je i u dio u kojem je raspravljao o trgovčevim tjelesnim sposobnostima uvrstio stavove koji imaju etičku konotaciju. To je moguće uočiti naprije u njegovoj tvrdnji da trgovčevo tijelo mora biti sposobno kao okretna sprava, budući da se $u$ suprotnom trgovac ili ne bi uhvatio posla kako treba, pa ne bi bilo željene zarade i ne bi časno dosegao cilj, ili bi ustrajao u obavljanju posla i pao u bolest i smrt. ${ }^{442} \mathrm{Na}$ temelju te tvrdnje Schiffler je 1996. godine zaključila da se Kotruljević brinuo o »odgoju cjelovita čovjeka, temelju obdržavanja, očuvanja ljudskoga života zasnovana na odjelotvorenju univerzalnih etičkih vrijednosti, napredovanju i zdravlja pojedinca i zajednice u cjelini. ${ }^{443} \mathrm{Na}$ prisutnost etičkog aspekta u Kotruljevićevu izlaganju o trgovčevu tijelu, nedvojbeno ukazuje i to da je pritom bio, kako kaže, vođen Aristotelovom tvrdnjom iz Nikomahove etike da su sve krajnosti loše (tucti li extremi songo viciosi), a slaganje s tom tvrdnjom dodatno je podupro stajalištem da su obje prethodno izložene krajnosti i neprilike velike i treba ih izbjeći, te da je trgovcu korisno i nužno imati spremno tijelo. ${ }^{444}$ Kotruljević je obrazložio da pod spremnim tijelom ne misli na to da trgovac mora biti nosač, jer čvrsti i snažni ljudi po svojoj prirodi uglavnom nisu umno sposobni (non sono abili al intelecto), budući da priroda ono što manjka na jednoj strani nadoknađuje na drugoj (la natura quello che manca in uno suplice nel altro), nakon čega je, ponovno se pozivajući na Aristotela i neimenovane filozofe, zaključio da mekoputni ljudi lakše uče i obratno (che carne molle sono de facile aprensione et cosi per contro contraria). ${ }^{445}$ Poglavlje o obilježjima trgovčeve osobe Kotruljević je dovršio stavom iz kojega je također moguće iščitati potrebu za trgovčevim istovremenim razvojem duševnih i duhovnih, ali i tjelesnih sposobnosti. Tako je zapisao da trgovac mora biti u stanju podnositi

${ }^{441}$ Ibid., pp. 133-134 [f. 11r]: »E cosi voli intendere nela rubrica de questo capitolo quando lo intitulai 'Del aptitudine dela persona', perche questo nome persona significa l' anima et il corpo.«/p. 353.

${ }^{442}$ Ibid., pp. 133-134 [f. 11r-v]: »Et perche le cose dicte sopra del actitudine dela persona del mercante reguardano solamente e la disposicione del animo, resta el suguignere brevemente dela aptitudine del corpo. [...] del corpo, el qual se non fusse acto come destro instrumento non potrebe suportare et supportandolo ne ricieverebbe incomodita ala qual di necessita siguirebbe infirmita e dopo morte. Onde di duo inconvenienti ne sequirebbe 1' uno: o veramente che non pigliando simili exercici come si convene e non sarebbe il proficto che si richiede e non verebbe al suo desiderato fine con honore, o che facendolo non potrebbe per la disaptitudine del corpo perseverare et perseverando cascarebe nela infirmita et morte.«/pp. 353-354.

443 Schiffler, »Praktično-etička dimenzija 'savršena trgovca' B. Kotruljevića«, p. 166. Isto vidi u: Schiffler, »Etičko-humanistička misao Benedikta Kotruljevića«, p. 131.

${ }^{444}$ Cotrugli, »Libro del arte dela mercatura«, libro I, capitulo 3 / Kotrulj, »Knjiga o vještini trgovanja«, knjiga I, poglavlje 3, pp. 134-135 [ff. 11v-12r]: »Et perche l' uno et l' altro di questi dui extremi et inconvenienti e grande e da schifar, lo diciamo et confermiamo ch' egli e sumamente utile et ancor necessario l' aver el corpo in bona disposicione, [...] Et perche dicimo che lo corpo sia abituato al supportare le fatiche, cosi anche dico come c' insegna Aristotile nel secundo del Ethica, che tucti li extremi songo viciosi, <... «. / p. 354.

445 Ibid., p. 135 [f. 12r] / p. 354. 
napore te $\mathrm{u}$ isto vrijeme imati mekoputno i nježno tijelo, a što ukazuje na plemenitost njegova uma (nobilita delo intelecto). ${ }^{446}$

\subsubsection{Filozofija odgoja u trećoj knjizi spisa o umijeću trgovanja}

Premda druga knjiga spisa o umijeću trgovanja, a kojoj je naslov »O vjeri koja dolikuje trgovcu«, eksplicitno ne sadrži Kotruljevićeve stavove o odgoju, a time ni stavove koji bi mogli biti sagledavani iz odgojnofilozofske perspektive, za pretpostaviti je da Dubrovčaninovo beziznimno zagovaranje trgovčeva njegovanja i upražnjavanja katoličkih vrijednosti i obredā implicitno uključuje usmjeravanje mladih ljudi prema razvoju vjerskih navada. Budući da druga knjiga ne sadrži Kotruljevićeve eksplicitne stavove o odgoju, smatram da njezin sadržaj ne zavređuje biti predmetom razmatranja iz odgojnofilozofske perspektive. No, treća knjiga sadrži Kotruljevićeve stavove koje je nesumnjivo moguće uvrstiti u područje filozofije odgoja. Ti se stavovi nalaze u predgovoru, drugom i trećem poglavlju treće knjige, pri čemu napominjem da se Kotruljević u predgovoru i u drugom poglavlju usmjerio na kritiku ondašnjeg društva i na ukazivanje potrebe za odgojem i obrazovanjem mladeži, dok je u trećem poglavlju upozorio na konkretna i nezaobilazna područja izobrazbe budućih trgovaca.

Dubrovački je mislilac u predgovoru trećoj knjizi, a koju je posvetio političkom životu trgovca, osudio društvo svojega vremena, ali i ponudio odgojna rješenja kojima bi se moglo odagnati uzroke takva stanja. Podsjećam da je sadržaj predgovora trećoj knjizi bio predmetom razmatranja u ranijim potpoglavljima, točnije u potpoglavlju koje se odnosilo na Kotruljevića kao poznavaoca povijesti filozofije, a onda i u potpoglavlju u kojem sam ukazivao na prisutnost etičke sastavnice u trećoj knjizi spisa o umijeću trgovanja. Kotruljevićeva analiza uzroka lošeg stanja u društvu sastojala se od toga da prosti ljudi, a posebice trgovci, koji ne traže nauk na pravom vrelu, često idu stopama svojih očeva, što najčešće završava tako da ih ili ne dostignu ili dostignu, ali ne i prestignu, zbog čega se svijet neprestano srozava i postaje kaljužom. ${ }^{447}$ Prema Kotruljevićevu mišljenju, to je ujedno uzrok tome da su trgovci često ispunjeni zabludama i lakoumnošću (pieno d'errori e levità) te da su bez traga razuma, štoviše

\footnotetext{
${ }^{446}$ Ibid., p. 135 [f. 12r]: »Deve adunche lo mercante essere supportante li affanni e havere carne sue molle e dilicate, le qual dimonstrano la nobilita delo intelecto, $<\ldots>\ll$. / p. 354.

${ }^{447}$ Cotrugli, »Libro del arte dela mercatura«, libro III, prohemio / Kotrulj, »Knjiga o vještini trgovanja«, knjiga III, predgovor, p. 237 [ff. 59v-60r]: »Et perche sogliono el piu dele volte li homini vulgari et maxime mercanti, li quali non ciercano la doctrina nel vero fonte, seguire li paterni vestigii et come sono li patri loro mercanti, cosi segueno li figlioli et continuo traendo ala mira o non li adjungono o se alguni v' agiungono, non li passano et cosi lo mundo continuo deteriorando e divenuto in sentina.«/p. 433.
} 
brojni od njih su, kako ističe, sveli trgovačko zvanje na praksu i poput majmuna čine što vide. ${ }^{448}$ Nakon toga, Kotruljević je ponudio rješenje koje se uvelike odnosi na odgoj mladih ljudi i na njihovo usmjeravanje prema usavršavanju u etičkom pogledu. To se rješenje sastoji od toga da dični i hvale dostojni sinovi (li figlioli ornati et comendatissimi) moraju ne samo oponašati svoje očeve, već ih i nadmašivati te prestizati u nekoj vrlini (excellere et passarli in qualche virtu), a tako bi svijet postajao sve savršeniji (lo mundo sarebbe intanto piu perfection), umjesto da kao tada tone u ponor. ${ }^{449}$ Da bi dokazao utemeljenost i uspješnost takva pristupa, dubrovački je mislilac naveo i nekoliko pozitivnih povijesnih primjera znamenitih ljudi koji su nadmašili svoje roditelje i koje bi mladi ljudi trebali uzimati za uzore. Kao one koji su bili neplemenita i niskog roda, ali su plemenitošću svojih umova dosegnuli vrhunac slave, Dubrovčanin je, među ostalim, naveo primjere, kako kaže, Varona mesara i Sokrata klesara kamena i mramora, koji su bili sinovi neznatnih otaca i tome usprkos bili prvi među slavnima. ${ }^{450}$

Odgojnofilozofsku sastavnicu sadrži i drugo poglavlje treće knjige Kotruljevićeva spisa naslovljeno »O trgovčevoj razboritosti« (»De prudentia delo mercante«). Kao što je moguće zaključiti već iz naslova tog poglavlja, a k tome i iz jednog od prethodnih potpoglavlja ovoga rada, tim poglavljem treće knjige dominira tematika pripadna etici. Međutim, Dubrovčanin je i to poglavlje prožeo promišljanjima koja spadaju u filozofiju odgoja. Na ovom ću mjestu podsjetiti na to da je Kotruljević razboritost smatrao općom vrlinom koja je, zbog toga što se služi slobodnom prosudbom, a ne ustaljenim zakonima i pravilima, ponajviše potrebna trgovcima, a onda i na to da je bio uvjeren da iz te vrline proizlaze četiri dodatne sposobnosti: 1) predviđanje; 2) promišljenost; 3) oprez; 4) poučljivost. ${ }^{451}$ Iz odgojnofilozofske i obrazovne perspektive najvažnija je posljednja od četiriju sposobnosti, dakle poučljivost (docilita). Razlog tome pronalazim u Dubrovčaninovoj tvrdnji da upravo ta sposobnost čini trgovca naklonjenim učenju i spoznavanju samoga sebe (docile et imparare im prima se) i drugih

\footnotetext{
${ }^{448}$ Ibid., pp. 237-238 [f. 60r]: »Dove sel ci e alcuno mercante e pieno d'errori e levità, sença alguno fundamento di ragione, imo piu anno riducto lo culto mercantile in praticha et come le scimie fanno quello vegono, sança fundamento alcuno di ragione.«/p. 433.

${ }^{449}$ Ibid., p. 238 [f. 60r] / p. 433.

${ }^{450}$ Ibid., p. 238 [f. 60r-v]: »Multi eciam furno da ignobili et vili patrimonio nati, i quali, pretermitendo l' exemplo de loro antecesori, per la nobilita del loro ingiegno sono venuti ad excelso fastigio de gloria, come si legie de Varone macellario et Socrate petraro o marmoraro, et de multi altri li quali de vilissimi padri nati veneno ad tanta excellencia che intra li gloriosi opteneno principato.«/ p. 434.

${ }^{451}$ Cotrugli, »Libro del arte dela mercatura«, libro III, capitulo 2 / Kotrulj, »Knjiga o vještini trgovanja«, knjiga III, poglavlje 2, pp. 245-246 [f. 63r]: »Avegna Dio che la prudencia sia comune virtu et conveniente ad ogni grado, stato et condicione de homini, niente di meno e l' e quodammodo piu pertinente, piu propria et piu conveniente alo mercante che al' altre generacioni di homini, pero che altre cose, sciencie et arte viveno et governanosse con cierti canoni et regole specialle, sola mercatura si governa per arbitrio, [...] Dela qualle prudencia prociedeno providencia, circumspectione, cautione et docilita.«/pp. 438-439, na p. 438.
} 
ljudi, nakon čega je dodao da onaj tko poznaje sebe poznaje sve (che qui se novit omnia novit). ${ }^{452}$ Da bi trgovac razvijao poučljivost, Kotruljević mu je predložio čitanje o brojnim stvarima te ponudio dva savjeta: 1) da ne misli da zna ono što ne zna; 2) da se ne bavi nepoznatim stvarima koje su mu nepotrebne i nejasne nauštrb stvari koje mu priliče i koje su mu potrebne. ${ }^{453}$ Potom je drugi savjet dodatno obrazložio na sljedeći način: bilo bi pogrešno da trgovac želi učiti geometriju ili astrologiju (giometria overo astrologia) nauštrb učenja moralne filozofije (la philosophia morale), dakle etike. ${ }^{454}$ Kao što sam upozorio u najavi, dubrovački mislilac nije ni u ovom poglavlju treće knjige izostavio kritiku ondašnje mladeži i trgovaca. Naime, zabilježio je da postoje brojni neuki i divlji mladići (multi inepti et bestiale gioveni) koji uživaju u plesu, gozbama i drugim nasladama (volumpta), a istodobno zapostavljaju učenje gramatike (il studio di gramaticha), retorike (arte oratoria) i drugih časnih znanosti (altre sciencie honorate). ${ }^{455}$ Što se pak tiče njegove kritike trgovaca, poručio je da je moguće pronaći brojne trgovce koji dobro znaju igrati, primjerice, šah i kockati se, zatim mačevati, hrvati, svirati, plesati, loviti, ribariti i slično, a znanost im stoji kao magarcu lira. ${ }^{456}$ Trgovce sklone tim radnjama oštro je osudio i nazvao ih čudnima i divljima (curiosi et bestiali) te dodao da se bave nevažnim stvarima i zanemaruju potrebne, a što je protivno razboritosti i poučljivosti koja je njezina kći (contra l'ordene de la prudencia overo docilita, che e sua figluola). ${ }^{457}$ Ta kći etičke vrline razboritosti od trgovca zahtijeva ne samo da raspolaže znanjem, već $\mathrm{i}$ to da je sposoban proslijediti dobar nauk drugima, pogotovo mladima i onima koji ovise o njegovu poučavanju. ${ }^{458}$

Sukladno najavi, treće poglavlje treće knjige spisa o umijeću trgovanja naslovljeno »O trgovčevu znanju« (»Dela sciencia delo mercante«) također zavređuje biti razmatrano iz perspektive filozofije odgoja. Taj zaključak temeljim i na prosudbi koju je 1994. godine pribilježio Ivica Martinović, rekavši da to poglavlje potvrđuje da je Kotruljeviću »humanistički odgoj postao zasebna tema u promišljanjima o savršenu trgovcu. « ${ }^{459} \mathrm{U}$ tom je

\footnotetext{
452 Ibid., p. 246 [f. 63v] / p. 439.

${ }^{453}$ Ibid., p. 246 [f. 63v]: »Et questo puo a sequire legendo multe cosse et pero ti ricordo, sempre che tempo ti avança, legi. Et in questo te devi guardare de dui cose, [...] La prima che non abi le cose incognite per cognite et che non li consentiamo et e presumptione. L' altro e di non dare opera a cose incognite non necessarie et multo obscure, lasando le cose ad noi pertinente et necessarie, <... « $/$. p. 439.

${ }^{454}$ Ibid., p. 246 [f. $\left.63 \mathrm{v}\right] /$ p. 439.

455 Ibid., pp. 246-247 [f. 63v-64r] / p. 439.

${ }^{456}$ Ibid., p. 247 [f. 64r]: »Et pero multi trovareti di nostri mercanti che se son dati a saper ben giocar a scachi, tavole, dadi, scrimire, lotare, sonare, dançare, caciare, pescare et cetera et di sciencia e tanquam asinus ad liram.«/p. 439.

${ }^{457}$ Ibid., p. 247 [f. 64r] / p. 439.

${ }^{458}$ Ibid., p. 247 [f. 64r]: »<...> la qual vole non solamente che lui sapia, ma vole anche che dia doctrina bona ad altri et maxime a sui gioveni et quelli che stano sotto la sua doctrina.«/p. 439.

${ }^{459}$ Martinović, »Benedikt Kotruljević (1)«, p. 9b.
} 
poglavlju, kako sam već ranije rekao, dubrovački mislilac upozorio na neizostavna područja obrazovanja budućih trgovaca. Podsjećam da se i u tom poglavlju ogleda isprepletenost etičkog i odgojnofilozofskog sloja treće knjige.

Polazišna točka Kotruljevićevih razmatranja o znanju i obrazovanju trgovaca sastoji se od njegova stava da je za obuku savršena i uglađena trgovca (lo mercante perfecto et compiuto) potrebno stvoriti iznimno svestrana čovjeka (uno homo universalissimo), koji je nadaren svim sposobnostima i koji se može sporazumijeti te pristupiti svakoj vrsti ljudi. ${ }^{460}$ Zatim je pobrojao, kako kaže, značajne, temeljne i prirodne znanosti koje trgovac mora poznavati, a bez kojih je ništavan i isprazan (inane et vacuo). ${ }^{461}$ Dubrovčanin je neizostavnima smatrao znanja koja potječu iz umijećā koja pripadaju triviju (trivium), znači trima nižim od ukupno sedam slobodnih umijeća (septem artes liberales) koja su u srednjovjekovlju postala temeljnim stupnjem naobrazbe: gramatika, retorika i dijalektika (logika). Kotruljević je taj stav potkrijepio brojnim obrazloženjima od kojih ću za ovu prigodu izdvojiti samo neka. Primjerice, kada je isticao nužnost poznavanja gramatike, zabilježio je da trgovac mora biti pismen i vičan latinskom jeziku, jer mu to omogućava da: 1) bolje razumije ugovore; 2) bolje razumije neku zapovijed i povlasticu; 3) razumije brojne narode i različite ljude; 4) razumije mnogo toga iz kršćanske vjere, poput misa i molitvi; 5) može pristupiti među gospodu i ugledne ljude, što ga čini višim od puka; 6) zna lijepo pisati pisma i voditi prepisku s gospodom i velikim vođama. ${ }^{462}$ Kada je pak naglašavao nužnost poznavanja retorike, poručio je trgovcu da, primjerice, treba biti u najmanju ruku dobar govornik te da govorništvo čini čovjeka rječitim i razumljivim, i to ne samo u latinskom nego i u pučkom jeziku. ${ }^{463} \mathrm{Da}$ je

${ }^{460}$ Cotrugli, $»$ Libro del arte dela mercatura«, libro III, capitulo 3 / Kotrulj, »Knjiga o vještini trgovanja «, knjiga III, poglavlje 3, p. 248 [f. 64r]: »Volendo consequentemente tractare dela scienca del mercante, quale e quanta deve essere, io mi vengo meno al pensarvi, per che la mi mena in infinitum, che volendo instituire lo mercante perfecto et compiuto mi bisognia fare uno homo universalissimo, dotato d' ogni faculta che possa intendere et comparere con ogni generacion di homini.«/p. 440.

${ }^{461}$ Ibid., p. 248 [f. 64r]: »Ma per volere a legiare quelle sciencie proprie et principali sença le quali lo mercante e inane et vacuo, diremo dele proprie e naturale sciencie le qualli de necessita deve sapere.«/p. 440.

${ }^{462}$ Ibid., pp. 248-249 [f. 64r-v]: »Et habino paciencia alguni ignoranti li quali o negano o vero dannano omnino lo mercante lo quale e sciente, inuno incorrono ad magiore insolençia et dicono che lo mercante non deve essere literato. [...] ma eciamdio lo mercante deve essere literato, [...] pero che questo gli e necessariissimo, che la gramaticha fa l' huomo inteligente ad cognoscere bene uno contracto et lo mercante ogni di fa li contracti. Lo fa eciamdio intendere uno comandamento, uno privilegio et quod maximum e pratico alo contraere. Lo fa eciamdio intendere multe nacioni et diverse gienti, come Ungari, Tedeschi, Françosi et multi altri. Lo fa eciamdio intendere multo dela Christiana religione, come sono le messe et le oracioni et quelle cose che per sua divocione si delectasse di legiere. Lo fa eciamdio la gramatica comparesciente intra signori et magnifici homini et lo fa essere egregio, che vol dira extra gregem, superiore al vulgo. [...] Falo eciamdio sapere ornatamente scrivere in litere et fare superscripcioni a signori et a gran maistri et quando e di bisogno sanno epistolare dove bisognia et exordire. «/p. 440.

${ }^{463}$ Ibid., pp. 248-249 [f. 64v]: »<...> ma eciamdio lo mercante deve essere literato, prima et almeno bono retoricho,per che questo gli e necessariissimo, [...] L' essere rethorico e necessario, perche non solamente l' 
Kotruljević znanje iz tih dvaju umijeća smatrao temeljnima, potvrđuje i, primjerice, njegov opis slučaja u kojem bi poklisari i poslanici, a da pritom nisu vični gramatici i retorici, podsjećali na magarca s lirom, pa čak i bili smatrani poluljudima ili životinjama, zbog toga što bi im nedostajalo, kako kaže, znanje bez kojega duša ne može baš kao ni jelo bez soli. ${ }^{464}$

Uz nastavak kritike ondašnjeg društva Kotruljević je ponudio obrazloženje svojeg ustrajanja na trgovčevu poznavanju slobodnih umijeća (le arti liberali) koja pripadaju triviju. Zabilježio je, naime, da trgovčevo znanje ograničava na gramatiku (gramatica), logiku (loyca) i retoriku (retorica) ne zato što mu poznavanje drugih ne bi uvećalo savršenstvo (perfectione), već zato što je svijet pokvaren (lo mundo e corrupto) pa se često događa da brojni ljudi ne žele znati. ${ }^{465}$ Međutim, Dubrovčanin je istaknuo i to da iako je plemenita stvar biti predstavnik svoje struke među sustručnjacima, kao, primjerice, filozof među filozofima (intra philosophi philosopho), trgovac mora biti najsvestranija osoba i više od drugih dolazi u doticaj s ljudima različita porijekla i staleža pa je korisno da uz spomenute znanosti i umijeća poznaje i druge svjetovne znanosti koje se više uče kroz praktično djelovanje (per pratica). ${ }^{466}$ Primjerice, naveo je da je trgovcu potrebna kozmografija (la cosmographia) jer mora znati položaj, mjesta i imena država, predjela i pokrajina, zatim poznavati trgovačke prilike i običaje, carine i stanja trgovačke robe, a onda i poznavati udaljenosti mjestā, luka i obala, dakle pomorsku kartu (la carta delo navicare). ${ }^{467}$ Dubrovački je mislilac u zaključnom dijelu poglavlja nabrojio još četiri znanosti koje bi trgovac trebao poznavati, a to su filozofija, astrologija, teologija i pravo, te ponudio obrazloženje koristi koju trgovac ima od poznavanja logike. Filozofiju

arte dela rethorica fa l' homo eloquente in lingua Latina, ma e lo fa eciamdio diserto in vulgari, la quale parte e multo ornamento dela persona delo mercante. «/p. 440.

${ }^{464}$ Ibid., pp. 249-250 [f. 65r]: »<..> che sono mandati per ambasciatori et oratori a principi et diversi signori et signorie, li quali per certissimo non esendo literati et rethorici sono tanquam asinus ad lyram et semihomines, imo bestie, perche lor mancha lo excelente condimento sença lo quale cosi como l' escha e l' cibo corporale sensa lo sale, cosi l' anima sença la sciencie esser non puo.«/p. 441.

${ }^{465}$ Ibid., p. 252 [f. 66r-v]: »E le arti liberali chiamano gramatica, loyca et retorica. Ala qual penuria di sciencia lo reducimo lo mercante, non perche non sia del' altre et molte sciencie le qual sapendole li seriano ad cumulo et augmento di perfectione, ma perche lo mundo e corrupto et e venuto ad tanta inopia di senno che non solamente non si curano di sapere, ma neanche vogliono sapere, <...>«. / p. 443.

466 Ibid., p. 253 [f. 66v]: »Ma gentil cosa e l' essere intra philosophi philosopho, intra oratori et historiographi oratore, intra loici loico, intra religiosi non ignorare lo culto Christiano et intra mercanti mercante, intra cortesani cortesano. Perche lo mercante e universalissima persona e quello ad cui vengono piu ale mano diverse generacione et condicione di homini che a nulla altra generacione, il perche oltra le prenominate sciencie et arte liberali e le di necessario a lo mercante sapere altre sciencie in agibilibus mundi le quali se imparano piu per pratica che per altra via.«/p. 443.

${ }^{467}$ Ibid., p. 253 [ff. 66v-67r]: »Et sono come la cosmographia, la quale e di bisognio non solamente sapere lo sito del orbe e lo nome dele patrie, regioni et provincie et terre particulari, ma e le di bisogno eciamdio sapere le condicioni et li usi mercantili et gabele di quele et condicioni d' ogni robe et mercanthie che si meteno et tragono d' ogni parte, pero che nol sapendo non intende quello che ad ogni parte et in sue stagioni si convene. Et piu li besognia sapere le distancie, li siti, porti, spagie et multo bene la carta delo navicare per sapere noligiare et asicurare. Et tuto quello avemo dicto e necessariissimo alo mercante. «/p. 443. 
(philosophia) bi, priopćava Kotruljević, trgovac trebao poznavati da bi spoznao naravne stvari (per cognoscere le cose naturali) i da bi, istančavajući um (a sotiglando intelecto), istraživao prirodu i ljudsku narav (la natura nostra), a ponajviše građu ljudskog tijela (humane compesioni), fizionomiju (le phisonomie) i ljudsku prirodu (nature de homini). ${ }^{468}$ Prema procjeni koju je 1994. godine izrekao Ivica Martinović, Kotruljevićevo naglašavanje trgovčeva poznavanja filozofije odnosilo se na filozofiju »koja se tiče naravnih stvari«, dakle na »filozofiju prirode i psihologiju. ${ }^{469}$ Kao što sam to naglasio u potpoglavlju o etici u trećoj knjizi spisa o umijeću trgovanja, Kotruljević je potrebu za trgovčevim poznavanjem logike obilježio etičkom dimenzijom. Podsjećam, poručio je da je izrazito potrebno da trgovac bude logičar (essere loyco) zbog razlikovanja istinitog od lažnog (discernere lo vero dai falso) te zbog pobijanja lažnih tvrdnji i silogizama (confundere li falsi argumenti et silogismi), jer postoje neki ljudi koji su po prirodi sofisti (homini di natura sophiste). ${ }^{470}$ Dubrovčanin je potom zapisao da bi astrologija (astrologia) bila na neki način najbolja znanost (optima sciencia) za trgovca, jer bi tako znao predvidjeti godišnji urod žita, ulja i drugih namirnica, kao i bolesti, ratove i slično. ${ }^{471}$ Inače, Kotruljević je zagovarao upotrebu spoznaja iz astrologije u predviđanju zdravstvenog stanja ljudi, dakle uvažavao je znanja iz takozvane astrološke medicine, i u petnaestom poglavlju treće knjige spisa o plovidbi. ${ }^{472}$ Trebao bi biti i teolog (theologo), jer će tako biti upućen u zakone, kanone i temelje katoličke vjere. ${ }^{473} \mathrm{Na}$ koncu, trebao bi biti pravnik (jurista), jer trgovac ne smije zanemarivati zakone da bi se znao čuvati od protivnika i braniti se. ${ }^{474}$ Tako bismo, zaključuje Kotruljević, mogli ići u beskonačnost i shvatiti da sve što čovjek treba znati priliči i trgovcu, zbog čega ne treba čuditi da je malo pravih trgovaca (li veri mercanti). ${ }^{475}$

\footnotetext{
${ }^{468}$ Ibid., pp. 253-254 [f. 67r] / p. 443.

${ }^{469}$ Martinović, »Benedikt Kotruljević (1)«, p. 9c.

${ }^{470}$ Cotrugli, »Libro del arte dela mercatura«, libro III, capitulo 3 / Kotrulj, »Knjiga o vještini trgovanja«, knjiga III, poglavlje 3, p. 254 [f. 67r] / p. 443.

${ }^{471}$ Ibid., p. 254 [f. 67r]: »Astrologia saria quodamodo optima sciencia alo mercante per sapere l' annate de grani, ogli et altre vitovaglie saper prodiciere morbi, guerre et simillia«. / pp. 443-444.

472 Vidi na pp. 171-173 ovoga rada.

${ }^{473}$ Ibid., p. 254 [f. 67r]: »Theologo chi dubita che saria optimo senno alo mercante per sapere la legie et li canoni et lo fundamento dela nostra fede.«/p. 444.

${ }^{474}$ Ibid., p. 254 [f. 67r]: »Jurista eciamdio non deveria ignorar le legie lo mercante per sapere guardarsi dali iniqui et defendere la caxione sua.«/p. 444.

475 Ibid., p. 254 [f. 67r]: »Et cusi in infinitum transcorrendo trovariamo tuto quello che de sapere uno homo convenirse debitamente alo mercante per non a legie ne loco il favolegiar vulgare che condamne le lectere et pero non maravigliarse pochi sono li veri mercanti.«/p. 444.
} 


\subsubsection{Filozofija odgoja u četvrtoj knjizi spisa o umijeću trgovanja}

Odgojnofilozofsku sastavnicu sadrži i posljednja, dakle četvrta knjiga Kotruljevićeva spisa o umijeću trgovanja. Ona se očituje u dvama poglavljima te knjige: šestom i sedmom. U šestom i sadržajem najbogatijem poglavlju četvrte knjige Kotruljević je razmatrao muškarčevu odgojnu ulogu prema ženi u braku, zatim je opisao kako se odgojni postupci u očinskoj kući odražavaju na narav žene, a onda i ukazao na postupke koje muž mora poduzeti ne bi li preodgojio svoju ženu. Sedmo pak poglavlje četvrte knjige sadrži Dubrovčaninova promišljanja o primjerenu odgoju i obrazovanju djece. U tim se dvama poglavljima, podsjećam na tvrdnje koje sam izložio u potpoglavlju o etici u četvrtoj knjizi spisa, isprepliću i prožimaju etička i odgojnofilozofska sastavnica.

Središnji dio šestog poglavlja četvrte knjige spisa o umijeću trgovanja naslovljenog »O ženi« (»Dela muliere«) sadrži Kotruljevićeva promišljanja o ispravnim muškarčevim postupcima prema ženi od trenutka sklapanja braka. Nakon što je, o čemu je bilo riječi u potpoglavlju o etici u četvrtoj knjizi, upozorio muškarce da tragaju za ženama koje posjeduju brojne vrline više nego za onima koje nude korist i ljepotu, dubrovački je mislilac zapisao stav da trgovcu, dakle muškarcu pripada odgovornost da ženi na u prvoj godini njihova braka uvede pravila i red u život (lo modo et ordene del vivere). ${ }^{476}$ Zatim je muškarcima savjetovao načine djelovanja kojima će postići navedeni cilj u bračnom odnosu. Naime, smatrao je da muškarac ne smije ženi nikada popustiti uzde, nego ih uvijek mora držati u ruci i ne smije joj dopustiti da ga ikada pobijedi. ${ }^{477} \mathrm{Uz}$ to, pribilježio je da muškarac ne smije ženu ozlojeđivati svojom osornošću, nego je mora umjereno milovati i poticati je blagom rukom, potruditi se da ga zavoli, ali i da ga se istovremeno boji te da ga štuje. ${ }^{478}$ Međutim, Dubrovčanin je bio uvjeren i u to da muškarac mora kažnjavati ženu, ali da u tome ne smije pretjerivati. ${ }^{479}$ Muškarcu je također savjetovao da ženu ne čini ljubomornom i sumnjičavom, nego joj treba uzvraćati

\footnotetext{
${ }^{476}$ Cotrugli, »Libro del arte dela mercatura«, libro IV, capitulo 6 / Kotrulj, »Knjiga o vještini trgovanja«, knjiga IV, poglavlje 6, pp. 306-307 [ff. 85v-86r]: »Deve lo mercante quando piglia mugliere in quello principio amunirla et darli lo modo et ordene del vivere el primo anno«. / p. 482.

${ }^{477}$ Ibid., p. 307 [f. 86r]: »< ..> et non li de lassare la briglia, ma sempre de tenere in mano et non li lasare vincere mai nulla punta.«/p. 482.

${ }^{478}$ Ibid., p. 307 [f. 86r]: »Et farli chariçie con temperamento et farla a mano dilicata, come si fa un sparvieri che lo fai come voi. Fa ch' ela te ami, tema et honori et che non pigli a sdegno la multa aspreça tua, $<\ldots>\ll$. / p. 482.

479 Ibid., p. 307 [f. 86r]: »<..> cosi la castigatione continua sença intervallo diventa dura et incorrigibile et non e piu doctrina, ma l' e scherço et gioco. Et ingengnate de non la condure al batere, perche come tu li meti la mano adosso, tu sei impaciato.«/p. 482.
} 
ljubav. ${ }^{480}$ Ženu ne bi trebao učiniti požudnom, jer mu je supruga, a ne bludnica. ${ }^{481}$ Prema njegovu sudu, odnos muškarca i žene trebao bi biti obilježen velikom umjerenošću, stidom u riječima i djelima, pristojnošću i čestitošću u razgovoru, a onda i vjernošću te uzdržanošću. ${ }^{482}$ Kao što sam ranije napomenuo, sljedeći primjer u kojem se ogleda odgojnofilozofska sastavnica šestog poglavlja četvrte knjige spisa o umijeću trgovanja odnosi se na Dubrovčaninovo razmatranje načinā kojima se odgojni postupci u očinskoj kući odražavaju na pet mogućih inačica naravi žena (le nature di donne) te muškarcima predložio radnje koje moraju poduzeti da bi ispravili štetne učinke tih odgojnih postupaka. Prvu inačicu ženske naravi obilježava to da je riječ o ženama koje žele lijepe riječi, a to su plemenita stvorenja koja su odgajana tankoćutno i dražesno, i ne žele osornost, jer njihovu narav ozlojeđuju oštre riječi i udarci. ${ }^{483}$ Prema Kotruljevićevu mišljenju, teško je pronaći žene takve naravi koje neće muškarca poštovati i častiti zbog plemenitosti njegove duše (per la gentileca del animo). ${ }^{484}$ Takve su žene sklone svakoj pouci i dobrim običajima, a blaženi su oni muškarci kojima takve zapadnu jer je za to potrebno imati puno sreće. ${ }^{485}$ Drugu vrstu ženske naravi moguće je prepoznati kod žena koje će se prestrašiti uzrujanog lica, jer su bojažljive (timide) i strašljive (inaudacie) te većinom malo vrijede, divlje su (bestialli) i teško ih se može poučiti. ${ }^{486}$ Zato ih muškarac treba poučavati s puno truda, dati im slobodu i poticati njihovu odvažnost (spingere audacia), pobuditi ih ljubavnim dodirom, oprezno im popuštati i zatezati uzde. ${ }^{487}$ Takva vrsta ženske naravi zahtijeva vještu ruku, a s njima muškarac mora dobro postupati da bi ih učinio vještima, čestitima i mudrima (experte, honeste et sagie), budući da su odgajane u strahu i neznalački (sotto temença et governo indocto). ${ }^{488}$ Kotruljević je potom zabilježio da treću

${ }^{480}$ Ibid., p. 312 [f. 88r]: »Non la far gielosa, non sospecta, rendili integramente l' amore sença diminucione.«/p. 485.

${ }^{481}$ Ibid., p. 312 [f. 88r-v]: »Non essere volentorosa, fa la donna et non meretrice, et non vi mostrare l' uno al' altro denudandovi li pudibundi.«/p. 485.

482 Ibid., p. 312 [f. 88v]: „Con gran temperança sia vergogna in paroli et in fati, costume et honesta nela converssacion, fede et moderacione et quanto con piu verecundia viverete, con piu amore et desiderio vi mantenerete. «/pp. 485-486.

${ }^{483}$ Ibid., p. 307 [f. 86r]: »Avisandote che diverse sono le nature di donne. Alcune vogliono bone parole et queste songo creature gentille et alevate in casa di lor patre dilicatamente et veçiosamente, et non vogliono aspeça, perche la natura loro piglia disdegno del' aspreça de parole o batiture.«/p. 482.

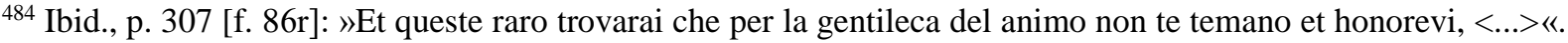
/ p. 482.

${ }^{485}$ Ibid., p. 307 [f. 86r]: »<...> et se li apicha ogni doctrina et bono costume et beati a chi tocano in parte che per cierto implurimum sono venture.«/p. 482.

${ }^{486}$ Ibid., p. 307 [f. 86r] / p. 482.

487 Ibid., p. 307 [f. 86r]: »Et queste tali se volno con multo ingiegno a doctrinare et darli liberta et spingere audacia, con chareçe d' amore excitarle et alargarli discretamente la briglia, et tirar a loco et tempo et con lo sperone.«/pp. 482-483.

${ }^{488}$ Ibid., pp. 307-308 [f. 86r-v]: »Et volci gran destreça di mano, come sai tu che 1' ai provato. Et queste son tentute in casa di lor patri sotto temença et governo indocto, sença alguno temperamento et io te dico che le citelle si vogliono tenir bene per farle experte, honeste et sagie.«/p. 483. 
vrstu ženske naravi posjeduju žene koje su ohole i divlje (superbe et bestiale), a uzrok tome nalazi se u njihovu bijednu odgoju bez ikakva reda (tenute vile in mal ordine) i u druženju sa sluškinjama, zbog čega im se kada dođu u muževu kuću čini kao da su iz zatvora došle na vlast. ${ }^{489}$ Muškarčev odnos prema ženama takve naravi uključuje i postupke koji su, kako sam to već naznačio u potpoglavlju o etici, vrlo dvojbeni iz etičke perspektive. Naime, smatrao je da takve žene treba često opominjati i prijetiti im batinama, zatim ako ne postanu srdačne, treba im gnjevno zaprijetiti, a za slučaj da se ni nakon toga ne poprave, muškarac treba primijeniti fizičku silu. ${ }^{490} \mathrm{Za}$ slučaj da posegnu za primjenom fizičke sile, Dubrovčanin je muškarcima savjetovao da se pobrinu da to drže u tajnosti zbog toga što: nema teže optužbe za ugledna čovjeka nego da tuče ženu, jer je žena vrlo slabo i nevrijedno stvorenje, štoviše nesavršen čovjek; budući da je žena neznatna i u muškarčevoj je vlasti, nisko je dizati ruku na nju; ne treba cijeniti muškarca koji primjenjuje silu bez pravog povoda, jer je nevrijedan onaj koji ženu ne zna dovesti u red dobrom poukom. ${ }^{491}$ Izlaganje o trećoj vrsti ženske naravi Kotruljević je zaključio tvrdnjom da je žena nesumnjivo onakva kakvom je muž učini, pa ako je loša, krivica pripada mužu. ${ }^{492}$ Prema Kotruljevićevu mišljenju, četvrtu vrstu ženske naravi posjeduju žene koje imaju malo mozga (poco ciervello), zatim koje lako nešto požele (ligiere voriano) i lako zaborave (dimenticano) ili smetnu s uma (smemorano), a takve su jer su od djetinjstva odgajane bez ikakve pouke (sença doctrina). ${ }^{493}$ Pamćenje, dodaje Dubrovčanin, najviše jača ponavljanjem i učenjem (frequentarla et imparare), jer tako ono postaje zdravije i učinkovitije (piu salubre et piu efficacie). ${ }^{494}$ Da bi dokazao točnost te tvrdnje, istaknuo je primjer svojih kćeri koje je dao poučiti gramatici i Vergilijevim stihovima, a to je učinio ne samo da bi one postale savršene gramatičarke i govornice (perfecte gramatiche et retorice), već zato da bi postale razborite (prudente), mudre (savie) i zato da imaju dobro, čvrsto i

${ }^{489}$ Ibid., p. 308 [f. 86v]: »Algune songo superbe et bestiale, et queste songo alevate in casa di lor patre et tenute vile et mal in ordine et potissime in conversacion di schiave, dale quali imparano ogni male costume. Le qual, come vengono in casa di suo marito, lor par essere venute di prigione in signoria e lo far di superbia bestialle, lor par essere madone. Son fate di serve libere, pigliano briglia et signoria bestialle.«/ p. 483.

490 Ibid., p. 308 [f. 86v]: »Queste se volgino multo amunire et minaciare del cominciare a menar le mano e farsele amorevole et minaciare desdegni et in ultimo, quando emendar non si voglino, giocha delo bastone, ma questo ti sia l' ultimo rimedio.«/ p. 483.

${ }^{491}$ Ibid., p. 308 [ff. 86v-87r]: »Et se la fortuna t' inducie a questo extremo, cielatelo chel sia secreto, pero che non puo essere piu carico ad un homo di condicione che batere la mugliere, perche la donna e multo fragile cose et vile creatura et e homo imperfecto, [...] Et pero ch' ela e cosi vile et in potestate tua, e non a mano ne piedi di prevalere, vile cosa e che tu extrenda mano in essa. Et de essere extimato da poco chi lo fa sença grande occasione, perche ben e da pocho chi non sa ridure con bona doctrina la donna ad suo costume, $<\ldots>\ll$. /p. 483.

492 Ibid., p. 308 [f. 87r]: »<..> che sença fallo tale e la donna quale lo marito la fa. E quando e trista se deve inculpare lo marito et non lei.«/p. 483.

${ }^{493}$ Ibid., pp. 308-309 [f. 87r] / p. 483.

${ }^{494}$ Ibid., p. 309 [f. 87r] / pp. 483-484. 
zdravo pamćenje (bona, salda et sana memoria), a od čega za njega nema većeg miraza pa je onog mladića koji se na njih namjeri smatrao blaženim (beato). ${ }^{495}$ Međutim, istaknuo je i to da se glupe žene vrlo teško mogu pritegnuti pa ih treba stalno opominjati i dodijeliti im ozbiljnu ženu koja će ih odgojiti tako da ih iz njihove lakoumnosti učini ozbiljnima (ligiereça ad gravitate). ${ }^{496}$ Naposljetku, žene koje obilježava peta vrsta naravi su, prema mišljenju dubrovačkog mislioca, trome pameti (hebete d' ingegno), dremljive (adormentate), tupa uma (grosse d'intelecto), masna tijela (grasse di corpo), spavalice (dormigliose) i nemarne (stracurate), samo su meso bez duha (tuto carne sença spirito), a takve su u očinskoj kući živjele slobodno (in liberta), rasterećene od posla i s divljim družicama (compagne bestiali) pa samo čekaju kada će se gostiti. ${ }^{497}$ Te mesnate (carnose), pripite (vinose), bludne (voluptuose) i divlje (bestiali) žene muškarac bi trebao opominjati na lijep način, naviknuti ih na suzdržljivost (abstinente) i odviknuti od juhe i umaka, koji ih čine pospanima, snenima i zaboravnima, kao i od lošeg društva (cative conversacioni), posebice od onih pred kojima gubi stid (non a vergogna). ${ }^{498}$ Da muškarcu pripada uloga preodgoja žene, moguće je dodatno potvrditi Kotruljevićevim stavom da bi muškarac u dobi od 28 godina trebao uzeti ženu u dobi od 16 godina, jer će mu to omogućiti da je učini onakvom kakvom je želi. ${ }^{499}$ Naposljetku, poglavlje »O ženi« Kotruljević je zaključio razmatranjem o razlozima za uspostavljanje braka. Među njima je kao jedan od glavnih razloga istaknuo prihvaćanje i odgoj djece (susceptione et educatione di figlioli). ${ }^{500}$

U sedmom poglavlju četvrte knjige spisa o umijeću trgovanja, a kojem je poglavlju naslov »O djeci« (»Deli figliuoli«), Kotruljević je izložio promišljanja o potrebnu odgoju i obrazovanju djece. Naglašavam i podsjećam da se i u tom poglavlju očituje isprepletenost etičke i odgojnofilozofske tematike. Početak poglavlja o djeci Kotruljević je posvetio razmatranju roditeljskih obaveza prema djeci, kao i razmatranju obaveza djece prema roditeljima. Zaključak koji je proistekao iz njegovih razmatranja bio je da su roditelji dužni djecu odgajati (educare), hraniti (nutrire) i učiti dobrim običajima (costumare), a djeca roditeljima zauzvrat

\footnotetext{
495 Ibid., p. 309 [f. 87r] / p. 484.

${ }^{496}$ Ibid., p. 309 [f. 87r]: »Et le sciervellate con multa dificulta si possono ridure et se voglino amunire spesso et quasi al continuo et haverli apreso una donna grave, che continuo circa li soi costumi per ridure quella liegereça ad gravitate.«/p. 484.

${ }^{497}$ Ibid., p. 309 [f. 87r-v] / p. 484.

${ }^{498}$ Ibid., p. 310 [f. $87 \mathrm{v}$ ] / p. 484.

${ }^{499}$ Ibid., p. 310 [f. 87v]: »Et infine, tolendo donna de XVI anni [...] et homo de XXVIII, farai la donna come vorai et haverai lla talle qualle la farai.«/pp. 484-485.

${ }^{500}$ Ibid., p. 314 [f. 89r-v]: »Devi haver perfecto amor, perche lo matrimonio fo instituto, [...] Et nota che per dui cagioni fo instituito lo matrimonio: susceptione et educatione di figlioli, <...>«. / p. 487.
} 
duguju poslušnost (obediencia). ${ }^{501}$ Iako se to ni na koji način ne odražava na narav odgojnih postupaka koje je izložio u nastavku poglavlja, dubrovački je mislilac imao potrebu ukazati na postojanje razlikovanja vrsta djece. Prema njegovu mišljenju, podjela djece bila je četveročlana: 1) zakonita i prirodna djeca (figlioli legitimi naturali), koja se rađaju iz pravoga braka; 2) prirodna (naturali) djeca, koja se rađaju kao plod slobodnog muškarca i slobodne žene koja još uvijek može postati nečijom suprugom; 3) zakonita (legitimi), točnije posvojena (adoptivi) djeca; 4) kopilad ili bastardi (spurii, cioe bastardi), dakle djeca koja su plod preljuba, incesta ili nekog drugog zakonom zabranjenog spolnog čina i isključena su iz očinskog nasljedstva. ${ }^{502}$ Središnji dio poglavlja o djeci otkriva Dubrovčaninove stavove o primjerenu odgoju i obrazovanju djece. Prema Kotruljevićevu mišljenju, odgoj i obrazovanje djeteta započinju već nakon odvajanja djeteta od dojilje, nakon čega je djetetu potrebno pronaći učitelja, koji će ga poučiti dobrim običajima, gramatici, retorici i nekom umijeću od kojega će zarađivati. ${ }^{503}$ Kada dijete odraste, nužno ga je, prema Kotruljevićevoj procjeni, uputiti nekom dobrom i učenom trgovcu da izuči struku. ${ }^{504}$ Djecu koja ne znaju ništa i koja nisu spremna naučiti od drugih, žestoko je osudio, štoviše nazvao ih je životinjama (le bestie). ${ }^{505} \mathrm{Na}$ muškarcu je, smatra Kotruljević, briga o tome da učitelj drži sinove u strahu i da iskazuju smjernost u razgovoru i ophođenju, jer tako uče do starosti častiti očevo ime. ${ }^{506}$ Posljednju odgojnu i životnu pouku u poglavlju o djeci Kotruljević je oblikovao na sljedeći način: djecu toliko lošega čeka da čim budu stjecali više razuma, tim će prije govoriti da ništa ne znaju, jer oni koji misle da znaju malo ili ništa, znaju mnogo, dok oni koji si umišljaju da znaju sve, uistinu ne znaju ništa. ${ }^{507}$

${ }^{501}$ Cotrugli, »Libro del arte dela mercatura«, libro IV, capitulo 7 / Kotrulj, »Knjiga o vještini trgovanja«, knjiga IV, poglavlje 7, p. 320 [f. 92r] / p. 492.

${ }^{502}$ Ibid., pp. 320-321 [f. 92r-v]: »Li figluoli son in quatro modi. L' uni sono figlioli legitimi naturali et questi nasceno del vero matrimonio. L' altri sono naturali et questi son nati de soluto et soluta, la qual ancor potria essere mugliere. Terci sono solamente legitimi et questi sono adoptivi. Quarti sono spurii, cioe bastardi et questi sono nati de adulterio o incesto o altro per legie damnato coito et questi sono exclusi da ogni heredita paterna.«/p. 492.

${ }^{503}$ Ibid., p. 323 [f. 93r-v]: »Poi che lo garçone e tracto dala nutricie, li deve dara uno bono maistro che l' insegni bon costumi et gramaticha et retorica et farli sapere qualche arte de pane adquirendo, perche venendo a perdere li beni dela fortuna non pervenga ad vilita, perche li mercanti sença dinari non vagliono in l' arte, come lo fabro, e l' orefecie sença feramenti.«/p. 494.

${ }^{504}$ Ibid., p. 323 [f. 93v]: »Da poi, come sono adulti, li de dare ad uno bono et docto mercante, che inparono l' arte, perche multi vogliono sença maistro essere maistro et non e possibile.«/p. 494.

${ }^{505}$ Ibid., p. 323 [f. 93v]: »Et chi ne per se sa ne d' altri impara sono da essere anumerati intra le bestie.«/ p. 494.

${ }^{506}$ Ibid., pp. 323-324 [ff. 93v-94r]: »Et fa chel l' integni in temore et che ti porteno reverencia in parlare et in conversare, [...] Et di quelli costumi boni et reverenti si fano l' abito che eciam in senectute et decrepita honorano el nome paterno.«/p. 495.

${ }^{507}$ Ibid., p. 325 [f. 94v]: »A quanto mal t' aspecta so cierto quando arai piu senno dirai e non ne so nulla. Et tucti quelli li qualli se stimano di saperne poco e nulla sono sufficienti et quelli che presumeno sapere tucto non ne sanno nulla.« / pp. 495-496. 


\section{FILOZOFSKA SASTAVNICA KOTRULJEVIĆEVA SPISA O PLOVIDBI}

Za razliku od spisa o umijeću trgovanja, koji je od sredine devedesetih godina 20. stoljeća sagledavan i iz filozofske perspektive u desetak radova koje su objavili istraživači hrvatske filozofske baštine, i koji je time poznatije Kotruljevićevo djelo, spis o plovidbi, koji je uobičajeno nazivati i De navigatione, spada među slabije istražene spise hrvatskih mislilaca. Doduše, tome je najviše doprinijela činjenica da je prva od dviju rukopisnih inačica prijepisa tog spisa pronađena tek 1995. godine u Sveučilišnoj knjižnici na Yaleu (Beinecke Rare Book and Manuscript Library), pri čemu dodajem da ga je pronašao akademik Darko Novaković, koji ga je u članku objavljenom 1995. godine u Vjesniku odredio kao »prvi hrvatski udžbenik plovidbe ${ }^{508}$

Godinu dana nakon toga, dakle 1996. godine, Novaković je ukratko obradio sadržaj spisa i uputio na neke od Kotruljevićevih izvora, a koji su najčešće bili filozofske naravi. ${ }^{509}$ Međutim, prosudbe o filozofskoj sastavnici spisa o plovidbe dosad su iznijela tek dvojica istraživača hrvatske filozofske baštine: Ivica Martinović i Davor Balić. Naime, Martinović se o spisu prvi put očitovao 1996. godine, usmjerivši se pritom na njegovu strukturu i sadržaj, kao i na Kotruljevićeve prikaze antičke i onodobne ruže vjetrova. ${ }^{510}$ Prvu ocjenu o filozofskoj sastavnici spisa Martinović je iznio 1999. godine, kada je zapisao da treća knjiga sadrži nauk iz filozofije prirode, $\mathrm{i}$ to ponajprije zbog »opisa meteoroloških i astronomskih pojava bitnih za plovidbu « ${ }^{511} \mathrm{U}$ radovima iz 2000. i 2011. godine zaključio je da trećom knjigom spisa $D e$ navigatione započinje »blistava hrvatska dionica renesansne prirodne filozofije«, zatim da je

\footnotetext{
${ }^{508}$ Darko Novaković, »Prvi hrvatski udžbenik plovidbe«, Hrvatski kulturni tjednik »Danica«, Zagreb, br. 48 (18. ožujka 1995), pp. 1-20, na p. 17, u: Vjesnik 56 (Zagreb, 1995), br. 17044 (18. ožujka 1995), p. 31.

${ }^{509}$ Darko Novaković, »Novopronađeni rukopis Benedikta Kotruljevića«, u: Vladimir Stipetić (ur.), Dubrovčanin Benedikt Kotruljević: hrvatski i svjetski ekonomist XV. stoljeća, međunarodni znanstveni skup, Dubrovnik 17-19. X. 1996. Radovi o životu i djelu Benedikta Kotruljevića, knjiga 1. (Zagreb: Hrvatska akademija znanosti i umjetnosti i »Hrvatski računovođa«, 1996), pp. 19-32. Isto vidi u: Darko Novaković, »Novopronađeni rukopis Benedikta Kotruljevića O plovidbi (De navigatione)«, u: Darko Novaković, $U$ krilu Vile Latinke. Rasprave o hrvatskom humanizmu (Zagreb: Ex libris, 2015), pp. 61-80.

${ }^{510}$ I.[vica] M.[artinović], »Benedikt Kotruljević«, u: Greta Pifat Mrzljak (autorica izložbe), Znanost u Hrvata: prirodoslovlje i njegova primjena / Centuries of Natural Science in Croatia: Theory and Application, [sv. 1], katalog izložbe održane od lipnja do listopada 1996. godine u Muzejskom prostoru Muzejsko galerijskog centra na Jezuitskom trgu u Zagrebu (Zagreb: Muzejsko galerijski centar, 1996), pp. 56-57.

511 Ivica Martinović, »Književni žanrovi hrvatskih filozofa od Stojkovića do Boškovića«, u: Fedora Ferluga Petronio (a cura di), Introduzione allo studio della lingua, letteratura e cultura croata / Uvod u studij hrvatskoga jezika, književnosti i kulture / Uvod v študij hrvaškega jezika, literature in kulture (Udine: Forum, 1999), pp. 107-116, na p. 108.
} 


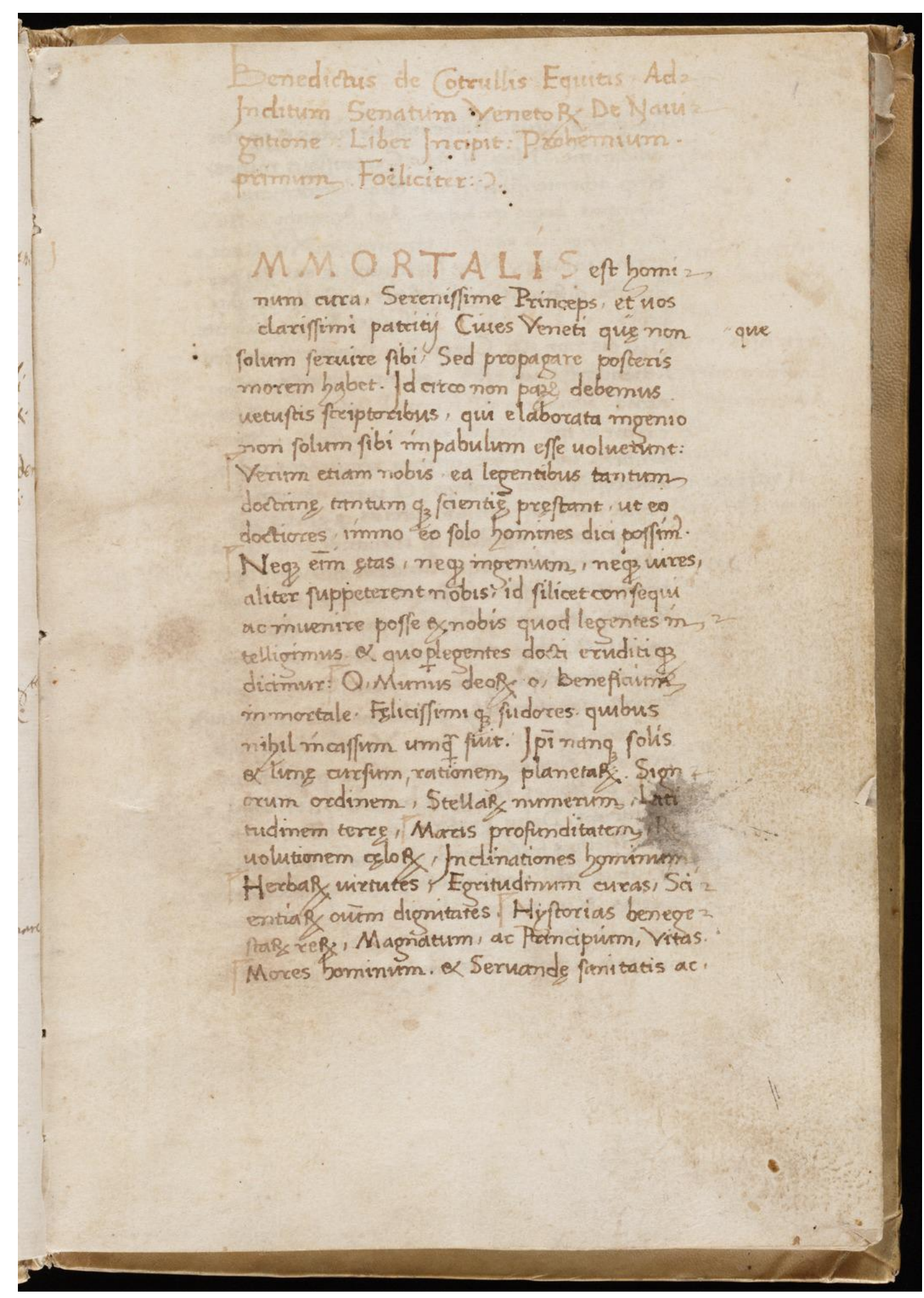

Slika 2. Lice (recto) 1. lista prvopronađene rukopisne inačice prijepisa Kotruljevićeva spisa De navigatione. Na tom listu počinje predgovor, a u kojem je Kotruljević najavio da će spis prožeti filozofskim temama, posebice onima koje pripadaju području filozofije prirode.

Preuzeto iz primjerka koji se čuva u Beinecke Rare Book and Manuscript Library u Yale University Library pod signaturom MS 557. 


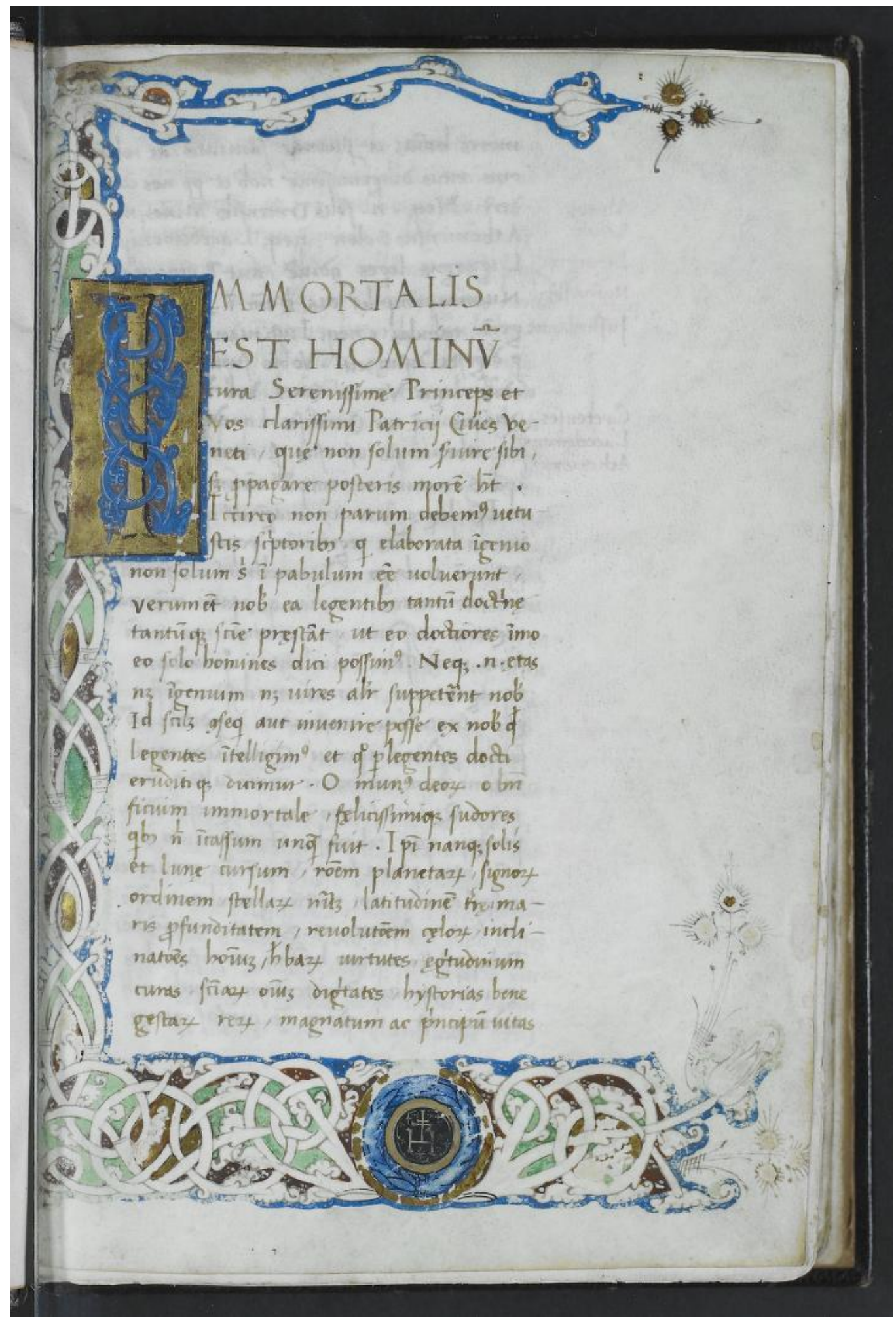

Slika 3. Lice (recto) 1. lista drugopronađene rukopisne inačice prijepisa Kotruljevićeva spisa De navigatione. Na tom listu počinje predgovor, a u kojem je Kotruljević najavio da će spis prožeti filozofskim temama, posebice onima koje pripadaju području filozofije prirode.

Preuzeto iz primjerka koji se čuva u zbirci Lawrence J. Schoenberg Collection pod signaturom MS ljs 473. 
u njoj Kotruljević prikazao krug »prirodnih pojava koje obrađuje Aristotelova Meteorologika« te da se pritom izričito pozivao na »Aristotelove prirodnofilozofske spise i Senekine Quaestiones naturales, a osobito rado i najčešće na prvi latinski komentar Aristotelove Meteorologike iz pera Alberta Velikog. « ${ }^{512} \mathrm{U}$ radu iz 2007. godine Martinović je ustvrdio da Kotruljeviću zbog De navigatione pripada istaknuto mjesto u »povijesti oceanografije, brodogradnje, navigacije, astronomije i meteorologije $\ll{ }^{513}$ Kao sljedeću od filozofskih prosudaba koje se odnose na taj spis, izdvajam onu iz 2010. godine koju je iznio Davor Balić, zaključivši da je Kotruljević u De navigatione bio izvrsno upućen u sadržaj prirodoznanstvenih spisa Platona, Aristotela, Seneke, Plinija Starijeg i Alberta Velikog. ${ }^{514}$ Posljednju prosudbu filozofskog sadržaja spisa o plovidbi također potpisuje Balić. On se, naime, u svojem izlaganju na znanstvenom skupu iz 2011. godine bavio istraživanjem izvorā Kotruljevićeve filozofije prirode, razvrstavši ih pritom u tri kategorije: 1) izvori kojima se Dubrovčanin služio neposredno, primjerice Ptolemej, Vergilije, Albert Veliki »koji je i najčešći izvor treće knjige spisa«, te Antonio Panormita; 2) izvori kojima se služio posredno, primjerice Anaksimandar, Heraklit, Empedoklo, Aristotel, Platon, Teofrast i Seneka; 3) izvori kojima se ponekad služio neposredno, a ponekad posredno, primjerice Izidor iz Sevilje. ${ }^{515}$ Dakle, za dosadašnja istraživanja filozofske sastavnice De navigatione moguće je zaključiti da su malobrojna te da su uglavnom polučila opće zaključke o prirodnofilozofskoj orijentaciji treće knjige spisa, te o filozofima i filozofskim izvorima u čitavu spisu. Međutim, ti zaključci nisu popraćeni detaljnom analizom sadržaja i konkretnim primjerima iz četiriju knjiga $D e$ navigatione.

Zbog toga smatram da bi sadržaj Kotruljevićeva spisa o plovidbi trebalo razmotriti iz perspektive Kotruljevićeva oslanjanja na nauke filozofā i izvore iz kojih je te nauke doznavao, potom istražiti prisutnost filozofije prirode u svim četirima knjigama, te, u konačnici, ispitati je li se Kotruljević u spisu bavio problematikom koja spada u još neku od filozofskih disciplina. Time ću se baviti u trima potpoglavljima koja slijede. Prvo potpoglavlje posvetit ću

\footnotetext{
512 Ivica Martinović, »Žanrovi hrvatske filozofske baštine od 15. do 18. stoljeća«, u: Pavo Barišić (ur.), Otvorena pitanja povijesti hrvatske filozofije (Zagreb: Institut za filozofiju, 2000), pp. 69-151, na pp. 73-74; Ivica Martinović, Žanrovi hrvatske filozofske baštine od 15. do 18. stoljeća (Split: Filozofski fakultet Sveučilišta u Splitu, 2011), pp. 16-17.

513 Ivica Martinović, »Benedikt Kotruljević«, u: Neven Budak (osmislio i uredio), Croatica: HR - Hrvatski udio u svjetskoj baštini, [sv. 1] (Zagreb: Profil international, 2007), pp. 170-175, na p. 171.

514 Davor Balić, »Vrste plovilā u Kotruljevićevu udžbeniku plovidbe«, Metodički ogledi: časopis za filozofiju odgoja 17/1-2 (2010), pp. 61-86, na p. 82.

515 Davor Balić, »Izvori Kotruljevićeve filozofije prirode u De navigatione (1464)«, u: Marita Brčić, Mira Matijević, Krešimir Babel (ur.), Simpozij Mediteranski korijeni filozofije 5. Split, 24.-26. ožujka 2011 (Zagreb - Split: Hrvatsko filozofsko društvo / Odsjek za filozofiju Filozofskog fakulteta Sveučilišta u Splitu, 2011), p. 21.
} 
odgovoru na pitanje je li se Kotruljević u De navigatione, baš kao u spisu o umijeću trgovanja, iskazao kao poznavalac povijesti filozofije, zatim ću u drugom potpoglavlju pružiti spoznaje o prirodnofilozofskom usmjerenju spisa, a u trećem ću otkriti da je Kotruljević svoja promišljanja o plovidbi protkao i etičkim temama.

\subsection{Benedikt Kotruljević kao poznavalac povijesti filozofije}

Baš kao što je to činio unutar svojih promišljanja o trgovanju, dubrovački se renesansni mislilac i prilikom razmatranja o plovidbi nerijetko služio spoznajama iz povijesti filozofije. Štoviše, povijest filozofije bila je ishodište, temelj i oslonac njegovih umovanja o plovidbi. No, za razliku od slučaja spisa o umijeću trgovanja, danas ne raspolažemo nijednim detaljnim istraživanjem koje bi ukazivalo na prisutnost pojedinih filozofa $\mathrm{i}$ filozofskih izvora $\mathrm{u}$ Kotruljevićevu spisu o plovidbi. Da se Kotruljević u raspravi o plovidbi iskazao kao poznavalac povijesti filozofije, potvrđuje sadržaj čitava spisa De navigatione. Budući da su primjeri kojima bih mogao potkrijepiti taj stav brojni, ovom prilikom izdvojit ću tek primjere iz poglavlja u kojem je, prema mojoj procjeni, njegovo poznavanje povijesti filozofije bilo najizraženije. Riječ je o prvom poglavlju prve knjige spisa De navigatione. Prilikom odabira poglavlja vodio sam se sljedećim dvama razlozima: 1) sadržaj tog poglavlja najbolje oslikava Kotruljevićevu upućenost u povijesnofilozofsku problematiku; 2) u tom poglavlju Kotruljević je povijesnofilozofske spoznaje izlagao kronološkim redoslijedom, dakle vodeći računa o razvoju filozofske misli tijekom povijesti.

Poglavlje kojim je Kotruljević otpočeo prvu knjigu spisa De navigatione naslovljeno je »Općenito o vodama« (»De acque in genere«). Nakon što je priopćio da mu je u spisu nakana raspravljati o umijeću plovidbe (tractare dell'arte del navigare), točnije o pomorskom umijeću koje je toliko dostojno da se istinskog i dobrog mornara može nazvati vitezom, Kotruljević je naglasio da tome mora prethoditi razumijevanje temeljnih postavki o vodama. ${ }^{516}$ Kada je iznosio općenite podatke o vodama, dubrovački se mislilac redovito oslanjao na spoznaje koje su izrekli dotadašnji filozofi. Najprije se oslanjao na učenja koja su zagovarali predsokratovci, zatim na učenja koja su zagovarali Sokrat, Platon i Aristotel, te,

\footnotetext{
${ }^{516}$ Cotrullis, »De navigatione«, libro I, capitulo $1 /$ Kotruljević, »O plovidbi«, knjiga I, poglavlje 1, p. 22: $»<\mathrm{H}>$ avendo mo ad tractare dell'arte del navigare, la quale è maritima e tanto digna che meritamente lo vero et bon marinaro se pò chiamare cavaliere, ello è necessario intendere alcuni fundamenti delle acque«. / p. 23 : »Budući da sada kanimo raspraviti o umijeću plovidbe, a riječ je o pomorskoj i toliko dostojnoj vještini da se istinskoga i dobroga mornara s punim pravom može nazvati vitezom, potrebno je shvatiti neke temeljne postavke o vodama, $<\ldots>\ll$.
} 
naposljetku, na učenja koja su zastupali brojni srednjovjekovni mislioci. Uvidom u kolikoću spoznaja kojima je Kotruljević raspolagao i izložio u prvom poglavlju prve knjige, smatram da je za utvrđivanje njegove upućenosti u povijest filozofije dostatno izdvojiti zapise iz tog poglavlja.

Dubrovački renesansni mislilac najprije se usmjerio na spoznaje koje su o vodi kao elementu i vodama općenito iznijeli antički grčki filozofi koje je među povjesničarima filozofije, a zbog toga što su živjeli, djelovali i stvarali prije znamenitog grčkog filozofa Sokrata, uvriježeno oslovljavati skupnim imenom predsokratovci. Od filozofā koje ubrajamo među predsokratovce Kotruljević je imenovao sljedeću šestoricu: Tal $(\Theta \alpha \lambda \tilde{\eta} \varsigma$, oko 624. pr. n. e. -

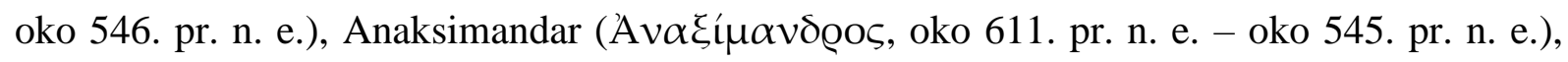

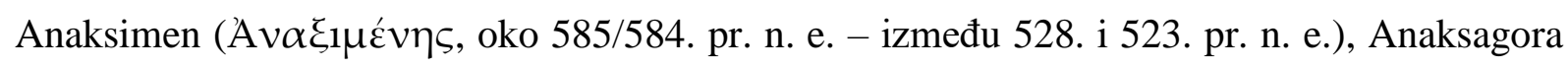

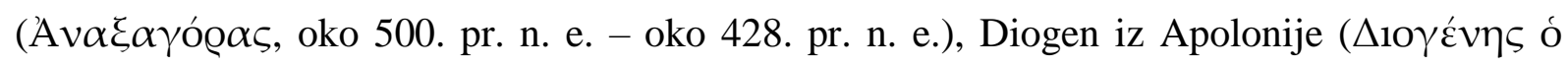

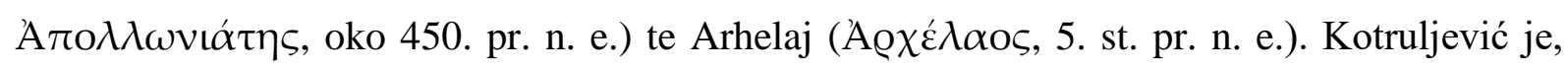
baš kao što je to činio u glavnini spisa o umijeću trgovanja prilikom oslanjanja na nauke filozofā, spoznaje o obilježjima njihovih nauka crpio iz sekundarnih izvora, dakle doznavao ih je posredno. Pritom nije propustio navesti imena autorā djelā koja su mu poslužila kao vrela njegovih saznanja. Tako doznajemo da je spoznaje temeljio na djelima koja su napisali

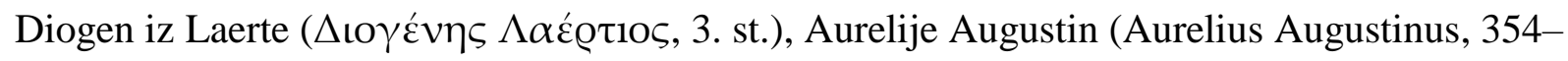
430) i Lucije Cecilije Laktancije Firmijan (Lucius Caecilius Lactantius Firmianus, 3.-4. st.). ${ }^{517}$

Kotruljević je, očekivano, najprije izložio znanja kojima je raspolagao o grčkom filozofu Talu i njegovu nauku. Valja naglasiti i to da je, također očekivano s obzirom na tematiku koja se odnosi na vodu, od šestorice imenovanih predsokratovaca Talu i njegovu nauku posvetio najviše pažnje. Temeljeći ih, kako sam prethodno naveo, na spoznajama trojice spomenutih mislilaca, Kotruljević je iznio podatke da je Tal: 1. Milećanin, Azijac, građanin Mileta, glava jonskih filozofa i jedan od sedmorice mudraca; 2. otkrivač astrologije, Velikog Medvjeda i veličine Sunca i Mjeseca; 3. otkrivač godišnjih doba; 4. prvi koji je raspravljao o prirodi te smjestio dušu u živa bića i tvrdio da je duša besmrtna; 5. dobio zlatni stolić koji su pronašli ribari prema savjetu delfskog Apolona koji je objavio da ga se uruči najmudrijem čovjeku; 6 .

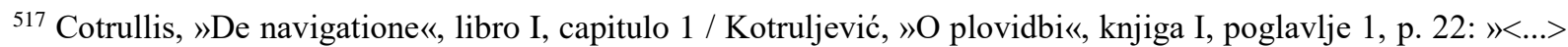
como scrive Agustino, [...] et etiam Dyogene Laertio, Lactantio Firmiano et multi excellenti scripturi, $<\ldots>\ll$. / pp. 23-25: »<...> kako piše Augustin [...] a isto tako i Diogen Laerćanin, Laktancije Firmijan i mnogi izvrsni pisci, $<\ldots>\ll$.
} 
da je živio u vrijeme Ahaza, kralja Judeje; 7. živio kreposno da bi si stvorio sljedbenike, pa je postao vrijedan divljenja ispitujući prirodu i zapisujući svoja istraživanja; 8. smatrao da je voda počélo stvari i da iz nje nastaju svi sastavni dijelovi svijeta i cjelokupan svijet; 9. da je bio onaj koji nijednu divnu stvar koju vidimo na svijetu nije pripisao Bogu. ${ }^{518}$

Kotruljević je svoje spoznaje o predsokratovcu Talu doista mogao doznati iz djelā koja su napisali Diogen iz Laerte, Augustin i Laktancije. Uz to, iz Dubrovčaninovih se zapisa može zaključiti da je znanja prikupljena iz djelā te trojice mislilaca sažeo i objedinio. Tako je, a što je i napomenuo, brojne podatke o Talu doznao iz osme knjige Augustinova djela De civitate Dei ( $O$ državi Božjoj). Doznao je, primjerice, to da je Tal porijeklom iz Mileta, nakon toga da je bio prvak jonske filozofije, zatim da je bio jedan od sedmorice mudraca koji se, za razliku od preostale šestorice koji su se odlikovali načinom života i bavili napucima za dobar život, predao istraživanju naravi stvari, zapisao svoja otkrića i stekao slavu, potom da je najdivnije bilo to što je na temelju astroloških izračuna uspješno proricao pomrčinu Sunca i Mjeseca, kao i to da je smatrao da je voda počélo stvari i da iz nje nastaju preostala počéla, cjelokupan svijet i sve u njemu, te, naposljetku, i to da cijelom svijetu nije pretpostavio nikakav božanski um. ${ }^{519}$ Iako izrijekom nije spomenuo naslov njegova djela, Kotruljević je podatke o Talu crpio

${ }^{518}$ Cotrullis, »De navigatione«, libro I, capitulo 1 / Kotruljević, »O plovidbi«, knjiga I, poglavlje 1, pp. 22-24: »Tales Milesius, Asiano, citadino de Mileto, como scrive Agustino, VIII De civitate Dei, et etiam Dyogene Laertio, Lactantio Firmiano et multi excellenti scripturi, fu principe de philosophi ionici et fo uno de quilli septe che forno chiamati sapienti, trovator d'astrologia et de l'Ursa Maiure et della grandecza del Sole et della Luna et trovò li tempi de l'anno et primo dispotò della natura et nelle cose animate misse la anima et dixe la anima esser inmortale. Allo quale fo data la tabula d'oro trovata dalli piscatori per consiglio de Apollo Delphico el quale revelò che al più savio sia data; et fo nel tempo de Achaç, re de Iudea. Et perché gli altri visseno attendendo allo vivere virtuoso, et questo Thales, per propagar succissori, scrutando la natura delle cose, comendando le sue desputationi alle lettere fo multo admirabile. Ma el extimò l'acqua esser principio delle cose et da $\cdot$ llei [prema Falchettinu transkriptu iz 2009. godine treba stajati: »dal lei «] prociedere tucti gli eliminti del mundo et esso / mundo. Niente delle cose mirabile che videmo in quisto mundo atribuì a dio. «/ pp. 23-25.

${ }^{519}$ Aurelius Augustinus, »De civitate Dei contra paganos«, liber VIII, caput 2, u: Patrologiae cursus completus, accurante J[acques].-P.[aul] Migne. Patrologiae Latinae. Tomus XLI. S.[anctus] Aurelius Augustinus. [Opera omnia, post Lovaniensium theologorum recensionem. Tomus septimus] (Parisiis: Apud Garnier fratres editores, et J.[acques]-P.[aul] Migne, successores, 1900), cc. 13-804, na cc. 225-226: »Ionici vero generis princeps fuit Thales Milesius, unus illorum septem qui appellati sunt Sapientes. Sed illi sex vitae genere distinguebantur, et quibusdam praeceptis ad bene vivendum accommodatis: iste autem Thales, ut successores etiam propagaret, rerum naturam scrutatus suasque disputationes litteris mandans eminuit; maximeque admirabilis exstitit, quod astrologiae numeris comprehensis, defectus solis et lunae etiam praedicere potuit. Aquam tamen putavit rerum esse principium, et hinc omnia elementa mundi ipsumque mundum, et quae in eo gignuntur, existere. Nihil autem huic operi, quod mundo considerato tam admirabile aspicimus, ex divina mente praeposuit.« Usp. [Aurelius Augustinus], »De civitate Dei«, VIII, 2, / [Aurelije Augustin], »O državi Božjoj«, VIII, 2, u: Aurelije Augustin, $O$ državi Božjoj / De civitate Dei, svezak prvi (knjiga I-X), latinski i hrvatski tekst, s latinskog izvornika preveo Tomislav Ladan, uvod napisali Agostino Trapè, Robert Russell, Sergio Cotta (Zagreb: Kršćanska sadašnjost, 1982), pp. 540-612, na pp. 542-544 / pp. 541-613, na pp. 543545: »Jonskoj vrsti filozofije prvakom bijaše Tales iz Mileta, jedan od onih što su nazivani Sedam mudraca. Šestorica ostalih odlikovali su se svojim načinom života i stanovitim naputcima prikladnima za dobar život; Tales je dočim - kako bi ostavio i sljedbenike iza sebe - istraživao narav stvari te zapisao svoja otkrića i time se proslavio, a najdivnije mu postignuće bijaše što je, upoznavši račun zvjezdoznanstva, uspijevao proricati 
i iz djela Diogena iz Laerte naslovljenog De vita et moribus philosophorum (Životi i mišljenja istaknutih filozofa). Budući da je iz tog doksografsko-biografskog djela mogao doznati obilje podataka o Talu, ovom prilikom izdvojit ću samo one podatke koji se razlikuju od onih koje je mogao doznati od Augustina, a koje je Dubrovčanin uvrstio u spis o plovidbi. Kotruljević je od Diogena iz Laerte mogao preuzeti podatak o tome da je Tal otkrio sazviježđe Malog, a ne Velikog Medvjeda, zatim da je prvi proučavao astrologiju, potom da je izjavio da su duše besmrtne, nakon toga to da je prvi utvrdio veličinu Sunca i Mjeseca, kao i to da je uspostavio godišnja doba te da mu je kao najmudrijem uručen tronožac koji su pronašli ribari, kako je nalagalo delfsko proročanstvo. ${ }^{520}$ Kada je preuzimao podatke o Talu od Laktancija Firmijana, Kotruljević je također propustio spomenuti naslov njegova djela. Međutim, sudeći prema sadržaju Dubrovčaninovih zapisa, podatke o Talu mogao je doznati iz petog poglavlja prve knjige djela tog kršćanskog mislioca pod naslovom Institutiones divinae (Božanske ustanove). Budući da je Laktancijevo očitovanje, pogotovo u usporedbi s Augustinovim i Diogenovim, škrto podacima, ovom ga prilikom prenosim u cijelosti. Pišući o svjedočanstvima znamenitih pjesnika i filozofa, Laktancije je za Tala zapisao sljedeće: da je bio jedan od sedmorice mudraca; da je bio prvi istraživač prirodnih uzroka; da je rekao da je voda element iz kojeg

pomrčinu Sunca i Mjeseca. Smatrao je, međutim, kako je voda pratvar stvari te da iz nje nastaju sva počela svijeta, sam svijet i sve što se u njemu rađa. $\mathrm{Nu}$, cijelome tomu djelu (svijetu, što nam se čini toliko divnim kad ga promatramo) nije pretpostavio nikakav božanski um.«

${ }^{520}$ Diogenes Laertius, De vita et moribus philosophorum. Libri X. (Lugduni: Apud Seb.[astian] Gryphium, 1546), liber primus., pp. 9-63, s. v. »Thales Milesius.«, pp. 17-26, na pp. 17-19: »Callimachus [Thales] inventorem fuisse minoris ursae, ac notasse illius stellas tradit, qua Phoenices navigant, [...] Putant plerique primum astrologiae secreta rimatum, solis defectus conversionesque praedixisse, [...] Sunt qui illum immortales animos primum dixisse asseverent, ex quibus est Choerilus poeta. Primus et solis cursum a conversione in conversionem reperit. Solisque magnitudini lunarem orbem comparatum, septingentesimam et vicesimam ilius partem esse, primus, ut quibusdam placet, dixit. [...] Principium omnium aquam esse dixit, et animatum mundum ac daemonibus plenum. Anni tempora, illorumque vicissitudines primum invenisse ferunt, [...] Quae vero de tripode a piscatoribus invento, sapientibusque a plebe Milesiorum dedicato, memorantur, manifesta sunt. Aiunt enim Ionicos adolescentes quosdam a piscatoribus Milesiis iactum retis emisse, capto deinde et educto tripode, orta contentio, non ante sedata est, quam Delphos a Milesiis missum, responsumque a deo est: [...] De tripode ex Phoebo quaris Milesia proles, / Huic tripodem addico cui fit sapientia prima. Datur ergo Thaleti, Thalesque illum alii dat, et rursus alius alii, donec ad Solonem ventum est.« Usp. Diogen Laertije, Životi $i$ mišljenja istaknutih filozofa, sa starogrčkog preveo Albin Vilhar. Predgovor napisao Branko Bošnjak (Beograd: Beogradsko izdavačko-grafički zavod, 1973), knjiga I, pp. 141, glava 1. - Tales, pp. 7-14, na pp. 7-8: »Kalimah za njega [Talesa] zna da je otkrio sazvežđe Malog Medveda, [...] Izgleda da je, prema nekim autorima, prvi proučavao astrologiju, da je prvi predskazao Sunčeva pomračenja i utvrdio ravnodnevice. [...] Neki, [...] pričaju da je on izjavio da su duše besmrtne. On je bio takođe prvi koji je utvrdio kretanje Sunca od solsticija do solsticija, i, prema tvrđenju nekih autora, on je prvi utvrdio veličinu Sunca (Sunčevog kruga), kao i veličinu Meseca (da iznosi sedamsto dvadeseti deo Sunčevog kruga). [...] Tales je za princip svega uzeo vodu i učio je da je svet živ i pun božanstava (demona). Priča se da je ustanovio godišnja doba [...] Dobro poznata priča o tronošcu koji su pronašli ribari, a koji su Milećani namenili mudracima, glasi ovako: 'Priča se da su neki jonski mladići od milećanskih ribara kupili njihov ulov. Pošto je zajedno s lovinom bio izvučen i tronožac, nastala je prepirka. Naposletku Milećani poslaše tronožac u Delfe, a bog je dao ovakvo proročanstvo (Anthol. Plan., VI, 51): Potomče Mileta, pitaš Feba za tronožac? / Odgovaram: - Ko je prvi u mudrosti, njegov je tronožac. I tako ga predadoše Talesu, ovaj ga preda drugome, ovaj, opet, drugome, dok ne dođe do Solona.' " 
sve nastaje; da je Bog bio um koji je sve stvari oblikovao iz vode, znači da je kao počélo svih stvari odredio vlagu te da je početak i uzrok njezina nastanka povjerio Bogu. ${ }^{521}$

Dakle, vrela Kotruljevićevih saznanja o predsokratovcu Talu bila su djela trojice mislilaca: Augustina, Diogena iz Laerte i Laktancija. Kotruljević je njihove zapise probrao, sažeo i objedinio. Međutim, kada je iznosio svoje spoznaje o Talu, Dubrovčanin je ponudio i podatke koje je pogrešno preuzeo iz djelā trojice spomenutih mislilaca, ali i podatke koji ne postoje u njihovim djelima. Kotruljević je, primjerice, pogrešno preuzeo podatak od Diogena iz Laerte da je Tal otkrio sazviježđe Malog Medvjeda, zapisavši da je Tal otkrio sazviježde Velikog Medvjeda, zatim je, također primjerice, iznio pogrešno tumačenje Augustinove tvrdnje da se Tal bavio istraživanjem naravi stvari za razliku od preostale šestorice mudraca koji su se bavili kreposnim životom, ponudivši podatak da se Tal bavio kreposnim životom, a stjecao sljedbenike na temelju ispitivanja naravi stvari. Podatak koji nije mogao pronaći u djelima te trojice mislilaca zasigurno je onaj koji se odnosi na to da je Tal živio u vrijeme kralja Ahaza. Naime, a što je zamijetio i u bilješci napomenuo Salopek, vladavina judejskog kralja Ahaza uglavnom se smješta u drugu polovicu 8. stoljeća pr. n. e., dok je, podsjećam, Tal živio od oko 624. pr. n. e. do oko 546. pr. n. e. ${ }^{522}$

Važno je napomenuti da se, sudeći prema kolikoći podataka koje je od njega preuzeo, Kotruljević uvelike pouzdao u podatke koje je u djelu Životi i mišljenja istaknutih filozofa ponudio znameniti doksograf i biograf Diogen iz Laerte. No, valja obratiti pažnju i na to da podatak o tome da Tal nijednu divnu stvar na svijetu nije pripisao Bogu ili božanskom umu nije mogao doznati od Diogena. Prilikom navođenja tog podatka nesumnjivo se priklonio Augustinovu zaključku, budući da Diogen nije posvetio nijedan redak toj tematici, dok je Laktancije tvrdio da je Tal Bogu dodijelio ulogu uma koji je oblikovao čitav svijet iz vode.

Kada je riječ o Kotruljevićevim spoznajama o preostaloj petorici predsokratovaca i njihovim naucima, one uvelike zaostaju za spoznajama o Talu, bilo po kolikoći bilo po kakvoći. Iako je i toj petorici posvetio određenu pozornost, Dubrovčanin nije krio namjeru da zapostavi njihove nauke, a zbog toga što su, u usporedbi s Talom, različito razumijevali i prosuđivali

${ }^{521}$ Lucius Caecilius Firmianus Lactantius, »Divinarum institutionum«, liber I, caput 5, u: Patrologiae cursus completus, accurante J[acques].-P.[aul] Migne. Patrologiae Latinae. Tomus VI. Lucii Caecilii Firmiani Lactantii. [Opera omnia, post Lovaniensium theologorum recensionem. Tomus primus] (Parisiis: Excudebat Sirou, 1844), cc. 111-822, na cc. 133-134: »Thales Milesius, qui unus e septem sapientium numero fuit, quique primus omnium quaesisse de causis naturalibus traditur, aquam esse dixit, ex qua nata sint omnia; Deum autem esse mentem, quae ex aqua cuncta formaverit. Ita materiam rerum posuit in humore; principium causamque nascendi constituit in Deo.«

${ }^{522}$ Cotrullis, »De navigatione«, libro I, capitulo 1 / Kotruljević, »O plovidbi«, knjiga I, poglavlje 1, p. 24 / p. 25 , bilješka 7: »Kotruljevićevo datiranje razlikuje se od općeprihvaćenoga koje Ahazovu vladavinu smješta u drugu polovicu 8. st. pr. Kr., a Talovo djelovanje na prijelaz 7. u 6. st. pr. Kr.« 
počélā stvari. ${ }^{523}$ Za Anaksimandra je zapisao tek podatak da je bio Talov slušalac, zatim za Anaksimena tek to da je bio Anaksimandrov učenik i da je počélo svih stvari smjestio u zrak, potom za Anaksagoru i Diogena da su bili Anaksimenovi slušatelji te da je Diogen iz Apolonije rekao da je zrak građa stvari, dok je za Arhelaja zapisao tek to da je naslijedio Diogenov nauk i da mu je Sokrat bio učenik. ${ }^{524}$ Iz sadržaja njegovih zapisa o tim misliocima, a pogotovo zbog toga što Diogen iz Laerte nije pisao o predsokratovcu Diogenu iz Apolonije, dok je Laktancije odlučio izostaviti podatke o Anaksimandru, Diogenu iz Apolonije i Arhelaju, može se zaključiti da je Kotruljević svoje spoznaje o tim misliocima u potpunosti temeljio na Augustinovu djelu $O$ državi Božjoj. Augustin je, naime, u drugom poglavlju osme knjige tog djela zabilježio istovjetne podatke onima koje je Dubrovčanin odlučio sažeti i prenijeti u spis o plovidbi. ${ }^{525}$

Prvo poglavlje prve knjige spisa o plovidbi pruža uvid i u razmjere Kotruljevićevih spoznaja o

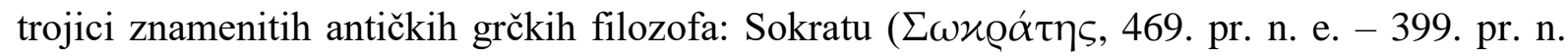

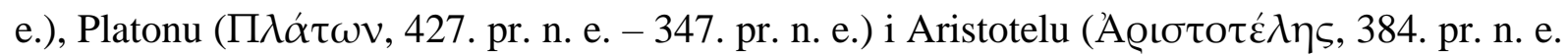
- 322. pr. n. e.). Prilikom očitovanja o njima i njihovim naucima, dubrovački mislilac nije imenovao svoje izvore.

Kada je riječ o Sokratu i Platonu, Kotruljević im nije posvetio veliku pozornost, a najvjerojatnije zbog toga što njihovim naucima nije pridavao veliki značaj u kontekstu govora o počélima stvari. Štoviše, toj dvojici znamenitih Grka namijenio je jednako malo prostora kao i predsokratovcima Anaksimandru, Anaksimenu, Anaksagori, Diogenu iz Apolonije i Arhelaju, znači uvrstio ih je u skupinu onih filozofa čija je mišljenja, podsjećam, zanemario zbog toga što su različito shvaćali počélā stvari. Zato je o njima odlučio iznijeti samo dva

${ }^{523}$ Cotrullis, »De navigatione«, libro I, capitulo 1 / Kotruljević, »O plovidbi«, knjiga I, poglavlje 1, p. 24: »Et per lassar delli altri philosophi multe oppinioni [...] li quali variamente intendevano et iudicavano delli principii delle cose, $\langle\ldots\rangle$ «. / p. 25: »Ostavljajući po strani mnoga mišljenja drugih filozofa [...] koji su svi različito shvaćali i prosuđivali počela stvari, $<$... $>$.

${ }^{524}$ Ibid., p. 24: $»<\ldots>$ de Aximandro, auditor del dicto Tales, et successive de Aximene, suo discipulo lo qual decte lu principio de tucte le cose allo aere, et Anaçagora, suo auditore, et Dyogene, auditore anche de Aximene, che dixe lu aere essere materia delle cose, et allo dicto succiese lo auditor suo Archelao, de cui discipulo fo Socrate $<\ldots>$ «. / p. 25.

${ }^{525}$ Augustinus, »De civitate Dei contra paganos«, liber VIII, caput 2, c. 226: »Huic [Thales Milesius] successit Anaximander, ejus auditor [...] Iste Anaximenem discipulom et successorem reliquit: qui omnes rerum causas infinito aeri dedit [...] Anaxagoras vero, ejus auditor [...] Diogenes quoque, Anaximenis alter auditor, aerem quidem dixit rerum esse materiam, [...] Anaxagorae successit auditor ejus Archelaus [...] Socrates hujus discipulus fuisse perhibetur, <... «. Usp. [Augustinus], »De civitate Dei«, VIII, 2, p. 544 / [Augustin], »O državi Božjoj«, VIII, 2, p. 545: »Njega [Talesa] je naslijedio Anaksimandar, njegov učenik [...] Njegov učenik i sljedbenik je Anaksimen, koji je uzroke svih stvari pripisao zraku; [...] Njegov pak učenik Anaksagora [...] Diogen, koji bijaše drugi učenik Anaksimena, reče kako je zrak pratvar iz koje nastaju sve stvari; [...] Anaksagoru je naslijedio njegov učenik Arhelaj. [...] Kažu kako Sokrat bijaše učenik Arhelaja; $<\ldots>\ll$. 
podatka. Naime, Kotruljević je najprije, a na što sam već ukazao ranije, Sokrata spomenuo kao Arhelajeva učenika. Tome je u nastavku rečenice dodao samo podatak da je Platon bio Sokratov učenik. ${ }^{526}$ Doduše, bilo bi preuzetno zaključiti da je Dubrovčanin tim postupkom nastojao omalovažiti značenje naukā te dvojice filozofa za povijest filozofije, ali se sa sigurnošću može tvrditi da mu njihovi nauci nisu bili presudni za izlaganje o tematici koja se odnosi na vodu.

Kotruljevićeve spoznaje i očitovanja o Aristotelu u potpunosti se razlikuju od njegovih očitovanja o predsokratovcima te o Sokratu i Platonu. Naime, o Stagiraninu nije priopćio nijedan podatak biografske naravi, niti je ponudio podatak o njegovoj povezanosti s bilo kojim od značajnih prethodnika, makar i onaj najopćenitiji, poput, primjerice, onoga da je bio Platonov učenik. Naprotiv, dubrovački je mislilac navodio Aristotelova djela kao neposredne izvore svojih spoznaja o vodi. Znači, Kotruljević je Aristotela i njegov nauk ocijenio važnim i nezaobilaznim u okviru rasprave o tematici vode, a svoju je upoznatost s likom i djelom tog grčkog filozofa iskazivao u obliku pozivanja na sadržaj njegovih djela. Potvrdu te tvrdnje pruža i podatak o tome da je dubrovački mislilac u prvom poglavlju prve knjige u jednom navratu Aristotela oslovio i samo »filozofom« (»lu philosophu«). Uz to, Kotruljević je u prvom poglavlju prve knjige izrijekom naveo da su mu kao izvori poslužila sljedeća četiri Aristotelova djela: De caelo et mundo (O nebu i svijetu), Physica (Fizika), Metaphysica (Metafizika) i De generatione et corruptione (O rađanju i nestajanju). Navedeni redoslijed Aristotelovih djela odgovara redoslijedu Kotruljevićevih navođenja, kao i kolikoći pozivanja na njihov sadržaj. U prvom poglavlju prve knjige Kotruljević se na sadržaj djela $O$ nebu $i$ svijetu pozvao pet puta, na sadržaj Fizike dvaput, dok se na sadržaj Metafizike te $O$ rađanju $i$ nestajanju oslonio tek jedanput. Međutim, nakon analize latinskih citata i talijanskih parafraza tvrdnji koje je Kotruljević pripisao Aristotelu, nameću se dva pitanja: tko je bio izvor Dubrovčaninovih spoznaja o sadržaju Stagiraninovih djela i je li na to pitanje moguće ponuditi odgovor koji bi bio jednoznačan i konačan?

Pokušaj jednoznačna i konačnog odgovora na ta pitanja ponudio je Damir Salopek dok je priređivao kritičko izdanje prijepisa i prijevoda spisa o plovidbi iz 2005. godine. Naime, u jednom slučaju Kotruljevićeva citata na latinskom jeziku koji navodno potječe iz Aristotelove Metafizike, Salopek je pokušao utvrditi na kojoj je inačici prijevoda Aristotelova djela Kotruljević temeljio taj citat. Riječ je o citatu za koji je Kotruljević priopćio da se nalazi u jednom od starih prijevoda Metafizike: »quia sic disposuit deus gloriosus et sublimis« / »jer je

${ }^{526}$ Cotrullis, »De navigatione«, libro I, capitulo 1 / Kotruljević, »O plovidbi«, knjiga I, poglavlje 1, p. 24: »<...> lo auditor suo Archelao, de cui discipulo fo Socrate che lassò Platone, suo auditore, $<\ldots . .<. /$ p. 25. 
tako uredio slavni i uzvišeni bog. « ${ }^{527}$ Salopek je pritom zaključio da je Kotruljević taj podatak doznao iz djela De sphaera ( $O$ sferi / O Zemlji), koje je napisao srednjovjekovni mislilac, svećenik i astronom Ivan iz Holywooda (Johannes de Sacrobosco, oko 1195-oko 1256). No, pouzdanost i valjanost tog Salopekova zaključka lakoćom se može osporiti. Prije svega, uvjeren sam da Kotruljević prilikom pisanja spisa nije navodio autore i sadržaj njihovih djela po sjećanju, već da se služio postojećim rukopisnim ili tada već tiskanim tekstualnim predlošcima njihovih djela ili komentarima njihovih djela. Zbog toga bi nemalo čudilo da sadržaj Dubrovčaninova zapisa, izuzev zanemarivih jezičnih lapsusa, u velikoj mjeri odstupa od tih predložaka. To se, nažalost, ne može reći o izvoru za koji se Salopek opredijelio da je bio vrelo Kotruljevićeva citata Aristotelova djela. Najprije podsjećam na to da je Kotruljević zapisao da mu je izvor bio neki od starih prijevoda Stagiraninove Metafizike, dok u djelu $O$

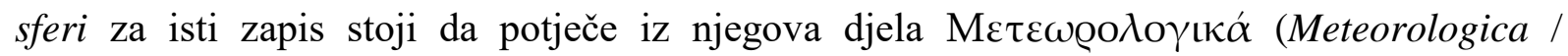
Meteora). ${ }^{528}$ Zatim napominjem da se Kotruljevićev zapis tek djelomično podudara sa zapisom iz djela $O$ sferi, jer on u inačici koju nudi Ivan iz Holywooda glasi: »Sic enim ea disposuit Deus gloriosus et sublimis. ${ }^{529} \mathrm{Uz}$ to, uvidom u djela suvremenikā Ivana iz Holywooda, zaključio sam da taj citat nije nešto što je Kotruljević mogao pronaći isključivo u djelu $O$ sferi. Služeći se jednakim kriterijima podudarnosti navoda, Salopek je tako mogao donijeti zaključak da se Kotruljević poslužio, primjerice, djelom francuskog filozofa, teologa i pisca političkih djela Ivana iz Janduna (Jean de Jandun / Johannes von Jandun / Johannes de Janduno, oko 1285-1328). Naime, u njegovu komentaru Aristotelova djela O nebu i svijetu nalazi se rečenica koju je, doduše, pripisao Albertu Velikom i koja glasi ovako: »sic ordinavit

527 Cotrullis, »De navigatione«, libro I, capitulo 1 / Kotruljević, »O plovidbi«, knjiga I, poglavlje 1, p. 28: »Et questo è anchi auctorità de Aristotile nel principio della Metaphisica et secunda la antiqua translatione dicie: quia sic disposuit deus gloriosus et sublimis.«/ p. 29: »Svojim autoritetom potvrđuje to i Aristotel na početku Metafizike, koji prema jednom starom prijevodu kaže: 'jer je tako uredio slavni i uzvišeni bog.' "

528 Johannes de Sacrobosco, »Tractatus de spera«, u: Lynn Thorndike, The Sphere of Sacrobosco and Its Commentators (Chicago: The University of Chicago Press, 1949), pp. 76-117, na p. 78: »<..> ut ait Aristoteles in libro Metheororum.«

529 Cotrullis, »De navigatione«, libro I, capitulo $1 /$ Kotruljević, $» O$ plovidbi«, knjiga I, poglavlje 1, p. 28, bilješka 18: „Cf. Sacrobosco, De sphaera 1, 'Quae sit forma mundi'[']: Ut ait Aristoteles in libro Metheororum (sic!). Sic enim ea disposuit Deus gloriosus et sublimis.«/ p. 29. Budući da Salopek nije načinio popis literature iz kojeg bismo mogli doznati kojim se izdanjem djela De sphaera poslužio kada ga je citirao u navedenoj bilješci, ovom ću se prilikom ponovno poslužiti relevantnim kritičkim izdanjem koje je 1949. godine priredio Lynn Thorndike. Važno je napomenuti da se zapis koji je Salopek crpio iz djela Ivana iz Holywooda (Sacrobosco) razlikuje od onoga koji nudi Thorndikeovo izdanje u tome što ne sadrži riječ »ea«. Međutim, zapisi se razlikuju zbog toga što je Thorndike načinio čistopis latinskog izvornika koji je temeljio na nekoliko dostupnih inačica djela De sphaera, ali je u bilješci uz tu rečenicu ponudio i inačicu koja je u potpunosti podudarna onoj koju je citirao Salopek. Usp. Sacrobosco, »Tractatus de spera«, p. 78: »Sic enim disposuit deus gloriosus et sublimis. « $\mathrm{Na}$ istoj stranici vidi i bilješku 57: »C, N, O, eds add ea." 
et disposuit gloriosus Deus et sublimis «. ${ }^{530}$ Dakle, Salopekov zaključak o tome da je Kotruljević tvrdnju koju je pripisao Aristotelu preuzeo iz djela De sphaera Ivana iz Holywooda po mnogočemu je upitan. Prvo zbog toga što Kotruljević kao izvor Aristotelove tvrdnje navodi drugo djelo, drugo zbog toga što Kotruljevićev zapis i zapis Ivana iz Holywooda nisu podudarni u izričaju i, treće, zbog toga što je Dubrovčanin s jednakom razinom podudarnosti sličnu tvrdnju mogao doznati i iz djelā drugih mislilaca.

O poteškoćama pri doznavanju izvorā Kotruljevićevih spoznaja o sadržaju Aristotelovih djela izvijestio je 2012. godine i Davor Balić. Istražujući filozofske izvore Dubrovčaninova spisa o umijeću trgovanja, Balić je upozorio na to da se Kotruljević, čak i onda kada je bio »neposredno upućen u sadržaj nekog Aristotelova djela ili, pak, djela koje je pripisao Aristotelu«, nije imao priliku »koristiti njihovim kritičkim izdanjima. « ${ }^{531}$ Zbog toga će, prema Balićevim spoznajama, »nastojanja koja streme doznavanju pozicija u Aristotelovim djelima, a koja se nastojanja zasnivaju na usporedbi Kotruljevićevih zapisa sa zapisima iz kritičkih izdanja Aristotelovih djela, gotovo redovito biti neuspješna«, a zato je, zaključuje Balić, »vrlo teško, ponekad i nemoguće, sa sigurnošću utvrditi izvore koji su Kotruljevića uputili u Aristotelov nauk. « ${ }^{532}$ Kada je 2009. godine priređivao prijepise dvaju dosad pronađenih rukopisnih inačica De navigatione, talijanski kartograf Piero Falchetta vjerojatno je uvidio spomenute poteškoće prilikom utvrđivanja izvorā Kotruljevićevih spoznaja o sadržaju Aristotelovih djela. Zato se u slučaju Kotruljevićeva pozivanja na stariji prijevod Aristotelove Metafizike u inačici prijepisa iz Schoenbergove zbirke nije opredijelio za izvor, dakle niti, kao što je to učinio Salopek, za djelo Ivana iz Holywooda, niti za, primjerice, djelo Ivana iz Janduna. ${ }^{533}$ Ipak, Falchetta je u brojnim slučajevima smatrao pouzdanijim uputiti na to da je pojedine pozicije iz Aristotelovih djela kojima se poslužio Kotruljević moguće pronaći u suvremenim kritičkim izdanjima Stagiraninova opusa. Primjerice, Kotruljević je u prvom poglavlju prve knjige uputio na to da su brojni filozofi tvrdili da zrak nije ništa te praznim

\footnotetext{
${ }^{530}$ [Ioannis de Ianduno], »Quaestiones super libros Aristotelis De coelo et mundo«, u: Ioannis de Ianduno in libros Aristotelis De coelo et mundo quae extant quaestiones subtilissimae: quibus nuper consulto adiecimus Averrois sermonem De substantia orbis (Venetiis: Apud Iuntas, 1552), ff. 2r-32v, na f. 10r: »Unde Albertus in libro, qui dicitur speculum Philosophiae dicit. sic ordinavit et disposuit gloriosus Deus et sublimis $<\ldots>$ «.

531 Davor Balić, »Filozofi i filozofski izvori u Kotruljevićevu spisu o umijeću trgovanja«, Cris: časopis Povijesnog društva Križevci 14 (Križevci, 2012), pp. 205-271, na p. 219a.

${ }^{532}$ Balić, »Filozofi i filozofski izvori u Kotruljevićevu spisu o umijeću trgovanja«, pp. 219b-220a.

${ }^{533}$ Usp. Benedetto Cotrugli, »De navigatione (1464-1465) Ms. Schoenberg 473«, u: Piero Falchetta, »Il trattato De navigatione di Benedetto Cotrugli (1464-1465). Edizione commentata del ms. Schoenberg 473 con il testo del ms. 557 di Yale«, Studi Veneziani 57 (2009), pp. 67-197, na p. 73. Vidi i: Benedetto Cotrugli, »De navigatione (1464-1465). Testo del ms. 557 della Yale University Library«, u: Piero Falchetta, »Il trattato De navigatione di Benedetto Cotrugli (1464-1465). Edizione commentata del ms. Schoenberg 473 con il testo del ms. 557 di Yale«, Studi Veneziani 57 (2009), pp. 199-333, na p. 203.
} 
prostorom smatrali onaj prostor koji je ispunjen zrakom, a što je, prema njegovim spoznajama, moguće doznati iz četvrte knjige Aristotelove Fizike. ${ }^{534} \mathrm{Na}$ tom mjestu u prijepisu rukopisa iz Schoenbergove zbirke Falchetta je zapisao da je riječ o stavu koji je moguće pronaći u četvrtom poglavlju četvrte knjige suvremenog talijanskog izdanja Aristotelove Fizike. ${ }^{535}$ I doista, uvidom u sadržaj četvrte knjige tog Aristotelova djela, moguće je pronaći obimne Stagiraninove odgovore onima koji su poricali da je zrak nešto te smatrali prostor ispunjen zrakom praznim. ${ }^{536}$

Naposljetku, o izvorima pomoću kojih se Kotruljević tijekom stvaranja spisa o plovidbi upućivao u Aristotelova djela moguće je ponuditi zaključak istovjetan Balićevu o doznavanju izvora Kotruljevićevih spoznaja o Aristotelovu nauku u spisu o umijeću trgovanja. Baš kao i u spisu o umijeću trgovanja, Kotruljevićeve je izvore o Aristotelovu nauku u De navigatione teško sa sigurnošću utvrditi. Dakako, utvrđivanje točnih vrela Kotruljevićevih spoznaja o Aristotelovu nauku bio bi izniman i hvalevrijedan doprinos ionako zapostavljenom

${ }^{534}$ Cotrullis, »De navigatione«, libro I, capitulo 1 / Kotruljević, »O plovidbi«, knjiga I, poglavlje 1, p. 26: »Però multi philosophi dissero che 1 llu [prema Falchettinu transkriptu iz 2009. godine treba stajati: »chellu«] aeru non era nulla nominando vacuo quello che era pieno de aere, come aducie Aristotile nello quarto della Phisyca.«/ p. 27: »Zato su mnogi filozofi rekli da zrak nije ništa, nazivajući praznim prostorom ono što je puno zraka, kao što navodi Aristotel u četvrtoj knjizi Fizike.«

535 Cotrugli, »De navigatione (1464-1465) Ms. Schoenberg 473«, p. 72, bilješka 19: »Aristoteles, Physica, IV.IV; cfr. ed. cit., p. 312 (ed. it. citata, pp. 80 sgg.).«

536 Aristotel, Fizika, IV, 6, 213a 20-213b 2. Talijanski prijevod Aristotelove Fizike vidi, primjerice, u: [Aristotele], »Fisica«, traduzione di Antonio Russo, u: Aristotele, Opere, volume primo (Milano: Arnoldo Mondadori Editore S.p.A., 2008), pp. 61-296, na pp. 144-145: »Bisogna, comunque, iniziare la ricerca prendendo in esame le teorie di quelli che ne sostengono l'esistenza e di quelli che, ali contrario, la negano, e in terzo luogo le opinioni comuni su tali argumenti. Quesi filosofi che, come Anassagora e gli altri che adducono le medesime argomentazioni, cercano di negare l'esistenza del vuoto, non confutano affatto ciò che generalmente gli uomini intendono per vuoto, ma soltanto gli errori in cui si suol cadere affermandone l'esistenza. Essi, per dimostrare che l'aria è qualcosa, si servono della contorsione degli otri, indicando, così, quanta sia la forza dell'aria, e la intercettano nelle clessidre. Gli uomini comuni, invece, affermano che il vuoto è un intervallo in cui non c'è alcun corpo sensibile; e poiché credono che ogni ente sia un corpo, essi affermano che il vuoto è ciò in cui non c'è nulla affatto; e perciò, secondo loro, quello che è pieno d'aria, è il vuoto. Pertanto, si dovrebbe dimostrare non già che l'aria è qualcosa, ma che non c'è altro intervallo tra i corpi né separabile né in atto, il quale penetri attraverso tutto il corpo in mode che quest'utlimo non sia continuo, come affermano Democrito e Leucippo e molti altri fisiologi, oppure se un tale intervallo sia qualcosa di esterno ad ogni corpo, pur essendo continuo ogni corpo <... « . Vidi i: Aristotel, Fizika, prijevod s izvornika i sedmojezični tumač temeljnih pojmova (grčki, latinski, engleski, francuski, njemački, talijanski, ruski) Tomislav Ladan, predgovor Danilo Pejović (Zagreb: Globus / Sveučilišna naklada Liber, 1988), 213a 20-213 b 2, pp. 96-97: »Razmatranje treba započeti uzevši one stvari koje govore oni što kažu da postoji 'prazno', zatim one što govore oni koji kažu da ono ne postoji, i treće zajednička mnijenja o tima. Oni dakle koji pokušavaju pokazati da ne postoji 'prazno' ne opovrgavaju ono što ljudi hoće reći pod /pojmom/ 'prazno', nego ono što griješeći govor, kao Anaksagora i oni koji takvim načinom pobijaju. Jer dokazuju da je zrak nešto, sučići mješine i pokazujući kako je silan zrak, i zatvarajući ga u vodenim urama. Ali ljudi hoće da je 'prazno' razmak u kojem nema nikakva sjetilnog tijela. I mnijući kako je svako biće tijelo, kažu kako je 'prazno' ono u čemu uopće nema ničega, pa stoga ono što je puno zraka da je 'prazno'. Ne treba dakle dokazivati to da je zrak nešto, nego da ne postoji razmak različit od tjelesa, niti izdvojiv niti kao biće djelatnošću, takav koji prožima cjelokupno tijelo, tako te ono nije neprekidno, kao što govore Demokrit i Leukip, i mnogi drugi među naravoslovcima, ili kao da postoji štogod izvan cjelokupnog tijela, koje je neprekidno.« 
Dubrovčaninovu opusu, no, a poradi obimnosti istraživanja, to bi trebao biti predmet zasebne studije.

Osim o antičkim misliocima, prvo poglavlje prve knjige Kotruljevićeva spisa o plovidbi otkriva i Kotruljevićeve spoznaje o misliocima koji pripadaju razdoblju Srednjega vijeka i njihovim naucima. Naime, Kotruljević se u tom poglavlju oslonio na nauke barem četvorice srednjovjekovnih mislilaca: Aurelije Augustin (Aurelius Augustinus, 354-430), Raban Mauro (Rabanus Maurus Magnentius, oko 780-856), Petar Lombardski (Petrus Lombardus, oko 1095-1160) te Albert Veliki (Albertus Magnus, oko 1193-1280). Sudeći prema kolikoći izravnih pozivanja, Kotruljević se uvjerljivo najviše oslanjao na Augustinova djela i nauk, i to čak dvanaest puta, a uvjerljivo najmanje na nauke koje su podastrli Raban Mauro i Petar Lombardski, tek po jedanput. Upravo ću služeći se kriterijem kolikoće Kotruljevićeva izravnog pozivanja na njihove nauke u nastavku izdvojiti po jedan primjer njegova pozivanja na nauk trojice srednjovjekovnih mislilaca, od onih najbrojnijih do onih najmalobrojnijih. Izdvojit ću primjer njegova pozivanja na nauk Augustina, Alberta Velikog i Petra Lombardskog, čime ću dokazati da je Kotruljević bio itekako upućen i u nauke mislilaca iz tog razdoblja povijesti filozofije.

Kao što sam već naglasio, Kotruljevićevo pozivanje na Augustina i njegov nauk nesumnjivo kolikoćom premašuje preostala pozivanja na nauke srednjovjekovnih mislilaca u prvom poglavlju prve knjige spisa De navigatione. Štoviše, kada bismo zbrojili njegova pozivanja na nauke drugih mislilaca (trinaest), dobili bismo broj gotovo jednak broju pozivanja samo na Augustina (dvanaest). Kotruljevićevu upućenost u Augustinov nauk dodatno osnažuje i podatak da ga je u dva navrata oslovio tek sljedećim riječima: »lo dicto doctore« (»spomenuti učitelj«). Prilikom pozivanja na Augustina, imenovao je čak pet njegovih djela i to sljedećim redoslijedom: De civitate Dei (O državi Božjoj), Contra Faustum (Protiv Fausta), De Genesi ad Litteram (Komentari uz Knjigu Postanka), De Trinitate (O Trojstvu) i Ad Orosium (Pitanja Oroziju). Budući da sam već ranije dokazao Kotruljevićevu upoznatost sa sadržajem Augustinova djela $O$ državi Božjoj, ${ }^{537}$ ovom ću prilikom izdvojiti tek primjer Dubrovčaninova oslanjanja na sadržaj još jednog od Augustinovih najznamenitijih djela: djela $O$ Trojstvu.

Raspravljajući o uzroku gibanja vode i preostalih prirodnina, Kotruljević je posegnuo za stavom za koji je kao izvor naveo treću knjigu spisa $O$ Trojstvu. Tom je prigodom zabilježio da je iz te knjige Augustinova djela doznao da se svako gibanje svakog stvorenog bića

${ }^{537}$ Vidi na pp. $111-115$ ovoga rada. 
pokorava Božjoj zapovijedi te se ponovno svodi upravo na nju kao prvog pokretača. ${ }^{538}$ Uvidom u tu knjigu Augustinova djela $O$ Trojstvu, doznao sam da je Kotruljević taj stav uistinu mogao doznati s mjesta koje je naveo kao svoj izvor, točnije iz četvrtog poglavlja treće knjige $O$ Trojstvu. ${ }^{539}$ Dakle, Kotruljević se na spomenutom mjestu još jednom iskazao kao poznavalac Augustinova opusa.

Prema kolikoći pozivanja, Albert Veliki sljedeći je srednjovjekovni mislilac na čiji se nauk Kotruljević oslanjao u prvom poglavlju prve knjige spisa o plovidbi. Naukom tog srednjovjekovnog filozofa podupirao je stavove u trima slučajevima, pritom se pozivajući na tri njegova djela: De meteoris ili Meteora ( $O$ meteorima ili Meteora), Metaphysica (Metafizika) i De causis proprietarum elementorum ( $O$ uzrocima svojstava elemenata). Budući da se Kotruljević najprije poslužio sadržajem Albertove rasprave o meteorima i budući da se, a zbog prevladavajuće prirodnofilozofske tematike, njezinim sadržajem obilno okoristio i u daljnjem tijeku spisa o plovidbi, ovom prilikom izdvojit ću primjer Dubrovčaninova pozivanja na Albertovo djelo Meteora. Osim toga, primjer koji sam odabrao omogućuje barem djelomičnu, ali nedvojbeno vrijednu spoznaju i o tome odakle je Kotruljević doznavao pojedinosti iz Aristotelova nauka.

Kotruljević je posegnuo za sadržajem Albertove rasprave Meteora onda kada je razmatrao obilježja naravi vode. Tada je, naime, zapisao da stav koji je, kako kaže, doznao iz Albertova djela Meteora da je voda vlažna po naravi, zatim da okružuje zemlju sa svih strana iako je lakša od nje, onda da je zbog vlažnosti i nježna, što joj omogućuje da prodre u dijelove te dijelove dijelova, pa je naposljetku dodao i to da je tako tvrdio i Aristotel u drugoj knjizi spisa

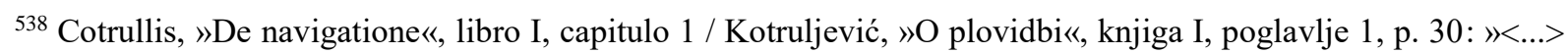
perché ogni moto de ogni natura creata obedisce allo divino imperio et ad ipso como primo motore se reduce, como vole Agustino in tertio De Trinitate«. / p. 31.

539 Aurelius Augustinus, »De Trinitate libri quindecim.«, liber III, caput 4, u: Patrologiae cursus completus, accurante J[acques].-P.[aul] Migne. Patrologiae Latinae. Tomus XLII. S.[anctus] Aurelius Augustinus. [Opera omnia, post Lovaniensium theologorum recensionem. Tomus octavus] (Parisiis: excudebatur et venit apud J.[acques]-P.[aul] Migne editorem, 1865), cc. 819-1098, na c. 874: »cum haec omnia quae per corporales motus in illo opere fiunt, Deus operetur, movens primitus invisibilia ministrorum, sive animas hominum, sive occultorum spirituum sibi subditas servitutes): quid mirum si etiam in creatura coeli et terrae, maris et aeris, facit Deus quae vult sensibilia atque visibilia, ad se ipsum in eis, sicut oportere ipse novit, significandum et demonstrandum, non ipsa sua qua est apparente substantia, quae omnino incommutabilis est, omnibusque spiritibus, quos creavit, interius secretiusque sublimior? « Usp. [Aurelije Augustin], »Treća knjiga. Božja očitovanja u Starome zavjetu i anđeli«, u: Sveti Augustin, Trojstvo, preveo, napisao uvod i bilješke Marijan Mandac (Split: Služba Božja, 2009), pp. 319-344, na p. 327: »Ono što se ljudskim rukama dovede do onoga vidljivoga oblika ne posvećuje se da postane veliko otajstvo, osim što nevidljivo djeluje Duh Sveti jer sve ono što se zbiva u onome djelu po tjelesnim pokretima vrši Bog. Najprije pokreće nevidljivo kod službenika: ljudske duše odnosno sebi podložne pokornosti skrivenih duhova. Što čudi ako Bog u stvorenju neba i zemlje, mora i zraka, tvori osjetno i vidljivo kojim hoće da se - kako sam zna da treba - očituje i pokaže. Njegova se supstancija po kojoj je ne pokazuje. Ona je posve nepromjenljiva i od svih duhova što ih je Bog stvorio nutarnjije i tajnovitije uzvišenija.« 
O rađanju i nestajanju zapisavši da će voda prodrijeti u dubinu zemlje i tamo se i zadržati. ${ }^{540}$ Te stavove o naravi vode Kotruljević je doista mogao pronaći u Albertovu djelu Meteora, točnije u njegovu šestom poglavlju drugog dijela druge knjige, no iz njega je zasigurno bio u mogućnosti doznati i Aristotelov stav o vodi da posjeduje sposobnost prodiranja u zemlju i zadržavanja u zemlji. ${ }^{541}$ Dakle, iz navedenog primjera ne samo da smo doznali da je Kotruljević bio upoznat s Albertovim naukom iz djela Meteora, nego i to da se tim djelom služio i za doznavanje podataka o obilježjima Aristotelova nauka.

Kao treći, posljednji primjer Kotruljevićeva pozivanja na nauke srednjovjekovnih mislilaca izdvajam pozivanje na nauk znamenitog talijanskog skolastičkog teologa, filozofa i biskupa Petra Lombardskog. Dubrovčanin je to učinio tek jednom, pri čemu ga nije imenovao, već ga je oslovio sljedećim riječima: »lu magistro delle Sententie« (»učitelj Sentencija«). U bilješci uz Kotruljevićevo pozivanje na Petra Lombardskog, Salopek je ponudio pojašnjenje da ga je Dubrovčanin tako oslovio zato što se tom prigodom oslanjao na njegovo djelo Quatuor libri Sententiarum (Četiri knjige promišljanja), ali i upozorio na to da je Kotruljević naveo da je riječ o trinaestoj, dok je, a prema današnjoj razdiobi, ustvari riječ o četrnaestoj distinkciji. ${ }^{542}$ Raspravljajući o različitom naučavanju crkvenih otaca o postojanju takozvanih gornjih i donjih voda, točnije o postojanju vode iznad i ispod nebeskog svoda, Kotruljević je posegnuo i za naukom Petra Lombardskog. Njemu je tom prilikom pripisao mišljenje, a koje je navodno izrekao i engleski srednjovjekovni povjesničar i teolog Beda Časni (Baeda Venerabilis, oko 673-735), da je nebeski svod, točnije zvjezdano nebo, stvoren i utvrđen gornjim i donjim vodama te da je potaknut prozirnošću neba kao primjer naveo kristal koji ima veliku čvrstoću i prozirnost, a koji je isto tako prirodno sazdan od vode, pa dodao da je način ukrućivanja

${ }^{540}$ Cotrullis, »De navigatione«, libro I, capitulo 1 / Kotruljević, »O plovidbi«, knjiga I, poglavlje 1, p. 28: »Alberto Magno nella sua Metaura dicie che ·ll'acqua [prema Falchettinu transkriptu iz 2009. godine treba stajati: »chell'acqua«] circunda undique la terra per natura del humido, avenga scia più legera / della terra, et circha termino alieno et con ciò scia che 'l humido scia subtile et lo sottile scia penetrativo delle parti et de parte delle parti, como dicie Aristotile in nel secundo De generatione, penetrarà l'acqua nel grosso della terra et contenderasse in essa.«/ p. 29.

541 Albertus Magnus, Meteora, liber II, tractatus 2, caput 6. Vidi, primjerice, u: Albertus Magnus, »Meteororum«, liber II, tractatus 2, caput 6, u: B.[eati] Alberti Magni, Ratisbonensis episcopi, Ordinis praedicatorum, Opera omnia, cura ac labore Augusti Borgnet, Sacerdotis dioecesis Remensis. Volumen Quartum. (Parisiis: Apud Ludovicum Vivès, 1890), pp. 477a-808b, na p. 550a-b: »Secunda autem causa est interminabilitas aquae: quia licet levior sit quam terra, tamen undique fluit ad ipsam ex naturahumidi quod quaerit terminum alienum: et cum humidum sit subtile, et subtile sit penetrativum partium, ut habetur in secundo de Generatione et Corruptione, penetrabit aqua in grossum terrae et continebitur inter ipsam."

542 Cotrullis, »De navigatione«, libro I, capitulo 1 / Kotruljević, »O plovidbi«, knjiga I, poglavlje 1, p. 32 / p. 33 , bilješka 14: »Nadimak 'magister sententiarum' nosio je Petrus Lombardus prema svome djelu Četiri knjige promišljanja (Quatuor libri Sententiarum), a koje su bile podijeljene na tzv. distinkcije. Broj distinkcije koji citira Kotruljević ne slaže se s danas prihvaćenom razdiobom«. 
inače tekuće i nepostojane vode opisan Božjim riječima: »On zatvara vodu u svoje oblake. «543 Ta promišljanja Kotruljević je zaista mogao doznati iz, doduše, ne trinaeste već četrnaeste distinkcije u drugoj knjizi Sentencija Petra Lombardskog. ${ }^{544}$

Kao što proizlazi iz sadržaja ovog potpoglavlja, već je na temelju analize sadržaja prvog poglavlja prve knjige spisa o plovidbi moguće doznati pojedinosti o Kotruljevićevu poznavanju povijesti filozofije i upućenosti u nauke dotadašnjih filozofa. Primjerima njegovih pozivanja na nauke koje su zagovarali predsokratovci, zatim Sokrat, Platon i Aristotel, a onda i Augustin, Albert Veliki te Petar Lombardski, ustanovio sam da je Kotruljević bio itekako upućen u povijesni razvoj filozofije i u nauke nemalog broja mislilaca, čime se već na početku spisa De navigatione nedvojbeno iskazao kao poznavalac povijesti filozofije. Pritom napominjem da navedeni zaključak može poslužiti tek kao jedna od smjernica za donošenje konačne prosudbe o Kotruljevićevoj filozofskoj lektiri u spisu o plovidbi. Dakako, za takvu je prosudbu potrebno poduzeti zasebno i obuhvatno istraživanje filozofā i filozofskih izvora u čitavu spisu. Dotad bi se, smatram, trebalo ustezati od donošenja zaključaka o Kotruljevićevoj naklonosti pojedinim filozofima i pojedinim filozofskim pravcima.

\subsection{Filozofija prirode u spisu o plovidbi}

Osim što se Kotruljević u spisu o plovidbi iskazao kao poznavalac dotadašnje povijesti filozofije, on je svoj spis o plovidbi u velikoj mjeri protkao i filozofskom tematikom. Naime, u četirima knjigama De navigatione nalaze se i njegova promišljanja filozofske, pretežito prirodnofilozofske naravi. Ta su promišljanja najbrojnija u trećoj knjizi spisa. Na prirodnofilozofski sadržaj treće knjige Kotruljevićeva spisa o plovidbi dosad su, podsjećam, ukazala tek dvojica istraživača hrvatske filozofske baštine: Ivica Martinović i Davor Balić.

\footnotetext{
${ }^{543}$ Ibid., p. 32: »Et però lu magistro delle Sententie, distinctioni XIII, et sondo parole de Beda, dicie che lo firmamento, lo quale è celo siderio, scia facto et solidato delle dicte acque mosso forse per la sua dyafanitate, unde induce lu exemplo dello cristallo lo quale è de grande saldecza et perspicacitate et nulla de mino è facto d'acqua per la virtù della natura. Ma in che modo le acque sopra li cieli se possono consolidare sendo liquide et labile, scripto è de Dio: qui ligat aquas in nubibus cęli.«/ p. 33.

544 Petrus Lombardus, Quatuor libri Sententiarum, liber II, distinctio 14. Vidi, primjerice, u: Petrus Lombardus, »Sententiarum libri quatuor«, liber II, distinctio 14, u: Patrologiae cursus completus, accurante J[acques].P.[aul] Migne. Patrologiae Latinae. Tomus CXCII. Petrus Lombardus magister Sententiarum. [Opera omnia. Tomus secundus] (Parisiis: Excudebatur et venit apud J.-P. Migne editorem, 1855), cc. 519-964, na c. 680: »Sciendum est quòd illius coeli describitur hic creatio, sicut ait Beda, super Genes., in quo fixa sunt sidera; cui suppositae sunt aquae in aere et in terrà, et suppositae aliae, de quibus dicitur: Qui legis aquis superiora ejus. In medio ergo fimamentum est, id est, sidereum coelum, quod de aquis factum esse credi potest. Chrystallinus enim lapis cui magna est firmitas et perspicuitas, de aquis factus est. Si quem verò movet quomodò aquae naturae fluidae et in ima labiles super coelum possint consistere, de Deo scriptum esse meminerit: Qui ligat aquas in nubibus suis.«
} 
Martinović je, naime, 1999. godine sadržaj treće knjige odredio kao »prirodnofilozofski spis aristotelovskog nadahnuća ${ }^{545}$ dok je 2000. i 2011. godine zaključio da upravo trećom knjigom Kotruljevićeva spisa De navigatione započinje »blistava hrvatska dionica renesansne prirodne filozofije ${ }^{546}$ Iz Balićeva istraživanja poduzetog 2010. godine doznajemo da su u spisu o plovidbi najčešći izvor Kotruljevićevih spoznaja o stajalištima brojnih filozofa bila prirodoznanstvena djela Meteora i Mineralia Alberta Velikog, ${ }^{547}$ dok iz njegova istraživanja iz 2011. godine doznajemo da je Albert Veliki bio »najčešći izvor treće knjige spisa $O$ plovidbi«. ${ }^{548}$ Budući da su neupitne točnosti, a i budući da su jedini, zaključci te dvojice istraživača zasluženo su se uvriježili u vrednovanju filozofskog sloja spisa o plovidbi. No, ni Martinović ni Balić svoje zaključke nisu potkrepljivali izdvajanjem pojedinačnih primjera niti su pristupali detaljnijoj analizi tema koje pripadaju korpusu tema iz filozofije prirode. Osim toga, razmjere i obuhvatnost zaključaka te dvojice istraživača nesumnjivo je moguće proširiti i na sadržaj prve knjige spisa o plovidbi. Iako je najbolju i najobuhvatniju prosudbu njezina sadržaja ponudio Martinović, rekavši da je riječ o oceanopisu, ${ }^{549}$ prva knjiga spisa zasigurno zaslužuje biti vrednovana i iz filozofske perspektive. Dostatnu potvrdu toga pruža sadržaj prethodnog potpoglavlja ovoga poglavlja, u kojem sam na primjeru sadržaja tek jednog poglavlja prve knjige ustanovio da je Kotruljević bio vrlo dobro upoznat s razvojem povijesti filozofije od antike do srednjovjekovlja. ${ }^{550}$ Jedini prikaz sadržaja spisa o plovidbi iz kojega je moguće zaključiti da čitav spis obiluje tematikom koja spada u filozofiju prirode ponudio je $\mathrm{i}$ 2015. godine objavio Žarko Dadić, povjesničar znanosti koji se bavio i istraživanjem hrvatske filozofske baštine. Omanjoj analizi i šturom prikazu pristupio je nakon što je zaključio da Kotruljević u cjelokupnom spisu o plovidbi »ne piše samo o plovidbi«, već i o »sustavu

\footnotetext{
545 Ivica Martinović, »Književni žanrovi hrvatskih filozofa od Stojkovića do Boškovića«, u: Fedora Ferluga Petronio (a cura di), Introduzione allo studio della lingua, letteratura e cultura croata / Uvod u studij hrvatskoga jezika, književnosti i kulture / Uvod v študij hrvaškega jezika, literature in kulture (Udine: Forum, 1999), pp. 107-116, na p. 108.

${ }^{546}$ Ivica Martinović, »Žanrovi hrvatske filozofske baštine od 15. do 18. stoljeća«, u: Pavo Barišić (ur.), Otvorena pitanja povijesti hrvatske filozofije (Zagreb: Institut za filozofiju, 2000), pp. 69-151, na p. 74; Ivica Martinović, Žanrovi hrvatske filozofske baštine od 15. do 18. stoljeća (Split: Filozofski fakultet Sveučilišta u Splitu, 2011), p. 17.

547 Davor Balić, »Vrste plovilā u Kotruljevićevu udžbeniku plovidbe«, Metodički ogledi: časopis za filozofiju odgoja 17/1-2 (2010), pp. 61-86, na p. 67.

548 Davor Balić, »Izvori Kotruljevićeve filozofije prirode u De navigatione (1464)«, u: Marita Brčić, Mira Matijević, Krešimir Babel (ur.), Simpozij Mediteranski korijeni filozofije 5. Split, 24.-26. ožujka 2011 (Zagreb - Split: Hrvatsko filozofsko društvo / Odsjek za filozofiju Filozofskog fakulteta Sveučilišta u Splitu, 2011), p. 21.

${ }^{549}$ Ivica Martinović, »Benedikt Kotruljević«, u: Neven Budak (osmislio i uredio), Croatica: HR - Hrvatski udio u svjetskoj baštini, [sv. 1] (Zagreb: Profil international, 2007), pp. 170-175, na p. 174. Isto vidi i u: Ivica Martinović, »Benedikt Kotrulj«, u: Ivica Martinović, Žanrovi hrvatske filozofske baštine od 15. do 18. stoljeća (Split: Filozofski fakultet Sveučilišta u Splitu, 2011), pp. 13-17, na p. 17.

${ }^{550}$ Vidi na pp. 111-124 ovoga rada.
} 
svijeta, prirodoznanstvenim pojavama i o astrologiji«, pa prosudio da »sve to pokazuje njegove stavove u prirodnoj filozofiji.« ${ }^{551} \mathrm{Da}$ bih ukazao na prisutnost filozofije prirode $\mathrm{u}$ spisu o plovidbi, u dvama potpoglavljima koja slijede obradit ću sadržaj prve i treće knjige spisa o plovidbi. Prema mojem sudu, u tim je knjigama najizraženiji Kotruljevićev interes za teme iz filozofije prirode. Takvim će pristupom biti omogućen neposredan uvid u mjesta na kojima se u tim knjigama očituje njihova prirodnofilozofska sastavnica, a posljedično će biti omogućeno i donošenje zaključka o prirodnofilozofskoj orijentaciji čitava spisa o plovidbi.

\subsubsection{Filozofija prirode u prvoj knjizi spisa o plovidbi}

Sadržaj prve knjige spisa o plovidbi ne otkriva samo Kotruljevića kao poznavaoca povijesti filozofije, nego i to da je filozofskom tematikom namjeravao prožeti čitav spis. Naime, Kotruljević je već u predgovoru spisu najavio da će se posvetiti temama koje pripadaju filozofiji prirode. Tom je prilikom zapisao da znanja kojima je tada raspolagao duguje učenosti i znanjima koja su čovječanstvu u nasljeđe ostavili stari pisci. ${ }^{552}$ Upravo je zahvaljujući tim piscima, koje je doduše propustio imenovati, raspolagao znanjima o prirodnofilozofskim temama, primjerice, o putanji Sunca i Mjeseca, izračunu planeta, redoslijedu nebeskih znakova, broju zvijezda, prostranstvu kopna, dubini mora, okretanju nebesa, sklonostima ljudi, svojstvima biljaka te liječenju bolesti. ${ }^{553}$ Da bih uputio na prisutnost prirodnofilozofske sastavnice u prvoj knjizi Kotruljevićeva spisa o plovidbi, $\mathrm{u}$ nastavku ću obraditi sadržaj prvih triju poglavlja te knjige. Prema mojem uvjerenju, upravo je u njima najizraženiji Kotruljevićev interes za teme pripadne filozofiji prirode.

Da je Kotruljević bio dosljedan najavi iz predgovora da će spis prožeti temama iz filozofije prirode, potvrđuje to da je raspravu o, kako ga tom prigodom naziva, umijeću plovidbe (tractare dell'arte del navigare) otpočeo razmatranjima o obilježjima vode u poglavlju koje je

551 Žarko Dadić, »Rukopis Benedikta Kotruljevića De navigatione iz 15. stoljeća«, u: Žarko Dadić, Povijest znanosti $i$ prirodne filozofije u Hrvata. S osobitim obzirom na egzaktne znanosti, knjiga I., Srednji vijek (Zagreb: Izvori, 2015), pp. 359-376, na pp. 360-361.

${ }^{552}$ Cotrullis, »De navigatione«, prohemium primum / Kotruljević, »O plovidbi«, prvi predgovor, p. 18: »Idcirco non parum debemus vetustis scriptoribus, qui elaborata ingenio non solum sibi in pabulum esse voluerunt verum etiam nobis ea legentibus tantum doctrinę tantumque scientię pręstant, ut eo doctiores, immo eo solo homines dici possimus.«/p. 19.

${ }^{553}$ Cotrullis, »De navigatione«, prohemium primum / Kotruljević, »O plovidbi«, prvi predgovor, p. 18: »Ipsi [vetustis scriptoribus] nanque solis et lunę cursum, rationem planetarum, signorum ordinem, stellarum numerum, latitudinem terrę, maris profunditatem, revolutionem cęlorum, inclinationes hominum, herbarum virtutes, egritudinum curas, scientiarum omnium dignitates, hystorias bene gestarum rerum, magnatum ac principum vitas, mores hominum et servandę sanitatis ac / religionis ritus diligentissime nobis et propter nos ediderunt.«/p. 19. 
naslovio »De acque in genere« (»Općenito o vodama«). Nakon što je umijeće plovidbe opisao kao pomorsko umijeće i kao umijeće koje je toliko dostojanstveno da se istinskog i dobrog mornara nesmetano može nazivati pravim vitezom (cavaliere), naglasio je nužnost stjecanja znanja o takozvanim temeljnim postavkama o vodama (fundamenti delle acque). ${ }^{554}$ Inače, iz zapisa koji prethodi posveti i predgovoru spisa može se zaključiti da je osoba koja je načinila prijepis ili zapisivala diktat spisa dubrovačkog mislioca smatrala vitezom (lat. eques, -itis; tal. cavaliere), dakle da ga je smatrala oličenjem istinskog i dobrog mornara, a taj zapis glasi: $»$ Vitez Benedikt Kotruljević dičnomu mletačkom senatu knjiga $O$ plovidbi započinje sa srećom« (»Benedictus de Cotrullis Equitis ad inclitum Senatum Venetorum De navigatione liber incipit«). Smatrajući postavke o vodama, kako kaže, pravim i izvornim temeljem pisanja rasprave, a i vlastito je pisanje okarakterizirao oblikom plovidbe, Dubrovčanin je u prvom poglavlju prve knjige najavio da će razmotriti u kojoj su mjeri vode element te u kojoj su mjeri plovne. ${ }^{555}$ Zbog takve najave, smatram da je Dadić utemeljeno pretpostavio da Kotruljević vodu »vjerojatno stavlja na početak izlaganja o pomorstvu, jer se po njoj, odnosno moru, plovi«, pa dodao da je Dubrovčanin tu tematiku razumijevao »u vrlo širokom smislu«i zaključio da bi to bilo »sve što sadržaj prvog poglavlja Kotruljevićeve prve knjige povezuje s pomorstvom. $\ll^{556} \mathrm{U}$ nastavku ovog potpoglavlja ukazat ću na Kotruljevićev odmak od pomorstva na koji je Dadić aludirao, a koji se odmak očituje u tome što je dubrovački mislilac tematici vode pristupao iz perspektive filozofije prirode, točnije razmatrao je vodu kao jedan od četiriju gradivnih elemenata svijeta.

Budući da je Kotruljević, a što sam ustanovio u prethodnom potpoglavlju, bio poznavalac povijesti filozofije, polazišna i nezaobilazna točka njegovih razmatranja o vodi kao elementu bio je nauk grčkog filozofa Tala. Osim što je ponudio brojne biografske podatke i pojedinosti njegova nauka koje je doznao od Augustina, Diogena iz Laerte i Laktancija Firmijana, dubrovački je renesansni mislilac o Talu ponudio sljedeća dva zaključka: 1 . Tal je smatrao da je voda počélo stvari iz kojega je nastao čitav svijet; 2. Tal nije pripisao zasluge Bogu ni za jednu od postojećih stvari u svijetu. ${ }^{557}$ Unatoč tome što je šturim zapisima iskazao upućenost u sadržaj njihovih nauka, Kotruljević je prilikom razmatranja vode kao elementa ipak odlučio,

\footnotetext{
${ }^{554}$ Cotrullis, »De navigatione«, libro I, capitulo 1 / Kotruljević, »O plovidbi«, knjiga I, poglavlje 1, p. 22 / p. 23.

${ }^{555}$ Ibid., p. 22: »<...> delle acque dalle quali [fundamenti delle acque], come da vero et orriginale fundamento, pigliarà principio questa nostra navigatione; et considerarimo le acque et quanto è elemento et quanto navigabile.«/p. 23.

${ }^{556}$ Dadić, »Rukopis Benedikta Kotruljevića De navigatione iz 15. stoljeća«, p. 361.

${ }^{557}$ Cotrullis, »De navigatione«, libro I, capitulo 1 / Kotruljević, »O plovidbi«, knjiga I, poglavlje 1, p. 24: »Ma el extimò l'acqua esser principio delle cose et da llei [prema Falchettinu transkriptu iz 2009. godine treba stajati: »lei«] prociedere tucti gli eliminti del mundo et esso / mundo. Niente delle cose mirabile che videmo in quisto mundo atribuì a dio.«/ p. 25.
} 
a zbog toga što su različito poimali počéla stvari, zapostaviti mišljenja predsokratovaca Anaksimandra, Anaksimena, Anaksagore, Diogena iz Apolonije, Arhelaja, kao i mišljenja Sokrata i Platona. ${ }^{558}$ Razvojni tijek promišljanja o počélima dosegnuo je, prema Kotruljevićevu mišljenju, vrhunac pojavom Mojsija, koji svojim stečenim i udahnutim znanjem te proročkim duhom zasigurno nije mogao griješiti kada je određivao počélo svih stvari. ${ }^{559}$ Da bi to dokazao, Kotruljević je potom posegnuo za početkom biblijske Knjige Postanka, posebice za onim dijelom koji se odnosi na drugi dan stvaranja svijeta, i iz nje izdvojio sljedeće tvrdnje: 1. »i Duh Božji lebdio je nad vodama«; 2. »I reče Bog: 'Neka bude svod posred voda da dijeli vode od voda!' Bog načini svod, i vode pod svodom odijeli od voda nad svodom. A svod prozva Bog nebo.«; 3. »'Vode pod nebom neka se skupe na jedno mjesto, i neka se pokaže kopno!' I bi tako. Kopno prozva Bog zemlja, a skupljene vode more. ${ }^{560}$ Kotruljevićevo isticanje Mojsija kao onoga koji nije mogao pogriješiti prilikom određivanja počéla svijeta, nesumnjivo upućuje na njegovo pristajanje uz kršćansko naučavanje o božanskom stvaranju svijeta te na zaključak da je Dubrovčanin Talovu nauku zamjerao dvije stvari: 1) to što je smatrao da je počélo svijeta voda; 2) to što Bogu pritom nije dodijelio nikakvu ulogu. Jednako je tako nesumnjivo da je, a ponovno u skladu s kršćanskim naukom, bio uvjeren da postoje vode iznad i ispod nebeskog svoda, kao i to da je vodu i zemlju smatrao dvama različitim gradivnim elementima svijeta.

Pristajanje uz kršćansku kozmogoniju Dubrovčanin je u daljnjem tijeku rasprave izrazio i ukazivanjem na razloge Mojsijeva isticanja važnosti trećeg dana stvaranja u Knjizi Postanka. Toga se dana, a nakon prethodnog međusobnog razdvajanja elemenata, zbilo odvajanje stvari proizašlih iz svakog zasebnog elementa, primjerice, trave i biljaka, kao onih stvari koje proizlaze iz elementa zemlje. ${ }^{561}$ Potom se Kotruljević ponovno usmjerio na tumačenje

\footnotetext{
${ }^{558}$ Ibid., p. 24: »Et per lassar delli altri philosophi multe oppinioni de Aximandro, auditor del dicto Tales, et successive de Aximene, suo discipulo lo qual decte lu principio de tucte le cose allo aere, et Anaçagora, suo auditore, et Dyogene, auditore anche de Aximene, che dixe lu aere essere materia delle cose, et allo dicto succiese lo auditor suo Archelao, de cui discipulo fo Socrate che lassò Platone, suo auditore, li quali variamente intendevano et iudicavano delli principii delle cose, <... « . / p. 25.

559 Ibid., p. 24: $»<\ldots>$ vegnamo ad Moysè el quale ebbe scientia acquisita et infusa inseme collo spiritu prophetico, el quale non poté errare dando lu principio ad tucte le cose create.«/p. 25.

${ }^{560}$ Ibid., p. 24-26: »Omni potente Dio disse Genesis primo: et spiritus Domini ferebatur super aquas, et poi sequitando giogne: dixitque Deus fiat firmamentum in medio aquarum et dividat aquas ab aquis, et fecit Deus firmamentum divisitque aquas quę erant sub firmamento ab aquis que erant super firmamentum, et vocavit Deus firmamentum cęlum. Et poi dice: congregentur aquę quę sub cęlo sunt in locum unum et appareat arrida factumque est ita, et vocavit Deus arridam terram congregationesque aquarum appellavit maria."/ pp. 25-27.

${ }^{561}$ Ibid., p. 26: »Tucte le predicte parole sondo pregne et piene de sententia, però che nella distintione del primo, tertio giorno dupplicie hornato è designato da Moysè et l'uno depende da l'altro. / Lu primo è distinctione delli elimenti inseme, l'altro è delli elementi et spetialmente de quelli che trahono orrigine dalla terra, como sondo le herbe et le piante.«/p. 27.
} 
prethodno izdvojenih citata iz Knjige Postanka koji se odnose na drugi dan stvaranja. Pojasnio je da u tvrdnji da je duh Božji lebdio nad vodama, i to po uzoru na Augustinovo tumačenje početka Knjige Postanka, pod nazivkom »voda« treba podrazumijevati čitavu elementarnu materiju, a zbog toga što je, tvrdi Dubrovčanin navodno slijedeći Aristotelov nauk iz djela $O$ nebu i svijetu te nauk koji je izložio srednjovjekovni mislilac Raban Mauro u glosi uz Knjigu Postanka, vlažna tvar osnova svakog miješanja. ${ }^{562}$ Biblijskim zapisom koji se odnosi na skupljene vode pod nebeskim svodom (more) koje će razotkriti kopno (zemlju) Mojsije je, tvrdi dubrovački umnik, neobrazovanoj svjetini zapravo htio ukazati na razlikovanje elementa vode od elementa zemlje, zbog toga što ta svjetina nije mogla pojmiti postojanje oku nevidljivog trećeg elementa: zraka. ${ }^{563}$ Baš kao i svjetina kojoj se Mojsije obraćao, prema spoznajama koje je Kotruljević navodno doznao iz Aristotelove Fizike, postojali su brojni filozofi koji su, zbog nevidljivosti koja je obilježje elementa zraka, tvrdili da prostor ispunjen zrakom valja smatrati praznim prostorom. ${ }^{564}$ Da bi pak uvećao vrijednost Mojsijevih spoznaja, Dubrovčanin je ustrajao na isticanju ispravnog načina tumačenja njegovih riječi u kontekstu razlikovanja elemenata. Zbog toga je bio uvjeren da je Mojsije zrak spomenuo u tvrdnji: »tama se prostirala nad bezdanima«, pri čemu je smatrao da je bezdan donja voda pomiješana sa zemljom unutar tame koja je zračno tijelo koje je bilo tamno prije negoli je stvoreno svjetlo. ${ }^{565} \mathrm{Uz}$ to, Kotruljević je zapisao da je Mojsije ukazao na to da su u prva tri dana stvaranja uklonjene tri bezobličnosti i to u sljedeća tri koraka: 1. nebo kojem pripada bezobličnost tame iz koje je nastalo svjetlo; 2. bezobličnost vode koja je u sredini i čini bezdan, jer je, kao što tvrdi Augustin u djelu Protiv Fausta, načinjena od neuređene množine vode; 3. bezobličnost koja čini to da je zemlja koja je bila prekrivena vodom postala

562 Ibid., p. 26: »Et per intendere questo che per nume dell'acqua, secundo Agustino, comperehendemo tucta la materia elementale, perché dicie: spiritus Domini ferebatur super aquas; perché lo humido materiale è principio de ogni mixto, como vole Aristotile nel tertio Del cęlo et mundo, et questo medesimo dicie Robano in glosa sopra l'Exodo [sic!].« / p. 27. O tome da je Kotruljević načinio pogrešku imenujući Maurovu glosu uz Knjigu Izlaska umjesto one uz Knjigu Postanka vidi: Ibid., p. 26 / p. 27, bilješka 9: »Očiti lapsus. Rabanova glosa odnosi se na Knjigu Postanka (v. bilj. 10 uz izvorni tekst).«

${ }^{563}$ Ibid., p. 26: »Alla parte che dice: congregentur aque, pone distintione fra questi dui eleminti, ciò è terra et acqua, delli quali soli parla Moysè, perché quisti dui soli elementi erano de esserno intisi da quillo vulgo primitivo et rude allo qual parlava, perché lu aero non se pò perciepere coscì colli occhi.«/ p. 27.

564 Ibid., p. 26: »Però multi philosophi dissero che 1 llu [prema Falchettinu transkriptu iz 2009. godine treba stajati: »chellu«] aeru non era nulla nominando vacuo quello che era pieno de aere, come aducie Aristotile nello quarto della Phisyca.«/ p. 27: »Zato su mnogi filozofi rekli da zrak nije ništa, nazivajući praznim prostorom ono što je puno zraka, kao što navodi Aristotel u četvrtoj knjizi Fizike.«

565 Ibid., p. 26: »Avengna che de isso aere possemo comprehendere havere facta mentione Moysè quando dixe: et tenebrę erant super faciem abissi, ché per lo abisso intendiamo l'acqua inferiore confusa colla terra et indistincta, per la faccia d'abisso intendemo el corpo dell'aero lo quale era tenebroso nançi della formatione della luce.«/p. 27. 
kopnom. ${ }^{566}$ Kotruljević je, dakle, tumačio Mojsijeve riječi u Knjizi Postanka nastojeći dokazati da iz njih proizlazi razlikovanje elemenata vode, zemlje i zraka, a u svojem se tumačenju ispomogao i naucima Augustina te Aristotela.

Nastavak Dubrovčaninovih prirodnofilozofskih promišljanja o vodama obilježio je govor o dodatnu kriteriju razlikovanja elemenata vode i zemlje koji se odnosi na njihovu sposobnost gibanja. Potaknut, kako tvrdi, zapisima iz drugog poglavlja Augustinovih Komentara uz Knjigu Postanka, Kotruljević je zabilježio da se elementi voda i zemlja razlikuju i po tome što se voda kao tekućina giba, dok zemlja posjeduje stabilnost zbog koje nije podložna nijednoj vrsti gibanja. ${ }^{567}$ Iako je najprije posegnuo za stavom tog srednjovjekovnog mislioca, Kotruljević ga je nastojao osnažiti oslanjanjem na Aristotelov nauk. To je učinio rekavši da Augustinov stav zasigurno odgovara istini, budući da je, prema njegovim spoznajama, to dokazano u drugoj knjizi Aristotelova spisa $O$ nebu i svijetu u kojoj stoji da se sve pokretno temelji na nepokretnome. ${ }^{568}$ Da je Augustin bio u pravu kada je priopćio da se voda razlikuje od zemlje po tome što je njezino gibanje uzrokovano nepomičnošću zemlje, Dubrovčanin je potkrijepio i sljedećim trima tvrdnjama: 1. zemlja je u središtu svijeta kao središte kruga; 2. druge stvorene stvari u stalnom su pokretu; 3. zemlja stoji nepomično, a sva se druga stvorena tijela po njoj gibaju. ${ }^{569}$ Tim trima tvrdnjama dodao je i stavove trojice mislilaca čija je mišljenja o toj tematici očito smatrao suglasnima: Aristotela, Augustina i Ambrozija. Tako je, ako je suditi prema njegovu navodu, iz druge knjige Aristotelova spisa $O$ nebu i svijetu, zatim drugog poglavlja Augustinovih Komentara uz Knjigu Postanka te trećeg poglavlja Ambrozijeva Hexamerona, doznao te potom i zastupao mišljenje da se voda po Božjoj moći nalazi iznad zemlje, kao i mišljenje da se voda zbog svoje naravi, koju joj je dakako podario Bog, giba prema dolje da bi u skladu s Božjim poretkom otkrila zemlju za život drugih živih bića. ${ }^{570}$ Dodatan oslonac u daljnjem obrazlaganju stava da se zemlja i voda razlikuju po

${ }^{566}$ Ibid., pp. 26-28: »Per queste tri cose Moysè mostra tri informità essere levate in quilli tri iorni. A lo cielo pertene la informità delle tenebre, perché inde fo l'origine dellu lume et questa fo la prima formatione. La secunda fo della / acqua la qual è meczana et per nume d'abisso è significata perché importa una inmensità inordinata delle acque, como vole Agustino Contra Fausto. La tertia informità è che ·lla [prema Falchettinu transkriptu iz 2009. godine treba stajati: »ch'ella«] terra fo facta arrida, che prima era cooperta d'acqua. «/pp. 27-29.

${ }^{567}$ Ibid., p. 28: »Augustino pune in questi dui eleminti un'altra diversità, secundo Super Genesis, ciò è all'acqua lo moto della fluxibilità et alla terra stabilità nullo motu imperante.«/ p. 29.

${ }^{568}$ Ibid., p. 28: »<...> la qual cosa è consona alla veritate, como si prova nel secundo De celo et mundo: ut omne mobile super inmobile fundetur, <...>«. / p. 29.

${ }^{569}$ Ibid., p. 28: »<..> perché la terra è nel meço del mundo come lo centro nel circulo. L'altre creature sondo in continuo movimento. Meritamente dunque essa stando ferma, tucte le altre creature corporali se moveno sopra essa, <... > $/$. p. 29.

${ }^{570}$ Ibid., p. 28: »Et per divina virtute l'acqua è sopra la terra et per virtute de sua natura prociedente da Dio è represso lo motu della acqua per discoprire la terra per divino ordine per la vita delli animanti, como prova lu 
kriteriju gibanja, a onda i stava da se gibanje vode i mirovanje zemlje zbiva prema Božjem naumu, Kotruljević je ponovno pronašao u Aristotelovu nauku, ali i u djelima Alberta Velikog. Dubrovački se mislilac poslužio Aristotelovim naukom ne bi li potvrdio uređenost svijeta u skladu s Božjom zamisli, a to je učinio oslanjajući se na neki od navodno postojećih starih prijevoda Aristotelove Metafizike. ${ }^{571}$ Sljedeće vrelo spoznaja dubrovačkog renesansnog mislioca bilo je djelo Meteora Alberta Velikog. Iz njega je, naime, navodno doznao sljedeće stavove: 1. voda je vlažna po naravi; 2. voda okružuje zemlju; 3. voda je zbog vlažnosti nježna, zbog čega može prodrijeti u sve dijelove zemlje; 4. prethodna tri stava zastupao je i Aristotel u drugoj knjizi spisa $O$ rađanju i nestajanju, pri čemu je rekao da voda prodire u dubinu zemlje te se u njoj i zadržava. ${ }^{572}$

Raspravu o temeljnim postavkama o vodama Kotruljević je nastavio dodatnim obrazlaganjem uzroka i naravi gibanja vode. Prema njegovu mišljenju, gibanje vode jest prirodno i odvija se po moći koju joj je dodijelio svemogući Bog, što potvrđuje činjenica da, pritom se ponovno oslanja na spoznaje Alberta Velikog ovoga puta iz jedne od knjiga njegove Metafizike, iako zahvaljujući moći zvijezda i gibanju Mjeseca možemo jasno zamijetiti plimu i oseku mora koje se odvijaju protivno gibanju mora, gibanje tih nebeskih tijela uzrokovano je Božjom moći. ${ }^{573}$ Prirodnost gibanja vode očituje se, bilježi Kotruljević, u tome što je gibanje i djelovanje niže prirode uzrokovano gibanjem više prirode, kao što naučava Aristotel u četvrtoj knjizi spisa $O$ nebu $i$ svijetu. ${ }^{574}$ No, dubrovački mislilac je, barem tako navodi, iz sadržaja djela Alberta Velikog O uzrocima svojstava elemenata doznao da postoje ljudi koji nekim konstelacijama zvijezda pripisuju moć uzrokovanja pojave poplave, dakle pojave

philosophu in secundo De celo et mundo, et Agustino, secundo Super Genesis, et Ambrosio nel tertio del suo Exameron.«/p. 29.

${ }^{571}$ Ibid., p. 28: »Et questo è anchi auctorità de Aristotile nel principio della Metaphisica et secunda la antiqua translatione dicie: quia sic disposuit deus gloriosus et sublimis.« / p. 29: »Svojim autoritetom potvrđuje to i Aristotel na početku Metafizike, koji prema jednom starom prijevodu kaže: 'jer je tako uredio slavni i uzvišeni bog.' «

572 Ibid., p. 28: »Alberto Magno nella sua Metaura dicie che ·ll'acqua [prema Falchettinu transkriptu iz 2009. godine treba stajati: »chell'acqua«] circunda undique la terra per natura del humido, avenga scia più legera / della terra, et circha termino alieno et con ciò scia che 'l humido scia subtile et lo sottile scia penetrativo delle parti et de parte delle parti, como dicie Aristotile in nel secundo De generatione, penetrarà l'acqua nel grosso della terra et contenderasse in essa.«/p. 29.

${ }^{573}$ Ibid., pp. 28-30: »Et nota che 'l moto dell'acqua è naturale datoli da l'omnipotente Dio, la quale cosa è ragionevele perché per virtù delle stelle et per moto della Luna claramente vedemo fluxo et refluxo dellu mare contra proprio moto, multo più per propria virtute de Dio, como recita Alberto in lo libro della sua Metaphisica.«/pp. 29-31.

${ }^{574}$ Ibid., p. 30: »Et quisto moto se dice naturale, perché la natura inferiore obedisce alla natura superiore per lo moto della quale havene l'operatione et lo movimento, como si prova nel quarto De cęlo et mundo.«/ p. 31 . 
samostalnog gibanja i prekomjernog prelijevanja vode preko zemlje. ${ }^{575}$ Uvažavajući mišljenje ljudi uvjerenih u moći zvijezda i njihove utjecaje na pojavu poplave, Kotruljević je istaknuo da bismo ipak točnijom trebali smatrati tvrdnju da je, a prema spoznajama koje je crpio iz Ptolemejeva Četveroknjižja, svaka stvar u Božjoj moći pa tako i svako gibanje zvijezda. ${ }^{576}$ Točnost Ptolemejeve tvrdnje Kotruljević je podupro Augustinovim i Aristotelovim naukom. Prema spoznajama koje je stekao iz trećeg poglavlja Augustinova djela O Trojstvu te iz osme knjige Aristotelove Fizike, Kotruljević je zabilježio stav da se svako gibanje svakog stvorenog elementa odvija prema Božjoj zapovijedi te se, u konačnici, i svodi na nju kao na prvog pokretača. ${ }^{577} \mathrm{U}$ svojim razmatranjima o gibanju kao kriteriju za razlikovanje elemenata vode i zemlje, Kotruljević se, dakle, pozivao na nauke koje su u svojim djelima izložili Aristotel, Ptolemej, Ambrozije, Augustin i Albert Veliki. Sudeći prema učestalosti Dubrovčaninova oslanjanja na njihove nauke, među izvorima njegovih stavova o gibanju vode prednjače Aristotelova i Augustinova djela. Kao što je moguće zamijetiti iz njegova dosad razmatranog sadržaja, prvo poglavlje prve knjige Kotruljevićeva spisa o plovidbi sadrži i raspravu o elementima i njihovu gibanju, a koja nesumnjivo spada u korpus prirodnofilozofskih rasprava. Međutim, valja napomenuti da je dubrovački mislilac nerijetko iskazivao potrebu za naglašavanjem stava da bismo prvim uzrokom trebali smatrati Boga, čiju je ulogu smatrao u potpunosti podudarnom ulozi koju je Aristotel dodijelio svojem prvom, nepokrenutom i nepokretnom pokretaču.

U posljednjem dijelu poglavlja o vodama Kotruljević je ponovno razmatrao tematiku kojom se bavio ranije, a koja se odnosi na postojanje voda iznad i ispod nebeskoga svoda. Dakako, dubrovački je mislilac pritom opet uputio na razlikovanje izloženo na početku Knjige Postanka, a u kojem stoji da je Bog odijelio vode od voda. ${ }^{578}$ Inače, rasprava o tumačenju početka Knjige Postanka te postojanju i naravi voda iznad nebeskog svoda bila je, prema istraživanju američkog stručnjaka za srednjovjekovnu filozofiju prirode i prirodne znanosti Edwarda Granta, vrlo aktualna među srednjovjekovnim crkvenim ocima. ${ }^{579}$ Slijedeći

575 Ibid., p. 30: »Avengna che alcuni adtribuiscono alle virtuti delle stelle che per diversi constellationi se generano alcuna volta li diluvii et allora le acque pro suo proprio moto se moveno sopra la terra $\dagger$ ultra $\dagger$ lo solito, como recita Alberto Magno in libro Proprietatibus elementorum, <...>«. / p. 31.

${ }^{576}$ Ibid., p. $30: »<\ldots>$ ma la prima è più vera, perché in potestate de Dio è ogni cosa / et ogni movimento delle stelle, como dicie Ptholomeo in Quadrupartitu, <... « / p. 31.

${ }^{577}$ Ibid., p. 30: »<..> perché ogni moto de ogni natura creata obedisce allo divino imperio et ad ipso como primo motore se reduce, como vole Agustino in tertio De Trinitate et Aristotile, octavo De fisico auditu.«/p. 31.

${ }^{578}$ Ibid., p. 30: »Trovandose acque superiori et inferiori nella Scriptura et trahemolo da quel dicto Genesis, primo: divisitque Deus aquas ab aquis etc.«/ p. 31.

${ }^{579}$ Edward Grant, »Celestial Orbs in the Latin Middle Ages«, Isis 78/2 (Chicago, 1987), pp. 153-173, na p. 160: »In its theological aspect the idea of the crystalline sphere developed from commentaries on Genesis 1:6-7, 
Augustina koji je, obrazlaže Grant, naglašavao potrebu za doslovnim razumijevanjem biblijskog teksta, a time i zagovarao postojanje voda iznad nebeskog svoda, glavnina kršćanskih autora usuglasila se oko takve interpretacije. ${ }^{580}$ Međutim, od razdoblja patristike pa do kraja Srednjega vijeka nastala su različita tumačenja voda iznad svoda, a zagovornike takvih tumačenja moguće je podijeliti u dvije skupine: skupinu koja ih je smatrala tekućima $i$ skupinu koja ih je smatrala krutima. ${ }^{581}$ Prvoj skupini je, izdvaja Grant, pripadao veći broj mislilaca, kao što su, primjerice, Ambrozije, Ivan iz Damaska, Robert Grosseteste, Richard iz Middletona, Bonaventura i Vincent iz Beauvaisa, dok su drugu skupinu činili Jeronim, Bazilije, Beda, kao i Petar Lombardski. ${ }^{582}$ Potreba za tumačenjem značenja biblijskih voda postojala je, ponovno se oslanjam na Grantove spoznaje, sve do 13. stoljeća, no ona je iščeznula s uvođenjem kozmoloških i astronomskih djela Aristotela i Ptolemeja, kao i djelā mnogih drugih mislilaca tijekom 12. i 13. stoljeća, zbog kojih su nastali pokušaji uvrštavanja voda iznad svoda u novonastalu kozmološku koncepciju. ${ }^{583}$ Primjerice, Vincent iz Beauvaisa, Toma Akvinac i brojni drugi poistovjetili su kristalnu sferu s devetom sferom koja je u Ptolemejevu astronomiju uvedena kao kugla u kojoj ne postoje zvijezde. ${ }^{584}$

Imajući u vidu navedenu raspravu koja je svoj vrhunac dosegnula u 13. stoljeću, a onda i to da je Martinović, podsjećam, treću knjigu Kotruljevićeva spisa o plovidbi okarakterizirao kao onu u kojoj se ogleda Dubrovčaninovo aristotelovsko nadahnuće, nameću se najmanje tri pitanja: kojoj je skupini mislilaca Kotruljević pripadao vezano uz tumačenje naravi nebeskih voda?; Jesu li njegovi stavovi bliži patrističkom, posebice augustinovskom, doslovnom razumijevanju biblijskog teksta ili su, pak, bliži tumačenju koje je u skolastici nastalo nošeno aristotelovsko-ptolemejskom kozmologijom i astronomijom?; Posljedično, ogleda li se aristotelovsko nadahnuće i u prvoj knjizi Kotruljevićeva spisa o plovidbi? Paušalan odgovor na ta pitanja moguće je ponuditi već nakon uvida u rezultate istraživanja poduzetog i

which spoke of a division of waters into those above the firmament and those below. From the time of the church fathers the meaning and significance of the waters above the firmament were much debated."

${ }^{580}$ Grant, »Celestial Orbs in the Latin Middle Ages«, p. 160: »Because the Bible itself spoke of waters above the firmament, Christian authors, following Augustine, were generally agreed on the necessity for a literal interpretation and were therefore committed to the existence of waters of some kind above the firmament.«

${ }^{581}$ Ibid., pp. 160-161: »From the time of the church fathers to the end of the Middle Ages one finds a variety of interpretations of the waters above the firmament. The interpreters divide essentially into two camps: those who thought of them as fluid and those who considered them to be solid and hard.«

582 Ibid., p. 161.

${ }^{583}$ Ibid., pp. 162-163: »Until the thirteenth century most authors were concerned with the need to explain the meaning of the biblical waters. But with the introduction of the cosmological and astronomical works of Aristotle, Ptolemy, and many others in the late twlfth and the thirteenth centuries, we find clear attempts to accomodate the supraheavenly waters to the new cosmology of nested orbs as well.«

584 Ibid., p. 163: »And, finally, Vincent of Beauvais, Thomas Aquinas, and many others identified the crystalline sphere with the ninth sphere that had been introduced into Ptolemaic astronomy as a starless orb.« 
izloženog u potpoglavlju »Benedikt Kotruljević kao poznavalac povijesti filozofije«, dakle uvidom u podatak da se Kotruljević u prvom poglavlju prve knjige De navigatione u najvećoj mjeri oslanjao na Augustinov, a potom na nauk Alberta Velikog. Treba istovremeno imati na umu da je Žarko Dadić izložio pogrešan podatak da se Kotruljević pri govoru o razlikovanju voda nije nijednom oslonio na nauk mislilaca koje je Grant naveo kao predvodnike rasprave o nebeskim vodama. ${ }^{585}$ Štoviše, Kotruljević je svoju upućenost u problematiku nesumnjivo izrazio izdvajanjem različitosti u naucima koje su zastupala barem četvorica mislilaca koje je Grant izdvojio kao predvodnike srednjovjekovne rasprave i kao one koji su zastupali stav da su vode iznad nebeskoga svoda u krutom obliku: Bazilije, Augustin, Beda Časni te Petar Lombardski. Osim na njihove nauke, oslanjao se i na stavove koje su o toj temi izložili Aristotel, Ptolemej i Origen.

Da je dubrovački mislilac bio itekako upoznat sa različitim stavovima pojedinih kršćanskih mislilaca o toj tematici, potvrđuje već tvrdnja da su nauci crkvenih otaca složni oko postojanja takve podjele voda, međutim njihovi se nauci razlikuju prema razumijevanju načina na koji se ta podjela zbiva. ${ }^{586}$ Osim što je ponudio toliko obuhvatnu odredbu, Kotruljević je, kako sam već istaknuo, obrađivao i nauke pojedinih antičkih i srednjovjekovnih mislilaca. Prvi mislilac

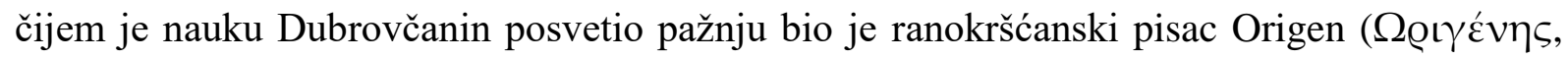
oko 185-oko 254). Iako tom prigodom nije imenovao svoj izvor, Kotruljević je zabilježio da je taj crkveni pisac naučavao o postojanju gornjih i donjih voda, te da je pritom donje vode nazivao demonima kojih je pun zrak koji nas okružuje. ${ }^{587}$ Kada je iznosio obilježja Origenova nauka o razlikovanju gornjih od donjih voda, dubrovački je umnik iznio i jednu pretpostavku o porijeklu Origenova nauka. Uputio je, naime, na mogućnost da je Origena na zagovaranje postojanja demona koji čine donje vode nagnao Platon koji je bića podijelio na dobre i zle demone, pri čemu im je dodijelio različita i odvojena mjesta. ${ }^{588}$

Prva od četiriju potvrda da se Dubrovčanin oslanjao na nauke barem četvorice srednjovjekovnih mislilaca koji su, kao što smo doznali od Granta, bili sudionici rasprave o naravi nebeskih voda pruža njegovo pozivanje na sadržaj Bazilijeva djela Hexameron. To je učinio kada je htio ukazati na to da se Bazilije nije slagao s naukom koji je zagovarao Origen.

\footnotetext{
585 Dadić, »Rukopis Benedikta Kotruljevića De navigatione iz 15. stoljeća«, p. 362.

${ }^{586}$ Cotrullis, »De navigatione«, libro I, capitulo 1 / Kotruljević, »O plovidbi«, knjiga I, poglavlje 1, p. 30: »Et vogliono li doctori che le une acque sciano sopra lu firmaminto, le altre socto lo firmamento, ciò è cielo, et in che modo scia questo, li doctori diversamente ne admaistrano. «/ p. 31.

${ }^{587}$ Ibid., pp. 30-32: »Origenes disse essere le acque superiori [...] Le inferiori acque chiama demonii delli quali è pieno quisto nostro aero. «/pp. 31-33.

${ }^{588}$ Ibid., p. 32: »Et anche forse trasse questa oppione Origenes mosso da Platone, lo qual divise le sustantie separate in calodemini et cachodemini assignando loro diversi lochi.«/ p. 33.
} 
Tada je priopćio da je veliki kapadocijski crkveni naučitelj Bazilije Veliki (B $\alpha \sigma i ́ \lambda \varepsilon 10 \varsigma$, oko 330-oko 379) u svojem Hexameronu odbacio nauk da postoje dobri i zli demoni koji borave na različitim mjestima, tvrdeći da su prema zapisima iz Biblije stvoreni svijet i njegov prirodni poredak načinjeni tako da budu na hvalu, slavu i blagoslov Stvoritelja. ${ }^{589}$ Bazilije je, dakle, zagovarao mišljenje da su vode iznad i ispod nebesa stvorene da bi hvalile i slavile svojeg Stvoritelja, unatoč tome što u donjim vodama borave različita zla. Drugi primjer koji nedvojbeno potvrđuje Kotruljevićevu upoznatost s raspravom o naravi nebeskih voda čini njegovo izravno upućivanje na jedanaestu knjigu Augustinova djela $O$ državi Božjoj. Naime, dubrovački je mislilac zabilježio da se Augustin nije slagao s Origenovim, a onda ni s Platonovim, naukom o postojanju dobrih i zlih demona. ${ }^{590}$ Ako je postojala i najmanja sumnja u Kotruljevićevu upućenost u srednjovjekovnu raspravu o nebeskim vodama, ona bi zasigurno trebala nestati onda kada je Dubrovčanin iznosio očitovanja koja sam odlučio izdvojiti kao treću i četvrtu, dakle pretposljednju i posljednju potvrdu. Ta njegova očitovanja obuhvaćaju mišljenja koja su o toj tematici iznijela dvojica mislilaca koje je Grant također izdvojio kao predvodnike srednjovjekovne rasprave: Beda Časni i Petar Lombardski. Pritom valja napomenuti da je Kotruljević mišljenje koje je zastupao Beda doznao posredstvom djela Petra Lombardskog. Bedino je mišljenje navodno doznao iščitavanjem stavova koje je u jednoj od distinkcija zapisao učitelj Sentencija (lu magistro delle Sententie), kako je u ono vrijeme bilo uvriježeno oslovljavati Petra Lombardskog. ${ }^{591}$ Salopek je, međutim, zamijetio da redni broj distinkcije na koju je tom prigodom uputio Kotruljević ne odgovara trenutnoj razdiobi Sentencija Petra Lombardskog, te napomenuo da je zapravo riječ o sadržaju četrnaeste, a ne trinaeste distinkcije. ${ }^{592}$ Nadovezujući se na prethodno izloženo Augustinovo mišljenje o svodu koji odijeljuje gornje od donjih voda, Kotruljević je priopćio da je Petar Lombardski u trinaestoj, a zapravo u četrnaestoj distinkciji druge knjige svojih Sentencija izložio Bedine stavove o tome da je svod, točnije zvjezdano nebo stvoreno i utvrđeno gornjim te donjim vodama. ${ }^{593}$ Osim toga, dubrovački je mislilac ukazao $\mathrm{i}$ na to da je Lombardski da bi oprimjerio svoje razumijevanje nebeskog svoda posegnuo za primjerom kristala koji ima veliku čvrstoću i prozirnost, a po prirodi je sazdan od vode, a onda i na to da je zagovarao

${ }^{589}$ Ibid., p. 32: »Et questa oppinione reprova Basilio nel suo Exameron demostrando el parole del psalmista et Daniele esserno dicte in quanto creatura considerata et suo congruo ordine della natura ad laude et gloria et benedictioni se inducie dello Creatore.«/p. 33.

590 Ibid., p. 32: »Et questa oppinione induce Agustino, XI De civitate Dei, et pertractandola non multo comenda.«/p. 33.

${ }^{591}$ Ibid., p. 32 / p. 33, bilješka 14.

592 Ibid., p. 32 / p. 33, bilješka 14

593 Ibid., p. 32: »Et però lu magistro delle Sententie, distinctioni XIII, et sondo parole de Beda, dicie che lo firmamento, lo quale è celo siderio, scia facto et dolidato delle dicte acque «. / p. 33. 
mišljenje da je način na koji gornje vode mogu ostati krute, usprkos tome što su tekuće i nepostojane, Bog odredio služeći se sljedećim riječima: »On zatvara vodu u svoje oblake. «594 Zapisi iz prve knjige Kotruljevićeva spisa De navigatione mogu se, dakle, upotrijebiti kao potvrda da je Grant je doista bio u pravu kada je tvrdio da su Beda i njegov poklonik Lombardski bili pripadnici one skupine sudionika srednjovjekovne rasprave o naravi nebeskih voda koji su zagovarali stav da su gornje vode u kristalnom, znači u krutom obliku i da zbog svoje čvrstoće ne propadaju ispod svoda. ${ }^{595} \mathrm{Uz}$ to, ti zapisi opovrgavaju Dadićevu tvrdnju i potvrđuju Kotruljevićevu upućenost u sadržaj spomenute srednjovjekovne rasprave.

Mislioci i stavovi na koje se Kotruljević odabrao osloniti u nastavku prvog poglavlja prve knjige spisa o plovidbi uvelike govore o njegovu stavu o toj tematici, a posljedično i pružaju odgovor na pitanje je li biblijske tekstove shvaćao doslovno ili je bio sklon njihovu tumačenju, kao i spoznaje o stavovima koje je zastupao vezano uz kozmologiju. Naime, odmah nakon što je dokazao da ima uvid i raspolaže znanjima o nauku koji su zastupali Beda i Lombardski, dubrovački je renesansni mislilac imao potrebu razmotriti što bi o njihovim promišljanjima mislio Augustin. Prvi argument koji govori protiv mišljenja koje su zastupala ta dvojica mislilaca nalazi se, bilježi Kotruljević, u drugom poglavlju Augustinovih Komentara uz Knjigu Postanka u kojem je taj srednjovjekovni mislilac tvrdio da su nebo i zvijezde vatrene, a ne vodene prirode. ${ }^{596}$ Kotruljević je potom kao Augustinov drugi argument izložio stav iz prvog poglavlja Komentara da se prilikom određivanja počéla ne bismo trebali upitati o tome što Bog može podnijeti, već o tome što može podnijeti priroda stvari. ${ }^{597}$ Prema Kotruljevićevim spoznajama, Augustin je upravo zbog tih dvaju argumenata korio neke ljude koji su se trudili osporavati razloge filozofā koji su nijekali postojanje gornjih voda zbog njihove težine koja ih prisiljava nadolje, jer je bio uvjeren u to da se voda usprkos svojoj

${ }^{594}$ Ibid., p. 32: $»<\ldots>$ mosso forse per la sua dyafanitate, unde induce lu exemplo dello cristallo lo quale è de grande saldecza et perspicacitate et nulla de mino è facto d'acqua per la virtù della natura. Ma in che modo le acque sopra li cieli se possono consolidaresendo liquide et labile, scripto è de Dio: qui ligat aquas in nubibus celi.«/p. 33.

595 Grant, "Celestial Orbs in the Latin Middle Ages«, p. 161: »Among those who thought of the supraheavenly waters as solid and hard we may include Jerome, Basil, and Bede, who likens the waters to 'the firmity of a crystalline stone' ('cristallini lapidis quanta firmitas'). Peter Lombard was probably aware of Bede's opinion and seems to approve of it in his famous and widely used Sentences, composed in the twelfth century, when he declares that the waters above the heaven are not in a vapory form but suspended by icy solidity (glaciali soliditate) to prevent their fall.«

${ }^{596}$ Cotrullis, »De navigatione«, libro I, capitulo 1 / Kotruljević, »O plovidbi«, knjiga I, poglavlje 1, pp. 32-34: »Ma questa oppinione Agustino nel secundo Sopra Genesis par che reprova: primo, perché pone lo cielo et le stelle esserino de natura de focho et non de acqua, <... $>$ «. / pp. 33-35.

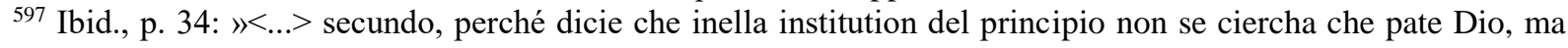
che pate la natura delle cose, $<\ldots>\ll /$ p. 35 . 
prirodi može zadržati iznad svoda uz pomoć Božje svemoći. ${ }^{598}$ Osim toga, Augustinu je, izvještava Dubrovčanin, bilo nezamislivo poricati postojanje voda na nebu zato što je tako zabilježeno u Knjizi Postanka, čiji autoritet daleko nadmašuje naše umske sposobnosti, pa je na primjeru zvijezde Saturn dokazao da ona posjeduje hladnu prirodu zbog blizine gornjim vodama, a trebala bi biti toplija od drugih zvijezda. ${ }^{599} \mathrm{Na}$ važnost koju je Augustinova misao imala za Kotruljevića nedvosmisleno ukazuje i činjenica da se odmah nakon što je izdvojio argumentaciju iz Komentara uz Knjigu Postanka usmjerio na argumentaciju koju je taj srednjovjekovni mislilac izložio u svojem znamenitom djelu $O$ državi Božjoj. Dubrovčanin je, kako kaže, iz jedanaeste knjige tog Augustinova djela izdvojio i drugi dokaz da bi se neka tvar koja je vodene prirode, baš kao što su vode iznad svoda, mogla opirati sili koja je vuče naniže i prebivati u visini. Augustin je, ističe Kotruljević, to dokazao na primjeru flegmatičke sluzi koja bi zbog vodene prirode trebala teći po sredini tijela naniže, dakle trebala bi se nalaziti u donjem dijelu tijela, a nalazi se u glavi, točnije u mozgu, jer joj priliči boraviti u najvišem dijelu duše, a po istom se principu to događa i s gornjim vodama. ${ }^{600}$

Iako bi se prema kolikoći pozivanja na njegov nauk moglo brzopleto zaključiti da je u pristupu tematici nebeskih voda bio isključivi pristaša Augustinova naučavanja, Kotruljević je u razmatranje uzimao i nauke onih mislilaca čija su kozmološka promišljanja izvirala i iz vrela koja nisu teološke prirode. Da je tome tako, potvrđuje činjenica da je nakon izlaganja Augustinova dokaza o suprotnom gibanju flegmatičke sluzi zabilježio stav da taj dokaz ne odstupa od mišljenja koje su zastupali astrolozi i filozofi da se, i to usprkos tome što se nama čini drugačije, stvari gibaju suprotno od smjera kojim bi se po prirodi zbog snage prvoga pokretača trebale gibati. ${ }^{601}$ Identitet ranije spomenutih, ali neimenovanih astrologa i filozofa Dubrovčanin je otkrio u nastavku. Astrolog kojeg je potom imenovao i čijim je naukom potkrijepio prethodno izneseno mišljenje bio je grčki matematičar, astronom, geograf i

\footnotetext{
${ }^{598}$ Ibid., p. 34: „<...> donde reprende alcuni li quali vogliono reprovare la ragione de philosophi li quali negano esserno acque sopra lo firmamento per lo piso loro lu quale pesa ingiù, diciendo questo pò venire per la omnipotentia de Dio.«/p. 35.

${ }^{599}$ Ibid., p. 34: »Et advengna che Agustino reprehenda quisto, tamen et non nega essendo acque sopra li cieli perché la Scriptura nel Genesis lo dicie, la auctorità della quale è multo maiure che la prospicacità del nostro ingingno, et provalo per la stella de Saturno la quale per la sua propinquitate alle acque l'è de natura fredda, la quale deveria essere più calda delle altre. «/p. 35 .

${ }^{600}$ Ibid., pp. 34-36: »Item pone l'altra ragione lo dicto doctore, XI De civitate / Dei, infine de flegma, la quale Greci pituita chiamano, la quale como le cose humide have mo lo suo moto al meço, o vero ingioso, perché quivi predomina la natura aquea, unde lu humor flegmaticho deveria havere locho nella inferior parte dello corpo humano, et è nel capo, ciò è nel celebro, perché gli convene nella più alta virtute della anima et coscì dice essere possibile dell'acqua.«/pp. 35-37.

${ }^{601}$ Ibid., p. 36: »Et questo non è contra la oppinione delli astrologi et philosophi li quali manifestamente dicono et nui vedemo contra, le cose moverse per contrario movimento et è lor naturale per la virtù del primo motore.«/p. 37.
} 


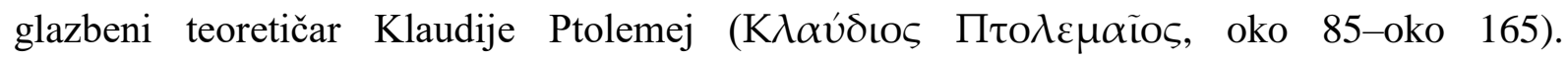
Kotruljević je, kako kaže, iz osmog »dodatka« (aditione) njegova znamenitog djela Almagest doznao da je potvrdu gibanja stvari u suprotnom smjeru od njihove prirode moguće pronaći u gibanju planeta i osme sfere nepomičnih zvijezda. ${ }^{602}$ Osim pozivanja na Ptolemeja, dokaz da Kotruljević nije bespogovorno slijedio Augustinovo učenje o nebeskim vodama, pruža i njegovo oslanjanje na Aristotelov nauk. Nadovezujući se na Ptolemejev stav o suprotnom gibanju planetā i zvijezda, dubrovački ranorenesansni mislilac istaknuo je da, a prema Aristotelovu nauku iz četvrtog dijela združenih spisa $O$ nebu $i$ svijetu, isto vrijedi i za gibanje elemenata u odnosu na nebeska tijela, a što se može oprimjeriti suprotnim gibanjem vode za vrijeme trajanja plime i za vrijeme trajanja oseke. ${ }^{603}$

Usprkos tome što je poznavao i izdvojio stavove koje su zastupali astrolozi i filozofi, a čijim je predvodnicima očito smatrao Ptolemeja i Aristotela, Kotruljević je argumentaciju u raspravi o nebeskim vodama ipak dovršio oslanjanjem na Augustinov nauk. Nastavljajući se na Aristotelov stav o suprotnoj naravi gibanja vode, Dubrovčanin je istaknuo da postoji podudarnost između Aristotelova i Augustinova stava o toj problematici. Ta podudarnost se, bilježi Kotruljević, očituje u tome što je Augustin u djelu Pitanja Oroziju naveo primjer ptica koje se gibaju prema gore usprkos tome što im je tijelo zemaljske naravi, a zbog čega bi se njihovo gibanje trebalo odvijati od sredine prema dolje, kao i primjer vatre koja je u potpunosti lagane prirode, a neprestano boravi na zemlji. ${ }^{604}$ Dodatno uporište za taj stav dubrovački je mislilac pronašao u još jednom primjeru iz Augustinova opusa. Mogućnost gibanja elemenata protivno njihovoj naravi oprimjerio je upućivanjem na obilježja magneta, o kojima je taj srednjovjekovni mislilac pisao u djelu $O$ državi Božjoj. Ta obilježja doznao je, kako bilježi, iz 21. poglavlja tog Augustinova djela, a u kojem stoji da magnet po naravi privlači i zadržava željezo koje usprkos svojoj težini ostaje visjeti u zraku zbog snage magneta. ${ }^{605}$ Potaknut navedenim Augustinovim zapisom, Kotruljević je okončao argumentaciju o vodama koje bi trebale boraviti iznad nebeskog svoda te ponudio vlastito tumačenje i zaključak. Iz cjelokupne rasprave došao je do zaključka da ako je moguće da je

${ }^{602}$ Ibid., p. 36: »Et questo se mostra nelli moti delle pianeti et della octava sphera, secundo Ptholomeo, nella octava aditione de l'Almagesto, et respecto dello orbe superiore, ciò è della octava spera.« / p. 37.

${ }^{603}$ Ibid., p. 36: »Item nelli moti delli eleminti respecto delli corpi cielesti, como recita Aristotile nello quarto De celo et mundo, como nel moto dell'acqua, la qual à fluxo et refluxo, li quali sondo contrarii moti.« / p. 37.

${ }^{604}$ Ibid., p. 36: »Item pone lo dicto doctore Agustino nelle Questioni ad Orosio exemplo doli uncielli como volano nello aero, con ciò scia che in loro è corpo terrestro prędominante, el moto del quale è al meço ingioso, et pone el exemplo del focho lo quale è de natura glieve et tamen perpetuo sta in terra.«/ p. 37 .

${ }^{605}$ Ibid., pp. 36-38: »Et questo medesimo potemo dire della calamita, della qual Agustino nel XXI De civitate Dei narra che de sua natura trahe et suspende lo ferro et essendo grave per la virtù della calamita sta suspeso nello / aeru, <... « / pp. 37-39. 
svemogući Bog dao magnetu takve sposobnosti, koje su nama neshvatljive, trebali bismo više-manje vjerovati da je bio u mogućnosti vodama dati sposobnost lebdenja, kao što je i Zemlji omogućio da visi posred zraka. ${ }^{606}$

U zaključnom dijelu prvog poglavlja prve knjige spisa $O$ plovidbi Kotruljević je pisao o prirodnofilozofskoj tematici poretka četiriju gradivnih elemenata svijeta, a što je prikazao i grafički. Premda postoje mnoge zemlje, primjerice, Afrika, Italija, Germanija, Hispanija, Galija te Britanija, zemlja je, bilježi Dubrovčanin, jedna i stoji u središtu najniže od elemenata. ${ }^{607}$ Počevši od neba, prvi je i najviši element vatra, potom slijedi zrak, treća je voda, a četvrta zemlja. ${ }^{608}$ Doduše, Kotruljević je zapisao da su neki sumnjali u najviši položaj vatre, čak i u njezino postojanje, jer je oku nevidljiva, a filozofi su njihovu sumnju osporavali time što su zastupali stav da vatru ne vidimo zbog zraka koji je gušći element od nje. ${ }^{609}$ Promišljanja o poretku elemenata namjeravao je dovršiti grafičkim prikazom ili, kako kaže, kružnom i sferičnom slikom (figura circulare et sperica) njihova redoslijeda od najvišeg prema najnižem: vatra, zrak, voda, zemlja. ${ }^{610}$

Prema mojim spoznajama, prirodnofilozofska sastavnica prve knjige Kotruljevićeva spisa $D e$ navigatione ogleda se još u njezinu drugom i trećem poglavlju. Nakon što je $\mathrm{u}$ prvom poglavlju obradio tematiku nebeskih (gornjih) voda, Dubrovčanin je drugo poglavlje posvetio tematici zemaljskih (donjih) voda, naslovivši ga »De lo mare in genere« (»Općenito o moru«). Raspravu o toj tematici otpočeo je odredbom mora. More je, bilježi dubrovački umnik, mjesto na koje je Bog zapovijedio da se skupe vode. ${ }^{611}$ Zatim je dodao da je, usprkos tome što razlikujemo i imamo nazive za brojna mora, u općenitom smislu more jedno, i to zbog toga što se sva mora nastavljaju jedno na drugo te se po Božjoj zapovijedi u more slijevaju svi izvori i sve rijeke. ${ }^{612}$ Nakon što je obrazložio razumijevanje mora, Kotruljević je dao do

${ }^{606}$ Ibid., p. 38: »<..> unde, se ·lla [prema Falchettinu transkriptu iz 2009. godine treba stajati: »la«] calamita à virtù dallu omnipotente Dio, specifica ad nui incomprehensibile, quanto più de mino credere, che pò dare alle acque virtù de stare suspese come anche in meço dello aere tene appesa la terra.«/p. 39.

${ }^{607}$ Ibid., p. 38: »Et avegna che multe terre sciano: Africa, Italia, Germania, Hispania, Gallia, Britannia et le altre, una nulla de mino è la terra, la qual sta nel centro più basso delli elimenti, $<\ldots>\ll /$ p. 39 .

${ }^{608}$ Ibid., p. 38: »<...> perché havimo, cominciando dal cielo, lo primo et lo suppremo elemento lo fochu, secundo et lo più soctano l'aeru, lo terço soctano l'acqua, lo quarto et lo più infimo la terra.«/ p. 39.

${ }^{609}$ Ibid., p. 38: »Dubitano alcuni del focho perché nollo videmo, a che respondeno li philosophi che lo focho non se vede da nui, perché lo aero, che sta opposto intra de nui et lo focho, è più grosso elemento che 'l focho, et le cose più dyafane et transparente non se pocçono mirare mediante li corpi più grossi, como se pondo vedere li corpi grossi mediante li corpi dyafani.«/p. 39.

${ }^{610}$ Ibid., p. 38: »Delli quali quattro elementi nui descrivimo qui disocto la sua figura circulare et sperica [...] foco / aero / acqua / terra«. / p. 39.

${ }^{611}$ Cotrullis, »De navigatione«, libro I, capitulo 2 / Kotruljević, »O plovidbi«, knjiga I, poglavlje 2, p. 38: »<L >o locho uno ne lo quale Idio commandò congregare l'acque, $<\ldots$.. «. / p. 39.

${ }^{612}$ Ibid., pp. 38-40: »Avenga che multi sciano li mari, come anche se dicto della terra, come Occeano, Tyreno, Adriatico, Indico, Egiptio, Ponthico, Ionico, Dispontico, Athlantico et delli altri, uno nulla di mino è in genere 
znanja da će tematici mora pristupiti iz perspektive filozofije prirode. Naime, priopćio je da mu je nakana razmotriti gibanje i mjesto donje vode. ${ }^{613}$

Na taj su ga postupak nagnale sljedeće Salomonove riječi iz prvog poglavlja Propovjednika: »odakle teku rijeke, onamo se vraćaju da ponovo počnu svoj tok«, jer je zbog njih posumnjao u to da more nije jedino mjesto na kojem se vode skupljaju, već da se one skupljaju i na nekom drugom mjestu. ${ }^{614}$ Uslijedio je Dubrovčaninov zapis u kojem stoji da je potrebno da se, prema razdiobi gibanja koju je navodno doznao iz prve knjige Aristotelovih spisa $O$ nebu $i$ svijetu, gibanje voda odvija prirodno, a ne prisilno, zbog toga što su vode u neprestanom toku i ponovno se skupljaju na mjestu iz kojega izviru. ${ }^{615}$

Baš kao što je to bio slučaj u obradi nebeskih voda, Kotruljević temi gibanja i mjesta zemaljskih voda nije pristupio jednostrano. To je dao do znanja time što je zapisao da među crkvenim ocima postoje dva različita pravca u razumijevanju gibanja voda. ${ }^{616}$ Zagovornici prvog pravca smatrali su, priopćava dubrovački mislilac, da je gibanje voda dvojako: 1) gibanje iz mora koje se odvija po načelima njegova gibanja, kako svjedoči Sveto Pismo; 2) gibanje koje se odvija podzemnim kanalima do mjesta na koje vode teku. ${ }^{617}$ Premda je, dodaje Kotruljević, drugo gibanje različito od prvoga i doima se suprotnim, ono je također prirodno zbog toga što potječe od višeg pokretača koji može biti ili snaga zvijezda i planeta na putanji kroz pojas zodijaka ili toplina koja privlači pare pomiješane s vodom ili zrak koji se nalazi u zemljanim isparavanjima, zbog kojih se voda giba prema gore u nastojanju da izbjegne prazan prostor. ${ }^{618}$ Kao izvor svojih spoznaja o prirodnosti druge vrste gibanja vode, Kotruljević je naveo komentar uz drugu knjigu Metafizike Alberta Velikog, koji je svoja znanja crpio iz nauka koje su zastupali crkveni oci: Jeronim u Komentaru uz Propovjednika i Izidor u trećoj

però che tucti continuano inseme; ne lo qual conflueno tucti li funti et fiumi per commandaminto della divina parola come nel Genesis«. / pp. 39-41.

${ }^{613}$ Ibid., p. 40: »Et nota che nci è una questione delle acque, quanto allo moto loro et locho«. / p. 41.

${ }^{614}$ Ibid., p. 40: »<...> per le parole di Salamone, Ecclesiastici primo: Ad locum unde exeunt flumina revertuntur ut iterum fluant, et coscì pare per le predicte essere altro locho per le acque che lo prenominato.«/ p. 41.

${ }^{615}$ Ibid., p. 40: »Perché sempre continuo fluxo concorrono allo locho prędicto, bisogna che '1 sia naturale, secundo la sententia d'Aristotile nel primo De celo et mundo, dove asigna la ragione intra lo moto violento et naturale. «/p. 41.

${ }^{616}$ Ibid., p. 40: »Ma circa questa questione li doctori ando dubitati diversamente.«/ p. 41.

${ }^{617}$ Ibid., p. 40: »Alcuni dicono lo moveminto delle acque essere dupplicie: 1'uno dallo mare da lo movimento che se li convene dalli principii proprii, come testa la Scriptura, lo secundo moto è in che modo per le vie subterranee, o vero meati, allo locho / donde flueno; $<\ldots>\ll /$ p. 41 .

${ }^{618}$ Ibid., p. 40: »<... et avenga che '1 moto sia diviso da lo primo et quasi opposito, nulla di mino e si pò chiamare naturale per la ragion de lo superior agente, il perché questo adtribuiscono o vero alle virtù delle stelle et delli pianeti nello circulo obliquo, o vero al color trahente li vapori ammixti all'acqua per evitare lo vacuo si move insuso.«/p. 41. 
knjizi Etimologija. ${ }^{619}$ Kotruljević je u nastavku obrazložio stavove koje su zagovarali pripadnici drugog pravca u razumijevanju gibanja donjih voda. Ti mislioci tvrdili su, izvještava Dubrovčanin, da povlačenje mora na mjesta rijeka, dakle pod zemlju, nije gibanje koje je moru svojstveno zbog njegove kolikoće, već zbog naravi gibanja elementa vode od koje je sačinjeno, dakle prema dolje. ${ }^{620}$ Svoje su mišljenje potkrijepili time što su bili uvjereni da iste vode nastaju ispod i iznad zemlje, jer kao što se pare uzdižu u zrak snagom Sunca i preostalih elemenata te se zbog njihove brojnosti i zgušnjavanja stvaraju kapi vode, tako se i vodene pare pod zemljom uzdižu unutar zemlje zbog topline koja nastaje gibanjem nebeskih tijela i koja privlači paru. ${ }^{621}$ Tako nastale pare unutar zemlje, nastavlja Kotruljević s prepričavanjem njihove argumentacije, izdižu se oko mjestā na zemlji koja su sklona isparavanjima, posebice oko planina gdje su ta mjesta čvrsta, šupljikava i hladna, te nastaju kapljice i, ovisno o količini, tvore rijeke. ${ }^{622}$ Dubrovački je mislilac potom ukazao na to da se to mišljenje pripisuje Aristotelu, koji je, navodno, u drugoj knjizi Metafizike zapisao da jednako kao što se iznad zemlje od mnoštva kapljica iznad zemlje stvara kiša, tako se zbiva i pod zemljom. ${ }^{623}$ Svoju priklonjenost tom Aristotelovu stavu Kotruljević je izrazio potkrepljivanjem vlastitim iskustvom kojim je potvrdio da na visokim i brdovitim mjestima nastaje najveća količina voda, a ne u ravnicama, što bi trebao biti slučaj kada bi vode proizlazile iz mora. ${ }^{624}$ Sklonost Aristotelovu stavu, a onda i misliocima koji su zastupali Aristotelov nauk, Kotruljević je izrazio i time što je, unatoč tome što nije naveo izvor svojih spoznaja, priopćio da je jednakog mišljenja bio i Toma Akvinac. ${ }^{625}$

Dubrovčanin je potom odlučio ukazati na to da postoji još jedno obilježje vode kao elementa. $\mathrm{Na}$ to ga je ponovno potaknuo nauk Alberta Velikog. Naime, Kotruljević je zaključio da vode imaju snažnu sklonost primati svojstva zemlje, a na koju djeluju Sunce i preostali elementi,

${ }^{619}$ Ibid., p. 40: »Della quale oppinione fo Alberto Magno nello commento sopra lo secundo della Metaphisica et have invitato li doctori antichi della Ecclesia li quali dicono questo, come Ieronimo Sopra l'Eclesiaste et Isidero nello tertio libro Ethimologiarum.«/p. 41.

${ }^{620}$ Ibid., p. 42: »Altri dicono lo contrario, che quisto regresso dello mare alli lochi delli fiumi socto terra e non sia di quillo in numero ma in specie, $<\ldots>\ll /$ p. 43.

${ }^{621}$ Ibid., p. 42: $\gg \ldots .>$ ché quelle medesime acque se generono sotto terra como sopra terra et questo per la elevantione delli vapori, unde dicono che, como se levano li vapori nello aieru per virtù del sole et delli altri eleminti et nello aere per constrictione de quilli vapori se generano gotte et de multe gotte congregate si fanno acque, coscì anchi li vapori sotto terra aquosi se elevano infra la terra per lo calore atrahente lo vapor generato per lo moto de corpi cielesti.«/p. 43.

${ }^{622}$ Ibid., p. 42: »E tal vapori, elevati circha li lochi della terra vaporosi et specialmente circha li monti dove sondo li lochi sollidi et spongiosi et compressi per lo fredo, quivi generano giocciole et de multe giocciole generate ne derrivano fiumi secundo el maior et minor congregatione, $<\ldots>\ll /$ p. 43.

${ }^{623}$ Ibid., p. $42: »<\ldots>$ et questo adtribuiscono ad Aristotile, lo qual par che questo dicha nel secundo della Me/taphisica, el quale dice, como de multe giocciole se genera la plugia, coscì anche infra la terra.«/p. 43.

${ }^{624}$ Ibid., p. 42: »Et questo se mostra perché in lochi alti et muntuosi si generano più acque et deveria essere lo contrario, ché, si dallo mare uscisseno, più si trovariano ne li piani.«/ p. 43.

${ }^{625}$ Ibid., p. 42: »Et de questa oppinione fo sancto Thoma d'Aquino, <... « / p. 43. 
što je, kako tvrdi, doznao iz Albertova djela Mineralia, premda ga je nazvao De lapidibus ( $O$ kamenju). ${ }^{626}$ Iz tog je Albertova djela navodno doznao da postoje tri primjera mjesta na kojima se događalo da se ili oborinske vode pretvaraju u kamenje te da se drveće bačeno u vodu pretvara u koralj (Pirineji) ili da se stvari koje upadnu u more pretvaraju u kamenje crvenkaste boje (Dansko more pokraj grada Lübecka) ili da se sve stvari koje se umoče u izvor postaju kamen (Götaland, južna Švedska). ${ }^{627}$

Nakon rasprave o naravi gibanja donjih voda, Kotruljević se vrlo kratko usredotočio na pitanje o mjestu donjih voda. Baš kao i na početku poglavlja, odgovor na pitanje o mjestu donjih voda Dubrovčanin je pronašao u Salomonovim riječima iz Propovjednika. Zbog toga je zaključio da je more pravo mjesto voda, jer je Salomon tvrdio: "Sve rijeke teku u more, i more se ne prepunja «. ${ }^{628}$ Salomonove je riječi potom osnažio naukom crkvenog oca Aurelija Ambrozija (Aurelius Ambrosius, 337/339-397) iz trećeg poglavlja njegova djela Hexameron, a u kojem je Ambrozije ukazao na prikladnost voda za život ljudi sljedećim stavom: »Voda potrebnom vlagom hrani zemlje, kojima kroz nekakve žile skrovito podaje vrlo koristan sok. $\ll^{629}$

Prirodnofilozofski sloj drugog poglavlja prve knjige spisa o plovidbi nalazi se i u završnom dijelu poglavlja. U njemu je, naime, dubrovački renesansni mislilac izložio svoje znanje o površini i zakrivljenosti mora. Prema njegovim spoznajama, more ima kružnu površinu i okružuje zemlju, premda je, prema Božjoj zapovijedi, zemlja otkrivena i predviđena

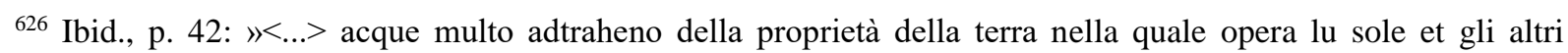
eliminti, come recita Alberto Magno in libro De lapidibus«. / p. 43.

${ }^{627}$ Ibid., pp. 42-44: »<...> et dicie experto essere in montibus Pireneis alcuni lochi nel quali le acque pluviali se converteno im• [prema Falchettinu transkriptu iz 2009. godine treba stajati: »im《] petre coscì li lingni giectati in alcune acque et mari si converteno im· [prema Falchettinu transkriptu iz 2009. godine treba stajati: »im«] petre et tegnono la figura de quilli ligni, et lo signo de questo è lo corallo, lo qual sença dubio de lingi et piante se ingienera. Et dicie che in nel tempo suo ne lo Mare Danico iuxa civitatem Lubiciensem fo trovato uno ramo grande de arbore nel quale era lu nido delli cielli et cielli piccoli nel nido et tucto era diventato im. [prema Falchettinu transkriptu iz 2009. godine treba stajati: »«] pietra pocho tendente al russo, la qual cosa non potiva essere facta altramente si non che l'arbore fo extirpato per onde et procelle nel tempo che in essa era lu nido et li cielli cadevano ne l'acqua et poi, per la virtù dellu lochu nel quale iacieva, im· [prema Falchettinu transkriptu iz 2009. godine treba stajati: »im《] pietra ogni cosa fo conversa. Et dicie lo dicto Alberto essere uno fonte in Gothia et tucte le cose che sse- [prema Falchettinu transkriptu iz 2009. godine treba stajati: »ch'esse«] buctano dentro deventa pietra, intanto che l'imperator Federico mandò uno guante sigillato che provasse. Lo qual guanto, essendo submerso per alcuni giorni la / mità d'isso et la mità del segillo, et la mità dello guanto tornò petra, restanta la mità della ciera et la mità dello guanto.« / pp. 43-45.

${ }^{628}$ Ibid., p. 44: »Chiaramente dunque appare lo mare essere proprio locho delle acque, como dice Salamone ne l'Ecclesiaste: Omnia flumina intrant in mare et mare non redundat, $<\ldots>\ll /$ p. 45.

${ }^{629}$ Ibid., p. 44: »<...> mare fosse proprio locho delle acque, come dicie Ambrosio nel tertio dello suo Exameron mostrando la comodità delle acque alla vita humana: Aqua terras necessario suffulsit amore, quibus per venas quasdam occulte haud utilem sucum subministrat.«/p. 45. 
isključivo za to da bi pružila ljudima mjesto za život. ${ }^{630}$ Da je more zaobljeno, iako se zbog velikog opsega kružnice doima ravnim, dokazuju i astrolozi služeći se, priopćava Kotruljević, sljedećim primjerom: potrebno je postaviti kladu u more za vrijeme bonace te barkom otploviti u suprotnom smjeru, a ubrzo nakon toga kladu više neće biti moguće uočiti, međutim tada se samo potrebno uspeti na jarbol $\mathrm{i}$ ona će ponovno biti vidljiva. ${ }^{631}$ Prema Dubrovčaninovim spoznajama, neki »tumačitelji perspektive« (»li prospectivi«) pronalaze uzrok gubljenju klade iz vida u tome što oko može gledati samo ravno, a more je zaobljeno. ${ }^{632}$ U preostalom dijelu prve knjige spisa o plovidbi, dubrovački se renesansni mislilac usmjerio na opis pojedinačnih mora koja sačinjavaju donje vode, što znači da ostatak prve knjige otkriva razloge zbog kojih je Martinović tu knjigu svrstao među oceanopise. Međutim, i u tom se dijelu prve knjige ispoljava njezin prirodnofilozofski sloj. Prema mojoj procjeni, to je uočljivo u njezinu trećem poglavlju, dakle u poglavlju naslovljenom »Dello mare Occeano in genere« (»Općenito o Oceanu«), a u kojem je Dubrovčanin obrađivao jedno od ishodišnih mora i nazivao ga Oceanom.

Prisutnost filozofije prirode u tom poglavlju moguće je zamijetiti već na njegovu početku. $\mathrm{Na}$ tom je mjestu, premda je propustio otkriti vrelo svojih spoznaja, opisao utjecaje koje nebeska tijela ostvaruju na gibanje četiriju elemenata. Mjesečev krug uzrokuje da se, bilježi Kotruljević, voda uzdiže iz Oceana kao svojeg pravog mjesta i pada u obliku kiše, baš kao što i Sunčev krug djeluje na vatru, zatim krug zvijezda stajačica na zemlju te kao što Večernjača i ostale zvijezde pokreću zrak. ${ }^{633}$ Osim tih, treće poglavlje prve knjige sadrži i Dubrovčaninova znanja o plimi i oseki. Iako Kotruljević ni tom prilikom nije imenovao svoj izvor, raspolagao je znanjima o tome da je Ocean dobio ime po obodu pojaseva, jer ga poput oboda okružuje pet zemaljskih pojaseva između arktičkog i antarktičkog pola, a to je i prikazao u spisu o

${ }^{630}$ Ibid., p. 46: »L'ambito dellu mare è circulare, como disopra havemo dicto, et circunda circum circa la terra non obstante lo habitaculo nostro scia remaso per divino iudicio, como se dicto, discoperto per dare lu habitaculu alli homini; <..> $>/$ p. 47.

${ }^{631}$ Ibid., p. 46: $»<\ldots>$ et che lu mare scia ritondo, se prova per li astrologi non obstante che per la amplixima circumferentia del compasso paria ad nui piano, [...] Provano li astrologi la rotundità del mare per exemplo materiale, ut puta: micti uno zocho dentro lo mare quando lo mare ene im. [prema Falchettinu transkriptu iz 2009. godine treba stajati: »im«] piana boriacia et tu intra in una barchecta et voltate allo in dericto, tu venerai ad perdere de vista lo çocho, et volendolo rividere sença tornarevi più innançi, monta su lu arbore et lo vederai, perché lo globo dellu mare te levava la vista de quello çocho, [...] Et chiaro è che quello / çocho non se perdeva per la longna distantia, perché tu lu rividi più da longa, ma el si perdeva per globo dellu mare. Coscì vedemo ogni iurno avenire delle vele che pareno che nolle vedemo del basso se non montano so ne lo alto.«/p. 47.

632 Ibid., p. 46 / p. 47.

${ }^{633}$ Cotrullis, »De navigatione«, libro I, capitulo 3 / Kotruljević, »O plovidbi«, knjiga I, poglavlje 3, p. 48: »Lu circulu della Luna infra li altri elimenti fa ascendere l'acqua da l'Occeano dellu lochu proprio et descendere im. [prema Falchettinu transkriptu iz 2009. godine treba stajati: »im«] plogie, come fa lo circulu del Sole nel focho et la spera delle stelle fixe in terra et Vespere et delle altre stelle moveno lo aeru. $/$ p. 49. 
plovidbi: 1. hladni pojas, 2. umjereni pojas, 3. žarki pojas, 4. umjereni pojas i 5. hladni pojas. ${ }^{634}$ Kada su u pitanju Dubrovčaninove daljnje spoznaje o utjecajima nebeskih tijela na četiri gradivna elementa svijeta, dakle spoznaje iz područja astrologije, one se očituju u njegovim razmatranjima o pojavama plime i oseke ili o, kako ih tom prigodom oslovljava, nadolaženju i povlačenju vode (accesso et recesso). Naime, plima i oseka se, bilježi Kotruljević, zbivaju uslijed djelovanja Mjeseca, koji ili usisnom snagom privlači ili potisnom snagom odvlači vodu od sebe, a to čini dvaput dnevno. ${ }^{635}$ Rast ili opadanje razine vode odvija se po načelu reciprociteta ovisno o rastu ili smanjivanju veličine Mjeseca, dok se, dodaje Kotruljević, u slučaju ravnodnevnice u Oceanu podižu veliki valovi, zbog čega za vrijeme Mjesečeva izlaska nastaje oceanski vrtlog koji stvara još veće valove i oluju. ${ }^{636}$ No, Kotruljević je raspolagao znanjima o pojavi oceanskog vrtloga i to bilo iz nekog nepoznatog izvora bilo iz vlastitog iskustva. Zapisao je, primjerice, da se taj vrtlog ili oluja naziva Ocean baga, zatim da nastaje svakih pet godina, onda da upija sve vode i snijegove te da, $u$ konačnici, ne lomi valove jer nastaje u Oceanu koji je izrazito dubok. ${ }^{637}$ Uz Ocean se, bilježi Dubrovčanin, mogu pronaći brojna mjesta puna pećina te brojne spilje u kojima se zbog usisavanja mora stvaraju vjetrovi, a koji svojim puhanjem privlače morske vode kroz pećine koje se šire u zemlji, zbog čega vode koje naviru silnim nastajima istjeruju vjetrove. ${ }^{638}$ Podrobnije spoznaje o spomenutim silovitim vjetrovima i posljedicama njihova nastanka i puhanja, Kotruljević je, barem kako tvrdi, doznao od Alberta Velikog (come recita Alberto Magno). Dubrovački je mislilac tako zabilježio da nastanak silovitih vjetrova u pećinama uzrokuje potrese, jer vjetrovi zatvoreni u udubljenim mjestima potresaju zemlju jakom trešnjom i uzrokuju njezino podrhtavanje. ${ }^{639}$ Osim toga, raspolagao je i sljedećim znanjima: 1.

${ }^{634}$ Ibid., p. 50: »Dicto è ancora Occeano quasi çonarum limbus perqué cinque çone del mundo in mudo del limbo circunda: polus arthicus / frigida zona / temperata zona / torrida zona / temperata zona / frigida zona / polus antharticus «. / p. 51.

${ }^{635}$ Ibid., p. 50: »Et Occeano se chiama uno accesso et recesso sequita la luna colla aspiratione della quale si trahe in dirieto et con inpulso dalla quale se refunde, perché ogni dì dui volte correre et recorrere si vede.«/p. 51.

${ }^{636}$ Ibid., p. 50: »Quando la luna cresce, lui cresce; quando la luna mancha, lui mancha; quando la luna è in equinocio, magior onde crescono nel mare Occeano. La voragine ne l'Occeano fa magior onde et tempestate nello exorto della luna.«/p. 51.

${ }^{637}$ Ibid., p. 50: »Questa voragine, la qual tucte le acquę et nevi resorbe, chiamasi Occeano mare de baga, perché quasi ogni cinque anni appare certa fortuna la quale se chiama baga et gli hommini dellu paese la cognoscono davanti che lla [prema Falchettinu transkriptu iz 2009. godine treba stajati: »ch'ella«] venga per multi anni, perché lu mare rivolgie certe baghe soctosopra. Et quistu mare per la sua profundità non rompe le onde, ché, se lle [prema Falchettinu transkriptu iz 2009. godine treba stajati: »selle«] rompesse, non se porria navigare.« / p. 51.

${ }^{638}$ Ibid., pp. 50-52: »Iuxta questo mare sondo lochi cavernosi et spelunche late patente, nella quale per le aspirationi delle acque si concepeno venti [...] et quisti per lo suo spirare traheno le acque dello mare per le caverne patente della terra dentro et innunante l'acque con grande impetu le discacciano. «/ pp. 51-53.

${ }^{639}$ Ibid., p. 52: »De questi venti se generano terremoti, come recita Alberto Magno, perché li venti inclusi in lochi conchavi non potendo oscire concoteno la terra con horribili tremori et fandola tremare; <... « / p. 53. 
podrhtavanje zemlje uzrokuje procjepe u zemlji, jer se udubljena i lomljiva mjesta zbog djelovanja vode i snage vjetrova urušavaju te uništavaju brojne gradove; 2. potres na zemlji jednak je grmljavini u zraku, zbog čega smo svjedoci tome da su potresi redovito popraćeni pojavom poplave na moru; 3. zbog svega navedenog otok Sicilija, budući da je ispunjen pećinama, posvuda izbacuje vatru i dim te velikom snagom vjetra izbacuje kamenje. ${ }^{640}$

Završetak trećeg poglavlja prve knjige Kotruljević je također posvetio temi pripadnoj filozofiji prirode. Opća razmatranja o Oceanu odlučio je okončati obrazlaganjem uzroka još jednog od obilježja tog mora: njegovu slanost. Nažalost, i tom je prilikom propustio imenovati izvore svojih spoznaja. Nakon što je objasnio pojavu da Ocean ne raste od kolikoće riječne, dakle slatke vode koja se u njega ulijeva i koju zadržava, Kotruljević je ustvrdio da Ocean također zadržava i svoju slanost. ${ }^{641}$ Tome je tako, bilježi Dubrovčanin, jer se tanki sloj slatke vode zbog manje gustoće nalazi na površini mora pa se zbog blizine Suncu isušuje, dok gušći i gorči dio mora ostaje dolje i čini Ocean slanim. ${ }^{642}$ Spoznajama o slanosti voda i razlikama u njihovoj gustoći Kotruljević je, također ne imenujući vrelo, pridodao i podatak o tome da se Mjesec hrani slatkom, a Sunce gorkom vodom. ${ }^{643}$ More se, dodaje Dubrovčanin, provlači kroz skrivene žile u zemlji i odlaže svoje gorčinu u nju, a slatka voda izbija u izvorima i vraća se natrag u more. ${ }^{644}$ Nakon toga je ponovio Salomonove riječi o gibanju donjih voda na koje se oslanjao i u prethodnom poglavlju, a koje su ukazivale na to da se rijeke vraćaju na mjesto s kojeg su potekle, dakle u more, sa svrhom da ponovno otpočnu svoj tok. ${ }^{645} \mathrm{Na}$ kraju razmatranja općih obilježja Oceana priopćio je i to da su »stari filozofi« (»li antichi filosophi«) smatrali da se zvijezde hrane u Oceanu. ${ }^{646}$

${ }^{640}$ Ibid., p. $52: »<\ldots>$ et da quilli anchi nasce lo hiato et apertioni della terra, per/ché li lochi concavi et fragili per le continue acque concussi dalli venti se rompono et cascano indentro, et fasi hiato per lo qual multe cità se sondo submerse et devorate. Lo terremoto in terra è como lo trono inello aero et vedemo che collo terremoto nascono et fannosi inundationi nello mare infuso de quillo spiritu o veramente nel suo grembo recievute. Et però Cicilia insula, la quale è cavernosa, quasi per tuctu eructa fochi et fumi, perché lo spiritu certando con lo focho fa la vampa et fumo, et multe volte per força magior de vento erupta petre «. / p. 53.

${ }^{641}$ Ibid., p. 56: »Lo Occeano non accresce per lo curso delli fiumi, perché le fiumare parte se consumano nelli vadi falsi, o venti, o vapori de lo sole, et parte per occulti meati retornano in sui fiumi; et però dura salso non obstante scia irrigato dalli fiumi dulci, perché per la caldeça dello sole se brugia et de acqua tenue, $<\ldots>\ll$. / p. 57.

${ }^{642}$ Ibid., p. 56: $»<\ldots>$ perché per la caldeça dello sole se brugia et de acqua tenue, la qual per la levità sua più facilemente la trahe lo sole et lassane la più grossa parte et più aspera la fa divintar salata. Et però la sumità del mare è più dolce, et la più profunda è più amara.«/p. 57.

${ }^{643}$ Ibid., p. 56: »E lo alimento / de la Luna è nelle dolcie acque et del Sole l'amare.«/p. 57.

${ }^{644}$ Ibid., p. 56: »Et lo dicto mare per occulte vene della terra discorre et dipone la amaritudine ne la terra et le dolcie erumpe nelli fonti et nello mare poi retorna, <... ««. / p. 57.

645 Ibid., p. 56: »<...> como è scripto: allo locho donde escono li fiumi retornano ut iterum fluant. Secundo quello: omnia flumina intrant in mare, <... « / p. 57.

${ }^{646}$ Ibid., p. 58: »E li antichi filosophi pensorno che $\cdot$ lle [prema Falchettinu transkriptu iz 2009. godine treba stajati: »le«] stelle pascono ne l’Occeano.«/p. 59. 


\subsubsection{Filozofija prirode u trećoj knjizi spisa o plovidbi}

Kao što sam već istaknuo, prirodnofilozofska sastavnica u spisu De navigatione prisutna je u prvoj i trećoj knjizi. Ipak, to ne znači da u preostalim dvjema knjigama Kotruljevićeva traktata o plovidbi nema ni spomena tema koje pripadaju filozofiji prirode, već znači da su u njima te teme zastupljene $\mathrm{u}$ mjeri zbog koje ne zavređuju biti obrađene $\mathrm{u}$ zasebnom potpoglavlju ovoga rada. Kada je riječ o drugoj knjizi spisa, dakle o knjizi u kojoj su najzastupljenija razmatranja o vrstama plovilā, njihovim dijelovima te članovima posade, $u$ njoj Dubrovčaninov interes za prirodnofilozofske teme nipošto nije iščeznuo. Da bih to potvrdio, izdvojit ću tek nekoliko primjera iz njezina sadržaja koji potvrđuju da je smatrao da astronomsko-astrološka, medicinska, meteorološka i alkemijsko-kemijska, dakle prirodnofilozofska znanja imaju značajnu ulogu za praktičnu izvedbu plovidbe. Primjerice, Kotruljević je u prvom poglavlju druge knjige upozorio na to da su znanja o zvijezdama, znači astronomsko-astrološka znanja, bila jedini oslonac za plovidbu od njezinih začetaka, te da su se tim znanjima služili i u njegovo vrijeme, ali su se zbog bolje točnosti uvela i pomorska pomagala, kao što su karte i kompasi. ${ }^{647} \mathrm{U}$ trećem je poglavlju tumačeći vrste galija upotrijebio i znanja medicinske naravi. Prema njegovu uvjerenju, obje vrste galija, male i velike, moraju biti dobre jedrilice i još bolje veslarice, a poteškoće koje to uzrokuje brodskim tesarima prilikom postizanja ravnoteže usporedio je s odnosom slezene i jetara: ono što je korisno za jetra štetno je za slezenu, kao i obrnuto. ${ }^{648} \mathrm{U}$ nastavku poglavlja poslužio se znanjima iz iskustva vrsnih brodskih tesara o djelovanju nebeskih tijela na promjenu fizikalnih svojstava tvari. Upozorio je, naime, na to da se utjecaj koji Sunčeve zrake ostvaruju na drvnu građu, koja se upotrebljava za izgradnju galija, očituje u promjeni svojstava drveta na način da ona strana galije koja je izložena Sunčevu zračenju postaje lakša, zbijenija, otpornija na vodu i izdržljivija, dok strana koja boravi u sjeni zadobiva suprotna svojstva pa

${ }^{647}$ Cotrullis, »De navigatione«, libro II, capitulo 1 / Kotruljević, »O plovidbi«, knjiga II, poglavlje 1, p. 96: »Et coscì roçamente erano facte le navi, coscì roçamente navigando havendo solamente reguardo alle stelle, [...] sì che per tucto andavano errando sença carta, sença bossola.«/p. 97.

${ }^{648}$ Cotrullis, »De navigatione«, libro II, capitulo 3 / Kotruljević, »O plovidbi«, knjiga II, poglavlje 3, p. 102: $»<\ldots>$ che le une se chiamano galee grosse, galeaçe o vero galee de mercanthia, le altre galee soctili, le quali le une et le altre non se fando sença grande mesura, perché queste hando ad havere dui conditioni le quali sonno quodam modo contrarii dentra di loro, come la milça et lo fecato, ché quello che è bono allo fecato è contrario alla milça recontra. Coscì è di bisogno che la galea sia bona velera et miglior rimera, et questo non tanto consiste inel iusto compasso quanto anchi in la qualità et è qualità dello lengame, lo qual è non de gravare più uno latu che l'altro; <... « / p. 103. 
postaje teža, rijeđa, manje otporna na vodu i smanjene izdržljivosti. ${ }^{649}$ Treće poglavlje druge knjige otkriva i to da je dubrovački mislilac bio upoznat i s, primjerice, osnovama alkemije ili kemije, jer, kao što je Salopek naznačio u bilješci, u to vrijeme nije postojalo razlikovanje alkemije od kemije. ${ }^{650} \mathrm{U}$ skladu s njihovim nerazlikovanjem u Kotruljevićevo doba, znanja koja danas pripadaju astronomiji i astrologiji odlučio sam skupno nazivati astronomskoastrološkim, dok sam ona znanja koja danas pripadaju alkemiji i kemiji odlučio skupno nazivati alkemijsko-kemijskim. Ističući nužnost mornareva poznavanja pomorske terminologije ne bi li odisao iskustvom, zabilježio je da bi se neiskusnim doimao onaj alkemičar ili kemičar koji ne bi raspolagao znanjem, primjerice, o tome da pod imenom Merkurija treba podrazumijevati živu, zatim pod imenom Sunca zlato te pod imenom Jupitera srebro. ${ }^{651}$ Dakle, iako temama pripadnim filozofiji prirode nije posvetio obilje prostora $\mathrm{u}$ drugoj knjizi, dubrovački ranorenesansni mislilac ipak nije propustio ukazati na važnost $i$ korisnost prirodnofilozofskih znanja za praktičnu izvedbu plovidbe.

O trećoj knjizi spisa De navigatione može se reći da je njezin cjelokupan sadržaj posvećen tematici koja pripada filozofiji prirode. Na ovom ću mjestu podsjetiti tek na dva zaključka koja su o njoj iznjedrila istraživanja Ivice Martinovića: 1) treća je knjiga »prirodnofilozofski spis aristotelovskog nadahnuća« ${ }^{652}$ 2) trećom knjigom otpočela je »blistava hrvatska dionica renesansne prirodne filozofije« ${ }^{653}$ Prevladavajuća vrela Kotruljevićevih spoznaja u toj knjizi činila su, kako bilježe Martinović i Balić, Aristotelova Meteorologika te drugi prirodnofilozofski spisi, zatim Senekini Quaestiones naturales, potom prvi latinski komentar Aristotelove Meteorologike, dakle Meteora, te Mineralia Alberta Velikog. ${ }^{654}$ Treću knjigu Dubrovčaninova spisa o plovidbi sačinjava čak dvadeset poglavlja u kojima je Dubrovčanin izložio svoja prirodnofilozofska razmatranja. U njima je tako ponudio brojne te opširne opise

${ }^{649}$ Ibid., pp. 102-104: »Io ò multo examinati li boni maistri et non trovò ragion che scrivere se poça, se non che dicono che quella parte della galea, che sta verso lu sole, diventa più legera et più calchata et quella diventa più dura alle acque et più regiente; quella che sta verso la umbria fa lo contrario.«/ pp. 103-105.

${ }^{650}$ Ibid., p. 106 / p. 107, bilješka 129: »Isto ono što je rečeno za 'astrologiju' (v. bilj. 6) vrijedi i za 'alkemiju' i 'alkemičara': ovaj je izraz u Kotruljevićevo vrijeme podjednako obuhvaćao i kemiju i alkemiju u današnjem smislu riječi."

${ }^{651}$ Ibid., p. 106: ॥Scì che intraviene necessariamente lo marinario sappia quisti nomi, ché altramente el non pare hagia dello pradicho, perché questo modo de parlare fa parire lo marinaro essere pradicho, / come intervene ancho de l'alchimia, ché bisogna intenda lo Mercurio per argento vivo, Sole per oro, Iove l'argiento etc. Altraminti non pare alchimista et coscì delle altre discipline.«/ p. 107.

${ }^{652}$ Martinović, »Književni žanrovi hrvatskih filozofa od Stojkovića do Boškovića«, p. 108.

${ }^{653}$ Martinović, "Žanrovi hrvatske filozofske baštine od 15. do 18. stoljeća«, p. 74. Isto vidi u: Martinović, Žanrovi hrvatske filozofske baštine od 15. do 18. stoljeća, p. 17.

${ }^{654}$ Martinović, »Žanrovi hrvatske filozofske baštine od 15. do 18. stoljeća«, pp. 73-74. Isto vidi u: Martinović, Žanrovi hrvatske filozofske baštine od 15. do 18. stoljeća, p. 16. O tome da su Kotruljevićeva vrela bila spisi Meteora i Mineralia Alberta Velikog te da je Albert Veliki bio najčešći izvor treće knjige spisa vidi u: Balić, »Vrste plovilā u Kotruljevićevu udžbeniku plovidbe«, pp. 66-67; Balić, »Izvori Kotruljevićeve filozofije prirode u De navigatione (1464)«, p. 21. 
i tumačenja pojava meteorološke naravi, zatim razmatranja tema iz astronomsko-astrološkog korpusa, a među kojima se nalaze i njegove spoznaje o takozvanoj astrološkoj medicini. Od pojava meteorološke naravi izlagao je o vjetrovima, dúgi, halou, krugu ili alothethi, nebeskoj strijeli ili munji te vatrama koje silaze iz zraka. Kada je riječ o razmatranjima astronomskoastroloških tema, obradio je problematiku dvanaest znakova zodijaka, svojstva sedam planeta, solsticije i ekvinokcije, kao i mjerenje vremena. Budući da je opširno raspravljao o pregršt pojava i razmatrao brojne teme, u dvama potpoglavljima koja slijede usmjerit ću se tek na one meteorološke pojave i astronomsko-astrološke teme koje su ga najviše zaokupljale i koje prevladavaju u trećoj knjizi. Prvo potpoglavlje odnosit će se na Kotruljevićeva razmatranja meteoroloških pojava, dok će se drugo ticati njegovih promišljanja o astronomsko-astrološkim temama.

\subsubsection{Meteorološke pojave u trećoj knjizi spisa o plovidbi}

Od meteoroloških pojava koje je obuhvatio sadržajem treće knjige, dubrovački mislilac je, a kao što je već utvrdio Martinović, najviše pozornosti posvetio vjetrovima, točnije njihovim uzrocima, obilježjima te ulozi u plovidbi. ${ }^{655}$ Da će u toj knjizi središnja tema biti upravo vjetrovi, Kotruljević je dao do znanja već u njezinu predgovoru. U njemu je naglasio da vjetrovi omogućavaju plovidbu, jer vode naša jedra (conduciere questa nostra vela), štoviše da su vjetrovi najvažniji dio plovidbe (la potissima parte ne la navigatione). ${ }^{656}$

Sustavno izlaganje o vjetrovima Kotruljević je započeo u prvom poglavlju treće knjige »O postanku vjetrova« (»Della generatione delli venti«). U njemu je pisao o postanku i prestanku vjetrova. Ne skrivajući podatak da svoje spoznaje temelji na sadržaju treće knjige spisa Meteora Alberta Velikog, najprije je izložio razlikovanje dviju vrsta suhe pare koje se izdižu iz zemlje. Prva od njih je, kako piše, zasebna, dok je druga umiješana u vlažnu paru. ${ }^{657}$ Kotruljević je zatim izložio razlikovanje dviju vrsta zasebne suhe pare, pri čemu je opisao pojave uzrokovane nastankom tih para. Prva vrsta zasebne suhe pare je rijetka (subtile), koja se izdiže u zrak i uzrokuje njegovo gibanje, a druga je gusta (grosso), koja se zadržava u

\footnotetext{
${ }^{655}$ Martinović, »Žanrovi hrvatske filozofske baštine od 15. do 18. stoljeća«, pp. 73-74. Isto vidi u: Martinović, Žanrovi hrvatske filozofske baštine od 15. do 18. stoljeća, p. 16.

${ }^{656}$ Cotrullis, »De navigatione«, libro III, prohemium / Kotruljević, »O plovidbi«, knjiga III, predgovor, p. 136 / p. 137.

${ }^{657}$ Cotrullis, »De navigatione«, libro III, capitulo 1 / Kotruljević, »O plovidbi«, knjiga III, poglavlje 1, p. 138: $»<\mathrm{N}>$ ellu vapore seccho el qual se leva dalla terra se gienera uno vapore absoluto et l'altro involuto nello vapore humido, secundo vole Alberto Magno al tertio libro della sua Metaura: <...> «. p. 139.
} 
utrobi zemlje. ${ }^{658}$ Svojim izdizanjem u zrak i sudarom s hladnoćom, rijetka zasebna para stvara vjetar, dok gusta, boraveći u utrobi zemlje, stvara potres. ${ }^{659}$ Kada je riječ o pojavama koje uzrokuje druga vrsta suhe pare, dakle pare koja je umiješana u vlažnu, Kotruljević je zapisao da takva para stvara ili uzrokuje gromove i munje. ${ }^{660}$ Preostali dio poglavlja odnosi se na detaljan opis nastanka, slabljenja te prestanka vjetra. Kotruljević je pritom ponudio tri odredbe izdignute rijetke zasebne pare u sudaru s hladnoćom: 1) ona je korijen, ishodište i načelo postojanja vjetrova; 2) ona je gradivo vjetrova i načelo njihova puhanja; 3) ona je materija vjetra. ${ }^{661}$ Potom je obrazložio svaku od tih odredaba. Prvu od njih temeljio je na tome što rijetka zasebna para u sudaru s hladnoćom prolazi zrakom, nakon čega se zbog hladnoće zgusne i snažno potisne zrak stvarajući vjetar. ${ }^{62}$ Drugu je temeljio na tome što kolikoća vjetrova odgovara kolikoći izdignute rijetke zasebne pare, a prestanak njezina izdizanja uzrokuje prestanak vjetrova. ${ }^{663}$ Treću je pak temeljio na tome što nakon prestanka vjetra Sunce svojim zalaskom stvara skrivenu vlagu, čije isparavanje stvara paru koja je po djelovanju topla, a po sposobnosti vlažna. ${ }^{664}$ Izdizanjem i sudarom takve pare s hladnoćom, nastaje voda i kiša, što uzrokuje slabljenje vjetra otežavanjem i onemogućavanjem izdizanja rijetke zasebne pare koja je njegova materija. ${ }^{665}$

Drugo i četvrto poglavlje treće knjige spisa Kotruljević je posvetio razmatranjima o nastanku, broju i obilježjima vjetrova. U drugom poglavlju najprije je, a što je naznačio u naslovu poglavlja »O broju vjetrova prema navodima starih« (»Dellu numero delli venti secundo gli antiqui«), izložio znanja kojima su o osobinama vjetrova raspolagali, kako ih naziva, »stari«

${ }^{658}$ Ibid., p. 138 / p. 139.

${ }^{659}$ Ibid., p. 138: $»<\ldots>$ et lo subtile absoluto pertingente l'aere, quando se ripercote dallo fredo, fa lo vento, e lo grosso residente nelle viscere della terra fa terremoto. «/p. 139.

${ }^{660}$ Ibid., p. 138: »Involuto nello vapore humido genera troni et baleni.«/ p. 139.

${ }^{661}$ Ibid., p. 138: »Aduncha, la radice et la orrigine delli venti è vapor lo qual salglie della terra, come se dicto, et lo principio dello essere suo <et> nasciere de quello; [...] Donque, lo vapore elevato è corpo dellu vento et principio dellu suo fiato, et la radicie in nella quale se aradicha lo suo essere, et la materia de esso vento. «/p. 139.

${ }^{662}$ Ibid., p. 138: »<..> et la materia sua è lo vapore lo qual è freddo et siccho, per la subtilitate sua trasciendente l'aere. Et quando se inspissa per la frigidità dello aere, fortimente caccia l'aere. «/p. 139.

${ }^{663}$ Ibid., p. 138: »Questo se cognosce, perché la quantità delli venti è secundo la quantità delli / vapori che salleno dalla terra et dalla acqua, perché si multi sonno li vapori, multi sonno li venti, et si pochi sonno li vapori, pochi sonno li venti. [...] Et però dapoi lo motu suo fiata lo vento et movese secundo la quantità dello vapore seccho; <...>«./ p. 139.

${ }^{664}$ Ibid., p. 138: »<...> et quando se leva la evaporatione de tal vapori, reposa lo vento et serenato lo tempo se desciende lo sole et fa la humidità occulta [...] in essa possa evaporare per lo vapore lo qual è in acto caldu et in potentia humido; <... $>$ «/ p. 139.

665 Ibid., p. 138: »<..> et è vapore aqueo lo qual allora saglie nellu aeru, et quando ne lo aere lo scontra lo freddo, se altera in acque et piove, et allora per la plogia se repusa lu vento, perché la humidità della plogia grava lo vapor sicco lo qual è in lo aere et continuo infredando la terra non la lassa vaporare lo vapor terrestre lo qual multiplica la materia dello vento, ciò è la plogia, perché humecta la terra et mancha la materia dello vapor siccho lo qual è materia del vento.«/p. 139. 
(»gli antiqui«). Poslužio se, kako kaže, spoznajama Marka Terencija Varona, Seneke i Izidora iz Sevilje, koji su istaknuli da prema zapisima starih autora postoji dvanaest različitih vjetrova. ${ }^{666}$ Stari su vjetrove razlikovali prema smjeru gibanja, pri čemu su, tvrdi Kotruljević, četiri vjetra smatrali glavnima (li principali venti). ${ }^{667}$ Jedan od njih puše s istoka i zove se subsolan ili levant, drugi puše s juga i zove se auster, treći puše sa zapada i zove se favonij, dok četvrti puše sa sjevera i zove se septentrion. ${ }^{668}$ Svakom od njih pridružena su, nastavlja Dubrovčanin, dva vjetra sa svake strane. ${ }^{669}$ Subsolanu ili levantu s desne strane puše vulteran, a s lijeve eur; austeru s desne strane puše euroauster, a s lijeve austerafrik; favoniju s desne strane puše afrik, a s lijeve kor; septentrionu s desne strane puše circij, a s lijeve akvilon. ${ }^{670}$

U nastavku drugog poglavlja Kotruljević je iznio etimologiju nazivlja vjetrova, a onda i njihova obilježja prema mišljenju »starih«. Subsolan je dobio naziv po tome što nastaje ispod sunca, eur po zori, jer nastaje na istoku, a vulteran po tome što visoko huji. ${ }^{671}$ Naziv auster nastao je, prema latinskoj etimologiji, po tome što srče vodu, dok su ga Grci nazivali not, jer su smatrali da prenosi kugu s juga prema sjeveru. ${ }^{672}$ Euroauster i austerafrik svoje su nazive dobili po susjednim vjetrovima euru i afriku te, dakako, po austeru. ${ }^{673}$ Austerafrik na grčkom ima, zapisuje Kotruljević, dva naziva. Prvi je libonot, po tome što su Grci afrik nazivali lips, a auster not, dok je drugi naziv zefir dobio po tome što cvijeće i trave ožive njegovim puhanjem. ${ }^{674}$ Favonij je, prenosi Kotruljević mišljenje »starih«, naziv dobio po tome što goji i hrani ono što izlazi iz zemlje, dok je afrik dobio ime po tome što započinje puhati u Africi. ${ }^{675}$

${ }^{666}$ Cotrullis, »De navigatione«, libro III, capitulo 2 / Kotruljević, »O plovidbi«, knjiga III, poglavlje 2, p. 140: $»<\mathrm{V}\rangle$ arro, astronomo diligente, et Seneca et Isidoro mecteno XII venti essere in numero secundo gli antiqui «. / p. 141.

${ }^{667}$ Ibid., p. 140 / p. 141.

${ }^{668}$ Ibid., p. 140: »< ..> lo uno vene dallo oriente et chiamase subsolano, ciò è levante, quia sub sole; da meço giorno vene austro; da ponente favonio; da septentrione vento del dicto nome. «/p. 141.

${ }^{669}$ Ibid., p. 140: »Chiaschesuno de quisti à dui venti da qua et dal là congiunti: < ..> «. / p. 141.

${ }^{670}$ Ibid., p. 140: »<..> subsolano o vero levante dallo latu dextro hane vulterano, dallo sinistro auro; austro dalla dextra hane euroaustro, dalla sinistra austroaffrico; favonio dalla dextra hane, ciò è verso meço giorno, africo, dalla sinistra verso aquilone hane choro; septentrione hane dalla dextra verso ponente circio, dalla sinistra verso levante hane aquilone.«/p. 141.

${ }^{671}$ Ibid., p. 140: »Subsolano se chiama secundo Isidoru, perché nascie socto gli raçi dellu sole in equinoctiali et dicitur quasi sub sole. Eurus, perché da eos, id est oriente vene. Vulturnus, eo quod alte tonat, <...>«./p. 141.

${ }^{672}$ Ibid., p. 142: »Auster dicitur quasi austum, eo quod aurit aquam. Et questo in greco se chiama nothus secundo li antiqui, perché alcuna volta genera pestilentia et però interviene più delle volte che, essendo mortalità $o$ vero pestilentia sopravento dalla parte meridionale, lo vento australe la reporta verso lo polo artico, $<\ldots>\ll /$ p. 143.

${ }^{673}$ Ibid., p. 142: »Euroaustro se chiama, perché dall'una parte hane euro, dall'altra austro. Austroaffrico simili modi, perché dall'una parte hane austro et dall'altra affrico.«/p. 143.

${ }^{674}$ Ibid., p. 142: »Et questo [austroaffrico] se chiama bibinotus, qo quod sit elipis, id est hinc inde notus. Çefiro in greco se chiama, perché li fiori et le herbe se vivicano per lo fiato suo. Zea enim in greco este vivere latine, $<\ldots>\ll$. / p. 143.

${ }^{675}$ Ibid., p. 142: »Favonius, perché fove et nutrica quello esce della terra. Africo, perché frequentemente in Africa piglia lu principio dello suo fiato.«/p. 143. 
Kor, koji još nosi nazive kaur i argest, svoj naziv duguje tome što djeluje kao da zatvara i privlači »krug vjetrova ${ }^{676}$ Septentrion je dobio naziv po tome što puše sa sjevera, točnije jer, kako navodi Kotruljević, dolazi od Malog Medvjeda gdje sedam zvijezda kruži oko sjevernog pola ${ }^{677}$ Circij je dobio naziv po tome što je združen s korom i ima njegov učinak, dok je akvilon, koji se ponekad naziva borej, dobio naziv po tome što veže i steže vode te raspršuje oblake. ${ }^{678}$ Međutim, stari su, dodaje Kotruljević, među glavnim vjetrovima razlikovali i dva stožerna vjetra (li venti cardinali), zbog toga što nastaju na mjestima gdje vjetar najjače puše i zbog toga što najčešće pušu u određeno godišnje doba. ${ }^{679}$ Prvi je septentrion, koji puše u proljeće i jesen, a njegova su obilježja hladnoća i suhoća. ${ }^{680}$ Uzrok takvim obilježjima nalazi se u tome što nastaje na najhladnijim sjevernim mjestima blizu voda koje ne isparavaju, kao i $\mathrm{u}$ tome što ne prolazi toplim krajevima. ${ }^{681}$ Kada je riječ o drugom stožernom vjetru austru, Kotruljević je izložio njegova obilježja, no propustio je navesti u koje godišnje doba najčešće puše. Prema njegovim zapisima, auster je topao, vlažan i silovit vjetar. ${ }^{682}$ Takav je zbog toga što nastaje u južnim krajevima, koji su topli i suhi, ali tijekom gibanja prema sjeveru prikuplja vlažnu paru i stvara kišu, te istodobno jača prikupljanjem tople i suhe pare iz zemlje. ${ }^{683}$ Osim

${ }^{676}$ Ibid., p. 142: »Choro, el quale fiata pon<en>nte, eo quod circulum ventorum quasi claudit et ad se trahit; quisto dalli antiqui era chiamata cauro et da multi se chiama vento argeste.«/p. 143.

${ }^{677}$ Ibid., pp. 142-144: »Septentrione se chiamava, perché vene dalla Ursa Minore dove VII stelle tereno lo circulo circa lu polo aquilonare.«/ p. 145.

${ }^{678}$ Ibid., p. 144: „Cirçio, perché l'è congiunto ad choro et hane alcuno suo effecto. Aquilone se chiama, perché liga le acque et stringe, et dissipa le lovule; et questo alcuna volta se chiama borreas dallo locho dove nascie, perché fiata da Yperborei monti.«/p. 145.

${ }^{679}$ Ibid., p. 144: »Intra li quali venti, avengna che quattro se chiamano li principali, nulla de mino dui sonno li venti cardinali, ciò è septentrione et haustro, perché nasceno in lochi dov'è lo magior fiato de vento et cierti tempi de l'anno fiatano frequentemente, <... « / / p. 145.

${ }^{680}$ Ibid., p. 144: $»<\ldots>$ perché nello auctumpno et primavera fiata septentrione; et questo è vento freddolo et sicco: $<\ldots>\ll$. / p. 145.

${ }^{681}$ Ibid., p. 144: $»<\ldots>$ et l'è [septentrione] freddo perché nascie in lochi frigidissimi dove se generano acque frigidissime / in aquilone, le quali acque non vaporano et però lo vento remane quivi friddo et siccu et puro; et nascie nelli monti alti li quali multo distano da nui et quelli monti sonno friddi, sotto li quali se rinso in longo spacio se congrega, et però è freddo. Li lochi per li quali fiata non sonno caldi et però nulla se ·lli [prema Falchettinu transkriptu iz 2009. godine treba stajati: »li«] accosta delli vapori elevati ma pervene ad nui puro.«/ p. 145.

${ }^{682}$ Ibid., p. 146: »Austro, ciò è meço giorno, è caldo et humido, lo qual à fiato vehemente.«/ p. 147.

${ }^{683}$ Ibid., p. 146: »Ell'è caldo non de natura de vapore ma de natura dello locho donde veno, perché ogni vento è de natura / freddo et secco, ma casuale è, perché lo exito dello fiato suo è principio della elevatione della materia sua dalli lochi meridionali li quali sonno caldi et sicchi secundo la sua natura. Et cominciando a fiatare per lo locho diventa caldo, et perché è caldo et aperitivo et resolutivo, et solve la materia dalla pocha rosada, et perché lo locho è sicco dove nascie, non pò prestare multo humore, ma lo fiato procedente, con ciò scia che al continuo li se accosta più et più della humidità dello locho per lo quale è prociesso lo fiato suo, trova lu locho verso septentrione più humido; et perciò che è più e più caldo dallo locho, allora apre più l'acqua et la terra, et trahe lo vapor humido continuo alla plogia, et lo vapor caldo et secco quasi al suo nutrimento della terra.«/p. 147. 
toga, njegovo puhanje, baš kao i puhanje drugih toplih vjetrova, uzrokuje i potiče nastanak tmurnih i gustih oblaka. ${ }^{684}$

Podsjetivši na to da je u drugom poglavlju izložio znanja o broju vjetrova kojima su raspolagali »stari filozofi« (li antiqui philosophi), Kotruljević je u četvrtom poglavlju, na što upućuje i njegov naslov »O broju vjetrova i o vjetrulji prema navodima suvremenih« (»Dellu numeru delli venti et della bossola $<$ de $>$ moderni $\ll)$, njihova znanja usporedio sa znanjima »suvremenih« (moderni). Usprkos takvoj najavi, Kotruljević nije u potpunosti ostvario cilj koji si je zadao već u naslovu poglavlja. Naime, iz sadržaja poglavlja moguće je doznati tek znanja koja je pripisao neimenovanim »suvremenim mornarima«. ${ }^{685}$ Jedini imenovani autor kojega je moguće sa sigurnošću ubrojiti u njegove suvremenike bio je talijanski pjesnik Antonio Beccadelli zvan Panormita (1394-1471), kojega je Kotruljević smatrao najslavnijim pjesnikom svojega doba (lo clarissimo della età nostra poeta). ${ }^{686}$ Pri usporedbi znanja starih sa znanjima suvremenih, Dubrovčanin je istaknuo da se, iako su stari smatrali da postoji dvanaest vjetrova, u vjetrovnici (la bossola) njegova vremena nalazi osam glavnih vjetrova (VIII venti principali) ${ }^{687}$ Kao što možemo doznati iz pojašnjenja koje je u bilješci uz hrvatski prijevod iz 2005. godine ponudio Salopek, Kotruljević je pod tih osam vjetrova vjerojatno podrazumijevao četiri stožerna (venti cardinali) i četiri međustožerna vjetra (venti intercardinali). ${ }^{688} \mathrm{U}$ stožerne vjetrove trebali bismo, dodaje Salopek, ubrojiti levant, oštro, pulenat i tramuntanu, a u međustožerne šiloko, lebić ili garbin, maestral i grego. ${ }^{689}$ Kotruljević je potom zapisao da se između tih vjetrova nalaze međuvjetrovi (li mezzanini), dok se između vjetrova i međuvjetrova nalaze vjetrovi koji se nazivaju četvrtine (le quarte). ${ }^{690}$ Sveukupno, dakle, postoji trideset i dva vjetra, od kojih osam glavnih vjetrova (četiri stožerna

\footnotetext{
${ }^{684}$ Ibid., p. 146: »Et però sempre al continuo ingrossa lo fiato et gli fiati caldi adducono più de novule turbide et spesse. «/p. 147.

${ }^{685}$ Cotrullis, »De navigatione«, libro III, capitulo 4 / Kotruljević, »O plovidbi«, knjiga III, poglavlje 4, p. 150: $»$ La qual sciencia è sola nelli moderni marinari experti nella arte, $<\ldots>\ll$. / p. 151.

${ }^{686}$ Ibid., p. 150: »La qual oppinione sequendo lo clarissimo della età nostra poeta laureato Antonio Panormita «. / p. 151.

${ }^{687}$ Ibid., p. $150 /$ p. 151.

${ }^{688}$ Ibid., p. 150 / p. 151, bilješka 193: »Iskaz: između vjetrova $i$ vjetra u sredini nije posve jasan i čini se suvišnim nakon prvog dijela rečenice. Razrješenje je moguće ako se pretpostavi da je na citiranome mjestu Kotruljević pod izrazom vjetrovi možda podrazumijevao četiri stožerna vjetra (venti cardinali) [...] a pod izrazom vjetar u sredini, neki od četiriju međustožernih vjetrova (venti intercardinali)«.

${ }^{689}$ Ibid., p. 150 / p. 151, bilješka 193.

${ }^{690}$ Ibid., p. 150: »Et intra li dicti venti sonno li meçanini intra venti et vento in meço, poi intra ogni vento e lo suo meçanino ci è l'altro vento, lo qual per tucto se chiama la quarta et non à altro nome.«/p. 151 .
} 
i četiri međustožerna), osam međuvjetrova i šesnaest četvrtina. Kotruljević je kao razlog takvom iscrpnom razlikovanju naveo preciznost pri usmjeravanju plovidbe. ${ }^{691}$

Osim iz spomenutih poglavlja, Kotruljevićeve spoznaje o vjetrovima možemo doznati iz još dvaju poglavlja treće knjige. Kotruljević je tako, primjerice, u trećem poglavlju obradio vjetrove koje je nazvao nestalnima (li venti erratici), dok je u devetom poglavlju razmatrao vrtložni vjetar (lo vento turbine). Prilikom izlaganja spoznaja o nestalnim vjetrovima i o vrtložnom vjetru, navodno se ponovno uvelike oslonio na sadržaj Albertova spisa Meteora. $\mathrm{Na}$ Alberta se izrijekom pozvao kada je izlagao spoznaje o razlikovanju dviju vrsta nestalnih vjetrova. Zapisao je da se razlikuju dvije vrste nestalnih vjetrova, pri čemu jedna vrsta češće puše uz morsku obalu i naziva se povjetarac (aura), dok druga vrsta češće puše na moru i naziva se autino ili imbato ili, kako tvrdi po uzoru na Alberta Velikog, altan. ${ }^{692}$ Kotruljević je potom najavio da je podatke o nestalnim vjetrovima doznavao i iz Senekina djela Quaestiones naturales (Prirodoznanstvena pitanja). Od Seneke je navodno doznao da pojedine vrste vjetrova češće pušu u nekim područjima, a ovisno o tome mogu poprimiti obilježja hladnoće, topline, suhoće i vlažnosti. ${ }^{693}$ Kada je riječ o Kotruljevićevim spoznajama o vrtložnom vjetru koje je izložio u devetom poglavlju, prvi od podataka koji je o njemu ponudio bio je da takav vjetar izlazi iz oblaka poput munje i groma, ali s većim naletom. ${ }^{694}$ Karakterističan je za ljeto, a kada se pojavi vitla slamu, prašinu i druge predmete sa zemlje. ${ }^{695}$ Vrtložni vjetar nastaje tako što se, tvrdi Kotruljević, dva oblaka otvaraju na suprotnim mjestima i iz njih pušu vjetrovi koji se potom sukobljavaju i vuku prema zemlji. ${ }^{696}$ Tijekom sukoba omataju se jedan oko drugoga i podižu u vis predmete sa zemlje. ${ }^{697}$ Tom prilikom Kotruljević je napomenuo da

${ }^{691}$ Ibid., p. 150: »Et tucti [venti] in numero sonno XXXII, li quali sonno tanto stricti adnumerati non per altro si non per più a ponto cartegiare al mectere della prua.«/p. 151 .

${ }^{692}$ Cotrullis, »De navigatione«, libro III, capitulo 3 / Kotruljević, »O plovidbi«, knjiga III, poglavlje 3, p. 148: $»<\mathrm{D}>$ elli venti erratici uno è più frequente nella ripa dellu mare et l'altro nello mare. In nella ripa per la debilità sua se chiama aura, quasi aereo fiato. In nellu mare quando fiata, se chiama secundo Alberbo Magno altanus quillo che nui diciemo autino o vero imbato. «/p. 149.

${ }^{693}$ Ibid., p. 148: »Et è da sapire che, advenga che tanti sciano li venti, tamen in alcuni regioni sogliono più fiatere l'uni venti che l'altri, come narra Seneca in libro De naturalibus questionibus, che in Gallia trahe circio più che nesciun altro, in Germania occidentale favonio, iusta li monti che -sse [prema Falchettinu transkriptu iz 2009. godine treba stajati: »chesse «] chiamano Alpi septentrione et in Mare Adriatico euro et euroastro. Et secundo le regioni sonno freddi, caldi, sicchi et humidi.«/p. 149.

${ }^{694}$ Cotrullis, »De navigatione«, libro III, capitulo 9 / Kotruljević, »O plovidbi«, knjiga III, poglavlje 9, p. 184: $»<\mathrm{C}>$ ome lo fulmen o vero sagiepta e lo trono, per quello medesimo modo escie lo vento de turbine da la novula, ma com• [prema Falchettinu transkriptu iz 2009. godine treba stajati: »con«] più grande impitu.«/p. 185.

${ }^{695}$ Ibid., p. 184 / p. 185.

${ }^{696}$ Ibid., p. 184: »Fasi quello vento perché se apre la novula in uno locho et altra per opposito ad altra parte, et quelli dui venti concorrono nel meço, et l'uno et l'altro de quelli è cacciato et caccia non in alto ma in terra. «/ p. 185.

${ }^{697}$ Ibid., p. 184: »Et per modo de circulo se retondano involgiendo insieme, saleno ad alto, tirano seco la polvere et corpi legieri.«/p. 185. 
je mišljenje »svih peripatetičara« (tucti quanti peripatetici) da taj vjetar najčešće nastaje uslijed hladnog ljeta za vrijeme grmljavinskog nevremena i da najavljuje grmljavinu za nekoliko dana ${ }^{698}$ Ukoliko je vrtložni vjetar jak, nastavlja Kotruljević, grmljavina će uslijediti već za nekoliko sati. ${ }^{699}$ Ukoliko nastaje zimi, nastaje za snježnog vremena i traje samo nekoliko sati. ${ }^{700}$

Praktičnu primjenu teorijskih spoznaja o uzrocima i obilježjima vjetrova, Kotruljević je otkrio i u petom poglavlju naslovljenom $\gg \mathrm{O}$ predviđanju nevremena« (»Delli pronostichi delli temporali«). Na njegovu početku istaknuo je da u težak dio plovidbe spadaju prepoznavanje predznaka gibanja nebeskih tijela, kao i sposobnost pretpostavljanja njihova gibanja, dakle sposobnost prognoziranja. ${ }^{701}$ Najavivši da svoje spoznaje temelji na mišljenjima koja su izrekli »filozofi, astrolozi i mornari« (de philosophi et de astrologi et de marinari), ${ }^{702}$ Kotruljević je izložio brojne primjere meteoroloških pojava povezanih s vjetrovima. Ovom prilikom izdvojit ću po dva primjera pojava koje uzrokuju vjetrovi, te onih koje su predznak nastanka vjetrova. Pri izlaganju primjerā pojava koje su uzrokovane vjetrom i onih koje su predznak nastanka vjetra, Kotruljević nije skrivao da se poslužio spisom Meteora Alberta Velikog. Iz njega je, priznaje Dubrovčanin, doznao da oluje nastaju kada se pri gibanju oblaka razvijaju jaki suprotni vjetrovi. ${ }^{703}$ Tako nastale oluje međusobno se sudaraju, isprepliću i uzburkavaju more. ${ }^{704}$ Kao drugi primjer naveo je nemirno vrijeme i kišnu oluju uzrokovane puhanjem oštra ili šiloka, dakle južnog ili jugoistočnog vjetra. Osim što se njihovim puhanjem more uzburka, događa se, dodaje Kotruljević, $\mathrm{i}$ to da se sredina neba razvedri, a njegovi krajnji dijelovi ostaju oblačni. ${ }^{705}$ Mornari su tu pojavu nazivali »tonzurom«, jer svojim

${ }^{698}$ Ibid., p. 184-186: „Oppinione de tucti quanti peripatetici et sententia è: quando la state è multo fredda, è tempo de troni et significa che 1 lli [prema Falchettinu transkriptu iz 2009. godine treba stajati: »li«] troni serranno presto infra pochi giorni; <... « / / p. 185-187.

${ }^{699}$ Ibid., p. 186: »<..> et si lu turbo è forte, non sequitano troni se non una hora o vero dui o meça.«/p. 187.

${ }^{700}$ Ibid., p. 186: »Et se si fa de inverno, è tempo de neve, perché novule nivose multo hanno in sé dello spiritu d'aere. Lo dicto vento non dura se non per pocha hora.«/p. 187.

${ }^{701}$ Cotrullis, »De navigatione«, libro III, capitulo 5 / Kotruljević, »O plovidbi«, knjiga III, poglavlje 5, p. 154: »Difficile parte de questa nostra navigatione è a cognoscere li signi et li pronostichi delli movimenti cielesti.« / p. 155.

702 Ibid., p. 154 / p. 155.

${ }^{703}$ Ibid., p. 154: »Alberto Magno nella sua Metaura pone che, quando nello alto per lo movimento delle novule appareno li venti forti oppositi, dicono li marinarii che significa tempestate per la oppositione delli venti, <...>«./ p. 155.

${ }^{704}$ Ibid., pp. 154-156: »<..> perché allora le procelle non havono libero fluxo ne lo mare per la oppositione delli venti, ma più tosto dui procelle scontrandose inseme se sullevano et remescolano, et affanneno le nave ché lo mare se gonfia.«/pp. 155-157.

${ }^{705}$ Ibid., p. 158: »Quando l'ostro o vero sciloccho fanno turbulento tempo et lo mare è agitato da dicti venti et fa fortuna con ploggia; et alcuna volta schiariscie lo meço del cielo remanente le extreme parte dello cielo nubilo, se significa che lo tempo è da durare et maxime quando repusa aliquantulum lu vento; < ... $>$ «. / p. 159 . 
oblikom podsjeća na srednjovjekovnu frizuru. ${ }^{706}$ S̆to se tiče pojava koje su predznak vjetrova, kao prvi primjer izdvajam zapise o nebeskoj dùgi ili iridi. Prema Kotruljevićevim spoznajama, mjesečeva se dùga uvijek pojavljuje noću i predznak je dugotrajnog nevremena obilježenog nestabilnim vjetrovima. ${ }^{707}$ Razlog zbog kojeg mjesečeva dùga najavljuje takve vremenske prilike, nalazi se u tome što se tijekom njezina nastanka nakuplja velika količina vlage u južnom i zapadnom vjetru. ${ }^{708}$ Drugi primjer nalazi se u razmatranjima o pojavi koja se naziva halo, krug ili alothetha. Napominjući da su Aristotelovi zapisi o toj pojavi vrlo zbunjujući (multo confuso), Kotruljević je zabilježio da je bolje rješenje posegnuti za sadržajem Senekina djela Prirodoznanstvena pitanja. ${ }^{709}$ Iz njega je, kako kaže, doznao da su mirovanje i samostalno raspršivanje prstenova koji čine krug predznak mirnog vremena, dok je njihovo pucanje s jedne strane predznak da će vjetar puhati upravo iz tog smjera. ${ }^{710}$

Irida ili nebeska dúga sljedeća je pojava meteorološke naravi kojoj je Kotruljević odlučio posvetiti zasebno poglavlje treće knjige svojega spisa naslovljeno »O iridi odnosno nebeskoj dugi« (»De yride o vero archo celestiale«). To, šesto poglavlje treće knjige Kotruljević je otpočeo etimološkim pojašnjenjem naziva te pojave. Naime, Dubrovčanin je zabilježio da se irida zbog raznovrsnih boja koje posjeduje nerijetko naziva i šarenim lûkom, a pokatkada i demonovim lûkom, jer riječ demon na grčkom jeziku može označavati razum, ali i, primjerice, jasnu i sjajnu zvijezdu. ${ }^{711}$ Kotruljević je podatak o višeznačnosti grčke riječi demon doznao od, kako ga naziva, Komentatora Etike. Kao što je zamijetio i zabilježio Falchetta, u tom je slučaju navodno riječ o izravnoj referenci na komentar Aristotelove Nikomahove etike koji je napisao Toma Akvinac. ${ }^{712}$ Dubrovački je mislilac u nastavku govora o iridi opisao nauk takozvanih teologa heziodista, a tako se, kako tvrdi Falchetta, oslovljavalo

\footnotetext{
${ }^{706}$ Ibid., p. 158: »<..> li marinari dicono: 'Lo cielo fa chiricha, e lo tempo repusa et bonaça fa chachaça.' «/p. 159.

707 Ibid., p. 158: »Et nota che yris de la luna appare sempre di nocte et sempre quando appare significa tempestate longna et vento instabile, <... $>\ll . /$ p. 159.

${ }^{708}$ Ibid., p. 158: »<...> perché non appare se [yris de la luna] non quando è grande materia de humore dello vento lo qual è da parte australe et occidentale, et quando la luna è multo meridionale. «/p. 159

${ }^{709}$ Ibid., p. 158: »Halo o vero corona / in lingua latina, de la qual se dirrà in suo capitulo separato, Aristotile mecte lu suo pronostico multo confuso. Tamen Seneca in libro De naturalibus questionibus lo mecte più ordinatamente«. / p. 159.

${ }^{710}$ Ibid., pp. 158-160: »<...> et dicie [Seneca] che, quando stando ferme et de per loro se destrueno, significa tempo tranquillu. Quando se rompe da una parte, significa vento da quella parte, et se in più lochi se intrarompe, significa tempestate.«/pp. 159-161.

${ }^{711}$ Cotrullis, »De navigatione«, libro III, capitulo 6 / Kotruljević, »O plovidbi«, knjiga III, poglavlje 6, p. 168: $»<\mathrm{C}>$ hiamase yris alcuna volta archo vario per la diversità delli colori, alcuna volta se chiama archus demonis, quia demon graece multa significat, com dicie lo commentatore Sopra la Heticha, perché alcuna volta significa intelligentia, alcuna volta stella chiara et lucida; <... «. / p. 169.

712 Cotrugli, »De navigatione (1464-1465) Ms. Schoenberg 473«, p. 150, bilješka 409: »Il commento di Tommaso d'Aquino all'Etica nicomachea di Aristotele.«
} 
pjesnike Hezioda (između 750. i 650. pr. n. e.) i Homera (između 8. i 7. stoljeća pr. n. e.), ${ }^{713}$ koji su bogovima pripisivali sve stvari koje se pojavljuju u prirodi, i to posebice one koje se pojavljuju na nebu. ${ }^{714}$ Teolozi heziodisti također su, bilježi Kotruljević, nazivali iridu demonovim lûkom ili lûkom mudracā, a njezino su pojavljivanje smatrali znakom Božje milosti, zbog toga što ni vatrom ni vodom ne škodi svijetu. ${ }^{715}$ Neškodljivost vatrene i vodene naravi iride svijetu, obrazlagali su, dodaje Dubrovčanin, time što se u njoj pojavljuje crvena boja koja proizlazi iz zapaljene vlage, što bi značilo da voda ne prevladava sasvim nad vatrom, dok zelena boja proizlazi iz nerazlučene vode, što pak ukazuje na to da vatra ne prevladava sasvim nad vodom. ${ }^{716}$ Još jednu potvrdu toga pruža, nastavlja Kotruljević, to da se irida obično pojavljuje za vremena koje je dijelom vedro, a dijelom vlažno, pri čemu vedrina nastaje od toplog i suhog, dakle od naravi vatre, a vlažnost iz hladnog i vlažnog, što pak pristaje naravi vode. ${ }^{717}$ Kotruljević je također zapisao da su heziodisti smatrali da takva obilježja iride upućuju na to da se ne bi trebao dogoditi ni vatreni ni vodeni potop potaknut umom koji upravlja svijetom, dodavši da se o tim dvjema pojavama očitovao Platon u Timeju i na drugim mjestima te da je iz takvih uvjerenja proizašlo pučko vjerovanje da trideset godina nakon pojavljivanja iride neće biti posljednjeg suda, točnije vatrenog potopa. ${ }^{718}$

Posljednji dio poglavlja o iridi Kotruljević je posvetio njezinim obilježjima i uvjetima njezina nastanka. Dùga je, tvrdi Kotruljević, okrugao ili gotovo okrugao lûk koji ne premašuje polukrug i koji se pojavljuje pri izlasku ili zalasku sunca, zbog toga što $u$ to doba sunčeve zrake slabe u parama koje se stvaraju na istoku ili na zapadu. ${ }^{719}$ Osim toga, dùga je, kako kaže, ogledalo Sunca i pojavljuje se samo nasuprot Suncu, što uzrokuje da čim je Sunce

713 Ibid., p. 150, bilješka 410: »Presso gli antichi i grandi poeti Esiodo e Omero erano chiamati 'teologi esiodei'.«

${ }^{714}$ Cotrullis, »De navigatione«, libro III, capitulo 6 / Kotruljević, »O plovidbi«, knjiga III, poglavlje 6, p. 168: $»<\ldots>$ et però l'exiodiste theologi, li quali atribuiscono tucte le cose alli dei, quelle che appareno nella natura et specialmente in cielo, <... « / p. 169.

715 Ibid., p. 168: »<..> lo chiamavano archus demonis, ciò è l'archo del savio, et dicievano l'archo essere signo / della clementia de Dio, perché né per focho né per acqua voleva nociere al mundo, <..>«. / p. 169.

716 Ibid., p. 168: "<..> perché ne lo archo appare colore rosso lo qual è dal humido inflammato et questo significa che ogni uno non prevale l'acqua sopra lo focho, perché lu focho hane alcuna cosa della sua operatione nello archo. Appare lo verde dallo aqueo non digiesto, il che significa che non ogni uno prevale lo focho sopra l'acqua, perché l'acqua à alcuna cosa della sua operatione; <... < . / p. 169.

${ }^{717}$ Ibid., p. 168: »<...> et de questo dicono uno altro signo, che lo archo non sole apparire si non nel tempo che in parte è serino et in parte humido: el serino, che haveno del caldo et sicco, che convene colle virtù del focho; lo humido, del freddo et humido colle potentie de l'acqua.«/ p. 169.

${ }^{718}$ Ibid., pp. 168-170: »Questo dicievano l'exiodisti essere signo che né d'acqua né di focho devia essere diluvio dato la intelligentia la qual governa lu mundo. Et inde è tracto lo antiquissimo uso del vulgo, che apparente lu archo, XXX anni è non deve essere lu iudicio, ciò è lo dilluvio dello focho, de qual diluvio del focho et de l'acqua se tracta nel Tymeo de Platone et in altri lochi.«/pp. 169-171.

${ }^{719}$ Ibid., p. 170: »Adoncha yris è archo rotundo o vero quasi retondo non excedente semicirculo et appare ne l'ortu o vero ne l'occaso dello sole, perché allora lo ragio dello sole se debilita in oriente nelli vapori et anche ne l'occidente et non pò radiare con lume chiaro.«/p. 171. 
višlje, lûk je manji, a čim je niže, lûk je veći. ${ }^{720}$ Nakon toga je dubrovački mislilac ukazao na vremenska razdoblja u kojima se irida najčešće pojavljuje te na porijeklo njezinih boja i teškoće prilikom njihova razlikovanja. Tako je zapisao da se dùga u različita vremena pojavljuje u različito doba dana, pa se, primjerice, u vrijeme jesenskog ekvinokcija i nakon njega može pojaviti u svako doba dana, dok se ljeti može pojaviti ujutro i navečer, ali ne i u podne. ${ }^{721}$ Što se pak tiče dùginih boja, Dubrovčanin je pribilježio da su boje iride ništa drugo negoli zrake Sunca koje su različito obojene vlagom pare i oblaka te napomenuo da su takve da ih čak ni slikari ne mogu naslikati. ${ }^{722}$ Kotruljević je poglavlje o iridi dovršio iznošenjem razlikovanja večernje ili mjesečeve dùge od dnevne ili sunčeve dùge. Kada je govorio o dùgi koja se pojavljuje noću, pripomenuo je da je filozofi nazivaju mjesečeva dùga, na što je upozorio i u poglavlju koje je posvetio predviđanju nevremena. ${ }^{723}$ I doista, a kao što sam već istaknuo ranije, u dijelu koji se odnosi na vjetrove Kotruljević je u petom poglavlju treće knjige »O predviđanju nevremena« pisao o vremenskim pogodama i nepogodama koje najavljuje pojavljivanje iride. Pritom se nije pozvao niti na jedan izvor. Čini se da se Dubrovčanin u ovom navratu u potpunosti oslonio na vlastito iskustvo i, možebitno, ponovno na znanja neimenovanih filozofa, astrologa i mornara. Kotruljević je, naime, ustvrdio da irida koja se pojavi ujutro najavljuje kišu, dok ona koja se pojavi uvečer najavljuje lijepo vrijeme. ${ }^{724}$ Unatoč postojanju toga pravila, Dubrovčanin je dodao da oko njega ne postoji opća suglasnost, zbog čega ga je opovrgnuo pripovijedanjem susreta sa seljakom iz talijanskog gradića Cerignole koji mu je razjasnio da večernjom dùgom valja smatrati onu koja se pojavi sa zapada, a jutarnjom onu koja se pojavi s istoka. ${ }^{725}$ Izlaganje o razlikama

${ }^{720}$ Ibid., p. 170: »Yris è specchio del sole et non resulta si non in opposito / del sole; et quanto lo sole è più alto tanto lo archo è minore, et quanto lu sole è inferiore tanto lu archo è magiore. «/p. 171 .

${ }^{721}$ Ibid., pp. 170-172: »Quisto archo in diversi tempi diversamente appare: nello equinoctio autumpnale et poi d'isso in ogni hora del giorno appare, et pò apparire la state de mautina et de sera, ma non a meço giorno, $<\ldots>\ll$. / pp. 171-173.

722 Ibid., p. 172: »<..> et gli coluri soi sonno varii, li quali li dipenturi non poçono pegnere. [...] non errò però in questo che disse yris essere sagipta de lo sole, perché in verità li colori dello archo cieleste non sone altro che li ragi de lo sole per la humidità dello vapore et della nube diversamente tincti, $<\ldots>\ll . /$ p. 173.

${ }^{723}$ Ibid., p. 172: »L'archo tamen lo qual appare de nocte se chiama secundo li philosophi archo della luna, come è dicto nel precedente capitulo, $<\ldots>\ll . /$ p. 173.

${ }^{724}$ Cotrullis, »De navigatione«, libro III, capitulo 5 / Kotruljević, »O plovidbi«, knjiga III, poglavlje 5, p. 158: »Lo arco cieleste yris, dello quale parlaremo nello suo capitulo più destiso, ciò è della natura sua, qui dirremo lu suo pronostico: la quale, quando appare la mautina, significa ploggia, la sera significa bon tempo per le ragioni dicte desopra dello aere rosso; <...> «. / p. 159.

${ }^{725}$ Ibid., p. 158: »<...> et però li marinari usano de dire: 'Arco de sera bon tempo mena, arco de mane impie le fontane.' Tamen questa regula e non me piare al tucto intesa, ma uno rustico alla Ciringiola in Puglia me ·lla [prema Falchettinu transkriptu iz 2009. godine treba stajati: »l'ha«] deschiario gintilmente. Arrivando io alla Ciringola, essendo plovito quillo giorno al continuo sença repuso, vedendo io lo arco che già era verso la sera, credendome indovinare dissi 'Archo de sera, haviremo bon tempo.' Respuse lu villano diciendo o vero ridendo: 'Signore, lo contrario. Nui haviremo grandissima acqua.' Io lo domandai: 'Perché?', e mi disse: 'Ché arco de sera s'intende quando appare de ponente et de mane quando appare de levante, et questo archo par da 
među dvjema iridama dovršio je, kako sam već istaknuo prilikom iznošenja Dubrovčaninovih spoznaja o vjetrovima, sljedećim tvrdnjama: 1) mjesečeva se dùga uvijek pojavljuje noću; 2) predznak je dugotrajnog nevremena obilježenog nestabilnim vjetrovima; 3) najavljuje takve vremenske prilike zbog toga što se tijekom njezina nastanka nakuplja velika količina vlage u južnom i zapadnom vjetru. ${ }^{726}$ Kada je riječ o sunčevoj dùgi, dubrovački mislilac je, a na koncu šestoga poglavlja treće knjige, zabilježio da se ona pojavljuje isključivo onda kada se Sunce nalazi u položaju nasuprot crvenila ispod oblaka. ${ }^{727}$

Sedmo poglavlje treće knjige spisa o plovidbi dubrovački je umnik posvetio meteorološkoj pojavi koju je oslovljavao trima terminima: halo, krug ili alothetha. Nakon što je na početku poglavlja naslovljenog »O halo, krugu, alothethi« (»De halon, area, alothethi«) obrazložio da se zapravo radi o grčkoj, latinskoj i arapskoj inačici imena za istu pojavu, Dubrovčanin je pribilježio da se ona pojavljuje na mnoštvu nebeskih tijela, jer ne okružuje samo Sunce i Mjesec, nego i veće zvijezde, kako je oslovljavao planete, poput Jupitera, Marsa i Merkura. ${ }^{728}$ Taj krug se, priopćava Kotruljević, može pojaviti u svako godišnje doba, najčešće ujesen, pa čak i u svako doba dana, a najčešće noću, dok se, primjerice, oko Mjeseca najčešće pojavljuje ujutro nakon svitanja. ${ }^{729} \mathrm{U}$ preostalom dijelu poglavlja o toj meteorološkoj pojavi Kotruljević je razmatrao uzroke nastanka kruga. Tom je prigodom istaknuo da je te podatke doznao iz Senekina djela Prirodoznanstvena pitanja. Kotruljević je tako citirao sadržaj Senekina djela i zapisao da je krug sjaj koji okružuje zvijezde i koji, poput slučaja bacanja kamena u ribnjak uslijed čega se na vodi stvaraju brojni krugovi od uskih do širokih, nastaje zbog toga što svjetlost Sunca, Mjeseca ili ostalih zvijezda suzbija zrak u krugove u nastojanju da prođe kroz

levante, però è tempo d'acqua.' Sì che io vidi che tucta nocte piobbe et lo giorno sequente. Però attiendi alla sententia dellu rustico, che ll'archo scia de sera e da parte occidentale.«/p. 159.

726 Ibid., p. 158: »Et nota che yris de la luna appare sempre di nocte et sempre quando appare significa tempestate longna et vento instabile, perché non appare se non quando è grande materia de humore dello vento lo qual è da parte australe et occidentale, et quando la luna è multo meridionale. «/p. 159 .

${ }^{727}$ Cotrullis, »De navigatione«, libro III, capitulo 6 / Kotruljević, »O plovidbi«, knjiga III, poglavlje 6, p. 172: $»<\ldots>$ et l'archo del sole non appare se non quando lo sole se oppune alla rosata la qual è socto la nube et non in nelli altri tempi, come è dicto.«/p. 173.

${ }^{728}$ Cotrullis, »De navigatione«, libro III, capitulo 7 / Kotruljević, »O plovidbi«, knjiga III, poglavlje 7, p. 172: $»<\mathrm{H}>$ alon chiamato in gręco, et in nostra lingua corona o vero area, in arabico alothethi, appare de multi corpi superiori, perché non solamente contene lo Sole et la Luna, ma etiamdio le stelle le quali sondo de più quantitate, come Iupiter, Marte et Mercurio lo qual, quantuche non scia delli magior, tamen per la sua propinquitate / ad nui, pare la sua quantitate magiore, et circa alcune stelle le qual sondo magior delle altre in quantitate.«/p. 173

${ }^{729}$ Ibid., pp. 172-174: »Lo tempo della apparitione de quisto circulo è universale, perché si vede la corona de verno, state, auctumpno et primavera, ma più in auctumpno che in altri tempi; et appare de giorno et de nocte ma più de nocte, et in ogni tempo de giorno /et de nocte ma più de nocte/, et la sera, et poi crepusculo, et la mautina a l'aurora circa la Luna.«/pp. 173-175. 
njih, a tekućina, zrak, gusta para i svako tijelo poprimaju otisak onoga što ih je potisnulo. ${ }^{730}$ Tome je pridodao i ostatak Senekina mišljenja da krug ne nastaje daleko od Zemlje, premda nas naš pogled vara i stvara pričin toga da krug okružuje zvijezde, a to je nemoguće zbog rijetkosti zraka u njihovoj blizini, kao i to da se krug može vidjeti u kupaonici, zatim oko zapaljene svjetiljke i nakon puhanja juga, a sve zbog neprozirnosti gustoga zraka. ${ }^{731}$ Spoznaje o meteorološkoj pojavi kruga u tom poglavlju Dubrovčanin je zaključio podatkom o vremenu njegova pojavljivanja. Napomenuo je da krug većinom nastaje noću, a danju vrlo rijetko. ${ }^{732}$ Međutim, Kotruljević je o toj pojavi pisao i na drugim mjestima u trećoj knjizi. Baš kao i u slučaju iride, o krugu je pisao i u petom poglavlju naslovljenom »O predviđanju nevremena« (»Delli pronostichi delli temporali«). Dubrovčanin je u tom poglavlju iznio mišljenje o Aristotelovoj i Senekinoj odredbi pojave kruga. Za Aristotelovu odredbu rekao je da je vrlo nejasna, dok je Senekinu ocijenio podrobnijom i točnijom, a ona glasi: 1. ukoliko prstenovi miruju i raspršuju se sami od sebe, vrijeme će biti mirno; 2. ukoliko se prstenovi kidaju s jedne strane, upravo će iz tog smjera puhati vjetar; 3. ukoliko se prstenovi kidaju na više mjesta, to označava nevrijeme. ${ }^{733}$

U osmom poglavlju treće knjige spisa o plovidbi dubrovački se ranorenesansni mislilac očitovao o munji ili, kako je naziva, nebeskoj strijeli. Prigodno ga je naslovio »O munji odnosno nebeskoj strijeli« (»De fulmine o vero sagiecta del cielo«). Kao nužan uvjet za razumijevanje toga što bi sijevanje ili bljesak (fulgure o vero lampo) te munja ili strijela (fulmine o vero sagiepta) trebali značiti, Dubrovčanin je preporučio nauk filozofā, posebice Seneke koji je zabilježio da bljesak pokazuje vatru, a strijela ili munja ono što je odapeto i

${ }^{730}$ Ibid., p. 174: »La causa d'esso pone Seneca in libro De naturalibus questionibus et dicie: 'Fulgore lo qual circunda le stelle, lo qual chiamano Greci halo, nui lo potemo chiamare corona. Se fa como quando giectano la petra in la piscina, vedemo l'acqua fare de multi cierchi, et lo primo essere stricto et gli altri magiori finché resta l'impito dello colpo. Tale se fa ne l'aere quando diventa più spesso, la lucie del Sole o della Luna o delle altre stelle volendo partirsi lo constrengie neli cierchi, perché lu humore et tucto lo corpo lo quale da lo colpo recieve la forma, in tale habbito se caccia quale è quello che è cacciato. Coscì lo aere, o vero vapore spisso, percossu se fa in tale forma. «/p. 175.

${ }^{731}$ Ibid., p. 174: »Tal cierchio non se fa lunga dalla terra, avegna che ·llo [prema Falchettinu transkriptu iz 2009. godine treba stajati: »lo«] nostro viso se inganna et stima che lo scia nel circhio delle stelle, perché vicino alle stelle non se pò generar tal cosa, perché lu aere quivi è multo tenue. Et questo se vede nel bagno: allumando la lucierna in tal modo per la obscurità dello aere spisso se fa; et quisto cierculo se sol generare dapoi del fiato dello austro.' «/ p. 175.

${ }^{732}$ Ibid., pp. 174-176: »Et rarissimo appare de giorno ma ut plurimum de nocte, et però alcuni Greci disseno che di giorno non appareno, ma questo non è vero, perché lu experiminto havimo visto multe volte in contrario.«/ pp. 175-177.

${ }^{733}$ Cotrullis, »De navigatione«, libro III, capitulo 5 / Kotruljević, »O plovidbi«, knjiga III, poglavlje 5, pp. 158160: »Halo o vero corona / in lingua latina, de la qual se dirrà in suo capitulo separato, Aristotile mecte lu suo pronostico multo confuso. Tamen Seneca in libro De naturalibus questionibus lo mecte più ordinatamente et dicie che, quando stando ferme et per loro se destrueno, significa tempo tranquillo. Quando se rompe da una parte, significa vento da quella parte, et se in più lochi se intrarompe, significa tempestate.«/pp. 159-161. 
ispaljeno iz zbijene vatre. ${ }^{734}$ Zatim je izdvojio sljedeća mišljenja starih teologa, mudraca i jednog filozofa: 1. stari teolozi Atal i Cecina tvrdili su da je bljesak raspršena vatra, a strijela zauzdana vatra izbačena potiskom; 2. svi mudraci, dakle i oni koji su istraživali prirodne i oni koji su istraživali božanske pojave, slagali su se u tome da je riječ o vatri, zatim da se ona nalazi u udubljenju oblaka, a onda i to da se bljesak i grmljavina događaju istovremeno, premda jedno zamjećujemo prije drugoga; 3. filozof Klidem pogrešno je tvrdio da je bljesak isprazna pojava, da se radi tek o odbljesku sunca ili zvijezda iznad oblaka punih vode, kao što se noću vidi samo odsjaj vesala, a to je pogrešno jer se odsjaj vesala može vidjeti samo u vodi, dok se bljesak nerijetko može vidjeti kako dolazi iz oblaka i oblikuje strijelu. ${ }^{735}$

Međutim, Kotruljević je bio skloniji prihvatiti mišljenja koja su o toj tematici izrekli drugi, posebice filozofski autoriteti. Naime, otklonio je mogućnost priklanjanja mišljenjima starih o pojavama bljeska i munje, poimenice Empedoklu, Anaksagori, Diogenu, Anaksimandru i Teofrastu, a opredijelio se za mišljenje Aristotela i Alberta Velikog koji kažu da te pojave nastaju samo iz pare koja je ili suha ili vlažna. ${ }^{736}$ Kada se, bilježi Dubrovčanin, uzdiže vlažna para koja sadrži svojstva vode, ona stiže u hladne visine, tamo se skuplja, zgušnjava i iz nje nastaju sumaglica, rosa i magla, a koju čine tamni oblaci koji su hladnoćom zraka pritisnuti prema zemlji i uzrokuju kišu, tuču i snijeg. ${ }^{737}$ Kada se, pak, uzdiže suha para okružena vlažnom, prilikom pristizanja vlažne pare na hladnije mjesto ona se počinje skupljati, pa se u njoj, baš kao u trbuhu, skuplja suha i topla para koja je lako zapaljiva i koja svojim komešanjem izaziva zapaljenje u obliku bljeska ili sijevanja. ${ }^{738}$ To je, dodaje Kotruljević, lako

${ }^{734}$ Cotrullis, »De navigatione«, libro III, capitulo 8 / Kotruljević, »O plovidbi«, knjiga III, poglavlje 8, p. 176: $» /\langle\mathrm{V}\rangle$ olendo intendere de fulgure o vero lampo, fulmine o vero sagiepta, ell'è da sapere secundo li philosophi et maxime Seneca: lo lampo è quillo che mostra lo focho, sagepta o fulmen è quello che escie et è mandato dallo focho cacciato.«/p. 177.

${ }^{735}$ Ibid., p. 176: »Et però dissero li antiqui theologi, Atila et naçi a lui Etina, che lo lampo è focho tracto fora et la sagiepta è focho constricto et gieptato in colpo. Tucti li savii naturali et divini se accordano in questo, che quello appare quivi è focho, secundo, che l'è ne la concavitate de le novole, tertio, che insieme è lampo e trono, avegna che più tosto se principie l'uno che l'altro. Verum uno philosophu, Clidonio, non hebbe questa oppinione diciendo che lo lampo era specie vana, non focho ma resplendentia de lo sole o vero delle stelle sopra le novule aquose, come la nocte appare lo splendore delli remi. Ma questo è falso, perché lo splendor delli remi non si vide se non in acqua, ma lo lampo spesso se vede de la novula et cade in sagiepta.« / p. 177.

${ }^{736}$ Ibid., p. 176: »Ma lassando multe oppinioni delli antiqui li quali diversamente ando intese queste cose, come Empedocles, Anaxagora, Diogenes, Anaximander et Teophrasto, pigliando la oppinione de Aristotile et Alberto Magno nel tertio libro della Metaura, li quali dicono che queste cose non sondo se non del vapore lo quale o vero è siccho o vero è humido.«/p. 177.

${ }^{737}$ Ibid., pp. 176-178: »Et quando salglie lu vapore humido per natura, perché è de natura d'acqua et dallo elemento d'acqua è levato, pervene in locho alto et deventa spisso nello locho freddo per la frigideça dello locho, et le parte loro se congregano et cominciano stare; et però diventano de impressione humida, le quali sonno nebula, rosada et nebia, / la qual non è altro si non novule obscure per la fredeça dello aere repressa ad terra et inde diventano ploggia et grandene et neve.«/pp. 177-179.

738 Ibid., p. 178: »Se ·llo [prema Falchettinu transkriptu iz 2009. godine treba stajati: »il«] vapor sicco salglie adpresso nello vapor humido, quando lo vapor homido pervene allo locho dello freddo et cominciase compremere, et compremese in lui lu vapor secco et caldo per caldeça accidentale come nel ventre; et in tal 
dokazati bacanjem jajeta u vatru i njegovim dugim prženjem, te kestenom u kojem, kada ga nerazrezanog i neslomljenog stavimo u vatru, nastaje para koja se širi i razbija ljusku, zbog čega kesten iskoči iz vatre i raspukne se uz glasan prasak. ${ }^{739}$ Kotruljević je pripomenuo da su se primjerom jajeta i kestena filozofi služili za pojašnjavanje pojave potresa, a tome je dodao i podatak da su s tim mišljenjem bili suglasni sljedeći mislioci: Anaksimen, Anaksimandar, Anaksagora, Heraklit, Seneka, Demokrit, Leukip i Asklepiodot. ${ }^{740}$

Nakon što je ukazao na mišljenja onih filozofa koji su pojavama sijevanja i munje pristupali kao prema pojavama prirodnog porijekla, Kotruljević je izdvojio podatke i o naucima onih mislilaca koji su te pojave pripisivali božanskom djelovanju. Razlog njihovu pripisivanju sijevanja i munje božanskom djelovanju nalazi se, bilježi Dubrovčanin, u čudesnosti i raznolikosti njihova učinka. ${ }^{741}$ Među tim misliocima isticali su se Atal i Cecina, dvojica ranije spomenutih teologa, koji su istraživali božanske pojave vezane uz poganske bogove te koji su smatrali da su gromovi izraz Jupiterove volje i da polučuju, primjerice, sljedeće učinke: oštećuju cvjetove na drveću bez tragova spaljivanja, rastapaju zlato u torbi bez ikakvih oštećenja na torbi, rastapaju ili probijaju mač bez da oštete korice i slično. ${ }^{742}$ Nakon te kratke ilustracije mišljenja koje su zastupala ta dvojica teologa koji su štovali poganske bogove, Kotruljević je osporio vrijednost njihovih nauka. To su, bilježi Dubrovčanin, zablude starih, jer se svemogući Bog, a u skladu s katoličkom vjerom i naukom Tome Akvinca (come vol

compressione dello vapor sicco nel ventre della novula si fa agitation grande dello vapor sicco et la agitation inducie inflammation actual nel vapor caldo et sicco, perché di natura è legiermente inflamante, come se vede della ventositate secca nel ventre del homo. Et questa è la ragione della inflammatione dello lampo o fulgore.«/p. 179.

${ }^{739}$ Ibid., p. 178: »Et provase questo per lo ovo misso nello focho et multo coctu, et per la castagna, come mecte Alberto Magno, messa nello focho caldo sença haverla perforata o rocta: quando lo humido se comincia ad resolvere, se gienera in isso vapore lo qual ciercando locho magiore rompe la scorça et salta dallo focho et scioppa con grande strepido.«/p. 179.

${ }^{740}$ Ibid., p. 178: »Et quisto medesimo exempio poneno li philosophi dello terremoto. Et in questa oppinione concorreno Anaximines, Anaximander, Anaxagoras, Eraclitus, Seneca, Democritus, Leoçippus et Asclipiadoti.«/p. 179.

${ }^{741}$ Ibid., p. 178: »Dicievano alcuni philosophi trono e lampo essere cosa divina per la mirabilità et la diversitate dello effecto loro.«/p. 179.

${ }^{742}$ Ibid., pp. 178-180: »Et pręcipui forono dui grandi in le cose divine de idoli ciò è Ascalus et Cetina, li quali disseno che era voluntà de Iove, però che è diverso e mirabile suo effectu: perché alcuna volta lede li fiori delli arbori, et non pare alcuno vestigio dello ardere; alcuna volta se squaglia l'oro in borsa, e la borsa è sana; alcuna volta squaglia o pertusa / lo cortello sença de fare la guaina; alcuna volta arde le calse de alcuno, et non fa mal a la carne; alcuna volta arde li pili del homo et petine et socto lo braccio, et non lede li membri; alcuna volta altera lo color dellu homo, et nolli fa più male; alcuna volta admaça, et nullo signo appare de arso o plagato; alcuna volta spaccha li ligni, et non abrusa; et alcuna volta, come dicie Seneca, percote lu vaso dello vino, et lo vino sta um· [prema Falchettinu transkriptu iz 2009. godine treba stajati: »un«] tempo et non si spande. Disseno alcuni philosophi che percosso animal venenoso perde lo venino et lo signale de ciò era che lo serpe percosso dalla sagiepta e mortu, infra pochi giorni averminiscie, et mortu de sua morte mai diventa verminoso, et questo per lo venino. Ad tucti fulminati intervene che percussi tucti hanno lo hodor del sulfo et lu fulminato sempre volta lu capo verso lo fulmine, ciò è donde venne. Et multe altre cose mirabile sonno notate dalli philosophi, per li quali disseno tucti quilli che antiquiçavano, che la sagiepta era adtributa allu re delli dei lo qual appellavano dio Iove.«/pp. 179-181. 
Sanctomaschi), služi nebeskim pojavama kao sredstvom i one moraju biti prirodne te nastajati prirodnim putem. ${ }^{743}$ Poglavlje o munji ili nebeskoj strijeli Kotruljević je zaključio spoznajama koje potječu iz, kako je naziva, prave znanosti o prirodi (vera sententia de naturali), a ona proizlazi iz naukā neimenovanih mudrih filozofa koji su grmljavinu pripisivali Jupiteru, koji je ništa drugo nego jedna od sedam zvijezda ili planeta i čija je sposobnost da podiže materiju jakih i suhih vjetrova, a to se posebice očituje ljeti kada je povezan s djelovanjem Marsa, pa se u to doba može prognozirati obilje grmljavine i sijevanja te ljudima prijeti opasnost od otrovnog zraka uzrokovanog užganim i kužnim parama. ${ }^{744}$

Posljednje poglavlje u trećoj knjizi spisa o plovidbi koje je Kotruljević posvetio trima pojavama meteorološke naravi deseto je po redu i nosi naslov »O vatrama koje silaze iz zraka« (»De fochi descendenti nello aere«). Poglavlje o vatrama koje silaze iz zraka dubrovački je mislilac otpočeo razlikovanjem njihovih vrsta. Vatre koje nastaju u zraku, bilježi Kotruljević, pokatkada silaze u velikom broju, a Seneka ih u djelu Prirodoznanstvena pitanja razlučuje sljedećim trima nazivima: vijenci, pitije i hazmata. ${ }^{745}$ Međutim, razlike među spomenutim vatrama nisu tek terminološke naravi. Vijenac je, ističe Dubrovčanin, pojava kada se poput vijenca na krugu pojavi otvor u zraku ispunjen vatrom, pitije su, pak, pojava kada se neka okrugla nakupina vatre giba, pa se nalazi u prostoru hladnoće, ili stoji, pa se nalazi u području topline, dok su hazmata pojava kada se jedan dio neba rastvori i čini se kao da želi progutati plamen. ${ }^{746}$ Prema Kotruljevićevim spoznajama, u slučaju pojave hazmata riječ je o jako zapaljenoj laganoj i rijetkoj pari u vlažnom oblaku koja ili ostavlja dojam kao da jedan dio svijeta bez zvuka izbacuje vatru ili, kada je plamen pare udaljen da ga se ne vidi

${ }^{743}$ Ibid., pp. 182-184: »Et quisti sonno gli errori delli antiqui perché, quantunque la fede cactholica, come vol Sanctomaschi, lo omnipotente Dio usa de queste cose come instrumento, nulla de mino e sonno naturale et naturalmente vengono gienerati, $<\ldots>\ll . /$ pp. 183-185.

${ }^{744}$ Ibid., p. 184: »<..> ma dicono che lli [prema Falchettinu transkriptu iz 2009. godine treba stajati: »chelli«] savii philosophi adtribuiscono lo tronar a Iove lo qual è una delle VII stelle o vero pianeti, lo qual hane elevar la materia delli venti forti et sicchi, specialmente quando est coniunctus in alcuna virtute con Marte nel tempo de state in signi aquilonari, ché allora se pò pronosticare che multi troni et sentille serrando nello aere; il perché è periculo <...> per la spestilentia de l'aere de multa futura corruptione / per li vapori acciesi pestipheri mescolati allo aere, perché Iove collo sole li levano et Marte acciendendo li corrompe, et coscì se fa aere venenoso; et questo è vera senentia de naturali.«/p. 185 .

${ }^{745}$ Cotrullis, »De navigatione«, libro III, capitulo 10 / Kotruljević, »O plovidbi«, knjiga III, poglavlje 10, p. 186: » $<\mathrm{G}>$ eneranose anche nello aere fochi che descendono alcuna volta in grande quantitate, li quali chiama Seneca, VII libro De questione naturali, corone, phisie et casmata.« / p. 187.

${ }^{746}$ Ibid., p. 186: »Corona è quando modo de corona in orbe appare appertura nello aere piena de focho. Phise sonno quando è una grandeça de focho, retondo come è uno utro, o va andando o sta in uno locho. Quando va anando, è ne lo locho de fredore, quando sta, è la regione calda. Casmata sonno quando uno spacio de lo cielo descende et la fiamma come volesse devorare.«/p. 187. 
već se vidi njegov odbljesak, kao da gori nekakav grad. ${ }^{747}$ Pojava vatri koje silaze iz zraka važna je i iz medicinske perspektive. Naime, te su vatre one zbog kojih nastaje kuga, jer su, a kao što smo imali već priliku doznati iz poglavlja o munji, uzrokovane djelovanjem Marsa, i to posebice u godini kada se nalazi u konjunkciji s Jupiterom, budući da kvare i truju zrak koji potom uzrokuje nastanak čireva i ranula. ${ }^{748}$ Osim što kvarenjem i trovanjem zraka mogu uzrokovati epidemiju kuge, Kotruljević je na kraju desetog poglavlja zabilježio da pojava vatri koje silaze iz zraka može biti uzrok i drugim posljedicama. Tako je pribilježio da u nauku bagdadskog astrologa Abū Ma'shara (Abū Ma'shar Ja' far ibn Muḥammad ibn 'Umar al-Balkhī, oko 787 - oko 886) stoji da vatre koje silaze iz zraka najavljuju smrt vladara i gospode. $^{749}$

Iako je deseto poglavlje treće knjige spisa o plovidbi u cijelosti posvetio tematici koja se odnosi na meteorološku pojavu vatri koje silaze iz zraka, ta je tematika zaokupljala promišljanja hrvatskog ranorenesansnog mislioca i na drugim mjestima. Primjerice, jedno od tih mjesta nalazi se u ranijem dijelu treće knjige De navigatione, točnije u njegovu petom poglavlju naslovljenom »O predviđanju nevremena«. Na tom mjestu razmatrao je, podsjećam, vremenske nepogode koje pojava vatri na nebu najavljuju svojim nastankom. Vatre koje se pojavljuju na nebu, naime, u slučaju kada se gibaju u različitim smjerovima označavaju nevrijeme zbog sukobljavanja vjetrova, a upravo je iz tog razloga $u$ to doba mornare obično obuzimao strah. ${ }^{750}$ No, u slučaju kada vatre miruju, označavaju mirno vrijeme zbog prestanka vjetrova, a što je bio dostatan razlog, kako ih Kotruljević naziva, starima da prinose žrtve nebeskim Blizancima Kastoru i Poluksu, jer su smatrali da su oni uzrok mirnog vremena budući da su oni zračni znak, pa kada je Sunce u njemu u doba ljetnog solsticija, vrijeme bude vrlo mirno i vedro. ${ }^{751}$

\footnotetext{
${ }^{747}$ Ibid., p. 186: »Allora multo infiamato vapore subtile raro è in nube aquosa, ma sença sonno par una parte del mundo gieptar focho; nello secundo modo quando è longi da la fiamma de lu vapore, in modo che la non pare ma solo resulta lo suo lume, allora par ardere alcuna citade.«/p. 187.

${ }^{748}$ Ibid., pp. 186-188: »Le significationi de quisti fochi havimo già dicti nel capitulo de pronostichi, et nulla de mino secundo l'effecto de Marte et specialmente, quando in quillo anno è coniuncto con Iove, significa pestilentie dallo aere venenoso, perché corrompono lo aere et fandolo venenoso specialmente generando posteme et ranole.«/ pp. 187-189.

${ }^{749}$ Ibid., p. 188: „Vole anchora Albionasar che questo alcuna volta significa morte de principi et gran signori.«/ p. 189.

${ }^{750}$ Cotrullis, »De navigatione«, libro III, capitulo 5 / Kotruljević, »O plovidbi«, knjiga III, poglavlje 5, p. 160: »Fochi apparenti in aere, quando vando qua et là, significa tempestate per lo conflicto delli venti, et questo allega Alberto Magno et dicie che allora soglono temere li marinari.«/p. 161.

${ }^{751}$ Ibid., p. 160: "Quando li fochi stanno quiti sença moverse su lu arboro o in altro locho, significa tempo tranquillo per la cessatione delli venti, et allora li antiqui sacrificavano ad Castore et Poluce, Gemini de lo cielo, perché pensavano che loro li davano tempo tranquillo. Et questo era divinuto perché Gemini è signo aereo et, quando lo Sole è in ipso, è la magior tranquilità che scia nel cielo, perché lu Sole se volta in Gemini quando va al $<$ sol $>$ sticio extivale, quando è grande serenità.« / p. 161.
} 


\subsubsection{Astronomsko-astrološka razmatranja u trećoj knjizi spisa o plovidbi}

Istraživanje prisutnosti prirodnofilozofske sastavnice treće knjige Kotruljevićeva spisa o plovidbi dosad se u ovom radu u potpunosti odnosilo na pojave meteorološke naravi. No, kako sam ranije najavio, astronomsko-astrološke teme također su zauzimale velik dio Dubrovčaninovih promišljanja iz filozofije prirode $u$ toj knjizi. Štoviše, temama iz astronomsko-astrološkog korpusa posvetio je čak devet poglavlja treće knjige, točnije od jedanaestog do devetnaestog. Zbog kolikoće sadržaja astronomsko-astrološke naravi, u nastavku ću izdvojiti tek ona Kotruljevićeva promišljanja koja, prema mojoj procjeni, najbolje oslikavaju dosege njegovih spoznaja iz astronomsko-astrološkog korpusa. Uz to, napominjem da, a za razliku od prve polovice, druga polovica treće knjige Dubrovčaninova spisa oskudijeva pozivanjima na izvore te, kako se čini, Dubrovčanin u njoj poseže ili za vlastitim iskustvom ili za usmenom predajom.

Kao što sam već pripomenuo, prvo poglavlje treće knjige koje se u potpunosti odnosi na astronomsko-astrološku problematiku jedanaesto je po redu i u njemu je Kotruljević razmatrao dvanaest nebeskih znakova, zbog čega ga je i naslovio »O dvanaest nebeskih znakova« (»Delli XII segni dello cielo«). Povod Dubrovčaninovu bavljenju znakovima zodijaka bila je, kako otkriva na početku poglavlja, korisnost te vrste znanja mornaru kakvog je namjeravao stvoriti zbog vremenskih prilika koje sa sobom nose, znači ponovno zbog poznavanja meteoroloških prilika ključnih za plovidbu. ${ }^{752}$ Međutim, valja napomenuti da je Dubrovčaninov interes za znanjima o znakovima zodijaka sezao i ponad meteoroloških predviđanja. Prema mojem mišljenju, on je ta znanja prikupljao i razmatrao zbog izučavanja posljedica koje dvanaest nebeskih znakova ostvaruju i na ljudske sklonosti te djelovanje, dakle i iz etičke perspektive. Zbog toga ću se u ovom potpoglavlju usmjeriti na korisnost poznavanja utjecaja znakova zodijaka iz perspektive meteoroloških predviđanja, dok ću se u potpoglavlju o etičkoj sastavnici spisa o umijeću plovidbe usmjeriti na njihove etičke implikacije. $^{753}$

Poglavlje o dvanaest nebeskih znakova, poimenice o znakovima Ovan, Bik, Blizanci, Rak, Lav, Djevica, Vaga, Škorpion, Strijelac, Jarac, Vodenjak i Ribe, dubrovački je renesansni mislilac otpočeo pojašnjavanjem strukture njihova prebivališta i položaja koji u njemu

\footnotetext{
${ }^{752}$ Cotrullis, »De navigatione«, libro III, capitulo 11 / Kotruljević, »O plovidbi«, knjiga III, poglavlje 11, p. 188: $»<$ S $>$ egni de lo cielo sonno XII, li quali havere in notiçia per le conditioni delli tempi che portano seco et è necessario allo marinaro come nui constituimo marinaro, $<\ldots$.. «. / p. 189.

${ }^{753}$ Vidi na pp. 188-194 ovoga rada.
} 
zauzimaju. Nebesa su, bilježi Kotruljević, podijeljena na pet pojaseva ili krugova, koji se zovu krugovima, jer se nalaze na opsegu sfere. ${ }^{754}$ Potom je ponudio odredbu zodijaka. Zodijak je, prema njegovim spoznajama, krug koji se sastoji od pet kuteva linija, a etimološko porijeklo vuče od grčke riječi zodia što znači znak, dok na latinskom znači životinja, pa se iz tog razloga naziva krugom koji sadrži znakove, ali i životinjskim krugom. ${ }^{755}$ Dvanaest znakova raspoređeno je, nastavlja Dubrovčanin, posred nebeskog svoda i stoje poprijeko, i to ravnomjerno po točno razdijeljenim krugovima koji su označeni imenom i likom životinje, zbog toga što Sunce ulazeći u njihovo područje poprima osobinu pojedine životinje. ${ }^{756}$ Iz toga proizlazi da je znak dvanaesti dio zodijaka, kroz koji Mjesec prijeđe svoj put u trideset dana i u svakom znaku boravi dva i pol dana, dok Sunce taj put prijeđe u dvanaest mjeseci i u svakom boravi po jedan mjesec. ${ }^{757} \mathrm{Na}$ koncu pojašnjavanja strukture i poretka nebeskih znakova, Kotruljević je ponovno istaknuo važnost njihova poznavanja. Naime, pribilježio je da se dvanaest znakova tiče mornarskog znanja te svakog drugog ljudskog djelovanja (ogni altro actu humano). ${ }^{758}$ Naposljetku, izložio je i razlikovanje znakova u tri grupe po četiri znaka kojima pripadaju svojstva četiriju elemenata prema njihovu redoslijedu: vatra - Ovan, zemlja - Bik, zrak - Blizanci, voda - Rak, pa isto tako sljedeća četiri i posljednja četiri. ${ }^{759}$ U preostalom dijelu poglavlja o dvanaest nebeskih znakova Kotruljević je, kako sam i ranije napomenuo, upozorio na obilježja vremenskih prilika za vrijeme boravka planetā u području pojedinih znakova, kao i na ljudske sklonosti i djelovanje, dakle na njihova etička obilježja. Ovom prilikom ću se, ponavljam, usredotočiti tek na meteorološki aspekt Kotruljevićevih promišljanja o znakovima zodijaka, dok ću njihov utjecaj na ljudsko djelovanje obraditi u zasebnom potpoglavlju. Dubrovčanin se, dakako, najprije usmjerio na vremenske prilike koje su posljedice boravka planetā u prvom znaku: Ovan. Kada se Mjesec nađe u području toga znaka, on zbog svoje vatrene prirode naznačuje toplo i suho vrijeme, koje obilježava vedrina i

\footnotetext{
754 Cotrullis, »De navigatione«, libro III, capitulo 11 / Kotruljević, »O plovidbi«, knjiga III, poglavlje 11, pp. 188-190: „<..> li quali sonno quisti, ciò è: Aries, Taurus, Gemini, Cancer, Leo, Virgo, Libra, Scorpio, Sagiptarius, Capricornus, Aquarius, Piscis. La habitation del cielo sta distencta de zone et le zone sonno cinque, le quali per ciò se chiamano zone o vero circuli perché stanno nel circuito della spera.«/pp. 189-191.

755 Ibid., p. 190: »Zodiaco è lo circulo lo quale costa de cinque anguli de le linee. Zodia in greco vol dire signo o vero animal in latino. Inde zodiaco se dicie animal o vero circulo havente signo, <..>«. / p. 191.

${ }^{756}$ Ibid., p. 190: »<..> perché stanno in meço del firmamento li XII signi per traverso posti equalmente per circuli destincti, li quali con nume et forme de animali sonno designati, perché lo Sole, intrando in quilli, acquista la proprietà delli animali.«/p. 191.

${ }^{757}$ Ibid., p. 190: »Lo signo è XII parte del zodiaco, et la Luna fa lu corsu suo in XXX giorni et in ogni signo stane dui giorni et meço; et lu Sole transscorre in XII misi et in ogni signo stane uno mese.«/p. 191.

${ }^{758}$ Ibid., p. 190 / p. 191.

${ }^{759}$ Ibid., p. 190: »< ..> li quali XII signi sonno spartuti a quattro a quattro. Li primi quattro hanno proprietà de IIII elementi con quisto ordine: focho, terra, aere, acqua - Aries, Taurus, Gemini, Cancer, et simili modo l'altri IIII et coscì per quillo medesimo ordine li terçi IIII.«/ p. 191.
} 
u kojem prevladava kratkotrajni istočni vjetar ili subsolan. ${ }^{760}$ Tome je dodao da Sunce ulazi u znak Ovna osamnaestog dana mjeseca ožujka, dakle na početku proljeća, a postoji i uvjerenje da je u tom znaku bio stvoren cjelokupan svijet. ${ }^{761}$ Kotruljević je o vremenskim prilikama koje uzrokuje boravak Sunca u Ovnu pisao i unutar izlaganja o porijeklu nazivka Ovan. Znak se, naime, zove tako jer je ovan straga slaba, a sprijeda snažna životinja, pa je tako i u vrijeme njegove vladavine stražnja strana Sunca slaba zbog hladnoće, a prednja strana snažna zbog topline, što je Kotruljević oprimjerio i time što ovan zimi leži na lijevom boku i tek se u proljeće okreće na desni bok, baš kao što i Sunce u to vrijeme stoji na lijevoj strani nebeskog svoda, dakle na jugu, te prelazi na desnu stranu, dakle na sjever. ${ }^{762}$ Kao posljednji podatak uz izlaganje o vremenskim prilikama za vrijeme vladavine Ovna, Dubrovčanin je napomenuo da se najbolje prognoziranje ili, kako kaže, ono što se naziva »upućeni mornar« odvija onda kada Mjesec uđe u onaj znak u kojem je Sunce za vrijeme mladog Mjeseca, pa se svakim danom uspinje za po dvanaest stupnjeva te tako za dva i pol dana ispunjava trideset stupnjeva, a to je upravo onoliko vremena koliko Mjesec, kako je ranije spomenuo, treba boraviti u području jednoga znaka. ${ }^{763}$

Za razliku od kolikoće podataka koju je dubrovački mislilac ponudio o vremenskim prilikama za vrijeme Ovna, njegovo izlaganje o preostalim znakovima može se ocijeniti šturim i oskudnim. Primjerice, za znak Bika zapisao je tek to da je zemljane prirode i da je hladan i suh, zatim da uzrokuje oblačno, hladno i suho vrijeme te da je u skladu s Venerom. ${ }^{764}$ Kada je riječ o nebeskom znaku Blizanci, Dubrovčanin je pribilježio tek to da se u vrijeme njegove vladavine udvostručuje snaga Sunca, a tome je tako ili zbog toga što se tada stvari umnažaju ili zbog toga što se Sunce podiže dva stupnja više iznad zemlje, zatim da Sunce ulazi u taj znak 18. svibnja i da se u njegovo vrijeme zrak mijenja pa započinju kiše i vrijeme se muti,

${ }^{760}$ Ibid., p. 190: »Et dirremo / che la Luna existente in Ariete fa lo tempo caldo et sicco de natura de focho, et fa serino, et predomina subsolano et non dura.«/p. 191.

${ }^{761}$ Ibid., p. 190: »Intra lu Sole in quisto signo a dì XVIII de março et in quisto signo de Ariete se dicie lo sole mundo essere facto, ne lo qual è lo Sol circa lu principio de primavera.«/p. 191.

762 Ibid., p. 190: »Chiamase Ariete perché, come ariete è animal debile allo dereto et davanti à alcuna forteça, coscì lo dereto dello Sole in quel tempo è debile per lo freddo che minuisce le sue forçe. La parte davanti che resguarda la state à alcune forçe dello caldo; o vero, come lo ariete, che de verno iacie nello lato sinistro, alla primavera comincia colcarese a lo lato dextro, coscì lo Sol in quillo tempo sta nel sinistro lato dello firmamento, ciò è nel meço giorno, et poi intra allo lato dextro, ciò è in aquilone.«/p. 191 .

${ }^{763}$ Ibid., pp. 190-192: »<..> et nota che sempre la Luna intra in quillo signo in lo qual è lo Sole quando la Luna è nova, et coscì va numerando ogni giorno XII gradi, ché dui dì e meço sonno XXX gradi, et tanto discurre per uno signo et questo è optimo pronostico o marinaro intendente.«/pp. 191-193.

${ }^{764}$ Ibid., p. 192: »<T>auro è signo sicundo et è de natura de terra, freddo et sicco; et fa tempo nubiloso, freddo et sicco; $[. .$.$] Tauro è [\ldots]$ conforme ad Venere.«/p. 193. 
dok razina mora počinje rasti. ${ }^{765}$ Kotruljević nije bio rječitiji ni u opisima vremenskih prilika u doba vladavine preostalih znakova. Za znak Rak zapisao je tek to da je dobio naziv po životinji koja se giba unatrag, budući da se u njegovo doba Sunce udaljava od nas, ali je riječ o znaku koji je u skladu s Mjesecom, zbog čega su meteorološki uvjeti hladni, vlažni, kišoviti i obilježeni puhanjem sjevernih vjetrova. ${ }^{766}$ Peti znak po redu, Lav, topao je i suh po naravi i Sunce u njega ulazi 19. srpnja, a nazvan je tako zbog toga što je lav okrutna i grozničava životinja, pa su upravo surovost i grozničavost obilježja vremenskih prilika za njegove vladavine. ${ }^{767}$ Djevica je, bilježi Kotruljević, znak koji je u skladu s Merkurom i u koji Sunce ulazi 18. kolovoza, a sa sobom donosi neplodno i nemirno vrijeme, ali istodobno i vrijeme u kojem rođene stvari dozrijevaju, kao i vrijeme koje je obilježeno hladnoćom i suhoćom te južnim vjetrovima. ${ }^{768}$ Sljedeći znak zodijaka po redu jest Vaga, koji se dobro slaže s Venerom i Sunce ulazi u njega 18. rujna, a ime mu potječe od toga što Sunce u njemu zastaje, jer tada dan i noć jednako traju te nastupa jesenska ravnodnevnica, i riječ je o znaku koji je po naravi topao i vlažan pa sa sobom donosi lijepo i vedro vrijeme. ${ }^{769}$ Vremenske prilike za vrijeme vladavine znaka Škorpion, koji je u skladu s Marsom i Sunce u njega ulazi 18. listopada, podudarne su škorpionu koji je otrovan i bode, zbog čega je vrijeme bolesno radi nejednoličnosti zraka koji je jutrima toliko hladan da štipa, a u podne toliko topao da uništava. ${ }^{770}$ Taj znak je, piše Dubrovčanin, hladan i vlažan te oblačan i kišan, zbog čega donosi oblačno i kišno vrijeme u kojem prevladavaju zapadni vjetrovi. ${ }^{771}$ Prema njegovim spoznajama, znak Strijelac u skladu je s Jupiterom i Sunce u njega ulazi 17. studenog, a dobio

765 Ibid., p. 192: »<G>emini è lo terço signo, coscì chiamato perché in quillo tempo la força dellu Sole se giemina, ciò è radoppia, perché allora le cose geminano o vero multiplicano, perché gli animali allora producono figlioli, o vero ché lu Sole se leva dui gradi più da terra. [...] Intra lu Sol in quisto signo XVIII de magio. [...] Et in fine delli dicti signi lo aere se comincia mutare a ploggia e lo tempo se turba. Lo mare comincia ingrossarse.«/p. 193.

766 Ibid., p. 192: »<C>ancro è animal retrogradu, ché allora / lu Sole se parte da nui, et è friddo et humido, pluvioso, [...] Usano venti septentrionali et fasi colla Luna.«/p. 193.

${ }^{767}$ Ibid., p. 194: "<L>eo è quinto signo, coscì chiamato perché lu leone è animal multo crudele et sempre febricitante. Coscì è quillo tempo crudele et genera febre. [...] Ell'è signo caldo et sicco, [...] Entra lu Sol in quisto signo XVIII de iulio.«/p. 195.

${ }^{768}$ Ibid., p. 194: »<V>irgo è sexto signo, perché come la virgine niente gienera, coscì quillo tempo è sterile, ma le cose generate fa maturare [...] Tempo da turbulento, freddo et sicco; [...] Regnano venti meridionali. Confiase con Mercurio. Intra lu Sol in isso a dì XVIII d'agusto.«/p. 195.

${ }^{769}$ Ibid., p. 194: »<L>ibra è septimo signo, dicto libra per la equalità de quillu mese, perché lo Sole, stando in quillo signo, lo giorno et la nocte è equalmente ponderata perché allora è equinoctio autunnale. Et è di natura caldo et humido, et fa lo tempo bello et claro; [...] Confiase multo con lo pianeto de Venus. Intra lo Sole in dicto signo XVIII Setembris.«/p. 195.

770 Ibid., p. 194: »<S>corpio è optavo signo, et cole lo scorpione è venenoso et pungie, così e el tempo de quello è morboso per la inequalitate dello aere, perché la mautina è freddo pungiente et a meço giorno calda che consuma. [...] et è conforme ad Marte. Intra lu Sol in quisto signo XVIII Octobris. «/p. 195.

${ }^{771}$ Ibid., p. 194: »È signo freddo et humido, nubiloso et aquoso, [...] Regnano li venti de ponente; tempo da nubiloso et aquoso.«/p. 195. 
je ime po tome što se u doba njegove vladavine u lovu najčešće upotrebljavaju strijele i zbog učestale pojave munja, ali je ipak riječ o znaku koji je topao i suh te donosi vedro vrijeme $u$ kojem prevladavaju istočni vjetrovi. ${ }^{772}$ Obilježja vremenskih prilika u doba vladavine znaka Jarac, koji je usklađen sa Saturnom i Sunce u njemu boravi od 18. prosinca, jesu: Sunce se tada nalazi na najvišem stupnju prema jugu i uspinje se prema nama poput jarca, potkraj prosinca najčešće padaju kiše, vremenske prilike obilježene su toplinom, vlažnošću, vedrinom te vjetrovitošću, $\mathrm{i}$ to posebice puhanjem južnih vjetrova ponajviše jugozapadnjaka. ${ }^{773}$ Vremenske prilike u razdoblju vladavine znaka Vodenjak, koji je u skladu sa Saturnom i u koji Sunce ulazi 18. siječnja, obilježene su obilnim kišama i vjetrovima, a znak je, inače, po naravi topao i vlažan. ${ }^{774}$ Posljednji, dakle dvanaesti znak zodijaka Ribe je, bilježi dubrovački mislilac, znak koji je u skladu s Jupiterom i u kojem Sunce boravi počevši od 15. veljače, a vrijeme je tada izrazito kišovito i oblačno, budući da je riječ o znaku koji je sjeverni, hladan, vlažan i kišan. ${ }^{775}$

Dvanaesto i trinaesto poglavlje treće knjige Kotruljevićeva spisa o plovidbi otkrivaju dodatan sloj njegovih astronomsko-astroloških razmatranja. Naime, u njima je, naslovivši ih »Tablica koja pokazuje u kojem je znaku Mjesec« (»La tavola in che signo è la Luna«) te »Mjesečeva tablica« (»La tavola della Luna«), ukazao na važnost koju je poznavanje položaja planetā, u ovom slučaju Mjeseca, imalo za praktičnu izvedbu plovidbe, posebice u navigacijskom smislu. Ono što je u naslovu dvanaestog poglavlja nazvao tablicom koja pokazuje u kojem je znaku Mjesec, a u naslovu trinaestog mjesečevom tablicom, zapravo su efemeride, tablice koje na temelju izračuna pružaju podatke o položaju i udaljenosti nebeskih tijela $u$ navigacijske svrhe. ${ }^{776}$ Unatoč tome što je u obama poglavljima najavio grafički prikaz efemerida koje je sadržajno opisivao, Kotruljevićev rukopis ne sadrži takve prikaze, a što nije

\footnotetext{
772 Ibid., p. 196: »<S>agiptario è nono signo, coscì chiamato / per la cacciascione la qual el più delle volte se fa colle sagiepte in quillo tempo, per li fulguri che allora cascano. Et è signo caldo et sicco, [...] conforme a Iuppiter. Intra lo Sol in quisto signo XVII Novembris. Tempo da chiaro [...] Regnano venti orientali.«/p. 197.

${ }^{773}$ Ibid., p. 196: $»<\mathrm{C}>$ apricorno è decimo signo, et come la capricorno se pascie in asperissime et vastissime ripe, coscì lo Sol è allora in altissimo grado verso lo meço giorno, o vero come lu capricorno sole sallire li monti, coscì lu Sole comincia sallire ad noi. [...] le ploggie le quali solgliono essere el più del volte circa li ultimi dì del dicto mese. È caldo et humido, ventoso, [...] et fase con Saturno. Intra lu Sole in dicto signo XVIII Decembris. Regnano venti meridionali, vento africo.«/p. 197.

774 Ibid., p. 196: »<A>quario è undecimo signo, perché allora è habundantia de acque et de venti. E caldo et humido, conforme ad Saturno. Intra lu Sol in quisto signo die XVIII mensis Ianuarii «. / p. 197.

775 Ibid., p. 196: »<P $>$ esce, duodecimo signo, perché come lo pesce è animal aquatico, coscì anche quello tempo è multo pluviloso, [...] conforme con Iuppiter. Intra lu Sole in questo mese o vero signo XV Februarii. Tempo da nubiloso et è signo septentrionale, freddo et humido, aquatico, <... « . / p. 197.

${ }^{776}$ Cotrullis, »De navigatione«, libro III, capitulo 12 / Kotruljević, »O plovidbi«, knjiga III, poglavlje 12, p. 198 / p. 199, bilješka 247.
} 
spriječilo obojicu priređivača prijepisa spisa da izrade vlastite prikaze prema Dubrovčaninovu predlošku. ${ }^{777}$

Da bi ukazao na vrijednost znanja o položaju planetā za mornare, Kotruljević je na početku dvanaestog poglavlja podsjetio na obilježja Sunčeva i Mjesečeva gibanja koja je izložio u poglavlju o dvanaest nebeskih znakova. Ponovio je sljedeće podatke: Sunce boravi u svakom znaku trideset dana; Mjesec boravi u svakom znaku dva i pol dana; u razdoblju od trideset dana Mjesec provede vrijeme u području svakog od dvanaest znakova, zbog čega se, brojanjem od prvog dana Mjesečeva pojavljivanja, može ustanoviti u kojem se znaku nalazi; Mjesec je uvijek mlad u onome znaku u kojem se nalazi Sunce. ${ }^{778} \mathrm{U}$ svrhu dokazivanja istinitosti tih tvrdnji, dubrovački ih je mislilac osnažio kratkim pravilom. To je, prema njegovu sudu, najlakše dokazati tablicom na kojoj bi u stupcima velikim slovima bili označeni mjeseci u godini, a na početku svakog retka bili bi označeni dani u mjesecu, dok bi središnji dio tablice bio ispunjen stupnjevima. ${ }^{779}$ Takvom tablicom treba se služiti na sljedeći način: pronaći redni broj dana u mjesecu te, vodeći se stupcima, pronaći ispod traženog mjeseca znak u kojem je toga dana Mjesec, a potom, vodeći se retcima, pronaći na koliko se stupnjeva nalazi. ${ }^{780} \mathrm{U}$ tako izrađenoj efemeridi i primjenom predloženih postupaka, Kotruljević je donio podatak da se 24. lipnja Mjesec nalazi u znaku Ovna na 17 stupnjeva. ${ }^{781}$

Neospornu upućenost u načine izrade i čitanja efemerida iskazao je i u sadržaju trinaestog poglavlja treće knjige. U njemu je opisao sadržaj efemeride koja nudi podatke o vremenu nastanka i mjestu boravka mladog Mjeseca, dakle nudi podatke o mjesečevim mijenama. Takva efemerida na početku svakog retka treba imati ispisane godine, u svakom stupcu mjesece, a u svojem središtu dane i vrijeme zbivanja pojedine mjesečeve mijene. ${ }^{782}$

${ }^{777}$ Ibid., pp. 198-200. / pp. 199-201. Vidi i: Cotrugli, »De navigatione (1464-1465) Ms. Schoenberg 473«, pp. $167-171$.

${ }^{778}$ Ibid., p. 198: »<Q> uando lo marinaro vole sapire in qual signo è la Luna, è necessario che 'l sappia che lu Sole, come se dicto, intra in Ariete a le XVIII de lo mese de março et demora XXX iurni in quillu signu, poi d'aprile intra in Tauro etc. Et sta in ogni signo giorni dui et meço sì che in XXX iurni cierca tucti li XII signi, et coscì numerando dallo primo dì de la Luna cognoscerai in que signo è la Luna. Et come se dicto nel precedente capitulo, sempre la Luna è nova in quillo signo in lo quale è lu Sole.« / p. 199.

779 Ibid., p. 198: »Et per cognoscere per regola brevemente, havimo voluto descrivere la tavola qui desocto et viderete le lictere grosse sonno delli misi in marso, aprile et coscì delle altre. Li numeri davanti sonno giorni de lo mese, li numeri dereto sondo li gradi; <..> «. / p. 199.

${ }^{780}$ Ibid., p. 198: $»<\ldots>$ et trovando lo numero davanti al giorno che tu dimandi, per recta linea tennevai et trovarai desocto quillo mese lo signo in lo quale è la Luna quel giorno; / et andando per lo dricto trovarai al quanti gradi et contando sempre li giorni della Luna: <..> «. / p. 199.

${ }^{781}$ Ibid., p. 198: »<..> a le XXIIII de iugno trova 24 et va per lineam sui al ç, che vol dir çugno, et trovarai Aries a gradi XVII.«/p. 199.

${ }^{782}$ Cotrullis, »De navigatione«, libro III, capitulo 13 / Kotruljević, »O plovidbi«, knjiga III, poglavlje 13, p. 200: $"<$ P $>$ er cognoscere quando fa la Luna et in che giorno, hora et punto sta la Luna, veda lo marinaro la infrascripta tavola. Et prima vederai lo anno Domini et poi vedi qual mese voi et per lineam rectam trovarai socto quello mese la sua casa.«/p. 201. 
Naposljetku, uz naputak da sate uvijek treba brojati od izlaska Sunca, Dubrovčanin je ponudio primjer za 1465. godinu u kojoj se, kako bilježi, mjesečeva mijena dogodila 25. ožujka u 17 sati i 637 točaka, što otprilike odgovara 17 sati i 35 minuta. ${ }^{783}$

Četrnaesto poglavlje treće knjige Kotruljevićeva spisa o plovidbi nosi naslov »O svojstvima sedam planeta« (»Della proprietà delle VII pianeti«). Već je iz naslova tog poglavlja lako zaključiti da je riječ o poglavlju u kojem će prevladavati prirodnofilozofske teme i to one astronomsko-astrološke naravi. Kao što sam naznačio prilikom izlaganja o poglavlju koje se odnosi na dvanaest nebeskih znakova, Kotruljevićev poriv za promišljanjem o astronomskoastrološkim temama proizašao je iz navigacijskih potreba za znanjima o meteorološkim pojavama te za znanjima o utjecaju nebeskih tijela na ljudsko djelovanje, znači o etičkim obilježjima ljudi za vrijeme u utjecaja pojedinih nebeskih tijela. Većinu četrnaestog poglavlja dubrovački je mislilac posvetio upravo dobroj ili lošoj naravi utjecaja koje pojedini planeti ostvaruju na ljudsko djelovanje. Budući da je u poglavlju o svojstvima sedam planeta pristupao astronomsko-astrološkoj tematici poglavito iz etičke perspektive, glavninu svoje analize njegova sadržaja uvrstit ću u potpoglavlje ovoga rada koje se odnosi na prisutnost etičke sastavnice u spisu o plovidbi. ${ }^{784}$

Ipak, poglavlje o svojstvima sedam planeta otkriva Kotruljevićeva stajališta o redoslijedu elemenata i planeta, dakle pruža uvid u njegovu zamisao strukture svijeta. Naime, na koncu tog poglavlja Kotruljević je najavio da će u spis uvrstiti kotač (la rota) koji pokazuje redoslijed elemenata $\mathrm{i}$ planeta te taj prikaz nazvao »Tablica sedam planeta i četiriju elemenata« (»Tavula delle VII pianeti et IIII elementi«), ${ }^{785}$ no to nije učinio. Iako se taj zapis nalazi u objema dosad pronađenim rukopisnim inačicama prijepisa spisa o plovidbi, prikazi koje su ponudila dvojica priređivača dosad poznatih prijepisa spisa razlikuju se po strukturi. Vođeni Kotruljevićevom zamišlju, Salopek ga je rekonstruirao i izradio kao sferični grafički prikaz redoslijeda elemenata i planeta, dok ga je Falchetta prikazao tabelarno. ${ }^{786}$ Prema Salopekovim riječima, Kotruljević se povinovao tradicionalnu prikazu geocentričnog sustava svijeta koji se temelji na Aristotelovu i Ptolemejevu tumačenju, a koji su svijet prikazivali na sljedeći način: u središtu se nalazi Zemlja sastavljena od četiriju elemenata, i to redom od

\footnotetext{
${ }^{783}$ Ibid., p. 200: »Ut puta: nel 1465, março, volta la Luna die XXV, XVII hore, punti 637, et sempre numera le hore da lo Sole.« / p. 201. Izračun vremena zbivanja mjesečeve mijene iz Kotruljevićeva primjera napravio sam na temelju Salopekova pojašnjenja uz prijevod Dubrovčaninova teksta: Ibid., p. 200. / p. 201, bilješka 249: »Točke su uzete iz hebrejskog načina računanja: 18 točaka $=1$ minuta.«

${ }^{784}$ Vidi na pp. 188-194 ovoga rada.

${ }^{785}$ Cotrullis, »De navigatione«, libro III, capitulo 14 / Kotruljević, »O plovidbi«, knjiga III, poglavlje 14, p. 202 : $»$ La rota lo mostra.«/ p. 203.

${ }^{786}$ Ibid., p. 204. / p. 205. Vidi i: Cotrugli, »De navigatione (1464-1465) Ms. Schoenberg 473«, p. 174.
} 
najnižeg prema najvišem (zemlja, voda, zrak, vatra), zatim iza nje dolazi sedam koncentričnih sfera koje nose sedam planeta, potom osma sfera zvijezda stajačica te, naposljetku, nepokrenuti i nepokretni prvi pokretač čitava gibanja. ${ }^{787}$

Sadržaj petnaestog poglavlja treće knjige spisa o plovidbi usko je povezan sa sadržajem četrnaestog poglavlja. To je razvidno već iz naslova koji je Kotruljević oblikovao na sljedeći način: »O vladavini sedam planeta u danu« (»Dello dominio delli VII pianeti in die«). U njemu je, naime, teme iz astronomsko-astrološkog korpusa doveo u vezu s temama koje se odnose na ljudsko zdravlje, dakle s temama iz medicine, te onima koje se odnose na ljudsko djelovanje, dakle s temama iz etike. Na ovom ću mjestu uzeti u razmatranje tek onaj dio petnaestog poglavlja koji se odnosi na Kotruljevićev izračun vremena u kojem planeti vladaju danom te na opis načina ostvarivanja njihova utjecaja na ljudsko zdravlje, a što spada u područje astrološke medicine.

Petnaesto je poglavlje dubrovački mislilac otpočeo pojašnjavanjem pojave da, prema njegovu mišljenju, svaki od sedam planeta vlada dijelovima dana koji se sastoji od dvadeset i četiri sata, računajući od sata Sunčeva izlaska. ${ }^{788}$ Pritom je ponovno opisao izračun i najavio grafički prikaz prema sljedećim uputama: najprije treba pronaći dan, zatim $q$ i traženi sat $\mathrm{u}$ danu, potom pronaći objekt ravno od gore prema dolje i tada je moguće pronaći planet označen crvenom bojom. ${ }^{789}$ Salopek je, na temelju Kotruljevićeva opisa, izradio tabelarni prikaz vladavine sedam planeta $\mathrm{u}$ danu. ${ }^{790}$ Dubrovčanin je u nastavku poglavlja ukratko obrazložio svrhu izračuna i način ostvarivanja utjecaja planeta na sate u danu. Prema njegovu mišljenju, takav izračun izrazito dobro služi pri započinjanju nekog posla, budući da planeti u sebi posjeduju različitu narav djelovanja koja može oblikovati tijek i ishod započetog posla, kako je zabilježio u četrnaestom poglavlju. ${ }^{791}$

Međutim, u petnaestom je poglavlju treće knjige Dubrovčanin opisao i utjecaje koje svaki od sedam planeta ostvaruje na ljudsko zdravlje. Pritom napominjem da to Kotruljevićevo opisivanje ukazuje na to da je bio upoznat sa znanjima koja spadaju u takozvanu astrološku medicinu. Radi se, naime, o disciplini koja, kako 1990. godine ističe američka povjesničarka

\footnotetext{
${ }^{787}$ Ibid., p. 204. / p. 205, bilješka 251.

${ }^{788}$ Cotrullis, »De navigatione«, libro III, capitulo 15 / Kotruljević, »O plovidbi«, knjiga III, poglavlje 15, p. 204: $»<\mathrm{D}>$ evemo intendere che li prenominati VII pianeti hanno dominio nelle parte dello giorno che per XXIIII hore se coglie, [...] et contase dalla hora che escie lu Sole.«/p. 205.

${ }^{789}$ Ibid., p. 204: »<..> come ne la pradica della infrascripta tavola se demostra, [...] Trovando lo giorno et poi lo I et le hore che tu voi, et hagiate l'obiecto desopra per directo et trovarete lo vostro pianeta de russo.«/p. 205.

790 Ibid., p. $206 . /$ p. 207.

${ }^{791}$ Ibid., pp. 204-206: „Serve multo questa cosa ad principar de le cose, perché li pianeti hanno in sí diverse nature de operationi secundo se dicto nel precedente capitulo.«/pp. 205-207.
} 
srednjovjekovne i renesansne medicine i znanosti Nancy Gillian Siraisi u djelu Medieval and early Renaissance medicine: an introduction to knowledge and practice, uključuje ništa drugo nego upotrebu astroloških tehnika u medicinske svrhe, ${ }^{792}$ a koja se na Zapadu ponajviše upražnjavala u razdoblju od 14. do 16 . stoljeća. ${ }^{793}$ Osim toga, astrološka medicina obuhvaća i znanja o djelovanju planetā na, kao što 1996. godine poručuje američka stručnjakinja za astrološku medicinu Eileen Nauman $\mathrm{u}$ djelu Medical Astrology, funkcionalnost ili disfunkcionalnost pojedinih organa ili čitavih organskih sustava u tijelu, a s obzirom na to $u$ kojem je znaku boravio planet $\mathrm{u}$ vrijeme nečijega rođenja. ${ }^{794}$ Kotruljevićeva upućenost $\mathrm{u}$ astrološku medicinu ogledala se u naznačavanju posljedica koje vladavina određenog planeta u pojedini sat u danu ostvaruje na ljudsko zdravlje. Iako je prema strukturi njegova izlaganja bilo za očekivati da će uz sate u kojima vlada svaki od planeta naznačiti i medicinske posljedice, dubrovački je mislilac to ipak propustio učiniti u slučaju Merkura i Mjeseca. Jedno od potencijalnih objašnjenja takve odluke moglo bi biti da je bio uvjeren da djelovanje upravo tih dvaju planeta nema ni korisnih ni štetnih učinaka na zdravstveno stanje ljudi. Prema Kotruljevićevim spoznajama, ako za vrijeme trajanja sata u kojem vlada planet Saturn netko upita za bolest, treba mu odgovoriti da će bolovati od glavobolje, vrućice u grudima i potištenosti, no neće od bolesti umrijeti, ali će kasno ozdraviti. ${ }^{795}$ Ukoliko tkogod postavi pitanje o tijeku svoje bolesti u Jupiterov sat, treba mu reći da će bolovati od bolesti krvi i da će umrijeti bude li bolovao 4., 7. ili 11. dana u mjesecu. ${ }^{796}$ Onome tko pitanje o sebi postavi tijekom vladavine Marsa, treba mu reći da će umrijeti od groznice. ${ }^{797}$ Kotruljević je bio najrječitiji pri opisu zdravstvenog stanja ljudi u vrijeme vladavine Sunca i Venere, što su ujedno i dva posljednja opisa koja je ponudio jer je, kako sam već napomenuo, Merkurov i Mjesečev utjecaj na zdravlje izostavio. Tijekom Sunčeva sata onome tko upita za svoju bolest treba odgovoriti sljedeće: bolovat ćeš od akutne groznice ili od trećednevke; ozdravit ćeš ako

792 Nancy G.[illian] Siraisi, Medieval and early Renaissance medicine: an introduction to knowledge and practice (Chicago: The University of Chicago Press, 1990), p. 135: „<... the term 'medical astrology' normally implies nothing more than the use of astrological techniques for medical purposes, $<\ldots>\ll$.

${ }^{793}$ Siraisi, Medieval and early Renaissance medicine: an introduction to knowledge and practice, p. 16: »<..> the actual practice of medical astrology was probably greatest in the West between the fourteenth and sixteenth centuries."

${ }^{794}$ Eileen Nauman, Medical Astrology, third revision (Cottonwood: Blue Turtle Publishing, 1996), p. 4a: »In medical astrology the planets indicate the functions or malfunctions of specific organs or systems in the body, depending on what sign the planet is posited in at birth."

${ }^{795}$ Cotrullis, »De navigatione«, libro III, capitulo 15 / Kotruljević, »O plovidbi«, knjiga III, poglavlje 15, p. 206 : $»<\ldots>$ in hora Saturno $[\ldots]$ se de l'infermo, dite che non morerà, ma tardo serrà libero; de che pate, diciti dolor de capo, ardor de pecto, de malanconia; <..>«. / p. 207.

${ }^{796}$ Ibid., p. 206: »Iuppiter: [...] Et se 'l te domanda de infirmo, dirai, se l'è IIII, VII, vel XI, morirà; se de quello pate, dirrai sangue; <... >«. / p. 207.

${ }^{797}$ Ibid., p. 206: »<..> in hora de Marte, dirai che morerà; che pate, dirrai causon; <...>«. / p. 207. 
se 5. i 7. dana u mjesecu budeš znojio toplim znojem, u protivnom ćeš nastaviti bolovati. ${ }^{798}$ Naposljetku, onome tko postavi pitanje o bolesti u Venerin sat, trebalo bi mu odgovoriti da će bolovati od trajne groznice, no da će ipak ozdraviti, ali s mukom. ${ }^{799}$

Od šesnaestog do devetnaestog poglavlja treće knjige De navigatione Kotruljević je pisao o još jednoj temi kojoj je također pristupio iz astronomsko-astrološke perspektive: o vremenu. Ta je poglavlja naslovio »O danu« (»Dello iorno«), »O egipatskim danima« (»Delli giorni egiptiaci«), »O solsticijima« (»Del solstitii«) i »O razmaku vremena« (»Del spatio del tempo«). U njima je prikazao načine mjerenja vremena koji uvelike ovise o položaju i gibanju nebeskih tijela.

Kotruljević je šesnaesto poglavlje treće knjige otpočeo razlikovanjem dviju vrsta danā: prirodni (naturale) dan i umjetni ili uobičajeni (artificiale o vero usuale) dan. Prirodni dan, tvrdi Kotruljević, obuhvaća vrijeme u kojem Sunce prijeđe čitavu Zemlju od istoka do zapada, pri čemu se izmjenjuju vrijeme dana i noći, te da se prirodni dan sastoji od 24 sata ${ }^{800}$ Umjetni ili uobičajeni dan obuhvaća vrijeme u kojem Sunce prelazi iznad naše hemisfere od svojeg izlaska do zalaska, zatim da se zove umjetnim jer je prikladan za ljudske običaje i umijeća te da je većinom dan, a manjim dijelom noć. ${ }^{801}$ Jedini slučaj u tom poglavlju u kojem je dubrovački mislilac dao do znanja da mu je izvor bio hispanski teolog, filozof, povjesničar i crkveni naučitelj Izidor iz Sevilje (Isidorus Hispalensis, između 560. i 570. - 636) i to u dijelu koji se odnosio na podjelu dana. Naime, Izidor je, pripominje Kotruljević, podijelio dan na tri dijela: 1) jutro, koje je rano i potpuno svjetlo; 2) podne, dakle sredina dana kada je dan bistriji; 3) večer, posljednji dio dana. ${ }^{802}$ Posljednji podatak koji je Kotruljević navodno preuzeo od tog španjolskog srednjovjekovnog mislioca u poglavlju o danu odnosio se na podjelu noći. Prema njegovu nauku, noć ima sedam dijelova: večer (vesper), sumrak (crepusculum), noćna tišina (conticinium), gluho doba noći (intempestum), kukurikanje

${ }^{798}$ Ibid., p. 206: »<..> nel hora del Sole, [...] Se dello infirmo, sci in V, VII iorno sudarà con sudore caldo serà libero; se ·nno [prema Falchettinu transkriptu iz 2009. godine treba stajati: »non«], li siquirà lo contrario; che pate, respondi: 'Acuta o terçana.' «/ p. 207.

${ }^{799}$ Ibid., p. 206: »Hora de Venere: [...] se de infirmo, serrà libero ma cum fatiga; / che pate, respondi: 'Febre continua.' «/ p. 207.

${ }^{800}$ Cotrullis, »De navigatione«, libro III, capitulo 16 / Kotruljević, »O plovidbi«, knjiga III, poglavlje 16, p. 208: $»<\mathrm{L}>\mathrm{O}$ iorno o vero dì è in dui modi, ciò è naturale et artificiale o vero usuale. Naturale è spacio nello quale lo Sole transcorre per tucta la terra de levante in ponente, spatio de iorno et de nocte, lo qual contene in sí XXIIII hore; <...>«. / p. 209.

${ }^{801}$ Ibid., pp. 208-210: »Iorno artificiale se chiama o vero usuale, nellu quale lu Sole tarda sopra lu nostro emisperio dallo ortu de lo Sole fin a lo occaso [...] Et dicto è usuale o vero artificale perché questo solo è apto allu usu et artificiu delli homini. Et chiamato è lo iorno alla meglior parte sença commemoratione della nocta, $<\ldots$.. «. / pp. 209-211.

${ }^{802}$ Ibid., p. 210: »Et secundo Isidoro, tri sonno le parte dellu giorno, ciò è: matina, meço giorno et sera. Matina se chiama lucie matura et piena, meço giorno se chiama quasi medidies, chè allora è meço dì o più puro giorno. Sera è ultima parte dellu giorno.«/p. 211. 
pijetlova (gallicinium), praskozorje (matutinum) i osvit (diluculum) ${ }^{803}$ Poglavlje $» \mathrm{O}$ danu« Kotruljević je dovršio iznošenjem dodatne višestruke podjele danā. Prema njegovim spoznajama, postoje sljedeće vrste danā: 1) zvjezdani (syderali) dani, tijekom kojih se zvijezde gibaju i ljudi se klone plovidbe; 2) borbeni (preliales) dani, tijekom kojih su kraljevi običavali ići u borbu; 3) umetnuti (interscalares) dani, koji čine višak u dvanaest mjeseci; 4) pasji (caniculari) dani; 5) dani solsticija (solstitiali); 6) dani ekvinokcija (equinoctiali); 7) sudbeni (fasti) dani, tijekom kojih su Rimljani objavljivali zakone; 8) zlokobni (nefasti) dani, dani koji su suprotni od sudbenih; 9) svečani (festivi) dani, dakle blagdanski i slavljenički dani; 10) loši (mali) dani, tijekom kojih su ljudi rastuženi više nego obično; 11) egipatski (egiptiaci) dani; 12) dani spasenja (dies salutis); 13) sudnji dani (dies iudicii), tijekom kojih će Bog suditi živima i mrtvima. ${ }^{804}$

Unatoč tome što je na kraju šesnaestog poglavlja treće knjige spisa o plovidbi izložio čak trinaest različitih vrsta danā, Kotruljević je zasebno poglavlje odlučio posvetiti tek jednoj vrsti. Riječ je o sedamnaestom poglavlju treće knjige u kojem je podrobnije pisao o danima koje je nazvao egipatskima (egiptiaci). Iako se radi o opsegom oskudnom i vrelima nepopraćenom poglavlju, ono ipak rasvjetljuje ključna obilježja te vrste danā. Egipatskim danima su, bilježi dubrovački umnik, Egipćani nazvali dva dana u mjesecu, zbog toga što su egipatski astrolozi pronašli sazviježđa koja su škodljiva za ljudsko djelovanje (humani acti) i zbog toga ih odlučili zabilježiti. ${ }^{805}$ Nejasno, međutim, ostaje kako se očituje navodna škodljivost tih sazviježđa po ljudsko djelovanje. Kotruljević je potom priopćio da nije moguće znati kada će se zbiti egipatski dani zbog nedostatnosti njegovih izračuna. ${ }^{806}$ Dubrovčanin je poglavlje o egipatskim danima zaključio iznošenjem pretpostavke da je moguće da su Egipćani te dane bilježili u kalendar zato što su otkrili da su upravo ti dani ispunjeni zvijezdama, ali ih je Crkva kasnije smatrala zabranjenima ili zbog toga da se ne bi činilo da

\footnotetext{
${ }^{803}$ Ibid., p. 210 / p. 211.

${ }^{804}$ Ibid., p. 210: »Et nota che li giorni alcuni sonno syderali, nelli quali se moveno li sideri et gli homini se absteneno dalle navigationi, altri preliales, [...] re solivane andare im. [prema Falchettinu transkriptu iz 2009. godine treba stajati: »in«] bactaglia, altri interscalares, li quali avançano alli XII misi, altri sonno caniculari, altri solstitiali, altri equinoctiali, altri fasti, nelli quali Romani publicavano le legie, altri nefasti sui contrarii, altri festi, ciò è festivi, quilli li quali sonno celebrati, altri mali, [...] perché in issi li homini sonno afflicti più de l'usato. Altri egiptiaci, altri dies salutis, altri dies iudicii in lo qual Dio iudicarà li vivi et li morti.«/p. 211.

${ }^{805}$ Cotrullis, »De navigatione«, libro III, capitulo 17 / Kotruljević, »O plovidbi«, knjiga III, poglavlje 17, p. 210: ${ }<\mathrm{G}>$ iorni egiptiaci sonno in ogni mese dui giorni dalli Egiptii comprensi, perché in Egipto erano alcuni astrologi li quali trovorno alcune constellationi / nocive alli humani acti in quilli giorni; però volsono che fusseno dalli homini notati.«/p. 211.

${ }^{806}$ Ibid., p. 210: »Nulla de mino li puncti de dicti giorni non potemo sapire per lo errore dello nostro compunto, $<\ldots>$ «. / p. 211.
} 
njihovim uvažavanjem nastavlja pogrešku Egipćana ili zbog toga što je Bog upravo u te dane nasrnuo na Egipat. ${ }^{807}$

Osamnaesto poglavlje treće knjige Kotruljevićeva spisa o plovidbi nosi naslov »O solsticijima« (»Del solstitii«). Usprkos tome što naslov poglavlja ne navodi na takav zaključak, dubrovački je renesansni mislilac u njemu izložio spoznaje o pojavi solsticija i o pojavi ekvinokcija. Prema podacima kojima je raspolagao, Sunčeva godina sadrži dva solsticija (ljetni i zimski) i dva ekvinokcija (proljetni i jesenski). ${ }^{808}$ Tijekom trajanja solsticija najveća je, tvrdi Kotruljević, razlika u trajanju dana i noći, jer se tada čini kao da Sunce stoji, a toj pojavi solsticij i duguje svoj naziv, te rastu dani odnosno noći, dok za vrijeme trajanja ekvinokcija dan i noć traju jednako. ${ }^{809}$ Potom je dodao da tijekom solsticija Sunce ulazi u znak Jarca ili Raka, dok tijekom ekvinokcija Sunce ulazi u znak Ovna ili Vage. ${ }^{810}$ Kotruljević je, na koncu, ukratko prikazao rimske, egipatske i grčke načine računanja vremena početka solsticija i ekvinokcija, pa zaključio poglavlje tvrdnjom da je u najstarije vrijeme godina bila podijeljena tek na dva dijela i dvije hemisfere, a da je tek kasnije nastupila i danas važeća podjela na četiri godišnja doba. ${ }^{811}$

Posljednje poglavlje treće knjige Kotruljevićeva De navigatione koje sadrži prirodnofilozofsku sastavnicu nedvojbeno je devetnaesto poglavlje naslovljeno »O razmaku vremena« (»Del spatio del tempo«). U tom izrazito kratkom poglavlju Dubrovčanin je, pritom se ne služeći nijednim od misaonih autoriteta, ponudio podatke o trajanju godine koje se rukovodi Sunčevim gibanjem. Najprije je odredio da je mjesec razmak vremena u kojem Sunce udaljujući se od jednog znaka boravi u drugom dovršavajući tako svoju kružnu

${ }^{807}$ Ibid., p. 210: »< ..> o vero forse trovorno quilli giorni ben constellati et però li ficieno annotare nel calandaro et la Ecclesia, per non parire sequitare lo errore loro, gli ha prohibiti, o vero che lo Signore in quelli giorni percosse Egipto.«/p. 211.

${ }^{808}$ Cotrullis, »De navigatione«, libro III, capitulo 18 / Kotruljević, »O plovidbi«, knjiga III, poglavlje 18, p. 212 : »Solsticii nello anno solare contingono dui, et dui equinoctii: solsticii nella state e nel verno, equinoctii im. [prema Falchettinu transkriptu iz 2009. godine treba stajati: »in«] primavera et auptumno.«/ Kotruljević, »O plovidbi«, III, 18, p. 213.

${ }^{809}$ Ibid., p. 212: »E lo solsticio è maxima inequalità del giorno et de la nocte, [...] et dicitur solstitium quasi solis statio però che allora stante lo Sole crescono li giorni o vero le nocte. Equinoctio è maxima equalità del giorno et della nocte, $<\ldots>$ «. / p. 213.

810 Ibid., p. 212: »E lo solsticio è maxima inequalità del giorno et de la nocte, o vero ingresso dello Sole nel Capricorno o Cancro; [...] Equinoctio è maxima equalità del giorno et della nocte, o veramente ingresso del Sole in Ariete o vero Libra.«/ p. 213.

${ }^{811}$ Ibid., p. 212: »<..> '1 solstitio hiemale è nancti la natività de Christo X giorni, ciò è XV Decembris, nel qual tempo lo Sol comincia riciercare più alti gradi o vero circuli. Et lo solstitio extivale è nacti la natività de Iohannes Baptista X iorni, nel qual tempo lo Sol comincia ad ritornare alli inferiori circuli, / donne de l'extivale solsticio iorno è maximo come lo giorno del solsticio hiemale è minimo. Ma secundo li Egiptii lo hiemale è XII Kalendas Ianuarii, secundo li Grecii VIIII Kalendas Ianuarii. Item in festo Sanctę Crucis o vero secundo gli altri XII Kalendas Aprilis è equinoctio vernale. Nello tempo antiquissimo lo anno in dui parte solemante era diviso, [...] et in dui emisperii; poi fo diviso in IIII parte, ciò è primavera, estate, autumpno et vernata.«/p. 213. 
putanju. ${ }^{812}$ Kao sljedeći i posljednji podatak o razmaku vremena dubrovački je mislilac priopćio da se godina dijeli na dvanaest mjeseci, jer Sunce prolazeći kroz zodijak obiđe područja dvanaest nebeskih znakova. ${ }^{813}$

Ako je uopće moguć govor o filozofskoj sastavnici posljednje knjige Kotruljevićeva spisa o plovidbi, koja je od pronalaska prve inačice rukopisnog prijepisa De navigatione do danas najčešće poimana kao portulan i kao peljar, onda je to isključivo moguće u kontekstu filozofije prirode. Kolikogod oskudijevala sadržajem, budući da je u dosadašnjim inačicama rukopisnih prijepisa pronađen tek njezin predgovor i prva dva poglavlja, i kolikogod bila usmjerena na praktičnu izvedbu plovidbe, ta knjiga ipak sadrži prirodnofilozofsku sastavnicu. Ovom prilikom izdvojit ću tek nekoliko primjera koji to potvrđuju. Naime, već je u predgovoru četvrtoj knjizi Kotruljević otkrio svoju teorijsku naklonost Ptolemeju i to $\mathrm{u}$ panegiričkom tonu. U takvu je ozračju dubrovački mislilac ustvrdio da je upravo Ptolemej razriješio problem lutanja po moru bez reda i bez mjera, time što je zasnovao znanost koja se na grčkom zove geografija, a na latinskom kozmografija. ${ }^{814}$ Tome je dodao da je bio veliki astrolog i geometar (fo grande astrologo et geometra) i pisao čudesna djela (scripse mirabilmente), zatim da je uredio i podijelio razmjere mora, neba i zemlje, potom izmjerio sve nebeskim mjerilom i sastavio kartu svijeta (lo mappamundo) kojom se Kotruljević poslužio za izradu pomorske karte (la cartha dello navigare) koja nas, kako kaže, uči ploviti po moru i ne dopušta nam da lutamo. ${ }^{815}$ Od Ptolemejeve karte baštinimo, bilježi Kotruljević, najtočnije izmjere prema paralelama te primjerenu projekciju, te mu mnogo dugujemo unatoč tome što se služio izmjerima filozofa Eratostena, koji je pronašao broj stadija i veličinu Zemljina opsega. ${ }^{816}$ Prirodnofilozofski aspekt četvrte knjige ogleda se i u njezinu prvom poglavlju »O pomorskoj karti« (»Della cartha de navigare«). Odredivši pomorsku kartu svestranim vodičem (universale guida) u njegovu naumu, izvijestio je da ona sadrži oznake vjetrova (venti), dakle oznake meteorološke pojave o kojoj je obilno promišljao u trećoj knjizi i koju je odredio

\footnotetext{
${ }^{812}$ Cotrullis, »De navigatione«, libro III, capitulo 19 / Kotruljević, »O plovidbi«, knjiga III, poglavlje 19, p. 214 : $»<\mathrm{M}>$ ese è spatio del tempo nello quale lo Phebo partendose da uno signo demora ne l'altro compito lo suo circulo«. / p. 215.

${ }^{813}$ Ibid., p. 214: »Parthese lu anno per dudici mesi, perché lo Sole andando lo zodiaco circunda XII regioni de li signi.«/p. 215.

${ }^{814}$ Cotrullis, »De navigatione«, libro IV, prohemium / Kotruljević, »O plovidbi«, knjiga IV, predgovor, p. 216 : $»<\mathrm{D}>$ apoi multi erranti per mare sença ordine et sença mesura trovò Claudio Ptholomeo, Alxandrino, in greco geografia in latino cosmografia, perché comos in greco vol dire in latino mundo.«/p. 217.

815 Ibid., p. 216 / p. 217.

${ }^{816}$ Ibid., p. 218: »Le mesure secundo li pararelli redusse questa discriptione in optime mesure et rationabile compasso. Quantunqua lui havesse le mesure de Erascotene philosopho, lo qual fo trovator dello numero delli stadii et dello circulo della terra, nulla de mino semo multi obligati ad Ptholomeo, perché allo giorno de ogi non erramo.«/p. 219.
} 
presudnom za uspješnu plovidbu, te milje (migla) i imena mjesta (nome delli lochi). ${ }^{817}$ Iako pruža za plovidbu prevažne podatke, iz Kotruljevićevih tvrdnji proizlazi da pomorska karta ipak ne dostaje za uspješno usmjeravanje plovidbe, već su potrebna i druga navigacijska pomagala: vjetrulja (la bossola), mezarole (le meçarole) te kompas (lo compasso). ${ }^{818}$ Osim tih sredstava, uspješno usmjeravanje plovila s obzirom na jačinu i smjer morske struje i vjetrova i dalje počiva na onome što dubrovački mislilac naziva slobodnom prosudbom mornara (arbitrio delli marinari). ${ }^{819}$ Dakle, unatoč tome što njezin preostali sadržaj možemo tek naslućivati, već iz predgovora i prvog poglavlja četvrte knjige spisa o plovidbi možemo zaključiti da je Kotruljević i u njoj ponovno imao potrebu istaknuti ključnu ulogu i iznimnu primjenjivost znanja iz filozofije prirode za plovidbu.

\subsection{Etika u spisu o plovidbi}

Iako je u spisu De navigatione najzastupljenija prirodnofilozofska tematika, Kotruljević ga je protkao i etičkom tematikom. Potvrdu tome pružaju sadržaj druge, dakle one u kojoj je raspravljao o građi, vrstama i opremi plovilā, i treće knjige spisa, dakle one u kojoj prevladavaju razmatranja o prirodnofilozofskim temama, kao što su, primjerice, pojave meteorološke naravi i astronomsko-astrološka tematika. Zbog toga što etički sloj sadrže dvije knjige spisa o plovidbi, a onda i zbog bolje preglednosti filozofske sastavnice u tom spisu, obilježja Kotruljevićevih etičkih promišljanja u De navigatione obradit ću u dvama potpoglavljima. Prvo ću posvetiti etičkom sadržaju druge knjige, dok ću se u drugom usmjeriti na etički sadržaj treće knjige spisa o plovidbi.

\subsubsection{Etika u drugoj knjizi spisa o plovidbi}

Kada su analizirali Kotruljevićev spis o plovidbi, istraživači hrvatske filozofske baštine redovito su se usmjeravali na njegovu prirodnofilozofsku sastavnicu, dok je etički sloj spisa

\footnotetext{
${ }^{817}$ Cotrullis, »De navigatione«, libro IV, capitulo 1 / Kotruljević, »O plovidbi«, knjiga IV, poglavlje 1, p. 218 / p. 219.

818 Ibid., pp. 218-220: »<...> la bossola è cosa necessarissima allo dricare della prora ad quello ventro per lo quale tu vidi che quillo locho te sta e dericto allo quale è tua intentione de voler andare. [...] Et al continuo devi voltare le meçarole lo giorno et la nocte, et intendere quante meglia hai navigato per tal vento per hore, et quante hore, et quanti per tal vento [...] Et però forno trovate le meglia et lo compasso nella carta dello navigare, la qual cartha se compassa in quisto modo, $<\ldots>\ll . /$ pp. 219-221.

${ }^{819}$ Ibid., p. 218: »<...> et coscì per arbitrio devi vedere se 1 la [prema Falchettinu transkriptu iz 2009. godine treba stajati: »sella«] corrente vene contraria allo ventro; l'una restora l'altra; secundo le forse loro è magior e minori, et questo è quello che se chiama arbitrio delli marinari.«/p. 219.
} 
ostao gotovo nezamijećen. Zbog takva stanja istraženosti danas raspolažemo tek s dvama člancima u kojima je naznačeno postojanje etičke sastavnice, i to u drugoj knjizi spisa $D e$ navigatione. Sadržaj te knjige Kotruljević je, ponavljam, u cijelosti posvetio vrstama plovilā i članovima brodske posade. Oba članka možemo zahvaliti istraživanjima koja je poduzeo te 2009. i 2012. godine objavio Piero Falchetta. U članku iz 2009. godine, taj talijanski kartograf ocijenio je sadržaj druge knjige dijelom Kotruljevićeva spisa u kojem se dubrovački mislilac usmjerio na pitanja koja se odnose na tehničku izvedbu plovidbe i na organizaciju života na brodu. ${ }^{820}$ Kada je razmatrao organizaciju života na brodu, Kotruljević se, piše Falchetta, posebice bavio sposobnostima službenikā i mornarā, dakle članovima brodske posade, kao i njihovim tjelesnim i moralnim kakvoćama (qualità fisiche e morali) potrebnim za uspješno izvršavanje dužnosti. ${ }^{821}$ Falchetta je istovjetne spoznaje o Kotruljevićevim razmatranjima kakvoća brodske posade izrekao i u članku iz 2012. godine. ${ }^{822}$ Dakle, danas raspolažemo tek Falchettinim opaskama o tome da se etička tematika u drugoj knjizi spisa De navigatione otkriva u Kotruljevićevu izlaganju obilježja koja trebaju posjedovati članovi brodske posade. Prije negoli detaljno izložim Kotruljevićeva promišljanja o etičkim obilježjima pojedinih članova brodske posade, smatram da je zbog lakšeg razumijevanja i preglednosti nužno ukazati na dvije stvari: na vrste plovilā i na redoslijed Kotruljevićeva izlaganja o članovima posade.

Kada je riječ o vrstama plovilā, važno je reći da je Kotruljević pisao o obilježjima članova posade na navama i galijama. U prvim trima poglavljima druge knjige spisa bilo mu je od velike važnosti upozoriti na razlikovanje u razumijevanju nazivka nava, a onda i na razlikovanje vrsta galija. Mišljenju »starih«, misleći na Vergilija, Seneku i Plutarha, koji su navom smatrali lađu, galiju i fustu, ${ }^{823}$ suprotstavio je mišljenje »suvremenih«, misleći pritom na sebe i na neimenovane vrsne brodske tesare njegova doba, koji su navom nazivali

\footnotetext{
${ }^{820}$ Piero Falchetta, $\gg 11$ trattato De navigatione di Benedetto Cotrugli (1464-1465). Edizione commentata del ms. Schoenberg 473 con il testo del ms. 557 di Yale«, Studi Veneziani 57 (2009), pp. 15-333, na p. 57: »Ma forse la materia di maggior interesse in questa parta più tecnica del testo, è quella relativa all'organizzazione della vita di bordo, $<\ldots>\ll$.

${ }^{821}$ Falchetta, $\gg I l$ trattato De navigatione di Benedetto Cotrugli (1464-1465). Edizione commentata del ms. Schoenberg 473 con il testo del ms. 557 di Yale «, p. 57: $<\ldots>$ e in particolare alle competenze degli ufficiali e dei marinai $[\ldots .$.$] e alle qualità fisiche e morali necessarie a ciascuno per poter svolgere al meglio i compiti$ che gli spettano."

${ }^{822}$ Piero Falchetta, »Benedetto Cotrugli et son traité De navigatione (1464-1465)«, The Historical Review / La Revue Historique 9 (2012), pp. 53-62, na p. 59.

${ }^{823}$ Cotrullis, »De navigatione«, libro II, capitulo 2 / Kotruljević, »O plovidbi«, knjiga II, poglavlje 2, p. 98: »In questo comprehendere possete che non erano tucte nave, ma pigliano ogni ligno per nave, etiam galee et fuste, $<$... « . / p. 99: »Po tome možete razumjeti da sve nisu bile nave, nego da su svaku lađu smatrali navom, pa i galije i fuste, $<\ldots>\ll$.
} 
određenu vrstu plovila, točnije velike trgovačke jedrenjake. ${ }^{824}$ Svrha Kotruljevićeva ustrajavanja na razlikovanju vrsta plovilā dodatno se otkriva u trećem poglavlju druge knjige. U njemu se u potpunosti usredotočio na galije, o kojima je zapisao da mogu biti lake ili velike. ${ }^{825} \mathrm{U}$ oba slučaja riječ je o brodovima koji trebaju biti, kako kaže, dobre jedrilice, ali još bolje veslarice. ${ }^{826}$ Dok su lake bile namijenjene ratovanju, velike galije ili galijace služile su za trgovanje. ${ }^{827}$ Budući da su mu kao iskusnu trgovcu i pomorcu važnije bile galijace, u ostatku spisa nazivao ih je samo galijama, čega ću se i ja pridržavati u ostatku rada.

Kotruljević je, naime, u trećem poglavlju druge knjige De navigatione »O galijama troveslarkama i dvoveslarkama prema navodima suvremenih« (»De galee trireme et bireme secundo li moderni«) pobrojio članove posade na galijama. U njih je najprije uvrstio službenike (offitiali, officiali), a pod tim je nazivkom, prema Salopekovu tumačenju, podrazumijevao »svaku osobu, osim običnih mornara i veslača, koja ima neko posebno zaduženje na brodu. «28 Dubrovački mislilac pobrojio je sljedeće službenike na galijama: kapetan (capitanio), patron (patrone), potpatron (sottopatrone), komit (comito), potkomit (soctocomito), dva savjetnika (dui consiglieri) kako nalaže katalonski običaj, dok mletački nalaže jednog člana savjeta (uno homo de consiglio) koji se naziva admiral (armiraglio), osam naukjera (VIII nauchieri), šest prodijera (VI prudieri), dva alijera (dui alieri) brodskog čamca, pisar (scrivano), zapisničar (scrivanello), aguzin (algoçino), trideset mornara (XXX

${ }^{824}$ Ibid., p. 98 / p. 99, bilješka 118: »U vrijeme nastanka ove rasprave riječ nave (< lat. navis) nije više značila samo 'lađa', nego je bila naziv i za određeni tip broda. Podrazumijevajući ovu 'dvojnost značenja' samorazumljivom, i Kotruljević je u ovoj rečenici upotrebljava u tom smislu, tj. hoće reći da sve antičke lađe nisu bile 'suvremene' nave kao tip broda, nego da su se samo zvale nave (tj. navis), pa čak i one koje su po tipu bile (kao današnje) galije i fuste <... «. Da su nave u Kotruljevićevo vrijeme bile smatrane zasebnom vrstom velikih trgovačkih jedrenjaka, vidi, primjerice, u: Josip Luetić, Pomorci i jedrenjaci Republike dubrovačke (Zagreb: Nakladni zavod Matice hrvatske, 1984), p. 227: »Na osnovi proučavanja arhivskih izvora moglo se zaključiti da je nava (ili nav) najveći (po nosivosti broda) i, s navigacijskog gledišta, najsigurniji tip jedrenjaka kojim su dubrovački pomorci od XV. do XIX. st. obavljali pomorsko-trgovačke zadatke ploveći svojim navama po Jadranskom i Sredozemnom moru kao i po Atlantskom oceanu i drugim svjetskim morima.«; Josip Luetić, Brodari i pomorci Dubrovačke republike (Zagreb: Nakladni zavod Matice hrvatske, 1997), p. 115: »Nava je spadala u najveći i s navigacijskog motrišta najsigurniji tip trgovačkog jedrenjaka. Mogla je [...] ispunjavati pomorsko-trgovačke nautičko-komercijalne zadaće i poslove po svim morima i oceanima.«

${ }^{825}$ Cotrullis, »De navigatione«, libro II, capitulo 3 / Kotruljević, »O plovidbi«, knjiga II, poglavlje 3, p. 102: $»<S>$ ondo secundo li antiqui trireme, le quale nui chiamamo galee et queste sondo in dui modi et non differiscono le une dalle altre se ·nno [prema Falchettinu transkriptu iz 2009. godine treba stajati: »non«] in meçura, che le une se chiamano gelee grosse, galeaçe o vero galee de mercanthia, le altre galee soctili, $<\ldots>\ll$. / p. 103: »Lađe, koje su stari nazivali troveslarke, mi zovemo galije. Njih ima dvije vrste i jedne se od drugih razlikuju jedino u mjeri, tako da se jedne zovu velike galije, galijace odnosno trgovačke galije, a druge se nazivaju lake galije. «

${ }^{826}$ Ibid., p. 102: »Coscì è di bisogno che la galea sia bona velera et miglior rimera, <... « / p. 103.

${ }^{827}$ Ibid., p. 104: $»<\ldots>$ le galeaçe se usano per mercantia perché sondo capace de multa robba [...] Le sottili se usano in bactaglia, solamente perché novi cape altro che 1 li [prema Falchettinu transkriptu iz 2009. godine treba stajati: »chelli«] hommini, arme et munitioni, <... «. / p. 105.

${ }^{828}$ Ibid., p. 105, bilješka 126. 
compagni), brijač (barbiero), poslužitelj obrokā (siniscalcho), veslar (remularo), kalafat (calafato), kuhar (cocho), brodski tesar (magistro d'asca), botar (botaro), od veslača treba biti šest spalijera (sei spalieri), kako običavaju imati Katalonci, ili portolati (portolati) i šest krijula (sei criule), kako običavaju imati Mlečani, patronov mali (moço dello padrone), aguzinov mali (moço d'algoçino), dva mala u skanduli (dui moçi de scandalaro), dva naukjerova mala (dui moçi de nauchieri), dva mala prodijera (dui moci de prudieri) te majordom odnosno gvardijan (maiordomo o vero guardiano). ${ }^{829}$ Međutim, Kotruljevićev popis službenika opovrgava Salopekovu tvrdnju da Dubrovčanin nije uvrstio mornare u brodske službenike. Na to je 2010. godine već upozorio Davor Balić, pri čemu je dodao da je taj Salopekov zapis moguće opovrgnuti i sadržajem sedmog poglavlja druge knjige, a u kojem je Kotruljević izdvojio mornare (marinari) kao službenike koji se, »jer vode plovidbu, moraju znati služiti pomorskom kartom i kompasom, kao što moraju poznavati i uzroke vjetrova te umijeće plovidbe, ali i 'biti vješti u prosudbi'. ${ }^{830}$ Ipak, Salopek je bio u pravu kada je zabilježio da Kotruljević popisu članova brodske posade nije pridružio veslače. Dakle, možemo zaključiti da je, kao što je to 2010. godine priopćio Balić, brodska posada na galijama u Kotruljevićevu spisu o plovidbi brojila barem osamdeset članova. ${ }^{831}$

Usprkos brojnosti članova posade na galijama, Kotruljević je etička obilježja pridjenuo isključivo onim članovima koji imaju zapovjedne ovlasti. Važno je skrenuti pozornost na to da u hrvatskom jeziku postoji obilje pomorskog nazivlja za pojedine članove zapovjednog lanca na brodovima, koje nazivlje nerijetko počiva na posuđenicama iz latinskog i talijanskog jezika, kao i na to da u hrvatskom jeziku, kao što je to 2005. godine napomenuo Salopek u predgovoru prijepisu i prijevodu spisa, »nema čvrsto ustanovljene pomorske

\footnotetext{
${ }^{829}$ Ibid., p. 108 / p. 109.

${ }^{830}$ Davor Balić, »Vrste plovilā u Kotruljevićevu udžbeniku plovidbe«, Metodički ogledi: časopis za filozofiju odgoja 17/1-2, pp. 61-86, na p. 79, bilješka 72: »Premda je u izdanju Kotruljevićeva djela iz 2005. godine na 105. stranici u 126. bilješci zapisano da 'naziv službenik (tal. official, offitial) kod Kotruljevića označava svaku osobu, osim običnih mornara i veslača, koja ima neko posebno zaduženje na brodu', Kotruljević je u svojem spisu $O$ plovidbi mornare nedvojbeno uvrstio u službenike. Utemeljenje za ovu tvrdnju, osim u Kotruljevićevu iskazu koji je u tekstu ovoga članka upravo zapisan, a glasi da u službenike na galiji spadaju i tridesetorica mornara (compagni), pronašao sam i u, primjerice, sedmom poglavlju druge knjige, dakle $\mathrm{u}$ onom u kojem je hrvatski renesansni mislilac pisao 'O naukjeru i ostalim službenicima na navi' ('Dello nauchieri et altri officiali de nave'). Naime, u spomenutom poglavlju Kotruljević je od ostalih brodskih službenika istaknuo i mornare (marinari) te zabilježio da se oni, jer vode plovidbu, moraju znati služiti pomorskom kartom i kompasom, kao što moraju poznavati i uzroke vjetrova te umijeće plovidbe, ali i 'biti vješti u prosudbi’.« Usp. Cotrullis, »De navigatione«, libro II, capitulo 7 / Kotruljević, »O plovidbi«, knjiga II, poglavlje 7, p. 120: »marinari sondo homini li quali hanno ad governare questa nostra navigatione et sondo dicti marinari da lo mare, in latino nautę a navigando. Quisti degiono sapire la cartha da navigare, bossola, et la ragion de li venti et lo arbitrio et infine tucta la presente nostra arte.«/p. 121.

${ }^{831}$ Balić, »Vrste plovilā u Kotruljevićevu udžbeniku plovidbe«, p. 79.
} 
nomenklature. $\ll^{832}$ Da bih otklonio možebitne terminološke nejasnoće i ostao dosljedan jedinom postojećem prijevodu spisa o plovidbi na hrvatski jezik, u ostatku rada oslovljavat ću članove brodske posade nazivljem kojem se priklonio Salopek. Etička obilježja, naime, moraju imati sljedeća četvorica članova zapovjednog lanca na brodovima: kapetan (zapovjednik broda), patron (brodovlasnik), komit (zapovjednik brodske posade) i naukjer (upravitelj broda te zapovjednik mornarā i veslačā).

Što se pak tiče redoslijeda izlaganja, napominjem da je Kotruljević članovima posade posvetio zasebna poglavlja. Međutim, pritom se nije, a čemu se u svojem članku čudio i Falchetta, pridržavao hijerarhije u zapovjednom lancu brodske posade koju je izložio u trećem poglavlju druge knjige: 1) kapetan; 2) patron; 3) komit; 4) naukjer. ${ }^{833}$ Naime, dubrovački mislilac odlučio se za sljedeći redoslijed izlaganja: 1) komit; 2) kapetan; 3) patron; 4) naukjer. Prema mojem mišljenju, Kotruljević je namjernim nepridržavanjem ranije izloženoj hijerarhiji htio odaslati poruku da su galije, što je uočljivo iz opsega njegovih opisa, učinkovitija vrsta trgovačkih brodova od nava. Tu tvrdnju temeljim na podatku da se odlučio najprije izlagati o obilježjima komitā koji su članovi zapovjednog lanca samo na galijama, ${ }^{834}$ zatim o

${ }^{832}$ D. [amir] S.[alopek], »Predgovor«, u: Benedikt Kotruljević, De navigatione / O plovidbi, priredio i preveo Damir Salopek (Zagreb: Ex libris, 2005), pp. 11-12, na p. 12. Da je kapetana u nautičkom upravljanju primjereno oslovljavati i s nazivkom nauclerius, a u trgovačkom sa patronus, patron ili paron, vidi, primjerice, u: Vladislav Brajković, s. v. »Kapetan«, u: Pomorska enciklopedija 3, I-Ko (Zagreb: Jugoslavenski leksikografski zavod, 1976), p. 464b. Da je patrona primjereno oslovljavati nazivcima paron ili parun, vidi, primjerice, i u: Vladislav Brajković, s. v. »Patron (paron ili parun; od lat. patronus gospodar)«, u: Pomorska enciklopedija 5, Mito-Pa (Zagreb: Jugoslavenski leksikografski zavod, 1981), p. 724b. Da je naukjera primjereno oslovljavati i s nazivcima naukijer ili naukleros, vidi, primjerice, i u: Vladislav Brajković, s. v. »Naukijer«, u: Pomorska enciklopedija 5, Mito-Pa, p. 259a. Da je naukjera primjereno oslovljati i s nazivkom nauklir, vidi, primjerice, u: Blaž Jurišić, »O našoj pomorskoj terminologiji «, u: Grga Novak, Vjekoslav Maštrović (ur.), Pomorski zbornik: povodom 20-godišnjice Dana mornarice i pomorstva Jugoslavije 1942-1962., knjiga I (Zagreb: JAZU; Zadar: Institut za historijske i ekonomske nauke, 1962), pp. 451-468, na p. 453a. Da je naukjera primjereno oslovljavati i s nazivcima nauclerius i noclerius, a patrona sa patronus, paron, patrun ili parun, vidi, primjerice, u: Ljerka Šimunković, Ivan Pederin, »Prilog proučavanju srednjolatinskoga pomorskog nazivlja u mletačkoj Dalmaciji u XIV. i XV. stoljeću«, Čakavska rič: polugodišnjak za proučavanje čakavske riječi 24/1-2 (1996), pp. 95-110, na p. 109. Da je kapetana primjereno oslovljavati s nazivkom kapitan, vidi, primjerice, u: Radovan Vidović, Pomorski rječnik (Split: Logos, 1984), s. v. »kapitan«, pp. 193a-205a. Da je patrona primjereno oslovljavati i s nazivcima parun i paron, vidi, primjerice, u: Radovan Vidović, Pomorski rječnik, s. v. »parun«, pp. 342b344a. Da je komita primjereno oslovljavati i s nazivcima comitus, chomitus, comittus i comito, vidi, primjerice, u: Radovan Vidović, Pomorski rječnik, s. v. »comitus, chomitus, comittus«, p. 524a. Da je naukjera primjereno oslovljavati i s nazivcima nakir i naukijer, vidi, primjerice, u: Radovan Vidović, Pomorski rječnik, s. v. »nakir«, pp. 311b-312a. Da se za neke od spomenutih članova zapovjednog lanca na brodovima koriste i drugi nazivci, vidi, primjerice, u: Ariana Violić-Koprivec, Jasenka Maslek, »O nekim nazivima za posadu dubrovačkih brodova«, Fluminensia: časopis za filološka istraživanja 27/1 (2015), pp. 49-70.

${ }^{833}$ Falchetta, $» 11$ trattato De navigatione di Benedetto Cotrugli (1464-1465). Edizione commentata del ms. Schoenberg 473 con il testo del ms. 557 di Yale«, p. 58: »Curiosamente l'elencazione del Cotrugli non segue l'ordine gerarchico di bordo, ma comincia con la figura del comito."

${ }^{834} \mathrm{Da}$ su komiti članovi zapovjednog lanca samo na galijama, svjedoči, primjerice, sljedeći Kotruljevićev zapis: Cotrullis, »De navigatione«, libro II, capitulo 4 / Kotruljević, »O plovidbi«, knjiga II, poglavlje 4, p. 110: $»<\mathrm{C}>$ ondurre la galea è grande magisterio, tanto nello vogare li remi quanto nello veligiare, / et tucto nella 
kapetanima i patronima koji su članovi zapovjednog lanca kako na galijama, tako i na navama, ${ }^{835}$ a naposljetku o naukjerima, čiji je položaj u zapovjednom lancu zavisan od vrste broda, pa dok su na galijama podređeni komitu, na navama obnašaju, kako i sam ističe, dužnosti jednake komitovima. ${ }^{836}$ Usprkos tome, u nastavku ću se pridržavati uvriježenog hijerarhijskog poretka među članovima zapovjednog lanca te redom iznijeti Kotruljevićeve stavove o kapetanu, patronu, komitu te naukjeru.

Kotruljević se već u uvodnim razmatranjima o članovima brodske posade, koja je izložio u trećem poglavlju druge knjige spisa, bavio etičkom problematikom. Nakon što je popisao opremu i članove posade, priopćio je da onaj tko hoće dobro opremiti galiju treba imati dobre službenike, ${ }^{837}$ a službenicima je, ponavljam, smatrao sve osobe koje imaju zaduženje na brodu, isključujući veslače. Dakle, pod opremu galije ne samo da je uvrštavao stvari potrebne za plovidbu i obranu, poput jedara, sidara i naoružanja, nego i članove posade. Uz to, napomenuo je da se galije mogu opremati dragovoljno (per bona voglia) ili pod silu (per força). ${ }^{838}$ Dragovoljno opremljene galije imaju plaćene službenike, mornare i veslače, dok se na prisilno opremljenim galijama veslači drže u okovima i lancima. ${ }^{839}$ Vođen učinkovitošću i uspješnošću u plovidbi i obrani, Kotruljević je smatrao opremanje galije pod silu primjerenijim, po uzoru na Katalonce koji su to činili zbog stalne izloženosti gusarskim i

prudentia del comito, <..> «. / p. 111: »Voditi galiju velika je vještina, koliko kad plovi na vesla, toliko kad jedri, i sve ovisi o razboritosti komita.«

${ }^{835}$ Time što u poglavlju o izboru i obilježjima kapetana nije naveo vrstu broda na kojoj obnaša dužnost, smatram da je Kotruljević podrazumijevao da je kapetan potreban na svakoj vrsti broda, pa tako i na navama i na galijama. Međutim, već je iz naslova šestog poglavlja druge knjige »O patronu nave i galije« (»Dello padrone de nave et de galea «) bjelodano da je Kotruljević patrone smatrao članovima zapovjednog lanca na navama $\mathrm{i}$ na galijama. O tome svjedoči i, primjerice, sljedeći Kotruljevićev zapis: Cotrullis, »De navigatione«, libro II, capitulo 6 / Kotruljević, »O plovidbi«, knjiga II, poglavlje 6, p. 114: »<P $>$ adrone de nave et de galee, et potissime de nave, per essere meritamente padrone, $<\ldots>\ll$. / p. 115: »Da bi patron nave i galije, a poglavito nave, bio pravi patron, $<\ldots . .<$.

${ }^{836} \mathrm{Da}$ su naukjeri podređeni komitu na galijama, potvrđuje, podsjećam, Kotruljevićev popis službenika na toj vrsti brodova: Cotrullis, »De navigatione«, libro II, capitulo 3 / Kotruljević, »O plovidbi«, knjiga II, poglavlje 3, p. 108 / p. 109. No, Kotruljević je već u naslovu sedmog poglavlja druge knjige »O naukjeru i ostalim službenicima na navi« (»Dello nauchieri et altri officiali de nave«) dao do znanja da ti službenici imaju ključnu zapovjednu ulogu na navama. O tome svjedoči i, primjerice, sljedeći Kotruljevićev zapis: Cotrullis, »De navigatione«, libro II, capitulo 7 / Kotruljević, »O plovidbi«, knjiga II, poglavlje 7, p. 118: »<N>auchieri de la nave è lo primo et lo principale governatore et commandatore in nave.«/p. 119: »Naukjer nave prvi je $\mathrm{i}$ glavni upravitelj i zapovjednik na navi.« Da su dužnosti naukjera na navi jednake onima komita na galiji, svjedoči, primjerice, sljedeći Kotruljevićev zapis: Cotrullis, »De navigatione«, libro II, capitulo 7 / Kotruljević, »O plovidbi«, knjiga II, poglavlje 7, p. 120: »Infine, lo nauchiere in nave è come lo gomito in galea et pari modo divino essere obediti bene.«/ p. 121: »Najzad, naukjer na navi je ono što je komit na galiji i čini se da na neki božanski način uspijevaju da ih se sluša.«

${ }^{837}$ Cotrullis, »De navigatione«, libro II, capitulo 3 / Kotruljević, »O plovidbi«, knjiga II, poglavlje 3, p. 104: »chi vol ben armare, bisogna havere galea armata [...] et anchi patroni, comiti, naucieri et tucti altri officiali; $<\ldots>\ll . /$ p. 105.

${ }^{838}$ Ibid., p. 108: »Armanose le galee alcuno per bona voglia, alcuni per força.«/ p. 109.

${ }^{839}$ Ibid., p. 108: »Le galee che 'sse [prema Falchettinu transkriptu iz 2009. godine treba stajati: »ch'esse«] armano per / voglia sondo pagati li offitiali, compagni et hommini da remo. Le galee per força tengnono li homini da rimo per força et ferrati et incathenati.«/p. 109. 
barbarskim napadima na njihovu obalu. ${ }^{840}$ Iz navedenog se može zaključiti da je Dubrovčanin dobru, kako kaže, »opremu« i njezinu učinkovitost u plovidbi pretpostavio slobodi veslačā.

$\mathrm{U}$ petom poglavlju druge knjige spisa naslovljenom »O pomorskom kapetanu« (»Dello capitano de mare«) dubrovački je mislilac razmatrao obilježja kapetana, dakle najvišeg člana zapovjednog lanca na navama i galijama. Da bi ukazao na njegovu prevažnu ulogu na brodu, ali i na obilježja koja mora imati, Kotruljević je napomenuo da kapetan na brodu mora biti sličan vojskovođi na kopnu (simile allu imperatore terreste) ${ }^{841}$ Dubrovčanin je tom prigodom naveo da je za opravdanjem te tvrdnje posegnuo za djelima vojne naravi iz pera grčkog filozofa Onasandra, rimskog senatora Frontina i rimskog pisca Vegecija ${ }^{842}$ Kotruljević je smatrao da su sljedeća etička obilježja nužna za obnašanje dužnosti kapetana: mora biti umjeren (temperato), suzdržan (continente), trezven (sobrio), uljudan u jelu (domestico nello magnare) te ne smije biti lakom (non avaro). ${ }^{843}$ Ističući da je u svakom ljudskom djelovanju potrebno dugotrajno iskustvo, a posebice u onom koje se tiče rukovođenja, ${ }^{844}$ Kotruljević je preostali dio poglavlja posvetio pohvalama mletačkog obrazovanja kapetana i patrona. Pritom je naglasio da se u Veneciji patroni i kapetani obrazuju od malih nogu, zbog čega im ne nedostaje nijedna stvar koja pripada pomorskom umijeću. ${ }^{845}$ Štoviše, zapisao je da Mlečani svojoj djeci prosljeđuju savršenstvo u pomorskom umijeću i to ukrcavanjem plemića, mladića i strijelaca u nave i galije sa svrhom navikavanja na more. ${ }^{846}$

${ }^{840}$ Ibid., p. 108: »Et questo fando aptissimamente Catalani, li quali, como se dicto, quantumque siano de quisto byasimati, tamen, chi derictamente considera lo bisongno et la vicinità de barbari et la commune abusione che sogliono fare le ginte d'arme, le quali essendo ad laudabile fine conducti fando de multi exacrabili danni et incommodi, li quali tucti communamente se tollerano. Sonno simili modo da esserno excusati li patroni delle galee, li quali lo vulgo chiama corsiri, li quali non havendo questa pradica. Non dubito che lle [prema Falchettinu transkriptu iz 2009. godine treba stajati: »chelle«] fuste delli Mori al continuo depredariano la costa de Catalongna, le isule Baleare et lo Reame de utraque Sicilia, donde sença fallo lo fructo che fando comporta l'abusione delli hommini per força et inde aviene che 'sse [prema Falchettinu transkriptu iz 2009. godine treba stajati: »chesse«] tollerando le galee per força, le qual veramente excedeno quelle che 'sse [prema Falchettinu transkriptu iz 2009. godine treba stajati: »che sse«] armano per bona voglia per multissime ragioni le quali se porriano adducere, $<\ldots>\ll . /$ p. 109.

${ }^{841}$ Cotrullis, »De navigatione«, libro II, capitulo 5 / Kotruljević, »O plovidbi«, knjiga II, poglavlje 5, p. 112 / p. 113.

842 Ibid., p. 112: »<..> come narra Onoxandro, De optimo imperatore, Vegiecio et Frontino, De re militari, $<\ldots>\ll$. / p. 113.

${ }^{843}$ Ibid., p. 112 / p. 113

${ }^{844}$ Ibid., p. 112: »Veramente in ogni et qualuncha exercitio / l'è necessaria longa experientia et maxime ad quelli li quali hando lo governo in mano, $<\ldots>\ll . /$ p. 113.

${ }^{845}$ Ibid., p. 112: »<..> lo qual non se porria dire pìu de quello è nella vostra cità de Venetia questa arte de mare et continuose patruni et capitanii quasi a cunabulis in modo che nulla cosa vi mancha che pertengna all'arte, $<\ldots>$ «. / p. 113.

${ }^{846}$ Ibid., p. 112: $»<\ldots>$ et per consequire perfectione ad vostri figlio li nella arte, havete inducto quella consuetudine laudabile, che vando vostri gentilhommini, iovini, balistreri, tanti per nave et tanti per galea, per assuefarli a cunabulis, $<\ldots>\ll$. / p. 113. 
Šesto poglavlje druge knjige »O patronu nave i galije« (»Dello padrone de nave et de galea«) sadrži Kotruljevićeva promišljanja o obilježjima patrona, dakle o obilježjima sljedećeg u nizu članova u zapovjednom lancu na brodovima. Za postajanje pravim patronom nave, a onda i galije, potrebno je, bilježi Kotruljević, ispuniti deset uvjeta. ${ }^{847}$ Budući da od tih deset uvjeta najveći broj njih sadrži savjete za pristojno ophođenje s ljudima i opise tjelesnih obilježja patrona, izdvojit ću samo one koji sadrže etičku sastavnicu. Naime, drugi uvjet koji patron mora ispunjavati sastoji se od toga da mora biti prijatan (piacievele) s mornarima, putnicima i trgovcima, štoviše da, kako je to bilo uobičajeno reći, mora biti poput bludnice (come la bagascia) ${ }^{848}$ Da bi dodatno naglasio nužnost patronove prijatnosti u odnosu s ljudima, Kotruljević je posegnuo za tvrdnjom koju je pripisao Ciceronu da pomirljivost (placabilità) lijepo pristaje velikim i uzvišenim ljudima. ${ }^{849}$

Zahvaljujući Salopekovim naporima u opremanju prijepisa i prijevoda spisa o plovidbi kritičkim aparatom, doznajemo da je tvrdnju koju je izrekao rimski govornik, državnik i filozof Marko Tulije Ciceron (Marcus Tullius Cicero, 106. - 43. pr. n. e.) Kotruljević preuzeo iz osamdeset osmog odlomka prve knjige njegova djela De officiis ( $O$ dužnostima) ${ }^{850}$ No, kada je pripremao prijepis druge inačice prijepisa spisa De navigatione, Falchetta je u bilješci uz navedeni Kotruljevićev spomen Cicerona napomenuo da se dubrovački mislilac tom prilikom doista poslužio tim zapisom iz Ciceronova djela, ali i je upozorio na to da je Kotruljević pogriješio kada je prijatnost (piacevolezza), dakle kakvoću koja proizlazi iz ugodnosti nečijeg tjelesnog izgleda svim ljudima, poistovjetio s pomirljivošću (placabilitas), točnije etičkim kakvoćama blagosti (clemenza) i popustljivosti (indulgenza). ${ }^{851}$ Ciceron je, naime, oštro se protiveći ljudima koji smatraju da se na neprijatelje treba žestoko srditi i da je takva srdžba obilježje muževa koji su velikog i hrabrog duha, zabilježio da nije ništa pohvalno niti dostojno velikog i vrlog muža kao pomirljivost (placabilitate) i blagost (clementia). ${ }^{852}$ Kotruljevićevo posezanje za Ciceronovim etičkim naukom iz djela De officiis nimalo ne treba čuditi, budući da je, a prema rezultatima istraživanja koje je 2012. godine objelodanio Balić, u

\footnotetext{
${ }^{847}$ Cotrullis, »De navigatione«, libro II, capitulo 6 / Kotruljević, »O plovidbi«, knjiga II, poglavlje 6, p. 114 / p. 115.

${ }^{848}$ Ibid., p. 114: "<..> secundo, l'è di bisogno che / lo patrone scia piacievele ad ogni uno, tanto ad marinari, vivati o mercatanti; et communamente se dicie che bisognia che lo scia come la bagascia, <...> «. / p. 115 .

${ }^{849}$ Ibid., p. 114: »<..> ché questa placabilità, come vol Tulio, sta bene ad magni et magnifici hommini; $<\ldots>\ll$. / p. 115.

${ }^{850}$ Ibid., p. 114, bilješka 130: »Cic. Off. 1, 88:«/ p. 115.

${ }^{851}$ Cotrugli, »De navigatione (1464-1465). Ms. Schoenberg 473«, p. 122, bilješka 280.

${ }^{852}$ Marcus Tullius Cicero, »De officiis ad Marcum filium«, I, 25, 88, u: M. Tullii Ciceronis Opera quae supersunt omnia, vol. VIII., ediderunt J.[ohann] G.[eorg] Baiter, C.[arl] L.[udwig] Kayser. (Lipsiae: Ex officina Bernhardi Tauchnitz, 1865), pp. 1-114, na pp. 26-27. Usp. Marko Tulije Ciceron, O dužnostima, prijevod Zvonimir Milanović (Zagreb: Nova Akropola, 2006), p. 53.
} 
trećoj knjizi spisa o umijeću trgovanja Kotruljević »najveći broj Ciceronovih stajališta [...] preuzeo iz djela De officiis« i to onda kada je »nastojao potkrijepiti svoj nauk o onakvu djelovanju trgovca koje će počivati na etičkim postavkama.« ${ }^{853} \mathrm{Na}$ temelju nekoliko reprezentativnih primjera Kotruljevićeva služenja Ciceronovim naukom iz tog djela u spisu o umijeću trgovanja, Balić je dokazao da je hrvatski renesansni mislilac bio »upućen u sadržaj djela De officiis. «854 Je li Falchetta bio u pravu tvrdeći da je Kotruljević pogriješio kada je poistovjetio prijatnost (piacevolezza) s pomirljivošću (placabilitas)? Budući da iz Kotruljevićeva uvjeta, baš kao ni iz Ciceronova stava kojim se tom prigodom poslužio, nije moguće uočiti poveznicu prijatnosti i pomirljivosti, možemo se složiti s Falchettom i zaključiti da je doista riječ o Dubrovčaninovoj omašci. Prema mojem sudu, Kotruljević je pomirljivost trebao izdvojiti kao dodatan uvjet koji patron mora ispunjavati. U svakom slučaju, izloženi primjer pruža potvrdu da se Kotruljević i u spisu De navigatione iskazao kao poznavalac Ciceronova etičkog nauka iz djela De officiis.

Sljedeći uvjet koji patron mora ispunjavati, a koji sadrži etički sloj, u Kotruljevićevu popisu zauzima peto mjesto. U njemu je naveo da patron mora biti trezven u jelu i piću (sobrio im bevere et in magnare), zbog toga što proždrljivost (la ingluvie) uništava svaki dobar posao. ${ }^{855}$ Da bi osnažio taj stav, Kotruljević je, barem kako navodi, posegnuo za sadržajem

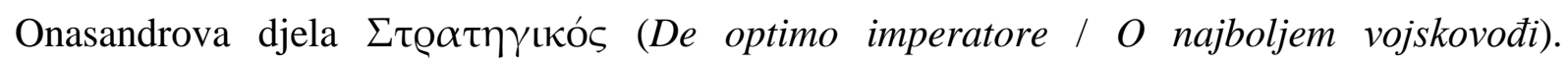
Dubrovčanin je, naime, tom prilikom preuzeo stav koji je pripisao tom grčkom filozofu o državnom službeniku da mora biti trezven da bi mogao bdjeti nad najvažnijim stvarima. ${ }^{856}$ Patronovu umjerenost u jelu i piću Kotruljević je dodatno potkrijepio tvrdnjom da se taj član zapovjednog lanca mora, zbog teških uvjeta i izbjegavanja malaksalosti tijekom plovidbe, priviknuti na prostu hranu. ${ }^{857}$ Kao sedmi uvjet naveo je da patron mora biti uljudan u razgovoru da bi sebi privukao kako mornare, tako i putnike te trgovce, iz čega proizlazi, smatra Kotruljević, da mora neprestano pronalaziti dobronamjerne varke i vabila (bon doli et

${ }^{853}$ Davor Balić, »Filozofi i filozofski izvori u Kotruljevićevu spisu o umijeću trgovanja«, Cris: časopis Povijesnog društva Križevci 14 (Križevci, 2012), pp. 205-271, na p. 230b.

${ }^{854}$ Balić, »Filozofi i filozofski izvori u Kotruljevićevu spisu o umijeću trgovanja«, p. 232b.

${ }^{855}$ Cotrullis, »De navigatione«, libro II, capitulo 6 / Kotruljević, »O plovidbi«, knjiga II, poglavlje 6, p. 114 / p. 115.

${ }^{856}$ Ibid., p. 114: „<...> et anchi como dicie Onoxandro, De optimo imperatore, parlando de magistratu: Sobrium etiam volo, ut rebus maximis vigilare comode possit.«/ p. 115.

${ }^{857}$ Ibid., p. 114-116: »Et anche, perché la vita della nave ut plurimum sole essere rustica, et lo padrone se deve adusare de quilli cibi grossi, perché, quando gli intrevene che non poçono havere d'altri cibi et la natura non essendo adusata, pate lesione et detrimento, et facielemente incorre ad / qualche infirmitate; < ..> «. / pp. 115117. 
inviaminti). ${ }^{858}$ No, ne smije pritom biti tako blag i ponizan (facile et humile) da se zauzima za svakoga tko bi ga mogao omalovažiti, ali ni tako oštar i krut (acierbo et duro) da potiče mržnju. ${ }^{859} \mathrm{U}$ prvom bi slučaju popustljivošću i blagošću (indulgentia et facilità) prouzročio raspuštenost potčinjenih, dok bi u drugom slučaju oštrinom ili strogošću (austeritate $o$ severitate) postigao da se potčinjeni odvrate od njega i postanu mu neprijatelji. ${ }^{860} \mathrm{U}$ devetom uvjetu naglasio je da patron mora biti lukav (astuto) poput upravitelja zamka i paziti da ne bude prevaren (advertire de non essere ingandato). ${ }^{861}$

Četvrto poglavlje »O komitu« (»De lo comito«) Kotruljević je posvetio obilježjima komita, dakle obilježjima zapovjednika brodske posade na galiji. Poglavlje je započeo tvrdnjom da je voditi galiju velika vještina bilo kad plovi na vesla, bilo kad jedri, te dodao da sve ovisi o razboritosti komita (tucto nella prudentia del comito). ${ }^{862}$ Razboritošću koju posjeduje, napominje Kotruljević, komit ne samo da treba voditi galiju, već treba, kao i svaki pomorac, znati razmjestiti teret u galiji tako da dobro plovi na vesla. ${ }^{863} \mathrm{Za}$ uspješno razmještanje tereta nužno je komitovo znanje, kao i poznavanje naravi svoje galije. ${ }^{864} \mathrm{Uz}$ to, komit mora, ističe Kotruljević, naći načina da ga se sluša, i to ponekad blagim, ponekad oštrim riječima i žestokim batinama, a za tu procjenu potreban mu je dobar osjećaj. ${ }^{865}$ Upravo zbog odabira primjerenih sredstava za postizanje poslušnosti, a onda i plovnosti, Kotruljević je naglasio da je upravljanje ljudima najveća muka i umijeće na svijetu (maggior fatigha del mundo et maior arte governare hommini). ${ }^{866}$ Oni koji upravljaju ljudima moraju paziti da ih ne obuzme sažaljenje (compassione), a uspješnost u tom umijeću ovisi o iskustvu i prirodnom osjećaju, posebice na galijama na kojima različiti ljudi brojni. ${ }^{867}$

\footnotetext{
${ }^{858}$ Ibid., p. 116: »<..> septimo, deve essere lu patrone de costumata conversatione per atrahere ad sí la brigata et dico tanti li compagni quanto vivati o merchanti. Et inde è che l'uno patrone trova al continuo bon doli et inviaminti più che l'altro, $<\ldots>\ll$. / p. 117.

${ }^{859}$ Ibid., p. $116 /$ p. 117.

${ }^{860}$ Ibid., p. $116 /$ p. 117.

${ }^{861}$ Ibid., p. $116 /$ p. 117.

${ }^{862}$ Cotrullis, »De navigatione«, libro II, capitulo 4 / Kotruljević, »O plovidbi«, knjiga II, poglavlje 4, p. 110 / p. 111.

${ }^{863}$ Ibid., p. 110: $»<\ldots>$ la qual prudentia have in sé, et quello che generalmente se richiede in ogni marinaro et anchi nel sapire stivare la galea per essere bona rimera.«/p. 111.

${ }^{864}$ Ibid., p. 110: »Et perché, como se dicto, molto consiste la sua scientia ne lo stivare, deve cognoscere la natura della sua galea, perché diverse nature ando le galee nello stivare.«/p. 111 .

865 Ibid., p. 110: »Bisongna ancora lo comito havere modo de farse obedire tal volta con bone parole, tal volta con acerbe parole et con violente bactiture, et ad questo bisongna bon sintimento«. / p. 111

866 Ibid., p. $110 /$ p. 111.

${ }^{867}$ Ibid., p. 110: »Et però quilli che governano se alcuna volta errano se $\cdot 1 l i$ [prema Falchettinu transkriptu iz 2009. godine treba stajati: »selli«] vole havere compassione, perché questa arte non è per ogni uno et non è totalmente demostrativa, et vien più dalla pradica et da sentiminto naturale et potissime le galee nelle quali sondo tante giente de tanta diversitate.«/p. 111.
} 
U sedmom poglavlju druge knjige naslovljenom »O naukjeru i ostalim službenicima na navi« (»Dello nauchieri et altri officiali de nave«) Kotruljević se usmjerio na obilježja naukjera, dakle upravitelja broda te zapovjednika mornarā i veslačā. Iako je naukjer na galiji podređen ranije spomenutim članovima zapovjednog lanca, on je, priopćava Kotruljević, prvi i glavni upravitelj te zapovjednik na navi. ${ }^{868}$ Zbog njegove važne uloge na navi, dubrovački mislilac izložio je sedam obilježja koja mora posjedovati. Međutim, ovom prilikom izdvojit ću tri obilježja u koja je uvrstio svoja etička promišljanja. Tako je, primjerice, kao drugo obilježje naukjera izdvojio da mora biti oštrouman (acer ingenio). ${ }^{869}$ Kada je podrobnije opisivao naukjerovu oštroumnost, Kotruljević je izdvojio tvrdnju koju je pripisao znamenitom grčkom epičaru Homeru da mora biti brz i okretan, zatim hitro razmišljati, potom brinuti za sve, kao i to da svojom pameću može predvidjeti buduće događaje. ${ }^{870}$ Potrebu za naukjerovom oštroumnošću Kotruljević je upotpunio i stavom da je dobar mornar, pa tako i naukjer, primoran žurno donositi odluke i bojati se spas nave povjeriti sudbini. ${ }^{871}$ Sljedeće etičko obilježje, a koje je izložio šesto po redu, nalazi se u obrazloženju stava da naukjer ne smije biti ni premlad ni prestar (né multo giovene né multo vecchio). ${ }^{872}$ Mlad ne smije biti da ne bi zbog velike smionosti (per troppa audacia) nesmotreno pogriješio, a star ne smije biti da ne bi nešto krivo učinio zbog prirodne slabosti (infirmità naturale). ${ }^{873}$ Zbog tih razloga Kotruljević je istaknuo da je najbolja srednja dob (optima conditione è mediocre), jer snaga i krepkost (força e llo vigore) vladaju u onome tko nije odviše mlad. ${ }^{874} \mathrm{Uz}$ to, naglasio je da ne vrijedi snaga tijela bez razboritosti duha (força dellu corpu sença prudentia dello animo), pa tako ne vrijedi ni um bez snage i zdrava tijela (ingingno sença le forçe et incolumità dellu соrpu). ${ }^{875}$ Tome je dodao da kao što tijelo bez razboritosti malo znači u vijeću, tako i duh koji je ostavila snaga u službi tijela ne može nijednu stvar obaviti zgodno i korisno. ${ }^{876}$ No, naposljetku je izložio stav da je najprikladniji (aptissimo) za obavljanje poslova onaj tko je

\footnotetext{
${ }^{868}$ Cotrullis, »De navigatione«, libro II, capitulo 7 / Kotruljević, »O plovidbi«, knjiga II, poglavlje 7, p. 118: $»<\mathrm{N}>$ auchieri de la nave è lo primo et lo principale governatore et commandatore in nave.«/p. 119 .

${ }^{869}$ Ibid., p. 118 / p. 119.

${ }^{870}$ Ibid., p. 118: " $<\ldots>$ et come dicie Homero: / Celerem et volucrem eum esse oportet, quo cogitatione currat pernix per omnia atque futura coniciat animo longeque prospiciat.«/p. 119.

${ }^{871}$ Ibid., p. 118: »<..> l'è constricto lo marinaro bono, sendo nauchieri, subito et raptim prendere consiglio et la salute della nave temere commectere alla ventura, <...>«./ p. 119.

${ }^{872}$ Ibid., p. 118 / p. 119.

${ }^{873}$ Ibid., p. 118 / p. 119

${ }^{874}$ Ibid., p. 118 / p. 119.

${ }^{875}$ Ibid., p. 118 / p. 119.

${ }^{876}$ Ibid., p. 120: "< ..> como lu corpu a cui manca la prudentia pocho vole allu consiglio, coscì lu animo abannonato delle forçe come ministri del corpo nulla cosa pò fare comodamente et utilmente.«/pp. 119-121.
} 
iskusio i jedno i drugo, točnije onaj tko posjeduje i razboritost i tjelesnu snagu. ${ }^{877}$ Posljednje, dakle sedmo obilježje sadrži stav da naukjer ne smije biti presmion (temerario) u svojem mišljenju, jer su, prema Kotruljevićevim spoznajama, takvi ljudi najopasniji i očajni (periculosissimi et [...] homini desperati). ${ }^{878}$ Naprotiv, naukjer mora biti postojan i staložen (saldo et repusato). ${ }^{879}$

\subsubsection{Etika u trećoj knjizi spisa o plovidbi}

Osim u drugoj, Kotruljević se etičkim temama bavio i u trećoj knjizi spisa o plovidbi. Riječ je, podsjećam, o onom dijelu spisa u kojem su tog dubrovačkog mislioca ponajviše zaokupljale teme koje potječu iz meteorološkog i astronomsko-astrološkog korpusa, dakle teme koje pripadaju filozofiji prirode. Zbog toga što u trećoj knjizi prevladavaju teme iz filozofije prirode, ne treba čuditi da je svoja etička uvjerenja u njoj izlagao usporedno $s$ prirodnofilozofskim, štoviše da je svoje spoznaje i stavove uvelike temeljio na odnosu i međusobnu utjecaju tih dviju filozofskih disciplina. To je činio u trima poglavljima posvećenim temama iz astronomije i astrologije, dakle temama koje pripadaju dvjema disciplinama među kojima u 15. stoljeću ne postoji jasno razlikovanje. Da u renesansi nije bilo jasnog razlikovanja tih dviju disciplina svjedoči, primjerice, podatak da se, podsjećam na prosudbu koju je iznijela Banić-Pajnić, u to doba "'astrologia' još uvijek rabi sinonimno s 'astronomia'《, unatoč tome što se tada »sve češće razlikuju 'znanstvena' od 'neznanstvene' astronomije ${ }^{880}$ Ipak, među tim dvjema disciplinama postoji razlikovanje koje se uvriježilo u tijeku njihova razvoja. Dok se, kako određuje Ivana Skuhala Karasman, astronomija bavi »gibanjima nebeskih tijela i njihovim međusobnim odnosima«, astrologija se bavi »utjecajima tih nebeskih tijela na zemaljske promjene ${ }^{881}$ Kotruljević je u spomenutim trima poglavljima izlagao svoja etička promišljanja u okviru tumačenja i predviđanja utjecajā nebeskih tijela na ljudsku narav i sklonosti, dakle u okviru teme koja, a što odgovara i odredbi koju je za tu disciplinu ponudio britanski stručnjak za klasičnu književnost Jim Tester u monografiji $A$

\footnotetext{
${ }^{877}$ Ibid., p. 120: »Et collui che à provato de ambedui le parte, collui è aptissimo all usu delle cose; < ..> «. / p. 121.

${ }^{878}$ Ibid., p. 120 / p. 121.

${ }^{879}$ Ibid., p. $120 /$ p. 121.

880 Erna Banić-Pajnić, »Renesansna filozofija«, u: Erna Banić-Pajnić (priređivačica sveska), Filozofija renesanse. Hrestomatija filozofije, sv. 3 (Zagreb: Školska knjiga, 1996), pp. 7-42, na p. 33.

${ }^{881}$ Ivana Skuhala Karasman, U potrazi za znanjem o budućem: predviđanje u srednjovjekovnoj $i$ renesansnoj prirodnoj filozofiji-H. Dalmatin, F. Grisogono i J. Dubrovčanin (Zagreb: Institut za filozofiju, 2013), p. 93.
} 
History of Western Astrology, pripada području astrologije. ${ }^{882}$ Kao što je priopćila Skuhala Karasman, ta disciplina »otvara prostor za primjenu teorijskih znanja u odabiru djelovanja kojim će se postići željeni ishod«, a što je posebice zamjetno »kod izrade horoskopa kao putokaza za djelovanje koji se temelji na teorijskim pretpostavkama o odnosu nebeskog i zemaljskog. $\ll^{883}$ Astrolozi su, naime, predviđali na temelju »pretpostavljenog odnosa i stalne veze koja postoji između gibanja nebeskih tijela i zemaljskih promjena«, a jedan od triju elemenata predviđanja čini zodijak koji sačinjavaju »sazviježđa koja se nalaze u pozadini Sunčevog gibanja kada se promatra sa Zemlje. $\ll^{884}$ Tako stečena znanja služila su, ponovno se oslanjam na spoznaje Skuhale Karasman, kao »smjernice za korisno i etički ispravno djelovanje. $\ll^{885}$ Astrolozi su, kako je 2014. godine istaknula talijanska povjesničarka filozofije i astrologije Ornella Faracovi, smatrali da se utjecaji zvijezda na čovjeka očituju u naravi čovjekovih raspoloženja, zatim u njegovoj tjelesnoj građi te moralnim nagnućima. ${ }^{886}$ Zbog toga se može zaključiti da je Kotruljević u trećoj knjizi De navigatione izlagao svoj etički nauk unutar razmatranja tema koje pripadaju astrologiji.

Prvo poglavlje treće knjige u kojem su zamjetni Kotruljevićevi etički stavovi zasigurno je jedanaesto poglavlje pod naslovom »O dvanaest nebeskih znakova« (»Delli XII segni dello cielo«). U jedanaestom poglavlju treće knjige Kotruljević je sustavno izložio obilježja znakova zodijaka: Ovan (Aries), Bik (Taurus), Blizanci (Gemini), Rak (Cancer), Lav (Leo), Djevica (Virgo), Vaga (Libra), Škorpion (Scorpio), Strijelac (Sagiptarius), Jarac (Capricornus), Vodenjak (Aquarius) i Ribe (Piscis). Prilikom iznošenja spoznaja o njima, upozorio je i na obilježja ljudi rođenih u pojedinom znaku, nerijetko im pridavajući i ona obilježja koja se mogu odrediti kao etička. Nakon što je prikazao etimologiju, astronomske i meteorološke pojave koje vladaju u vrijeme Ovna, Kotruljević je zapisao da će onaj tko bude rođen u tom znaku biti koristan (utile), miroljubiv (pacifico) i dostojan zavisti (invidioso). ${ }^{887}$ Upozorivši na to da je riječ o čvrstu znaku (signo firmo), zbog čega je u vrijeme kada Sunce

${ }^{882}$ Jim Tester, A History of Western Astrology (Suffolk: The Boydell Press, 1987), p. 11: »Astrology is the interpretation and prognostication of events on earth, and of men's characters and dispositions, from the measurement and plotting of the movements and relative positions of the heavenly bodies, of the stars and planets, including among the latter the sun and moon."

${ }^{883}$ Skuhala Karasman, U potrazi za znanjem o budućem: predviđanje u srednjovjekovnoj i renesansnoj prirodnoj filozofiji-H. Dalmatin, F. Grisogono i J. Dubrovčanin, p. 28.

${ }^{884}$ Ibid., p. 77.

885 Ibid., p. 158.

${ }^{886}$ Ornella Faracovi, »The Return to Ptolemy«, u: Brendan Dooley (edited by), A Companion to Astrology in the Renaissance (Leiden - Boston: Brill, 2014), pp. 87-98, na p. 96: »The influence of the stars operates on the human through the temperament of his humors, bodily constitution and moral inclinations, $<\ldots>\ll$.

${ }^{887}$ Cotrullis, »De navigatione«, libro III, capitulo 11 / Kotruljević, »O plovidbi«, knjiga III, poglavlje 11, p. 190 / p. 191. 
uđe u taj znak dobro obavljati dugotrajne poslove koji se zasnivaju na postojanosti (stabilitate), čovjek rođen u znaku Bika bit će lopov (latro) i dobar trgovac (bono mercante). ${ }^{888} \mathrm{Za}$ onoga tko se rodi u znaku Blizanaca, dakle u trećem znaku zodijaka, Kotruljević je zabilježio da je ljubavnik (amator) i mudrac (savio). ${ }^{889}$ Čovjek rođen u znaku Raka, nastavlja Dubrovčanin, bit će hvaljen (laudato) i veliki lopov (gran latro) ${ }^{890}$ Lav, dakle peti znak zodijaka, ima i sljedeća dva naizgled oprečna obilježja: koleričan (colerico) je i postojan (stabile). ${ }^{891}$ Ljudi rođeni u tom znaku bit će siromašni (povero), sretni (fortunato) i osrednji (mediocre). ${ }^{892}$ Onaj tko se rodi u znaku Djevice će, prema Kotruljevićevim spoznajama, biti hvaljen (laudato) i mudar (savio). ${ }^{893}$ Dubrovčanin je potom pisao o Vagi, dakle o sedmom znaku zodijaka. Tada je priopćio da će čovjek rođen u tom znaku biti pravičan (ricto) i tužan (dolente). ${ }^{894}$ Opisavši znak Škorpiona, među ostalim, kao čvrst (firmo) i ravnodušan (flematico), naglasio je da će onaj tko se rodi u njemu biti dobar pjevač (bon cantor) i trgovac (mercatante) ${ }^{895}$ Budući da je riječ o znaku koji je po naravi koleričan (colerico), ne treba čuditi da će čovjek rođen u znaku Strijelca biti sretan (fortunato) i ljubavnik (amatore). ${ }^{896}$ Tko se rodi u znaku Jarca, dakle u desetom znaku, bit će, napominje Kotruljević, lovac (cacciatore), zao (malo) i siromašan (povero). ${ }^{897}$ Sljedeći znak zodijaka, znači Vodenjak, uzrokuje da će čovjek rođen u njegovo doba biti mudar (savio) i zao (malo). ${ }^{898}$ Opisujući posljednji, dvanaesti znak, Kotruljević je naveo da su Ribe ravnodušan (flemmatico) znak, a za onoga tko se rodi u njemu da će biti muško (masculino) i ljubavnik (amante). ${ }^{899}$

Etičku sastavnicu sadrži i četrnaesto poglavlje treće knjige spisa o plovidbi. Riječ je o poglavlju naslovljenom »O svojstvima sedam planeta« (»Della proprietà delle VII pianeti«). U njemu je Kotruljević prikazao razlikovanje i obilježja sedam planeta, i to na način na koji su to učinili, kako ih naziva, »naši astrolozi« (li nostri astrologi). ${ }^{900}$ Po uzoru na te, doduše neimenovane astrologe, Dubrovčanin je ukazao i na utjecaje planetā na ljudsko djelovanje.

\footnotetext{
${ }^{888}$ Ibid., p. 192 / p. 193.

${ }^{889}$ Ibid., p. 192 / p. 193.

${ }^{890}$ Ibid., p. 192 / p. 193.

${ }^{891}$ Ibid., p. 194 / p. 195.

${ }^{892}$ Ibid., p. 194 / p. 195.

${ }^{893}$ Ibid., p. 194 / p. 195.

${ }^{894}$ Ibid., p. 194 / p. 195.

${ }^{895}$ Ibid., p. 194 / p. 195.

${ }^{896}$ Ibid., p. $196 /$ p. 197.

${ }^{897}$ Ibid., p. 196 / p. 197.

${ }^{898}$ Ibid., p. 196 / p. 197.

${ }^{899}$ Ibid., p. 196 / p. 197.

${ }^{900}$ Cotrullis, »De navigatione«, libro III, capitulo 14 / Kotruljević, »O plovidbi«, knjiga III, poglavlje 14, p. 200 / p. 201.
} 
Pritom je redovito iznosio etička obilježja koje prevladavaju kod ljudi tijekom utjecaja svakog od sedam njemu znanih planeta. Kotruljević je o planetima izlagao redoslijedom od Zemlji najudaljenijeg do najbližeg planeta: Saturn, Jupiter, Mars, Sunce, Venera, Merkur i Mjesec. Takav redoslijed planeta odgovara, kako 2011. godine bilježi, primjerice, Snježana PaušekBaždar, »općeprihvaćenoj renesansnoj zamisli o položaju planeta«. ${ }^{901}$

Kotruljević je najprije izložio spoznaje koje se odnose na obilježja Saturna. Opisavši ga kao najudaljeniji planet koji u svakom znaku zodijaka boravi dvije i pol godine te koji svoju putanju dovrši za trideset godina, dubrovački je mislilac dodao da je riječ o planetu koji je loš znak (signo malo). ${ }^{902}$ Tijekom trajanja Saturnova utjecaja ljudi su, bilježi Kotruljević, skloni razmatranju (contemplanti) i misaoni (pensorosi), zatim neporočni (casti) i vrlo lukavi (ben astuti), profinjena uma ('ssutile ingiengno) i vrlo oštroumni u obavljanju kako korisnih, tako i štetnih poslova (acutissimi a bben et mal fare). ${ }^{903}$ Kada je pisao o drugom planetu, dakle o Jupiteru, Kotruljević ga je opisao kao planet koji boravi u svakom znaku godinu dana te koji dovrši svoju putanju za dvanaest godina, ali i kao planet koji je dobar (bono). ${ }^{904}$ Prema spoznajama dubrovačkog mislioca, njegov utjecaj čini ljude sposobnima za vladanje (apti ad signoria), umjerenima (temperati), divnima (magnifici), a njihovo srce prikladnim za, kako kaže, uzvišene stvari (de core apto ad cose alte). ${ }^{905}$ Začudo, jedino u slučaju kada je iznosio obilježja Marsa, znači trećeg planeta, Kotruljević nije opisao utjecaj koji taj planet ostvaruje na ljudsko djelovanje. Ipak, zabilježio je da je riječ o planetu koji boravi u svakom znaku tri dana i koji dovrši svoju putanju za dvije godine, ali i o planetu koji je po naravi loš (malo), pun krvi (sanguinoso), crvenkast (rubicundo), gnjevan (irativo) te goropadan od snage i smjelosti za velika umijeća (furioso de forteça et de virtù ad grande arte). ${ }^{906}$ Zbog čega je dubrovački renesansni mislilac odabrao upravo Mars kao planet o čijem utjecaju na ljudsko djelovanje neće zabilježiti nijednu riječ? Je li u pitanju manja nedosljednost u izlaganju ili svjesna odluka? Smatram da je Kotruljević, iako to odudara od dosadašnjeg tijeka njegova izlaganja, obilježja ljudi tijekom trajanja Marsova utjecaja uvrstio u opis planeta. Dakle, smatram da je bio uvjeren da su ljudi pod utjecajem Marsa gnjevni te goropadni od snage i

\footnotetext{
901 Snježana Paušek-Baždar, »Federik Grisogono i alkemija« / »Federik Grisogono and Alchemistry«, Acta medico-historica Adriatica 9/2 (Rijeka, 2011), pp. 173-188, na p. 179.

${ }^{902}$ Cotrullis, »De navigatione«, libro III, capitulo 14 / Kotruljević, »O plovidbi«, knjiga III, poglavlje 14, p. 200: »Saturno è lu più alto pianeta de tucti, et sta in ogni signo dui anni et meço, et compie lu cursu suo in XXX anni et è signo malo.«/p. 201.

903 Ibid., p. 200 / p. 201.

${ }^{904}$ Ibid., p. 200: »Iuppiter, bono et secundo pianeta, sta in ogni signo uno anno et compie lu suo cursu in XII anni.«/p. 201.

905 Ibid., p. 200 / p. 201.

${ }^{906}$ Ibid., p. 200 / p. 201.
} 
smjelosti za velika umijeća. O obilježjima planeta koji je naveo kao četvrti po redu, znači o Suncu, Kotruljević se vratio načinu izlaganja koji je njegovao u slučaju prvih dvaju, a onda i ostalih planeta. Tako je najprije priopćio da se Sunce nalazi u sredini pojasa, zatim da boravi u svakom znaku trideset dana te da svoju putanju dovrši za godinu dana. ${ }^{907}$ Dodavši da je Sunce planet koji je po naravi znak koji je osrednji (mediocre), Dubrovčanin je utjecaj koji ono izvršava na ljude opisao na sljedeći način: čini ljude vedrima (chiari), plemenitima (nobili), savršenima (perfecti), velike inteligencije (de grande intelligentia), velike učenosti i mudrosti (de grande doctrina et sapientia), punima milosrđa i istinoljubivosti (pieni da carità et verità de dire). ${ }^{908}$ Venera je, bilježi Kotruljević, dobar znak (signo bono) i peti planet, koji boravi u svakom znaku dvanaest dana i koji svoju putanju dovrši za trideset dana, odnosno za godinu dana, a giba se retrogradno kao i Merkur. ${ }^{909}$ Prema znanjima kojima je Kotruljević raspolagao, Venerin utjecaj na ljude ostvaruje se tako što ih čini vjernima (de natura gliali), željnima kićenja (vagi da adornarse), uljudnima (cortesi), darežljivima (largi), te sklonima raskoši i ispraznu uživanju (inclinati ad luxuria et vano dilecto). ${ }^{910}$ Sljedeći planet o kojem je Kotruljević iznio svoje spoznaje bio je Merkur. Taj planet boravi u svakom znaku trideset osam dana i dovrši svoju putanju za tristo trideset dana. ${ }^{911}$ Međutim, za razliku od sadržaja dosadašnjih opisa naravi i utjecaja planeta na ljude, Kotruljević je u slučaju Merkura zapisao i sljedeći stav: to je znak koji je za dobre dobar, a za loše loš (cum boni bono, cum / mali malo). ${ }^{912}$ Osim toga, od Kotruljevića doznajemo i to da Merkur utječe na uspješnost ljudi u obnašanju određenih poslova, pa ih čini dobrim govornicima (belli parlaturi), trgovcima (mercanti), zastupnicima (procuratori), sucima i odvjetnicima (iudici et advocati), kao i dobrim pregovaračima u svakoj stvari (tractatori d'ogni cosa). ${ }^{913}$ Kao posljednji, dakle kao sedmi planet, Kotruljević je naveo Mjesec. Najbliži je Zemlji, boravi u svakom znaku dva dana i osam sati, a svoju putanju dovrši za trideset dana. ${ }^{914}$ Kotruljević je zapisao da u razdoblju Mjesečeva utjecaja ljudi postaju dobri (pigri), priprosta uma (de basso ingengio), prevrtljivi (mutabile), nepouzdani (sença fede), nepostojani i s malo razuma (sença fermeça et

\footnotetext{
${ }^{907}$ Ibid., p. 200: »Sole, lo qual è in meço della zona, sta in cieschaduno signo XXX giorni et compie lu cursu suo in uno anno.«/p. 201.

${ }^{908}$ Ibid., pp. 200-202 / pp. 201-203.

${ }^{909}$ Ibid., p. 202: »Venus, quinto pianeto, sta in ciascheduno signo XII giorni et compie lo suo curso in XXX iorni o vero in uno anno, per la retrogradatione come Mercurio. [...] et è signo bono.«/p. 203.

910 Ibid., p. 202 / p. 203.

${ }^{911}$ Ibid., p. 202: »Mercurio, sexto pianeto, sta in ciaschaduno signo XXXVIII giorni. Compie lu cursu suo in CCCXXX giorni.«/p. 203.

912 Ibid., p. 202 / p. 203.

913 Ibid., p. $202 /$ p. 203.

914 Ibid., p. 202: »Luna è septima pianeta et lo più infimo verso la Terra, et sta in ogni signo dì dui et hore VIII, et compie lu cursu suo in XXX giorni.«/p. 203.
} 
com $\cdot$ pocha ragione), dodavši da tada imaju žensko srce (cor feminile) koje ne zna što hoće i koje se neprestano žali na sve što mu se događa. ${ }^{915}$

Kao što sam napomenuo u ranijem dijelu rada, sadržaj petnaestog poglavlja treće knjige Dubrovčaninova spisa o plovidbi uvelike se oslanja na spoznaje koje je izložio u četrnaestom poglavlju. ${ }^{916}$ To nimalo ne začuđuje, budući da se Kotruljević u petnaestom poglavlju bavio utjecajima koje svaki od sedam planeta ostvaruje na ljudsko djelovanje u razdoblju od dvadeset četiri sata, pa ga je zato i naslovio »O vladavini sedam planeta u danu« (»Dello dominio delli VII pianeti in die«). Ranije sam obradio one dijelove petnaestog poglavlja koji se odnose na astronomsko-astrološke izračune i narav djelovanja planeta, kao i one koji se odnose na isprepletenost tih disciplina s medicinom, zbog čega preostaje da se usmjerim na one dijelove koji se odnose na prožetost astronomsko-astroloških spoznaja s etikom.

Na temelju svojstava koja je pripisao svakom od sedam planeta u prethodnom poglavlju, dubrovački je ranorenesansni mislilac u petnaestom poglavlju podrobno opisao utjecaje koje planeti ostvaruju na ljudsko djelovanje, kao i na uspješnost izvršavanja određenih radnji započetih tijekom jednog dana. Jednako kao što je to učinio u prethodnom poglavlju, svoje razmatranje započeo je utjecajima koje vrši najudaljeniji planet od Zemlje: Saturn. O Saturnovu satu Kotruljević je zabilježio sljedeće: onaj tko tada započne posao uspjet će u svemu, ali se neće obogatiti; onaj tko tada pita za nekog tata, treba mu reći da je hirovit, mlad, potišten i lopov po naravi; onaj tko tada pođe na putovanje, odmah će otići na željeno mjesto i vratit će se sretno. ${ }^{917}$ Onaj tko započne posao u Jupiterovu satu treba znati da će njegov udes u treće, najzrelije životno doba biti sretan, a što se tiče onoga tko je tada na putovanju, treba znati da će na putovanju pretrpjeti brojne nedaće, ali će se ipak sretno vratiti. ${ }^{918}$ Prema Kotruljevićevim spoznajama, umrijet će onaj tko se u Marsov sat primi posla, dok će biti pokraden onaj tko bude putovao i neće dobiti natrag stvar koju izgubi, a ako netko tada pita za lopova, treba mu reći da je kolerik. ${ }^{919}$ Za vrijeme Sunčeva sata, bit će bogat i sretan onaj tko bude obavljao neki posao, uspješno će otputovati i doputovati te će pronaći sve što traži

915 Ibid., p. 202 / p. 203.

916 Vidi na p. 171 ovoga rada.

${ }^{917}$ Cotrullis, »De navigatione«, libro III, capitulo 15 / Kotruljević, »O plovidbi«, knjiga III, poglavlje 15, p. 206 : »Et nota che, se alcuno demandasse de se havendo lo motu in hora de Saturno, ditile che prosperarà excepto che de richeçe; [...] se de alcuno latrone, di' che 'l è lunatico, iovene, malanconico, latro naturalmente; se de camino, di' presto andarai allo locho che va et prosperamente retornarà.«/ p. 207.

${ }^{918}$ Ibid., p. 206: »Iuppiter: se alcuno te dimandarà de sí medesimo havendo certo motu nella hora de Iove, diraili: 'Fortuna tua nella tertia etate per tucto te sarrà prospera.' [...] se 'l te dimanda de alcuno che è a camino, di' che patirà multi incomodi ma nel hore torno li venerà bene.«/p. 207.

919 Ibid., p. 206: „Se alcuno te domandarà da sí medesimo havente certo moto in hora de Marte, dirai che morerà; [...] se de cammino alcuno, dirrai serrai arrobato; se de cose perdute, dirrai: 'La cosa toa non haverai.' Si della complexione dellu latro, di' che 'l è colerico.«/p. 207. 
ukoliko se potrudi. ${ }^{920}$ Kada je riječ o satu u kojem vlada Venera, dubrovački je mislilac savjetovao da se tada nužno obave svi poslovi koji zahtijevaju okretnost, zatim da će onaj tko bude tada obavljao neki posao biti uspješan u tome, ali će poginuti od tuđega noža, potom da će onaj tko bude putovao biti zarobljen ili će umrijeti u vodi te da onaj tko bude tražio neku izgubljenu stvar neće ništa dobiti natrag. ${ }^{921}$ U Merkurov je sat, nastavlja Dubrovčanin, dobro kupovati, uputiti čovjeka na strojarski zanat, sijati i saditi, te započeti putovanja morem i kopnom, a umijeća na koja izvršava osobit utjecaj su: slikanje, pisanje, pjevanje i umijeća koja uključuju drvo. ${ }^{922}$ Izlaganje o utjecajima koje svaki od sedam planeta ostvaruju na ljudsko djelovanje tijekom dana, Kotruljević je zaključio spoznajama o satu u kojem vlada Mjesec. Prema njegovu mišljenju, ljudi bi se u Mjesečevu satu trebali baviti stvarima koje se odnose na tekućine, kao što su, primjerice, vino, ulje, plovidba morem i potraga za vodom, a onaj tko se rodi u taj sat bit će sretan u svim tekućim stvarima, kao i poštovan od svojih nadređenih, potom dobivati stvari od drugih te umrijeti bogat. ${ }^{923}$

${ }^{220}$ Ibid., p. 208: „Se alcuno te domandarane havendo certo motu in nel hora del Sole, respundi: 'Ricco et fortunato serrai.' [...] Se de lo cammino, respondi che inel'andare et in nel tornare haverà prosperità; se fatigarà, trovarà.«/p. 209.

${ }^{921}$ Ibid., p. 208: »Hora de Venere: tucte le cose che spectano alla legereça se deveno operare. Unde, se alcuno havendo certo motu in hora de Venere te dimandarà de sé, dirrai che haverà bene ma morirai de cultello altrui; [...] Se de cammino alcuno, respondi serrà preso o morirà ne l'acqua; se de cosa peduta, di' che nolla recuperarà.«/p. 209.

922 Ibid., p. 208: »Hora de Mercurio: bono è comparare, mettere lu homo ad arte mechanica, semenare et piantare, cominciare lo cammino per mare et per terra. [...] Le arte li sonno bone specialmente pingere, scrivere et cantare, et ciò que altre arte de legname.«/p. 209.

${ }^{923}$ Ibid., p. 208: »Hora della Luna: è bono ciò che pertene ad cose liquide, come è vino, oglio, andare per mare et ciercare l'acqua. [...] chi perde in hora sua, parte rihaverà et parte non. Chi nascie in hora sua, haverà bona fortuna in tucte le cose liquide, et serrà honerato dalli soi magiori, et de cose d'altri haverà et infin delle cose morirà riccho.«/p. 209. 


\section{ZAKLJUČAK}

Istraživanje filozofske sastavnice u opusu dubrovačkog ranorenesansnog mislioca Benedikta Kotruljevića (oko 1416-1469) poduzeo sam na temelju sadržaja njegovih dvaju dosad pronađenih spisa. Prvi je bio spis o umijeću trgovanja, koji je Kotruljević dovršio 1458. godine i koji je, prema aktualnim spoznajama, naslovio Libro del arte dela mercatura. Taj je spis doživio svoju recepciju od dvojice najznačajnijih hrvatskih renesansnih filozofa: Frane Petrića i Nikole Vitova Gučetića. Prepoznavši vrijednost njegova sadržaja, Petrić je priredio, uredio i 1573. godine objavio prvo tiskano izdanje spisa o umijeću trgovanja. Gučetić je pak 1591. godine u svojem najznačajnijem djelu Dello stato delle Republiche (O ustroju država) spis o umijeću trgovanja ocijenio iznimno korisnim za sve izučavatelje tog umijeća koji žele znati »kako se pravedno i k tome vrlo uspješno trguje.« Drugi Kotruljevićev spis koji sam istražio iz filozofske perspektive bio je onaj o plovidbi, a koji je dubrovački mislilac dovršio 1464. godine i kojeg je uvriježeno nazivati De navigatione. Zakašnjelu recepciju spisa De navigatione treba pripisati tome što je rukopisna inačica njegova prijepisa prvi put pronađena tek 1995. godine.

Sadržaj tih dvaju spisa pritom sam razmotrio iz perspektive Dubrovčaninove upućenosti u povijest filozofije te iz perspektive zastupljenosti tematike pripadne pojedinim filozofskim disciplinama. U spisu o umijeću trgovanja istražio sam Kotruljevićevo poznavanje povijesti filozofije i sagledao četiri knjige spisa iz perspektive zastupljenosti tematike iz dviju filozofskih disciplina: etike i filozofije odgoja. Što se tiče spisa o plovidbi, u njemu sam istražio Dubrovčaninovo poznavanje povijesti filozofije, a onda i razmotrio čitav spis iz perspektive prisutnosti tema iz dviju filozofskih disciplina: filozofije prirode i etike.

O Kotruljevićevu poznavanju povijesti filozofije u spisu o umijeću trgovanja danas raspolažemo jednom iscrpnom i obuhvatnom studijom Davora Balića iz 2012. godine pod naslovom »Filozofi i filozofski izvori u Kotruljevićevu spisu o umijeću trgovanja«. Ta je studija iznjedrila podatke o tome da se dubrovački mislilac unutar svojih promišljanja o trgovanju služio filozofskom mišlju više od dvadeset mislilaca iz dotadašnjih razdoblja povijesti filozofije, pri čemu se »najčešće pozivao na stajališta koja je pripisao Aristotelu, Ciceronu, Seneki, Augustinu i Tomi Akvincu«. Zbog upotpunjavanja uvida u Kotruljevićevu filozofsku lektiru u spisu o umijeću trgovanja i zbog otkrivanja razine do koje su sezale Kotruljevićeve povijesnofilozofske spoznaje, istražio sam tko su bili preostali mislioci na čija se filozofska promišljanja Kotruljević oslanjao u manjoj mjeri, a potom i utvrdio odakle je 
crpio svoje spoznaje o njima. Utvrdio sam da u popis Dubrovčaninove filozofske lektire zavređuju biti dodani i Kalisten iz Olinta, Zenon iz Kitija, Marko Terencije Varon, Valerije Maksim, Gaj Plinije Sekundo Stariji, Gaj Plinije Cecilije Sekundo Mlađi, Gaj Julije Solin, Bazilije Veliki, Ivan Zlatousti, Izidor iz Sevilje, Dante Alighieri, Francesco Petrarca, Giovanni Boccaccio te Antonino Pierozzi ili Antonin iz Firence.

Spis o umijeću trgovanja Kotruljevića razotkriva i kao etičara. Dosadašnja istraživanja tog aspekta Dubrovčaninova spisa bila su najčešće usmjerena na treću i četvrtu knjigu spisa, a redovito su nudila zaključke općenite naravi i nisu bila popraćena analizom pojedinih stavova. Da bih ukazao na to da je spis o umijeću trgovanja u cijelosti prožet etičkom tematikom, poduzeo sam detaljnu analizu i ponudio cjelovit pregled etičke sastavnice u svim četirima knjigama Kotruljevićevih promišljanja o trgovanju. Temeljne postavke o nužnosti etičkog djelovanja trgovaca dubrovački je mislilac izložio već u predgovoru svojega spisa. U njemu je zastupao stav da bi trgovci po uzoru na učene ljude trebali zanemarivati tjelesna i izvanjska dobra te da bi trebali ustrajavati na stjecanju i usavršavanju izvrsnosti vlastite duše i vrline. U predgovoru spisa o umijeću trgovanja Kotruljević je inzistirao na tome da ljudi trebaju smjerati putem besmrtnika ustrajavanjem na duševnim dobrima. Trgovcima je tako poručio da se bave umijećem koje je utemeljeno na etičnom djelovanju i koje je namijenjeno onima koji imaju volju i želju stjecati časno. Znači, Kotruljević je stavovima iz predgovora cijelom spisu o umijeću trgovanja dodijelio etički predznak.

Utvrđivanje prisutnosti etičke sastavnice u prvoj knjizi Dubrovčaninovih umovanja o trgovanju temeljio sam na poglavljima u kojima je etički sloj najizraženiji: prvom, drugom, trećem i osamnaestom. U prvom poglavlju prve knjige Kotruljević je iznio četiri polazišne točke svojih razmatranja o umijeću trgovanja, a koje su ujedno temelj njegovih kasnijih etičkih stavova. Te polazišne točke oblikovao sam na sljedeći način: 1) bez teoretiziranja o prirodi stvorenoj od Boga nemoguća je praksa utemeljena na razumu; 2) trgovanje je praktično umijeće koje potječe iz prirode, a čija se uspostava odvijala po redoslijedu Bogpriroda-praksa-teorija; 3) novac je počélo trgovačkog umijeća; 4) trgovačko umijeće nema prijeko potrebnu teorijsku osnovu. Budući da je smatrao da dobrobit iz trgovanja osjećaju pojedinac i zajednica te budući da je bio iznenađen tadašnjim stanjem u trgovačkoj praksi, Kotruljevićev je cilj bio ponuditi teorijsku osnovu i tako uspostaviti trgovanje kao umijeće koje se ravna po općim i posebnim pravilima. S ostvarivanjem tog cilja otpočeo je u drugom poglavlju prve knjige, nudeći sljedeću odredbu trgovanja: trgovanje je umijeće ili disciplina koja pravedno (iustamente) uređuje trgovačke poslove među ovlaštenim osobama, a zbog 
očuvanja ljudskog roda. Za Kotruljevića pojam pravedno podrazumijeva kupovinu ili prodaju robe po pravednoj cijeni (preço iusto). No, naveo je i to da postoji roba kojom nije dopušteno trgovati unatoč uspostavi pravedne cijene (svete, založene, položene i ukradene stvari) te roba kojom je uvijek i svakome strogo zabranjeno trgovati (otrovi, kocke, stvari za vlastitu ili obiteljsku upotrebu i stvari koje se kupuju kao dar drugima). Etički sloj trećeg poglavlja prve knjige ogleda se u tome da je Kotruljević čovjeka odredio kao biće koje ima slobodnu volju, izvrstan um i razboritost. Na temelju toga može se zaključiti da je čovjeka poimao bićem koje ima mogućnost samoodređivanja, što znači da je zagovarao mišljenje karakteristično za renesansnu filozofsku misao: čovjek je secundus Deus ili Deus in terris. Osamnaesto poglavlje prve knjige također sadrži etičku sastavnicu. U njemu je Kotruljević izrekao zabranu određenih vrsta djelovanja trgovcima, i to zbog toga što ta djelovanja nisu spojiva sa skromnošću, postojanošću, ozbiljnošću i ćudorednošću (modestia, saldeça, gravita et morigeratione). Iz tog poglavlja doznajemo da je Dubrovčanin trgovce shvaćao kao riznicu ljudskih vrijednosti ( $l$ ' archa delo thesauro humano), zbog čega moraju biti čestiti i uzdržani (honesto et moderato).

Prisutnost etičke sastavnice u drugoj knjizi Kotruljevićevih umovanja o trgovanju utvrdio sam služeći se primjerima iz predgovora toj knjizi te iz njezina prvog, trećeg i četvrtog poglavlja. U predgovoru je Kotruljević bio uvjeren da čovjek posjeduje savršen razum (perfecta ragione) koji nazivamo mudrošću (la chiamamo sapiencia) i pomoću kojega razumije božanske stvari. U prvom poglavlju druge knjige spisa o umijeću trgovanja Kotruljević je istaknuo nužnost trgovčeva pohađanja mise, kao i njezinu važnost za etički aspekt trgovčeva života, zbog toga što ona tješi dušu, prosvjetljuje um, čisti od porokā (purgativo deli vicii), potvrđuje vrline (ratifficativo dele virtu), liječi zablude (medico deli errori) te upućuje na dobar put (dispositivo ala bona via). Treće poglavlje druge knjige također sadrži Kotruljevićeve etičke stavove. Primjerice, Kotruljević je naglasio da trgovac treba gajiti vrlinu velikodušnosti u pružanju ruke siromahu. Uz to, tvrdio je da je opće dobro (ben commune) uvijek važnije od vlastita (ben proprio). Četvrto poglavlje druge knjige Dubrovčanin je također protkao etičkom tematikom. Zamijetivši da trgovci neprestano griješe, odlučio je upozoriti na dopuštene i nedopuštene ugovore. Svoju pozornost pritom je u najvećoj mjeri posvetio lihvi (usura), upućujući pritom u dvama slučajevima na potrebu za trgovčevim pravednim djelovanjem u zajednici. Etički sloj tog poglavlja ogleda se i u Kotruljevićevim razmatranjima pravedne cijene (preço justo), pravedne zarade (justo lucro) i pravedna trgovanja (justa mercantia). Uz to, osudio je trgovce koji ne znaju poslovati bez laži, zakletvi 
i krivokletstava, a nedopuštenima je i zabranjenima smatrao poslove u koje spadaju lihva (usura), simonija (simonia) i krađa (furti).

Treća knjiga Kotruljevićeva spisa o umijeću trgovanja posvećena političkom životu trgovca u cijelosti je etičke naravi. U predgovoru je Kotruljević najavio da će se najprije baviti dobrom čestitosti (bene honesto), koje je začin života čovjeka svake dobi, položaja i načina življenja, te da će se potom usmjeriti na moralni i politički život (lo vivere morale et politico) s obzirom na vrlinu (circa le virtu) koja pristaje svakom izvrsnom trgovcu (mercante optimo). U prvom je poglavlju Kotruljević branio društveni ugled trgovaca i isticao njihov doprinos ljudskoj zajednici. Trgovačko dostojanstvo i zvanje branio je iz četiriju razloga: 1) trgovci doprinose općem dobru zajednice; 2) trgovci korisno i čestito upravljaju kućanstvima i privatnim dobrima; 3) trgovci se privatno i javno kreću u širokom krugu ljudi; 4) trgovci uživaju povjerenje u društvu jer pouzdano čuvaju pologe i pošteno plaćaju dugove. Svakoj od vrlina koje moraju odlikovati trgovca posvetio je zasebno poglavlje: razboritost (prudentia), pouzdanje (confidentia), sreća (fortuna), poštenje (integrita), marljivost (diligentia), okretnost (facilitate), lukavost (astucia) ili prepredenost (callidita), građanska skladnost (urbanita), pravednost (justitia), postojanost (constancia), ugled (auctorita), darežljivost (liberalita), smirenost (tranquilita), skromnost (modestia) i umjerenost (temperantia). Najvažnijim je pritom smatrao trgovčevo posjedovanje triju vrlina: razboritost, pravednost i umjerenost. Za Kotruljevića je razboritost vlina koja čini glavni dio čestitosti, zatim koja služi trgovcu za razlučivanje dobra od zla te koja se sastoji od pamćenja prošlih, razmatranja sadašnjih i predviđanja budućih događaja. Prema Dubrovčaninovu uvjerenju, iz te vrline proizlaze sljedeće četiri sposobnosti: 1) predviđanje, koje trgovcu služi za predviđanje budućnosti; 2) promišljenost, koja trgovcu služi za izbjegavanje porokā suprotnih promišljenosti i koristi; 3 ) oprez, koji trgovcu služi za razlučivanje dobra od zla, koristi od štete, pravog od krivog te laži od istine; 4) poučljivost, koja trgovca čini sklonim učenju, kao i spoznavanju sebe i drugih. U jedanaestom poglavlju treće knjige spisa o umijeću trgovanja Kotruljević je otkrio da pravednost znači svakome dati što je njegovo i da je to vrlina koja u sebi sadrži brojne druge vrline. Trgovac mora biti pravedan u upravljanju novcem i u dijeljenju pravde. Posljednje, osamnaesto poglavlje treće knjige dubrovački je mislilac otpočeo odredbom umjerenosti: umjerenost je vrhovna vrlina (summa virtu) koja sa sobom nosi brojne druge vrline. Da bi ga obilježavala umjerenost, trgovac mora biti: 1) umjeren u uspjehu i u nevolji; 2) umjeren u jelu i piću; 3) umjeren u govoru; 4) umjeren u trgovanju; 5) umjeren u prijateljstvu i u ljubavi. Kotruljević je tada priznao da svoj stav temelji na Aristotelovoj odredbi vrline iz druge knjige 
Nikomahove etike: vrlina je stanje koje se nalazi u sredini. Iz etičke perspektive važna su još dva poglavlja treće knjige spisa o umijeću trgovanja: poglavlje o trgovčevu znanju i poglavlje o trgovčevim pohvalnim osobinama. Kada je razmatrao trgovčevo znanje, Kotruljević je naglasio da obuka savršena trgovca (lo mercante perfecto) ima za svrhu stvaranje najsvestranijeg čovjeka (uno homo universalissimo). Zbog toga je jasno da je dubrovački mislilac bio zagovornik trgovčeva postizanja renesansnog ideala univerzalne ljudske obrazovanosti. Neznanju je etičke konotacije pridao porukama da su neznalice općenito zli te da je zlo suprotno dobru koje je vrlina (e lo male e opposto a lo bene, lo quale e virtu). Među znanjima koja su od velike važnosti iz etičke perspektive izdvojio je logiku, zato što ona trgovcu omogućava razlikovanje istinitog od lažnog. Kada je pisao o trgovčevim pohvalnim osobinama, Kotruljević je poručio da trgovac mora biti: razgovorljiv i okretan u ophođenju s dobrima, ali ne i sa zlima; ljubazan i dobroćudan, blaga i ljupka lica, svakome ugodan, a posebno vedar i veseo kod prodaje i kupnje; slavan jer slava čini čovjeka čistim i gade mu se poroci u težnji za slavom; čist s jednom suprugom, zato što snošaj razara novčanik i osobu te smanjuje um i zato što postoje brojni ludi i bezumni ljudi koji se prepuštaju razbludi puti; postojan i ne smije lamatati rukama ili nogama ni trzati se tijelom kao što to čine lakoumni i divlji ljudi; postojan i zreo, a nimalo lakomislen; svestran i znati se ophoditi sa svim ljudima. Što se tiče porokā, trgovac ne smije biti srdit, osvetoljubiv, drzak, tvrdoglav, hirovit, opsjenar, tašt, rasipan, divlji, bučan ni izjelica.

Da bih ukazao na to da je u četvrtoj knjizi Kotruljevićeva spisa o umijeću trgovanja posvećenoj trgovčevu ekonomskom životu (la vita yconomica) prisutna etička sastavnica, obradio sam sadržaj njezina predgovora, kao i sadržaj trećeg, četvrtog, šestog, sedmog, osmog te desetog poglavlja. Već u predgovoru četvrtoj knjizi moguće je doznati da je Kotruljević pod ekonomskim životom smatrao način trgovčeva upravljanja kućanstvom i obitelji, koji počiva na filozofskim, posebice etičkim i političkim zasadama. Dubrovčaninovi stavovi iz predgovora svjedoče o tome da je izjednačavao vrijednost ispravna trgovčeva djelovanja $u$ političkoj, dakle javnoj, i ekonomskoj, dakle privatnoj, sferi života. Osim toga, Kotruljević je osudio trgovce koji pridaju veliku važnost poslovanju i stjecanju materijalnih dobara, svodeći ih na razinu iracionalnih životinja i zvijeri čiji je život obilježen porokom beskrajne pohlepe. U trećem je poglavlju smatrao da uspješan glavar kućanstva mora biti razborit, častan, pristojan i čestit. Etički sloj sadrži i četvrto poglavlje četvrte knjige spisa o umijeću trgovanja. U njemu je Kotruljević tvrdio i to da bi svakom trebalo pripasti ono što je njegovo zbog istinske pravednosti. U šestom poglavlju razotkriva se Dubrovčaninovo uvjerenje o tome da 
žene moraju posjedovati tri dobra: čestitost (bene honesto) koja proizlazi iz njihovih vrlina, korist (bono utile) koja se sastoji od miraza, nasljedstva i bogatstva, te nasladu (ben delectabile) koja se očituje kao ljepota. Muškarac bi pritom trebao tražiti ženu koju odlikuje čestitost, jer su preostala dva dobra prolazna. Da bi je obilježavala čestitost, žena mora biti: razborita, postojana, ozbiljna, mila, revna, blaga, skromna, milosrdna, nježna, pobožna, velikodušna, suzdržana, stidljiva, marljiva, trezvena, suzdržljiva, oštroumna i radina. No, žena mora pritom voditi računa o tome da radom ukloni dokolicu ( $l$ ' oçio) i siromaštvo (la poverta). Odnos bračnih drugova trebao bi, zaključuje Kotruljević, biti obilježen umjerenošću, stidom u riječima i djelima, pristojnošću i čestitošću u razgovoru, a onda i vjernošću te uzdržanošću. Kotruljević je pisao i o preljubu. Muškarac svojim preljubom ženi oduzima čast, djeci čini nepravdu, a sebi sramotu. Brak se, zaključuje Kotruljević, mora temeljiti na savršenoj ljubavi (perfecto amor), a ustanovljen je zbog dvaju razloga: prihvaćanja i odgoja djece te izbjegavanja bluda. U sedmom poglavlju četvrte knjige spisa o umijeću trgovanja Kotruljević je očinsku ulogu u suzbijanju mladenačke rasipnosti svojih sinova, te u sprečavanju sinova da postanu smioni i umišljeni. Deseto poglavlje četvrte knjige sastoji se od Kotruljevićevih stavova da se trgovac treba umiroviti u pedesetoj godini života, jer tada prestaje imati pronicljiv um, krepku krv i odvažno srce potrebne za trgovanje, a postaje mudriji u političkim i građanskim stvarima. Trgovac bi se, smatra Kotruljević, trebao posvetiti pustinjačkom životu, zbog toga što je takav način življenja blažen, anđeoski, svet i filozofski ([vita] philosophica) te se u njemu kriju opća vrlina (universal virtu), vrlina bez greške (virtu sença erore), život bez sumnje (vita sença dubio), najbolji život (vivere primario) te spasenje kršćana.

Filozofska sastavnica spisa o umijeću trgovanja ispoljava se i u Kotruljevićevim promišljanjima o temama koje pripadaju filozofiji odgoja. Iz te perspektive obradio sam predgovor spisu, zatim treće poglavlje prve knjige, potom predgovor, drugo i treće poglavlje treće knjige te šesto i sedmo poglavlje četvrte knjige. Budući da je čitav spis prožet etičkom tematikom, ne čudi da su Kotruljevićevi stavovi odgojnofilozofske i etičke naravi nerijetko međusobno isprepleteni.

Predgovor spisu sadrži kritiku ondašnje neotesane i nevješte mladeži koju ne odlikuje razboritost, nakon čega je Kotruljević otkrio didaktičku svrhu čitava spisa o umijeću trgovanja koji treba služiti za poučavanje budućih naraštaja. Prema Kotruljevićevu mišljenju, trgovanje se ravna prema općim i posebnim pravilima koja mladići i momci moraju dobro razumjeti da bi ostvarili cilj tog umijeća, dakle časno stjecanje bogatstva. Krivicu za to što su trgovci 
njegova vremena bili neznalice i nevični književnosti, Kotruljević je prepoznao u tome što su loše odgajani (male alevati).

U trećem poglavlju prve knjige spisa o umijeću trgovanja dubrovački je mislilac iznio odgojne smjernice za pospješivanje ljudskog otpora utjecajima viših nebeskih tijela. Trgovcu koji namjerava dijete usmjeriti na bavljenje trgovanjem savjetovao je da obrati pozornost na prirodne sklonosti, a može zaključiti da je ono sposobno baviti se trgovanjem ukoliko je živahne naravi, ugodna izgleda, izvrsne ćudi, teži časti i dobiti, želi dobivati bitke te nije prevrtljivo ni lutalica. Osim toga, Kotruljević je naglasio da je za usmjeravanje mladog čovjeka u trgovanje i za njegovo postajanje savršenim trgovcem potrebno ispunjavanje sljedećih triju preduvjeta: 1) treba biti sin trgovca, jer će tako imati unutarnje vrline slične očevima; 2) treba ga od malena upoznavati s pravilima i ustrojstvom discipline te se pobrinuti da upija kretnje, običaje i razgovore trgovaca; 3) treba biti uporan i ustrajan u izvršavanju posla. No, Kotruljević nije inzistirao samo na duševnom i duhovnom razvoju mladih ljudi, već i na razvoju njihovih tijela koja moraju biti sposobna kao okretna sprava. Dubrovčanin je pritom kao smjernicu za ispravan duševni, duhovni i tjelesni razvoj mladih ljudi istaknuo Aristotelov stav da su sve krajnosti loše (tucti li extremi songo viciosi).

Iako druga knjiga spisa ne sadrži Kotruljevićeve odgojnofilozofske stavove, moguće je pretpostaviti da je u njoj implicirao usmjeravanje mladih ljudi u pravcu upražnjavanja katoličkih vrijednosti i obreda. Treća knjiga nesumnjivo otkriva Dubrovčaninove stavove iz filozofije odgoja. Kotruljević je već u njezinu predgovoru ponudio odgojna rješenja pomoću kojih bi se moglo odagnati probleme koje je zamijetio u ondašnjem društvu. Naime, temeljni je problem vidio u tome što mladi trgovci koji ne traže nauk na pravom vrelu najčešće slijede svoje očeve, umjesto da ih nadmašuju u nekoj vrlini. U drugom poglavlju Kotruljević je istaknuo važnost trgovčeva razvoja poučljivosti, dakle jedne od četiriju sposobnosti koje proizlaze iz razboritosti. Trgovac to može postići čitanjem, zatim time da ne misli da zna ono što ne zna te time da se ne bavi nepoznatim, nepotrebnim i nejasnim stvarima. Bilo bi, tvrdi Kotruljević, pogrešno da trgovac uči geometriju ili astrologiju nauštrb učenja moralne filozofije (la philosophia morale). Dubrovčanin je po istom kriteriju osudio mladiće koji uživaju u nasladama, a zanemaruju učenje gramatike, retorike i drugih časnih znanosti. Poučljivost, koja je kćer razboritosti, zahtijeva da trgovac raspolaže znanjem, ali i sposobnošću proslijeđivanja dobrog nauka drugima. Treće poglavlje treće knjige spisa o umijeću trgovanja rasvjetljuje trgovčevo obrazovanje, točnije otkriva znanja koja je Kotruljević smatrao prijeko potrebnima trgovcima. U ta znanja spadaju ona koja potječu iz 
trivija, dakle iz triju nižih od sedam slobodnih umijeća (septem artes liberales): gramatika, retorika i dijalektika. Budući da je trgovac najsvestranija osoba, on bi trebao poznavati i svjetovne znanosti koje se uče praksom, kao što je, primjerice, kozmologija. Uz to, trgovac bi, dodaje Dubrovčanin, trebao poznavati i filozofiju, astrologiju, teologiju i pravo. Filozofiju bi trebao poznavati zbog spoznavanja naravnih stvari te zbog istraživanja ljudske prirode i naravi. Dubrovački je mislilac astrologiju smatrao najboljom znanošću za trgovca, zbog toga što bi pomoću nje mogao predvidjeti godišnje urode, bolesti i ratove. Trgovac treba biti i teolog, zato što će tako poznavati zakone, kanone i temelje katoličke vjere, te pravnik, zato što će se tako znati zakonima štititi od protivnika.

Četvrta knjiga spisa također sadrži odgojnofilozofsku sastavnicu. Njezino šesto poglavlje osvjetljava odgojnu ulogu koju je Kotruljević namijenio muškarcima u odnosu prema ženama. Muškarčev je zadatak da u prvoj godini braka uvede ženi pravila i red u život. Uz to, Kotruljević je zabilježio da postoji pet inačica naravi žena (le nature di donne), koje nastaju ovisno o odgoju kakav su imale u očinskoj kući. Prva i najpoželjnija inačica ženske naravi odlikuje plemenite žene koje su odgajane tankoćutno i dražesno, zbog čega poštuju i časte muškarca zbog plemenitosti njegove duše. Druga vrsta ženske naravi prepoznatljiva je po tome što su takve žene bojažljive i strašljive, jer su odgajane u strahu i neznalački. Treću vrstu ženske naravi posjeduju žene koje su ohole i divlje, zato što su odgajane bijedno i bez ikakva reda. Četvrta inačica ženske naravi obilježava žene koje imaju malo mozga, pa lako nešto požele i lako zaborave, jer su od djetinjstva odgajane bez ikakve pouke. Petu inačicu ženske naravi imaju žene koje su trome pameti, dremljive, tupa uma, masna tijela, spavalice i nemarne. Poglavlje o ženama Kotruljević je zaključio stavom da su glavni razlozi za uspostavljanje braka prihvaćanje i odgoj djece. U sedmom poglavlju četvrte knjige spisa o umijeću trgovanja Kotruljević je iznio svoja stajališta o odgoju i obrazovanju djece. Roditelji su, tvrdi, dužni djecu odgajati, hraniti i učiti dobrim običajima, dok djeca roditeljima zauzvrat duguju poslušnost. Odgoj i obrazovanje djeteta počinju već nakon njegova odvajanja od dojilje, potom mu je potrebno pronaći učitelja koji će ga poučiti dobrim običajima, gramatici, retorici i nekom umijeću od kojega će zarađivati, dok ga kada odraste treba usmjeriti nekom dobru i učenu trgovcu da izuči struku.

Da bih ocjelovio pregled i ponudio sintezu Kotruljevićeve filozofske misli, istražio sam prisutnost filozofske sastavnice i u Kotruljevićevu drugom dosad poznatom spisu: spisu o plovidbi ili u spisu De navigatione. I u tom spisu Kotruljević se iskazao kao poznavalac povijesti filozofije, a prožeo ga je i temama iz filozofije prirode i etike. 
Premda danas ne raspolažemo nijednim obuhvatnim istraživanjem filozofā i filozofskih izvora u spisu o plovidbi, povijest filozofije bila je ishodište, temelj i oslonac Kotruljevićevih promišljanja i u tom spisu. Za dokazivanje te tvrdnje poslužio sam se sadržajem prvog poglavlja prve knjige De navigatione naslovljenog »Općenito o vodama« (»De acque in genere«). Dubrovački je mislilac u tom poglavlju otkrio svoje spoznaje o predsokratovcima i njihovim naucima, potom o Sokratu, Platonu i Aristotelu te njihovim naucima, a onda i o srednjovjekovnim misliocima i njihovim naucima.

Kotruljević je, naime, u prvom poglavlju prve knjige imenovao sljedeću šestoricu predsokratovaca: Tala, Anaksimandra, Anaksimena, Anaksagoru, Diogena iz Apolonije i Arhelaja. Spoznaje o njima temeljio je na djelima koja su napisali Diogen iz Laerte, Aurelije Augustin i Lucije Cecilije Laktancije Firmijan. Dubrovčanin je uvjerljivo bio najupućeniji u Talovu biografiju i nauk, pri čemu je najveći broj podataka preuzeo iz djela De vita et moribus philosophorum (Životi $i$ mišljenja istaknutih filozofa) Diogena iz Laerte. Kotruljevićeve spoznaje o preostaloj petorici predsokratovaca kolikoćom i kakvoćom značajno zaostaju za spoznajama koje je izložio o Talu. Razlog za to bila je tematika vode, koju je, za razliku od njih, Tal odredio kao počélo. Spoznaje o preostalim predsokratovcima sažeo je i preuzeo iz Augustinova djela $O$ državi Božjoj.

Kada je iznosio podatke o Sokratu, Platonu i Aristotelu te njihovim naucima, Kotruljević nije imenovao svoje izvore. Spoznaje koje je izložio o Sokratu i Platonu jednako su oskudne kao one koje je izložio o petorici predsokratovaca i svode se tek na po jedan biografski podatak. Očitovanja o Aristotelu i njegovu nauku sastoje se od Kotruljevićeva navođenja njegovih djela kao neposrednih izvora spoznaja. Aristotela i njegov nauk Kotruljević je ocijenio neizostavnim u raspravi o tematici vode, a u jednom ga je slučaju oslovio tek riječju »filozof« (»lu philosophu«). Kotruljević je u prvom poglavlju naveo naslove sljedećih četiriju Aristotelovih djela: De caelo et mundo (O nebu i svijetu), Physica (Fizika), Metaphysica (Metafizika) i De generatione et corruptione (O rađanju i nestajanju).

Prvo poglavlje prve knjige De navigatione rasvjetljuje i znanja koja je Kotruljević imao o srednjovjekovnim misliocima i njihovim naucima. U tom se poglavlju Dubrovčanin oslonio na nauk Aurelija Augustina, Rabana Maura, Petra Lombardskog i Alberta Velikog. Kotruljević se, oslovljavajući ga u dvama navratima riječima »lo dicto doctore« (»spomenuti učitelj«), poslužio sa sljedećih pet Augustinovih djela: De civitate Dei (O državi Božjoj), Contra Faustum (Protiv Fausta), De Genesi ad Litteram (Komentari uz Knjigu Postanka), De Trinitate (O Trojstvu) i Ad Orosium (Pitanja Oroziju). Izdvojio sam primjer Kotruljevićeva 
oslanjanja na djelo $O$ Trojstvu. Dubrovački mislilac bio je izvrsno upućen u sadržaj tog Augustinova djela. U trima slučajevima u kojima se pozivao na Alberta Velikog, Kotruljević je imenovao tri njegova djela: De meteoris ili Meteora ( $O$ meteorima ili Meteora), Metaphysica (Metafizika) i De causis proprietarum elementorum (O uzrocima svojstava elemenata). Kao primjer sam obradio njegovo oslanjanje na djelo Meteora. Na temelju tog primjera zaključio sam da se u prvom poglavlju prve knjige tim djelom služio kao vrelom spoznaja o obilježjima Aristotelova nauka. Oslovivši ga »lu magistro delle Sententie« (»učitelj Sentencija«), Kotruljević se u jednom navratu oslonio na djelo Quatuor libri Sententiarum (Četiri knjige promišljanja) Petra Lombardskog.

Uz to što se i u njemu iskazao kao poznavalac povijesti filozofije, filozofsku sastavnicu Kotruljevićeva spisa o plovidbi u najvećoj mjeri sačinjavaju promišljanja koja pripadaju filozofiji prirode. Zbog toga su i istraživanja kojima danas raspolažemo uglavnom ukazivala na prisutnost prirodnofilozofske sastavnice spisa, ali isključivo iz perspektive treće knjige $u$ kojoj je ta sastavnica najzastupljenija.

Sa svrhom produbljivanja i proširivanja dosadašnjih spoznaja te donošenja zaključka o prirodnofilozofskoj orijentaciji čitava spisa, na prisutnost prirodnofilozofske sastavnice u spisu o plovidbi ukazao sam na temelju sadržaja njegove prve i treće knjige. U tim je knjigama najizraženiji Kotruljevićev interes za teme iz filozofije prirode. Međutim, njegov interes za prirodnofilozofske teme zamjetan je u drugoj i u četvrtoj knjizi spisa o plovidbi. Da će spis prožeti prirodnofilozofskom tematikom, dubrovački je mislilac dao do znanja već u njegovu predgovoru. To je očito iz njegove tvrdnje da je raspolagao znanjima o sljedećim temama iz filozofije prirode: putanji Sunca i Mjeseca, izračunu planeta, redoslijedu nebeskih znakova, broju zvijezda, prostranstvu kopna, dubini mora, okretanju nebesa, sklonostima ljudi, svojstvima biljaka te liječenju bolesti.

Prilikom utvrđivanja prisutnosti prirodnofilozofske sastavnice u prvoj knjizi Kotruljevićeva spisa o plovidbi služio sam se prvim trima poglavljima te knjige. U prvom poglavlju Kotruljević je naglasio nužnost mornareva stjecanja znanja o temeljnim postavkama o vodama. Vode je pritom odredio pravim i izvornim temeljem pisanja spisa te najavio da će istražiti u kojoj su mjeri one element i u kojoj su mjeri plovne. Prirodnofilozofska sastavnica tog poglavlja zamjetna je u Dubrovčaninovim promišljanjima o obilježjima vode kao elementa, zatim o naravi njezina gibanja, potom o razlikovanju nebeskih (gornjih) od zemaljskih (donjih) voda te o poretku četiriju gradivnih elemenata svijeta (vatra, zrak, voda, zemlja). Uz to što se tom poglavlju iskazao kao upućenik u dotadašnju povijest filozofije, 
Kotruljević je ipak nedvosmisleno zagovarao stav da je Bog počélo čitavoga svijeta, a time i uzrok svakog gibanja te uzrok postojanja i poretka elemenata. Među filozofskim vrelima za kojima je posezao u argumentaciji, svakako prednjače Augustinova djela, a za njima puno ne zaostaju djela koja je napisao Aristotel. Kotruljević je, sudeći po kolikoći pozivanja te naravi stavova i zaključaka do kojih je došao, u prvoj knjizi bio izrazito sklon Augustinovu nauku i doslovnu razumijevanju biblijskog teksta. Međutim, čak i onda kada se čini da ga je bespogovorno slijedio, dubrovački mislilac nije izostavljao mišljenja koja su o pojedinim temama izložili filozofi i astronomi. Štoviše, u dijelu u kojem je govorio o suprotnoj naravi gibanja vode, Augustinove je stavove podupirao Aristotelovom i Ptolemejevom filozofijom prirode koje je, čini se, smatrao komplementarnima s Augustinovim naukom. Upravo se u tome što je nastojao sagledati i pomiriti stavove koje je zastupao kršćanski novoplatonizam na čelu s Augustinom, te stavove koje su zastupali najutjecajniji suprotstavljeni poganski filozofi i astronomi, na čelu s Aristotelom i Ptolemejem, očituje još jedno obilježje Kotruljevićeve misli koje je karakteristično za renesansu: sinkretizam. Na koncu, time što je upućivao na sličnosti kršćansko-augustinovske i aristotelovsko-ptolemejske tradicije, smatram da je za prvo poglavlje prve knjige spisa o plovidbi moguće donijeti zaključak da je ono dokaz da je dubrovački mislilac bio blizak Aristotelovu nauku iz filozofije prirode. Prirodnofilozofska sastavnica drugog poglavlja prve knjige ogleda se u Kotruljevićevu razmatranju naravi gibanja i mjesta donjih, zemaljskih voda, znači mora. Dosljedno stavovima koje je zastupao u prvom poglavlju, dubrovački je mislilac i u razmatranju tematike mora bio sklon kršćanskom nauku. Svoje je stavove nerijetko potkrepljivao naukom koji je izložio Aristotel, kao i naucima koje su zagovarali Aristotelovi pristaše, primjerice Albert Veliki i Toma Akvinac. Posljednju potvrdu prisutnosti prirodnofilozofske sastavnice u drugom poglavlju prve knjige pružaju stavovi o kružnoj površini mora, dakle o njegovoj zaobljenosti. Da bi to dokazao, Kotruljević se poslužio spoznajama i eksperimentom koji su provodili astrolozi postavljajući kladu u more za vrijeme bonace. Prirodnofilozofski sloj posjeduje i treće poglavlje prve knjige spisa o plovidbi. To je uočljivo već na početku poglavlja iz Kotruljevićeve razdiobe i prikaza pet zemaljskih pojaseva između arktičkog i antarktičkog pola: 1) hladni pojas, 2) umjereni pojas, 3) žarki pojas, 4) umjereni pojas i 5) hladni pojas. Sastavnica koja se odnosi na filozofiju prirode očituje se, primjerice, i u Dubrovčaninovu bavljenju utjecajima koje nebeska tijela ostvaruju na gibanje elemenata: Mjesec utječe na uzdizanje vode i njezino padanje u obliku kiše, Sunce utječe na vatru, zvijezde stajačice na zemlju, a Večernjača i 
ostale zvijezde utječu na gibanje zraka. Mjesečev utjecaj na vodu Kotruljević je dokazao uzrokovanjem sljedećih pojava: plime, oseke, oceanskog vrtloga, vjetrova te potresā.

Dvadeset poglavlja treće knjige Kotruljevićeva spisa o plovidbi u cijelosti su prožeta temama iz filozofije prirode. Obrada prirodnofilozofskog sadržaja treće knjige odnosila se na Dubrovčaninove opise i tumačenja meteoroloških pojava, te na promišljanja o astronomskoastrološkim temama.

Od pojava meteorološke naravi Kotruljević je izlagao o vjetrovima, dúgi, halou, krugu ili alothethi, nebeskoj strijeli ili munji te vatrama koje silaze iz zraka (vijenci, pitije i hazmata). Pritom je najveću pažnju posvetio vjetrovima i njihovim uzrocima, obilježjima i ulozi u plovidbi. Štoviše, već je u predgovoru trećoj knjizi dao do znanja da vjetrovi omogućavaju plovidbu i da su najvažniji dio plovidbe. U prvom poglavlju pisao je o postanku i prestanku vjetrova. Tom je prilikom, po uzoru na Alberta Velikog, zaključio da vjetar stvara rijetka zasebna para koja se izdiže iz zemlje i sudara se s hladnoćom. Rijetku zasebnu paru odredio je trojako: 1) kao korijen, ishodište i načelo postojanja vjetrova; 2) kao gradivo vjetrova i načelo njihova puhanja; 3) kao materiju vjetra. Prilikom pojašnjavanja druge odredbe rijetke zasebne pare zabilježio je da kolikoća vjetrova odgovara kolikoći izdignute rijetke zasebne pare, pa prestanak njezina izdizanja znači i prestanak vjetrova. Drugo poglavlje treće knjige spisa o plovidbi sadrži Dubrovčaninove spoznaje o broju i osobinama dvanaest različitih vjetrova koje su poznavali »stari«. Spoznaje o tome navodno je stekao od Marka Terencija Varona, Seneke i Izidora iz Sevilje. Stari su, prema kriteriju smjera gibanja, razlikovali četiri glavna vjetra (li principali venti): subsolan ili levant (s istoka), auster (s juga), favonij (sa zapada) i septentrion (sa sjevera). Svakom od njih pridružena su i dva vjetra sa svake strane: subsolanu ili levantu s desna puše vulteran, a s lijeve eur; austeru s desna puše euroauster, a s lijeva austerafrik; favoniju s desna puše afrik, a s lijeva kor; septentrionu s desna puše circij, a s lijeva akvilon. Stari su među glavnim vjetrovima razlikovali dva stožena vjetra (li venti cardinali): septentrion i auster. Četvrto poglavlje sastoji se od Kotruljevićeve usporedbe znanja, kako ih tada naziva, »starih filozofa« (»li antiqui philosophi«) sa znanjima »suvremenih mornara« (»moderni marinari«). Naime, u vjetrovnici Kotruljevićeva doba nalazilo se osam glavnih vjetrova, od kojih četiri stožerna (levant, oštro, pulenat, tramuntana) i četiri međustožerna (šiloko, lebić ili garbin, maestral, grego). Između tih vjetrova nalaze se međuvjetrovi (li mezzanini), a između vjetrova i međuvjetrova vjetrovi koji su nazivali četvrtinama (le quarte). U Kotruljevićevo doba postojalo je, dakle, razlikovanje trideset $\mathrm{i}$ dvaju vjetrova: osam glavnih (četiri stožerna i četiri međustožerna), osam međuvjetrova i 
šesnaest četvrtina. Kotruljevićeva promišljanja o vjetrovima sadrže treće i deveto poglavlje. U tim dvama poglavljima oslanjao se na spoznaje Alberta Velikog. U trećem poglavlju Dubrovčanin je izložio razlikovanje dviju vrsti nestalnih vjetrova: prvu čini povjetarac ili aura i ona češće puše uz morsku obalu, a drugu čini autino ili imbato ili altan koja češće puše na moru. Kotruljević je istaknuo da je neke podatke o nestalnim vjetrovima doznavao i iz Senekina djela Quaestiones naturales (Prirodoznanstvena pitanja), poput onoga da pojedine vrste vjetrova češće pušu u nekim predjelima i ovisno o tome poprimaju obilježja hladnoće, topline, suhoće i vlažnosti. U devetom poglavlju dubrovački je mislilac zapisao da vrtložni vjetar izlazi iz oblaka s većim naletom od munje i groma, zatim da je karakterističan za ljeto i da vitla predmete sa zemlje. Prema mišljenju, kako kaže, »svih peripatetičara« (»tucti quanti peripatetici«), takav vjetar najčešće nastaje tijekom hladnog ljeta za vrijeme grmljavinskog nevremena. U petom je poglavlju dubrovački ranorenesansni mislilac otkrio praktičnu primjenu teorijskih znanja o uzrocima i obilježjima vjetrova. Prema njegovu uvjerenju, u težak dio plovidbe spada prepoznavanje predznaka gibanja nebeskih tijela i prognoziranje njihova gibanja. Svoje je spoznaje temeljio na mišljenjima koja su izrekli »filozofi, astrolozi i mornari« (»de philosophi et de astrologi et de marinari«). Iako je Dubrovčanin u tom poglavlju iznio brojne primjere meteoroloških pojava povezanih s vjetrovima, izdvojio sam po dva primjera pojava koje uzrokuju vjetrovi te onih pojava koje su predznak nastanka vjetrova. Kotruljević je priznao da se pritom služio spisom Meteora Alberta Velikog. Prva pojava koju uzrokuju vjetrovi bila je oluja, dok drugu čine nemirno vrijeme i kišna oluja. Prva pojava koja je predznak vjetrova bila je, bilježi Kotruljević, mjesečeva dùga, a druga je pojava bila halo, krug ili alothetha.

Kotruljevićeva razmatranja o astronomsko-astrološkim temama u trećoj knjizi spisa o plovidbi obuhvaćala su dvanaest znakova zodijaka, dvije efemeride, svojstva sedam planeta, solsticije i ekvinokcije, kao i mjerenje vremena. Iako je tim temama posvetio devet poglavlja treće knjige, usmjerio sam se na ona poglavlja u kojima se, prema mojem sudu, ponaviše očituju njegova astronomsko-astrološka znanja. Kotruljević je u tom dijelu treće knjige rijetko imenovao svoje izvore, zbog čega pretpostavljam da je svoja znanja temeljio na vlastitu iskustvu ili na usmenoj predaji. Dubrovački je mislilac uvjerljivo najviše pažnje posvetio tematici dvanaest znakova zodijaka. Znanja o zodijaku smatrao je korisnima mornarima i to zbog vremenskih prilika koje sa sobom nose i zbog utjecaja koje znakovi ostvaruju na ljudske sklonosti i djelovanje. Kotruljević je pritom rasporedio znakove u tri grupe po četiri znaka kojima pripadaju svojstva četiriju elemenata po njihovu redoslijedu, pa tako, primjerice, vatra 
pripada Ovnu, zemlja Biku, zrak Blizancima, a voda Raku. Druga prirodnofilozofska tema kojoj je Kotruljević posvetio podosta pažnje bila su svojstva sedam planeta. Toj je temi posvetio čitavo četrnaesto poglavlje treće knjige spisa o plovidbi, a u tom je poglavlju izložio redoslijed elemenata i planeta, točnije izložio je svoju zamisao strukture svijeta. Dubrovčanin je bio poklonik tradicionalnog geocentričnog sustava svijeta koji se temelji na Aristotelovoj i Ptolemejevoj zamisli: u središtu se nalazi Zemlja sastavljena od četiriju elemenata od najnižeg do najvišeg (zemlja, voda, zrak, vatra), iza nje se nalazi sedam koncentričnih sfera za svaki od sedam planeta, zatim dolazi osma sfera koja pripada zvijezdama stajačicama, a onda, na koncu, dolazi nepokrenuti i nepokretni pokretač čitava gibanja. Osim toga, Dubrovčanin se u petnaestom poglavlju iskazao kao poznavalac astrološke medicine, i to zbog toga što je opisao utjecaje koje pojedini planeti vrše na ljudsko zdravlje. Primjerice, zapisao je da će onaj tko postavi pitanje o bolesti u vrijeme vladavine Saturna dugo bolovati od glavobolje, vrućice i potištenosti, ali da neće umrijeti.

Kotruljevićev spis o plovidbi ima i etičku sastavnicu. To sam utvrdio analizom sadržaja druge knjige, dakle knjige u kojoj je u najvećoj mjeri razmatrao građu, vrste i opremu plovilā, i treće knjige, dakle knjige u kojoj je u najvećoj mjeri razmatrao meteorološke pojave i astronomskoastrološku tematiku. Naznaku prisutnosti etičke sastavnice u drugoj knjizi De navigatione možemo zahvaliti člancima koje je 2009. i 2012. godine objavio talijanski kartograf Piero Falchetta. U njima je zabilježio da je Kotruljević prilikom razmatranja organizacije života na brodu izložio tjelesne i moralne kakvoće koje bi trebale obilježavati članove brodske posade da bi uspješno izvršavali svoje dužnosti.

Etička sastavnica druge knjige spisa o plovidbi očituje se u tome što je Kotruljević propisao etička obilježja četvorici članova zapovjednog lanca na brodovima: kapetanu (zapovjedniku broda), patronu (brodovlasniku), komitu (zapovjedniku brodske posade) i naukjeru (upravitelju broda te zapovjedniku mornarā i veslačā). Osim toga, iz trećeg je poglavlja zamjetno da je Kotruljević poimao članova posade tek dijelom opreme na galijama, a koje se mogu opremati dragovoljno (per bona voglia) ili silom (per força). Zbog učinkovitosti i uspješnosti plovidbe i obrane, Kotruljević je zagovarao prisilno opremanje galije veslačima koje se drži u okovima i lancima. Znači, uspješnost plovidbe pretpostavio je slobodi veslačā. Kada je u petom poglavlju pisao o etičkim obilježjima kapetana, dubrovački mislilac se, kako kaže, služio znanjima koja je doznao od grčkog filozofa Onasandra, rimskog senatora Frontina i rimskog pisca Vegecija. Zbog toga je istaknuo da kapetan na brodu mora biti sličan vojskovođi na kopnu i zato mora biti: umjeren (temperato), suzdržan (continente), uljudan u 
jelu (domestico nello magnare) te ne smije biti lakom (non avaro). Za patrona je pak u šestom poglavlju zabilježio da mora biti prijatan (piacevele), trezven u jelu i piću (sobrio im bevere et in magnare), uljudan u razgovoru, kao i lukav (astuto). Kotruljević je u četvrtom poglavlju kao glavno etičko obilježje komita istaknuo razboritost, jer, kako kaže, cjelokupno vođenje galije počiva na razboritosti komita. U sedmom je poglavlju naveo četiri obilježja naukjera: oštrouman (acer ingenio), srednje dobi (optima conditione è mediocre) te postojan i staložen (saldo et repusato).

Etičku sastavnicu posjeduje i treća knjiga spisa De navigatione. Budući da u toj knjizi prevladava prirodnofilozofska tematika, Kotruljević je u njoj iznosio svoje etičke nazore usporedno s prirodnofilozofskim. Štoviše, njegovi nazori proizlaze upravo iz odnosa i međusobna utjecaja tih dviju filozofskih disciplina. Naime, etičke je stavove bilježio u trima poglavljima koja je posvetio astronomsko-astrološkim temama. U njima je tumačio i predviđao utjecaje nebeskih tijela na ljudsku narav i sklonosti te razmatrao predviđanja etički ispravnog djelovanja na temelju dvanaest znakova zodijaka. U jedanaestom je poglavlju ljudima rođenim u pojedinom znaku zodijaka pridao etička obilježja te istaknuo djelatnosti u kojima će biti uspješni. Primjerice, o osobi rođenoj u znaku Ovna zabilježio je da će biti korisna (utile), miroljubiva (pacifico) i dostojna zavisti (invidioso), dok će, također primjerice, osoba rođena u znaku Vodenjaka biti mudra (savio) i zla (malo). U četrnaestom poglavlju Kotruljević je prikazao utjecaje koje pojedini planeti vrše na ljudsko djelovanje i etička obilježja koja odlikuju ljude tijekom njihova utjecaja. Primjerice, zabilježio je da je Jupiter dobar i čini ljude sposobnima za vladanje, umjerenima, divnima i čini njihova srca prikladnim za uzvišene stvari, dok je, također primjerice, Merkur je planet koji je za dobre dobar, dok je za loše loš znak. Petnaesto poglavlje sadrži Dubrovčaninove spoznaje o utjecaju planeta na ljudsko djelovanje i na uspješnost obavljanja određenih radnji započetih u pojedinom satu tijekom dana. Primjerice, o Saturnovu satu zabilježio je sljedeće: onaj tko tada započne posao uspjet će u svemu, ali se neće obogatiti; onaj tko tada pita za nekog tata, treba mu reći da je hirovit, mlad, potišten i lopov po naravi; onaj tko tada pođe na putovanje, odmah će otići na željeno mjesto i vratit će se sretno.

Naposljetku, u radu sam ponudio sintezu Kotruljevićeve filozofske misli izložene u njegovim dvama dosad pronađenim spisima: spisu o trgovanju i spisu o plovidbi. Poduzeta analiza prisutnosti filozofske sastavnice u četirima knjigama spisa o umijeću trgovanja iznjedrila je sljedeće zaključke: 1) Kotruljević se u njemu iskazao kao poznavalac povijesti filozofije; 2) čitav spis sadrži etičku sastavnicu; 3) prva, treća i četvrta knjiga spisa imaju 
odgojnofilozofsku sastavnicu. Na temelju analize filozofske sastavnice spisa o plovidbi došao sam do sljedećih zaključaka: 1) Kotruljević se u tom spisu iskazao kao poznavalac povijesti filozofije; 2) prva i treća knjiga posjeduju prirodnofilozofsku sastavnicu; 3) u drugoj i trećoj knjizi prisutna je etička sastavnica. Uz to, utvrdio sam da se u Kotruljevićevim promišljanjima u tim dvama spisima očituju barem četiri glavna obilježja renesansnog filozofskog mišljenja: 1) nadogradnja srednjovjekovnih spoznaja antičkim uzorima; 2) sinkretizam; 3) postavljanje čovjeka i njegova djelovanja u središte pozornosti; 4) stvaranje ideala svestrano obrazovana čovjeka. Dakle, Kotruljević se u svojim spisima iskazao kao istinski predstavnik renesansnog filozofskog mišljenja. 


\section{POPIS CITIRANE LITERATURE}

\subsection{Benedikt Kotruljević}

Cotrugli, Benedetto / Kotrulj, Benedikt. 2009. »Libro del arte dela mercatura«, pp. 113-334 / »Knjiga o vještini trgovanja«, pp. 335-503, u: Benedikt Kotrulj, Libro del arte dela mercatura / Knjiga o vještini trgovanja, priredila i prevela Zdenka Janeković Römer (Zagreb - Dubrovnik: Hrvatska akademija znanosti i umjetnosti, Zavod za povijesne znanosti u Dubrovniku i Hrvatski računovođa, 2009).

Cotrugli Raugeo, Benedetto. 1573. Della mercatura et del mercante perfetto. (In Vinegia: All'Elefanta, 1573). Primjerak se čuva u Bogišićevoj biblioteci u Cavtatu pod signaturom BB C I $3 / 26$.

Cotrugli, Benedetto. 2009. »De navigatione (1464-1465) Ms. Schoenberg 473«, u: Piero Falchetta, $» I l$ trattato De navigatione di Benedetto Cotrugli (1464-1465). Edizione commentata del ms. Schoenberg 473 con il testo del ms. 557 di Yale«, Studi Veneziani 57 (2009), pp. 67-197.

Cotrugli, Benedetto. 2009. »De navigatione (1464-1465). Testo del ms. 557 della Yale University Library«, u: Piero Falchetta, »Il trattato De navigatione di Benedetto Cotrugli (1464-1465). Edizione commentata del ms. Schoenberg 473 con il testo del ms. 557 di Yale«, Studi Veneziani 57 (2009), pp. 199-333.

[Cotrullis, Benedictus de]. 1464. Benedictus de Cotrullis Equitis Ad Inclitum Senatum Venetorum De Navigatione. Liber Incipit: Prohemium. primum. Foeliciter. Rukopis se čuva u Beinecke Rare Book and Manuscript Library u Yale University Library pod signaturom MS 557.

[Cotrullis, Benedictus de]. 1464. L'Arte del Navegare. Rukopis se čuva u zbirci Lawrence J. Schoenberg Collection pod signaturom MS ljs 473. 
Cotrullis, Benedictus de / Kotruljević, Benedikt. 2005. »De navigatione«, pp. 18-234 / Benedikt Kotruljević, »O plovidbi«, pp. 19-235, u: Benedikt Kotruljević, De navigatione / O plovidbi, priredio i preveo Damir Salopek (Zagreb: Ex libris, 2005).

\subsection{Ostala citirana literatura}

Albertus Magnus. 1890. »Meteororum«, u: B.[eati] Alberti Magni, Ratisbonensis episcopi, Ordinis praedicatorum, Opera omnia, cura ac labore Augusti Borgnet, Sacerdotis dioecesis Remensis. Volumen Quartum. (Parisiis: Apud Ludovicum Vivès, 1890), pp. 477a-808b.

Alighieri, Dante. 1976. »Pakao«, u: Dante Alighieri, Djela, knjiga druga, priredili Frano Čale i Mate Zorić, preveli Mihovil Kombol, Mate Maras (Raj XVIII-XXXIII) (Zagreb: Sveučilišna naklada Liber / Nakladni zavod Matice hrvatske, 1976), pp. 11-189.

Andrei, Filippo. 2012. Boccaccio the Philosopher: The Language of Knowledge in the Decameron, a dissertation submitted in partial satisfaction of the requirements for the degree of Doctor of Philosophy in Romance Languages \& Literatures in the Graduate Division of the University of California, Berkeley. Committee in charge: Professor Steven Botterill, Chair, Professor Albert Russell Ascoli, Professor Ignacio Enrique Navarette. (Berkeley: University of California, 2012).

Appendini, Francesco Maria. 1803. Notizie istorico-critiche sulle antichità storia e letteratura de' Ragusei divise in duet omi e dedicate all'Eccelso Senato della repubblica di Ragusa. Tomo II. (Ragusa: Dalle stampe di Antonio Martecchini, 1803), s. v. »Benedetto da Giacomo Cotrugli«, pp. 98-100.

Aquinas, Thomas. 1895. Summa theologiae II-II, u: Sancti Thomae Aquinatis Doctoris angelici Opera omnia iussu impensaque Leonis XIII P. M. edita. Tomus octavus. Secunda secundae Summae theologiae a quaestione I ad quaestionem LVI, ad Codices manuscriptos Vaticanos exacta cum commentariis Thomae de Vio Caietani Ordinis praedicatorum S. R. E. Cardinalis, cura et studio fratrum eiusdem Ordinis (Romae: Ex Typographia Polyglotta, 1895). 
Aristotel. 1988. Fizika, prijevod s izvornika i sedmojezični tumač temeljnih pojmova (grčki, latinski, engleski, francuski, njemački, talijanski, ruski) Tomislav Ladan, predgovor Danilo Pejović (Zagreb: Globus / Sveučilišna naklada Liber, 1988).

[Aristotele]. 2008. »Fisica«, traduzione di Antonio Russo, u: Aristotele, Opere, volume primo (Milano: Arnoldo Mondadori Editore S.p.A., 2008), pp. 61-296.

Augustin, Aurelije. 1982. O državi Božjoj / De civitate Dei, svezak prvi (knjiga I-X), latinski i hrvatski tekst, s latinskog izvornika preveo Tomislav Ladan, uvod napisali Agostino Trapè, Robert Russell, Sergio Cotta (Zagreb: Kršćanska sadašnjost, 1982).

Augustinus, Aurelius. 1865. »De Trinitate libri quindecim.«, u: Patrologiae cursus completus, accurante J[acques].-P.[aul] Migne. Patrologiae Latinae. Tomus XLII. S.[anctus] Aurelius Augustinus. [Opera omnia, post Lovaniensium theologorum recensionem. Tomus octavus] (Parisiis: excudebatur et venit apud J.[acques]-P.[aul] Migne editorem, 1865), cc. 819-1098.

Augustinus, Aurelius. 1900. »De civitate Dei contra paganos«, u: Patrologiae cursus completus, accurante J[acques].-P.[aul] Migne. Patrologiae Latinae. Tomus XLI. S.[anctus] Aurelius Augustinus. [Opera omnia, post Lovaniensium theologorum recensionem. Tomus septimus] (Parisiis: Apud Garnier fratres editores, et J.[acques]-P.[aul] Migne, successores, 1900), cc. 13-804.

Sveti Augustin. 2009. Trojstvo, preveo, napisao uvod i bilješke Marijan Mandac (Split: Služba Božja, 2009).

Bacotich, Arnolfo. 1930. »Benedetto Cotrugli da Ragusa primo scrittore di scienze mercantili (1458)«, Archivio storico per la Dalmazia 5/9 (1930), pp. 183-190.

Balić, Davor. 2004. »Benedikt Kotruljević o trgovčevim vrlinama«, u: Davor Balić, Hrvatska renesansna etika, magistarski rad iz filozofije obranjen 20. prosinca 2004. godine na Filozofskom fakultetu Sveučilišta u Zagrebu. Voditelj: Ante Čović (Zagreb: Filozofski fakultet Sveučilišta u Zagrebu, 2004), pp. 3-11. 
Balić, Davor. 2010. »Vrste plovilā u Kotruljevićevu udžbeniku plovidbe«, Metodički ogledi: časopis za filozofiju odgoja 17/1-2 (2010), pp. 61-86.

Balić, Davor. 2011. »Izvori Kotruljevićeve filozofije prirode u De navigatione (1464)«, u: Marita Brčić, Mira Matijević, Krešimir Babel (ur.), Simpozij Mediteranski korijeni filozofije 5. Split, 24.-26. ožujka 2011 (Zagreb - Split: Hrvatsko filozofsko društvo / Odsjek za filozofiju Filozofskog fakulteta Sveučilišta u Splitu, 2011), p. 21.

Balić, Davor. 2012. »Filozofi i filozofski izvori u Kotruljevićevu spisu o umijeću trgovanja«, Cris: časopis Povijesnog društva Križevci 14 (Križevci, 2012), pp. 205-271.

Banić-Pajnić, Erna. 1991. Duhovno-povijesna raskršća: poruke renesansne filozofije (Zagreb: Hrvatsko filozofsko društvo, 1991).

Banić-Pajnić, Erna. 1996. »Renesansna filozofija«, u: Erna Banić-Pajnić (priređivačica sveska), Filozofija renesanse. Hrestomatija filozofije, sv. 3 (Zagreb: Školska knjiga, 1996), pp. $7-42$.

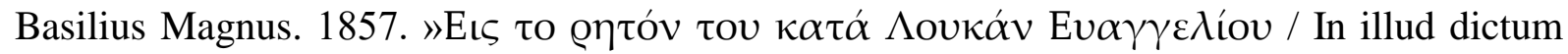
Evangelii secundum Lucam«, u: Patrologiae cursus completus, accurante J.-P. Migne. Patrologiae Graecae Tomus XXXI. Sanctus Basilius Caesariensis episcopus. (Lutetiae Parisiorum: Excudebatur et venit apud J.-P. Migne editorem, 1857), cc. 261-278.

Blank, David. 2012. »Varro and Antiochus«, u: David Sedley (edited by), The Philosophy of Antiochus (New York: Cambridge University Press, 2012), pp. 250-289.

Boschetto, Luca. 2005. „Tra Firenze e Napoli. Nuove testimonianze sul mercante-umanista Benedetto Cotrugli e sul suo Libro dell'arte di mercatura«, Archivio storico Italiano 163/4 (Firenze, 2005), pp. 687-715.

Brajković, Vladislav. 1976. s. v. »Kapetan«, u: Pomorska enciklopedija 3, I-Ko (Zagreb: Jugoslavenski leksikografski zavod, 1976), p. 464b. 
Brajković, Vladislav. 1981. s. v. »Naukijer«, u: Pomorska enciklopedija 5, Mito-Pa (Zagreb: Jugoslavenski leksikografski zavod, 1981), p. 259a.

Brajković, Vladislav. 1981. s. v. »Patron (paron ili parun; od lat. patronus gospodar)«, u: Pomorska enciklopedija 5, Mito-Pa (Zagreb: Jugoslavenski leksikografski zavod, 1981), p. $724 b$.

Bratić, Bojana. 1995. »Uno scrit[t]ore[-]mercante raguseo del XV secolo: Benedetto Cotrugli e il suo trattato 'Della mercatura et del mercante perfetto' ", Italica Belgradensia 4 (Belgrado / Beograd, 1995), pp. 121-241.

Brčić, Marita. 2009. »Kotruljevićev nauk o pravednu trgovcu: podudarnosti i razlike s Aristotelovim poimanjem pravednosti«, Cris: časopis Povijesnog društva Križevci 11 (Križevci, 2009), pp. 135-143.

Brehaut, Ernest. 1912. An Encyclopedist of the Dark Ages: Isidore of Seville, submitted in partial fulfilment of the requirements for the degree of doctor of philosophy in the Faculty of Political Science in Columbia University (New York: Columbia University, 1912).

Burckhardt, Jacob. 1860. Die Cultur der Renaissance in Italien. Ein Versuch (Basel: Druck und Verlag der Schweighauser'schen Verlagsbuchhandlung, 1860).

Cassirer, Ernst, Kristeller, Paul Oskar, Randall, jr. John Herman (selections in translation, edited by). 1948. The Renaissance Philosophy of Man (Chicago: Phoenix books, University of Chicago Press, 1948).

Cassirer, Ernst. 1927. Individuum und Kosmos in der Philosophie der Renaissance, softcover reprint of the hardcover 1st edition 1927 (Wiesbaden: Springer Fachmedien Wiesbaden $\mathrm{GmbH}, 1927)$.

Chrysostomus, Sanctus Joannes. 1862. »Commentarius in Sanctum Matthaeum Evangelistam

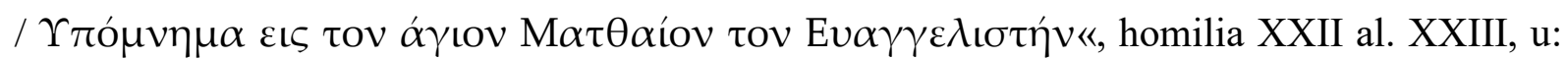
Patrologiae cursus completus, accurante J.-P. Migne. Patrologiae Graecae Tomus LVII. 
Sanctus Joannes Chrysostomus. (Lutetiae Parisiorum: Excudebatur et venit apud J.-P. Migne editorem, 1862), cc. 13-472, na c. 308.

[Cicero, Marcus Tullius]. 1865. »De officiis ad Marcum filium«, u: M. Tullii Ciceronis Opera quae supersunt omnia, vol. VIII., ediderunt J.[ohann] G.[eorg] Baiter, C.[arl] L.[udwig] Kayser. (Lipsiae: Ex officina Bernhardi Tauchnitz, 1865), pp. 1-114.

Ciceron, Marko Tulije. 2006. $O$ dužnostima, prijevod Zvonimir Milanović (Zagreb: Nova Akropola, 2006).

Coleman-Norton, P.[aul] R.[obinson]. 1930. »St. Chrysostom and the Greek Philosophers«, Classical Philology 25/4 (Chicago, 1930), pp. 305-317.

Curnow, Trevor. 2011. The Philosophers of the Ancient World: An A to Z Guide (London: Bristol Classical Press, 2011), s. v. »Valerius Maximus«, p. 276.

Curren, Randall. 2003. »Introduction«, u: Randal Curren (edited by), A Companion to the Philosophy of Education (Oxford: Blackwell Publishing Ltd, 2003), pp. 1-4.

Dadić, Žarko. 2015. »Rukopis Benedikta Kotruljevića De navigatione iz 15. stoljeća«, u: Žarko Dadić, Povijest znanosti i prirodne filozofije u Hrvata. S osobitim obzirom na egzaktne znanosti, knjiga I., Srednji vijek (Zagreb: Izvori, 2015), pp. 359-376.

DelCogliano, Mark. 2010. Basil of Caeserea's Anti-Eunomian theory of names: Christian theology and late-antique philosophy in the fourth century trinitarian controversy (Leiden Boston: Koninklijke Brill NV, 2010).

D’Onofrio, Sandro. 2011. s. v. »Isidore of Seville«, u: Henrik Lagerlund (Ed.), Encyclopedia of Medieval Philosophy: Philosophy Between 500 and 1500 (Dordrecht: Springer Science+Business Media B.V., 2011), pp. 573b-575a.

Dover, Paul. 2013. »Reading 'Pliny's Ape' in the Renaissance: the Polyhistor of Caius Julius Solinus in the first century of print«, u: Jason König, Greg Woolf (edited by), Encyclopaedism 
from Antiquity to the Renaissance (New York: Cambridge University Press, 2013), pp. 414443.

Edelheit, Amos. 2014. Scholastic Florence: Moral Psychology in the Quattrocento (Leiden Boston: Koninklijke Brill, 2014).

Falchetta, Piero. 2009. »Il trattato De navigatione di Benedetto Cotrugli (1464-1465). Edizione commentata del ms. Schoenberg 473 con il testo del ms. 557 di Yale«, Studi Veneziani 57 (2009), pp. 15-333.

Falchetta, Piero. 2012. »Benedetto Cotrugli et son traité De navigatione (1464-1465)«, The Historical Review / La Revue Historique 9 (2012), pp. 53-62.

Faracovi, Ornella. 2014. »The Return to Ptolemy«, u: Brendan Dooley (edited by), $A$ Companion to Astrology in the Renaissance (Leiden - Boston: Brill, 2014), pp. 87-98.

Filipović, Vladimir. 1956. Filozofija renesanse $i$ odabrani tekstovi filozofa, Filozofska hrestomatija, sv. 3 (Zagreb: Nakladni zavod Matice hrvatske, 1956).

Florentia, Sanctus Antoninus de. 1756. »De usura in emtione, et venditione.«, capitulum septimum, II-IV, cc. 169-192, u: Sanctus Antoninus de Florentia, »De avaritia, et speciebus eius.«, titulus primus, cc. 13-448, u: Sancti Antonini Archiepiscopi Florentini Ordinis Praedicatorum Summa moralis ad autographorum fidem nunc primum exacta, et adnotationibus illustrata, cura, et studio ff. Thomae Mariae Mamachi, Antonini Ceccherelli et Dionysii Remedelli, II. partis, volumen I. (Florentiae: Ex typographio Petri Caietani Viviani, 1756).

Fortin, Ernest L. 2002. Dissent and Philosophy in the Middle Ages: Dante and His Precursors, translated by Marc. A. LePain (Lanham: Lexington Books, 2002).

Garin, Eugenio. 1954. Medioevo e Rinascimento: studi e ricerche (Bari: Gius, Laterza \& Figli, 1954). 
Garin, Eugenio. 1986. L’Umanesimo italiano. Filosofia e vita civile nel Rinascimento (Roma - Bari: Laterza, 1986).

Gautier Dalché, Patrick. 1996. »L'usage des cartes marines aux $\mathrm{XIV}^{\mathrm{e}}$ et $\mathrm{XV}^{\mathrm{e}}$ siècles«, u: Spazi, tempi, misure e percorsi nell'Europa del Bassomedioevo, atti del XXXII Convegno storico internazionale, Todi, 8-11 ottobre 1995 (Spoleto: Centro italiano di studi sull'alto Medioevo, 1996), pp. 97-128.

Gerl, Hanna-Barbara. 1989. Einführung in die Philosophie der Renaissance (Darmstadt: Wissenschaftliche Buchgesellschaft, 1989).

Gilson, Étienne. 1948. Dante the Philosopher, translated by David Moore (London: Sheed \& Ward, 1948).

Girardi Karšulin, Mihaela. 1993. Hrvatski renesansni aristotelizam (Zagreb: Hrvatsko filozofsko društvo, 1993).

Gozzi, Nicolò Vito di. »Dello Stato delle Republiche secondo la mente d'Aristotile con essempi Moderni«, u: Nicolò Vito di Gozzi, Dello stato delle Republiche secondo la mente di Aristotele con essempi moderni Giornate otto (In Venetia: Presso Aldo, 1591), pp. 1-408.

Grafton, Anthony. 1988. »The availability of ancient works«, u: Charles B. Schmitt (general editor), Quentin Skinner, Eckhard Kessler (editors), Jill Kraye (associate editor), The Cambridge History of Renaissance Philosophy (New York: Cambridge University Press, 1988), pp. 767-791.

Grant, Edward. 1987. »Celestial Orbs in the Latin Middle Ages«, Isis 78/2 (Chicago, 1987), str. 153-173.

Griffin, Miriam. 2007. »The Younger Pliny’s Debt to Moral Philosophy«, Harvard Studies in Classical Philology 103 (Cambridge and London, 2007), pp. 451-481. 
Grzybowski, Jacek. 2015. Cosmological and Philosophical World of Dante Alighieri: The Divine Comedy as a Medieval Vision of the Universe (Frankfurt am Main: Peter Lang GmbH, 2015).

Gučetić, Nikola Vitov. 2000. »O ustroju država«, u: Nikola Vitov Gučetić, O ustroju država, prevele Snježana Husić, Natka Badurina, priredio i napisao uvodnu studiju Marinko Šišak (Zagreb: Golden Marketing / Narodne novine, 2000), pp. 73-478.

Gulin, Danimir, Dražić Lutilsky, Ivana, Glasnović, Branka (ur.). 2008. Znanstveni skup »Benedikt Kotruljević 2008.» (Zagreb: Ekonomski fakultet Zagreb, 2008).

Habek, Mladen. 1994. »Kotruljevićevo djelo u svjetskoj računovodstvenoj misli«, Računovodstvo, revizija i financije 11 (studeni, 1994), pp. I-XIV.

Hankins, James (edited by). 2007. The Cambridge Companion to Renaissance Philosophy (Cambridge: Cambridge University Press, 2007).

Helm, Anne J. van der, Postma, Johanna. 2000. »La Riegola del Libro. Bookkeeping Instructions from the Mid-Fifteenth Century«, u: Accounting and History: A selection of papers presented at the 8th World Congress of Accounting Historians, Madrid, Spain, 19-21 July 2000 (Madrid: Asociación Española de Contabilidad y Administración de Empresas, 2000), pp. 147-178.

Hildebrand, Stephen M. 2007. The trinitarian theology of Basil of Caesarea: a synthesis of Greek thought and biblical truth (Washington, D. C.: The Catholic University of America Press, 2007).

Hirst, Paul H.[eywood]. 2003. »Foreword«, u: Nigel Blake, Paul Smeyers, Richard Smith, Paul Standish (edited by), The Blackwell Guide to the Philosophy of Education (Oxford: Blackwell Publishing Ltd, 2003), pp. xv-xvi.

Howard, Peter. 2015-2021?. s. v. »Pierozzi, Antonino«, u: Marco Sgarbi (ed.), Encyclopedia of Renaissance Philosophy (Cham: Springer International Publishing, 2015-2021?), pp. 1-4. 
Huizinga, J.[ohan]. 1919. Herfsttij der Middeleeuwen: studie over levens-en gedachtenvormen der veertiende en vijftiende eeuw in Frankrijk en de Nederlanden (Haarlem: H. D. Tjeenk Willink \& zoon, 1919).

[Ianduno, Ioannis de]. 1552. »Quaestiones super libros Aristotelis De coelo et mundo«, u: Ioannis de Ianduno in libros Aristotelis De coelo et mundo quae extant quaestiones subtilissimae: quibus nuper consulto adiecimus Averrois sermonem De substantia orbis (Venetiis: Apud Iuntas, 1552), ff. 2r-32v.

Isidorus Hispalensis. 1850. »Etymologiarum libri XX.«, u: Patrologiae cursus completus, accurante J[acques].-P.[aul] Migne. Patrologiae Latinae. Tomus LXXXII. Sancti Isidori Hispalensis. [Opera omnia, recensente Faustino Arevalo. Tomi tertius et quartus] (Parisiis: Venit apud editorem, in via dicta d'Amboise, prope portam vulgo d'Enfer nominatam, seu Petit-Montrouge, 1850), cc. 73-1098.

Janeković Römer, Zdenka. 2009. »Benedikt Kotrulj u potrazi za savršenim trgovcem«, u: Benedikt Kotrulj, Libro del arte dela mercatura / Knjiga o vještini trgovanja, priredila i prevela Zdenka Janeković Römer (Zagreb - Dubrovnik: Hrvatska akademija znanosti i umjetnosti, Zavod za povijesne znanosti u Dubrovniku i Hrvatski računovođa, 2009), pp. 15111.

Jurić, Đurđica. 1995. Djelo Bene Kotruljevića i hrvatska gospodarska misao, magistarski rad, mentor: Anđelko Runjić (Zagreb: Sveučilište u Zagrebu, Ekonomski fakultet, 1995).

Jurišić, Blaž. 1962. »O našoj pomorskoj terminologiji«, u: Grga Novak, Vjekoslav Maštrović (ur.), Pomorski zbornik: povodom 20-godišnjice Dana mornarice i pomorstva Jugoslavije 1942-1962., knjiga I (Zagreb: JAZU; Zadar: Institut za historijske i ekonomske nauke, 1962), pp. 451-468.

Kheil, Karel Petr. 1906. Benedetto Cotrugli Raugeo (Dubrovčan). Příspěvek $k$ dějinám účetnictví. (V Praze: Bursik \& Kohout, 1906). 
Kraye, Jill. 2007. »The revival of Hellenistic philosophies«, u: James Hankins (edited by), The Cambridge Companion to Renaissance Philosophy (New York: Cambridge University Press, 2007), pp. 97-112.

Kristeller, Paul Oskar. 1964. Eight Philosophers of the Italian Renaissance (Stanford: Stanford University Press, 1964).

Kristeller, Paul Oskar. 1990. »Ms. 557. cart. XV. 66 fols.«, u: Paul Oskar Kristeller (compiled by), Iter italicum, Volume V (Alia itinera III and Italy III), Sweden to Yugoslavia, Utopia, supplement to Italy (A-F) (Leiden - London: E. J. Brill / The Warburg Institute, 1990), pp. $282-283$.

Lactantius, Lucius Caecilius Firmianus. 1844. »Divinarum institutionum«, u: Patrologiae cursus completus, accurante J[acques].-P.[aul] Migne. Patrologiae Latinae. Tomus VI. Lucii Caecilii Firmiani Lactantii. [Opera omnia, post Lovaniensium theologorum recensionem. Tomus primus] (Parisiis: Excudebat Sirou, 1844), cc. 111-822.

Laertius, Diogenes. 1546. De vita et moribus philosophorum. Libri X. (Lugduni: Apud Seb.[astian] Gryphium, 1546).

Laertije, Diogen. 1973. Životi i mišljenja istaknutih filozofa, sa starogrčkog preveo Albin Vilhar. Predgovor napisao Branko Bošnjak (Beograd: Beogradsko izdavačko-grafički zavod, 1973).

Lombardus, Petrus. 1855. »Sententiarum libri quatuor«, u: Patrologiae cursus completus, accurante J[acques].-P.[aul] Migne. Patrologiae Latinae. Tomus CXCII. Petrus Lombardus magister Sententiarum. [Opera omnia. Tomus secundus] (Parisiis: Excudebatur et venit apud J.-P. Migne editorem, 1855), cc. 519-964.

Luetić, Josip. 1984. Pomorci i jedrenjaci Republike Dubrovačke (Zagreb: Nakladni zavod Matice hrvatske, 1984). 
Luetić, Josip. 1997. Brodari i pomorci Dubrovačke Republike (Zagreb: Nakladni zavod Matice hrvatske, 1997).

Martinović, Ivica. 1994. »Benedikt Kotruljević (1)«, Zbor 4, br. 2(29), prilog u: Mi list mladih: glasilo katoličke mladeži 18 (ožujak, 1994), br. 3, pp. 9a-9d.

Martinović, Ivica. 1994. »Benedikt Kotruljević (2)«, Zbor 4, br. 3(30), prilog u: Mi list mladih: glasilo katoličke mladeži 18 (travanj, 1994), br. 4, pp. 9a-9d.

Martinović, Ivica. 1994. »Prva povijest hrvatskog umijeća plovidbe«, Naše more: pomorski znanstveni časopis 41/3-4 (Dubrovnik, 1994), pp. 181-183.

M.[artinović], I.[vica]. 1996. »Benedikt Kotruljević«, pp. 56-57; »Benedikt Kotruljević«, pp. 108-109, u: Greta Pifat Mrzljak (autorica izložbe), Znanost u Hrvata: prirodoslovlje $i$ njegova primjena / Centuries of Natural Science in Croatia: Theory and Application, [sv. 1], katalog izložbe održane od lipnja do listopada 1996. godine u Muzejskom prostoru Muzejsko galerijskog centra na Jezuitskom trgu u Zagrebu (Zagreb: Muzejsko galerijski centar, 1996).

Martinović, Ivica. 1999. »Književni žanrovi hrvatskih filozofa od Stojkovića do Boškovića«, u: Fedora Ferluga Petronio (a cura di), Introduzione allo studio della lingua, letteratura e cultura croata / Uvod u studij hrvatskoga jezika, književnosti i kulture / Uvod v študij hrvaškega jezika, literature in kulture (Udine: Forum, 1999), pp. 107-116, na pp. 107-108.

Martinović, Ivica. 2000. »Žanrovi hrvatske filozofske baštine od 15. do 18. stoljeća«, u: Pavo Barišić (ur.), Otvorena pitanja povijesti hrvatske filozofije (Zagreb: Institut za filozofiju, 2000), pp. 69-151, na pp. 73-74.

Martinović, Ivica. 2007. »Benedikt Kotruljević«, u: Neven Budak (osmislio i uredio), Croatica: HR - Hrvatski udio u svjetskoj baštini, [sv. 1] (Zagreb: Profil international, 2007), pp. $170-175$.

Martinović, Ivica. 2011. Žanrovi hrvatske filozofske baštine od 15. do 18. stoljeća (Split: Filozofski fakultet Sveučilišta u Splitu, 2011). 
Maximus, Valerius. 1888. »Factorum et dictorum memorabilium«, u: Valerii Maximi factorum et dictorum memorabilium libri novem. Cum Iulii Paridis et Ianuarii Nepotiani epitomis, iterum recensuit Carolus Kempf. (Lipsiae: in aedibus B. G. Teubneri, 1888), pp. $3-$ 472.

Mayer, Wendy. 2015. »Shaping the Sick Soul: Reshaping the Identity of John Chrysostom«, u: Geoffrey D. Dunn, Wendy Mayer (Edited by), Christians Shaping Identity from the Roman Empire to Byzantium: Studies Inspired by Pauline Allen (Leiden - Boston: Koninklijke Brill, 2015), pp. 140-164.

Mayer, Wendy. 2017. »John Chrysostom: Moral Philosopher and Physician of the Soul«, u: Doru Costache, Mario Baghos (edited by), John Chrysostom: Past, Present, Future (Sidney: AIOCS Press, 2017), pp. 193-215.

Muljačić, Žarko. 1995. »Sličnosti i razlike Petrisova izdanja Kotruljevićeva traktata (Mleci, 1573, P) i najstarijeg dosad poznatog prijepisa (Napulj, 1475, R) izgubljenog autografa (1458)«, Prilozi za istraživanje hrvatske filozofske baštine 21 (1995), pp. 57-65.

Nachod, Hans. 1959. »Introduction«, u: Ernst Cassirer, Paul Oskar Kristeller, John Herman Randall, jr. (edited by), The Renaissance Philosophy of Man: Petrarca, Valla, Ficino, Pico, Pomponazzi, Vives, sixth impression (Chicago: The University of Chicago Press, 1959), pp. 23-33.

Natali, Carlo. 2013. Aristotle: His Life and School (Princeton and Oxford: Princeton University Press, 2013).

Nauman, Eileen. 1996. Medical Astrology, third revision (Cottonwood: Blue Turtle Publishing, 1996).

Novaković, Darko. 1995. »Prvi hrvatski udžbenik plovidbe«, Hrvatski kulturni tjednik »Danica«, Zagreb, br. 48 (18. ožujka 1995), pp. 1-20, na p. 17, u: Vjesnik 56 (Zagreb, 1995), br. 17044 (18. ožujka 1995), p. 31. 
Novaković, Darko. 1996. „Novopronađeni rukopis Benedikta Kotruljevića«, u: Vladimir Stipetić (ur.), Dubrovčanin Benedikt Kotruljević: hrvatski i svjetski ekonomist XV. stoljeća, međunarodni znanstveni skup, Dubrovnik 17-19. X. 1996. Radovi o životu i djelu Benedikta Kotruljevića, knjiga 1. (Zagreb: Hrvatska akademija znanosti i umjetnosti i »Hrvatski računovođa«, 1996), pp. 19-32.

Novaković, Darko. 2015. „Novopronađeni rukopis Benedikta Kotruljevića O plovidbi (De navigatione)«, u: Darko Novaković, U krilu Vile Latinke. Rasprave o hrvatskom humanizmu (Zagreb: Ex libris, 2015), pp. 61-80.

Paasche Grudin, Michaela, Grudin, Robert. 2012. Boccaccio's Decameron and the Ciceronian Renaissance (New York: Palgrave Macmillan, 2012).

Paušek-Baždar, Snježana. 2011. »Federik Grisogono i alkemija« / »Federik Grisogono and Alchemistry«, Acta medico-historica Adriatica 9/2 (Rijeka, 2011), pp. 173-188.

Petrarca, Franciscus. 1862. »Epistola VIII. Franciscus Petrarca Andreae Dandulo duci Venetorum«, liber undecimus, u: Franciscus Petrarca, Epistolae de rebus familiaribus et variae, studio et cura Iosephi Fracassetti, volumen secundum (Florentiae: Typis Felicis Le Monnier, 1862), pp. 124-134.

Piotrowicz, Paulina. 2013. $»$ L'immagine del mercante modello in Il libro dell'arte di mercatura di Benedetto Cotrugli«, Iuvenilia Philologorum Cracoviensium / Źródła Humanistyki Europejskiej 6 (2013), pp. 349-361.

Plinius Caecilius Secundus, Caius. 1966. »C. Plinius Baebio Macro suo s.«, liber III, epistula V, $\S 10$, u: C. Plini Caecili Secundi epistularum libri decem, recognovit brevique adnotatione critica instruxit R.[oger] A.[ubrey] B.[askerville] Mynors (Oxonii: e typographeo Clarendoniano, 1966), pp. 72-75. 
Plinius Secundus, C.[aius]. 1856. »Naturalis historiae libri VII-XV.«, u: C.[aii] Plini Secundi Naturalis historiae libri XXXVII., recognovit atque indicibus instruxit Ludovicus Ianus. Vol. II. Libb. VII-XV. (Lipsiae: sumptibus et typis B. G. Teubneri, 1856), pp. 1-302.

Polo Saibanti, Claudio de. 1985. »Arte del Navigare, manoscritto inedito datato 1464-1465«, u: Carla Clivio Marzoli, Giacomo Corna Pellegrini, Gaetano Ferro (a cura di), Imago et mensura mundi: atti del IX Congresso internazionale di storia della cartografia (Roma: Istituto della Enciclopedia Italiana, fondata da Giovanni Treccani, 1985), pp. 71-79.

Preus, Anthony. 2007. Historical Dictionary of Ancient Greek Philosophy (Lanham Maryland - Toronto - Plymouth: The Scarecrow Press, Inc., 2007).

Preus, Anthony. 2015. Historical Dictionary of Ancient Greek Philosophy, second edition (Lanham - Boulder - New York - London: Rowman \& Littlefield, 2015), s. v. »Callisthenes of Olynthus.«, p. 92.

Radičević, Rikard. 1987. Rudnik blaga Bene Kotruljevića (Zürich: Manuskript sastavio Rikard Radičević, 1987).

Ravlić, Pavao. 1999. »Benedikt Kotruljević kao preteča Luce Paciolija u prikazu dvostavnog knjigovodstva«, Računovodstvo, revizija i financije 9 (rujan, 1999), pp. 109-114.

Runjić, Anđelko. 1975. »O Benku Kotruljiću i njegovu djelu«, u: Benedetto Cotrugli Raugeo, Della mercatura et del mercante perfetto. Libri quattro, biblioteka reprint izdanja Liber Croaticus (Zagreb: Savez računovodstvenih i financijskih radnika Hrvatske, Sveučilišna naklada Liber, 1975), pp. 243-258.

Sacrobosco, Johannes de. 1949. »Tractatus de spera«, u: Lynn Thorndike, The Sphere of Sacrobosco and Its Commentators (Chicago: The University of Chicago Press, 1949), pp. 76117. 
Salopek, Damir. 2003. »Rasprava De navigatione Benedikta Kotruljevića«, u: Dunja Fališevac, Josip Lisac, Darko Novaković (ur.), Hrvatska književna baština, knjiga 2. (Zagreb: Ex libris, 2003), pp. 11-14.

S.[alopek], D.[amir]. 2005. »Predgovor«, u: Benedikt Kotruljević, De navigatione / O plovidbi, priredio i preveo Damir Salopek (Zagreb: Ex libris, 2005), pp. 11-12.

Sangster, Alan. 2014. Libr. XV: Cotrugli and de Raphaeli on business and bookkeeping in the Renaissance (Stirling: Lomax Press, 2014).

Schiffler, Ljerka. 1992. Humanizam bez granica: hrvatska filozofija u europskom obzoru (Zagreb: Hrvatsko filozofsko društvo, 1992).

Schiffler, Ljerka. 1996. »Praktično-etička dimenzija 'savršena trgovca’ B. Kotruljevića«, u: Vladimir Stipetić (ur.), Dubrovčanin Benedikt Kotruljević: hrvatski i svjetski ekonomist XV. stoljeća, međunarodni znanstveni skup, Dubrovnik 17-19. X. 1996. Radovi o životu i djelu Benedikta Kotruljevića, knjiga 1. (Zagreb: Hrvatska akademija znanosti i umjetnosti i »Hrvatski računovođa«, 1996), pp. 161-169.

Schiffler, Ljerka. 1996. »Etičko-humanistička misao Benedikta Kotruljevića«, Prilozi za istraživanje hrvatske filozofske baštine 22 (1996), pp. 117-142.

Schmitt, Charles B.[ernard] (general editor), Skinner, Quentin, Kessler, Eckhard (editors), Kraye, Jill (associate editor). 1988. The Cambridge History of Renaissance Philosophy (Cambridge: Cambridge University Press, 1988).

Sheldon-Williams, I. P. 1967. »The Greek Christian Platonist Tradition from the Cappadocians to Maximus and Eriugena«, u: A.[rthur] H.[ilary] Armstrong, The Cambridge History of Later Greek and Early Medieval Philosophy (New York: Cambridge University Press, 1967), pp. 425-533.

Sherwin-White, A.[drian] N.[icholas]. 1969. »Pliny, the Man and His Letters«, Greece \& Rome 16/1 (Cambridge, 1969), pp. 76-90. 
Singleton, Charles S. 1949. »Dante and Myth«, Journal of the History of Ideas 10/4 (Philadelphia, 1949), pp. 482-502.

Siraisi, Nancy G.[illian]. 1990. Medieval and early Renaissance medicine: an introduction to knowledge and practice (Chicago: The University of Chicago Press, 1990).

Skuhala Karasman, Ivana. 2013. U potrazi za znanjem o budućem: predviđanje $u$ srednjovjekovnoj $i$ renesansnoj prirodnoj filozofiji - H. Dalmatin, F. Grisogono $i$ J. Dubrovčanin (Zagreb: Institut za filozofiju, 2013).

Smarr, Janet Levarie. 2014. »Introduction: A Man of Many Turns«, u: Victoria Kirkham, Michael Sherberg, Janet Levarie Smarr (edited by), Boccaccio: A Critical Guide to the Complete Works (Chicago and London: The University of Chicago Press, 2014), pp. 1-20.

Solinus, Caius Iulius. 1864. »Collectanea rerum memorabilium sive Polyhistor.«, IX, 18-20, u: C.[aii] Iulii Solini Collectanea rerum memorabilium. Recognovit Th.[eodor] Mommsen. (Berolini: in aedibus Friderici Nicolai, 1864), pp. 2-231.

Stipetić, Vladimir. 1994. „Beno Kotruljević prvi je upoznao svijet s dvostrukim računovodstvom. Iznenađujući novotkriveni rukopis Bene Kotruljevića«, Računovodstvo, revizija i financije 10 (listopad, 1994), pp. Ia-VIIIb.

Šimunković, Ljerka, Pederin, Ivan. 1996. »Prilog proučavanju srednjolatinskoga pomorskog nazivlja u mletačkoj Dalmaciji u XIV. i XV. stoljeću«, Čakavska rič: polugodišnjak za proučavanje čakavske riječi 24/1-2 (1996), pp. 95-110.

Tester, Jim. 1987. A History of Western Astrology (Suffolk: The Boydell Press, 1987).

Trovato, Stefano. 2009. »Il manoscritto De navigatione in Marciana: cronaca di un acquisto mancato tra 1913 e 1914«, Studi Veneziani 57 (2009), pp. 549-556. 
Tucci, Ugo. 1990. »Introduzione«, u: Benedetto Cotrugli Raguseo, Il libro dell'arte di mercatura, a cura di Ugo Tucci (Venezia: Arsenale Editrice, 1990), pp. 3-128.

Tucci, Ugo. 2005. »La trasmissione del mestiere del marinaio a Venezia nel Medioevo«, u: La trasmissione dei saperi nel Medioevo (secoli XII-XV), diciannovesimo Convegno internazionale di studi, Pistoia, 16-19 maggio 2003 (Pistoia: Centro italiano studi di storia e d'arte, 2005), pp. 111-126.

Duzer, Chet van. 2013. »Benedetto Cotrugli’s Lost Mappamundi Found-Three Times«, Imago Mundi: The International Journal for the History of Cartography 65/1 (2013), pp. 114.

Vasoli, Cesare. 1969. Umanesimo e Rinascimento (Palermo: Palumbo, 1969).

Vekarić, Nenad. 1996. »Dubrovački rod Kotrulj«, u: Vladimir Stipetić (ur.), Dubrovčanin Benedikt Kotruljević: hrvatski i svjetski ekonomist XV. stoljeća, međunarodni znanstveni skup, Dubrovnik 17-19. X. 1996. Radovi o životu i djelu Benedikta Kotruljevića, knjiga 1. (Zagreb: Hrvatska akademija znanosti i umjetnosti i »Hrvatski računovođa«, 1996), pp. 3352.

Vidović, Radovan. 1984. Pomorski rječnik (Split: Logos, 1984), s. v. »kapitan«, pp. 193a205a.

Vidović, Radovan. 1984. Pomorski rječnik (Split: Logos, 1984), s. v. »nakir«, pp. 311b-312a.

Vidović, Radovan. 1984. Pomorski rječnik (Split: Logos, 1984), s. v. »parun«, pp. 342b344a.

Vidović, Radovan. 1984. Pomorski rječnik (Split: Logos, 1984), s. v. »comitus, chomitus, comittus«, p. 524a.

Violić-Koprivec, Ariana, Maslek, Jasenka. 2015. »O nekim nazivima za posadu dubrovačkih brodova«, Fluminensia: časopis za filološka istraživanja 27/1 (2015), pp. 49-70. 
Vujić, Mih.[ajlo] V. 1909. »Prvo naučno delo o trgovini Dubrovčanina Benka Kotruljića«, Glas Srpske kraljevske akademije, br. 80 (Beograd, 1909), pp. 25-123.

Wróbel, Piotr. 2009. »Benedykt Cotruglio (Benko Kotruljević): człowiek na granicy dwóch światów i dwóch epok«, Balcanica Posnaniensia: acta et studia 16 (2009), pp. 125-138.

Yamey, Basil S. 1994. »Benedetto Cotrugli on bookkeeping (1458)«, Accounting, Business \& Financial History 4/1 (1994), pp. 43-50.

Zanato, Tiziano. 1993. »Sul testo della 'mercatura' di Benedetto Cotrugli (A proposito di una recente edizione)«, Studi veneziani 26 (1993), pp. 15-65.

Zebić, Milorad. 1963. Život i rad Dubrovčanina Benka Kotruljića. Sa prevodom njegovog spisa O trgovini i savršenom trgovcu (Titograd: Udruženje knjigovođa Crne gore, 1963). 


\section{PRILOZI}

\section{Prilog 1: Popis izdanjā cjelovita Kotruljevićeva spisa o umijeću trgovanja}

1) Cotrugli Raugeo, Benedetto. 1573. Della mercatura et del mercante perfetto. (In Vinegia: All'Elefanta, 1573). Primjerak se čuva u Bogišićevoj biblioteci u Cavtatu pod signaturom BB C I $3 / 26$.

2) Cotrugli Raugeo, Benedetto. 1573. Della mercatura et del mercante perfetto. (In Vinegia: All'Elefanta, 1573). Primjerak se čuva u Biblioteca Nazionale Marciana u Veneciji pod signaturom 133 D 225.

3) Cotrugli Raugean, Benoit. 1582. Dela marchandise, et du parfaict marchant, traduict de l'Italien de Benoit Cotrugli Raugean, par Iean Boyron (Lyon: Par les heritiers de François Didier, à l'enseigne du Fenix, 1582).

4) Cotrugli Raugeo, Benedetto. 1602. Della mercatura et del mercante perfetto (Brescia: Alla Libraria del Bozzola, 1602).

5) [Kotruljić, Benko]. 1963. »O trgovini i o savršenom trgovcu«, u: Milorad Zebić, Život i rad Dubrovčanina Benka Kotruljića. Sa prevodom njegovog spisa $\mathrm{O}$ trgovini i savršenom trgovcu (Titograd: Udruženje knjigovođa Crne gore, 1963), pp. 113-203.

6) Cotrugli Raugeo, Benedetto. 1975. Della mercatura et del mercante perfetto. Libri quattro, biblioteka reprint izdanja Liber Croaticus (Zagreb: Savez računovodstvenih i financijskih radnika Hrvatske, Sveučilišta naklada Liber, 1975).

7) Kotruljević, Beno. 1985. O trgovini i o savršenu trgovcu, pripremili i obradili Rikard Radičević i Žarko Muljačić (Zagreb: Jugoslavenska akademija znanosti i umjetnosti, 1985).

8) Cotrugli Raugeo, Benedetto / Kotruljević Dubrovčanin, Beno. 1989. Della mercatura et del mercante perfetto. I O trgovini i o savršenom trgovcu, pretisak izdanja iz 1573. godine i 
usporedni prijevod na hrvatskom jeziku. Preveo prof. dr. Žarko Muljačić (Dubrovnik: Dubrovački trgovačko-turistički sistem, 1989).

9) Cotrugli Raguseo, Benedetto. 1990. Il libro dell'arte di mercatura, a cura di Ugo Tucci (Venezia: Arsenale Editrice, 1990).

10) Kotruljević, Benedikt. 2005. Knjiga o umijeću trgovanja, s talijanskoga preveo Žarko Muljačić. Tekst 13. poglavlja [prve knjige] prevela Karmen Milačić (Zagreb: Binoza press, 2005).

11) Cotruglio, Benedykt. 2007. Księga o sztuce handlu, tłumaczenie, wstęp i przypisy Piotr Wróbel i Jacek Bonarek (Kraków: Towarzystwo Wydawnicze »Historia Jagellonica«, 2007).

12) Kotrulj, Benedikt. 2009. Libro del arte dela mercatura / Knjiga o vještini trgovanja, priredila i prevela Zdenka Janeković Römer (Zagreb / Dubrovnik: Hrvatska akademija znanosti i umjetnosti, Zavod za povijesne znanosti u Dubrovniku i Hrvatski računovođa, 2009).

13) Cotrugli, Benedetto. 2016. Libro de l'arte de la mercatura, a cura di Vera Ribaudo, premessa di Tiziano Zanato (Venezia: Edizioni Ca’ Foscari - Digital Publishing, 2016).

14) Kotruljević, Benedikt. 2016. Knjiga o umijeću trgovanja, s talijanskog preveo Žarko Muljačić (Zagreb: Lider media d.o.o., 2016).

15) [Cotrugli, Benedetto]. 2017. »The Book of the Art of Trade«, u: Carlo Carraro, Giovanni Favero (eds.), Benedetto Cotrugli - The Book of the Art of Trade, With Scholarly Essays from Niall Ferguson, Giovanni Favero, Mario Infelise, Tiziano Zanato and Vera Ribaudo (Cham: Springer International Publishing, 2017), pp. 23-172. 


\section{Prilog 2: Popis rukopisnih inačica prijepisā i izdanjā Kotruljevićeva spisa o plovidbi}

1) [Cotrullis, Benedictus de]. 1464. Benedictus de Cotrullis Equitis Ad Inclitum Senatum Venetorum De Navigatione. Liber Incipit: Prohemium. primum. Foeliciter. Rukopis se čuva u Beinecke Rare Book and Manuscript Library u Yale University Library pod signaturom MS 557.

2) [Cotrullis, Benedictus de]. 1464. L'Arte del Navegare. Rukopis se čuva u zbirci Lawrence J. Schoenberg Collection u pod signaturom MS ljs 473.

3) Cotrugli, Benedetto. [s. a.]. De Navigatione (1464-65), trascricione del testo del ms. 557 della Beinecke Rare Book and Manuscript Library (Yale University), a cura di Piero Falchetta

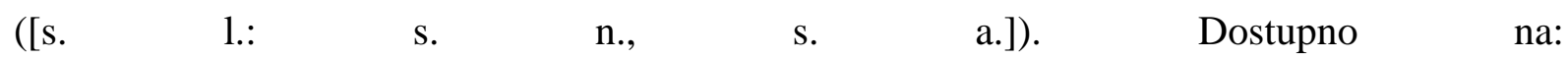
http://193.206.197.50/cms/images/stories/Testi_HSL/Cotrugliy.pdf (pristupljeno 1. studenog 2019. godine).

4) [Kotruljević, Benedikt]. 2003. »Benedictus de Cotrullis Equitis ad Inclitum Senatum Venetorum De Navigatione Liber«, u: Dunja Fališevac, Josip Lisac, Darko Novaković (ur.), Hrvatska književna baština, knjiga 2. (Zagreb: Ex libris, 2003), pp. 15-127.

5) Kotruljević, Benedikt. 2005. De navigatione / O plovidbi, priredio i preveo Damir Salopek (Zagreb: Ex libris, 2005).

6) Cotrugli, Benedetto. 2009. »De navigatione (1464-1465) Ms. Schoenberg 473«, u: Piero Falchetta, »Il trattato De navigatione di Benedetto Cotrugli (1464-1465). Edizione commentata del ms. Schoenberg 473 con il testo del ms. 557 di Yale«, Studi Veneziani 57 (2009), pp. 67-197.

7) Cotrugli, Benedetto. 2009. »De navigatione (1464-1465). Testo del ms. 557 della Yale University Library«, u: Piero Falchetta, »Il trattato De navigatione di Benedetto Cotrugli (1464-1465). Edizione commentata del ms. Schoenberg 473 con il testo del ms. 557 di Yale«, Studi Veneziani 57 (2009), pp. 199-333. 


\section{7. ̌̌IVOTOPIS}

Demian Papo rođen je 14. travnja 1991. godine. Živi u Osijeku. Na Filozofskom fakultetu Sveučilišta Josipa Jurja Strossmayera je 2009. godine upisao engleski jezik i književnost i filozofiju. Pod vodstvom mentora izv. prof. dr. sc. Davora Balića obranio je 2014. godine diplomski rad pod naslovom Ivan Stojković: prvi hrvatski renesansni filozof.

Počevši od 2013. godine, s izlaganjima iz područja povijesti hrvatske filozofije redovito sudjeluje na znanstvenim skupovima u organizaciji Hrvatskog filozofskog društva, posebice na međunarodnom znanstvenom skupu Dani Frane Petrića u Cresu i na znanstvenom skupu Mediteranski korijeni filozofije u Splitu.

Radove iz područja povijesti hrvatske filozofije objavio je u časopisima Filozofska istraživanja i Metodički ogledi. Osim toga, uredio je knjižice sažetaka triju studentskih filozofskih simpozija u organizaciji Odsjeka za filozofiju Filozofskog fakulteta u Osijeku, Udruge studenata filozofije »logOS« i Hrvatskog filozofskog društva: Sveučilište, filozofija, obrazovne politike (2014), Društvo, jezik, mit (2015) i Filozofija u književnosti (2016).

Od 2013. godine član je Hrvatskog filozofskog društva, u kojem je bio izabran za člana Nadzornog (2014-2016) i Upravnog odbora (2016-2018). Od 2015. godine je član »Kruga mladih urednika« u časopisima Filozofska istraživanja i Synthesis philosophica. Od 2016. godine je član Programskog odbora međunarodnog znanstvenog skupa »Hrvatska filozofija u interakciji i kontekstu« u sklopu Dana Frane Petrića. Od 2018. godine je tajnik ogranka Hrvatskog filozofskog društva u Osijeku pod nazivom »Osječki filozofski krug«.

Radio je 2014. godine kao nastavnik engleskog jezika u I. (Općoj) gimnaziji u Osijeku, a od prosinca 2014. godine do lipnja 2015. godine radio je kao pomoćnik u nastavi u Osnovnoj školi »Tin Ujević« u Osijeku. Od listopada 2015. godine radi kao asistent na Odsjeku za filozofiju Filozofskog fakulteta Sveučilišta Josipa Jurja Strossmayera u Osijeku.

\subsection{Bibliografija}

Papo, Demian, Potlimbrzović, Hrvoje. 2018. „Marijan Petras: filozof odgoja, filozof kulture i filozof tehnike«, Filozofska istraživanja 38/2 (2018), str. 235-246.

Papo, Demian. 2016. »Vuk-Pavlovićevi stavovi o Lockeovu nauku«, Metodički ogledi: časopis za filozofiju odgoja 23/2 (2016), str. 29-41. 
Papo, Demian. 2015. »Studentski filozofski simpoziji u Osijeku: od početaka do danas (20112015)«, u: Luka Matić i Demian Papo (ur.), Društvo, jezik, mit: 5. Studentski filozofski simpozij Odsjeka za filozofiju Filozofskog fakulteta Sveučilišta Josipa Jurja Strossmayera u Osijeku, Udruge studenata filozofije »logOS« i Hrvatskog filozofskog društva. Knjižica sažetaka simpozija, Osijek, 28. i 29. svibnja 2015 (Osijek: Filozofski fakultet Sveučilišta Josipa Jurja Strossmayera u Osijeku, 2015), str. 73-87. 